\title{
International aspects of the CCCTB in Europe
}

Citation for published version (APA):

Pereira, T. A. (2014). International aspects of the CCCTB in Europe. [Doctoral Thesis, Maastricht University]. Maastricht University. https://doi.org/10.26481/dis.20141210tp

Document status and date:

Published: 01/01/2014

DOI:

10.26481/dis.20141210tp

Document Version:

Publisher's PDF, also known as Version of record

\section{Please check the document version of this publication:}

- A submitted manuscript is the version of the article upon submission and before peer-review. There can be important differences between the submitted version and the official published version of record.

People interested in the research are advised to contact the author for the final version of the publication, or visit the DOI to the publisher's website.

- The final author version and the galley proof are versions of the publication after peer review.

- The final published version features the final layout of the paper including the volume, issue and page numbers.

Link to publication

\footnotetext{
General rights rights.

- You may freely distribute the URL identifying the publication in the public portal. please follow below link for the End User Agreement:

www.umlib.nl/taverne-license

Take down policy

If you believe that this document breaches copyright please contact us at:

repository@maastrichtuniversity.nl

providing details and we will investigate your claim.
}

Copyright and moral rights for the publications made accessible in the public portal are retained by the authors and/or other copyright owners and it is a condition of accessing publications that users recognise and abide by the legal requirements associated with these

- Users may download and print one copy of any publication from the public portal for the purpose of private study or research.

- You may not further distribute the material or use it for any profit-making activity or commercial gain

If the publication is distributed under the terms of Article $25 \mathrm{fa}$ of the Dutch Copyright Act, indicated by the "Taverne" license above, 


\section{INTERNATIONAL ASPECTS OF THE CCCTB IN EUROPE}

Tiiu Albin Pereira 



\section{International Aspects of the CCСТB in Europe DISSERTATION}

to obtain the degree of Doctor at the Maastricht University, on the authority of the Rector Magnificus,

Prof. Dr. L.L.G. Soete

in accordance with the decision of the Board of Deans, to be defended in public

on Wednesday, 10 December 2014, at 10:00 hours

by

Tiiu Albin Pereira 


\section{Supervisors:}

Prof. Dr. R.G. Prokisch

Prof. Dr. H.T.P.M. van den Hurk

\section{Assessment Committee:}

Prof. Dr. R.H.C. Luja (Chairman)

Mr. Dr. J.H.M. Arts

Prof. Dr. Y. Brauner, Levin College of Law, University of Florida, United States of America

Prof. Dr. dr. h.c. N. Herzig, em.

Mr. Dr. M.G.H. Schaper

ISBN: 978-90-5681-441-0

NUR: 828

Printed in the Netherlands by Océ Business Services, Maastricht.

Cover design by Canon Design Studio Maastricht

(C) 2014 by T. Albin Pereira

All rights reserved. No part of this publication may be reproduced, stored in a retrieval system, or transmitted, in any form or by any means, electronic, mechanical, photocopying, recording, or otherwise, without the prior permission in writing from the author. 
For my husband Gonçalo and our daughter Alice 



\section{Acknowledgements}

The very first time I arrived to Maastricht was for my master studies in the beginning of February 2008. Although it was freezing cold, the town was full of colour and everybody was in celebration mood - it was Carnaval Soon I realised that this charming town was perfect for continuing my studies. Writing this doctoral dissertation during the past few years in Maastricht University was a great privilege. This intellectual challenge I had set myself enhanced my personal and professional growth and I am grateful for this opportunity.

I thoroughly enjoyed the multicultural and inspiring ambience in Maastricht and I am sincerely thankful for all those who were part of this experience. I would like to acknowledge a few people specifically that have touched my life in this time.

I would like to express my greatest gratitude to my supervisors Prof. Rainer Prokisch and Prof. Hans van den Hurk who have supported my research from the first draft to the book as it is today. I am particularly thankful to Rainer who invited me to stay in Maastricht and who encouraged me to know more about tax law and think beyond borders. I appreciate his enthusiasm in relation to my research and his invaluable comments during our up-date meetings. Likewise, I am grateful to Hans for all the discussions, his advice and motivation throughout my research. I wish to thank him for his availability and being a steadfast supervisor. I thank both Rainer and Hans for their trust and the freedom they gave me in my research.

I would like to thank the members of my Assessment Committee, Prof. Raymond Luja, Dr. Hans Arts, Prof. Yariv Brauner, Prof. Norbert Herzig and Dr. Marcel Schaper for taking the time to read my manuscript and for their worthy comments on my dissertation. I extend my sincere thanks to Prof. Brauner for giving me the opportunity to carry out part of my research at Levin College of Law (University of Florida), where I had an unforgettable experience and got a taste of US taxation. I am sincerely thankful for his friendliness, hospitality and availability throughout my time in Gainesville. I also appreciate the kindness of Prof. Walter Hellerstain for his comments on my thesis regarding US state taxation when we met in Vienna on the conference on the CCCTB organised by Institute for Austrian and International Tax Law of the Vienna University back in 2012. 
I am deeply grateful to Prof. Ana Paula Dourado for the opportunity to attend GREIT Lisbon Summer Courses. I am proud that I had a chance to assist her in organising some outstanding tax law events in Lisbon. This experience considerably enlarged my network of international and EU tax law scholars.

I wish to express my appreciation to my colleagues at the Law Faculty of Maastricht University, especially my fellow $\mathrm{PhD}$ researchers. My time as a $\mathrm{PhD}$ researcher would not have been as amusing as it was without my amazing roommates Mandy Gabriël, Fernando de Man and Frank Nellen. I thank you three for the inspiration you provided and also for your support and encouragement throughout these years. I have truly enjoyed being part of the Tax Law Department, which unites many wonderful people. I am very grateful to Carol Ní Ghiollarnáth, a former colleague at our department, for her excellent job in proofreading my manuscript. Finally, I am especially thankful to Arthur Denie who supported me in pursuing further academic research already during my master studies at the university.

I had the most invaluable experience during my internship with DG TAXUD of the European Commission in 2011. I had the good fortune that I had just joined the team of Corporate Tax Initiatives when the Commission proposed the long-awaited CCCTB Directive. During these six months, I had the chance to work with the true experts of the CCCTB and hence learn from their experience. I wish to thank my former colleagues from DG TAXUD of the European Commission for making my internship truly enjoyable. I hope that I will cross paths again with these marvellous people in the future. I specifically wish to thank Tom Neale, Declan Kelly, Laurent Chappuis, Chiara Putzolu, Juan Lopez Rodriguez, Franco Roccataglia, Jaap Tilstra, Pere Moles Palleja, and Adam Zalasinski. I am very grateful to Uwe Ihli for his excellent supervision and for making my experience with the Commission complete. There are not enough words to thank Ioanna Mitroyanni, with whom I have had numerous discussions on the CССТВ. I am deeply indebted to you for your time and dedication, your invaluable comments on my dissertation as well as professional and personal advice during my research period.

On a more personal note, I wish to thank my Estonian friends. My deepest thanks go to Helen Rajalo who has been the most fantastic friend for more than a decade and, despite the distance, has always 
been available to me. I also thank Katrin Abroi, Margit Milvere, Katri Pekri, Helen Tootsi, Merit Kaljuste, Kairi Koit, Elo Madiste, Urzula Välb, Ranno Tingas, Margus Jõemaa, Tõnis Vahesaar and Tõnis Jakob for their friendship and availability during my visits in Estonia. I thank you, Gea Saarva, for your encouragement and growing friendship during the past years. My super-thanks go to Liia Rannala, who introduced me to international taxation, who always believed in me and supported me in pursuing further academic research. Helen Pahapill deserves special thanks for supervising my first international tax law paper and for inspiring and motivating me to gain further knowledge and experience in international taxation. Finally, I am deeply grateful to Inga Klauson who encouraged me to go to Maastricht in the first place. I truly cherish the moments we have had together, Inga.

My time in Maastricht would not have been the same without the marvellous people I met throughout my studies and who became my friends. I wish to thank Jurjen Knarren, Michel Matos, Catarina Araújo, Lars Leskovar, Ruxandra Vlasceanu, Evgeniya Shamanova, Dawn Connolly, Patrick Wittenstein, Gonzalo Garfias von Fürstenberg, Maria Paz Godoy, Elianne Janssen, Rob Ruth, Tural Taghiyev, Rita Szudoczky, Daniel Smit, João Santos Pinto, Jana Tali, Daniel Philippe and Delphine Isorez.

My heartfelt thanks go to my family who have supported me throughout this journey. You, Ema, Isa, Enely, Terje, Thea and Teele, my little nieces and nephew, Taavi and Chris, are the reason that I am where I am today. I also thank my family in Portugal Maria José, Catarina, João, Susana, Matilde, Leonor and Zé - for welcoming me with open hearts. Muito obrigado a todos! I am proud to have become part of this family, too.

My husband Gonçalo and my daughter Alice are the most important people in my life and hence deserve a special paragraph. Gonçalo, I am deeply indebted to you for your support during the past few years. You have been the most wonderful companion in my Maastricht journey and I am sincerely grateful to have you in the journey of my life. You have helped me to grow not only personally, but also professionally. Above all, I am grateful for the most gorgeous daughter we have together. I admire Alice for her beautiful soul, her capability to see everything as an adventure, her clever mind and the love she gives us. She is the biggest source of inspiration one 
could wish for. I love you both from the bottom of my heart and hence I want to dedicate this book to you two.

The manuscript of this book was completed on 1 January 2014. Consequently, later developments have not been taken into account.

Tiiu Albin Pereira

Luxembourg, 27 October 2014 


\section{TABLE OF CONTENTS}

List of Abbreviations ...................................................................................

List of Figures ............................................................................... xix

List of Examples ............................................................................. $\mathrm{xx}$

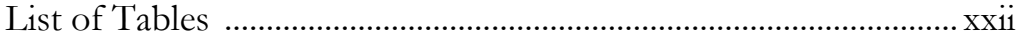

PART I: General Introduction

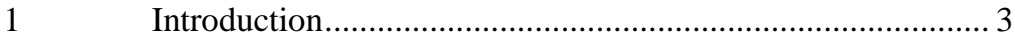

1.1 The Problem of the EIM …................................................ 3

1.2 The CCCTB Initiative .......................................................... 4

$1.3 \quad$ Research Questions ......................................................... 7

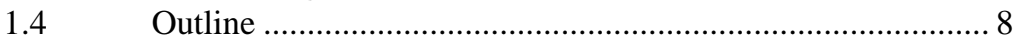

PART II: Business Taxation in the EU and US Subnational Setting

$2 \quad$ Direct Taxation and the EIM …........................................ 13

2.1 Harmonisation of Direct Taxes in the EU ........................... 15

2.1.1 Call for Harmonisation of Corporate Income Tax ............... 18

2.1.2 Tax Sovereignty of EU Member States ............................ 25

2.1.2.1 Discriminatory Restrictions ........................................... 27

2.1.2.2 Comparability Element ...................................................... 30

2.1.2.3 Non-Discriminatory Restrictions ("Quasi-Restrictions") .... 31

2.1.2.4 Disparities .......................................................................... 32

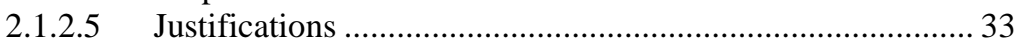

2.1.3 Principles of Subsidiarity and Proportionality ................... 35

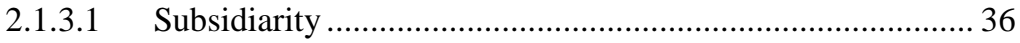

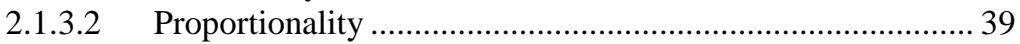

2.1.3.3 CCCTB in the Light of Subsidiarity and Proportionality .... 40

2.1.4 Enhanced cooperation ...................................................... 44

2.1.5 Definition of a Third Country ............................................. 48

2.1.5.1 DTC-countries ................................................................ 49

2.1.5.2 Member States of the European Free Trade Agreement ...... 51

2.1.5.3 Overseas Territories and Countries of the Member

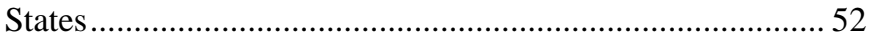

2.1.5.4 Association and Partnership Countries ............................... 54

$2.2 \quad$ The CCCTB Initiative ......................................................... 55

2.2.1 Optional v Compulsory Application of CCCTB .................58

2.2.2 Other Remarks ................................................................ 59

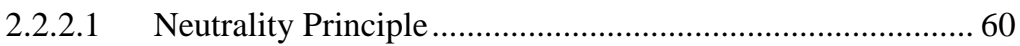

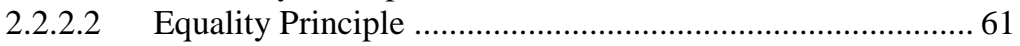

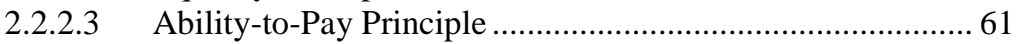

3 Evaluating the US Experience in Corporate Taxation with Formulary Apportionment 
3.1 Doing Business in the United States ................................6 63

3.2 Federalism-Based Limitations on State Taxation ................ 65

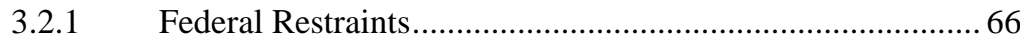

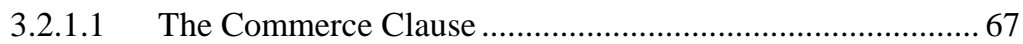

3.2.1.2 Due Process Clause .......................................................... 71

3.2.2 The US Bilateral DTCs ................................................... 73

3.3 The Sub-National Approach ............................................ 74

3.3.1 Formula Apportionment.................................................. 77

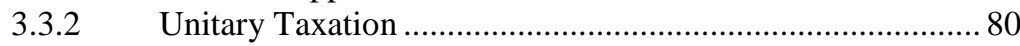

3.3.3 Combined Reporting ...................................................... 85

3.3.3.1 The territorial scope of the Combined Reporting................ 90

3.3.3.2 Worldwide Combined Reporting ........................................ 91

3.3.3.3 International Considerations of Worldwide Combined Reporting ....................................................... 97

Conclusion ................................................................ 99

PART III: The Proposed CCCTB Directive

4 Eligible Companies and the Definition of a Group of

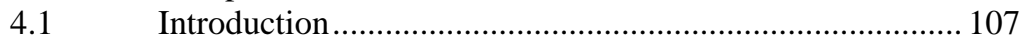

Eligible Companies .......................................................... 108

4.2.1 Exhaustive List of Companies .......................................... 109

4.2.1.1 The "Similarity-Requirement" ....................................... 112

4.2.1.2 Companies Established .................................................... 118

4.2.1.3 Subject-to-Tax Requirement ............................................ 121

4.2.1.4 Preliminary Conclusions ..................................................... 126

4.2.2 Residence ..................................................................... 127

4.2.2.1 Dual Resident Companies .................................................. 130

4.2.2.2 CCCTB Tie-Breaker Rule .................................................. 137

4.2.2.3 Place of Effective Management ......................................... 140

4.2.2.4 Preliminary Conclusions .................................................... 142

4.2.3 Definition of Permanent Establishment ............................. 143

4.2.3.1 DTC Application................................................................. 146

4.2.3.2 EU Law Aspects .............................................................. 150

4.2.3.3 Preliminary Conclusions ................................................... 151

4.2.4 Possible Scenarios under the Proposed CCCTB Directive ............................................................................ 152

4.3 Binding Effect of the Option and the All-In/All-Out Principle for Consolidation ................................................... 153

4.3.1 The Binding Effect .......................................................... 153

4.3.2 The All-In/All-Out Principle ........................................... 156

4.4 Group Entitlement.............................................................. 159

4.4.1 Definition of a CCCTB Group ...................................... 160

4.4.2 Qualifying Subsidiaries ................................................... 167

4.4.2.1 The Two-Part Test ............................................................ 168 
4.4.2.2 The Ownership Test.......................................................... 170

4.4.2.3 The Control Test .......................................................... 173

4.4.2.4 The Profit Entitlement Test.................................................. 177

4.4.2.5 The Period Threshold......................................................... 178

4.4.2.6 Preliminary Conclusions ..................................................... 179

4.4.3 Permanent Establishments ................................................. 180

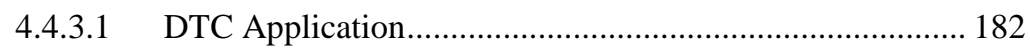

4.4.3.2 Enhanced Cooperation ........................................................ 183

4.4.3.3 EEA Treaty Application ..................................................... 186

4.4.3.4 Permanent Establishment as a Top-Level Entity of a

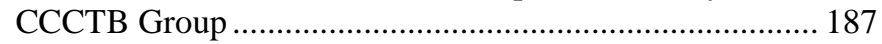

4.4.3.5 The Need for the Notion of Permanent Establishment ...... 189

4.4.3.6 Preliminary Conclusions .................................................. 190

4.5 Conclusions.................................................................... 191

5 Definition of the CCC Tax Base …………....................... 195

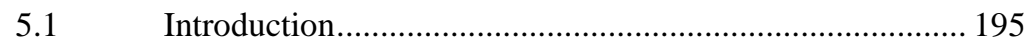

5.2 Consolidated Tax Base …………………………………....... 196

5.2.1 Allocating Taxing Jurisdiction Between States ................. 199

5.2.2 Principle of Realisation.................................................... 202

5.2.3 Type of Income …………………………....................... 203

5.3 Outbound Investment: Taxation of Foreign Income of CCCTB Group Members .................................................. 204

5.3.1 Income from Foreign Permanent Establishments .............. 205

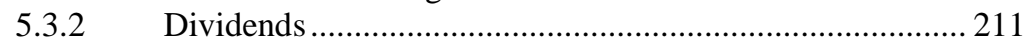

5.3.2.1 Dividends from Foreign Direct Investment ....................... 214

5.3.2.2 Dividends from Portfolio Investment ............................... 222

5.3.3 Interest and Royalty Income ............................................ 223

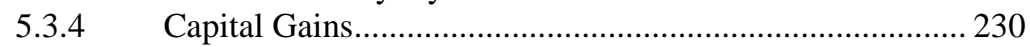

5.3.5 Preliminary Conclusions .................................................... 233

5.4 Inbound Investment: Taxation of Source Income of CCCTB Non-Resident Companies ..................................... 235

5.4.1 Income From CCCTB-Located Permanent Establishments ................................................................ 237

5.4.2 Income from Immovable Property ..................................... 241

5.4.3 Preliminary Conclusions .................................................... 243

$5.5 \quad$ Corporate Reorganisations .................................................. 244

5.5.1 Entering a CССТВ Group.................................................. 244

5.5.2 Leaving a СССТВ Group ................................................ 248

5.5.3 Merger or Division Involving Third-Country

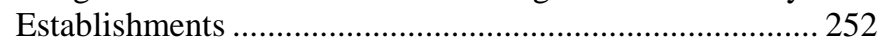

5.5.4 Transfer of Assets Towards Third Countries ..................... 256

5.5.4.1 The Concept of "Permanent Establishment"......................... 258

5.5.4.2 Type of Transferred Asset ……………………................... 263

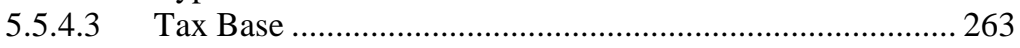

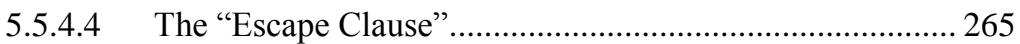


5.5.5 Preliminary Conclusions ................................................ 270

5.6 Flashback to US Sub-National Experience ....................... 273

5.6.1 Apportionable Tax Base............................................... 274

5.6.2 Dividend Taxation............................................................. 275

5.6.3 Geographical Limitations............................................... 279

5.6.4 The US DTC Limitations ................................................ 279

5.6.5 Preliminary Conclusions ................................................. 280

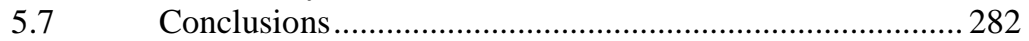

$6 \quad$ Consideration of Losses …............................................... 287

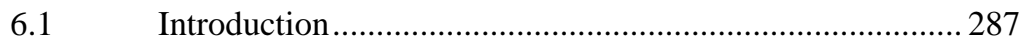

6.2 Treatment of Losses in the CCCTB Directive ....................... 290

6.3 Limitations on Cross-border Loss Compensation within a Group of Companies ..................................................... 295

6.3.1 Enhanced Cooperation and the Issue of Final Losses in the CCСТВ......................................................................... 298

6.3.2 Preliminary Conclusions .................................................... 307

6.4 Limitations on Cross-Border Loss Compensation within

a Company ............................................................... 308

6.4.1 Outbound investment: Compensation of Losses of a

Foreign Permanent Establishment...................................... 310

6.4.1.1 Application of Base Exemption Method ............................ 312

6.4.1.2 Application of Tax Exemption Method ............................. 315

6.4.1.3 Consideration of Final Losses of a Foreign Permanent

Establishment in the context of Enhanced Cooperation..... 319

6.4.2 Inbound Investment: Compensation of the Losses of a

Permanent Establishment of a Non-Resident Company .... 322

6.4.3 Compensation of Losses by a Permanent Establishment ... 327

6.4.4 Preliminary Conclusions ...................................................... 328

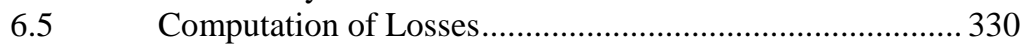

6.6 Conclusions .................................................................. 332

7 Elimination of Double Taxation and Ensuring Single

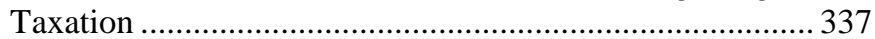

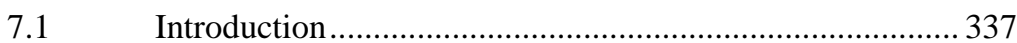

7.2 (Elimination of) Double Taxation in the EU ........................ 339

7.3 Effectiveness of Member States' DTCs ............................ 342

7.4 Elimination of Double Taxation under the CССТВ …....... 353

7.4.1 Economic and Juridical Double Taxation ........................... 354

7.4.2 Outbound investment .......................................................... 356

7.4.2.1 Exemption Method........................................................... 356

7.4.2.2 Credit Method ................................................................... 359

7.4.2.3 Business income................................................................ 365

7.4.2.4 Dividends ................................................................... 368

7.4.2.5 Interest and Royalty Income ............................................ 370

7.4.2.6 Preliminary Conclusions .................................................... 372 


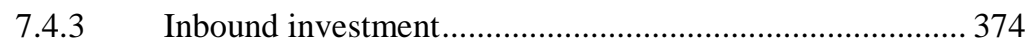

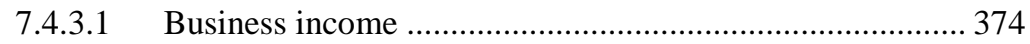

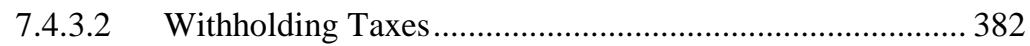

7.4.3.3 Elimination of Double Taxation by Third Countries .......... 386

7.4.3.4 Preliminary Conclusions .................................................... 386

7.5 Avoidance of Double Non-Taxation under the CСCTB .... 388

7.5.1 Application of the Subject-to-Tax Test and the SwitchOver Clause............................................................. 392

7.5.2 Preliminary Conclusions ....................................................... 394

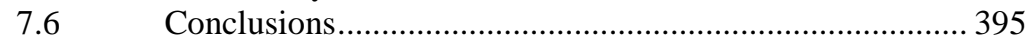

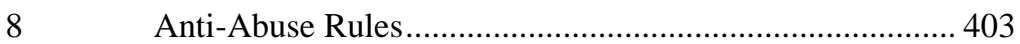

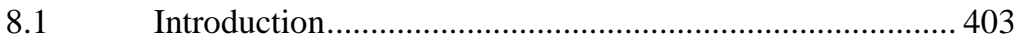

8.2 Concept of "Abuse" under EU Law.................................... 405

8.3 Anti-Abuse Rules under the СССТВ Directive .................. 411

8.3.1 General Anti-Abuse Rule................................................. 414

8.3.1.1 The Escape Clause ............................................................ 423

8.3.2 Thin Capitalisation and Limitations on Interest

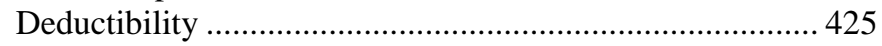

8.3.2.1 Associated Enterprises ........................................................ 428

8.3.2.2 Absence of an Agreement on the Exchange of Information .................................................................... 429

8.3.2.3 Low Taxation in a Third Country ...................................... 432

8.3.2.4 The Escape Clause ………………………....................... 434

8.3.2.5 DTC Application............................................................. 438

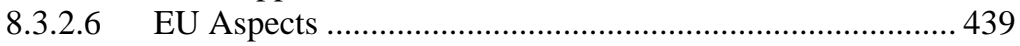

8.3.2.7 An Alternative Interest Limitation Rule ............................. 443

8.3.3 Controlled Foreign Company (CFC) Rules ....................... 444

8.3.3.1 Computation of CFC Income ............................................. 459

8.3.3.2 EU Aspects ..................................................................... 461

8.3.3.3 The US Experience with CFC Taxation................................... 465

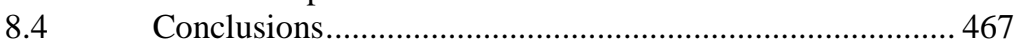

\section{PART IV: Conclusion}

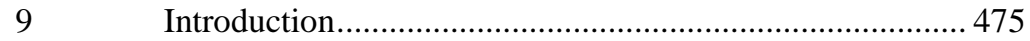

$10 \quad$ Main Findings of the Research ………………................ 475

10.1 Subjective Scope of the CCCTB and Group Definition .... 475

10.2 The CCC Tax Base ……………………………................. 477

$10.3 \quad$ Consideration of Losses ....................................................... 481

10.4 Elimination of Double Taxation and Ensuring Single Taxation ...................................................................... 482

10.5 Anti-Abuse Rules............................................................ 483

$10.6 \quad$ Last Remarks ............................................................. 485

10.7 Implications of the Research.............................................. 487

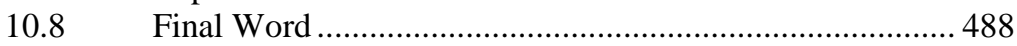


$11.1 \quad$ Literature ........................................................................ 491

11.2 European Union Documents ..............................................511

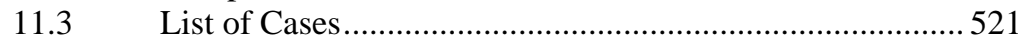

Curriculum Vitae ..................................................................... 529

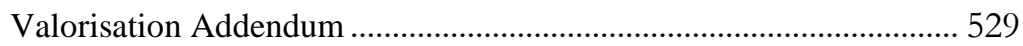


List of Abbreviations

AG

AOA

APC

CCCTB

CCTB

CEN

CIN

CFC

CJEU

COST

DRD

DTC

EC

ECR

EEA

EEC Treaty

EFTA

EFTA Court

e.g.

etc.

et seq.

EIM

EMU

EPC

EU

EUCIT

EU law

FDI

FTB

GAAR

HTB

HST

i.e.

ibid.

IRC
Advocate General

Authorised OECD Approach

Association and Partnership Countries

Common Consolidated Corporate Tax

Base

Common Corporate Tax Base

Capital Export Neutrality

Capital Import Neutrality

Controlled Foreign Corporation

Court of Justice of the European

Union

Committee on State Taxation

Dividend Received Deduction

Convention for the Avoidance of

Double Taxation

European Community

European Court Reports

European Economic Area

Treaty Establishing the European

Community

European Free Trade Association

Court of Justice of the European Free

Trade Association

exempli gratia / for example

et cetera / and so forth

et sequentia / and the following

European Interal Market

European Monetary Union

European Private Company

European Union

European Union Corporate Income

Tax

Law of the European Union

foreign direct investment

Franchise Tax Board

General Anti-Abuse Rule

Harmonised Tax Base

Home State Taxation

id est / that is

ibidem / in the same place

Internal Revenue Code 
$\mathrm{MNE}$

MTC

NCCUSL

nyr

OTC

OECD

OECD MC

OJ

p.

para(s).

Proposed CCCTB Directive TEC

TEU

TFEU

SAAR

SME

TEU

TEC

TFEU

UDITPA

UK

UN

UN MC

US

US MC

VCLT
Multinational Enterprise

Multistate Tax Commission

National Conference of

Commissioners on Uniform State

Laws

not yet reported

Overseas Territories and Countries

Organisation for Economic Co-

operation and Development

OECD Model Convention on Income and Capital

Official Journal of the European

Communities/Union

page

paragraph(s)

European Commission (2011a)

Treaty establishing the European

Community

Treaty on the European Union

Treaty on the Functioning of the

European Union

Specific Anti-Avoidance Rule

Small and Medium Size Enterprise

Treaty on European Union

Treaty on Euopean Community

Treaty on the Functioning of the

European Union

Uniform Division of Income for Tax

Purposes Act

United Kingdom

United Nations

UN Model Tax Convention

United States

US Model Income Tax Convention

Vienna Convention on the Law of

Treaties 


\section{LIST OF FIGURES}

Figure 1: Combined reporting for states with a corporate income tax.......86 


\section{LIST OF EXAMPLES}

Example 1: Dual-residence under CCCTB-proposal 130

Example 2: Effect of paragraph 8.2 on Article 4 OECD MC on the application of the CCCTB system: place of effective management in a Member State

Example 3: Effect of paragraph 8.2 on Article 4 OECD MC on the application of the CCCTB system: place of effective management in a third country

Example 4: Place of effective management as a permanent establishment in the CCCTB jurisdiction

Example 5: Denial of group membership due to the existence of a DTC with a third country

Example 6: Absence of uniform tie-breaker rule ................................. 139

Example 7: 'All-in/all-out principle'

Example 8: A non-resident first-tier subsidiary with subsidiaries and permanent establishments in the CCCTB jurisdiction ................................................................ 161

Example 9: EU sister companies of a third-country company ........... 165

Example 10: A CCCTB group consisting of subsidiaries and permanent establishments of a third-country company...... 166

Example 11: Shares in a subsidiary that are attributed to a permanent establishment in a third country ....................... 167

Example 12: A two-part test and profit entitlement ........................... 169

Example 13: CCCTB resident company controlled by a CCCTB non-resident company .................................................... 172

Example 14: Indirect control via a third-country company ................ 175

Example 15: Permanent establishment as a top-level entity of a CCCTB Group ............................................................. 188

Example 16: Withholding tax on interest payments ........................... 201

Example 17: Calculation of the income of a foreign permanent

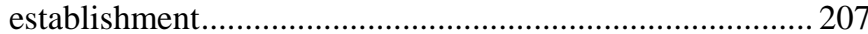

Example 18: Dividend classification .............................................. 213

Example 19: Interest limitation on tax-exempt dividends.................. 219

Example 20: Interest deduction limitation .......................................... 221

Example 21: Real estate as a permanent establishment ..................... 242

Example 22: Disposition of assets of a permanent establishment...... 246

Example 23: Double taxation due to the application of the CCCTB sharing mechanism............................................................ 247

Example 24: Change of residence following an intra-group transfer of asset .............................................................................. 251

Example 25: Merger of a CCCTB principal taxpayer........................ 253

Example 26: Merger of a CCCTB group member with a third-

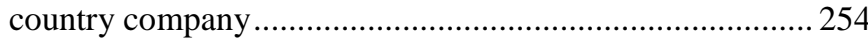

Example 27: Division of a CCCTB subsidiary …............................ 255 
Example 28: Transfer of an asset from a head office to its thirdcountry permanent establishment when the definition under the DTC is broader than that under the CCCTB ...... 259

Example 29: Transfer of an asset from a head office to its thirdcountry permanent establishment when the definition under the DTC is narrower than that under the CCCTB .... 260

Example 30: Transfer of an asset from a CCCTB-located permanent establishment to a third-country head office, where the definition of a permanent establishment under the DTC is narrower than that under the CCCTB

Example 31: Transfer of an asset from a CCCTB-located permanent establishment to a third-country head office, where the definition of a permanent establishment under the DTC is broader than that under the CCCTB

Example 32: Final losses of a CCCTB group .................................... 304

Example 33: Losses of an exiting parent company ............................ 306

Example 34: Consideration of foreign permanent establishment's losses and subsequent recapture under CCCTB ................. 318

Example 35: Final losses of a foreign permanent establishment on entering a CCCTB group

Example 36: Final losses of a foreign permanent establishment on leaving a CCCTB group.

Example 37: Consideration of (final) losses of a CCCTB-located permanent establishment in the home State

Example 38: Elimination of double taxation of a foreign permanent establishment................................................. 367

Example 39: Double taxation arising due to formula

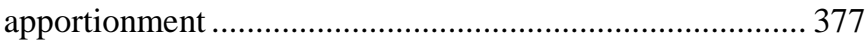

Example 40: CFC income of a CCCTB group.................................. 449

Example 41: CFC income is attributed to a permanent establishment of a non-resident company .......................... 453

Example 42: Income of a CFC......................................................... 455

Example 43: Taxes paid in third States............................................ 460 


\section{LIST OF TABLES}

Table 1: Definition of permanent establishment .............................. 152

Table 2: Eligibility criteria under the current proposed CCCTB

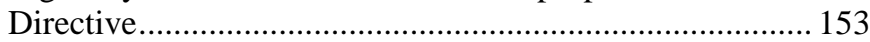

Table 3: Revised criteria for the CCCTB-eligibility .......................... 153

Table 4: Double taxation of CFC income ........................................ 456 

PART I: GENERAL INTRODUCTION 
Doing business across Europe, companies find themselves struggling with (currently) 28 different tax regimes, which often leads to double taxation, high advisory and administrative costs and tax-related restructuring costs. All this puts them at a disadvantage compared to multinationals carrying out their activities in other parts of the world, such as in the US, Japan and the BRIC countries (Brazil, Russia, India, and China). Such a result hinders the attainment of the general goals as defined in the Lisbon strategy ${ }^{1}$ and runs counter to the priorities set for Europe 2020 - a strategy for smart, sustainable and inclusive growth. ${ }^{2}$ One should remember that the objective of the Treaty of Rome ${ }^{3}$ was to establish a single common market, ${ }^{4}$ which would increase the volume and the gain from trade between the Member States. ${ }^{5}$ Article 3 of the TFEU6 ${ }^{6}$ calls for the establishment of an internal market, ${ }^{7}$ one without obstacles to the freedoms as listed in the Treaty. It can be regarded as the most ambitious example of political and economic integration designed in recent times. ${ }^{8}$ Despite several achievements, national governments have not accomplished the optimal functioning of the EIM in the area of direct taxes. Furthermore, several initiatives taken by the European Commission in this field have not been successful or sufficient. In addition, compliance with the jurisprudence of the CJEU is insufficient as well as inefficient to achieve an effective functioning of the EIM.

\footnotetext{
${ }^{1}$ European Commission (2005d), 532.

2 European Commission (2010a).

${ }^{3}$ I.e. the EEC Treaty (signed in 1957).

${ }^{4}$ It is generally agreed that the US is a single market, and the EU, even if it had remained the EEC, has long had the objective of creating a single market - an objective that was made explicit in the Single European Act. Mclure (2007), 143.

${ }^{5}$ Kaye (2007), 227.

${ }^{6}$ Consolidated version of the Treaty on the Functioning of the European Union. The TFEU (originally the EC Treaty) is based on the EEC Treaty, as replaced by the Treaty of Maastricht and amended by the Treaty of Amsterdam (signed in 1997), the Treaty of Nice (signed in 2001) and the Treaty of Lisbon (signed in 2007). The TFEU entered into force on 1 December 2009.

7 The European Economic Community has developed from a "Common Market" to a "Single Market" and thereafter to an "Internal Market", and from an "Economic and Monetary Union" to a "European Union".

8 Kaye (2007), 227.
} 
A well-functioning corporate tax system is a key factor for growth, which generates revenue not only from business income but also in terms of labour income, consumption and social security contributions. Taxes levied on pan-European business income by Member States reflect their historical origins and remain inappropriate for the most efficient functioning of the EIM. ${ }^{9}$ In particular, taxation based on the arm's length principle/AOA, as commonly used by Member States, is neither easy to administer nor cost efficient. Furthermore, it often leads to double taxation and over taxation. ${ }^{10}$ The failing application ${ }^{11}$ of these approaches makes one seek alternative ways for the EU, such as a corporate tax system based on formula apportionment, ${ }^{12}$ as currently (successfully) practiced by some US states.

\subsection{The CCCTB INITIATIVE}

In 1999, having recognised the major tax obstacles to the functioning of the EIM, the Council of the European Union (sometimes referred to as the Council of Ministers) invited the European Commission to carry out a study on company taxation in the EU. In 2001, the latter published a study, ${ }^{13}$ which presented a twin-track strategy to tackle corporate tax obstacles and tax-induced inefficiencies in the EIM, and the related communication. ${ }^{14}$ Since then, the European Commission has analysed a number of technical possibilities for providing companies with the necessary consolidated tax base for their panEuropean activities. The policy of the European Commission is to

\footnotetext{
${ }^{9}$ By comparison, one may argue that the basic structure of state corporate income taxes in the United States is more appropriate for an internal market. McLure (2008), 2.

${ }^{10}$ Note that the OECD is of the opinion that, since it is difficult to achieve the required degree of cooperation and agreement among States on common group definitions, apportionment formulae and a common tax base, formulary apportionment would lead to double or non-taxation of income. See OECD (2010b), para. 3.64. Also in 2013, in its BEPS report, the OECD stated that "moving to a system of formulary apportionment of profits is not a viable way forward" (OECD (2013), 14).

11 McIntyre (2004), 947.

${ }^{12}$ In addition to the US sub-national taxation, other examples of cross-jurisdiction allocation or apportionment systems can be found in the practice of the Canadian provinces, the Swiss cantons and in German federal law for the purposes of apportioning the tax base between its municipalities. The description and application of these systems will not be discussed in the current dissertation.

${ }^{13}$ European Commission (2001a).

${ }^{14}$ European Commission (2001d).
} 
mitigate tax distortions, facilitate cross-border economic activities and reduce the high compliance and administrative costs while carrying out pan-European activities. In the light of the foregoing, it identified a number of options which could provide a solution for the European corporate tax system: HST, ${ }^{15}$ HSB, ${ }^{16}$ EUCIT, ${ }^{17}$ and CCCTB. Due to the lack of support for the former two proposals from the Member States, the European Commission continued enhancing a combination of the latter two options, i.e. CCCTB for MNEs and a possible pilot scheme for HST with respect to SMEs ${ }^{18}{ }^{19}$ Following the developments in the sphere of corporate taxation, it was concluded that companies would only be able to take full advantage of the EIM ${ }^{20}$ if they had the possibility of using a CCCTB for their pan-European activities. ${ }^{21}$ As a result, on 16 March 2011, the European Commission proposed ${ }^{22}$ a Council Directive on a CCCTB, ${ }^{23}$ targeting both SMEs and MNEs. In the accompanying impact assessment, ${ }^{24}$ the European Commission had considered four main policy options for EU corporate tax scenario: 25

1) An optional CCTB, ${ }^{26}$ which would establish one set of tax base rules across the Union for qualifying companies.

\footnotetext{
${ }^{15}$ An EU-wide group taxation system under which the tax base for the entire group having cross-country activities would be computed on the basis of the tax rules applicable to the parent company ("home State") tax rules and then shared between the countries involved on the basis of a predetermined formula and taxed by each country at its own tax rate.

${ }^{16}$ An EU-wide group taxation system under which a single compulsory harmonised tax base would apply across the EU. The HSB rules would replace the applicable national rules.

${ }_{17}$ An EU-wide group taxation system under which a new, single corporate tax code would apply across the EU. In the purest form, it would be administered by a new single authority, include the acceptance of the single EU-wide tax rate and the revenues would go to the Union budget to fund EU institutions and activities, with any excess allocated to Member States.

${ }^{18}$ The definition of SMEs is set forth in European Commission (2003a).

19 As established in European Commission (2001a) and confirmed in European Commission (2003b).

${ }^{20}$ Note that the EIM is not equal to the territory of the European Union and it affects it with various degrees of intensity. Pistone (2010), 44.

${ }^{21}$ European Commission (2004), 1.

22 See also European Commission Press Release IP/11/319 from 16 March 2011.

${ }^{23}$ European Commission (2011a).

${ }^{24}$ European Commission (2001b).

25 Ibid., 52-53.

${ }^{26}$ Note that on 16 August 2011, French President Nicolas Sarkozy and German Chancellor Angela Merkel held a joint press conference in Paris in which the former announced that France and Germany would develop a set of proposals for 2013 regarding the introduction of a CCTB for companies operating in those two
} 
However, separate accounting/arm's length principle would remain applicable between group members.

2) A compulsory CCTB, which would require all qualifying companies to compute their tax base according to one set of common rules. Equal to the first option, separate accounting/arm's length principle would remain applicable for intra-group transactions.

3) An optional CCCTB would establish one set of rules for the calculation of an EU-wide corporate tax base and include the element of consolidation of group members' results. The consolidated tax base would be shared across the relevant Member States according to a pre-determined apportionment formula.

4) A compulsory CCCTB would require all eligible EU resident companies (and EU-located PEs) to calculate their tax base according to one set of rules and the tax base would be shared between the relevant Member States according to a pre-established formula.

Taking into account a number of factors, as analysed in the impact assessment, the European Commission has proposed an optional CCCTB $^{27}$. However, the system endorses the "all-in/all-out" principle, so that when the parent company opts into the system, all the qualifying group members in the CCCTB Member States will have to become part of the CCCTB group. Further to that, the proposed system has been built on the residency principle, so that all the income of residents is included in their tax base. Non-residents can participate in the system to the extent that they have a taxable presence in a CCCTB Member State through a permanent establishment. Double taxation arising due to the taxation of worldwide income would be eliminated through the exemption or credit method depending on the type of income. Finally, in addition to the common set of rules on the computation of the corporate tax

countries and the adoption of a common corporate tax rate. Bundesministerium der Finanzen (2012).

27 Another two alternatives were considered to have sufficient merits to pass through the administrative and political process of the establishment of common rules for EU-wide activities: optional CCTB or optional CCTB with loss consolidation. In such cases, the transactions between group members would remain subject to transfer pricing rules. The development of the CCTB with loss consolidation was referred to in the "Pact for the Euro" on 11 March 2011. The author does not intend to address prospective issues in respect to the mentioned alternatives. 
base, in case of a group, the CCCTB arena would include an element of apportionment of the consolidated tax base according to a predetermined formula. The latter would consist of three evenly weighted factors: assets, payroll and sales.

\subsection{RESEARCH QUESTIONS}

In the current dissertation, the author focuses exclusively on those international aspects of the CССТВ, which, in the opinion of the author, form the necessary basis for even considering the possible introduction of the common European corporate tax system. It is true that the overarching purpose of the CCCTB is to eliminate corporate tax obstacles and tax-induced inefficiencies for businesses across the European Union. However, the CCCTB, if introduced, will certainly have an impact on the worldwide corporate tax system existing today and its future developments.

Third countries, for the purposes of the current thesis, are all nonEU Member States. Given that some third countries have a special relationship with the EU (e.g., Member States of the EFTA) or certain EU Member States (e.g., overseas territories and countries of the EU Member States), the author will also consider these special connections in the framework of the CCCTB. ${ }^{28}$ Moreover, one cannot forget the wide network of DTCs that Member States have with third countries. Therefore, throughout the study, the author will pay special attention to the application of the CCCTB Directive (as proposed) in conjunction with Member States' DTCs with third countries.

Due to a number of negative signals from the Member States, the author considers it likely that the CСCTB will be introduced, at least in the first step, in the setting of enhanced cooperation between a minimum of 10 Member States. In such a case, those EU Member States that will opt out of the system will also be considered to be third countries for the purposes of the Directive. Importantly, as the acquis communautaire will remain applicable to those Member States, the CCCTB regulatory framework would have to reflect such matters. The author has recognised that the European Commission, when proposing the CCCTB Directive, has not considered the CCCTB in

${ }^{28}$ Vide infra at 2.1.5. 
the setting of enhanced cooperation, because it could do so only as a last resort.

Given that the European Commission has worked on the CCCTB already for more than a decade and proposed the corresponding Directive, the aim of the dissertation is not to replicate this work. Instead, the author will critically review a number of provisions of the proposed CCCTB Directive, analyse the policy behind them and assess how they fit in to the global setting. Furthermore, considering that the CCCTB is designed as a comprehensive solution to the restrictions posed by Member States on cross-border businesses, the research uses a wide selection of the CJEU's case law to put the CCCTB within the context of EU law.

In the light of the foregoing, this study has two central research questions:

(i) Does the proposed CCCTB Directive properly consider the existing international framework of corporate tax systems?

(ii) What are the necessary changes to be made in the proposed CCCTB Directive if the CCCTB system were introduced in the framework of enhanced cooperation?

\subsection{OUTLINE}

The dissertation is divided into four parts. The first part, which comprises of Chapter I, gives a general introduction to the dissertation. Part II sets forth the framework for the group taxation system with formula apportionment in two jurisdictions: the EU and the US. Considering that different systems form the basis for the the two jurisdictions (confederation for the EU and federation for the US) ${ }^{29}$ as well as the respective ages of the unions (approximately 50 years of the EU compared to over 200 years of the US), ${ }^{30}$ it is important to understand the core principles of the business taxation of the two systems. In Chapter II, the author describes the general regulatory system of the EU with regard to the harmonisation of direct taxes and achievements so far. Also in this Chapter, the author

\footnotetext{
${ }^{29}$ Some scholars refer the EU also as a "fully-developed form of federation". Kaye (2007), 199.

30 The Unites States of America was formed in 1787 and the European Economic Community was created in 1958. The Treaty of Maastricht established the European Union under its current name in 1993.
} 
explains the restraints primary EU law places on Member States with regard to legislating in the field of direct taxes. Thereafter, the author focuses on the sub-national business taxation in the US in Chapter III. In particular, the dissertation attempts to benefit from the more than half a century of US states' experience with apportionment and group taxation based on unitary taxation. By the end of this part, the reader should have a solid understanding of whether and to what extent the EU can benefit from the experience of the US states with regard to the CCCTB.

Part III is the core of this dissertation. It comprises Chapters IV to VIII, each focused on unravelling a specific set of provisions in the proposed CCCTB Directive. In particular, this part (i) defines the subjective scope of the CCCTB Directive and gives the criteria for CCCTB group definition (Chapter IV); (ii) it discusses the definition of the CCC tax base (Chapter V); (iii) it explains the consideration of losses (Chapter VI); (iv) it addresses the elimination of double taxation and ensures single taxation; and finally (v) provides for an overview about anti-abuse rules.

Finally, part IV presents the main conclusions of this dissertation based on the problems identified in relation to third countries. The author draws conclusions for the viability of each proposed approach to solve the problems concerning the relationship between EU and third countries. In that regard, attention is paid to the institutional efficiency rather than economic efficiency of the methods. 
PART II: BUSINESS TAXATION IN THE EU AND US SUBNATIONAL SETTING 
The Treaties provide for shared competence to regulate direct taxes in the EU. Consequently, there are no general taxation rules in the $\mathrm{EU}$ and Member States remain free to set the criteria that determine the scope of direct taxation. ${ }^{31}$ Even though the Member States have broad sovereignty in the area of direct taxation, ${ }^{32}$ they must exercise their taxing powers in a manner consistent with the Union law. ${ }^{33}$ This general premise is reflected in the broad range of national taxation policies within the Union, which have, however, resulted in a number of obstacles for EU-wide corporate groups engaged in cross-border activities. The most significant impediments can be identified as the following:

1) Compliance with 28 national tax systems and transfer pricing rules - most of the current corporate income taxation rules applicable in Member States are based on the separate accounting/arm's length approach, which means that group members in different Member States are treated as independent taxpayers. Therefore, the tax base is calculated on an entity-by-entity basis and (if applicable) all intra-group transactions are subject to transfer pricing rules. However, such complexities in taxation reduce the business efficiency of strongly integrated groups and thus may no longer serve as the most appropriate method for profit allocation.

2) High administration and compliance costs - currently, each individual company is usually responsible for the calculation of its tax liability and for the submission of its tax return in conformity with the corresponding Member State's national tax law. Due to that, pan-EU groups of companies face increased administration and compliance costs. According to the European Commission's survey, the socalled CCCTB "one-stop-shop" would reduce compliance

\footnotetext{
${ }^{31}$ Cases Royal Bank of Scotland (C-311/97), para. 19; Gilly (C-336/96), paras. 24 and 30.

${ }^{32}$ For the competence of the EU, see Articles 3-6 of the TFEU and Art 5 of the TEU.

33 Cases Scbumacker (C-279/93), para. 21; Futura (C-250/95), para. 19; Cadbury Schweppes (C-196/04), para. 40.
} 
costs up to 7 per cent and substantially save compliance time. ${ }^{34}$

3) Cross-border losses - one of the biggest tax obstacles to the EIM is the consideration of cross-border losses within one company. Whereas losses of foreign permanent establishments may usually be taken into account at the level of the headquarters (because of the principle of worldwide taxation of residents), only a few Member States provide for some form of cross-border offset of losses within a group of companies. ${ }^{35}$ Due to the limited possibilities for crosscountry loss offsets within the EU, companies engaged in extra-territorial activities often face over-taxation. According to the European Commission, allowing the immediate consolidation of profits and losses for computing the EUwide taxable bases of multinational groups would be a step towards the goal of achieving the specific objective of reducing over-taxation in cross-border situations. Furthermore, this would in turn improve the tax neutrality conditions between domestic and cross-border activities to better exploit the potential of the EIM. ${ }^{36}$

4) Double (non-) taxation - the existence of the network of DTCs between the Member States and with third countries does not provide for an efficient solution for the elimination of double taxation and double non-taxation within the EIM, because such treaties are designed to function in a bilateral context in the international arena, rather than in a closely integrated market. ${ }^{37}$ Furthermore, the existing EU legislation on corporate tax matters addresses only a few specific problems. ${ }^{38}$

5) Tax planning, tax avoidance and evasion - the existing arm's length/AOA approach for calculating the corporate tax base within each EU Member State provides possibilities for multinational corporate groups to shift taxable profits between EU countries in which they operate. This is typically

\footnotetext{
34 Explanatory Memorandum to the Proposed CCCTB Directive, 5.

35 Agúndez-García (2006), 7.

36 European Commission (2001b), 26.

${ }^{37}$ Explanatory Memorandum to the Proposed CCCTB Directive, 4.

38 Recital 3 of the Proposed CCCTB Directive.
} 
achieved through the strategic manipulation of transfer prices of intra-group transactions or by altering the financial structure of the group members. ${ }^{39}$ The CCCTB would eliminate the need for pricing intra-group transactions and therefore reduce tax planning within the EU opportunities significantly.

The core objective of the founding Treaties is the economic integration of the Member States and the establishment of the EIM. Therefore, obstacles, including those caused by taxation, to the fundamental freedoms have to be abolished. The national laws of the Member States must be approximated to the extent that it is necessary for the functioning of the EIM, although the scope of such actions is a political decision. ${ }^{41}$ The approximation of the (tax) laws of the EU Member States implies two types of integration:

(1) Policy integration, i.e. positive integration either by means of harmonisation ("Union approach") or coordination ("soft approach") and where the action is taken by the European Commission, the European Parliament and the Council of the EU; ${ }^{42}$ and

(2) Market integration, i.e. negative integration via the abolition of national provisions and practices of the Member States that are discriminatory or restrictive and where the action is taken by the national courts, the CJEU and the European Commission.

As a consequence of the transposition of the acquis communautaire into the domestic law of each new Member State, and considering that the TFEU does not directly specify provisions on direct taxes, the

\footnotetext{
39 Agúndez-García (2006), 8.

40 The use of the term "tax harmonisation" is actually misleading, insofar as it stands for the establishment of identical tax bases, rates and systems throughout the EU as a result of action at the Union level. Therefore, with regard to direct taxation, it is more accurate to refer to "approximation" - i.e. the establishment of a range of possibilities for the Member States to choose from - and "coordination" - i.e. action in the form of directives, conventions, recommendations, guidelines, etc., taken by the European Commission or a Member State to affect the procatices of the member countries. Kaye (1996), 110. In spite of this, EU law does not seem to differentiate between "approximation of laws", "harmonisation" and the "introduction of a common system". Szudoczky (2012), 114.

${ }^{41}$ Article 5 of the TEU.

${ }^{42}$ Sometimes also called "Council of Ministers".
} 
immediate impact of the EU has first been felt in the area of indirect taxation. Contrary to indirect taxation, which since the beginning called for harmonisation to achieve a single market without obstacles to the free movement of goods and supply of services (Article 113 of the TFEU), the borders of unifying direct taxation within the EIM are looser. ${ }^{43}$

Under the Lisbon Treaty, Article 115 of the TFEU is an exception to Article 114 of the TFEU.44 According to the former, EU legislation aims at the approximation of domestic laws, regulations or administrative provisions of the Member States that directly affect the establishment or functioning of the EIM by means of directives. ${ }^{45}$ Thus, Article 115 of the TFEU neither excludes issuing directives in the field of direct taxation nor encourages harmonisation. ${ }^{46}$ One could argue that the reason for excluding the harmonisation of direct taxes was that the original six Member States preferred to retain their power to undertake their domestic social and economic objectives. ${ }^{47}$ On the other hand, one should not forget that, currently, there are already three corporate tax directives that have been adopted by the Member States: the Parent and Subsidiary Directive, ${ }^{48}$ the Interest and Royalty Directive ${ }^{49}$ and the Merger Directive. ${ }^{50}$ Similarly, Article

43 Even though direct taxation is not explicitly mentioned under the list of the Union's competences set forth in Articles 3-6 of the TFEU, Article 4(2)(a) of the TFEU on the shared competence certainly contains the Union's powers to act in the field of direct taxation.

${ }^{44}$ Article 114 of the TFEU provides for the approximation of laws which have as their object the establishment and functioning of the EIM and requires qualified majority voting at the Council. This is the opposite approach to the Treaty of Nice in which Article 94 of the TEC (115 of the TFEU) requires unanimity.

45 Directives are addressed only to Member States and do not directly amend national law. Instead, they create an obligation for the Member States to transpose their provisions into national legislation. Directives are binding upon the Member States as to the result to be achieved but leave the national authorities free to choose the form and method of compliance. Regulations have a general application and they are binding and directly applicable in each Member State. See Article 288 of the TFEU.

${ }^{46}$ Hrehorovska (2006), 162.

${ }^{47}$ McLure (2007), 133.

48 Council Directive 2011/96/EU on the Common System of Taxation Applicable in the case of Parent Companies and Subsidiaries of Different Member States.

${ }^{49}$ Council Directive 2003/49/EC of 3 June 2003 on a Common System of Taxation Applicable to Interest and Royalty Payments made between Associated Companies of Different Member States.

${ }^{50}$ Council Directive 2009/133/EC on the Common System of Taxation Applicable to Mergers, Divisions, Partial Divisions, Transfers of Assets and Exchanges of 
115 of the TFEU provides the legal basis for the CCCTB Directive. By adopting the unanimity rule ${ }^{51}$ in Article 115 of the TFEU, Member States avoided giving the power to define direct taxes to the Union. ${ }^{52}$ As it stands today, because the Treaty requires the unanimous agreement ${ }^{53}$ of all Member States for the adoption of EUwide tax policies, each individual Member State possesses a veto power in relation to prospective EU tax policies that the Council considers for adoption.

Article 352 of the TFEU authorises the Council to adopt appropriate measures if action by the Union should prove necessary to attain one of the objectives set out in the Treaties but where the Treaties have not provided the necessary powers. If that is the case, the Council may, acting unanimously on a proposal from the European Commission and after obtaining the consent from the Parliament, exercise such power. ${ }^{54}$ The CJEU has recognised the close link between the internal and external powers of the Union and has based the Union's external competence in the fields of the provision of services, movement of workers and the harmonisation of laws on the doctrine of implied powers. The authority of the Union to deal with Member States' DTCs concluded with third countries is implied in its internal authority under the Union primary and secondary law. According to the Court, the Union has external powers not only in cases where it had effectively exercised its internal powers, ${ }^{55}$ but the external competence is implied in the Union's competence, as such, if it is necessary for the attainment of the Treaty objective. In the light

Shares Concerning Companies of Different Member States and to the Transfer of the Registered Office of an SE or SCE between Member States.

51 Fundamentally, there is a conflict between the unanimity rule and the single market principles: while the unanimity requirement appears to provide the Member States with unlimited sovereignty, the single market provisions have the potential to limit that sovereignty. McLure further wonders whether, at the time the Treaty of Rome and the subsequent treaties were drafted, the founders of the [EU] were aware of the inherent conflict. McLure (2007), 143. Similar to the EU Treaties, the US Constitution says little about taxing powers and says nothing explicit about the power to levy direct taxes. Hellerstein \& McLure (2004), 88.

52 McLure (2007), 133.

53 The European Commission failed in its (political) effort to seek for an agreement on approval of proposals on tax matters which are deemed essential for the (better) functioning of the EIM through qualified majority (instead of unanimity) at the Intergovernmental Conference in Nice in December 2000.

${ }^{54}$ For instance, Council Regulation 2137/85 on the European Economic Interest Grouping (EEIG) was based on Article 352 of the TFEU.

${ }^{55}$ Case Commission v Council [ERTA] (22/70). The ERTA outcome was confirmed in case Kramer (Joined Cases C-3/76, C-4/76 \& C-6/76). 
of the above, in concluding DTCs with third countries, the Union may have to be involved to the extent that certain provisions of those DTCs risk distorting intra-Union trade or resulting in discrimination vis-à-vis nationals of Member States. ${ }^{56}$

\subsubsection{CALl FOR HARMONISATION OF CORPORATE INCOME TAX}

The main priority within the common market after signing the Treaty of Rome in 1957 was the elimination of distortions caused by trade barriers. The authors of the EEC Treaty clearly recognised the need to harmonise indirect taxes and therefore provided the juridical basis for such action. On the contrary, there was no specific provision concerning the harmonisation of direct taxes. ${ }^{57}$ As a rule, Member States retain the competence to establish the conditions on which income and capital should be subjected to taxation, to the extent that they do not infringe upon the fundamental freedoms.

In the first decades of the existence of the EEC, the Member States assumed that the harmonisation of direct taxation is a significant part of the establishment of the single market. A number of today's achievements (as well as failures) in the field of direct taxes were originally proposed by the Neumark committee ${ }^{58}$ in its Report in $1962 .{ }^{59}$ The report emphasised the nature and importance of each of the tax obstacles and the solutions to be considered, including the need for the approximation of national laws with regard to the corporate tax base. In 1966, the Segré committee, chaired by Professor Claudio Segré, reported on the establishment of an integrated capital market within the Community. ${ }^{60}$ The latter committee concluded that tax considerations should not influence the choice of investments or transactions, nor should they affect an

\footnotetext{
56 Hinnekens (1994), 156-157.

${ }^{57}$ Nevertheless, the Treaty of Rome contained some articles that had a bearing on direct tax matters and could have been used as a basis for Community action, such as Article 52 with regard to freedom of establishment and Article 67 on free movement of capital. Furthermore, Article 100 of the Treaty granted the European Commission the power to implement Directives in order to harmonise any activities of the member countries which direct affected the establishment or functioning of the Common Market.

58 The Committee was established by the Commission in 1960 and was chaired by Prof. Dr. Fritz Neumark.

${ }^{59}$ The committee's report is reproduced in Thurston (1963).

${ }^{60}$ European Commission (1966).
} 
investor's choice between direct $^{61}$ and indirect investment. The European Commission adopted a number of recommendations contained in the two mentioned reports in its programme for harmonisation of direct taxes. ${ }^{62}$ The European Commission believed that more action was necessary to attain the following objectives:

(1) The liberalisation of capital movements;

(2) The removal of obstacles to industrial combinations; and

(3) The approximation of the bases for the assessment of taxes on company profits. ${ }^{63}$

Following the European Commission's 1967 programme, which addressed problems caused by the differences in the national corporate income tax systems, the so-called van den Tempel Report ${ }^{64}$ revealed the magnitude of the task and the difficulty of finding appropriate and acceptable solutions to the various problems.

In its Action Programme for Taxation of July 1975, ${ }^{65}$ the European Commission expressed its disappointment with regard to the achievement of economic and monetary union but assured that the economic and monetary union remains the priority objective. It further announced that it would reduce substantially the scope of the proposal relating to direct taxation and concentrate on essentials by restricting community measures to those that it considered utterly necessary. In the same year, the Commission proposed a draft Directive concerning the harmonisation of company taxation and withholding tax on dividends. ${ }^{66}$

${ }^{61}$ The Court defines the concept of "direct investment" under Council Directive 88/361/EEC for the implementation of Article 67 of the Treaty (i.e., liberalisation of capital movements). Pursuant to the explanatory notes of the Directive, the concept should be understood in its widest sense and "serve to establish or to maintain lasting and direct links between the person providing the capital and the entrepreneur to whom or the undertaking to which the capital is made available in order to carry on an economic activity". Furthermore, the share must enable the shareholder to participate effectively in the management of the company or in its control. See also case Holböck (C-157/05), paras. 33-35.

62 European Commission (1967).

${ }^{63}$ Easson (1992), 605.

${ }^{64}$ European Commission (1970).

${ }^{65}$ European Commission (1975b).

${ }^{66}$ European Commission (1975a). The Directive was withdrawn in 1990 because, according to the Commission, it no longer met the needs of a more fully integrated market. 
After a long time and a number of failures, it became clear that Member States were not willing to give up their sovereign powers in relation to this issue. ${ }^{67}$ In 1980, the European Commission identified that the elimination of border controls and the alignment of corporate tax burdens were the most fundamental objectives. ${ }^{68}$ However, in the same report, the European Commission perceived that, although a common system might be desirable, "any attempt to resolve the problem by way of harmonisation would probably be doomed to failure". Still, it announced therewith its intention to draft proposals on the establishment of a common base for the determination of business profits. However, the European Parliament rigorously criticised the draft proposal and effectively refused to express its opinion on it, maintaining that action in respect of corporate tax systems without achieving equivalence of the bases of assessment would be pointless at best. ${ }^{69}$ The proposal was eventually withdrawn in $1990 .{ }^{70}$

In 1985, the Council approved the Commission's White Paper on Completing the Internal Market ${ }^{71}$ - a Europe without internal frontiers - by the end of 1992. The White Paper outlined a programme to remove the remaining physical, technical and fiscal barriers to trade between Member States. In 1989, the Commission abandoned the idea of systematically "harmonising" Member States' corporate tax systems and started supporting "approximation" and "coordination" for the purposes of economic integration. ${ }^{72}$ This approach together with the White Paper paved the way for three proposals, adopted in 1990, for the development of the EIM: the Parent and Subsidiary Directive, ${ }^{73}$ the Merger Directive and the Arbitration Convention. ${ }^{74}$ However, the "Loss Directive", 75

\footnotetext{
${ }^{67}$ Munin (2008), 4.

${ }^{68}$ European Commission (1980).

${ }^{69}$ Easson (1992), 608.

${ }^{70}$ Meanwhile, in 1984, the Commisson had also proposed to harmonise the rules for the carry-over of losses, but this proposal was also later withdrawn. See European Commission (1984).

${ }^{71}$ European Commission (1985b).

72 Blumenberg \& Minor (1992), 563.

${ }^{73}$ It is noteworthy that, even though the scope of the Parent and Subsidiary Directive is considerably smaller than the proposed CCCTB Directive, it took the Council over 20 years to adopt the Directive: the European Commission proposed the first proposal already on 16 January 1969.

74 Convention on the Elimination of Double Taxation in Connection with the Adjustment of Profits of Associated Enterprises (90/436/EEC).

${ }^{75}$ European Commission (1991).
} 
submitted to the Council on 28 November 1990 was withdrawn after the Commission published its communication entitled "Towards an Internal Market without Tax Obstacles"76 in 2001.

Another major event in 1990 was the publication of the "Guidelines for Company Taxation" 77 in which the European Commission devoted its efforts to more specific topics based on three ideas:

1) Direct tax measures should be geared to the completeness of the EIM;

2) They should respect the principle of subsidiarity; and

3) Member States should be consulted with regard to all the initiatives.

Progress in the area of direct taxation started appearing once the European Commission adopted a flexible approach by encouraging convergence, approximation and coordination rather than harmonisation. ${ }^{78}$ With this view, and pursuant to the afore-mentioned guidelines on company taxation, Commissioner Christiane Scrivener - the first Commissioner for taxation - established a Committee of Independent Experts on Company Taxation, ${ }^{79}$ chaired by Onno Ruding (the Ruding Committee ${ }^{80}$ ) to identify future proposals on company taxation after 1992. On 18 March 1992, the Ruding Committee issued a report ${ }^{81}$ (commonly known as the Ruding Report) reflecting the results of their research on the distortions of investment decisions in the EIM and proposing solutions for overcoming such problems. ${ }^{82}$ The Committee concluded that distortions do arise in pan-European activities and that their elimination cannot be left to market forces and tax competition. The

\footnotetext{
${ }^{76}$ European Commission (2001d).

${ }^{77}$ European Commission (1990).

${ }^{78}$ Kaye (1996), 142.

79 The Ruding Committee was established in December 1990 and it held its first meeting in January 1991.

80 The other members of the Committee included J.L. Descours (France), A.J. Rädler (Germany), F. Vanistendael (Belgium), K. Messere (U.K.), L. Gascon (Spain), C. Gatto (Italy) and D. de Buitleir (Ireland).

${ }^{81}$ European Commission (1992a), 16.

82 The recommendations by the Ruding Committee to impose a minimum tax rate on business income earned in the EU, dating back to 1992, are still being actively discussed. Yet, it is relatively unlikely that the EU Member States will agree to the harmonisation of corporate tax rates anytime soon, even though several analyses point out the distortions in the location of corporate investment that occur with the current disparities. Graetz (2003), 531.
} 
Ruding Committee put forward a number of proposals, which in general can be divided into two categories: (1) those designed to eliminate double taxation of cross-border income flows; and (2) those designed to harmonise corporate tax systems of Member States. ${ }^{83}$ With regard to the latter, it is noteworthy that the Committee's attitude is apparent in the change of emphasis from the Commission's earlier programmes as expressed in the 1967 and 1975 proposals. By doing this, the Committee left open the question whether corporate tax systems need to be harmonised at all. ${ }^{84}$ The underlying approach of the recommendations resembles rather a "soft" harmonisation, which aims at creating a level playing field for fair competition between Member States by setting minimum standards for European tax legislation. ${ }^{85}$ Moreover, it appears that the Committee did not see a possibility for a single corporate income tax imposed on a Union-wide unitary basis, with revenues apportioned among the Member States based on a formula. ${ }^{86}$ The European Commission responded to the report with its Communication of 24 June 1992.87 While being supportive with regard to the proposals concerning the elimination of cross-border double taxation, the Commission believed that the recommendations concerning corporate tax harmonisation went beyond what was necessary at the Community level..$^{88}$

In 1996, Commissioner Mario Monti announced his "new global approach" to taxation matters. ${ }^{89}$ Following the examination carried out by a high-level taxation policy group,,$^{90}$ the Council adopted conclusions concerning tax policy - the "tax package" - that included three tax measures: (1) a proposal for an Interest and Royalty Directive; ${ }^{91}$ (2) a proposal for a Savings Directive; ${ }^{92}$ and (3) a Code of Conduct for businesses. ${ }^{93}$ The course of action initiated by Commissioner Monti and being implemented by the European

\footnotetext{
${ }^{83}$ European Commission (1992b), para. 19.

84 Easson (1992), 632.

85 Aujean (2008), 18.

86 Easson (1992), 636.

${ }^{87}$ European Commission (1992b).

88 Ibid., paras. 20-22.

${ }^{89}$ European Commission (1996).

90 The High-level taxation policy group is a group consisting of personal representatives of the finance ministers of the Member States.

${ }^{91}$ European Commission (1998a).

92 European Commission (1998b).

93 European Commission (1997).
} 
Commission since 1997 indicates a shift from traditional harmonisation to coordination aiming at voluntary measures by various member countries. ${ }^{94,}, 55$ One may argue that the "tax package" was an outcome of weighing the interests of various Member States rather than for the benefit of the EIM by bringing together national laws of the Member States. ${ }^{96}$

Today, the enlargement of the EU and the significant differences in tax rates and tax bases across Europe still raise questions about the limits of national sovereignty over direct taxes and the need to harmonise corporate taxes. ${ }^{97}$ The combination of the unanimity requirement for taxation matters at the Council, the large number of Member States and the differences in the (political) interests and priorities of these countries has led to a virtual deadlock. ${ }^{98}$ Nevertheless, the CJEU, in the creation of a common interpretation of the four freedoms and non-discrimination clause guaranteed by the Treaty has limited the Member States freedom to a great extent and therefore imposed "negative" harmonisation. Furthermore, because of the supremacy" of EU law over national laws and the direct effect of EU law, ${ }^{100}$ national courts of Member States take part of the negative integration within the $\mathrm{EU}$ on a daily basis. ${ }^{101}$ Considering the large number of cases brought before the Court,

\footnotetext{
${ }^{94}$ Understandably, in 1998, all political interest in both the Member States as well as the Commission was focused on the final steps towards the EMU - the Euro was adopted on 1 January 1999.

${ }^{95}$ Ruding (2002), 4.

${ }^{96}$ Calvo (2000), 40:2, 40:4.

${ }^{97}$ Hrehorovska (2006), 158.

98 Ruding (2002), 3.

99 "Supremacy" means that EU law - i.e. the Treaty, the general principles, secondary legislation and international agreements to which the EU is a party prevails over incompatible national provisions of the Member States international law. The constitutional theory of EU law's supremacy was confirmed in case Costa v E.N.E.L. (6/64). In terms of taxation, the Court has confirmed the supremacy of the Union law by requiring that the Member States exercise their competence on direct taxation consistently with Union law (case ICI (C-264/96), para. 19 and the case law referred therein).

100 "Direct effect" entails that, where Union law is clear, precise and unconditional enough to be considered justifiable, Union law may be relied upon by individuals before national courts. The Court articulated the doctrine for the first time in case $V$ an Gend en Loos (26/62). It is worthwhile to note that the notion of "direct effect" was not "invented" by the CJEU but it is a compilation of legal norms and principles, i.e. the doctrine of "self-executing treaties", developed by national courts in some countries to ensure Treaty enforcement. Bezborodov (2007), 662.

${ }^{101}$ Jezzi (2010), 94.
} 
approximation of direct taxation serves as the optimal solution for the achievement of the goals of the EIM provided in the Treaty of Lisbon.

In May 2001, the European Commission again supported the idea of the approximation instead of the harmonisation of EU direct tax laws. ${ }^{102}$ It further emphasised that, as a main priority for tax policy, the EU must focus on the elimination of tax obstacles for all forms of cross-border economic activity of individuals and companies operating in the European Union. It stressed that, as long as Union rules are respected, Member States are free to design their tax systems. The focus on the taxpayer became linked to the general objectives of the EIM, as expressed at the Lisbon meeting of the European Council of March 2000, of making the EU the most competitive and dynamic knowledge-based economy in the world by 2010. ${ }^{103}$ In October 2001, the Commission again contributed to the debate of corporate tax harmonisation/approximation in the EU by issuing a study on "Company Taxation in the Internal Market". 104 This report marked a significant reorientation of the Commission's strategy with regard to EU corporate tax policy compared to its previous standpoints, by:

(1) stressing the benefits of a consolidated tax base accompanied by formula apportionment for European multinationals;

(2) endorsing Member States' competition with regard to corporate income tax rates; and

(3) signalling a greater degree of political commitment of the European Commission to company tax reform. ${ }^{105}$

Supplementing and building on the previous report, the European Commission announced its view of necessary actions and what can be realistically achieved in the area of EU company taxation. ${ }^{106}$ In 2008, the European Parliament provided for a Resolution ${ }^{107}$ which urged the Commission to investigate further the possibilities for providing companies with a CCCTB. Following the global economic and financial crisis which occurred in the end of the first decade of

\footnotetext{
102 European Commission (2001e), 23.

103 European Council (2000).

104 European Commission (2001a).

105 Sørensen (2004), 91.

106 European Commission (2001d).

107 European Parliament (2008).
} 
the $21^{\text {st }}$ century, the year 2010 was marked as a "new beginning" for European economic development. ${ }^{108}$

\subsubsection{TAX SOVEREIGNTY OF EU MEMBER STATES}

By signing the Treaty of Rome ${ }^{109}$ and the following amendments, Member States delegated part of their sovereignty to a supranational organisation for the purposes of attaining the common interests of the Community. In other words, Member States are sovereign as long as they respect EU policy integration and the fundamental freedoms of EU citizens. ${ }^{110}$, 111 As a general matter, the Treaties do not provide any legal basis for the imposition of taxes ${ }^{112}$ by the Union itself but they leave this power to the Member States. Since there is no sovereign supranational EU government setting the taxation rules, the Member States have so-called "pooled sovereignty" (or "shared sovereignty") in the sense that they cooperate in making policies on issues of common interest. ${ }^{113}$ Because of the supremacy of EU law, Member States would be pari passu limited in their liberty to exercise their own taxing rights, as long as the Union is entitled to a "nonexclusive" competence and the principle of subsidiarity is complied with. ${ }^{114}$

As mentioned earlier, there are two means of integration (harmonisation) in the EU and both of them imply loss in Member States' sovereignty: (1) positive harmonisation, i.e. adoption of similar (not identical) sub-national laws, and (2) negative harmonisation, i.e. prohibition of sub-national policies that would create obstacles to the

\footnotetext{
108 See in particular European Commission (2010a).

109 Similarly, the US Constitution provides dual-sovereignty for the states and the federal government and reserves for the states the right to establish their own tax systems. See also infra Chapter I3.

${ }^{110}$ For the purposes of EU primary law, companies and firms formed in accordance with the law of a Member State and firms having their registered office, central administration or principal place of business wihin the Union shall be treated equally to individuals having the nationality of an EU Member State (Article 54 of the TFEU). See e.g. cases ICI (C-264/96), para. 20; Saint-Gobain (C-307/97), para. 35; Metallgesellschaft (Joined Cases C-397/98 \& C-410/98), para. 42; Marks \& Spencer (C446/03), para. 30; X Holding (C-337/08), para. 17.

111 Case Schempp (C-403/03), paras. 15 et seq.

112 Some provisions of the Treaty have a "fiscal" object but they do not give the power to levy taxes just as the Member States also do not pursue the same function (i.e. to raise money for government expenses). Sacchetto, 803.

113 McLure (2007), 124.

${ }^{114}$ Jezzi (2010), 92.
} 
creation of the EIM. With regard to the latter, the CJEU - because of its double role as judge of legitimacy and keeper of the European Treaties $^{115}$ - has performed a significant amount of (negative) integration within the EU. In its judgments that address direct taxation, the Court has repeatedly held that, although direct taxation falls within its competence, the Member States must none the less exercise that competence consistently with Community law. ${ }^{116}$ Again, due to the supremacy of EU law, Member States are obligated to remove all tax provisions that result in a barrier to pan-European movement. ${ }^{117}$ This requirement has priority over the sovereignty of Member States, which means that the latter cannot invoke an exception of national sovereignty in the implementation of the fundamental freedoms. ${ }^{118}$

The applicability of Union law to Member States' DTCs with third countries raises an additional question as to the extent of Union competence over these treaties. According to Article 351 of the TFEU, unless a DTC falls within the grandfathering clause of the provision, Member States will also have to respect the Union acquis with regard to their DTCs concluded with third countries. However, this does not imply that DTCs with third countries become ineffective but that Member States must waive the rights that they derive from such DTCs, provided that this does not adversely affect the third country's rights under that DTC. Conversely, the third country is not bound by the Union acquis. ${ }^{119}$ One may suggest that the Union's external (tax) competence derives from Article 352 of the TFEU, which provides the basis for so-called "implied powers". The Union's competence to deal with Member States' DTCs with third countries is implied in its internal authority under the Union's primary and secondary law. The Court accepts external Union powers not only in cases in which the Union effectively exercised its internal powers, ${ }^{120}$ but the Court considers that the external competence is an implied Union competence if it is essential for the attainment of a

\footnotetext{
115 Sacchetto, 806.

116 See, for instance, cases Royal Bank of Scotland (C-311/97), para. 19; Manninen (C319/02), para. 19; Marks \& Spencer (C-446/03), para. 29.

117 As evidenced by the impact of covert discrimination based on residence - which typically constitutes one of the main connecting factors of countries' taxing jurisdiction - the reluctance of Member States to give up (part of) their tax sovereignty has been felt, in particular, in the field of direct taxation.

118 Vanistendael (2003), 143.

${ }^{119}$ For further discussion, vide infra at II7.3.

${ }^{120}$ Case Commission v Council [ERTA] (22/70).
} 
Treaty objective. ${ }^{121}$ Hence, when Member States conclude DTCs with third countries, the Union may have to be involved to the extent that these DTCs fully or partially risk to result in intra-EU trade restrictions or to lead tax discriminations vis-à-vis EU nationals. ${ }^{122}$ Furthermore, it is generally accepted that in matters harmonised by directives, EU law precludes Member States from entering into commitments with third countries to the extent that those commitments would affect the Union directives so issued or could detract from their significance. ${ }^{123}$ Consequently, Member States remain competent to negotiate and conclude their DTCs with third countries, but they should nevertheless coordinate and consult with the Union with respect to the provisions which risk frustrating intraEU relations harmonised by directives. ${ }^{124}$ This conclusion implies that, when negotiating and concluding DTCs with third countries, Member States should also take into account the aims and principles of the CCCTB Directive as soon as it is adopted.

\subsubsection{DISCRIMINATORY RESTRICTIONS}

The EIM implies the abolition of obstacles ${ }^{125}$ to the fundamental freedoms ${ }^{126}$ between the Member States. ${ }^{127}$ In this regard, one can essentially distinguish between two types of restrictions: ${ }^{128}$ discriminatory restrictions (so-called "true restrictions") and non-

\footnotetext{
${ }^{121}$ Hinnekens (1994), 156.

122 Ibid., 157.

123 Ibid., 157.

124 Ibid., 157.

125 Refusal of entry/deportation, discriminatory and non-discriminatory measures that impede market access, also called "restrictions" to the free movement. Bernard (2010).

126 The fundamental freedoms include: (1) the free movement of goods (Article 34 of the TFEU); (2) the free movement persons, including EU citizens (Article 21 of the TFEU), workers (Article 45 of the TFEU) and freedom of establishment (Article 49 of the TFEU); (3) freedom to provide or receive services (Article 56 of the TFEU); and free movement of capital and payments (Article 63 of the TFEU). ${ }^{127}$ Article 3(1)(c) of the TEC was repealed, in substance, by Articles 3 and 6 of the TFEU.

128 As a general acceptance, the concept of restriction overlaps with the general rule of non-discrimination prescribed in Article 18 of the TFEU prohibiting discrimination. Nevertheless, the concept of restriction is broader than discrimination because it also includes other barriers to the exercise of the fundamental freedoms, so-called non-discriminatory restrictions. Bezborodov (2007), 671 .
} 
discriminatory restrictions (so-called "quasi-restrictions"). ${ }^{129}$ According to the CJEU, discrimination consists of (1) the application of different rules to (objectively) comparable situations or (2) the application of the same rule to different situations, with a consequence that one of the nationals of another Member State is subject to worse treatment. ${ }^{130}$ Hence, discrimination is a relative concept and always requires comparative analysis.

The TFEU contains several clauses concerning non-discrimination. Article 18 of the TFEU enshrines the general requirement of nondiscrimination on grounds of nationality without prejudice to any special provisions contained in the Treaty. Thus, it applies independently only to situations governed by Union law in respect of which the Treaty does not provide a specific prohibition of discrimination. ${ }^{131}$ Furthermore, Article 49 and Article 56 of the TFEU prohibit each Member State from discriminating against nationals of other Member States wishing to establish or provide services in the former Member State. Article 63 of the TFEU does not explicitly forbid discrimination of nationals but simply prohibits any restriction of the free movement of capital. Nevertheless, one can conclude that despite the different wording of the Treaty provisions, at least as far as direct taxation is at issue, the non-discrimination tests applied by the CJEU have converged almost completely. ${ }^{132}$ The EU fundamental freedoms are primary in relation to the general nondiscrimination clause. ${ }^{133}$ Therefore, the scope of application of the

129 See opinion of Advocate General Geelhoed delivered on 23 February 2006 on case Test Claimants in Class IV of the ACT Group Litigation (C-374/04), paras. 36-55. According to the Advocate General, "quasi-restrictions" result inevitably from the co-existence of national tax systems. Accordingly, certain disadvantages for companies active in cross-border situations result directly and inevitably from this juxtaposition of systems, in particular from: (1) the existence of cumulative administrative compliance burdens; (2) the existence of disparities between national tax systems; and (3) the necessity to divide tax jurisdiction, meaning dislocation of the tax base. On the contrary, "true restrictions" go beyond those resulting inevitably from the existence of national tax systems and disadvantageous tax treatment should follow from discrimination resulting from the rules of one jurisdiction.

${ }^{130}$ Cases Schumacker (C-279/93), para. 30; Royal Bank of Scotland (C-311/97), para. 26; Schempp (C-403/03), paras. 21-26.

131 Cases Royal Bank of Scotland (C-311/97), para. 20; Baars (C-251/98), para. 23; Metallgesellschaft (Joined Cases C-397/98 \& C-410/98), para. 38.

132 Smit (2011b), 231.

133 Article 18 of the TFEU applies independently only to situations governed by Union law in respect of which the Treaty lays down no specific prohibition of discrimination (cases Metallgesellschaft (Joined Cases C-397/98 \& C-410/98), para. 38; 
latter is rather limited compared to the articles providing the freedoms. ${ }^{134}$

Even though the TFEU only explicitly prohibits direct discrimination based on nationality, the CJEU has held that the rules regarding equality of treatment forbid not only direct discrimination by reason of nationality but also indirect discrimination, which, by the application of other criteria of differentiation, lead to the same result. ${ }^{135}$ In other words, indirect discrimination results in measures, which appear neutral in form in relation to nationality, but they have a greater impact on nationals of other Member States in substance, leading to the same result as direct discrimination, such as residence. ${ }^{136},{ }^{137}$ Such restrictions are subject to factual and empirical analysis similar to the comparative analysis carried out based on the direct discrimination clause on nationality. ${ }^{138}$

Another important factor stemming from the Court's jurisprudence is that the provisions of the fundamental freedoms cover not only hostState situations, but they also prohibit the origin-State from hindering the exercise of those freedoms by its own nationals in another

Weigel (C-387/01), para. 57). The same is true if the relevant facts are governed by a free movement provision included in an APC (see below). See e.g. case Echouikh (C$336 / 05)$, para. 63. In other words, to the extent that an investment is already governed by one of the economic freedoms included in the TFEU, an APC or any other international EU law arrangement, one can no longer invoke the general nondiscrimination clause under Article 18 of the TFEU in order to obtain a higher degree of protection in the case of discriminatory taxation of investment. Smit (2011b), 453.

134 It is noteworthy that, even though the articles on the fundamental freedoms take precedence over Article 18, the Court has frequently referred to that article. Lyal (2003).

135 Cases Sotgiu (152/73), para. 11; Biehl (C-175/88), para. 13.

136 Note that, different from other fields, because in direct matters residence is an essential connecting factor, different treatment on the grounds of residence is rather the norm than the exception. For instance, the Court has repeatedly held that, in direct tax matters, the situations of residents and non-residents in the host State are not generally comparable and thus different treatment between them is not per se discrimination (cases Royal Bank of Scotland (C-311/97), para. 27; Schumacker (C279/93), para. 31). Due to this peculiarity, it might be delicate to make a distinction between discrimination and restriction in direct taxation because, in many cases, the decisive comparison is not based on nationality or origin but the comparison is between the cross-border and comparable domestic situation.

137 Cases Commerzbank (C-330/91), para. 15; Lankhorst-Hohorst (C-324/00), para. 28.

138 For instance, indirect discrimination appears in case Schumacker (C-279/93) from the host State perspective and in case Marks \& Spencer (C-446/03) from the origin State perspective. 
Member State. Since Daily Mail, ${ }^{139}$ the Court has confirmed several times that different treatment based on the place the capital of a taxpayer is invested constitutes a discriminatory restriction ${ }^{140}$ on free movement. ${ }^{141}$

\subsubsection{COMPARABILITY ELEMENT}

As stated above, discrimination can arise through the application of different rules to (objectively) comparable situations or through the application of the same rule to different situations. Therefore, the assessment of discrimination (under the general non-discrimination clause or the prohibition of discriminatory restrictions) requires a preliminary scrutiny of the comparability of two situations and the respective tax treatment by the relevant Member State in order to assess whether a national treatment of a Member State complies with the general non-discrimination clause or the fundamental freedoms. A comparison is carried out between the situations of those of (i) a national and a non-national in a host-State setting or (ii) a national that has not exercised a fundamental freedom and a national who has exercised it in an origin-State setting. ${ }^{142}$

The general approach of the Court in assessing comparability is to determine an appropriate comparator, which rests on the premise of "less favourable treatment" arising due to the existence of a (selective) restriction. Typically, in cases concerning direct taxation, such a restriction takes the form of either (i) the denial of a "tax advantage" 143 or (ii) the application of a "tax disadvantage". ${ }^{144},{ }^{145}$

\footnotetext{
${ }^{139}$ Case Daily Mail (81/87), para. 16.

140 Article 18 of the TFEU does not cover reverse discrimination (case Van Hiltenvan der Heijden (C-513/03), para. 47 et seq.). However, different treatment by a Member State of its own nationals residing in other Member States in comparison to its own nationals resident in that Member State is prohibited (case Eman and Sevinger (C-300/04), para. 58). It is also noteworthy that favouring cross-border situations compared to purely internal situations may be challenged under EU state aid rules or principles of harmful tax competition under EU Code of Conduct. Helminen (2011), 54.

141 Cases ICI (C-264/96), para. 21; Marks \& Spencer (C-446/03), para. 31.

142 Jezzi (2010), 115.

143 See for instance cases Manninen (C-319/02), Marks \& Spencer (C-446/03) and ICI (C-264/96) from the perspective of a origin-State and Ritter-Coulais (C-152/03) and Aberdeen Property Fininvest Alpha (C-303/07) from host-State perspective.

144 See for instance cases Cadbury Schweppes (C-196/04) and Bosal Holding (C-168/01) from origin-State perspective, and Scorpio (C-290/04) from host-State perspective. 145 Jezzi (2010), 122.
} 
Further, the Court looks either at (i) the legal situation (e.g. in Avoir Fiscal ${ }^{46}$ ) or (ii) the factual situation (e.g. in Schumacker ${ }^{147}$ ). Finally, the Court has been clear that the key element in establishing the comparability is the consideration of the "purpose" of the relevant national provision. ${ }^{148}$

Direct tax systems typically differentiate between residents and nonresidents irrespective of their nationality. This occurs because residence is an essential connecting factor with regard to a State's taxing sovereignty. Thus, from the perspective of the host State (inbound investment), the Court typically focuses on the different treatment of residents and non-residents. ${ }^{149}$ From the perspective of the home State (outbound investment), the comparison is generally made between residents who earn domestic and foreign income or hold property in different jurisdictions. ${ }^{150}$

\subsubsection{NON-DiSCRIMINATORY RESTRICTIONS ("QUASI- RESTRICTIONS")}

Even though the wording of (some of) the fundamental freedoms as contained in the Treaty refers to different treatment on the grounds of nationality, as follows from the jurisprudence of the CJEU, all the fundamental freedoms prohibit both (direct and indirect) discrimination and non-discriminatory restriction. ${ }^{151}$ Unlike the overarching non-discrimination clause, which looks only at the comparability-element, the concept of restrictions aims at abolishing all border obstacles ${ }^{152}$ to the EIM despite their extent ${ }^{153}$ (unless explicitly

\footnotetext{
146 Case Commission v France [Avoir Fisca] (270/83)

147 Case Schumacker (C-279/93).

${ }^{148}$ For instance, case Denkavit II (C-170/05).

${ }^{149}$ For instance, case Schumacker (C-279/93), para. 30-38.

${ }^{150}$ For instance, case Manninen (C-319/02), para. 22-24.

151 See e.g. case 81/87 Daily Mail. See also Helminen (2011), 61.

152 "[M]easure, even though it is applicable without discrimination on grounds of nationality, is liable to hamper or to render less attractive the exercise by Community nationals, including those of the Member State which enacted the measure, of fundamental freedoms guaranteed by the Treaty. Case Kraus (C-19/92), para. 32.

153 The restriction approach does not include a general scale as to the size of the obstacle: it suffices that there is an impediment or restriction or there is liable to be one. Case Corsica Ferries France (C-49/89), para. 8: "the articles of the [TFEU] concerning the free movement of goods, persons, services and capital are fundamental [Union] provisions and any restriction, even minor, of that freedom is prohibited. Case Bosal Holding (C-168/01), para. 27: "might be dissuaded".
} 
mentioned in the Treaty). In other words, in case of nondiscriminatory restrictions, one only needs to establish that the national measure treats the exercise of freedom of movement less advantageously ${ }^{154}$ than an internal situation, without the need to ascertain that the measure affects particular non-nationals. Nondiscriminatory restrictions include national treatments that are restrictive because they are either even-handed or not comparable (rather than being discriminatory) but they have a dissuasive effect on the exercise of the fundamental freedoms. ${ }^{155}$ It follows that rules that directly impede market access, even if they were to apply without distinction, are liable to render free movement illusory. Such rules can thus be considered to be incompatible with the Treaty freedoms. ${ }^{156}$ In such cases, the Court analyses the compatibility of a national provision with the EU law in the light of the (non-discriminatory) restriction theory, as developed in Dassonville ${ }^{157}$ and Cassis de Dijon. ${ }^{158}$

\subsubsection{DISPARITIES}

It was concluded above that non-discriminatory restrictions or "quasi-restrictions" can also be caught by the Treaty freedoms. However, it is clear that the Treaty freedoms are not concerned with any disparities in treatment that arise from variations between two or more national tax systems coexisting in the EU, such as the difference in tax rates or in the structure of the tax base. In spite of the fact that such disparities have distorting effects on taxpayers' decisions, the Court accepts them "so long as they affect all persons

154 That is, any measure which prohibits, impedes or renders less attractive the exercise of freedom of movement.

155 The basis of this development is case Riseria Luigi Geddo (2/73), in which the Court defined such a "quantitive restriction to mean "measures which amount to a total or partial restraint of, according to the circumstances, imports, exports or goods in transit". The Court added that measures having equivalent effect not only take the form of restraint described; whatever the description or technique employed, they can also consist of encumbrances having the same effect. In the landmark case Keck and Mitthouard, the Court held that "quantitative restrictions on imports and all measures having equivalent effect are prohibited between Member States. The Court has consistently held that any measure which is capable of directly or indirectly, actually or potentially, hindering intra-Community trade constitutes a measure having equivalent effect to a quantitative restriction" (case Keck and Mithouard (Joined Cases C-267/91 \& C-268/91), para. 11. See also opinion of Advocate General Lenz delivered on 20 September 1995 in case Bosman (C-415/93), para. 197.

156 Cases Konle (C-302/97), para. 44; Commission v France (C-483/99), para. 41.

157 Case Dassonville (8/74).

158 Case Cassis de Dijon (120/78). 
subject to them in accordance with objective criteria and without regard to their nationality". ${ }^{159}$ In the same vein, the Court goes on by saying that "the Treaty offers no guarantee to a citizen of the Union that transferring his activities to a Member State other than that in which he previously resided will be neutral as regards taxation." 160 Member States are entitled to design their tax systems and they are under no obligation to offset the disadvantages that are a result of a "non-tax-harmonised" internal market. Thus, disadvantages arising from disparities are the inherent consequence of tax sovereignty remaining at the level of Member States. ${ }^{161}$

\subsubsection{JUSTIFICATIONS}

A restrictive national measure is not necessarily prohibited. Member States may be able to demonstrate that the application of a restrictive national measure is justified in the presence of the grounds explicitly mentioned under the relevant free movement provision or on the basis of an overriding reason of public interest listed in Article 52 TFEU, i.e. public policy, public security or public health (so-called written justifications). However, since Cassis de Dijon, ${ }^{162}$ discriminatory restrictions and non-discriminatory restrictions, which hinder free movement, may also be justified based on "public" or "general interest" and "imperative requirements" - i.e. objective justifications ${ }^{163}$ (so-called unwritten justifications). This is the so-called "rule of reason" test. ${ }^{164}$ The Court initially only applied the written justifications in the case of non-discriminatory restrictions with the consequence that direct and indirect discrimination continued to be subject to the more limited written justifications. Nevertheless, following further developments, the CJEU now accepts that discriminatory measures may also be justified by the rule of reason. ${ }^{165}$ By accepting certain unwritten justifications, the Court has recognised

\footnotetext{
${ }_{159}$ Cases Perfili (C-177/94), para. 17; Schempp (C-403/03), para. 34.

160 Case Alpine Investments (C-384/93), para. 27; Schempp (C-403/03), para. 45.

161 Weber (2006), 588.

162 Case Cassis de Dijon (120/78).

163 Case Säger (C-76/90), para. 15.

164 The Court elaborated on the necessary requirements for the national measure to satisfy the rule of reason test in case Gebhard (C-55/94), para. 37.

165 Smit (2011b), 256. However, see Lyal (2003), 74: "Where there is real discrimination, it should be excusable only on the grounds set out in the Treaty /.../ [rule of reason] justifications amount in practice to grounds for the conclusion that there is an objective, relevant difference between domestic and trans-frontier situation."
} 
that specific national interests are worthy of protection and should, thus, take precedence over the free movement provisions. ${ }^{166}$

The Court further elaborated on the necessary requirements for the national measure to satisfy the rule of reason test. ${ }^{167}$ Accordingly, national measures liable to hinder or make less attractive the exercise of fundamental freedoms guaranteed by the Treaty must fulfil four conditions:

(1) they must be applied in a non-discriminatory manner, ${ }^{168}$

(2) they must be justified by imperative requirements in the general interest,

(3) they must be suitable for securing the attainment of the objective which they pursue;

(4) they must not go beyond what is necessary in order to attain it.

The Court has accepted a number of public-interest grounds ${ }^{169}$ that justify national measures liable to hinder or make less attractive the exercise of fundamental freedoms. With regard to CCCTB, if the situation of eligible and non-eligible companies is considered to be comparable, the Commission could argue that the reason for the introduction of CCСТВ - the requirement to eliminate in a unified manner all corporate tax obstacles to cross-border activities in the EIM under the tax strategy adopted since 2001 - was itself an objective justification for the CCСТВ.

\footnotetext{
166 Bernard (2010), 511.

167 Case Kraus (C-19/92), para. 37.

168 The reason for the non-discriminatory requirement is that if a Member State does not regard its own products to be harmful, it might be challenging to set forth reasonable grounds that same Member State could have for considering identical or similar products from other Member States to be harmful enough to justify a limitation on their importation. Terra \& Wattel (2012), 59. However, some exceptions to this approach can be found in the Court's jurisprudence on direct taxation. See, in particular, cases Bachmann (C-204/90); Scbumacker (C-279/93); Gilly (C-336/96).

${ }^{169}$ Such grounds can generally be divided into four groups: (1) market externalities (e.g. protection of environment); (2) civil liberties (e.g. protection of human dignity); (3) socio-cultural practices (e.g. combating illegal employment); and (4) preservation of public order (e.g. the effectiveness of fiscal supervision). See further Bernard (2010), 512-516. Majority of justifications used in direct tax case law fall under the latter category.
} 


\subsubsection{PRINCIPLES OF SUBSIDIARITY AND PROPORTIONALITY}

In a typical federal State, the Constitution has a crucial role in solving cross-border disputes between the central administration and the subdivisions by laying down specific principles and mechanisms for arbitration. For instance, the US Constitution provides for a split between the sovereignty of the states and the federal government. ${ }^{170}$ On the contrary, because the EU is a "mixed form" of confederation and federation and there is no constitution as such for the EU, 171 Member States remain free to determine their policies to the extent that those competences have not been transferred to the Union. The Treaty of Lisbon catalogues three areas of competences of the Union as exclusive, shared and complementary competences. ${ }^{172}$ Since the two-level legitimate lawmakers have overlapping competences, they may face conflicting policies and interests. When Member States disagree with a Union approach that does not reflect a balance with national interests, it likely steers to political disapproval. The issue is particularly noticeable when the Union law aims to touch on the most sensitive and traditional national competences, such as taxation.

Both the Union and the Member States have the right to legislate in the field of direct taxation. However, one must not forget that the EU legislation is subject to two additional conditions initially developed in the CJEU's judgments and later integrated into the TEC ${ }^{173}$ by the Treaty of Maastricht: (i) the principle of subsidiarity and (ii) the principle of proportionality. As it appears from the 20 April 1990 Communication, the European Commission was committed to the principle of subsidiarity in tax matters already before the TEU. ${ }^{174}$ Today, the principles are mentioned in the TEU, ${ }^{175}$ as amended by the Lisbon Treaty, ${ }^{176}$ which refers to the Protocol $^{177}$ on the application of the principles and assigns the

\footnotetext{
170 Kaye (2007), 191-192.

171 Albeit the TEU does not use the expression "Constitution", it gives the impression of being effectively a sort of constitution since it includes the fundamental rules and values by which those in authority considered themselves to be bound. Hinnekens (2012), 63.

172 Articles 3-6 of the TFEU.

173 Article 5(2) and (3) of the TEC.

174 European Commission (1990), 10. See also European Commission (1992a), para. 20.

175 Article 5 of the TEU.

176 Article 3b of the Treaty of Lisbon; European Commission (2010c), 3.

177 Protocol (No. 2) on the Application of the Principles of Subsidiarity and Proportionality.
} 
national parliaments of Member States the task of monitoring the compliance of the Union legislative proposals with the principle of subsidiarity. ${ }^{178}$

\subsubsection{SUBSIDIARITY}

The principle of subsidiarity ${ }^{179}$ defines the boundaries between the responsibilities of the Member States and the Union, i.e. who should act?180 Thus, it governs the scope of Union action only where it has shared competence with the Member States or complementary competence to support, coordinate or supplement the Member States' action. ${ }^{181}$ As it stands today, the Union shall take action only if:

(1) the objectives of the Union cannot be sufficiently accomplished by the Member States separately (so-called "necessity test"), and

(2) can be better achieved by the Union (so-called "value-added test" or "compared effectiveness" test). ${ }^{182}$

Accordingly, the individual Member States should remain free to determine their national policy and legislation, including taxation rules, unless such arrangements would lead to discrimination or distortions. The Union does not take action with regard to achieving one of the Union goals ${ }^{183}$ (except in the areas which fall within its

178 In addition to the Protocol, the Inter-Institutional Agreement on Subsidiarity provides guidance on how the two principles should be applied.

179 Subsidiarity originates from Roman Catholic doctrine. It assumes the primacy of the central goal and assumes that there will be no conflict between the objectives of different levels involved. In that sense, subsidiarity aims at allocating functions within a structure that has a clear hierarchy but common, undisputed goals. Davies (2006), 78. In the field of direct taxation within EIM, the principle of subsidiarity was presented to the public in 1990 with a view to facilitate replacing the initial aim of comprehensive harmonisation of tax with coordination or the approximation of national laws. Rogers-Glabush (2009), 406.

${ }^{180}$ European Commission (2010c), 2.

181 Szudoczky (2012), 95.

182 European Commission (2009a), 22. The Impact Assessment Guidelines provide for further guidance to the European Commission on how to assess the compliance of an act that it intends to propose with the principle of subsidiarity. Furthermore, after the Treaty of Lisbon, Protocol 2 contains a more specific requirement to provide a statement for proposals to make it feasible to appraise the compliance with the principles (Article 5). See also European Commission (2010c), 3.

183 A point of criticism may arise due to the fact that the principle of subsidiarity, as it currently stands, places the emphasis on the Union goals and asks only who should be the one to do the implementing work - i.e. the Union or the Member 
exclusive competence), unless it is more effective than action taken at the national, regional or local level. ${ }^{184}$ Although the reform of corporate tax systems in the EU is essential to comply with the requirements of the EIM, full harmonisation of direct taxes could be in breach of the principle of subsidiarity. Notably, since the Treaty does not explicitly cover direct taxation, its full harmonisation would be incompatible with the Union law. It is worth noting that, some level of direct taxation with the EIM is acceptable, as evidenced by the existence of the other EU corporate tax directives. Since the creation of the EIM, a number of distortions, mainly related to crossborder activities, have been resolved by coordinated action or approximation of Member States' laws at the EU level. Once agreed upon, in such situations, the sovereignty of the Member States has been limited.

The EU direct tax directives generally tackle obstacles that discourage or hinder cross-country ${ }^{185}$ commercial activity within the EU. One

States - rather than providing a method to balance the interests of the Union and those of the Member States. For further discussion, see for instance, Davies (2006), 67-68.

184 The Treaty of Lisbon provides for a considerable increase of the role of national parliaments at the EU level. For the first time, their function (Article 12 of the TEU) is referred to explicitly in the main body of the Treaty: "National Parliaments contribute actively to the good functioning of the Union", including in the capacity of ensuring compliance with the principle of subsidiarity (Articles 5 of the TEU and 69 of the TFEU). According to Protocol No. 2, the European Commission is obliged to notify its Proposals to national parliaments at the same time as to the Union legislator (i.e. the Council and the European Parliament). Any national parliament may then, within eight weeks from the date of transmission of the draft legislative act, send a reasoned opinion if they consider that the principle of subsidiarity has not being complied with. Each national parliament has two votes which, in case of bicameral systems, means that each chamber has one vote. Where the reasoned opinions on the non-compliance represent at least one third of all the votes allocated to the national parliaments (i.e. in 2010, 18 out of 54), the European Commission has to review the Proposal and either maintain, amend or withdraw it (i.e. the "yellow card" procedure). Finally, the Commission must give reasons for its decision. It is noteworthy that the Protocol also provides for another procedure (i.e. the "orange card" procedure). Under this procedure the rights of national parliaments are somewhat stronger compared to the "yellow-card' procedure. However, this procedure cannot be used in the case of proposals concerning taxation, because the "orange card" procedure can only be used where the legislative act is to be adopted by the Council by ordinary legislative procedure with qualified majority voting in the Council. Legislative acts in the field of taxation can only be based on Articles 113 (indirect taxes) or Article 115 (direct taxes) of the TFEU, which both require a unanimous vote in the Council.

185 The Protocol on Subsidiarity attached to the Treaty of Amsterdam listed the cross-border nature of the subject-matter of a legislative act as a key indication of 
may claim that, by definition, the tax directives comply with the principle of subsidiarity because only harmonised (or coordinated) rules can reduce (or eliminate) distortions resulting from existing disparities within the EIM. As far as the CJEU is concerned, the Court has never annulled or declared invalid a Union act on the ground that it infringed the principle of subsidiarity. ${ }^{186}$ Indeed, as demonstrated in the 'Working Time Directive', in the opinion of the Court, the Council has the responsibility under Article 154 of the TFEU (Article 138 of the TEC) to adopt minimum standards in order to contribute to the improvement of health and safety. Once the Council has found that it is necessary to improve the existing level of protection and to harmonise the conditions in this area, while maintaining the improvements made, achievement of that objective through the imposition of minimum requirements necessarily presupposes Community-wide action. ${ }^{187}$ Furthermore, in procedural terms, the Court held in Germany v. European Parliament and Council that Article 296 of the TFEU (Article 253 of the TEC) did not require that Community measures explicitly refer to the principle of subsidiarity. It sufficed that the recitals of the measure made it apparent that the Community institutions believed that the aims of the measure could best be attained by Community action. ${ }^{188}$ It is noteworthy that the Treaty of Lisbon reformed the Protocol on the application of the principle of subsidiarity in order to improve and reinforce the monitoring of the Union action. Among others, the current Protocol includes an obligation for the European Commission to consult widely and to accompany draft legislative acts with a statement demonstrating compliance with the principles of subsidiarity and proportionality.

Likewise, the European Commission claims that the proposed CCCTB Directive is in line with the subsidiarity principle ${ }^{189}$ as

compliance with the principle of subsidiarity. Even though this condition does not appear from the relevant Protocol attached to the Treaty of Lisbon, the substance of the principle did not change.

${ }^{186}$ For further discussion, see Szudoczky (2012), 99-102.

187 Case United Kingdom v. Council (C-84/94), paras. 46-47.

188 Case Germany v European Parliament and Council (C-233/94).

189 Assessments of whether the legislative work of the Commission complies with the principles of subsidiarity and proportionality is done via three key stages of the policy development: 1) a preliminary analysis in roadmaps which provide a preliminary description of Commission major initiatives; 2) a fuller analysis of subsidiarity as part of the impact assessment; and 3) justification of the principles in the explanatory memorandum and recitals of each legal proposal. European Commission (2010c), 4. 
" $[\mathrm{N}]$ on-coordinated action, planned and implemented by each Member State individually, would replicate the current situation, as companies would still need to deal with as many tax administrations as the number of Member States in which they are liable to tax". ${ }^{190}$ Therefore, taking into account that independent action by each Member State would fail to achieve the aims of the EIM, a common approach at the level of the Union seems to be inevitable. ${ }^{191}$

\subsubsection{PROPORTIONALITY}

The principle of subsidiarity is closely related to the principle of proportionality, which requires that any action by the Union should not go beyond what is necessary to achieve the objectives of the Treaty. The proportionality principle is a vehicle for ensuring a proper balance between the interest of Member States and that of the EU. The principle requires an assessment of the measure in the light of the (Union) goal192 it aims to achieve. The legal doctrine of the principle of proportionality is normally defined through a threepronged test:

(1) Whether the measure actually contributes to the accomplishment of the set goal (i.e. it is suitable);

(2) Whether it goes further than necessary to achieve that goal (i.e. it is necessary); and

(3) Whether the cost of Member State interests is disproportionately large compared to the goal to be attained (so-called "true proportionality" or proportionality stricto sensu). ${ }^{193}$

\footnotetext{
${ }^{190}$ Explanatory Memorandum to the proposed CCCTB Directive, 9. See also Recital 26 of the Proposed CCCTB Directive and European Commission (2001b), 15-16.

191 The proposed CCCTB Directive has already indicated a significant impact on the future design of corporate tax systems in the EU. Even if the Directive fails to achieve full implementation among the Member States, it might serve as a blueprint for prospective national corporate tax reforms.

192 The principle of proportionality is a broader and more flexible standard compared to the principle of subsidiarity. Unlike the latter, the proportionality principle can accommodate an appropriate balance between the interests of the Member States and those of the EU. Szudoczky (2012), 102.

193 Especially in the light of the latter requirement, one should note that the principle of proportionality requires the acknowledgment of national autonomy. Although it is generally accepted that the desire of Member States to preserve their uniqueness and autonomy is in itself legitimate, the Court has never explicitly confirmed it. Davies (2006), 71.
} 
The proportionality test in EU law, however, does not accommodate a three-pronged test. In particular, the TEU defines the principle only through the second part of the test, i.e. the necessity. ${ }^{194}$ In the CJEU's jurisprudence, in many cases one can distinguish only the first two prongs of the rest, i.e. the suitability and necessity. ${ }^{195}$ Nevertheless, one can also find cases in which the Court used the three-pronged test. ${ }^{196}$ It is noteworthy that, even though the TEU requires the Union action to comply with the principle of proportionality, Article 6 of the Protocol 2 annexed to the Lisbon Treaty suggests that national parliaments of Member States may oppose draft legislation only on grounds of disrespecting the principle of subsidiarity.

\subsubsection{CCCTB IN THE LIGHT OF SUBSIDIARITY AND PROPORTIONALITY}

In the assessment of the Union action with the principles attention must be paid to the expressions "sufficiently" and "better" contained in the wording of the provision. One may attempt to interpret these words in the sense that, even if the Member States cannot eliminate the whole problem which creates an obstacle to the EIM, the Member States may still be in a position to solve the problem "sufficiently". The Protocol on the application of the principles of subsidiarity and proportionality sheds some light in that matter by setting out the following criteria:

(1) Whether action at Union level would produce clear benefits by reason of scale and effects;

(2) Whether the issue includes cross-border aspects which cannot be satisfactorily regulated by action of Member States individually;

(3) Whether the action of Member States individually or the lack of Union action would conflict with the requirements of the Treaty or would otherwise ${ }^{197}$ significantly damage Member States action.

\footnotetext{
194 Article 5(4) of the TEU.

195 Case British American Tobacco (C-491/01), para. 122.

196 Case Fedesa and others (C-331/88), para. 13. According to Brenncke, the Court has used the three-pronged test particularly in the context of the common agricultural policy, while in the case of harmonisation measures, based on Article 114 of the TFEU (Article 95 of the TEC), the Court has only resorted to the two-pronged test. Brenncke (2010), 1811, footnote 73.

197 Davies correctly points out that here the word "otherwise" does not refer to the interests of the Member States with regard to their autonomy and local preference,
} 
The European Commission has included its justifications with regard to the compliance with the CCCTB proposal with the principles of subsidiarity and proportionality in the Explanatory Memorandum ${ }^{198}$ of the proposed Directive and its Impact Assessment. ${ }^{199}$ The CCCTB offers Member States an opportunity to reconsider their corporate tax systems from a more sustainable and transparent perspective while allowing their businesses to enjoy easier access to the EIM. According to the European Commission, the CCCTB is designed to tackle fiscal impediments resulting from the existence of (then) 27 different tax systems that businesses carrying out pan-European activities face. It believes that the objectives of the CCCTB cannot be sufficiently achieved by the Member States alone. ${ }^{200}$ The building blocks of the CCCTB system target cross-border transactions (such as cross-border loss relief) that could only be materialised under a common EU regulatory umbrella. The question is whether these objectives could be achieved by the Member States through voluntary coordination in the form of soft law. ${ }^{201}$ Clearly, the communications with the purpose of encouraging such coordination between the Member States issued by the European Commission in the past have not led to desirable results. ${ }^{202}$ Furthermore, as evidenced by the large number of cases brought before the CJEU and infringement procedures initiated against Member States by the European Commission, the progress of removing (tax) obstacles within the EIM during a period of more than half a century has been insufficient. Hence, the approximation of corporate income taxation serves as the optimal solution for the achievement of the goals of the EIM provided in the Treaty of Lisbon. In a similar vein, the Court found that a directive for the harmonisation of national laws on deposit-guarantee schemes was in line with the subsidiarity principle. The Court came to this conclusion since the action taken by the

but it indicates that the Member States interests are here being assimilated with those of the Union. Davies (2006), 72.

198 Explanatory Memorandum to the Proposed CCCTB Directive, 9.

${ }^{199}$ European Commission (2001b), 15.

${ }^{200}$ Explanatory Memorandum to the Proposed CCCTB Directive, 9.

201 Note that soft law has been a successful means to deal with Member States' national tax systems. For example, the Primarolo group, which was established by the EU's finance ministers at a Council meeting on 9 March 1998, assessed Member States tax measures that fell within the scope of the Code of Conduct for business taxation. In its report of November 1999, the group identified 66 tax measures with harmful features (40 in EU Member States, 3 in Gibraltar and 23 in dependent or associated territories). See further Council of the European Union (1999).

202 European Commission (2006m); European Commission (2006p). 
Member States in response to the Commission's recommendation with regard to the introduction of deposit-guarantee schemes had not fully achieved the desired result in Deposit Guarantee Scheme. ${ }^{203}$ When the Commission proposed the Directive on CCCTB, a number of Member States ${ }^{204}$ had a negative opinion ${ }^{205}$ on the proposed CCCTB Directive in respect to subsidiarity (and proportionality) 206,207

203 Case Germany v European Parliament and Council (C-233/94), para. 27.

204 The Commission received in total 13 votes from 9 Member States' national parliaments that considered that the CCCTB Proposal infringes the principle of subsidiarity within the established time frame (8 weeks, i.e. 18 May 2011): Bulgaria (2 votes), Ireland Dail Lower House (1 vote), Malta (2 votes), the Netherlands Tweede Kamer (Lower House) (1 vote), Poland Sejm (Lower House) (1 vote), Romania Camera Deputatilor (Lower House) (1 vote), Sweden (2 votes), Slovakia (2 votes), and the United Kingdom House of Commons (Lower House) (1 vote). On the other hand, the Commission also received a "positive" opinion on the subject matter from the National Parliaments of Belgium, Luxembourg, Portugal and Italy. Interestingly, the two Chambers of the National Parliament of Czech Republic sent two contradicting opinions: while the Lower House delivered its belated "negative" opinion on subsidiarity, the Senate submitted its "positive" opinion on the issue. Furthermore, Denmark indicated that its Parliament could not take a position and the Romanian Chamber of Deputies sent a follow-up.

205 Following an initiative of President Barroso, which was reflected in the European Commission's communication (European Commission (2006q)), in September 2006 the Commission started to send its new legislative proposals and consultation papers to national parliaments, inviting them to react to engage in a dialogue on its proposals. Jans \& Piedrafita (2009). The European Commission has committed itself to replying to the opinions received within three months. The opinions of national parliaments received by the Commission in the context of such political dialogue differ considerably in length, format, scope, and focus. Considering that the subsidiarity control mechanism will form part of its wider political dialogue with the national parliaments, the opinions received might contain a mix of political comments on substance and considerations on subsidiarity, even though the Commission invites the national parliaments to distinguish between those two aspects in the context of subsidiarity.

206 The European Commission proposed the Directive on a CCCTB on 16 March 2011 and the lettre de saisine together with the last language version were sent to the national parliaments on 23 March 2011 (i.e. the start of the eight-week deadline). Thus, the national parliaments or any chamber of a national parliament had time to send their reasoned opinions against the proposed CCCTB Directive based on subsidiarity by 18 May 2011 (however, the Secretariat General extended the deadline until 20 May 2011).

207 To analyse all of the opinions submitted by Member States would go too far, considering the limits of the current dissertation. However, for a comprehensive overview, the author suggests referring to Szudoczky (2012), 111-126. The Commission's replies to Member States national parliaments that had raised a concern on subsidiarity are available at the Platform for EU Interparliamentary Exchange (IPEX). 
As per the proportionality principle, the proposed CCCTB is clearly suitable and necessary for achieving the desired result. The fact that the system will be optional for companies only confirms this point of argumentation. If the Directive had been proposed as compulsory legislation, concerns about the proportionality of the measure might be discussed. As per the third element of proportionality - the stricto sensu proportionality - the European Commission has pointed out that the positive impact of the system should outweigh possible additional financial and administrative costs which national tax authorities would have to undergo for the purposes of implementing the system at a first stage. ${ }^{208}$ The light justification of the proposal in the light of the proportionality principle triggered many Member States' reaction (despite that the Protocol on the subsidiarity and proportionality does not foresee the possibility to challenge a proposal in the light of the proportionality principle by national parliaments). For example, the Maltese Parliament has expressed particular concerns with regard to the compliance of the proposal with the stricto sensu proportionality criterion, because it would hinder Member States' national autonomy and their sovereignty to structure their socio-economic circumstances, both at the central level as well as at the regional or local level.

One point of concern on the compliance of the proposal with the two principles is that the Directive would also be available to eligible companies (either as a single taxpayer or as a domestic group) which do not pursue cross-country activities. By way of comparison, the German Bundesrat and the Dutch Parliament expressed doubts about the compliance with the principle of subsidiarity in the Proposal for a EPC $^{209}$. In its answer, the European Commission emphasised that "including a cross-border requirement as a condition for setting up [an EPC] would be inconsistent with the objective of the proposal, notably to contribute to the completing and improving the functioning of the internal market and to make it more accessible for SMEs."210 The same reasoning could equally apply to the proposal for the CCCTB Directive.

\footnotetext{
208 Explanatory Memorandum to the Proposed CCCTB Directive, 10.

${ }^{209}$ European Commission (2008b).

${ }^{210}$ European Commission (2009b), 6.
} 


\subsubsection{ENHANCED COOPERATION}

In the beginning of the Community (EU), making political decisions on tax policy in Europe was difficult because of the unanimity requirement of the Council. Today, ${ }^{211}$ however, if some Member States oppose certain measures which move towards European integration, the remaining Member States can continue to work closer together via enhanced cooperation, while still complying with the institutional framework of the EU.212 The possibility for enhanced cooperation allows the latter Member States to move forward at different speeds and/or different goals by pushing ahead with a proposal, which was blocked because of the unanimity requirement, to achieve an even closer integration with respect to the "three pillars" of the EU.213

The Treaty of Lisbon ${ }^{214}$ refined enhanced cooperation and introduced the following changes:

211 The Treaty of Amsterdam first incorporated the concept of "enhanced cooperation" into the Treaty of Maastricht, as regards the judicial cooperation on criminal matters and into the TEC. The Treaty of Nice introduced further changes that aimed at simplifying the mechanism and thereby making it easier for a group of countries to move ahead of the rest in certain policy areas. The Treaty of Maastricht included separate provisions on enhanced cooperation for each of the three pillars (i.e. the European Community, the Common Foreign and Security Policy, and Justice and Home Affairs). With regard to the economic and tax matters of the Union (i.e. the first pillar), the criteria for enhanced cooperation could be found in Articles 43 and 44(a) of the TEU and, in terms of procedure, Article 11 of the TEC (all Articles as listed in the consolidated version of the treaties before the Treaty of Lisbon).

212 Such a mechanism has already been used successfully in the fields of divorce law and patents. On 23 October 2012, following the official requests of ten Member States, the Commission adopted a proposal for a Council Decision, which would authorise the introduction of a financial transaction tax (FTT) in the EU through enhanced cooperation.

${ }^{213}$ It may be worth noting that the US Constitution (Article 1, section 10, cl. 3) also allows a US state, with the consent of Congress, to enter into an agreement or compact with another state to increase their power at the expense of federal power. This clause is generally referred as the "compact clause". The clause allows states that are willing to combine their forces to take action within the framework of the Constitution when the problem affects more than one state and, at the same time, action by the federal government would be impossible. The clause should be distinguished from the prohibition on the states to enter into a treaty, alliance or confederation (Article 1, section 10, cl. 1 of the US Constitution). The states have entered into a compact in a few fields of legislation, including taxation. Fabbrini (2012), 10-12.

214 The provisions on enhanced cooperation are now in Article 20 of the TEU and Articles 326-334 of the TFEU. 
(i) Enhanced cooperation must be open to those Member States that initially did not participate in it at any time. Hence, if a Member State initially did not opt for a Union measure, it may opt for it in a later phase. In fact, the European Commission and the participating Member States have to promote the participation by as many Member States as possible.

(ii) The authorisation given by the Council to proceed with enhanced cooperation must always receive the Parliament's consent instead of a mere consultation with it. Therefore, the Parliament's opinion in tax matters is binding on the Council, which, in practice, equals the power to veto.

(iii) The authorisation of the Council would be achieved by the unanimous vote, but only of the Member States participating in the enhanced cooperation; ${ }^{215}$

(iv) The minimum number of Member States necessary to initiate such a procedure is ten..$^{216}$

Taxation falls within the Union pillar without distinguishing between direct and indirect taxation and, in respect of direct taxation, without distinguishing between personal and corporate taxation. ${ }^{217}$ Thus, the adoption of the CCCTB via enhanced cooperation is feasible under the Treaty, as long as such cooperation helps to further the objectives of the Union in terms of the undistorted functioning of the EIM. ${ }^{218}$ Following the reactions of several Member States, ${ }^{219}$ as a first step, the CCCTB will probably be adopted via enhanced cooperation. In that case, those Member States that will not opt (at least not in the first stage) for the CCCTB will also be treated as third countries.220 The current dissertation will follow that premise and address the related taxation aspects.

\footnotetext{
215 The Member States not participating in the enhanced cooperation may take part in the deliberations, but they may not vote.

${ }^{216}$ After Croatia joined the EU on 1 July 2013.

217 TFEU Part Three Title VII: Common rules on competition, taxation and approximation of laws.

${ }^{218}$ Cerioni (2006), 188.

${ }^{219}$ For instance, as discussed earlier, a number of Member States tried to oppose the CCСТВ Directive based on the subsidiarity principle. On the other hand, many Member States, lead by France and Germany, have indicated strong support for the project (see for instance, the six-point plan presented at the Eurozone meeting in February 2011 on how to improve the competitiveness of the Eurozone).

${ }^{220}$ Even though in this dissertation the author labels such Member States as third countries, being still part of the EU, their taxation treatment will have to respect the acquis communautaire.
} 
In the light of the above, if the CCСТВ is introduced via enhanced cooperation, it must further the objectives of the Union in terms of the undistorted functioning of the EIM and not conflict with the following:

(1) The general principles of EU law, including the requirement for non-discrimination and proportionality;

(2) The TFEU provisions on the fundamental freedoms, competition and State aid for enterprises, as well as the relevant secondary law and the interpretations given by the CJEU; and

(3) The soft law issued by the Union's institutions (communications, resolutions, etc.). ${ }^{221}$

A CCCTB would introduce benefits that would go beyond the already existing acquis communautaire. In addition to the main character of cross-border loss-relief, the CCCTB would allow eligible groups of companies to eliminate ${ }^{222}$ both transfer pricing issues as well as the risk of double taxation with regard to intra-group transactions (dividends, restructurings and interest and royalty payments). ${ }^{223}$ However, considering that the CCCTB would be available only to a specific group of companies, one may question whether such an advantage sufficiently eliminates distortions to the EIM without infringing the principles of non-discrimination and the prohibition of restriction. In the current dissertation, the author intends to analyse the most important taxation aspects arising from the compatibility of a CCCTB, if adopted via enhanced cooperation, with EU law and propose solutions.

One could claim that harmonisation causes regulatory monopolies and hinders the development of better rules by means of legislative competition.224 If a CCCTB were introduced via enhanced cooperation between a limited number of Member States, in order to achieve its objective, it would have to "compete" with national

\footnotetext{
${ }^{221}$ Cerioni (2006), 188-189.

222 Until the CCCTB, the Code of Conduct on transfer pricing and the EU corporate tax directives, together with the interpretation given by the CJEU via its case law on the application of the directives, have already considerably reduced the risk of double taxation.

223 Cerioni (2006), 191.

${ }^{224}$ Hey (2008), 103.
} 
provisions concerning the corporate tax base ${ }^{225}$ of each of the participating Member States. ${ }^{226}$ Thus, the optional character of the CCCTB would motivate the EU legislators to design attractive provisions and, if necessary, subject them to continuous revision and improvement. However, it is important to keep in mind that Member States are limited in competing with the CCCTB rules by the prohibition of state aid and the fundamental freedoms prescribed by the Treaty. It is noteworthy that some Member States have tried to argue that Articles 107 to 109 TFEU, which set forth the restrictions on state aid within the Union are not applicable to tax measures, but the European Commission and the Court of First Instance have rejected it. ${ }^{227}$

On the contrary, it could be argued that, if the CCCTB was introduced in the setting of enhanced cooperation and it would be more favourable than the rules regarding the tax base of all nonparticipating Member States, it could strengthen the attractiveness of the participating Member States as business locations at the expense of the non-participating Member States. Therefore, such enhanced cooperation would be in breach of the proportionality principle because it would go beyond what is necessary to achieve the purpose of eliminating, in a unified manner, major cross-border tax obstacles within the participating Member States.228 At the same time, if the CCCTB rules reflected the elements of the tax base of the participating Member States, even if they were (considerably) more beneficial than those applicable in non-participating Member States, this argument would become difficult to uphold. Generally speaking, the CCCTB will establish a new tax system, which can freely define its scope. Therefore, making the CССТВ dependent on the laws applicable in non-participating Member States would hinder the reasons for enhanced cooperation.

\footnotetext{
225 It is noteworthy that, since the CCCTB will be optional for companies and does not deal with tax rates, it is possible that a Member State will apply a different tax base for companies that participate in the CCCTB and those that continue to apply the domestic tax base in order to compensate for the different levels of tax liability between those two types of companies (i.e. maintain the same effective tax rate). Member States will continue to decide their own corporate tax rates, as is their sovereign right and the Commission has agreed with such an approach. European Commission (2011c).

226 Cerioni (2006), 189.

227 Kaye (2007), 241.

${ }^{228}$ Cerioni (2006), 190.
} 
The starting point is that the CCCTB Directive is binding only on the Member States (that opt in). 229 Thus, all countries and territories not bound by the Directive will be considered third countries.230 Although the Treaty provisions will mainly influence the application of the CCCTB Directive in intra-EU situations, it is equally challenging to study the effect of the free movement of capital ${ }^{231}$ on situations involving CCCTB Member States and third countries. This is because, even though the application of the fundamental freedoms is generally limited to intra-EU movements, ${ }^{232}$ the freedom of capital movement encompasses both the internal scope in the EU, designed to safeguard the movement of financial assets Member States, and the external scope, concerned with maintaining the free flow of capital or payments between EU Member States and non-Member States. ${ }^{233}$

Furthermore, ideally, all of the EU Member States will opt for the CCCTB regime. However, as seen earlier, the Member States' reaction to the CCCTB proposal from March 2011, on the one hand, and the existing legal framework for enhanced cooperation, on the other hand, allows one to speculate that the CCCTB will be introduced, at least in the first stage, via enhanced cooperation. The

229 Article 52(1) of the TEU provides for the geographical application of the Treaty, i.e. Member States which, according to customary international law and Article 26 of VCLT, are bound to the treaty. Thus, each State that is not mentioned in Article 52(1) of the TEU is not bound to the treaty and is therefore considered to be a third country. However, Article 52(1) of the TEU does not establish the substantive, personal and territorial scope of the fundamental freedoms; the latter is dependent on the actual content and wording of the free movement provision itself. Smit (2011a), 42-43.

${ }^{230}$ Case Commission v Ireland (61/77), para. 46: "[A]s institutional acts adopted on the basis of the treaty, the regulations apply in principle to the same geographical area as the treaty itself."

231 As noted earlier, different to the other fundamental freedoms, the free movement of capital includes both an internal and external dimension. The latter implies that Member States have to grant a similar treatment to third-country nationals as to nationals of the EU Member States. Therefore, for the purposes of this thesis, for situations not involving nationals of EU Member States, only the effects of free movement of capital on the application of the CCCTB will be analysed. With regard to Member States not part of the CCCTB system (i.e. where the CCCTB is prospectively adopted via enhanced cooperation) both the freedom of establishment and the free movement of capital provisions may be considered.

232 The other basic freedoms may only indirectly affect cross-border situations involving non-EU Member States. Fontana \& Tenore (2007), 590-592.

233 Opinion of Advocate General Cruz Villalón delivered on 9 December 2010 on case Prunus and Polonium (C-384/09), para. 20. 
current CCCTB legal framework obviously does not reflect such an outcome (as the Treaties allow the use of enhanced cooperation as a "last resort"). Therefore, the author will also analyse those tax specific aspects in the current dissertation. Thus, for the purposes of the current study, the author divides "third countries" broadly into two main clusters:

1) EU Member States that have not opted for the CCCTB (i.e. CCCTB is introduced via enhanced cooperation); and

2) Non-EU Member States.

Throughout the dissertation, the author will analyse the functioning of the CCCTB in the light of the CCCTB Member States' DTCs with non-participating EU Member States and with third countries.

With regard to the second group of third countries - i.e. all non-EU Member States - several subcategories of third countries can be identified. The sub-categorisation reflects the specific legal relationships between, on the one hand, the EU or Member States and, on the other hand, certain territories outside the EU:

a. Member States of the European Free Trade Agreement (EFTA);

b. Overseas territories and countries of the Member States (OCTs); 234

c. Association and Partnership Countries (APCs);

d. All others.

\subsubsection{DTC-COUNTRIES ${ }^{235}$}

Countries with which the CCCTB Member States have concluded a DTC, including those with non-participating Member States in the setting of enhanced cooperation deserve special attention. The main concern is that one of the essential components of the CCCTB

\footnotetext{
${ }^{234}$ Smit considers that such territories could be regarded either (i) part of a EU Member State and thus subject to freedom of establishment (Article 49 of the TFEU) and free movement of capital provisions (Article 63 of the TFEU); (ii) third countries and hence subject to Article 63 of the TFEU; or (iii) countries with a status of sui generis ("second countries") with a consequence that neither Article 49 nor Article 63 of the TFEU would be applicable. The latter is because, legally speaking, these provisions apply only between Member States and between Member States and third countries. Smit (2011a), 41.

${ }^{235}$ For the purposes of this study, the author will assume that DTCs are based on the 2010 OECD Model Convention, unless explicitly stated in the relevant part.
} 
system lies within the sharing mechanism (formula apportionment), which uses different allocation factors for attributing profits to an enterprise than those used in DTCs (the arm's length principle). ${ }^{236}$ Further issues relate to the elimination of double taxation of inbound and outbound investment and the requirement of non-discrimination in DTCs. In the case of inevitable conflict between the two means of law, one would have to decide which would prevail. On the other hand, Member States are bound by the supremacy of EU law and, according to Article 351 of the TFEU, EU law is regarded as having supremacy over treaty law, subject to a grandfathering clause. On the other hand, Member States have to respect their international obligations which, in the present case, stem from their DTCs. The proposed CCCTB Directive is clear that the Directive will override agreements between (participating) Member States, ${ }^{237}$ but it is silent about the DTCs with third countries. The author considers that the European Commission has been careful in interfering with the Member States' international affairs. A "dictatorial" approach would trigger objections by Member States to all rules which would hinder their international obligations and standards agreed upon by the States, such as those established in Articles 26, 27, 31-33, and 60 of the VCLT. ${ }^{238}$ It appears from the Convention that any conflict with existing DTCs with third countries would not be acceptable: each treaty in force is binding upon the parties and shall be performed in good faith. Therefore, Union law cannot require from Member States to violate their international obligations, not even to a minimum extent, to comply with the principal aims of the EIM. As the author will discuss below in this dissertation, in order to meet the requirements of both EU law and DTCs, Member States may be obliged to give up certain taxing rights without reciprocity on the side of the third country. ${ }^{239}$ Indeed, the supremacy of EU law does not cover third countries. Such a one-way obligation to give up taxing rights and the requirement to renegotiate conflicting provisions of DTCs might dissuade Member States from supporting the CCCTB. Hence, the provisions of the CССТВ Directive require careful drafting.

\footnotetext{
${ }^{236}$ For further discussion, read OECD(2010), 37-41, section c.

237 Article 8 of the proposed CCCTB Directive.

238 Vienna Convention on the Law of Treaties concluded in Vienna, 23 May 1969.

${ }^{239}$ For further analysis, vide infra II7.3.
} 


\subsubsection{Member States of the European Free Trade AGREEMENT}

The EFTA is an intergovernmental organisation between four European countries - Iceland, Liechtenstein, Norway, and Switzerland - that promotes free trade and economic integration to the benefit of its Member States. With the exception of Switzerland, these countries are also part of the Agreement on a European Economic Area (EEA). The EEA Agreement ${ }^{240}$ integrates these three countries into the EIM of the EU without giving them the political rights and obligations as conferred on the EU Member States. ${ }^{241}$ The Agreement includes the acquis communautaire with regard to the fundamental freedoms and competition law, as well as the principle of general non-discrimination clause and prohibition of state aid. Both the CJEU and the EFTA Court have recognised the need to ensure that the rules of the EEA Agreement, which are identical in substance to those of the Treaty, are interpreted uniformly. ${ }^{242}$ It is noteworthy that the EEA Agreement only contains Union law that was in force at the time it was negotiated. Hence, the changes made to the Union law as of the Treaty of Maastricht were not adopted into the EEA Agreement. Thus, for instance, the provisions on the free movement of capital are not equal in the TFEU and the EEA Agreement.243 In addition, the EU direct tax directives, such as the Parent and Subsidiary Directive, are not part of the Agreement as they were adopted under articles that were not part of the EEA Agreement (Article 115 of the TFEU, which is also the basis for the CCCTB Directive). Therefore, these directives are not applicable to EEA Member States. ${ }^{244}$

There is a specific economic and legal connection between the EU and the fourth EFTA country, Switzerland. Unlike the other three EFTA countries, Switzerland opted to conclude bilateral agreements

\footnotetext{
240 Agreement on the European Economic Area (EEA).

${ }^{241} \mathrm{It}$ is noteworthy that the CJEU is competent to interpret the provisions of the EEA Agreement in so far as Union law is concerned. See further Smit (2011b), 347348.

${ }^{242}$ Case Keller Holding (C-471/04), para. 48 and the case law cited therein; EFTA Court case Fokus Bank (E-1/04), para. 23.

243 Thus, the free movement of capital in the EEA Agreement does not have an external scope.

244 However, the cases could still be analysed under other provisions of the Agreement, such as the prohibition of restrictions on the freedoms and the general non-discrimination clause.
} 
with the EU, such as the Free Trade Agreement of 1972, ${ }^{245}$ the bilateral agreement on the free movement of persons ${ }^{246}$ and the agreement of taxation of savings, which includes provisions equivalent to the earlier provisions of the Parent and Subsidiary Directive. 247

\subsubsection{OVERSEAS TERRITORIES AND COUNTRIES OF THE MEMBER STATES}

Rather than being sovereign States with international legal personality, OCTs are integrated into a Member State due to special historical, social and/or political reasons. Even though being formally part of a Member State, ${ }^{248}$ the Treaty applies to them only partially or does not apply at all. Under Article 29 of the VCLT, the Treaty is binding on the States in respect of their entire territory, unless a different intention stems from the Treaty. Indeed, Article 355(2) of the TFEU reflects such a "different intention" of the EU and provides that OCTs are covered by "[t]he special arrangements for association set out in Part Four". Nevertheless, Advocate General Villalón considered in Prunus and Polonium that, even though the Treaty is unclear on the matter, Article 355 of the TFEU read in conjunction with Article 52 of the TEU indicates that the arrangements applicable to OCTs are lex specialis to the general provisions of the Treaty. ${ }^{249}$ Therefore, the provisions applicable to OCTs are not immune to the influence of the general provisions of the Treaties. The Advocate General further concluded that there is no straightforward answer as whether an OTC should be treated as a

\footnotetext{
245 Agreement between the European Economic Community and the Swiss Confederation (1972).

246 Agreement between the European Community and its Member States, of the One Part, and the Swiss Confederation, of the Other, on the Free Movement of Persons (2002).

247 Agreement between the European Community and the Swiss Confederation Providing for Measures Equivalent to Those Laid Down in Council Directive 2003/48/EC on Taxation of Savings Income in the Form of Interest Payments (2004), Article 15. It is worthy to note that the provisions of the named Agreement correspond to the provisions of the Parent and Subsidiary Directive before the Council Directive 2003/123/EC of 22 December 2003, which broadens the scope and improves the operation of the Council Directive 90/435/EEC (now Council Directive 2011/96/EU).

248 The definition of a territory of a Member State is only a matter of domestic law of each State and not the EU law.

249 Opinion of Advocate General Cruz Villalón delivered on 9 December 2010 on case Prunus and Polonium (C-384/09), paras. 28-36.
} 
Member State or a third country. Accordingly, "the answer varies on a case-by-case basis ${ }^{250}$ according to the relevant legal framework and taking into careful consideration the objectives pursued by the special arrangements for association laid down in Part Four of the TFEU."251 Furthermore, in the absence of a specific set of rules in the decisions on association, a general freedom laid down in the Treaty, such as the freedom of capital movement, which is applicable to all third countries without exception, is equally applicable to OCTs. ${ }^{252}$ Likewise, the Court in Prunus and Polonium expressly considered that the OCTs are to be treated as third countries to which the provisions of free movement of capital are applicable. 253

In the same vein, one could argue that OCTs should be treated as third countries also with regard to the freedom of establishment. Since freedom of establishment does not apply to third country nationals, OCTs are not protected by the respective freedom. ${ }^{254}$ Smit argues that one should make a difference between the personal and territorial scope of the freedom(s) to determine whether they are applicable in each particular case. Accordingly, if a company of any OTC of a Member State qualifies as a national of that Member State (ratione personae) under the domestic laws of the latter, it should be regarded a national of the Member State with regard to the freedom of establishment. On the other hand, he recognises that, as per the territorial scope (ratione loci), it is desirable to treat OCTs as third countries to the extent that they are not bound by the freedom of establishment as prescribed in the Treaty. Such a conclusion is confirmed in N., in which the Court has analysed the case based on the freedom of establishment, even though it concerned companies that were established by a national of a Member State but which were effectively managed from one of the OCTs of the relevant Member State. ${ }^{255}$ In the end, for the freedom of establishment to be applicable, both the personal and territorial scope of the provision must be fulfilled. For the purposes of further analysis, third countries will be regarded only those OCTs which fail to meet the personal

\footnotetext{
250 Smit classifies such OCTs into four categories according to the extent that they are bound to the Treaty. Smit (2011a), 47-48.

251 Opinion of Advocate General Cruz Villalón delivered on 9 December 2010 on case Prunus and Polonium (C-384/09), para. 39.

252 Ibid., paras. 57-58.

253 Ibid., paras. 28-31.

254 Smit (2011a), 49-56.

255 Case N. (C-470/04), paras. 11 and 28.
} 
scope of the freedom of establishment, i.e. EU non-nationals. In such cases, only the free movement of capital may be relevant.

\subsubsection{ASSOCIATION AND PARTNERSHIP COUNTRIES 256}

The Union's legal personality includes both internal and external legal capacity, which confers on the Union a treaty-making competence and authorises it to negotiate and conclude treaties with international organisations and third countries. ${ }^{257}$ Thus, the EU relations with third countries extend beyond the TFEU to the extent that the EU participates in international agreements establishing partnerships, associations and cooperative relations with third countries. ${ }^{258}$ Such agreements are binding upon the Union and the Member States. ${ }^{259}$ The Union has entered into a large number of bilateral and multilateral mixed 260 economic integration agreements with third countries - $\mathrm{APCs}^{261}$ - for instance:

(1) Pre-Accession Agreements with EU candidate countries so-called European Agreements;

(2) Association Agreements (AAs) with the Mediterranean States and Chile;

(3) Stabilization and Association Agreements (e.g. Macedonia);

(4) Ankara Agreement with Turkey;

(5) Partnership and Cooperation Agreements (PCAs).

${ }^{256}$ For thorough analysis, see Smit (2011b), 349-369.

257 The Union's legal personality is laid down in Articles 47 of the TEU and 335 of the TFEU. The Court has confirmed the international legal capacity in case Costa $v$ E.N.E.L. (6/64) and case Commission v Council [ERTA] (22/70), para. 14.

258 According to Articles 216 and 217 of the TFEU, the Union may conclude agreements with third countries or international organisations. For general issues concluding external agreements, see Article 218 of the TFEU.

259 Article 216 of the TFEU prescribes that international agreements and commitments are binding on the institutions of the Union and on its Member States (see also the opinion of the Court Inland Waterways (1/76), paras. 3 and 7). Furthermore, because treaties concluded by the Union take precedence over secondary acts of the Union institutions, those acts must be interpreted in the light of the international agreements. As per Member States, the "mixed" agreements are binding also because of public international law stemming from the VCLT enshrining the principle pacta sunt servanda. Bezborodov (2007), 661.

260 These agreements are "mixed" in the sense that they cover areas in relation to which the Union and the Member States have a shared competence to jointly conclude external agreements. Thus, being "mixed" agreements, APCs must be ratified and are binding on two levels: the EU and national level.

${ }^{261}$ European Commission (2007c). 
Typically, APC provisions are more limited in their scope and have broader derogations than the provisions of the TFEU and, hence, cannot provide for complete protection against cross-border restrictions to the free market. ${ }^{262}$ Considering that the APCs differ from each other to a major or minor extent, the analysis of the CCCTB in relation to these third countries will be rather abstract. It is noteworthy, however, that, as a rule, APCs include provisions related to the freedom of establishment ${ }^{263}$ and/or the free movement of capital. ${ }^{264}$ These provisions may not always be reciprocal, whereas greater obligations are typically imposed on the third country vis-à-vis the Union and the Member States. The provisions prescribing the freedoms have a direct effect and are very similar or even equal in their wording and structure to the respective provisions in the TFEU. However, the textual similarity between the two does not imply their similar interpretation. Instead, the freedoms are interpreted with reference to the underlying object and purpose ${ }^{265}$ of the agreements:

\begin{abstract}
"TThe extension of the interpretation of a provision in the Treaty to a comparably, similarly or even identically worded provision of an agreement concluded by the Community with a non-member country depends, inter alia, on the aim pursued by each provision in its particular context and that a comparison between the objectives and context of the agreement and those of the Treaty is of considerable importance in that regard." "266
\end{abstract}

\footnotetext{
262 Bezborodov (2007), 683.

263 However, the freedom of establishment in PCAs AAs typically covers only secondary establishment by means of subsidiaries and branches. Thus, they do not deal with primary establishments. Bezbodorov argues that the freedom of establishment in PCAs and AAs implies only a mere liberalisation of capital, not of enterprise as such, even with regard to the operation of subsidiaries and branches. Ibid., 683.

264 Considering that the provisions of free movement of capital included in the TFEU apply also to situations involving third countries, the PCAs usually enjoy two-dimensional protection from the European Union side: based on Article 63 of the TFEU and based on the provisions of the respective APC.

265 Reference to the object and purpose of an international agreement is in line with Article 31(1) VCLT, which requires a treaty to be interpreted in good faith in accordance with the ordinary meaning of the terms in their context and in the light of their object and purpose.

266 Case Metalsa (C-312/91), para. 11. The Court has reiterated this understanding in case Leyla Ecem Demirkan (C-221/11), forthcoming, para. 47 and case law cited therein.
} 
The first proposition of a harmonisation of corporate taxes appeared in Neumark Report, which put forward three lines of action, including favouring the harmonisation of corporate tax bases and rates throughout Europe. ${ }^{267}$ After several major and minor attempts to step towards more integrated EIM as well as a decade of discussions on CCCTB in both the Commission and the Council, on 16 March 2011, the Commission finally presented the respective draft Directive. The Commission rightly concludes that removing obstacles resulting from the coexistence of Member States systems and thereby improving market access, increasing competition, as well as encouraging investment and innovation has placed the Commission's focus on the CCСТB project. ${ }^{268}$ It believes that companies will only be able to take full advantage of the EIM if they can benefit from a CCCTB for their pan-European activities. ${ }^{269}$

Due to number of political discussions and technical concerns, it has been suggested that, for the purposes of speeding up the adoption of a common corporate tax system, the process of harmonising corporate taxes in the EIM could be introduced in two phases: (i) at first establishing a CCTB and thereafter (ii) developing consolidation and the necessary sharing formula (i.e. the CCCTB).

A CCTB would allow companies to calculate their tax base according to the same set of rules but without consolidation. Although such a system would provide fewer benefits to businesses, the lack of consolidation requirement would make it easier to apply because it would eliminate the need for agreement on a sharing mechanism of a tax base the between the respective Member States while it would also include lower administrative and compliance costs. ${ }^{270}$ However, one may speculate that a CCTB operated independently in each Member State, over the course of time, would be reverted into 28 diverse bases because national interest would overrule the interests of the internal market as a whole. ${ }^{271}$ In addition to that, a CCTB may be less attractive for businesses.

A CCCTB would embrace the element of consolidation in addition to the common set of rules for the calculation of the corporate income

\footnotetext{
267 Thurston (1963), 134-145.

268 European Commission (2012a).

269 European Commission (2004), 1.

270 European Commission (2004), 2-3.

271 European Commission (2006o), para. 3.3.
} 
tax base. Yet, this implies that the Member States need to come to a consensus on the sharing formula, ${ }^{272}$ which may be even more complex than establishing the uniform corporate tax base provisions. Nevertheless, the possibility for consolidation is an essential factor of bringing the greatest benefits to the EIM and contributes most to the Lisbon goals, mainly because it would solve the critical issues of loss off-set and transfer pricing within the group of companies. ${ }^{273}$

An increasing number of businesses, academics and EU officials have come to believe that the solution to the deficiencies of corporate taxation in an integrated market is to switch from the current arm's length/source-rule regimes to unitary formulary taxation similar to those applied by several US states. However, the idea of a CCCTB for EU establishments has found full support neither by all Member States nor by the whole business area. ${ }^{274}$ The four main obstacles brought forward are:

(1) The unanimity vote 275 of the Council of Ministers, but which could be overcome by enhanced cooperation between a number of Member States;

272 According to Chapter 15 of the proposed CCCTB Directive, the general sharing formula consists of three evenly weighted factors: assets, payroll and sales.

Share $\mathrm{A}=\left(\frac{1}{3} \frac{\text { Sales }^{\mathrm{A}}}{\text { Sales }^{\text {Group }}}+\frac{1}{3}\left(\frac{1}{2} \frac{\text { Payroll }^{\mathrm{A}}}{\text { Payroll }_{\text {Group }}}+\frac{1}{2} \frac{\text { No of employees }^{\mathrm{A}}}{\text { No of employees }^{\text {Group }}}\right)+\frac{1}{3} \frac{\text { Assets }^{\mathrm{A}}}{\text { Assets }^{\text {Group }}}\right) *$ Con' $^{\text {d Tax Base }}$

In particular:

- The asset-factor would consist of all fixed tangible assets;

- The labour-factor would comprise of both payroll and the number of employees (each item counts for half); and

- The sales-factor would follow the principle of destination and consist of total sales of a group member (sales by destination).

Furthermore, the proposed CCCTB Directive includes a "safeguard clause" which entitles competent authorities, either on the request of the principal taxpayer or a competent authority, to use an adjusted formula if the general formula does not fairly represent the share of a group member. For sector specific activities, an adjusted formula could be used to reflect the specificities of certain industries (e.g. credit institutions, insurance undertakings, oil and gas industry, and shipping, inland waterways transport and air transport).

${ }^{273}$ European Commission (2006o), para. 3.3.

274 Hrehorovska (2006), 159.

275 Although the Treaty has been amended several times to allow for the adoption of various harmonisation measures by only a qualified majority vote for the Council, a unanimous vote has remained as a rule by the TFEU for tax legislation (Article 115 of the TFEU). The Commission has proposed a qualified majority voting for the introduction of minimum requirements in the tax field and the adoption of coordination provisions in order to remove direct obstacles to the exercise of the Treaty freedoms but has so far not been successful in this respect. Kaye (2007), 
(2) The technical complications of CCCTB has made the Member States more reluctant;

(3) The fear that CCCTB would be a step towards harmonisation of tax rates across Europe; and

(4) From the business perspective, reduction of tax planning opportunities.

\subsubsection{OPTIONAL V COMPULSORY APPLICATION OF CCCTB}

The CCCTB could be established as optional, i.e. eligible companies could choose to apply the СССТВ or national rules, or compulsory, i.e. all eligible companies in the CССТВ jurisdiction would have to apply the CCCTB principles. ${ }^{276}$ Whether the CCCTB should be mandatory or optional should be decided with reference to the ultimate idea of the project: one the one hand, the CСCTB aims to simplify and ease cross-border investment but, on the other hand, reduce profit-shifting opportunities. ${ }^{277}$ As it currently stands, the CCCTB will be introduced as an optional system for companies. 278 This means that even if a Member State participates in the CCCTB via enhanced cooperation, there may be companies of the same Member States that will apply the system and those that will not, depending on their decision of participation. ${ }^{279}$ Even though optional, the proposed CCCTB rules foresee an "all-in/all-out" principle for groups of companies, i.e. companies which fulfil the conditions for forming a CCCTB group have to consolidate if they opt into the system of common rules. Moreover, once the option has been made, it would be effective for five years (including for those companies that cease to be part of the group during the group term) and, unless prior notice is given to the competent authorities, it would be automatically renewed for successive three years. 280

203. To replace the unanimity rule with simple majority or qualified majority as defined in the Treaty (Article 238 of the TFEU), a unanimous vote of all the Member States is required. McLure (2007), 125.

${ }^{276}$ Interestingly, also the possibility to make it compulsory in one Member State and voluntary in another has been pointed out. European Commission (2006a), para. 29.

277 Hey (2008), 95.

278 Article 6 of the proposed CCCTB Directive.

279 To the extent that such a situation does not involve the relationship with third countries, the current dissertation does not address those aspects that arise will due to the choice of companies from EU Member States that make the CCCTB available for their companies.

280 Article 105 of the proposed CCCTB Directive. 
From a functional perspective, in case of an optional system, the intricacy of operating two parallel corporate tax regimes (i.e. the CCCTB and the national rules) might introduce more complexity instead of simplification. Moreover, the uncertainty over some technical aspects, such as the administration of the CСCTB and the overlap with tax treaties, might dissuade companies from opting for the CCCTB. ${ }^{281}$ On the other hand, the optional application of the CCCTB at the business level might encourage Member States' tax legislators to create a close link between the domestic and CCCTB tax base, for instance by using the CССТВ rules as a blueprint for the domestic tax base rules. In such a case, the disadvantage of running two parallel corporate tax systems by Member States would be considerably smaller.

Due to the fact that the primary goal of the CCCTB project is to improve the EIM rather than Member States' domestic economies, the European Commission, together with the European Parliament, is of the opinion that the CCCTB should, in the first place, be introduced as optional for companies. ${ }^{282}$ An elective nature of the CCCTB might more likely gain the support of (all) Member States and business as well design the CCCTB in a manner that makes it as competitive as possible and as simple and uniform as possible across the Union. ${ }^{283}$

\subsubsection{OTHER REMARKS}

The introduction of a common set of rules across the EU would most probably require changes to all member countries' laws. This provides an opportunity to consider various choices in order to reach the most optimal solution. ${ }^{284}$ By doing that, the drafters of the CCCTB must take into account a number of general principles of taxation or rules. The author will list some of these rules below.

\footnotetext{
281 Panayi (2008), 115.

282 European Parliament (2012).

283 European Commission (2006o), para. 3.4.

284 There is a dilemma in the sense that the closer the definition of a tax base is to an optimal one, the more radical are the changes are that the Member States need to make. This, however, might reduce the acceptance of the changes by the latter and therefore threatens the achievement of the new (common) rules. Gammie et al. (2005), 10 .
} 


\subsubsection{NEUTRALITY PRINCIPLE}

Neutrality is a key concept in the economic analysis of corporate taxes. The principle requires that economic decisions should be made without regard to fiscal consequences, i.e. tax considerations should be irrelevant in deciding between different forms of investment or business organisations. ${ }^{285}$ The accomplishment of an EIM is an appearance of the neutrality principle. ${ }^{286}$ Neutrality in taxation is usually analysed from two different perspectives.287 First, capital export neutrality $(\mathrm{CEN})$ aims at home market neutrality so that an investor in a given country faces the same tax, irrespective of the country he invests. CEN is typically achieved by the taxation of the accrued worldwide income of residents by providing the credit method for relieving international juridical double taxation. ${ }^{288} \mathrm{CEN}$ may be associated with the principle of free movement of capital, because it establishes equal treatment between the capital invested at home and that invested abroad and thus it has an effect similar to Article 63 of the TFEU. 289

Second, capital import neutrality (CIN) aims at creating a level playing field for similar investments within the given jurisdiction so that all investors, irrespective of their residence, are taxed in the same way in a given country. CIN is typically realised by applying the exemption method to mitigate international juridical double taxation. ${ }^{290}$ In terms of foreign direct investment, CIN may be associated with the requirement of freedom of establishment and, with regard to portfolio investment, with free movement of capital. ${ }^{291}$

\footnotetext{
285 Rogers-Glabush (2009), 181.

286 Kok (2010), 668.

287 Other public finance concepts related to the principle of neutrality are: (i) "capital ownership neutrality" (CON), which requires that taxation does not influence the incentive to transfer ownership of assets across countries; (ii) "national ownership neutrality" (NON), which aims at maximising national economic welfare by creating a disincentive to invest abroad (without absolute prevention of such investment); (iii) "corporate residence neutrality" (CRN), which requires that all residence states either (1) stop levying corporate income taxes (like in CIN); or (2) impose identical taxes of the type consistent with CEN. McLure (2007), 159.

$288 \mathrm{~A}$ pure CEN system is achieved if all countries operated a pure residence-based tax system or, in other words, if source states exempted the income of foreign investors from tax. Gammie et al. (2005), 13; McLure (2007), 157 footnote 129.

289 Bezborodov (2007), 682.

290 A pure CIN system is achieved if all countries tax profits at source only. Gammie et al. (2005), 13.

291 Bezborodov (2007), 682.
} 
Thus, within the EIM, CIN is particularly important when analysing the competition conditions confronted by economic agents and, compared to (pure) CEN, CIN is easier to administer and more cost efficient. ${ }^{292}$

\subsubsection{EQUALITY PRINCIPLE}

The widely recognised equality criterion (fairness principle) has two dimensions: (i) vertical equity, which requires that taxpayers in unequal situations should be treated unequally; and (ii) horizontal equity, which assumes that taxpayers who are in the same economic circumstances should be treated equivalently. ${ }^{293}$

\subsubsection{ABILITY-TO-PAY PRINCIPLE}

The ability-to-pay principle requires that the tax burden is distributed as evenly as possible according to each taxpayer's economic capacity to bear the burden relative to the other taxpayers. Therefore, residence taxation seems to fit better with the ability-to-pay principle, especially because the residence country is in the position to take account of the personal circumstances of the taxpayer properly and to provide for the redistribution of income. ${ }^{294}$ With regard to corporate taxation, the ability-to-pay principle should be understood from its objective perspective (as opposed to subjective perspective, which applies only to individuals). In particular, the objective abilityto-pay reflects the net principle, according to which expenses related to the generation of certain income should be deducted.

\footnotetext{
${ }^{292}$ European Commission (2001a), 135-136.

${ }^{293}$ European Commission (2001a), 26.

${ }^{294} \operatorname{Vann}(2010), 301$.
} 
Both the United States of America 295 and the European Union 296 were founded in part due to the need for economic unity. According to the US Constitution, all powers not delegated to the federal government are retained by the states and each state is regarded as "sovereign" within its own sphere of operation. To comply with US corporate taxation rules, two distinct sources of laws must be taken into account: national, i.e. federal, and sub-national, i.e. state taxation rules. These two systems were established based on dissimilar means of subjecting businesses to tax. Therefore, businesses in the US must deal with at least two ${ }^{297}$ different sets of rules. Despite that, the fact that the states have adopted comparable tax rules places US firms in an advantageous position compared to multinationals acting globally. Indeed, the states' enhanced application of formulary apportionment is mainly due to the ability to work under the umbrella of the federal tax system and the use of common accounting. These common elements of taxation, in conjunction with the lack of barriers to interstate business and income flows (such as the removal of tax obstacles to cross-state expansions or mergers), provide companies with an environment that motivates them to become functionally integrated, have centralised management and pursue economies of scale. ${ }^{298}$

The discussions on the EU common corporate tax rules have often used the US states' experience as a reference point, given their success in the application of formula apportionment for the purposes of taxing business income. The states' experience shows that formula apportionment can be an alternative method for sharing (unitary) business profits between the states only if the latter use a similar

\footnotetext{
295 The US was formed in 1787 with a view to provide a solution to the mutual envies and aggressions of the states by means of custom barriers and other economic repayments. Kaye (2007).

296 In 1958, the European Economic Community was established and the 1992 amendment to the Single European Act by the Treaty of Maastricht established the European Union.

${ }^{297}$ If a company has business only in one of the US states, it must comply with the rules of federal taxation and that of the particular US state. However, if business is carried out in multiple US states, it must deal with, in addition to the federal system, multiple US states' systems. In some cities, a third level of taxation by means of municipal taxes may additionally be imposed.

298 Graetz (2003), 417.
} 
definition of the tax base. The proposed CCCTB provides for both a common set of rules in terms of determining the corporate tax base as well as a formula for sharing the proceeds from such a tax base. However, due to the differences in the legal framework of the US and that of the EU, the core question is whether the US states' experience can indeed serve as proper reference point for the EU CCCTB. In order to find the answer, the author will first briefly describe the main characteristics and approaches adopted by US states in their taxation system, subject to jurisprudence. The main findings are presented in the conclusion of this chapter.

\subsection{DOING Business In THE UNITED STATES}

The basic legislation ${ }^{299}$ of US taxation is the IRC, a codification of the currently applicable provisions of income tax statutes dating back to 1913. The provisions of the Code have full force as long as they are consistent with the US Constitution. 300 The federal government uses a dual jurisdictional standard and taxes residents ${ }^{301}$ on their worldwide ${ }^{302}$ income and non-residents on their source income. The tax law makes a distinction between domestic and foreign profits, i.e. a multinational corporate group generally isolates the income earned in its foreign operations from the income earned in its domestic operations. For federal tax purposes, the operations of foreign group

\footnotetext{
${ }^{299}$ Following the IRC, the sources of US tax law include hierarchically: (1) US DTCs qualify as a law but do not have overarching priority or precedence compared to the statutes, and vice versa; (2) Treasury Regulations issued by the US Treasury Department expound and expand the Code and have the force of laws as long as they are compatible to the Code; (3) Internal Revenue Service Rulings are issued in response to specific transactions and situations of taxpayers and must be in compliance with both the Code and the Regulations; (4) The American Jobs Creation Act of 2004 is considered to be the most broad-ranging statute on international taxation of the US since the 1986 Act and aims to give incentives for exports. Isenbergh (2005), xv and 224.

300 Signed on 17 September 1787 and ratified in 1789.

${ }^{301}$ The concept of "residence" with respect to corporate taxation is defined in the US as those that are incorporated in the U.S instead of using the concept of "place of effective management." Corporations are considered to be domestic if they are formed under the laws of one of the U.S. states or the District of Columbia, regardless of any other connection to the jurisdiction. All the other corporations are considered foreign (thus, they are organised under the laws of a foreign jurisdiction) irrespective of the extent of the economical connection to the United States' jurisdiction. Weiner (1999), 2.

302 Since adopting the corporate income tax following the $16^{\text {th }}$ Amendment in 1913.
} 
members ${ }^{303}$ are not consolidated ${ }^{304}$ and multinationals have to follow a transaction-based approach based on separate accounts they keep for their affiliates situated in each country.

For non-resident taxation, the federal rules use a source-based approach. The rules differ depending on whether the income is effectively connected to trade or business or whether it is from categories of income known as fixed and determinable, annual and periodical income (non-business dividends, interest, rentals, royalties, etc.). ${ }^{305}$ In addition, US-located branches of foreign companies are subject to a "branch profits tax" correspondent to US business' "dividend equivalent amount" and a "branch level interest tax".306

The US states' corporate tax laws generally employ a source-based principle, ${ }^{307}$ although some provisions reflect residence principles. ${ }^{308}$ Contrary to the federal separate accounting approach, for state tax purposes, multistate enterprises do not price each transaction but they apportion the enterprise's total income to each state according to the share of total business activity located in each state - i.e. through the application of formula apportionment. Formula apportionment can be defined as a method for determining the income of a single enterprise or a group of associated enterprises attributable to a state by reference to a formula that assigns a proportionate share of the enterprise's or associated enterprises' income to the state by reference

\footnotetext{
303 A non-US member of corporate group is subject to tax only on the proportion of its business income that is effectively connected to its trade or business in the US. Peters (2001), 1305. Furthermore, tax on foreign profits of such subsidiaries is deferred until their income is repatriated to the US parent by means of a dividend, subject to anti-avoidance (e.g. subpart F) rules.

304 Ault \& Arnold (2004), 320. For domestic groups, the US has a highly developed consolidation system under which an 'an affiliated group' of corporations must have a domestic parent corporation which owns at least 80 per cent of the stock of another domestic corporation.

305 Pomp \& Oldman (2005), 10-6.

306 Such tax aims to treat certain interest paid by or allowed as a deduction for the US trade or business as if it were paid by a US corporation is applied and, as a result, the recipient of the interest may be subject to a withholding tax on such income.

307 Prima facie, formulary apportionment can be seen as a system of territorial or source taxation in the sense that it forecloses taxation of global profits on a residence basis and represents a method for establishing a geographical link between income and taxing jurisdictions. Thus, it does not constitute a system of source taxation as the term generally accepted in traditional international tax law. Mayer (2009), Chapters 2.3.1.3 and 2.3.1.9.

308 State taxation on "residence basis" means the attribution of income to the location of corporate recipients of that income. Carlson \& Galper (1984), 19.
} 
to the factor or factors that (are deemed to) reflect the underlying income-generating activities within the state. 309 The use of formula apportionment is most relevant when a single taxpayer or a group of commonly controlled corporations conduct integrated economic activity in more than one state (so-called unitary taxation, which will be discussed below). If a state accepts formula apportionment as a method of income allocation of a group of commonly controlled corporations, as a theoretical and practical matter, it should allow reporting of the income of those entities on a consolidated or combined basis. A number of US states apply a "combined reporting" system to report the income of a unitary business. In that case, for computing total taxable income, the parent company treats its out-of-state affiliates as part of a single entity and applies the apportionment factors of the affiliated group of corporations. On the contrary, if a state uses separate company reporting, each member of an affiliated group reports its income to each state on a separate company basis and uses the apportionment factors of the single entity. The author will return to the matter further below.

\subsection{FEDERALISM-BASED LIMITATIONS ON STATE TAXATION}

The US Constitution provides for dual sovereignty between, on the one hand, the federal government and, on the other hand, the US states. The starting point is that the former has limited rights enumerated in the Constitution, whereas the States have powers by default. ${ }^{310}$ In case of concurrent powers of the states and the federal government, one must take into account the principles of supremacy and preemption. ${ }^{311}$ There is a clear tension between, on the one hand, the states' interest in exercising their taxing power and, on the other hand, the nation's desire for fostering economic unity, but the Constitution says almost nothing ${ }^{312}$ about state taxation. ${ }^{313}$

\footnotetext{
${ }^{309}$ Hellerstein (2005), 105.

310 Mitroyanni (2008), 75

311 Supremacy clause of the Constitution (US Constitution Article VI) means that valid federal law overrides otherwise valid state law in cases of conflict between the two. Preemption, by contrast, means that states are deprived of their power to act in a given area, regardless of any conflict with federal law. In other words, states lose their concurrent lawmaking powers through pre-emption by Congress. There is no explicit preemption clause in the US Constitution and its source has been subject to discussion in literature. Read, for instance, Gardbaum (1994), 767-815.

312 Except the Import-Export Clause (U.S. Constitution, Article I, Section 10, Clause 2) and the Duty of Tonnage Prohibition (U.S. Constitution Article I, Section 10, Clause 3).

313 Hellerstein (2007), 68.
} 
Furthermore, even though Congress ${ }^{314}$ is essentially not restricted in limiting or expanding the states' taxing rights (at least as far as it concerns the interstate ${ }^{315}$ commerce), it has enacted relatively little legislation in this respect. ${ }^{316}$ Still, the US states' freedom to levy taxes is limited by two fundamental constitutional principles: the Commerce Clause and Due Process Clause, ${ }^{317}$ which will be discussed below.

\subsubsection{FEDERAL RESTRAINTS}

The fact that the US Constitution does not contain a unanimity requirement, such as that in the TFEU, allows the states enjoy less freedom from legislative restrictions imposed from above compared to the EU Member States, although the latter must nevertheless exercise their sovereignty subject to judicially imposed constraints similar to those in the EIM rules. ${ }^{318}$ In the light of the Preemtion Clause, states are deprived of their power to act in a given area, regardless of any conflict with federal law. Therefore, while in the EU the Member States have unanimously agreed to give the EU exclusive competence in a specific field, the absence of such a unanimity requirement in the US gives Congress broader rights to deprive the states of concurrent lawmaking powers. Furthermore, the states' taxation powers have been limited due to the US constitutional clauses of commerce and due process. The Commerce Clause the Due Process Clause, or both, have been interpreted by the US Supreme Court to restrict state apportionment of income and other state measures of multistate or multinational enterprise to the unitary business performed in the state. ${ }^{319}$

\footnotetext{
314 I.e. the US House of Representatives and the US Senate.

315 Corporations that have all their activities only in one state are normally referred to as "in-state" or "intrastate" corporations. Corporations that conduct their activities in more than one state are usually called "multistate" or "interstate" corporations.

316 Hellerstein (2007), 69.

317 It is noteworthy that the US Constitution Article I Section 8 Clause 18 provides for the "Necessary and Proper Clause", which has been understood to authorise Congress's actions, even if they are not express constitutional powers that serve to accomplish other policies within the express constitutional powers. The preemption clause is presumably derived from the Necessary and Proper Clause. Gardbaum (1994), 781-782.

318 McLure (2007), 139.

319 Hellerstein (1984), 68.
} 
It is interesting to note that, despite the general definition of the two clauses in the Constitution without a specific reference to taxation, the US Supreme Court has developed a comprehensive tax-specific interpretation of the clauses over the years. The jurisprudence of the Supreme Court, therefore, seeks to create a balanced allocation of taxing rights within the federal framework and, thereby, protect interstate commerce from multiple and discriminatory taxation. ${ }^{320}$ One can argue that, instead of granting Congress the explicit power of imposing restrictions on US state taxation, the US Supreme Court has adopted for itself the "institutional role of declaring state legislation, which impeded the free flow of commerce, unconstitutional" and, thereby, become the protector of common market. ${ }^{321}$ By comparison, since Van Gend en Loos, in which the Court held that the Community constitutes a new legal order of international law $\mathrm{l}^{322}$ for the benefit of which states have limited their sovereign rights, ${ }^{323}$ and Costa $v$ Enel in which the Court articulated that the Treaty has created its own legal system that binds the Member States, ${ }^{324}$ the CJEU has been accused of having its own agenda - to aim for stronger harmonisation within the EU. 325

\subsubsection{The COMMerce Clause}

Initially, the Articles of Confederation granted the states (but not Congress) the power to regulate foreign and interstate commerce. Such a distribution of power turned out to be impracticable, because it allowed the states to continue their hostility towards cross-border commerce, and it also indicated to the states' inability to deal cohesively with foreign trade relations. Consequently, the Federal Constitution replaced the Articles of Confederation in order to bring national economic unity, without discriminatory and retaliatory state retaliation against commerce from other states and countries. ${ }^{326}$

\footnotetext{
320 Mitroyanni (2008), 75-76.

321 Schoettle (1984), 85-86.

322 See e.g. Witte (de) (2010); Avella (2012), 101-105.

323 Case V an Gend en Loos (26/62).

324 Case Costa v E.N.E.L. (6/64), para. 3: "By contrast with ordinary international treaties, the EEC Treaty has created its own legal system which on the entry into force of the Treaty, became an integral part of the legal system of the Member States and which their courts are bound to apply".

325 For further discussion on the Court's role, see Hosson (2006), 294-304.

326 Pomp \& Oldman (2005), 1-1.
} 
Under the Commerce Clause, the US Congress has the power to regulate commerce with foreign Nations and among the several States and with the Indian Tribes. ${ }^{327}$ The clause has three areas of application: (i) the Foreign Commerce Clause, ${ }^{328}$ (ii) the Interstate Commerce Clause, ${ }^{329}$ and (iii) the Indian Commerce Clause. ${ }^{330}$ Thus, by its terms, the Commerce Clause is an affirmative grant of power to Congress to enact laws that restrict states power over activity affecting commerce. When Congress enacts laws within the scope of the Commerce Clause, these laws preempt any state law in a given area.

In the light of the above, the Commerce Clause of the US Constitution explicitly grants Congress the power to regulate commerce, while it remains silent about the rights and obligations of the states. However, the US Supreme Court has construed this affirmative grant as including implied restraints on permissible state action even in the absence of congressional legislation limiting state power. The judicially-developed principle prohibits the states from regulating interstate commerce by passing legislation that improperly burdens or discriminates ${ }^{331}$ against interstate commerce. ${ }^{332}$ Therefore, the clause is known as the "dormant" or "negative" Commerce Clause. ${ }^{333}$

327 U.S. Constitution (Article I, Section 8, Clause 3).

328 The Foreign Commerce Clause was invoked by US Supreme Court in case Japan Line (441 U.S. 434) and it aims to promote uniformity and to allow the federal government to set an appropriate, uniform level of regulation of trade with other nations. Wilson (2007), 753.

329 The Interstate Commerce Clause has been used to invalidate a state measure as unconstitutional in three ways: (1) facial discrimination against interstate commerce (unless there is no other way for the state to accomplish a legitimate goal); (2) if a law is not facially discriminatory, but has discriminatory purpose or effect, and (3) if a law is facially neutral but creates undue burden on interstate commerce. Wilson (2007), 749-750.

${ }^{330}$ For the purposes of the current dissertation, the first two clauses, the Foreign Commerce Clause and the Interstate Commerce Clause, deserve more attention.

331 In this context, "discrimination" implies differential treatment of intrastate and interstate economic interests that benefits the former and burdens the latter.

332 Even though the Commerce Clause does not say anything about taxation or even contain guarantees akin to the single market provisions in the TFEU, the US Supreme Court's interpretation of the provision has effects analogous those to the single market. McLure (2007), 135.

333 "Dormant" because the restraints on state action remain inactive until the Court invokes them to invalidate state legislation; "negative" because they reflect the "negative implications" of the Commerce Clause. Hellerstein \& Hellerstein (1998-), 4.01. For further discussion on the dormant Commerce Clause, see Slattery (2009), 1243-1280. 
The Commerce Clause has been one of the principal sources for judicial doctrine setting restrictions on state taxation on cross-border activities since the late $19^{\text {th }}$ century. ${ }^{334}$ In respect of taxation, throughout the years, the US Supreme Court has interpreted the Commerce Clause in three different ways:

(1) All state regulation or taxation of interstate commerce is prohibited;

(2) The states have the power to regulate and tax interstate commerce unless prohibited or pre-empted by Congress; or

(3) The states have the power to regulate or tax some, but not all, interstate commerce, subject to limitations imposed by the Court in the light of the (dormant) Commerce Clause. ${ }^{335}$

In Smith v. Alabama ${ }^{336}$ and Freeman v. Hewit, ${ }^{337}$ the US Supreme Court differentiated between the "direct" and "indirect" impact on commerce and prohibited any state taxation imposed directly on an interstate transaction, despite its fair apportionment and nondiscriminatory nature. ${ }^{338}$ However, in Complete Auto Transit, ${ }^{339}$ the US Supreme Court repudiated such form over substance approach and ruled that state taxes are in principle constitutional, so long as the taxpayer does not prove otherwise. Complete Auto Transit provides for a "four-prong test" of the Commerce Clause, according to which state taxation on cross-state business within a state is legitimate, provided that:

(1) it is applied to an activity "with substantial nexus on the taxing State";

(2) it is fairly apportioned;

(3) it does not discriminate against interstate commerce; and

(4) it is fairly related to the services provided by the State. ${ }^{340}$

In Japan Line, 341 the US Supreme Court for the first time explicitly and clearly held that foreign commerce is entitled to a broader scope of judicial protection under the Commerce Clause than interstate commerce, because it suffers from a greater risk of multiple taxation and implicates federal policy towards other nations. Thus, with regard

\footnotetext{
334 Kaye (2007), 223.

335 Pomp \& Oldman (2005), 1-2.

336 Case Smith v. Alabama (124 U.S. 465).

${ }^{337}$ Case Freeman v. Hewit (329 U.S. 249).

338 Mitroyanni (2008), 78.

${ }^{339}$ Case Complete Auto Transit Inc. (430 U.S. 274).

${ }^{340}$ Houghton, Hogroian \& Weinreb (2004), 458, and Kaye (2007), 225.

${ }^{341}$ Case Japan Line (441 U.S. 434).
} 
to Foreign Commerce Clause, the court supplemented the four-prong test with two additional prongs:

(1) whether the tax creates a substantial risk of international multiple taxation; and

(2) whether the tax impairs ${ }^{342}$ federal uniformity with regard to the regulation of commercial relations with foreign governments (i.e. speaking with "one voice").

The Court, however, distinguished Japan Line, which involved a property tax, from Mobil Oi ${ }^{343}$ in which it rejected the argument that Vermont income tax on dividends from its foreign subsidiaries was in conflict with the federal policy of avoiding double taxation of international income and, thus, contrary to the Commerce Clause. ${ }^{344}$

Some scholars argue that the prohibition on discriminatory taxation based on the Commerce Clause has served its historic purpose to create a single market in the US and should now be left aside. In addition, the US Supreme Court has noted that its judicial application of constitutional principles to the large number of state tax cases has left much room for controversy and confusion and little precise guidance for the states in the exercise of their taxing power. Moreover, it has become difficult to differentiate convincingly between prohibited tax discrimination and generally permitted direct government subsidies ${ }^{345}$ (the EU has avoided such inconsistencies via state aid provisions laid down in the TFEU). ${ }^{346}$

\footnotetext{
342 According to the US Supreme Court, one must make a distinction between state law that has "foreign resonances" and those that "implicate foreign affairs". According to the Court, there are two factors that are relevant to determine whether a state regulation actually implicates foreign affairs and thus violates federal policy: (1) it implicates foreign policy issues, which must be left to the Federal Government, or (2) violates a clear federal directive. Case Container Corp. (463 U.S. 159).

343 Case Mobil Oil Corp. (445 U.S. 425).

${ }^{344}$ Hellerstein (1984), 61.

345 See further Hellerstein \& Coenen (1996), 789-878.

346 Kaye (2007), 226, 240-241.
} 
The Due Process Clause of the Fourteenth Amendment ${ }^{347}$ consisting of procedural, substantive, and jurisdictional aspects 348 assures that states must operate within the law and provide fair procedures. In respect to state taxation, the US Supreme Court invoked the Clause to invalidate states' extraterritorial taxation in 1903 (i.e. 35 years after including the Clause in the US Constitution). ${ }^{349}$ The Due Process Clause imposes essentially two restrictions on state taxation of cross-border activities, as confirmed in Moorman: 350

(1) No tax may be imposed unless there is some definite link, some minimal connection (or nexus) between the taxing State and the person, object, or activity over which it is asserting jurisdiction; and

(2) The value attributed to the State for tax purposes must be rationally related to values connected with the taxing State. 351

It follows that both the Commerce Clause and the Due Process Clause limit a state's taxing right if (i) the "nexus" 352 between the form of economic activities or physical presence between the state

\footnotetext{
347 Amendment XIV (1868) Section 1: "[N]or shall any State deprive any person of life, liberty, or property, without due process of law." There is also a Due Process Clause of the Fifth Amendment, which restricts the Federal Government.

348 Pomp \& Oldman (2005), 3-1.

${ }^{349}$ Hellerstein (1984), 64.

350 Moorman Manufacturing Co. (437 U.S. 267).

351 The division of income or other tax base of businesses by formulary apportionment has been challenged several times under the Due Process Clause. However, it has been rejected by the US Supreme Court on the ground that there is no violation as long as the method used is "fairly calculated" to divide the portion of income between states. Hellerstein (1984), 65.

352 Even though each state has its own statutory definition of "nexus" or "doing business" in the state, these definitions are subject to overriding constitutional restraints. It is generally expected that a company must either have employees or rent or own property in a state to have a nexus there. In addition, in contrast to national nexus (or PE) rules, nexus for state corporate income tax purposes may exist even without a physical presence in the state, unless restricted by Public Law 86-272 (involving nexus in connection with income from the sale of tangible personal property in interstate commerce). Fox et al. (2009), 398. Public Law 86-272 was enacted in 1959 as a reaction to Northwestern States Cement Co. (358 U.S. 450), which held that the states could tax income derived from interstate commerce. The statute prevents states from taxing non-domiciliary corporations that only solicit orders for sales of tangible personal property to be filled by shipment from outside the state. Hildreth, Murray \& Sjoquist (2005), 829.
} 
and the person, object, or activity is insufficient, or (ii) the income is not fairly apportioned. It is noteworthy that the "nexus" requirement contained in the two clauses is not identical, although, as the U.S. Supreme Court in Quill 533 noted, the distinction has not always been precise in the Court's jurisprudence. The Court further explained that the nexus requirement in the two clauses reflects different constitutional concerns and policies. The nexus requirement of the Commerce Clause is informed not so much by concerns about fairness for the individual defendant, like under the Due Process Clause, as by structural concerns about the effects of state regulation on the national economy. In other words, the principal concern of the Commerce Clause is national economic unity and the effects of state regulation on the national economy. ${ }^{354}$ The Due Process Clause, on the other hand, focuses on the fundamental fairness of the government activity in a sense that it requires the connection, which a taxpayer has with a state, to be substantial enough for the latter to exercise its taxing right over him. While the "substantial nexus" requirement of the Commerce Clause implies the existence of some physical in-state presence with regard to the requirement that a seller collect retail sales taxes on sales to in-state consumers 355 intrastate presence, such a requirement is not present under the "minimum contact" test of the Due Process Clause. ${ }^{356}$

With regard to the second restraint on state taxation - the tax must be fairly related to the intra-state presence of the person, property or transaction - the Court has not made an explicit distinction between these requirements of the Commerce Clause and the Due Process Clause. However, the Court has observed that the 'fairness' condition includes both theoretical and practical components. According to the former element, the apportionment formula shall not be inherently arbitrary, so that the imposition of the formula by every jurisdiction would lead to over-taxation of the income of a unitary business. In addition, the factor or factors must reflect a reasonable sense of how income is generated. From the practical fairness consideration, the

\footnotetext{
353 Case Quill Corp. (504 U.S. 298).

354 Hellerstein (2007), 109, 111.

355 Most state courts have held that the physical-presence requirement has no application to state corporate income taxes, although the US Supreme Court has not addressed this question.

356 Case Quill Corp. (504 U.S. 298).
} 
formula must not project the taxing right of the state plainly across its borders, and may not create grossly distorted results..$^{357}$

In light of the above, the constitutional principles of the Commerce Clause and the Due Process Clause play an important role in the US market integration. One notices that these principles are fundamentally different from the "equal treatment" requirement found in the Treaties. ${ }^{358}$ For instance, the US non-discrimination clause contained in the Commerce Clause is not the same as the EU non-discrimination clause, because it compares the treatment of intrastate with interstate economic interests, rather than relying on a comparability-justification test based on nationality, as explained afore.

\subsubsection{THE US BILATERAL DTCS}

In contrast to the EU Member States, the US states were not independent nations at the time they began to impose income taxes, and they have never been allowed to conclude DTCs. ${ }^{359}$ The US DTCs, negotiated at the federal level, generally provide that they apply to, amongst others, federal income taxes as imposed by the IRC. Therefore, the US DTCs generally do not apply to state and local income taxes and corporate franchise taxes, except the nondiscrimination provisions. ${ }^{360}$ Following this premise, the US DTCs do not directly limit the states from exercising their taxation over income from businesses, which create a sufficient nexus with the state. ${ }^{361}$

A question whether the US DTCs prevent state taxation indirectly should be analysed by reference to the states' statutory language. But, even if a state's legislation defines gross business income with reference to the definition provided for in the IRC, it does not necessarily mean that income, which is exempted from federal tax due to effective DTC, is also exempted from state taxation. For instance, even if the US does not levy (federal) corporate income tax

\footnotetext{
357 Hellerstein (2007), 113-114.

358 The only connection between those two is probably that both of them were allocated tax-related content largely due to the respective Court's jurisprudence (i.e. the Supreme Court in the US and the CJEU in the European Union). Mitroyanni (2008), 81-82.

359 McLure (2007), 140.

360 Article 24(7) US MC 2006 extends its scope to taxes imposed by political subdivisions and local authorities.

361 Faber (2000), 1047.
} 
over the business income of a foreign entity due to the absence of a permanent establishment in its territory, the states almost invariably claim tax on the gross income of the business if the latter satisfied the broad nexus condition within that state's jurisdiction, as limited by the Constitution. ${ }^{362}$ On the other hand, the IRC Section 894(a)(1) requires the provisions of the code to be applied to any taxpayer with due regard for any DTC obligations of the US which would apply to such a taxpayer. Hence, income, which is exempted due to a DTC, shall not be included in the gross income of the relevant taxpayer under the federal rules. However, it is unclear whether this provision also limits states' taxing rights if its legislation makes a reference to the gross income as defined in the IRC. ${ }^{363}$

In sum, the relationship between the US DTCs and state taxes is somewhat vague, although the general understanding is that DTCs do not affect the US subnational taxation. This problem, however, is often solved in practice because many states provide statutory and administrative exemptions and safe harbour rules to simplify matters and enhance in-state business interests. ${ }^{364}$

\subsection{THE SUB-NATIONAL APPROACH}

As referred to above, the states employ a type of mixed system of source and territorial-based taxation (although non-business income is often assigned to the state of commercial domicile, i.e. to the "residence" state). There are two main approaches to imposing state taxes: (i) levying a franchise $\operatorname{tax}^{365}$ on the privilege of conducting business in the state, as measured by net income, or (ii) directly taxing the income derived from or attributable to the state. ${ }^{366}$

It was discussed earlier that, to the extent that the states respect the constitutional principles, they are substantially sovereign with regard to setting their taxation rules. 45 states and the District of Colombia have broad-based corporate income tax. The corporate income taxes have many similar features and they share many common concepts

\footnotetext{
362 Ibid., 1048-1049.

363 Ibid., 1049.

364 Mayer (2009), Chapter 3.2.3.

365 The term "franchise tax" in state taxation refers to income taxes, capital stock taxes, or property taxes imposed on a corporation.

366 Pomp \& Oldman (2005), 10-5.
} 
and doctrines. ${ }^{367}$ In fact, the federal definition of income serves to be a starting point in almost all states for calculating the (preapportionment) taxable income, which is thereafter modified on state-specific basis. ${ }^{368}$

Another significant source of influence on state corporate income taxes with respect to the uniformity of concepts and doctrines ${ }^{369}$ is the Uniform Division of Income for Tax Purposes Act UDITPA, published by the NCCUSL ${ }^{370}$ and the American Bar Association in 1957. A large number of the states with corporate income taxes have adopted the model statute and the income tax laws of most nonUPIDTA states also generally conform to the UDITPA. ${ }^{371}$

UDITPA and almost all states give separate accounting (as used for the US federal tax purposes as well as by most countries) a secondary importance. Instead, formula apportionment ${ }^{372}$ and specific allocation are considered dominant methods. ${ }^{373}$ Typically, there are two main steps a corporation has to take to calculate its taxable income in a particular state. First, it has to calculate its total taxable base. In general, corporate income is divided into two categories: (i) business income and (ii) non-business income. ${ }^{374}$ Non-business income is

\footnotetext{
367 Ibid., 10-1.

368 McLure (2008), 20.

369 Interestingly, even though the UDITPA offered a common basis for the interstate distribution of corporate income, many other essential issues, such as nexus, were not included.

370 The NCCUSL was formulated by seven states with a view to creating uniformity in state laws in the late $19^{\text {th }}$ century. Ten years after its creation, all the states had appointed their representatives to the NCCUSL. Hildreth, Murray \& Sjoquist (2005), 827.

371 The fact that about half of the 45 states with corporate income taxes have adopted the model statute and the income tax laws of most non-UPIDTA states generally conform to UDITPA shows that UDITPA provides a modicum of uniformity. McLure (2008), 20. However, there has been a growing tendency for states to deviate from UDITPA. Only eight states still retain the original equally weighted three-factor formula; most states have double-weighted sales formulas and close to ten have single-sales factors.

372 "Apportionment" in general terms indicates the application of some kind of fraction to distribute an aggregate income between different jurisdictions. "Formulary apportionment" (or the synonymous terms "formula apportionment" or "formulary allocation") refers to a method by which a predetermined formula is used for cross-border apportionment of income between appropriate jurisdictions. Mayer (2009), Chapter 2.

373 Pomp \& Oldman (2005), 10-1.

374 The MTC subjects the determination of business and non-business income to a "transactional" and "functional" test. Under the "transactional test", business
} 
generally assigned to a designated state by using specific allocation rules. By far, the most important type of non-business income is income from intangible financial assets, such as interest and dividends. ${ }^{375}$ Generally, non-business income from intangibles is typically allocated to the taxpayer's commercial domicile (i.e. residence-principle), which may be different from the state where the business is incorporated and non-business income from tangible property is allocated to the state of situs of the tangible property.

The second step is to use a formula apportionment (either based on the Massachusetts formula ${ }^{376}$ or an adjusted formula ${ }^{377}$ ) to the taxing state to identify what portion of business income (as calculated in step one) compared to the total income of a corporation may be taxed by a state with which the necessary nexus exists. ${ }^{378}$ To apply the formula, the state must determine the percentages according to the formula it has chosen: the numerator of each factor would be the in-state amount of the respective factor, and the denominator is the total amount of the factor for the company. ${ }^{379}$ The (typically) three percentages are averaged to reach a single percentage - so-called apportionment percentage. The income attributed to a state via apportionment formula is thereafter taxed at the state's statutory tax rate.

As Pomp and Oldman put it, corporate income should ideally be seen as a pie: formula apportionment should determine the size of a state's

income comprises only income that arises from transactions and activity in the regular course of business. Under the "functional test", business income also includes income arising from the acquisition, management, and disposition of property that forms an integral part of the taxpayer's regular trade or business operations. MTC (1973), Reg. IV.1.(a).

375 Note that a substantial amount of such income is still treated as apportionable business income.

376 The Massachusetts formula assigns equal weight to fractions of total payroll, property and sales (gross receipts).

377 Over the past three decades, the states have gradually given up the equally weighted three-factor formula in favour of formulas that assign a greater (if not exclusive) weight on the sales factor.

378 Pomp \& Oldman (2005), 10-1.

379 It is noteworthy that, while the proposed CCCTB's sharing formula attributes income to group members (i.e. not to taxing jurisdictions), the US states use the formula to assign the income of a corporate taxpayer (or a combined group of corporate taxpayers) to various states. A typical subnational formula would thus appear as follows:

Share State A $=\left(\frac{1}{3} \frac{\text { State A Sales }}{\text { Total Sales }}+\frac{1}{3} \frac{\text { State A Pay roll }}{\text { Total Payroll }}+\frac{1}{3} \frac{\text { State A Property }}{\text { Total Property }}\right) *$ Tax Base 
slice of the pie. Non-business income can be imagined as a scoop of ice-cream that a state gets in addition to the slice of the pie. ${ }^{380}$ Since the rules of corporate income tax base calculation as well as the apportionment formulas 381 differ among the states, some part of company's income may be taxed twice whereas some of it may be under-taxed.

A multistate business income is typically reported either by means of separate, consolidated or combined reporting. Under the separate reporting method, each individual company having a nexus in a state has to file a return including the income of that individual company and then apportion the income according to the formula set by that state in which the numerator represents the instate activity and the denominator represents the total "everywhere" of each factor of the company. ${ }^{382}$ Consolidated and combined reporting are alternative ways of treating separate corporations as a group (with offset of intragroup losses and gains and other transactions).

\subsubsection{FORMULA APPORTIONMENT}

The states have developed three general approaches for determining taxable income of a corporation, which would comply with the US Constitution: (i) separate accounting, (ii) formula apportionment and (iii) specific allocation. Formulary apportionment is the dominant method used by states and the US Supreme Court has granted considerable latitude in applying this approach. The states have a broad leeway to design their formulas, as long as they comply with the principles established by the Commerce Clause and Due Process doctrine. ${ }^{383}$

Formulary apportionment was first used in the late $19^{\text {th }}$ century in connection with the determination of property tax obligations of transcontinental railroad companies. ${ }^{384}$ Wisconsin, being the first to

\footnotetext{
380Pomp \& Oldman (2005), 10-1.

381 Contrary to the US sub-national approach, it has been acknowledged from the outset that the harmonisation of corporate income tax bases within the EU would include a uniform definition of group and tax base. In addition, different from the US states' practice, the CCCTB Member States would not be able to change the preestablished apportionment formula to reflect their specific interest, subject to the "safeguard clause" mentioned afore.

382 Fox et al. (2009), 399.

383 Kaye (2007), 239.

${ }^{384}$ Roin (2010), 20.
} 
introduce corporate income tax, found the separate accounting to be too impractical because only a few corporations kept state-by-state calculations of income. Hence, it approached corporate taxation by relying on a formula based on "business transacted" and "property located" within or outside the state. ${ }^{385}$ Later formulas incorporated a payroll factor in addition to the property factor. However, because these factors tended to apportion income to states where the production took place, it became politically unacceptable to the states that had a little or no portion of production but served as the market for goods produced elsewhere. Thus, a sales factor was added to the formula. 386

The application of formula apportionment by a number of US states pushed the separate accounting method aside by the late 1930s. However, the application of formula apportionment by a large number of states made the states as well as taxpayers concerned about the lack of uniformity in corporate taxation rules. A committee of the National Tax Association reacted to such concerns by introducing a model multistate business income tax in 1922, recommending implementing an evenly weighted three-factor property, payroll, and sales ${ }^{387}$ - formula developed by Massachusetts. $^{388}$ In 1957, the National Conference of Commissioners on Uniform State Laws and the American Bar Association published the UDITPA. This document can be regarded as the basic document to support the application of uniform tax rules at the US sub-national level and which includes the recommendation for the three-factor apportionment formula. 389

Until the early 1980s, virtually all states employed UDITPA's evenly weighted three-factor formula. After Moorman, ${ }^{390}$ in which the Iowa's use of the so-called single-factor sales formula was not considered incompatible with the US Constitution, there has been a shift to assign greater weight (typically one half) to sales and a correspondingly lower weight to payroll and property. ${ }^{391}$ Whatever the proportion of the factors is, the sum of the weights must equal

\footnotetext{
385 Ibid., 20.

386 Pomp \& Oldman (2005), 10-13.

387 Since the term "sales" includes also other receipts than sales, some authors use the term "revenue" or "receipts" instead.

388 Roin (2010), 21.

389 McIntyre (2004), 920.

390 Moorman Manufacturing Co. (437 U.S. 267).

391 McLure (2008), 20.
} 
one (1) in order to avoid over-apportionment and underapportionment of the firm's net income to each state which has the respective taxing jurisdiction. ${ }^{392}$ The idea of assigning a heavier weight to the sales factor is to apportion the income of manufacturing and merchandising businesses between the production state and the market state in a more balanced way. Due to differences in states' apportionment formulas and the application of nexus rules, the amount of income to be allocated is typically less than the total income of a business. ${ }^{393}$

Not all of a corporation's income is necessarily subject to apportionment. A state cannot tax business income in the absence of a sufficient nexus between the state and the income. In that case, an alternative method is to use "unitary business" 394 taxation, which is also accepted by the US Supreme Court. ${ }^{395}$ The latter is used to combine functionally integrated operations of a multinational enterprise (or a single company) into a single taxable unit and the income of such a "unitary business" is divided between the state and the rest of the world based on a formula, taking into account the corporation's activities related to the particular jurisdiction. However, even in the case of the "unitary taxation" approach, a part of a corporation's income may remain outside of apportionment, i.e. nonbusiness income or investment income. As mentioned earlier, such income is normally subject to specific allocation rules that generally allocate the income to only one state, instead of dividing it among several states. ${ }^{396}$

\footnotetext{
${ }^{392}$ Dubin (2010), 563.

${ }^{393}$ Fox et al. (2009), 399.

394 The term "unitary" is derived from the U.S. Supreme Court requirement that a state cannot require a related corporation which does not have a direct nexus with the state to include its income in a combined report unless it is engaged in a unitary business with one or more related entities which do have a direct nexus with the state. See McIntyre (2004), 917.

395 In Case Mobil Oil Corp. (445 U.S. 425), the U.S. Supreme Court noted that the "linchpin of apportionability in the field of state income taxation is the unitarybusiness principle". Thus, the income of a group of corporations from conducting a unitary business has a nexus with all of the states in which the unitary business in conducted. Further, it follows from Allied-Signal (504 U.S. 768) that a state can have a nexus to tax a unitary business even on income that is generated by the out-ofstate business if those activities had a sufficient link to the in-state activities. 396 Pomp \& Oldman (2005), 10-26.
} 


\subsubsection{UNITARY TAXATION}

Every state must apply the concept of "unitary taxation", which is either mandatory or elective for businesses, to determine a taxable group. ${ }^{397}$ This obligation lies with the fact that federal constitutional principles limit the states' ability to include income in the taxpayer's apportionable tax base to income arising from a unitary business. ${ }^{398}$ Unitary taxation rests on a number of principles created for computing corporate tax base at the sub-national level and is closely related to the tax base division via formulary apportionment. The objective of such a method is to levy taxes on a portion of the income of a multinational enterprise while disregarding the organisational borders of that enterprise. ${ }^{399}$ Therefore, contrary to the arm's length principle, which treats the members of a group as independent entities pursuing individual goals, the principal theory of unitary taxation is that the income earned by a group engaged in a common enterprise is effectively the income of the enterprise and not the income of the members of that enterprise. 400 There is a conceptual clash between the arm's length method and unitary taxation: the former is fact-specific and applied on transaction-bytransaction basis, while the latter is fully formulaic and computed by reference to (global) figures accumulated on an annual basis. ${ }^{401}$

The concepts "formula apportionment" and "unitary taxation" are not equivalent. The former refers to the process of using a formula to assign a portion of the total income of a company and its branches, which operate in several jurisdictions, to each individual location. The latter refers to the process of combining functionally integrated operations of a multiple-entity affiliated corporate group, which operate as a single economic enterprise, into a single unit for taxation purposes. In the case of a single corporation having activities in more than one state, unitary taxation allows a state to determine the entity's entire income by formulary apportionment if the activities constitute a unitary business. All the states that tax corporate income have implemented formula apportionment, but only some of the states

397 Note that a corporate group or even a single company may simultaneously conduct more than one unitary business. In that case, a state can tax an apportioned share of the income of a unitary business only to the extent that is carried out in part within that state.

398 Case Container Corp. (463 U.S. 159).

399 McIntyre (2004), 917.

400 Ibid., 923.

401 Houghton, Hogroian \& Weinreb (2004). 
have extended the corporate income tax to cover the multiple entities of a unitary business, while the others restrict the scope of the formula to separate entities. ${ }^{402}$

The unitary taxation first originates in the field of property taxation of railroads, telegraph and express companies in the late $19^{\text {th }}$ century. When the states enacted income taxation, the methodology was almost immediately adapted to determine "source" in cases where businesses conducted their activities in several jurisdictions. ${ }^{403}$ Hence, increased capital mobility called for the establishment of the unitary taxation principle in order to fit the US market in its first steps towards integration. ${ }^{404} \mathrm{It}$ is based on the theory that activities in each of the states where a company is active contribute to its overall business. The system apportions the profit of a unitary group to the states on a mathematical "approximation" of the income "that is reasonably related to the activities conducted within the taxing state." 405

The unitary taxation approach has abandoned the need to look at each individual entity and make a difference between source- and residence-based taxation. ${ }^{406}$ Members of the unitary business are combined and effectively treated as a single unitary business, irrespective of legal or geographical borders. 407 To be part of a unitary group, a corporation must undertake a common enterprise with the other members of the group. What counts is the fact that the commonly controlled corporations and divisions of the group must be engaged in an integrated economic activity. ${ }^{408} \mathrm{It}$ is assumed that the various parts of a unitary business are interdependent and of mutual benefit so as to form an integral business rather than several entities. ${ }^{409}$

The determination of integration lies with two tests: (i) technical (control) and (ii) substantive. The former means that the corporation must be controlled, directly or indirectly, by a common parent

\footnotetext{
402 Weiner (1999), 17.

403 Miller (1984), 132.

404 Mitroyanni (2008), 111.

405 Graetz (2003), 411-412.

406 Mitroyanni (2008), 107-108.

407 Weiner (2006), 70-71.

408 Ibid., 70.

${ }^{409}$ Peters (2001), 1306.
} 
corporation or by some consortium of related owners. ${ }^{410}$ The formal ownership threshold criterion can vary from state to state, but most US states require the existence of more than 50 per cent direct or indirect ownership by a common parent or a consortium of associated owners, which is generally determined by reference to a minimum ownership of voting stock. 411 Consequently, the formation of a consolidated group for federal tax purposes will not necessarily coincide with a unitary group for state corporate tax purposes. ${ }^{412}$ The second element of the integration test requires that a corporate group must have substantive business characters that broadly point to a unity of the business activity instead of the corporate structure it has been formed in. ${ }^{413}$ In sum, a unitary business is a business that has common control and management, integrated operations and typically a flow of value among the related entities. ${ }^{414}$

While the states have a certain degree of uniformity with regard to the definitions of the tax base and the apportionment formula, the uniform determination of unitary business is looser. There is no globally accepted definition of the notion and the UDITPA, for instance, does not even mention the notion of a unitary business. The MTC, ${ }^{415}$ however, does define unitary business in its proposed approach in its Proposed Model Statute on Combined Reporting 416 and a certain amount of consistency can also be derived from the principles assigned to it over the years. Nevertheless, due to the absence of uniform, clear legal margins, the determination of a sufficient integration test can be quite a challenge, because it relies

\footnotetext{
410 McIntyre (2004), 919.

411 Ibid., 919.

412 Fox et al. (2009), 401.

413 Mitroyanni (2008), 106.

414 Weiner (2006), 70-71.

415 The MTC was established by seven states in 1967 to encourage states to adopt uniform state tax laws and regulations, as well as to function as a vehicle for suggesting legislative and regulatory changes. In 2012, 19 states and the District of Columbia are members of the Multistate Compact, 28 other states additionally participate in some form in the MTC either as sovreignty members or as associate and project members. MTC (2014).

416 According to the Model Statute, a unitary business means "a single economic enterprise that is made up of either of separate parts of a single business entity or of a commonly controlled group of business entities that are sufficiently interdependent, integrated and interrelated through their activities so as to provide a synergy and mutual benefit that produces a sharing or exchange of value among them and a significant flow of value to the separate parts". MTC (2006), Section 1, F.
} 
strongly on individual judgement. In fact, the US states are free to do it so broadly that it would encompass all the potential activities of a group of commonly controlled entities. ${ }^{417}$ Because of variations of statutory language, the unitary group in one state might or might not coincide with the unitary business in other states.

As said earlier, the concept of unitary taxation originates in the $19^{\text {th }}$ century property tax cases. A study of the US states' regulations and courts' jurisprudence reveals that different approaches to the definition of a unitary business is used. In general, one may establish four categories of (non-cumulative ${ }^{418}$ ) tests, which indicate that a unitary business exists:

(1) the Three Unities Test, ${ }^{419}$ i.e. unity of ownership, unity of operation, and unity of use in the centralised executive force;

(2) the Contribution/Dependency Test, ${ }^{420}$ i.e. whether a company of a state is dependent on, or contributes to, the business of an out-of-state company. Examples of contribution or dependency include intercompany loans, sales of products or provisions of services and shared executive forces and staff functions;

(3) the Factors of Profitability Test, 421 i.e. functional integration (e.g. intercompany flow of goods and services), centralised management (e.g. shared directors and officers), economies of scale that give rise to the increased profitability of

\footnotetext{
417 Yet, a "fairly broad" definition is even desirable not restricted under comprehensive US constitutional doctrines. McIntyre (2004), 939.

418 For instance, the California Court of Appeal has held that the "three unities test" and the "contribution/dependency test" are alternative tests and that, as long as one of them is fulfilled, unitary business will not be denied just because the other test is not met. See A.M. Castle \& Co. (36 Cal.App.4th 1794).

${ }^{419}$ Case Butler Brothers v. McColgan (315 U.S. 501). The Court ruled that the "unity of use and management of a business which is scattered through several States may be considered when a State attempts to impose a tax on an apportionment basis." The Court articulated that factors, such as functional integration, centralisation of management and economies of scale, relate to the business as a whole, rather than to a single, identifiable source. In this case, the California Supreme Court had also enunciated the "three unities test" for determining the presence of a unitary business (Butler Brothers v. McColgan (17 Cal.2d 664)). The California Franchise Tax Board has provided some further guidance on the substance of these elements in California FTB 'Internal Procedural Manual. Multistate Audit Technical Manual'. Furthermore, the MTC has provided instructions on the matter in MTC (1973).

${ }^{420}$ Case Edison California Stores v. Mc Colgan (30 Cal.2d 472).

421 Cases Case Mobil Oil Corp. (445 U.S. 425); F.W. Woolworth Co. (458 U.S. 354); Allied-Signal (504 U.S. 768).
} 
integrated businesses (e.g. collective negotiation and purchase of goods and services); and

(4) the Flow of Value Test, ${ }^{422}$ i.e. there is some sharing or exchange of value between or among various businesses.

Even though the US Supreme Court has upheld the unitary business principle, in general, and has identified characteristics of a unitary business, the application of those rules, as well as the state-specific guidelines, have proven to be difficult to apply in practice and, consequently, heavily litigated. ${ }^{423}$ Charles McLure has proposed to rearrange the US Supreme Court standards and establish a three-stage test, by consecutively verifying:

(1) the existence of common control via ownership and management;

(2) the existence of shared expenses, economic interdependence such as economies of scale or scope, intra-group transactions, vertical integration, or other economic interdependencies; and

(3) the substantiality of the interdependence, so that they would fail to produce a satisfactory division of profits between members of the group. ${ }^{424}$

Conversely, Jerome Hellerstein has propounded an Interdependence of Basic Operations Test, which drifts away from the judicial and state practices. He suggests that an entity forms part of a unitary group if a considerable portion (e.g. one quarter to one third) of its gross receipts from basic operations are obtained from affiliated companies. $^{425}$

States applying unitary taxation must deal with two distinct elements: (i) formula apportionment, which concerns the division of income base, and (ii) combined reporting, which is used to report the income of a unitary business. Miller points out that, in California's view, both

422 Case Container Corp. (463 U.S. 159): "The functional meaning of this requirement is that there be some sharing or exchange of value not capable of precise identification or measurement - beyond the mere flow of funds arising out of a passive investment or a distinct business operation - which renders formula apportionment a reasonable method of taxation". The Court also enunciated at 178: "[t]he prerequisite to a constitutionally acceptable finding of unitary business is a flow of value, not a flow of goods."

${ }^{423}$ Fox et al. (2009), 404.

424 McLure (1984), 106-108.

425 Mayer (2009), Chapter 3.2.2.3. 
elements must be included, and adds that "authorising formula apportionment without providing for combined reporting is similar to supplying an armed force with tanks that cannot move". ${ }^{426}$

\subsubsection{COMBINED REPORTING}

The choice of the state corporate income tax filing method (separate, consolidated or combined reporting) in case of multistate businesses depends on each states' understanding of the most appropriate and effective measure. A number of US states apply a "combined reporting system" to report the income of a unitary business. In that case, instead of relying on the separate books of each member of an affiliated group of corporations engaged in a single unitary business and adjusting prices of inter-corporate transactions, the income of each member is combined with that of all the members, with appropriate eliminations and deferrals of inter-corporate transactions. ${ }^{427}$ Combined reporting is arguably the only effective way for any state to impose a fair and uniform corporation income tax on multistate and multinational enterprises while gaining (or maintaining) control over its taxable base. ${ }^{428}$ Also, the US Supreme Court has recognised that combined reporting is a better method for measuring the income of a unitary business and a safeguard against taxpayer's manipulation. ${ }^{429}$

426 Miller (1984), 132.

427 Peters (2001), 1305-1306.

${ }^{428}$ McIntyre, Mines \& Pomp (2001), 700.

${ }^{429}$ Case Container Corp. (463 U.S. 159) with regard to US-based multinational corporation in the light of the Commerce Clause and the Due process Clause; Case Barclay's Bank and Colgate Palmolive (Joined Cases 512 U.S. 298) with regard to foreign-based multinational company in the light of the Foreign Commerce Clause. 
Figure 1: Combined reporting for states with a corporate income tax. 430

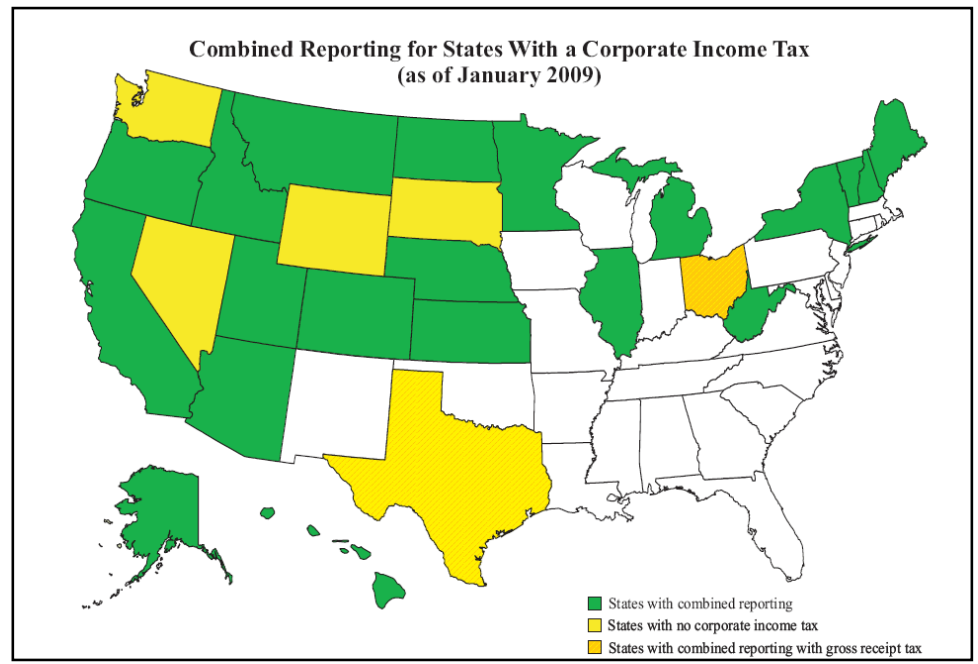

The term "combination" means a procedure of cumulating the results of commonly controlled legal entities engaged in a single unitary business into a single report - the "combined report". 431 A combined report is an accounting document prepared on behalf of a group of companies engaged in the common enterprise and which gives information of the aggregate taxable income of each member of that common enterprise. 432 Hence, the combined report includes only the income and activities of a single unitary business - the income of other businesses of a corporation or a group of companies are excluded from that combined report.

Combined reporting is typically seen as a filing method as it presupposes submitting a single return of a unitary business. However, combined reporting is also a "logical extension" of formula apportionment. ${ }^{433}$ Thus, the practical effect of combined reporting is providing a method of allocating or apportioning the income of a controlled group of entities among the states in which the group is engaged in unitary business, while eliminating intercompany transactions. ${ }^{434}$ The interaction of the combined income and the

\footnotetext{
430 Fox et al. (2009), 400.

431 Miller (1984), 136.

432 McIntyre (2004), 918.

433 McIntyre, Mines \& Pomp (2001), 702.

${ }^{434}$ Fox \& Luna (2010), 8.
} 
combined factors of the apportionment formula is intended to report a reasonably correct taxable income for each member of the unitary group which is subject to the jurisdiction of the taxing state. ${ }^{435}$

The apportionment formula applied in the combined report performs an additional function to that performed by the apportionment formula used for the net income of a single entity. ${ }^{436} \mathrm{~A}$ combined reporting system does not necessarily have to be paired with formulary apportionment: both of the methods, the combined reporting as well as formula apportionment, can operate independently. The operation of combined reporting without formula apportionment implies that the income of the combined group is allocated to a jurisdiction by using other methods, such as source rules. ${ }^{437}$ Formula apportionment can be applied independently from unitary taxation/combined reporting in the case of tax base division of a single corporate or non-corporate taxpayer deriving cross-state income in the same way as in case of income of a common group. 438 The experience of Canada and the Swiss cantons also indicates that it is possible to apply formulary apportionment without supplementing it with combined reporting. ${ }^{439}$

The preparation of a combined report begins by determining a group's common enterprise. As explained earlier, defining a unitary business is a challenging process, which implies the examination of the economic relationship and understanding the interaction between and among entities, whether those entities are established as single corporations with divisions, affiliated corporations, or non-affiliated corporations. ${ }^{440}$ After determining the unitary group, one must establish which members of the group are eligible or required to be part of the combined report. Typical limitations include certain types of firms, e.g. REITs, territorial limitations, water's edge limitation, or specific anti-abuse provisions, or entities that receive majority of their income from intangibles.

\footnotetext{
435 Peters (2001), 582.

436 Ibid., 582.

437 Currently, all the US states use formulary apportionment, whereas only some use combined reporting. McIntyre (2004), 919.

438 Roin (2010), 33.

439 McIntyre (2004), 918.

${ }^{440}$ Fox et al. (2009), 421.
} 
The operation of the combined reporting system requires four other important steps:

(1) The preparation of a combined report that determines the taxable income ${ }^{441}$ of the combined group under a state law (i.e. pre-apportionment income);

(2) The combined group calculates its apportionment percentage based on the appropriate apportionment formula, using the aggregate factors that helped to generate the preapportionment income and the aggregate taxable income of the combined group;

(3) The combined group calculates its taxable income apportioned to the state by multiplying the preapportionment income (step 1) by the relevant apportionment percentage (step 2).

(4) The members of the combined group make the calculations necessary for intrastate pro-rata apportionment. Only those members that have a "nexus" with the state are taxable by the state. ${ }^{442}$

Unless a state permits one company to submit the entire combined report of the group and pay tax on behalf of all of the members of the respective unitary group, the income apportioned to a state is allocated back to each company of the group based on its individual contribution to the factors. In that case, each member of the unitary group is liable to file its own tax return and pay its own tax in states in which a sufficient nexus exists. ${ }^{443}$

While the goal of a combined reporting/formula apportionment system is to apportion taxable income to jurisdictions that have a nexus to tax that income, it may happen that taxable income is apportioned to a jurisdiction that cannot tax that income (i.e. "nowhere income"). For instance, this can happen due to the lack of a (sufficient) "nexus" under the Commerce Clause or Due Process Clause or because of Public Law 86-282. The idea of "throwback" and "throwout" rules is to require a corporation to pay tax on income

${ }^{441}$ Calculation of the taxable income of a group is also complex because, in addition to combination of the operations of multiple entities and eliminating intercompany transactions, it must still deal with transfer pricing issues with entities outside the unitary group, prospectively with different fiscal years and accounting methods prescribed by the states, and determine whether income is apportionable (typically business income) or allocable (typically non-business income) to the state.

442 McIntyre (2004), 921-922.

${ }^{443}$ Fox et al. (2009), 400. 
that another state does not tax. "Throwback" rules allocate an apportionment factor to income, which would be situated in a jurisdiction that cannot tax it, to another jurisdiction that can do it. "Throwout" rules accomplish the same result by treating the factors attributable to a jurisdiction, which cannot tax, as if they did not even exist. ${ }^{444}$

Any state that includes sales "throwback" rule and allows or requires a combined report (or consolidated return) has to deal with the JoyceFinnigan issue. ${ }^{445}$ Joyce and Finnigan are two alternative approaches for determining the sales-factor numerator. Under the Joyce approach, ${ }^{446} \mathrm{a}$ "nexus" is ascertained at the level of each individual entity and sales made by an entity without a sufficient nexus in the combined reporting state are excluded from the combined report numerator if that member is protected under Public Law 86-272. On the contrary, under the Finnigan approach, ${ }^{447}$ the group as a whole is regarded as the taxpayer for apportionment purposes and thus all sales of the unitary group are included in the sales factor numerator in the combined report. 448

The fact whether a combined report or single-entity return is more advantageous to the taxpayer depends on the relationship between the factors of the apportionment formula contributed by each member of the group and the net income generated by those factors. ${ }^{449}$ McIntyre claims that combined reporting would result in a fairer sharing of tax revenue between states, reduce substantially tax avoidance and evasion opportunities of multinationals, and simplify

\footnotetext{
444 "Throwback" rules are appropriate in relocating sales in situations where the ties to the state where the purchaser is located are too nebulous that would allow that state to levy tax. "Throwout" rules, however, are more suitable in relocating the property and payroll factors of the enterprise. McIntyre (2004), 941-944.

445 The issue may arise even in states that do not have sales throwback rules. See, for instance, case Disney Enterprises Inc. (10 N.Y.3d 392).

${ }^{446}$ Case Appeal of Joyce, Inc. (No. 66 SBE 069).

447 Case Appeal of Finnigan Corporation (No. 88-SBE-022).

448 Since both approaches, Joyce and Finnigan, are acceptable to the extent that they are applied consistently by the states, the possibility to choose between the two may create odd results. For instance, a sale from a Joyce state (with a throwback rule) to a Finnigan state will be included in the sales factor numerator in both states (i.e. double-taxation of sales). In the opposite situation, a sale from Finnigan state to a Joyce state can be excluded from both states numerator's (i.e. double non-taxation of sales). Fox \& Luna (2010), 16.

${ }^{449}$ Peters (2001), 582.
} 
compliance of tax authorities as well as taxpayers. ${ }^{450}$ However, one may wonder whether the application of combined reporting to determine the taxable income of a unitary business results in the taxation of extraterritorial values (prohibited by the Due Process Clause), discrimination against interstate commerce (a violation of the Commerce Clause) and, if extended beyond the water's edge of the United States, violation of US DTC obligations. ${ }^{451}$

\subsubsection{THE TERRITORIAL SCOPE OF THE COMBINED REPORTING}

For years, the division of geographical contours of the US federal and sub-national tax systems has been a source of conflict with respect to the principles and practices of taxing the commercial income of multinational corporations. In this respect, four basic models can be established:

- Worldwide unitary combination under which a combined group covers all companies engaged in unitary business, despite the place of business, the jurisdiction in which the activities take place or in which profits arise;

- Domestic worldwide combination under which, in case of non-US headed groups, the foreign parent company and its non-US subsidiaries are excluded;

- Domestic combination under which only profits arising from activities within the US and all profits earned by companies incorporated in the US are included in the combined report; ${ }^{452}$ and

- Water's edge combination under which only profits arising from the activities taking place in the US are included. 453

The US subnational practice indicates two main approaches with regard to the determination of geographical borders of combined reporting of a unitary business:

(i) States applying "worldwide unitary combination" and, thus, deeming that foreign companies are engaged with domestic affiliates, even if the former lacks of activities in that state; and

\footnotetext{
450 McIntyre (2004), 918.

451 McLure (1984), 90.

452 Therefore, foreign branches of US-incorporated companies are included, while their foreign subsidiaries are not.

453 Mayer (2009), Chapter 3.2.4.3.
} 
(ii) States applying water's edge ${ }^{454}$ approach and separate accounting to foreign affiliates operating outside the US. ${ }^{455}$

\subsubsection{WORLDWIDE COMBINED REPORTING}

Both "worldwide combined reporting" and "water's edge combined reporting" are designed to calculate in-state corporate taxable income, although they employ fundamentally different principles. ${ }^{456}$ While worldwide unitary combination seeks to aggregate US companies' income and apportionment factors of their foreign affiliates to determine the combined income of the entire group, the effect of the water's edge rule is that the states do not look beyond the nation's borders in computing in-state corporate income. In case of the latter, a domestic source of each foreign affiliated company is treated under separate accounting on an arm's length basis. ${ }^{457}$ Hence, under the water's edge approach, states respect the legal distinction between separately incorporated firms irrespective of the economical or legal relationship between the affiliated members. ${ }^{458}$ Even though worldwide combined reporting would be consistent with the unitary taxation principle, many states have enacted legislation that exempts (some) foreign income and entities from the combined report. ${ }^{459}$ As Roin ${ }^{460}$ puts it: '[T] he "water's edge" restriction on the reach of unitary taxation is a result of a combination of economic and political pressures placed on those states which flirted with worldwide combination measures'.

\footnotetext{
454 Most states use the term "water's edge taxation/election/limitation" as to mean "domestic combination" rather than "water's edge combination". In the case of elective water's edge combined report, companies can typically decide to exclude some foreign entities from both the computation of combined income and the formulary apportionment factors, or even disregard some foreign-source income of domestic members of a unitary group. Fox et al. (2009), 405. In theory, since the idea of a combined group is to tax the common income of an enterprise irrespective of its legal organisational structure, the application of a combined reporting system should require foreign corporations to be included in the combined group, if they participate in the group's common enterprise. If a combined report excludes foreign activities carried out by a foreign corporation but includes those conducted via a foreign branch, one would reach an undesirable result, as form would prevail over substance. McIntyre (2004), 945.

455 Mclure (ed.) (1984), xvii.

${ }^{456}$ Carlson \& Galper (1984), 2.

457 Ibid., 2.

458 McLure (1986), 47.

${ }^{459}$ Fox et al. (2009), 405.

460 Roin (2010), 23.
} 
The idea of worldwide combination originates from the $20^{\text {th }}$ century and it reflects the needs of apportioning the revenues of a single company carrying out cross-state business. ${ }^{461}$ The leading state to introduce combined reporting in 1930s was California in search of a method of combating a practice of the motion industry of producing film properties in California but transferring them out of state for distribution. ${ }^{462}$ Also in the 1930s, the League of Nations conducted the first comprehensive analysis of the international taxation of business income with a view to avoiding double taxation of such income. During that study, the League of Nations examined the apportionment system of Massachusetts, New York and Wisconsin, but it rejected them due to the fact that they were not, and could not be, designed for multiple political and economic systems. ${ }^{463}$

The determination of a corporation's tax liability under the worldwide combined reporting system should, broadly speaking, follow three elements:

1) The total income of the multinational in all jurisdictions;

2) The value of the certain apportionment factor situated in the state employing the worldwide unitary approach; and

3) The value of the group's apportionment elements in all jurisdictions. ${ }^{464}$

The combined income is apportioned between states by taking into account the ratios of in-state values of the standard factors - sales, property and payroll. ${ }^{465}$ As a result, the worldwide combination affects the equivalent rates on sales, payroll and property, as they depend on the worldwide profitability of the transnational group of affiliated companies. Thus, if the profitability is not geographically uniform, the change in range of combination triggers the change of the effective tax rate applied on sales, payroll or property situated in the taxing state. ${ }^{466}$

In general, if a state has implemented an optional worldwide combination, every member of a combined group must agree with

\footnotetext{
461 Mitroyanni (2008), 145.

462 Miller (1984), 137.

463 Milton (1984), 185.

${ }^{464}$ Carlson \& Galper (1984), 24.

465 Ibid., 2.

466 McLure (1986), 35.
} 
the election, which is then binding for a number of years. ${ }^{467}$ For instance, in Massachusetts, the worldwide election is binding for the tax year for which it was made and the nine years after, and any corporation entering the unitary group after the year in which the election was made will be deemed to have waived any objection to such inclusion and will be included in the group. 468 In a similar vein, elective water's edge combination is typically binding for a number of years, with a possible automatic extension of the period as well as a limitation on re-election (so-called "waiting period") if the election has been terminated, subject to waivers of such restrictions in appropriate cases. ${ }^{469}$

The application of worldwide combined reporting has been a source of a great number of administrative and judicial proceedings between multinationals and state tax authorities. The general argument of businesses is that the extension of taxing rights over the water's edge of the US causes distortion and wrong apportionment of foreign source income. ${ }^{470}$ In Matson Navigation, ${ }^{471}$ the California Supreme Court upheld the state's rule that the (franchise) tax liability arose from income attached to activities in both interstate and foreign commerce, where the California portion was determined upon the basis of the percentage of overall transactions that originated in California, despite the relevant reference in the tax statute. It is worthwhile noting that, until the 1960s, there was no specific link between the worldwide combination and the determination of (franchise) tax liability but the focus was on reporting income fairly. 472 At that time, separate accounting was the general approach, while combined reporting and the formulary apportionment were used only in case of tax avoidance matters. ${ }^{473}$

\footnotetext{
467 As a matter of comparison, the proposed CCCTB Directive does not foresee a possibility for a taxpayer to choose taxation based either on its worldwide or water's edge income. The concept of optionality in the proposed CCCTB Directive stands for the option to participate in the system. It is noteworthy that once a company opts into the system, it must do so in respect of all companies which meet the requirements for forming a group. The option would be binding for a minimum of five tax years, which can be prolonged thereafter (Article 105 of the proposed CCCTB Directive).

468 Donovan, Nagle \& Wellings (2009), 418.

${ }^{469}$ McIntyre, Mines \& Pomp (2001), 735.

${ }^{470}$ Hellerstein (1984), 69.

471 Case Matson Navigation Co. (6 Cal.2d 557).

472 Mitroyanni (2008), 145.

473 Ibid., 146.
} 
Honoluhut74 and Superior ${ }^{475}$ represent a substantial shift towards worldwide combination, as the California Supreme Court stated that, whenever there is a unitary business, formulary apportionment and worldwide combination must be used. ${ }^{476}$ After that, the California FTB became increasingly aggressive in promoting the unitary method and applying it to multinationals. ${ }^{477}$ Worldwide combined reporting became a rule in computing franchise tax in California throughout the 1960s and 1970s and, in July 1972, the FTB institutionalised the practice through the introduction of a set of working rules for incorporating foreign corporations into combined reports. ${ }^{478}$ The other US states approached the issue later. For instance, Florida adopted mandatory worldwide combined reporting in 1983 and other states gave it serious consideration. ${ }^{479}$

Taxpayers, the US government, as well as foreign governments reacted negatively to the worldwide combined reporting. However, the US Senate rejected the initially negotiated water's edge approach, which would have precluded the US states from requiring that United Kingdom-controlled corporate taxpayers use combined reporting to compute their state income, in the DTCs ratification stage in 1978. The final version of the DTC prohibited state tax discrimination against British nationals, but it did not oblige the states to use separate accounting or the water's edge approach. This particular history of Senate action is a strong indication that the Congress implicitly has permitted the states to apply the worldwide combined reporting method. ${ }^{480}$

In the beginning of 1980s, the COST (now referred to as the Council on State taxation) invited its members and staff to oppose the state imposition of worldwide combined reporting and provided testimony in many state legislative hearings on that issue. 481 The California worldwide reporting method was discussed in the US Supreme Court for the first time in 1983 in Container. 482 In that case, the taxpayer was a US-based multinational company with subsidiaries across the US

\footnotetext{
474 Case Honolulu Oil Corp. (60 Cal.2d 417).

475 Case Superior Oil Co. (60 Cal.2d 406).

476 Miller (1984), 139.

477 Houghton, Hogroian \& Weinreb (2004), 458.

478 Mitroyanni (2008), 146.

479 Houghton, Hogroian \& Weinreb (2004), 458.

480 Case Barclay's Bank and Colgate Palmolive (Joined Cases 512 U.S. 298).

481 Houghton, Hogroian \& Weinreb (2004), 458.

482 Case Container Corp. (463 U.S. 159).
} 
and abroad. It challenged the three-factor apportionment formula against its conformity with the US constitutional clauses of Commerce and Due Process. The US Supreme Court acknowledged that it can often be impossible to allocate values with precision and concluded that there is no constitutional requirement to have a single US sub-national formula apportionment. Nevertheless, according to the court, if a state adopts a formula apportionment, it shall not apply it in an unfair or discriminatory manner. The Court added that, if some income not having its source in the taxing State, is subject to taxation, the requirements were not infringed. 483

In the aftermath of Container, a working group consisting of federal and state government representatives as well as business community members was formed to reach an agreement on the application of worldwide combination. ${ }^{484}$ In 1984, the Worldwide Unitary Taxation Working Group issued a report inviting the states to limit the combined report method to water's edge unitary combination for both US and foreign companies. In transmitting the report to the president, Treasury Secretary announced that, if by July of 1985 there were no sufficient signs of appreciable progress by the states, he would recommend federal legislation giving effect to the water's edge limitation. ${ }^{485}$ Almost immediately after the 1984 report, a number US states enacted the water's edge approach as an alternative to worldwide combination. ${ }^{486}$ In California, which is the most significant supporter of the worldwide unitary combination among the US states, worldwide combined reporting was more enduring. Due to the pressure from many multinationals, as well as from the US Treasury Department, the water's edge approach became an option for California taxpayers in 1986 and was liberalised in 1993.487

In Container, the US Supreme Court did not give its opinion on whether the same conclusion can be made in case of foreign-owned multinational companies. However, the matter was clarified in the joined cases of Barclays and Colgate-Palmolive ${ }^{488}$ a decade later, in which the court did not find California's worldwide combined reporting system to infringe the Commerce Clause and Due Process Clause of

\footnotetext{
483 Ibid.

${ }^{484}$ Houghton, Hogroian \& Weinreb (2004), 458.

485 Peters (2001), 577.

486 Houghton, Hogroian \& Weinreb (2004), 459.

487 McIntyre (2004), 944.

488 Case Barclay's Bank and Colgate Palmolive (Joined Cases 512 U.S. 298).
} 
the US Constitution. It further ruled that Congress, and not the Executive Branch, has the constitutional power to regulate foreign commerce. Thus, if Congress has refrained from exercising its authority to prohibit state-mandated worldwide combined reporting, it does not imply that the Executive Branch communications, which express federal policy but lack the force of law, can render unconstitutional an otherwise valid, congressionally condoned, state use of worldwide combined reporting. ${ }^{489}$

While the Court has repeatedly upheld the worldwide combined reporting method, one could argue that a mandatory water's edge combination could be tested against the Foreign Commerce Clause. In particular, in case of pure domestic combination, a foreign incorporated enterprise would be deprived of the opportunity to combine its affiliates under the same terms as domestic enterprises. On the other hand, combined reporting limited only to US corporations have been upheld against Foreign Commerce Clause attacks, for instance in Caterpillar ${ }^{490}$ and E.I. du Pont de Nemours. ${ }^{491}$

The main question in Caterpillar ${ }^{92}$ was whether the state's water's edge apportionment formula violates the Commerce Clause by taxing royalty and interest payments received from foreign subsidiaries of a unitary business without subjecting them to global apportionment (i.e. as if they were made by unrelated businesses). The court opinioned that royalty and interest payments from one domestic member of the unitary group to another do not change the combined net income of the water's edge group because a receipt for one constitutes a deduction (expense) for another. In a similar vein, such payments cannot be characterised as income of the foreign payers but as income of the domestic recipients. Since the foreign members of Caterpillar's unitary group were considered unrelated businesses, whose income is not taxed, the proper comparison for assessing discrimination was between the foreign members of the unitary group

\footnotetext{
489 In fact, the US states did not, in principle, return to worldwide combination after Barclay's Bank and Colgate Palmolive (Joined Cases 512 U.S. 298). The MTC work, however, indicates that it prefers rather broad unitary filings. The MTC Model Combined Reporting Statute (2006) provides for a rather wide scope of (elective) "water's edge" by including all domestic and foreign income of the members of a unitary group, to the extent that it is generated in, or attributed to, sources within the US. MTC (2006), Section 5.A.

${ }^{490}$ Case Caterpillar Inc. (No. 97-779).

${ }^{491}$ Case E.I. du Pont De Nemours (675 A.2d 82).

${ }^{492}$ Case Caterpillar Inc. (No. 97-779).
} 
and unrelated domestic entities. The court held that the state law treated foreign subsidiaries like similarly situated domestic entities and no discrimination occurred against the foreign subsidiaries.

In E.I. du Pont de Nemours493 the court reminded that the worldwide combined reporting method "is widely acknowledged as a fair and accurate method of estimating a multijurisdictional corporation's taxable business activities in the state". It further ruled that each calculation on the basis of the "Augusta Formula" 494 is a permissible means of ensuring that the state does not tax extraterritorial values, and that assessed tax reasonably reflects the scope of the taxpayer's business activity in that state. ${ }^{495}$ Thus, the formula does not violate the US constitutional principles of Due Process or Foreign Commerce.

\subsubsection{INTERNATIONAL CONSIDERATIONS OF WORLDWIDE COMBINED REPORTING}

As follows from above, the US federal and subnational level use different systems of corporate taxation, i.e. separate accounting and worldwide unitary combination respectively. The two techniques are not, by themselves, contrary to the basic principles of international taxation. However, when viewed jointly, the effect of the conflict

493 Case E.I. du Pont De Nemours (675 A.2d 82).

494 The "Augusta Formula" computes tax liability by using the worldwide reporting method as a way of checking the fairness of a multijurisdictional unitary business' tax liability. Under the formula, the taxable income is determined as follows:

(A) Statutory water's edge method with foreign source dividends included in the taxpayer's apportionable business income;

(B) Worldwide combined reporting method;

(C) Statutory water's edge method with foreign source dividends excluded from the taxpayer's apportionable business income.

The taxable income of the taxpayer is if:

1) $\mathrm{B}>\mathrm{A}$ : The taxpayer pays the amount calculated under the water's edge statute with foreign subsidiaries dividends included and receives no factor relief;

2) $\mathrm{B}<\mathrm{C}$ : The taxpayer pays the amount calculated under the water's edge reporting method with foreign subsidiaries dividends excluded and receives no factor relief;

3) $\mathrm{A}>\mathrm{B}>\mathrm{C}$ : The taxpayer pays the amount calculated under the worldwide reporting method and receives factor relief, i.e. adjusts the denominators of the payroll, sales, and property factors to account for the inclusion of the foreign subsidiaries' dividends to reach this result.

495 Peters (2001), 579. 
between the two systems is sharpest in the international arena. ${ }^{496}$ The US multinationals complain that the application of worldwide unitary combination triggers extraterritorial or double taxation and, therefore, they are at a disadvantage compared with foreign competitors. Furthermore, extraterritorial taxation causes covert discrimination between residents and non-residents since competing firms involved in the same industry may be subject to different levels of taxation on equivalent amounts of income, depending on the activities of affiliated companies in other jurisdictions. ${ }^{497}$

The federal rules for taxing multinationals were developed with foreign considerations in mind, whereas the state rules are frequently applied to cross-border transactions without taking into account their international implications. The federal government argues that the conflict between the federal and state affairs in respect of the application of separate accounting and worldwide unitary combination on international businesses impedes the ability of the United States to "speak with one voice" and to conduct a coherent economic policy in its dealings with other countries. ${ }^{498}$ On the other hand, the states with worldwide combined reporting argue that the federal approach would result in a loss of tax revenue, administrative difficulties due to the application of separate accounting at arm's length or on an independent basis and interference into states' fiscal sovereignty. 499

In order to justify one or the other approach, one must consider that the national position must reflect the following:

- Constitutional jurisprudence - implies ensuring that the free flow of commerce among states and nations is not hindered due to excessive taxation and lawful procedures are followed;

- Congressional legislative activity - within the structure of the US federal system, international tax policy should be developed by the federal government and not by individual states; and

- Network of DTCs - these independently negotiated treaties between the US and foreign countries indicate a strong

\footnotetext{
${ }^{496}$ Carlson \& Galper (1984), 21.

497 Ibid., 25. In the same vein, one can argue that when a State taxes worldwide income of its residents and eliminates double taxation by means of credit method, the tax system leads to covert discrimination.

498 Ibid., 21.

499 Ibid., 5-7.
} 
national interest in international tax harmonisation to encourage the flow of international trade and investment. ${ }^{500}$

\subsection{CONCLUSION}

The EIM can achieve its "distinct competitive advantage"501 compared to other markets through the introduction of common rules in areas that affect its proper functioning. However, the states' success with formula apportionment is largely due to factors which are unique to the states, such as the ability to work under the umbrella of the federal tax system, to rely upon federal tax administration through the IRS, and to use common accounting and similar tax practices. ${ }^{502}$ The fact that the US subnational definition of income includes a substantial amount of uniformity and that they use formula apportionment for dividing income among the states with a sufficient nexus reduces compliance costs as well as over and under taxation of corporate income in various states. Hence, it is clear that the basic structure of US state corporate income taxes fits well with the principles of an internal market. Unlike the US states, which form part of a pretty well defined whole - a nation state - the EU Member States are in a fundamentally different situation - forming part of a new creature. Whether this structure will work well with the idea of an internal market in the end boils down to the question of the "chicken and the egg".

Some scholars suggest that US states might oppose federal intervention because it would threaten their sovereignty. ${ }^{503}$ One may recall that the US Constitution provides for a split between the sovereignty of the states and the federal government. Due to that division, the federal government cannot interfere and cross-state businesses cannot demand complete uniformity of the states' tax system, to the extent that the latter is not maleficent. In case of malicious tax systems, the states are limited by the US Constitutional Clauses of Commerce and Due Process. By comparison, the EU Member States are free to determine their policies, to the extent that

500 Ibid., 2-4.

501 European Commission (2004), 1.

502 Weiner (1999), 19.

503 In 2001, the MTC held a number of public seminars on state taxation and federalism. While, in its report of the seminars, the MTC supported state control over state taxation, it called the states to give up of their individual sovereignty by agreeing to common tax provisions. Hildreth, Murray \& Sjoquist (2005), 858. 
they have not transferred these competences to the Union and as long as they respect the fundamental freedoms of EU citizens. The EU Treaties do not provide any legal basis for the imposition of taxes directly by the Union. Thus, the Member States remain free to determine the scope of direct taxation in their jurisdiction. However, one could argue that the Member States do have shared sovereignty in the sense that they cooperate in making policies on issues of common interest. Yet, such a two-level legitimate law making may trigger conflicts in establishing policies and interests, which may decelerate the EU integration process.

While the US states have independent sovereignty, the fact that US Constitution does not contain a unanimity requirement, such as that in the TFEU, results in the states actually enjoying less freedom from legislative restrictions imposed from above than the EU Member States. The US states must respect the principle of supremacy as well as preemption. The former is included in the US Constitution and is similar to the Supremacy Clause included in the TFEU in the sense that it looks for a conflict between two levels of law. In the US, federal law overrides state law and, in the EU, EU law overrides Member States' national law. The US Preemption Clause has an effect similar to a situation in which EU Member States have given up a certain competence, i.e. the Union has the exclusive competence to regulate certain field. Therefore, while in the EU, the Member State has unanimously agreed to give the EU exclusive competence in a specific field, the absence of such a unanimity requirement in the US gives Congress broader rights to deprive the states of concurrent law-making powers.

Furthermore, US states are subject to judicially imposed constraints that are different from those within the EIM. The US Constitution includes the Commerce Clause and Due Process Clause. The Commerce Clause has three areas of application: (i) the Interstate Commerce Clause; (ii) the Foreign Commerce Clause; and (iii) the Indian Commerce Clause. Considering the difference in the intergovernmental structure between the EIM and the US, the interpretation of the fundamental freedoms in the EU is carried out from a different angle than the interpretation of the US Commerce Clause concerning interstate taxation. In other words, the fact that EU Member States subject their residents to worldwide taxation means there is no prerequisite for a specific "nexus" between the income and the Member State for the latter to subject that income to taxation, contrary to the US Constitutional requirements. The only 
condition of the Member States is that its taxation measures must respect the freedoms, which is hence different from the prohibition of interstate commerce. ${ }^{504}$

One can try to assimilate (not equate) the effect of the Commerce Clause to the EU non-discrimination / restriction requirements with regard to EU citizens, because it renders a state law unconstitutional if: (i) it causes facial discrimination against interstate commerce; (ii) if a law has discriminatory purpose or effect, or (iii) it creates undue burden on interstate commerce. It is noteworthy that, in the light of the US Supreme Court's jurisprudence, the Foreign Commerce Clause provides for a broader scope of judicial protection for foreign commerce than interstate commerce. The Court held in Japan Line that the Foreign Commerce Clause requires an analysis whether (i) a state tax creates a substantial risk of international multiple taxation; and (ii) whether it impairs the federal government speaking with "one voice". By comparison, EU law is more concentrated on protecting free movement within the EU, rather than the movement between the EU and third countries. ${ }^{505}$

It is interesting to note that while the constitutional principles and the respective jurisprudence in the US concentrates on the protection of "commerce" from malicious state practices, the EU law primarily focuses on the protection of (EU) citizens from discriminatory and restrictive Member State laws. 506 As one may recall, the US states may tax business income if there is a sufficient link between the state and the person, object or activity ("nexus"), while most EU Member States tax based on residence and source principles. Thus, considering that the states employ substantially dissimilar criteria for taxation, it is self-evident why the focus of protection in the two cases differs.

As discussed earlier, the geographical borders of a unitary group in the states are limited to either the water's edge approach or worldwide definition. The states' worldwide combination is derived from the idea of a unitary business, which looks at the business integrity rather than structural borders of the group. Furthermore, the worldwide combination has resulted from constitutional restraints,

\footnotetext{
504 Mitroyanni (2008), 114-115.

505 The only fundamental freedom that includes both internal and external dimension is the free movement of capital.

506 From an EU law perspective, the closest comparison with the US jurisprudence is the CJEU's case law on the free movement of services.
} 
especially after Barclays, which triggered a number of litigation procedures against states applying water's edge limitation, e.g. Caterpillar. ${ }^{507}$ On the contrary, the current policy approach in a number of EU Member States is the application of water's edge consolidated groups (typically limited to the Member State's borders). In a similar vein, the proposed CCCTB Directive employs a water's edge definition of a group, in the sense that a taxpayer can opt for a CCCTB, provided that it is a resident in accordance with the Directive or has taxable presence in the EU by means of a permanent establishment. ${ }^{508}$ Considering that the EU Member States are fundamentally in a different position than the US states, the choice for a water's edge limitation appears appropriate. For example, while the US states are not generally limited by US DTCs with other countries, the EU Member States are bound by their bilateral (and multilateral) agreements. Hence, a worldwide taxation approach in the CCCTB Directive would likely give rise to conflicts with Member States' DTCs with third countries. Moreover, as the author will discuss below, even though the Court has not yet found double taxation as such infringing EU law, the EU is far less tolerant with regard to double taxation than the US. The latter highlights tax competition and deregulation rather than harmonisation as leading to market efficiency.509 A CCCTB group definition with a global dimension could lead to double taxation, although the CCC tax base would not lead to an overlap of the group's worldwide income in the EU. Since the formula apportionment implies fundamentally different principles, the taxpayers could, in effect, be subject to double taxation if the respective third country did not reflect the group's taxation in the EU.

While the common belief is that the EIM requires rules for further development, one must not ignore that there are also a number of inconsistencies and points for consideration ${ }^{510}$ in the US sub-national taxation rules. The widespread adoption of state tax systems in the early $20^{\text {th }}$ century caused a lack of uniformity in state corporate taxation. Early commentators have already criticised, decades ago,

\footnotetext{
507 See generally Peters (2001).

508 Article 6 of the proposed CCCTB Directive.

${ }^{509}$ Mitroyanni (2008), 152.

${ }^{510}$ For example, one may question whether there is a need for a distinction between business and non-business income. McLure, for instance, argues that this distinction makes little economic sense and complicates compliance and administration, especially because some investment income is treated as business income. McLure (2008), 21.
} 
that "the tax methods are almost as numerous as the taxing jurisdictions". ${ }^{111}$ In order to solve the inconsistencies, a number of steps were taken. For instance, even though the working committees of the National Tax Association have focused on the lack of tax policy uniformity across the states and proposed a model tax system, it recognised that agreement between the states would be difficult, if not impossible, to achieve in practice. ${ }^{512}$ The initial attempt by states, themselves, to find uniformity in state taxation dates back to the late 19th century when representatives of seven states were sent to a conference that culminated in the formation of the NCCUSL. In 1957, the NCCUSL, together with the American Bar Association, published the UDITPA. Further, the Congressional study of state taxes (i.e. the Willis Committee ${ }^{513}$ ) resulted in a proposal for federal legislation that would have essentially eliminated the diversity between state corporate income taxation. ${ }^{514}$ However, most states opposed the substantive and procedural recommendations of the Willis Committee Report ${ }^{515}$ because of the fear of loss of tax sovereignty.516 As a matter of reaction to the Willis Committee proposals, in 1967, the Multistate Tax Compact was agreed and its executive body MTC was established to encourage states to adopt uniform state tax laws and regulations, as well as to provide a vehicle for suggesting legislative and regulatory changes. ${ }^{517}$

In conclusion, considering that the proposed CCCTB rules employ a sharing mechanism to the tax base similar to the one used by states of the US, it is rather natural for a comparison to be made between the two systems. However, due to the fact the legal and institutional framework as well as the historical development of the EU considerably differs from that of the US, at least as far as taxation is concerned, there is a fundamental difference between the two markets. Hence, reference to the experience of the US states with formula apportionment for the purposes of approximation of laws in

\footnotetext{
${ }^{511}$ Hildreth, Murray \& Sjoquist (2005), 828.

512 Ibid., 828.

513 Special Subcommittee of the House Judiciary Committee, initiated in accordance with Public Law 86-272, as amended, in 1961.

514 The proposals employed a number of principles, such as a uniform nexus standard based on the in-state presence of an employee or realty; substantial conformity with the federal definition of taxable income; full apportionment of all income (i.e. no allocation of non-business income), etc. McLure (2008), 23.

515 House Committee on the Judiciary (1964).

516 McLure (2008), 23.

517 Roin (2010), 21.
} 
the EU is less relevant. Moreover, while the EU endorses cooperation between the Member States for the better functioning of the EIM, the US states find themselves in a different setting. Indeed, although they are part of one federal market, they often compete for other purposes, subject to few federal limitations, within a single, pretty well defined and regulated market. 
PART III: The PROPOSED CCCTB DIRECTIVE 
Defining the borders of eligible companies is one of the central issues in adopting an EU-wide corporate tax system. This is because the subjective scope of the CCCTB Directive will directly affect the CCC tax base. The earlier CCCTB working documents indicate that the initial idea was to limit the scope of the Directive to companies with establishments in at least two Member States. However, following the developments, ${ }^{519}$ the proposed CCCTB Directive makes the common fiscal rules available to all EU resident companies and EU-located PEs of third country companies ("single taxpayers"520) and to "groups of companies". 521

The principal aim of the current Chapter is to explain which companies (and permanent establishments), according to their place of establishment or (tax) residence (or location), should be covered by the proposed CCCTB Directive, i.e. definition of eligible companies and group of companies. The author will review the relevant provisions of the CCCTB proposal to assess whether they comply with the requirements of EU law and Member States' DTCs with third countries. In the current Chapter, the author will focus only on cases that include inbound and outbound investments towards third countries. The key issues discussed below are the following:

(1) Eligibility of individual entity, i.e. which third-country establishments should be allowed to calculate their tax base under the CCCTB rules;

\footnotetext{
518 The main Commission working papers dealing with the personal scope of the CCCTB are European Commission (2005c) and the subsequent related working papers European Commission (2006b), European Commission (2006c), European Commission (2006d), European Commission (2006f) and European Commission (20061).

519 See in particular European Commission (2007a), para. 10 et seq. and the subsequent working paper European Commission (2007b).

520 Note that during the CССТВ preparatory work, it was also discussed whether taxpayers in which the level of ownership was greater than 50 per cent and less than 75 per cent should be entitled to opt for the application of the common rules but not for consolidation with a CCCTB group. Participations with lower levels of ownership would have been automatically excluded from the application of the CCCTB rules. See European Commission (2007a), para. 6.

521 Article 1 of the proposed CCCTB Directive.
} 
(2) Effect on a group level, i.e. which third country establishments will be affected by the option of the group's parent company?;

(3) Threshold for ownership in an entity to be included into a CCCTB group.

The criterion of qualifying a person as a (resident or non-resident) taxpayer under the proposed CCCTB Directive depends on whether the person is eligible to opt for the CCCTB system. The eligibility of third-country companies is set forth in the Directive as follows:

According to Article 2(2) of the (draft) Directive:

"[The] Directive shall apply to companies established under the laws of a third country where both of the following conditions are met:

(a) the company has a similar form to one of the forms listed in Annex I;

(b) the company is subject to one of the corporate taxes listed in Annex II"

According to Article 4(1) of the (draft) Directive, a "taxpayer" is:

"[A] company which has opted to apply the system provided for by this Directive."

Therefore, according to Article 4(5) of the (draft) Directive, a "nonresident taxpayer" is:

"[A] taxpayer which is not resident for tax purposes in a Member State /.../"

Article 6(1) and (2) of the proposed CCCTB Directive lays down the criteria for opting into the system. Accordingly, a third-country company may opt into the system either as:

(1) A resident for tax purposes in a Member State; or

(2) A non-resident for tax purposes in a Member State in respect of a permanent establishment maintained by it in a Member State."

The definition of residence for CCCTB purposes is provided in Article 6(3) of the proposed CCСТB Directive as follows: 
" $[A]$ company that has its registered office, place of incorporation or place of effective management in a Member State and is not, under the terms of an agreement concluded by that Member State with a third country, regarded as tax resident in that third country /.../."

\subsubsection{EXHAUSTIVE LIST OF COMPANIES}

By drawing the limits of the personal scope of CCCTB by way of an annex, the CCCTB proposal follows a technique that has already been used in the other EU corporate tax instruments - the Merger Directive, ${ }^{522}$ the Parent and Subsidiary Directive, ${ }^{523}$ and the Interest and Royalty Directive. 524 While the list of CCCTB-eligible company forms available in CCCTB Member States is exhaustive in Annex I, 525 the list of companies established in a non-Member State is nonexhaustive. Instead, the latter companies are subject to a condition that they take a "similar" form to one of the forms listed in Annex I. One may wonder whether such a non-exhaustive list for thirdcountry companies is indeed desirable for CCCTB purposes. In particular, one should do the following:

(i) decide whether there is need for a list of eligible company forms. If yes, then

(ii) choose whether the list should be exhaustive or nonexhaustive. If non-exhaustive, then

(iii) decide whether the form must be "similar" to one of the forms as listed in Annex I.

\footnotetext{
522 Council Directive 2009/133/EC on the Common System of Taxation Applicable to Mergers, Divisions, Partial Divisions, Transfers of Assets and Exchanges of Shares Concerning Companies of Different Member States and to the Transfer of the Registered Office of an SE or SCE between Member States.

523 Council Directive 2011/96/EU of 30 November 2011 on the Common System of Taxation Applicable in the case of Parent Companies and Subsidiaries of Different Member States. It is noteworthy that, for instance, the Austrian domestic law also refers to the Annex to the EU Parent-Subsidiary Directive in order to determine whether a non-resident company can be a group parent. Alternatively, the non-resident company must be comparable to a resident company and has its place of management in the EEA. Jann, Schuch \& Toifl (2012).

524 Council Directive 2003/49/EC of 3 June 2003 on a Common System of Taxation Applicable to Interest and Royalty Payments made between Associated Companies of Different Member States.

525 According to Article 2(1)(a) of the proposed CCCTB Directive, the Directive applies to companies established under the laws of a Member State if they take one of the forms listed in Annex I of the Directive.
} 
The main purpose of including a list of eligible company forms is normally the wish to secure the application of a tax system to entities that are taxable persons in the respective countries. ${ }^{526}$ This approach has also been adopted in the three other EU corporate tax directives. However, with regard to the CCСТВ Directive, this argument is rather weak regarding third-country companies, because such companies would be included in the CCCTB system to the extent that they have a taxable presence within the CCCTB jurisdiction by means of a permanent establishment or due to their tax residency. Therefore, the fact that all the other corporate tax directives include such a list is irrelevant because the latter do not extend their scope to third-country establishments.

Another argument for including a list of eligible companies could be the fact that $\mathrm{a}(\mathrm{n})$ (exhaustive) list of company forms would allow Member States to either limit or expand the application of the system only to those company forms that fit into their taxation system and thereby control their tax revenue. The fact that third-country company forms can enter the system if they take a "similar" form to one of the forms as listed by Member States in the Annex provides the Member States with a certain authority to control which thirdcountry companies could participate in the system. Taking into account the political sensitivity of the CCCTB project because of the Member States fear of loss in tax revenue, ${ }^{527}$ a list of third-country company forms seems to be a reasonable choice from the Member States' perspective. On the other hand, the choice of company forms that fits into one Member State's tax system might not fit into that of another. For instance, if a third-country company form is considered as a transparent entity in one CCCTB Member State while it is opaque in another, the inclusion of a list of company forms may provide that company with an opportunity to opt into the system even if it is carrying out its business in the latter jurisdiction. The issue becomes more challenging if the investors of a company have limited liability but are (electively) treated as transparent for taxation purposes, such as in case of limited liability companies (LLCs) in the US. In such a case, the qualification for the CCCTB would depend on the election of a particular company rather than its legal form.

\footnotetext{
526 Maisto (2013), 133.

527 See, for instance, Cline et al. (2010). See also the (negative) opinions of the Ireland Dail and Netherlands Tweede Kamer on subsidiarity and footnote 207.
} 
The inclusion of a list of eligible company forms supports the effectiveness of the all-in/all-out principle. In such a case, a company would not be able to choose the jurisdiction that fits better into its group structure. In other words, the existence of a list would avoid situations in which certain affiliates are considered "similar" in one Member State but not in another. Once the option for the CCCTB is made at the group level, all pre-approved company forms, which fulfil the rest of the eligibility criteria, would have to become part of the group despite the Member State of their taxable presence (residence or a permanent establishment). On the other hand, the existence of a list of company forms in the CCCTB Directive could undermine the effectiveness of the all-in/all-out principle. In particular, a group could exclude certain entities by establishing them in a form which does not feature in the list.

If one supports the inclusion of a list of eligible company forms, one has to decide whether such a list of third-country companies should be exhaustive. On the positive side, an exhaustive list increases clarity and simplicity of defining the personal scope of the CCCTB. On the downside, such a list decreases the flexibility of applying the regime to new legal forms of establishments introduced by Member States. Taking into account a vast number of company forms used globally, it seems rather challenging to adopt a complete list of third-country company forms eligible for the CCCTB. Furthermore, an exhaustive list may be - to some extent - arbitrary, because Member States would be given the discretion to choose which companies can benefit from the common system (in any event they would need to justify their choice). On the other hand, a non-exhaustive list would allow avoiding, especially in the first years of CCCTB, the otherwise difficult question of which non-EU entities would fall under the personal scope of the CCCTB based on a similarity test. ${ }^{528}$

It appears that the European Commission has chosen a "mid-way" in the proposed CCCTB Directive. The latter will be authorised, under the comitology procedure, to adopt annually a list of third-country company forms, which shall be considered to be similar to the company forms enumerated in the Annex I. Moreover, the fact that a company form is not included in the list does not automatically preclude the application of the CCCTB system to that form. ${ }^{529}$ Such an approach provides for legal certainty and is expected to reduce

528 Staringer (2008), 123.

529 Article 3 of the proposed CCCTB Directive. 
administrative complexity, while it also allows flexibility in order to comply with the equality principle. On the other hand, an incomplete list may turn out to be difficult to apply in practice because of a lack of guidance on the actual procedure of dealing with non-listed thirdcountry company forms. For example, issues related to the designation of the responsible authority/Member State to decide on the eligibility of a company, whether other Member States would be bound by that decision and whether the decision applies only to one particular case or influences all entities having the same form may arise. ${ }^{530}$ Furthermore, if companies established in CCCTB Member States are limited by an exhaustive list (i.e. Annex I), whereas companies established in third countries are subject to a nonexhaustive list, the current CССТВ framework might place the latter in a more advantageous situation compared to the former. ${ }^{531}$ While such an approach is consistent with the idea of making the EU a more competitive location for international investments, 532 it is inconsistent with the key objective of the CСCTB, i.e. the achievement of a single market via the removal of all tax obstacles to the freedom of establishment. Based on Article 54 of the TFEU, companies and firms formed in accordance with the law of an EU Member State are supposed to be the (first) beneficiaries of the freedom of establishment. 533

\subsubsection{THE "SIMILARITY-REQUIREMENT"}

Overall, from the author's perspective, the European Commission's choice of a non-exhaustive list of third-country company forms seems sustainable. However, one must also ascertain whether it is justified that such a list is limited to the extent that the company form is similar to one of the annexed company forms. First, one might try to argue against such a similarity test due to the non-discrimination requirements, such as that provided in Member States' DTCs corresponding to Article 24(1) of the OECD MC. Article 24(1) of the OECD MC prohibits unjustified (direct) discrimination based on

\footnotetext{
${ }^{530}$ Confédération Fiscale Européenne (2012), 107.

531 Nevertheless, one should bear in mind that only EU-located permanent establishments and residents can participate in the CCCTB system. From a practical perspective, this would normally imply that the latter would have to comply with the corporate tax and company law rules in the Member State of its location.

532 Recital 4 of the Preamble of the proposed CCCTB Directive.

${ }^{533}$ Cerioni (2011), 516.
} 
nationality. ${ }^{534}$ Each discrimination analysis requires the comparison of the relevant situations. In the present case, it seems reasonable to plead that different forms of establishment are in principle not in comparable situations. Therefore, their different treatment does not constitute discrimination.

A question remains, however, whether they become comparable if, for instance, both companies - those established under the laws of a CCCTB Member State and those established in third countries - are resident in the CCCTB jurisdiction. From the author's point of view, the similarity requirement would lead to discrimination if the two forms of establishments were in similar circumstances. In sum, the denial of the CCCTB application to companies of third countries that have a DTC with the relevant CCCTB Member State, and that are dissimilar to those listed in Annex I but that are residents in one of the CCCTB Member States, would violate the DTC nondiscrimination obligation. In this case, CCCTB Member States would have to assess in each case whether a third-country company is resident in any of the CCCTB Member States. Such information could be obtained from Member States' tax authorities or be provided by each taxpayer, for instance, based on a certificate of residence issued or confirmed by the relevant Member State. However, as will be discussed below, the proposed CCCTB Directive requires the company to be resident only within the CCCTB jurisdiction, also under relevant DTCs. Therefore, the taxpayer would also have to prove that it is not a resident outside of the CCCTB jurisdiction under any of the relevant DTCs.

The same conclusion applies if the third-country company opts for the CCCTB system as a non-resident via its CCCTB-located permanent establishment. In general, the DTC non-discrimination provision (Article 24(3) of the OECD MC) prohibits Contracting States from taxing permanent establishments more heavily than their own resident companies. If a Member State normally taxes the profits attributed to such a permanent establishments under its domestic law with a corporate income tax, it is self-evident that the country considers the non-resident to be a corporation. In that case, the Member State should be consistent and allow the application of the CCCTB system even to companies that are not similar to

534 The OECD MC defines the nationality of legal persons as one "deriving its status as such from the laws in force in that Contracting State", in particular where it has been incorporated or registered. OECD Comm. on Article 24, para. 17. 
corporations listed in the Annex of the CCCTB Directive. It is only in that case that the DTC non-discrimination provision would not be hindered. This conclusion does not imply that the CCCTB Directive would be void or inapplicable. Without prejudice to Article 351 of the TFEU, Member States would be obliged to renegotiate their exiting DTCs to bring them in line with their EU obligations, including those stemming from the CCCTB Directive. ${ }^{535}$ However, until they are renegotiated, Member States would have to respect their international obligations that they have undertaken in their DTCs with third countries.

If the CCCTB were introduced via enhanced cooperation, the freedom of establishment set forth in the TFEU would require the equal treatment of companies of CCCTB Member States and those of non-Member States, provided that those companies were objectively in comparable circumstances. The CJEU has held that, since company law of the Member States has not been fully harmonised at the Union level, the fact that there is no company with a legal form identical to that of a company resident in another Member State cannot in itself justify a difference in treatment, because it would deprive the freedom of establishment of all effectiveness. ${ }^{536}$ Freedom of establishment aims to guarantee the benefit of national treatment in the host Member State by prohibiting any discrimination based on the place where companies have their seat. ${ }^{537}$ From the author's perspective, the CCCTB system is a tax system that can freely define its scope, i.e. by reference to a set of legal persons taking a specific legal form listed in Annex I. ${ }^{538}$ It does not create a definite advantage to companies. Consequently, companies from non-participating Member States, by default, could not rely on the non-discrimination requirement to escape from the application of the similarity-criterion. Actually, the same approach is normally taken at the national level, where the scope of corporate income taxes is limited to certain legal forms. Hence, Article 2(2)(a)

\footnotetext{
535 For further discussion, vide infra at 7.7.2.

536 Case Aberdeen Property Fininvest Alpha (C-303/07), para. 50.

537 Cases Test Claimants in Class IV of the ACT Group Litigation (C-374/04), para. 43; Denkavit II (C-170/05), para. 22; Burda (C-284/06), para. 77; Aberdeen Property Fininvest Alpha (C-303/07), para. 38.

538 It is also noteworthy that case law in the field of company law, in particular, Überseering (C-208/00) and Inspire Art (C-167/01), only require Member States to recognise the legal capacity of foreign legal persons (the legal status as a person as such) rather than suggesting how to recognise specific legal forms in foreign jurisdictions.
} 
of the proposed CCCTB Directive ensures that the legal form requirement is applied to ensure compliance with the personal scope of the Directive rather than giving access to an advantage. Consequently, it is not contrary to the freedom of establishment to exclude companies established in non-CCCTB Member States from Annex I of the CCCTB Directive but instead to subject them to the similarity requirement in the same way as companies from other third countries. In any event, it seems unlikely that companies of nonCCCTB Member States would not meet the similarity requirement in the case of enhanced cooperation.

Based on the conclusions put forward earlier, the DTC nondiscrimination clause, if applicable, could still require CCCTB Member States to recognise companies from non-CCCTB Member States (in the setting of enhanced cooperation) despite the fact that they have a similar form to companies listed in Annex I. This is true only if these companies are in comparable circumstances to companies from CCCTB Member States, in particular, due to their residency or the existence of a permanent establishment in the CCCTB jurisdiction. In any event, only those companies that fall within the personal scope ${ }^{539}$ of the relevant DTC could benefit from the non-discrimination clause. Consequently, even if companies from non-CCCTB Member States could not rely on the treaty freedoms to disregard the similarity-criterion, they could do so based on the DTC non-discrimination clause. The DTC-network between EU Member States is rather complete and, thus, it could offer a rather broad base for protection against discrimination based on the legal form.

In the same vein, provisions on the freedom of establishment set forth in the EEA Agreement do not require the unconditional recognition of companies from EEA Member States for CCCTB purposes. Unless there is a DTC applicable between the relevant States, as discussed above, these companies would have to meet the similarity criterion in order to be eligible.

If an entity cannot benefit from the DTC non-discrimination clause (e.g., it is not a person for the purposes of the DTC or there is no DTC between the relevant States) as per the similarity requirement, one must establish criteria for "similarity" for the CCCTB purposes. Such a similarity approach is applied by most Member States in their

539 Article 1 of the OECD MC. 
domestic law in determining which foreign entities are subject to their domestic corporate income tax rules on a non-resident basis. Given their experience, those Member States may wish to continue with their practice also in assessing the CCCTB-eligibility. This however may lead to different criteria for similarity applicable in various Member States. ${ }^{540}$ Indeed, a third-country company form might not qualify as "similar' in one Member State but qualify in another. For example, partnerships may be treated as opaque (thus subject to corporate income tax) in one Member State but transparent in another Member State, because the transparency of these entities is usually defined by comparing the legal characteristics of such an entity in the light of domestic company law of the source State. Therefore, clear guidance at the Union level as to which elements must be included in the assessment (e.g. similar corporate legal structure) is desirable.

Next, the similarity criterion requires an assessment based on the entire list included in Annex I, as the wording requires the thirdcountry company to take "one of the forms". Thus, the comparison is not limited to the forms in the Member State where the company carries out its business through a permanent establishment or where it resides. Instead, the comparison must be made across the CCCTB jurisdiction. Without clear guidelines, the assessment might be challenging, especially if one considers that the Member States have drawn up the Annex reflecting their tax rules applicable to their establishments. One may claim that the similarity requirement is met if the entity is subject to a corporate tax listed in Annex II in one of the CCCTB Member States. Indeed, if the establishment were subject to corporate income tax either because of its residency or because of the existence of a permanent establishment in a CCCTB jurisdiction, it is evident that the Member State treats the company similarly to companies established within its jurisdiction. ${ }^{541}$ On the contrary, if the Member State subjected the income of an entity to personal income taxation (e.g. in case of transparent entities having a permanent establishment in the Member State), it is rather obvious to exclude them from the CCCTB.

Another issue concerns the (non-) transparency of the entity in the third country. For instance, if an entity is considered transparent in its

\footnotetext{
540 Staringer (2008), 123.

${ }^{541}$ Note that for instance the Parent and Subsidiary Directive does not extend its benefits to all companies subject to corporate income taxes in Member States.
} 
home country but opaque in one of the CCCTB Member States, it is questionable whether the entity meets the similarity criterion and could opt for the CCСТВ. ${ }^{442}$ While companies established in the CCCTB Member States must be subject to a corporate tax listed in Annex II, ${ }^{543}$ the same requirement has not been set forth for thirdcountry establishments. In other words, the latter do not have to be subject to corporate taxes in their home State. The requirement for a third-country company to participate in the CCCTB system is that it has a taxable presence in the CCCTB jurisdiction due to residency ${ }^{544}$ or the existence of a permanent establishment. Consequently, it appears to be irrelevant whether the income of the third-country company is taxed in the hands of the entity itself or its stakeholders (in the case of a transparent entity) in its home State.

If an entity, which is considered transparent in its home State, opts into the CCCTB system as a resident taxpayer or through its CCCTBlocated permanent establishment, its income will be included into both the CCC tax base as well as the tax base of the stakeholders due to the principle of worldwide taxation (if applicable in their country of residence). In principle, the fact that behind the structure is an individual instead of a corporation should not itself represent a problem for the application of the CCCTB system. This is because all the income of the taxpayer, calculated in accordance to the CCCTB rules, would be included in the CCC tax base and shared between the relevant Member States. The only concern is that if the stakeholders of the transparent entity were individuals, they would take advantage of the CCCTB system, even though they were not meant to do so. 545 The question is whether the EU should in fact be concerned about such an outcome, even if participation in the CCCTB leads to a

542 The proposed CCCTB Directive deals with transparent entities in Chapter XV. However, the relevant articles do not deal with the issue whether a transparent entity may participate in the CCCTB system but with the treatment of income of CCCTB group members having interest in such entities. Notably, Article 85 therein provides for the rules determining the transparency in case of third-country companies. According to the general rule, the question of transparency shall be determined according to the law of the Member State of the taxpayer holding the interest in such an entity. From the author's perspective, such an approach is not appropriate, because being a term included in the (proposed) Directive, the criteria of transparency becomes part of EU law and can be thus defined only by reference to the latter.

543 Article 2(1)(b) of the proposed CCCTB Directive.

544 As defined in Article 6 of the proposed CCCTB Directive. For further discussion, see I4.2.2 below.

545 Maisto (2013), 135. 
favourable tax result for the taxpayer. In any event, in practice it is rather difficult to predict whether participation in the CCCTB system leads to a broader or narrower tax base compared to the tax base calculated under Member States' national rules. Above all, one must remember that the CCCTB aims to "tackle some major impediments to growth in the Single Market", ${ }^{446}$ such as heavy administration burdens and high compliance costs, and thereby increase the competitiveness of the EU. The importance of third-country businesses and investment in the $\mathrm{EU}$ is indisputable. Against this background, the adherence to the legal fiction of the separate corporate personality of the shareholders for the purposes of similarity is weak. Moreover, differentiating between two types of investors - corporate or individual - works against the international neutrality principle.

\subsubsection{COMPANIES ESTABLISHED}

Article 2(2) of the proposed CCCTB Directive requires third-country companies be "established" for the purposes of CCCTB-eligibility. In that regard, two main questions arise. First, what is "establishment"? Second, how does the CCCTB system deal with migrating companies? The second issue may be bifurcated as follows: (i) if a company established in a third country migrates to a CCCTB jurisdiction, will it become subject to Article 2(1) as a CCCTB establishment or continue to be subject to Article 2(2) as a nonCCCTB establishment?; or, vice versa, (ii) if a company established in a CCCTB Member State migrates to a third country, will it remain subject to Article 2(1) or become subject to Article 2(2) of the proposed CCCTB Directive?

The concept of "company" has been defined in the proposed CCCTB Directive by reference to Annex I. However, the term "established" has not been described therein. ${ }^{547}$ This does not imply that Member States can interpret the term in accordance with their national law. Indeed, the fact that it is included in the Directive implies that it is an EU term, which can be defined only by reference to EU law, subject to the interpretation given by the CJEU. With

\footnotetext{
546 Explanatory Memorandum of the proposed CCCTB Directive.

547 It is noteworthy that the other EU corporate tax Directives do not use the term "established" for a company to fall under the personal scope of the respective Directive. See Article 2(1) of the Parent and Subsidiary Directive; Article 3 of the Merger Directive; Article 3 of the Interest and Royalty Directive.
} 
regard to CCCTB Member States, the word "established" is less important because Article 2(1) of the Directive should always be read in conjunction with Annex I. ${ }^{548}$ However, in respect of third-country establishments, CCCTB Member States would have to accept all company forms that have a similar form to one of the forms listed in Annex I. Hence, there seems to be little need for the requirement to be "established".

With regard to EU establishments, Article 49 of the TFEU prohibits the imposition of restrictions on the freedom of establishment of nationals of a Member State (i.e. Member State of the primary establishment) in the territory of another Member State. Moreover Article 49 prohibits restrictions on nationals of a Member State setting up agencies, branches or subsidiaries in the territory of another Member State (i.e. secondary establishment). According to Article 54 of the TFEU, companies and firms can rely on the freedom of establishment (i) if they are formed in accordance with the law of a Member State and (ii) they have their registered office, central administration or principal place of business within the Union. According to the second sentence of Article 54 of the TFEU, "companies and firms" formed in accordance with a Member State's law means entities with a profit-making purpose. Consequently, the concept of establishment involves the actual pursuit of economic activity through a fixed establishment in another Member State for an indefinite period. ${ }^{549}$ In the case of secondary establishment in a host Member State, in the light of the jurisprudence of the CJEU, 550 it is not necessary for the company to carry on economic activity in its home Member State (i.e. the Member State of primary establishment). Hence, if the CCCTB is adopted by means of enhanced cooperation, a CCCTB Member State should recognise that a company is "established" in a non-CCCTB Member State (i) if it is set up for the purposes of exercising an economic activity (i.e. the profit-making

\footnotetext{
548 It is noteworthy that in the late 1960s, the original six Member States negotiated on the Convention on the Mutual Recognition of Companies and Bodies Corporate. According to Article 1 of the Convention, "establishment" covered companies established under civil or commercial law, which granted them the capacity of persons having rights and duties and having their statutory registered office in the territories to which the Convention applied.

549 Opinion of Advocate General Darmon delivered on 7 June 1988 on case Daily Mail (81/87), para. 5; case Factortame II (C-221/89), para. 20. For further analysis on the matter, see European Commission (2001c). See also Smit (2011b), 44 et seq. ${ }^{550}$ Cases Segers (79/85), para. 16; Centros (C-212/97), paras. 17 and 29; Inspire Art (C$167 / 01)$, para. 87.
} 
purpose) (ii) on a permanent basis (or at least a lasting one) within the CCCTB jurisdiction, (iii) despite whether the company exercising the freedom of (secondary) establishment) carries out economic activities in its home State. In the end, the fact whether or not the company carries on economic activities in the home State does not affect the application of CCCTB rules. What matters is that the company has a subsidiary or a permanent establishment within the CCCTB jurisdiction which is taxed according to the CCCTB rules. Whether the home State of the company (i.e. the parent company or the head office) taxes the income does not affect the calculation or the use of CCC tax base. In any event, artificial transactions affecting the CCC tax base would be caught by the CCCTB GAAR. ${ }^{551}$ Against this background, the eligibility requirement of being "established" appears to be an unnecessary requirement in the case of enhanced cooperation. In fact, the same conclusion should apply to entities from non-EU Member States (despite that the freedom of establishment is not applicable to them).

Another question is what the consequences are if a company established in a third country migrates to a CCCTB Member State or, vice versa, a company established in a CCCTB Member State migrates to a third country. Further, it may be questioned whether it makes a difference that the transferring company is formed under national law that follows the incorporation theory or the real seat theory and/or whether the destination country follows one or the other theory. ${ }^{552}$ Since the proposed CCCTB Directive is silent on the issue, one must refer to the national law of the countries involved. In case of migration within the EU (in the setting of an enhanced cooperation), the relevant States must further respect EU law, ${ }^{553}$ as

\footnotetext{
${ }^{551}$ For a further discussion on GAAR in general, vide infra at II8.3.1.

552 The incorporation theory links the existence, internal affairs and dissolution of a company to the jurisdiction in which it has been incorporated (i.e. where the statutory seat of the company is), irrespective of its activities carried out in other states. Contrary to this, the real seat (i.e. actual centre of administration) theory looks for a substantial connection between a company and the legal system for the formation and establishment of legal personality. Importantly, the incorporation States recognise the legal personality of companies that have been formed in other States but which have their place of effective management in their jurisdiction without the requirement of re-incorporation. However, the real seat theory requires both the actual centre of management and incorporation or registration to be in that jurisdiction in order to recognise its legal personality. Panayi (2009), 459-460.

553 There is no Union legislation that deals with corporate migration per se. Thus, corporate migration within the EU must be assessed in the light of general TFEU provisions, in particular, freedom of establishment and ad hoc legal instruments, such
} 
interpreted in the light of the relevant case law of the CJEU. ${ }^{54}$ The absence of uniform rules in the field of company law might thus complicate the application of the CCCTB rules. This again suggests that the term "established" is an unnecessary requirement of CCCTBeligibility.

\subsubsection{SubJECT-TO-TAX REQUIREMENT}

Whether one is a taxable person is typically tested via its subjective tax liability, which means first, qualifying someone as a taxpayer, and/or its objective tax liability, which refers to taxing specific income or capital. It is not surprising that the proposed CCCTB Directive includes a subject-to-tax test for the purposes of determining a CCCTB eligible company, given that a similar requirement has also been included in the other corporate tax directives. ${ }^{555}$ The test in the Parent and Subsidiary Directive and the Merger Directive is met if a company is not personally exempt from tax (or taxed at a 0 per cent tax rate) $)^{556}$ and in the Interest and Royalty Directive the test is met if the income received is taxed.

With regard to third countries, the subject-to-tax criterion is set forth in Article 2(2)(b) of the proposed CCCTB Directive. Accordingly, the company must be "subject to one of the corporate taxes listed in Annex II" of the Directive in order to opt into the system. It seems that, different from the personal scope of the OECD MC, the proposed CCCTB Directive does not require a third-country establishment to be subject to the most comprehensive tax liability in

as Council Regulation 2157/2001 on the Statute for European Company (SE) and Directive 2005/56/EC on Cross-Border Mergers of Limited Liability Companies. See further Panayi (2009), 461-462.

${ }^{554}$ Unfortunately, due to limited time and space, further analysis of the issue is outside the scope of this dissertation.

555 Article 2(1)(c) of of the Parent and Subsidiary Directive; Article 3(c) of the Merger Directive. Article 1 of the Interest and Royalty Recast Directive of 11 November 2011 requires the income to be taxed in the recipient Member State, rather than requiring the person to be subject to tax itself in that State.

556 Staringer (2008), 126. The differentiation between the effective exemption (the zero per cent condition) and low taxation may give rise to disagreements. For example, it is questionable whether a 0.1 per cent taxation should be rounded down to zero or whether it counts as taxation. The literal reading of the Directives would lead to the conclusion that only personal exemption and taxation at zero per cent would lead to the inapplicability of the benefits. However, acceptance of very low taxation, such as that of 0.1 per cent, seems to be consistent with the wording of the Directive, even if this was not the intention of the drafters of the Directives. 
its country of origin by reason of its domicile, residence, place of management, or any other criterion of similar nature to benefit from the CCCTB Directive. Thus, the Directive does not require the thirdcountry company to be subject to tax as a resident or even as a nonresident in its country of establishment in order to be entitled to opt for the CCCTB. Therefore, a third-country company may qualify as an eligible company as long as it is subject to tax within the CCCTB jurisdiction due to its residency or the existence of a permanent establishment. A reason for this could be that the CCCTB system aims to deal with the calculation of the tax base of the group (or a single taxpayer) and the use of that base (via the sharing mechanism set forth in Article 86) within the CCCTB jurisdiction. ${ }^{557}$ In case such a company is a resident in a CCCTB Member State or has a permanent establishment there, the tax base allocated to it will be taxable in accordance with the rules of that Member State. ${ }^{558}$ Therefore, the taxation rules of a third-country company subject to tax in the CCCTB jurisdiction in its country of origin, residence (in case of double-residency) or business location fall outside the territorial scope of the CCCTB. In other words, the application of the Directive for the calculation and the use of the CCC tax base can be achieved even if the other country does not exercise its taxing right. In sum, as long as a third-country company has a taxable presence within the CCCTB jurisdiction (because of either residency or the existence of a permanent establishment), the objective of the (proposed) CCCTB Directive can be achieved. Whether and to what extent that income is also taxable in the third country does not fall within the scope of the CCCTB Directive.

Unlike the Parent and Subsidiary Directive and the Merger Directive, 559 the proposed CCCTB Directive does not contain a condition that the company must not have the possibility or an option to be exempt. In fact, the absence of this requirement is justified. The other EU corporate tax directives aim to enhance pan-

\footnotetext{
557 Article 1 of the proposed CCCTB Directive; emphasis added.

558 The proposed CCCTB Directive does not deal with the (final) tax liability of the company in its country of origin, residence or business location (as the CCCTB does not deal with tax rates and the timing of the tax liability). Each relevant Member State where the group has a member can decide whether, and if so at which rate, it wishes to tax the income allocated to that particular group member. See, however, Article 103 of the proposed CCCTB Directive, which defines 'tax liability' of CCCTB group members.

${ }^{559}$ The Interest and Royalty Directive merely requires that the company is subject to tax "without being exempt".
} 
European movement by means of the elimination of double taxation. Therefore, these directives include the above-mentioned condition because there is no reason to require a Member State to prevent double taxation if, in effect, there is no double taxation from the beginning. The subject-to-tax criterion has less importance in the CCCTB Directive because its purpose is different from those of the earlier EU corporate tax directives. It provides uniform rules for the calculation and the use of the tax base within the CCCTB jurisdiction, without being concerned about the final tax liability of the taxpayer. Double taxation of CCCTB group members on their CCC tax base is automatically avoided due to the application of the sharing mechanism. Finally, the Member States are free to set both the relevant tax rates and timing of taxation of such a tax base under their national law, without the need for coordination at the EU level. In the light of this reasoning and the aim of the (proposed) CCCTB Directive, the proposed CCCTB framework actually seems to limit the tax sovereignty of the Member States by imposing the subject-totax requirement. Therefore, Member States could see it as an opportunity to challenge the proposed CCCTB Directive against the subsidiarity principle. As a counter argument, the absence of this requirement could lead to undesired tax planning where heavier weight of factors would be allocated to the Member State where a group member would be exempted from tax or would have the option of being exempt. Yet again, the CCCTB should not be concerned with the final tax liability in the Member State as the latter should be free to decide their policy as to which entities and which income to tax.

The latter discussion can be taken further to discuss the difference between subjective and objective exemptions. One can imagine a situation in which a company is subject to tax while most of its income is objectively exempt. For example, some countries may condition the exemption from corporate taxation on the fact whether the company's profits are distributed to the shareholders immediately after the closure of the fiscal year. In such a case, depending on the company, it may or may not be objectively taxable. Hence, the question here is not whether the person is transparent or opaque but whether it decides to distribute the profits, so that the profits become taxable with a personal income tax in the hands of the stakeholders. In such a case, the income is still taxed, but it is taxed in the hands of a different person. Another example concerns situations in which a country's tax policy supports exempting certain type of income from corporate tax. For instance, some countries have opted not to tax or 
to tax at a low rate income from the provision of health care or educational services. In the light of the premise that CCCTB Member States are free to determine the tax liability of group members in their territory, it is still correct to claim that an entity providing said services is "subject" to corporate income tax in that CCCTB Member State even if the latter normally exempts all or most of its income.

The subjective scope of the proposed CCCTB Directive requires the person to be subject to corporate income tax within the CCCTB jurisdiction (Annex II). However, one could argue that the Directive should be available not only to entities that are subject to corporate income tax but also to entities that are subject to business income tax. ${ }^{560}$ For example, assume that a non-resident company is considered to be an opaque entity in its country of establishment but transparent in the CCCTB Member State in which it carries out business through a permanent establishment. In such a case, the CCCTB Member State would normally subject the business income attributed to the permanent establishment to personal income tax rather than corporate income tax. However, as the permanent establishment would be carrying out business in the territory of the Member State similarly to entities subject to corporate income tax, restricting their access to the CCCTB system would infringe the principle of neutrality, because it would favour certain stakeholders over the others. Therefore, for the purposes of the CCCTB Directive, it should be essential whether the income is derived from business, rather than looking at whether it is subject to corporate income tax in a Member State.

Next, with regard to companies established in CCCTB Member States, the list of taxes is not exhaustive in the sense that it includes the phrase "a similar tax subsequently introduced"561 in Article 2(1)(b) of the proposed CCCTB Directive. Interestingly, this condition has not been included with regard to the eligibility criteria of third-

\footnotetext{
560 If a CCCTB Member State levied a branch profit tax, it would not be an indication that the third-country company is similar from a taxation perspective to that of a CCCTB-established company. A branch profit tax is typically levied on the total profits of the branch, after the deduction of the tax paid on its profits. Hence, the branch profit tax functions as a withholding tax on dividends, which would be due had the branch been a subsidiary of a foreign company distributing its profits. 561 It is worth noting that the Parent and Subsidiary Directive uses different wording: "[A]ny other tax which may be substituted for any of the above taxes" (emphasis added). The OECD MC uses the language of "any identical or substantially similar taxes" (emphasis added).
} 
country companies. However, the European Commission is entitled to update the respective annexes annually, so that the scope in terms of third-country entities will also be broader. Nevertheless, this difference could matter if a Member State introduced a tax before the update of the respective annex. In that case, companies from CCCTB Member States could be eligible for CCCTB before companies from third countries, even if they were otherwise in a similar situation. In the case of enhanced cooperation, such a difference may restrict the freedom of establishment as per the option to choose the most appropriate form of secondary establishment. ${ }^{562}$ Specifically, if a company established in a non-CCCTB Member State wished to participate in the CCCTB system, it would have to set up a subsidiary in the CCCTB jurisdiction rather than a branch, even if both of these entities were objectively comparable (subject to similar taxation) in the host State (i.e. CCCTB Member State). Indeed, a subsidiary would be able to opt into the system before the European Commission amends the respective annex, whereas, in the case of a branch, the head office could exercise the option only after the respective amendment. This limitation would remain even if, at national level, the company of a CCCTB Member State and a non-CCCTB Member State were both subject to the same, newly introduced "similar tax". Accepting the participation of both residents (i.e. the subsidiary) and non-residents (i.e. the head office with a branch) in the CCCTB system under the condition that they are subject to a "similar tax subsequently introduced" would in no case undermine the purpose of enhanced cooperation, if used.

Last, in the setting of enhanced cooperation, excluding EU entities subject to corporate income tax in non-CCCTB Member States from the subjective scope of the CCСТB Directive would not infringe the freedom of establishment, even if those entities were subject to similar taxation in their home State compared to companies in CCCTB Member States. Under EU law, there is nothing wrong with treating companies differently that are in dissimilar situations. Being subject to tax in a non-CCCTB Member State does not put such entities in objectively comparable circumstances to entities subject to (corporate income) tax in CCCTB Member States. The situations of the two companies become comparable if the host State (CCCTB Member State) exercises its taxing power over the non-CCCTB

562 See for instance cases Commission v France [Avoir Fisca] (270/83), para. 3 and 22; Saint-Gobain (C-307/97), para. 43. 
company. 563 Consequently, the current CCCTB proposal correctly makes the system available only to those entities that are subject-totax within the CCCTB.

\subsubsection{PRELIMINARY CONCLUSIONS}

Introducing an exhaustive list of eligible company forms for the purposes of defining the personal scope of the CCCTB would certainly bring some benefits, such as clarity, simplicity and legal certainty. However, these benefits would not outweigh the difficulties with regard to the effectiveness and functioning of the CCCTB system. Against this background, with regard to third countries, there is little need for an exhaustive list of company forms for the purposes of CCCTB eligibility. Even if such a list were nonexhaustive, the downsides of including a list would not be eliminated. In such a case, each Member State would have to assess whether a third-country company is similar to one of the companies enumerated in the Annex of the Directive (i.e. not only in its jurisdiction). Under the current CCCTB proposal, it is unclear which factors would have to be taken into account to determine such similarity. Absence of strict guidelines on identifying the similarity of company forms creates complexity, reduces legal certainty and adds tax-planning opportunities. Moreover, the similarity requirement would prospectively infringe the non-discrimination requirement contained in Member States' DTCs if the third-country company was a resident or carried on its business via a permanent establishment in a CCCTB Member State. Nor should it matter whether a company is "established" in a third country. Differentiating between different types of investors depending on the form of their investment is not in line with the international neutrality perspective.

From the author's perspective, the criterion for eligibility should be that the entity is subject-to-tax in a CCCTB Member State. This would not imply that the entity should be subject to corporate income tax, but it would suffice if the country taxed the business income of the entity. This would make the CCCTB system available to a wider scope of businesses and respect the neutrality principle. Moreover, whether the profits of a CCCTB-eligible entity are taxable in the third country falls outside the territorial scope of the CCCTB

${ }^{563}$ Cases Saint-Gobain (C-307/97), para. 47; Amurta (C-379/05), para. 41. 
Directive. The objective of the CCCTB system can be achieved without being concerned about such issues.

\subsubsection{RESIDENCE}

For taxation purposes, taxable persons are usually divided into three main groups: (i) fully taxable; (ii) taxed only on local source of income; and (iii) not taxed at all. The former consists of persons who have a strong connection to a State because of political, social or economic foundations, i.e. tax residents. In the case of companies, such a personal jurisdictional connection is typically established due to (i) formal legal connection, e.g. incorporation or registry of the seat in the commercial register, and/or (ii) economic or commercial connection, e.g. the place of management, principal business location, or residence of shareholders. In relation to the CCCTB system, there are two core questions regarding the jurisdictional connection: (i) what is the extent of contact required between a taxpayer and a CCCTB Member State; and (ii) whether jurisdiction over one CCCTB group member confers jurisdiction over other members of the group.

For the purposes of the CCCTB, a company would remain tax resident in its respective country and residence in any of the CCCTB Member State would create a nexus to the CCCTB. ${ }^{564}$ Initially, some experts considered that adopting a uniform definition of residence within the CCCTB framework might not be the optimal solution, because national legislation of Member States already define the concept. ${ }^{565}$ The concern was that it would be unclear how a common definition of residence would be applied in practice, e.g., in the event of disputes on residence (especially concerning DTCs). ${ }^{566}$ Relying on Member States national law would definitely create an advantage, because it would eliminate unnecessary complications in relation to existing DTCs of Member States with third countries. On the other hand, from an EU law perspective, reference to Member States' national law would be conceptually wrong, because being a term used in EU law, it would have to be given an autonomous meaning. Moreover, reference to Member States' national laws, which have

\footnotetext{
${ }^{564}$ European Commission (2005c), para. 23.

565 In such a case, the CCCTB Directive would have had to make a specific reference to Member States' national law. Otherwise, the concept of residence would still be considered an EU term and interpretation of it based on domestic law would be conceptually wrong.

${ }^{566}$ European Commission (2006a), para. 34.
} 
been designed taking into account their needs and policies, might have created a different scope of companies covered by CCCTB rules in Member States and thus potentially affected the apportionable CCC tax base. ${ }^{567}$ Furthermore, companies would still have to deal with several sets of residency rules (and practices). 568 Finally, a nonunified definition would allow taxpayers to manipulate the "all-in/allout" principle by leaving certain companies outside the CCCTB group by moving residence to a country with a narrower definition of tax residency. ${ }^{569}$

The 2011 CCCTB proposal follows the discussions held on a workshop in $2010^{570}$ and provides for a harmonised definition of "residence" in Article 6(3):

"[A] company that has its registered office, place of incorporation or place of effective management and is not, under the terms of an agreement concluded by that Member State with a third country, regarded as a tax resident in that third country shall be considered resident for tax purposes in that Member State" (emphasis added).

Accordingly, it uses three non-cumulative connecting factors for establishing tax residence: registered office, place of incorporation and place of effective management. These residency criteria are generally consistent with the OECD MC definition in the sense that the latter requires a company to be liable to tax in the contracting State by reason of the its place of effective management or any other criterion of a similar nature. Therefore, as far as the criterion of place of effective management is concerned, the CCCTB proposal secures that eligible entities are resident for the purposes of both the common system and the DTCs (drafted on the OECD MC).

With regard to the two other criteria - incorporation and registered office - the solution is not so straightforward. The general understanding is that incorporation and registered office do not fall under "any other criterion of a similar nature" as set forth in Article 4(1) of the OECD MC, because they cannot be considered as "any

\footnotetext{
567 European Commission (2005c), para. 23.

568 Ibid., 9.

${ }^{569}$ European Commission (2006c), para. 16.

570 European Commission (2010b), para. 6.
} 
other criterion of a similar nature". ${ }^{571}$ Instead, they are equivalent to citizenship of individuals, which normally does not create a residency nexus with a State. ${ }^{572}$ If one agrees with this premise, a company having its place of incorporation or place of registered office in a Member State would be deemed to be a resident for the purposes of the CCCTB, while it would not fulfil the personal scope of the respective DTC with a third State. This may play a role, for instance, with regard to the amount of acceptable credit for foreign income taxes as set forth in Article 76 of the proposed CCCTB Directive. For example, if a company, which is a CCCTB resident due to its incorporation in a CCСТB Member State, derived income from a third country (e.g., interest or royalties), the source country would not be obliged to limit its taxing right based on a DTC with the Member State, because the person would not be a resident for the purposes of the convention. ${ }^{573}$ In such a case, the DTC would not conflict with the provisions of the CCCTB Directive and, consequently, Member States would not be under an obligation to renegotiate the terms of their DTCs. ${ }^{574}$ Under the proposed rules, the income as well as the source tax would be shared between the CCCTB group members based on the apportionment formula. ${ }^{575}$ In practice, this implies that the Member State of establishment, which negotiated the (narrower) scope the relevant DTC application, can share the credit for (unlimited) withholding tax between the members of the group. On the other hand, this Member State can enjoy a wider scope of taxation of persons from the other DTC contracting State, because the CCCTB does not impose limitations on the levying of withholding tax on such payments. ${ }^{576}$

\footnotetext{
571 Vogel (1997), 232-233. If one accepts this premise, there will be no need to solve dual residency issues of legal persons under the "tie-breaker rule", because incorporation (even if included into domestic definition) would not create residency for DTC purposes.

572 See, however, Article 4(1) of the US MC and Article 4(1) of the UN MC 2001, which explicitly list incorporation as criteria for residency.

573 Article 1 of the OECD MC.

574 For further discussion on the applicability of Member States DTCs with third countries, vide infra at II7.3.

575 If the residency criteria of the DTC were fulfilled, the tax to be shared between the group members would be reduced to the amount prescribed in the relevant DTC.

576 Importantly, the source tax charged on interest and royalties would have to be shared based on Article 77 of the proposed CCCTB Directive. However, withholding tax on dividends paid to a non-resident as well as any other source taxation of any other type of income of non-residents would not be shared between the group members.
} 
DTCs normally provide for criteria for solving dual residence issues through tie-breaker rules. The proposed CCCTB Directive includes a tie-breaker rule only with regard to dual (or multiple) residency issues for inter-CCCTB Member States cases. In such cases, residency is attributed to the State in which the place of effective management of the company is located. ${ }^{577}$ However, there is no tie-breaker rule regarding companies from third countries. The proposed Directive only requires a company to be resident in the Member State based on a DTC between the Member State and the third country in Article 6(3) of the proposed Directive. By comparison, the Merger Directive and Parent and Subsidiary Directive consider dual resident companies eligible only if the latter are considered to be resident of $a$ Member State under the effective DTC concluded between $a$ Member State and the respective third country. ${ }^{578}$ Therefore, in the case of a DTC with a third country, while the two earlier directives require the company to be a resident of $a$ Member State (i.e. not to be "outside the Union"), the proposed CССТВ Directive requires a company to be resident in that Member State. Therefore, the former Directives provides for a broader personal scope. For instance, if a company is deemed to be a DTC resident of a third country under the DTC with Member State A, but a DTC-resident of a Member State B under the DTC with Member State B, it is questionable whether the company can benefit from the CCCTB Directive.

\footnotetext{
577 Article 6(4) of the proposed CCCTB Directive. With regard to shipping enterprises for which place of effective management is aboard a ship or boat, Article 6(5) of the proposed CCCTB Directive provides for an identical rule to that provided in Article 8(3) of the OECD MC. Accordingly, the place of effective management of such an enterprise is deemed to be situated in the home harbour of the ship or boat, or if there is no such home harbour, in the Member State of residence of the operator of the ship or boat. The inclusion of the equal wording avoids inconsistencies with Member State's DTCs with third countries.

578 Article 3(1)(b) of the Merger Directive and Article 2(1)(b) of the Parent and Subsidiary Directive.
} 
Example 1: Dual-residence under CCCTB-proposal

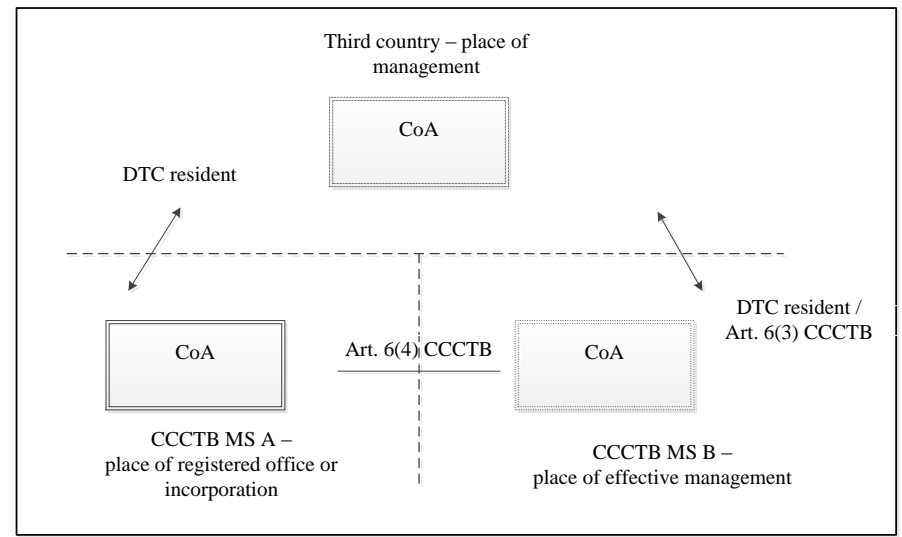

In the example above, it seems that the simultaneous application of paragraphs 3 and 4 of Article 6 of the proposed CCCTB Directive could solve the issue, provided that the company has its registered office, place of incorporation or place of effective management in the Member State. Thus, one would first need to solve the dual residency issue between the Member States and only then look at the relevant DTC of the "winner Member State". Consequently, the company (CoA) could opt for the CCCTB as a resident company of Member State B, because it fulfils one of the CCCTB residency criteria and it is resident in that Member State based on a DTC with that third country. From the author's perspective, such a solution would not lead to an infringement of Member States' obligations undertaken in their DTCs with third countries. In particular, due to the OECD "winner/loser State" approach, a company can be deemed a resident only in one State. ${ }^{579}$ Hence, the fact that under one DTC, the third country would be attributed the "winner-State" status becomes irrelevant when the same State is attributed the "loser-State" status in another DTC. Another remark relevant here is that the proposed CCCTB Directive refers only to the tie-breaker rule in case of the existence of a DTC with a third country. Hence, if an EU-established company qualifies as a resident company under the CCCTB rules as well as under any third country domestic law, and if there is no DTC between the relevant countries, the company may still opt for the CССТB.

579 OECD Comm. on Article 4, para. 8.2. 
As mentioned, the OECD uses the "winner/loser State" approach since 2008. In the following example, assume that a third country has agreed to different withholding tax rates on interest income in its DTC with Member State A (A DTC) and with Member State B (B DTC). Further, assume that the A DTC solves dual-residency by giving preference the place of incorporation, ${ }^{580}$ while the place of effective management is decisive in B DTC. (Example 2: Effect of paragraph 8.2 on Article 4 OECD MC on the application of the CCCTB system).

Example 2: Effect of paragraph 8.2 on Article $4 \mathrm{OECD} \mathrm{MC}$ on the application of the CCCTB system: place of effective management in a Member State

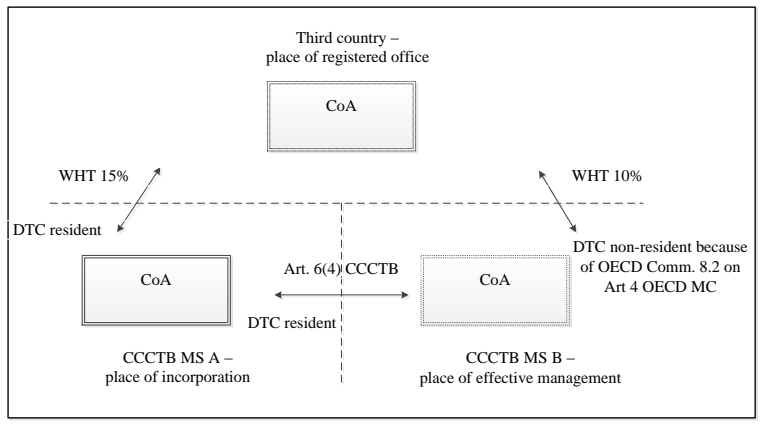

If, under the DTC between the Member States, dual residency is solved by preferring the place of incorporation (although highly unlikely), Member State A would be considered as the "winner State" for the purposes of that DTC. However, the outcome under the DTC between the Member States would be irrelevant for CCCTB purposes, because the Directive would override the DTC. ${ }^{581}$ Hence, under the proposed CCCTB Directive, the taxpayer would be deemed to reside only in the Member State in which the place of effective management is located, i.e. Member State B. This conclusion would not affect CoA's residency for A DTC purposes. This is because DTC's based on the OECD MC examine the "winner/loser State" criterion only in the light of DTCs rather than

\footnotetext{
580 For instance, DTCs based on the US MC give preference to the place of incorporation (Article 4(4) of the 2006 US MC). See, for example, reservations on Article 4 of the OECD MC, paras. 27 and 31 and positions of non-member countries therein, para. 5 .

581 Articles 6(4) and 8 of the proposed CCCTB Directive.
} 
the global/EU outcome. Nevertheless, the Member States' DTC outcome would affect the application of B DTC due to the "winner/loser State" approach. Accordingly, the third country would consider the company to be a non-resident in Member State B for the purposes of B DTC, even though the company continued to be a resident for CCCTB purposes in Member State B. In the light of this example, Member States should clarify in their DTCs with third countries that, for the purposes of determining the residence of companies, one must assess whether the person remains "subject to the most comprehensive tax liability" in that Member State under the CCCTB rules, despite the existence of a DTC with another CCCTB Member State.

The solution would be slightly different in case the place of effective management of the company was located in a third country while its registered office and place of incorporation were in different Member States. In practice, it is rather unlikely that a company's place of incorporation and registered office are located in different States. However, for the purposes of academic exercise, one can assume that, under the DTC between Member State A and a third country, dual residency is solved by giving preference to the place of effective management of the company, while under the DTC between Member State B and the third country the place of incorporation is decisive. (Example 3: Effect of paragraph 8.2 on Article 4 OECD MC on the application of the CCCTB system: place of effective management in a third country)

Example 3: Effect of paragraph 8.2 on Article 4 OECD MC on the application of the CCCTB system: place of effective management in a third country

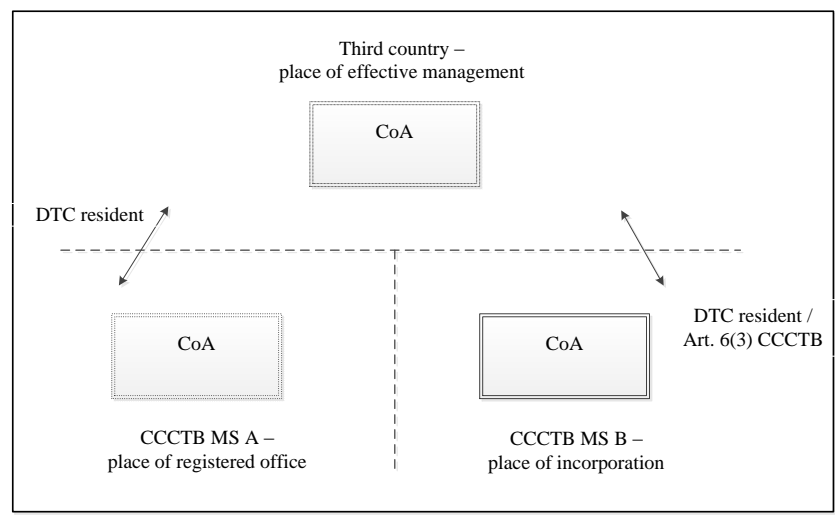


In this case, the taxpayer would fulfil the CCCTB residency criteria in both CCCTB Member States. However, because its place of effective management is in neither of the Member States, the tie-breaker rule of Article 6(4) of the proposed CCCTB Directive would not apply. The question is whether the Member States could refer to their DTC to solve the dual-residency issue, as the (proposed) CCCTB Directive is unable to do so. Article 8 of the proposed CCCTB Directive gives preference to the Directive over Member States' DTCs with each other to the extent that they include conflicting provisions. The fact that the Directive does not solve the issue of dual residence of the taxpayer in this particular case does not imply that the (proposed) CCCTB Directive is in conflict with the provisions of the DTC between the Member States. Consequently, from the author's perspective, if the Directive is unable to solve the issue, Member States should be entitled to refer to the tie-breaker rule in their DTC. Finally, if the DTC between the Member States did not provide a solution (e.g., the tie-breaker rule was based on the place of effective management), one could argue that Member States' DTCs with third countries should lead to the solution. In the example earlier, this would imply that the company could opt for the CCCTB only in Member State B in which it has its DTC residency.

In the next example, assume that a company was incorporated in a third country while its registered office and place of effective management were located in different Member States.

Example 4: Place of effective management as a permanent establishment in the CCCTB jurisdiction

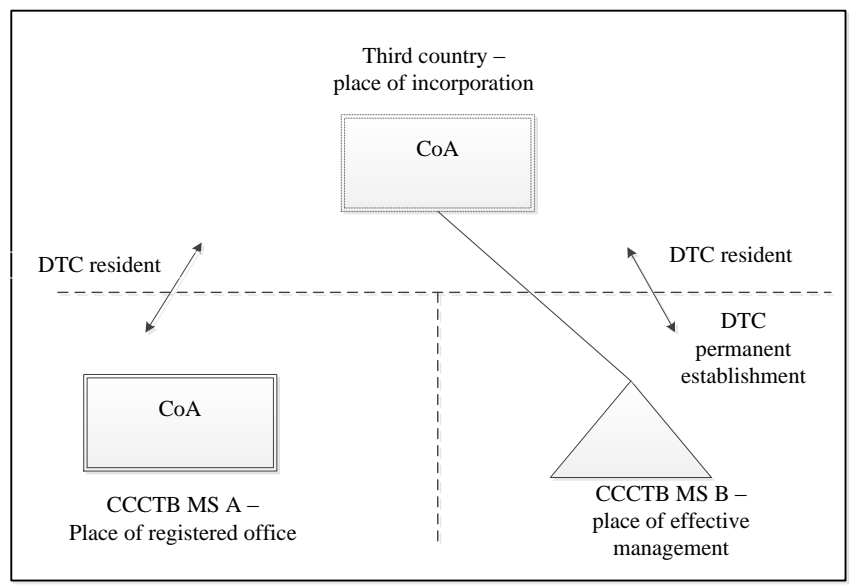


In this example, under the proposed CCCTB rules, the company would be deemed to be resident only in Member State B, given its place of effective establishment is in that Member State. However, in the light of the fact that Member States' DTCs with third countries override the conflicting provisions with the CCCTB Directive (until renegotiated or if they are grandfathered), if the tie-breaker rule in the DTC between Member State B and the third country was based on the place of incorporation, the company would be deemed to be a resident only in that third country. However, place of effective management located in the EU might constitute a permanent establishment ${ }^{582}$ for that company, which would allow the third country company to opt for the CССTB based on Article 6(2) of the (proposed) CCCTB Directive.

In some DTCs, double residency of companies is solved through the mutual agreement procedure. ${ }^{583}$ This approach tries to allocate a person's residency only to a state where the economic links to the jurisdiction are closer and takes into account the domestic laws, fiscal culture and practice of the contracting States. Hence, it aims at reflecting better the economic reality of each business. However, as a downside, this method relies strongly on the subjective opinion of the competent authorities. In a CCCTB scenario, if the tie-breaker in a Member State DTC with a third country was based on the mutual agreement procedure, the residency would be solved only between those the authorities from those countries. The bilateral nature of the DTCs would not allow the involvement of tax authorities from other CCCTB Member States, even though the outcome could affect the tax base of the whole CCCTB group.

Another question is whether a company established in a CCCTB Member State, but deemed to be resident under the relevant DTC in a third State and that company has a permanent establishment in another CCCTB Member State, could form a CCCTB group with that permanent establishment.

582 Article 5(2) of both the US MC and the OECD MC give a non-exhaustive list of examples (e.g., place of management) that are deemed to give rise to a permanent establishment but only if the conditions under the basic rule (Article 5(1)) are met.

583 Many DTCs concluded by the Baltic countries do not include a specific tiebreaker rule in their DTCs but they solve the issue in accordance with the mutual agreement procedure (e.g. Estonia-France concluded on 28 October 1997). 
Example 5: Denial of group membership due to the existence of a DTC with a third country

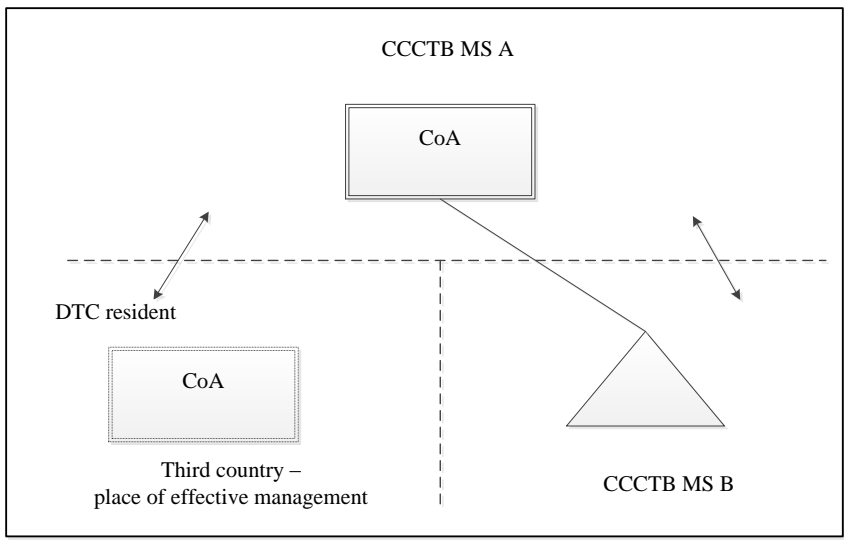

Under Article 49 of the TFEU, for the purposes of both the primary and secondary establishment, the investor has to be a national of a Member State. According to Article 54 of the TFEU, companies and firms formed in accordance with the law of a Member State and having their registered office, central administration or principal place of business within the Union are considered to be nationals of the Member State and thus fall under the scope of the freedom of establishment. The concept of establishment involves the actual pursuit of an economic activity through a fixed establishment in another Member State for an indefinite period. A dual-resident company, which is established in an EU Member State, can be denied access to the freedom of establishment if: (i) it does not carry on genuine economic activities through a branch in an EU Member State, or (ii) the activities lack a sufficient degree of independence, management or control within that Member State. ${ }^{584}$ If that dualresident company has a permanent establishment in a CCCTB Member State, through which it carries on genuine economic activities, 585 the CCCTB Directive could not exclude the application of the system to permanent establishments of EU-established companies that are deemed to be tax resident outside the EU (provided that they still satisfy the conditions of Article 54 of the

\footnotetext{
${ }^{584}$ Smit (2011b), 771.

585 Due to the fact that 'permanent establishment' is a tax concept, which implies carrying on activities through a fixed place of business, the author does not see a possibility that the activities of a permanent establishment are not "genuine enough".
} 
TFEU). Nevertheless, as a non-resident, the company could not opt into the CCCTB system itself and thus could not form a CCCTB group with its CCCTB-located permanent establishment. It is noteworthy that if the Member State of establishment did not have a DTC with the third country, the company would have remained resident within the CCCTB jurisdiction. In such a case, it would have been eligible to opt into the system itself and to form a CCCTB group with the permanent establishment accordingly.

In conclusion, the fact that the proposed CCCTB Directive does not include a separate tie-breaker rule for solving dual residency cases with third countries avoids prospective conflicts with Member States' DTCs with third countries. Given that such DTCs will override conflicting provisions of the CCCTB Directive until they are renegotiated, ${ }^{586}$ the inclusion of an overarching CCCTB tie-breaker rule may appear unnecessary, at least from a short-term perspective. Nevertheless, relying on Member States' bilateral DTCs may result in a number of inconsistencies with regard to the eligibility of companies as well as make the system more sensitive for tax planning. Therefore, in the author's opinion, a uniform CCCTB tiebreaker rule is desirable.

\subsubsection{CCCTB TIE-BREAKER RULE}

Since dual residency of companies in practice is less common than dual residency of individuals, ${ }^{587}$ the tie-breaker rules applicable to companies in Member State national laws and DTCs are respectively less comprehensive. The most common rule for solving dual residency of corporations is based on a factual test: it deems a company to be a resident only in the country where the place of effective management ${ }^{588}$ is located. Some DTCs, however, deviate from this practice and give preference to other criteria based on a legal test, for example, incorporation, ${ }^{589}$ solve the issue by the mutual

\footnotetext{
${ }^{586}$ For further discussion, vide infra at II7.3.

587 OECD Comm. on Article 4, para. 21.

588 Alternative expressions in DTCs include "place of general management", "centre of its administrative or practical management", "actual centre of management", "where the company is managed and controlled", and "real organ of management". Couzin (2002), 166.

589 See, for instance, Reservations on Article 4 of the OECD MC, paras. 27 and 31. Alternative expressions in DTCs include "place of creation" or "place of registration”. Ibid., 166.
} 
agreement procedure, 590 or provide a combination of the above, based on a sequential test. ${ }^{591}$ The place of effective management also serves as the connecting factor for a tie-breaker rule in Article 4(3) of the OECD MC because "[i]t would not be an adequate solution to attach importance to a purely formal criterion like registration". ${ }^{592}$ As referred to earlier, in intra-CCСТВ situations, dual residency of companies is solved by a preference for place of effective management in Article 6(4) of the proposed CCCTB Directive. If the CCCTB Directive introduced a tie-breaker rule, which would affect situations across the CCCTB water's edge, it would be desirable to draft those rules in line with the intra-CCCTB scenarios. Place of effective management could then serve as the criteria for solving the issue in both cases. However, as discussed earlier, in some cases, such a solution could conflict with the Member States' DTCs with third countries (until renegotiated).

The introduction of a CCCTB tie-breaker rule could be approached from three perspectives: (i) create a uniform rule for all inter-CCCTB and intra-CCCTB scenarios; (ii) refer to Member States domestic law and DTCs; or (iii) use the combination of the two. The first option seems desirable, but it may lead to unnecessary complications in relation to potential conflicts with Member States' international obligations. Without prejudice to Article 351 of the TFEU, Member States would be obliged to renegotiate their existing DTCs to bring them in line with their EU obligations, including those stemming from the CCCTB Directive. The second option relies solely on Member States' national law and DTC provisions. While this rule respects Member States' international agreements, it may lead to inconsistencies and undesired tax planning. To illustrate, assume that a third country has a DTC with CCCTB Member State A but not with any other CCCTB Member State. A company (CoA),

\footnotetext{
${ }^{590}$ For instance, Convention between the Republic of Austria and the Republic of Bulgaria for the Avoidance of Double Taxation with Respect to Taxes on Income and on Capital (entry into force: 3 February 2011), Article 4(3). In case a mutual agreement procedure does not lead to a result, a company might be considered not to be a resident of either Contracting State for the purposes of enjoying benefits under the DTC. See, for instance, Convention between Canada and the Portuguese Republic for the Avoidance of Double Taxation and the Prevention of Fiscal Evasion with Respect to Taxes on Income (entry into force: 24 October 2001), Article 4(3).

591 For instance, Convention between Canada and the Czech Republic for the Avoidance of Double Taxation and the Prevention of Fiscal Evasion with Respect to Taxes on Income (entry into force: 28 May 2002), Article 4(3).

592 OECD Comm. on Article 4, para. 22.
} 
incorporated in CCCTB Member State B, has its place of effective management in the third country. (Example 6: Absence of uniform tie-breaker rule)

\section{Example 6: Absence of uniform tie-breaker rule}

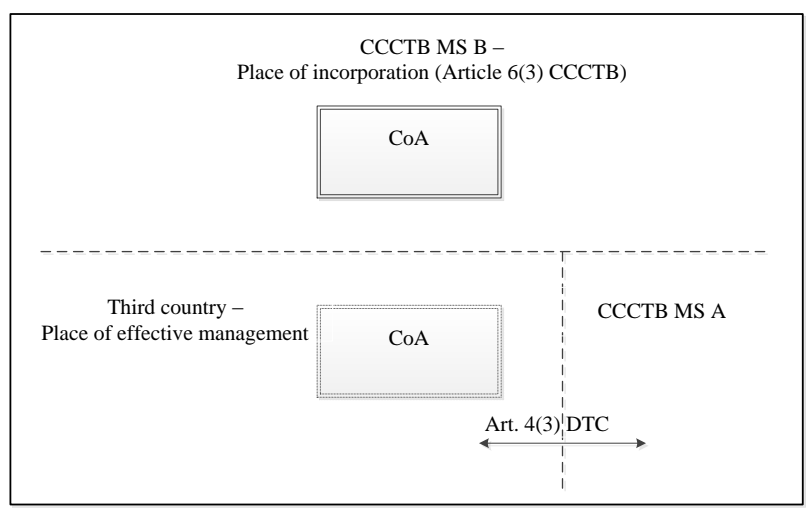

It was explained above that the personal scope of the proposed CCCTB Directive is narrow in the sense that it requires a company to be resident in the Member State based on a DTC between the Member State and the third country in Article 6(3). It appears that the effect of the DTC between (the) Member State A and the third country does not influence the company's residence in Member State B under the CCCTB rules, which uses incorporation as a connecting factor for residency. Consequently, in the absence of a uniform tie-breaker rule, the company would be a resident within the CCCTB jurisdiction even if its place of effective management was located outside the territorial borders of the system. This, however, would make the CCCTB system sensitive for tax planning as the third-country company could opt in or out of the CCCTB in the Member State where it is established and which does not have a DTC with the third country, depending on the needs of the company (and its CCCTB located affiliates). A uniform tie-breaker rule would solve the issue by, for instance, requiring the place of effective management to be within the CCCTB jurisdiction. In case of conflicts with Member States' DTCs with third countries, to the extent that the rights of third countries are affected, such a solution would need to respect the Member States' international obligations until they have been able to renegotiate the conflicting provisions of the DTCs. For further discussion, see section II7.3 below. 


\subsubsection{3}

The place of effective management is often the dominating connecting factor for solving dual residency of companies, also in case of DTCs based on the OECD MC. Against this premise, one might find it desirable to provide a general definition, or at least a direction, for determining the notion. If such companies form part of a CCCTB group, their existence will affect the CCC tax base and the respective share attributed to each group member.

Although a precise definition of the notion of "place of effective management" is desirable, it could introduce uncertainty about its interpretation. The preparatory works of the CCCTB pointed towards the definition of the place of effective management as interpreted in the OECD MC. ${ }^{593}$ It is noteworthy that, even though the OECD MC uses the term "place of effective management" in Article 4 for defining residency and solving dual-residency issues, it does not define the concept in the OECD MC. However, the concept is defined in the commentaries of the OECD MC, i.e. the place of effective management is the "place where key management and commercial decisions that are necessary to conduct the entity's business are in substance made" and which is to be decided on caseby-case basis taking into account all relevant facts and circumstances. ${ }^{594}$ Some scholars however argue that there is no agreement in the OECD MC on the meaning of the concept of place of effective management, especially as evidenced by the change made in 2008,595 and they wonder whether the term should rather be abandoned. 596 The issue is more complex given that countries often use the same or a similar term in their domestic law and therefore interpret the concept of place of effective management in the light of their domestic law. Indeed, the term "place of effective management is not defined in the OECD MC and, according to Article 3(2) of the OECD MC, any term not defined therein shall, unless the context

593 European Commission (2005c), para. 24. It is noteworthy that in 2008, the OECD further developed the concept of place of effective management in its report of 21 April 2008 (OECD (2008a).

594 OECD Comm. on Article 4, paras. 24-24.1.

595 OECD (2008b), Section B, para. 7, available at

http://www.oecd.org/tax/taxtreaties/41032078.pdf, accessed 17 August 2012.

${ }^{596}$ For instance, Avery Jones (2008), 183-186. 
otherwise requires, 597 have the meaning that it has at that time under the domestic law of the State applying the DTC (emphasis added). The phrase "unless the context otherwise requires" implies that an interpretation of the DTC term based on domestic law is not necessarily correct, because it might lead to a different result depending on the country. However, the (proposed) CCCTB Directive does not include a provision similar to Article 3(2) of the OECD MC. Consequently, given that the term 'place of effective management' is included in the (proposed) Directive, it should be considered an EU term and hence interpreted only in the light of EU law.

If the CCCTB Directive provided the criterion of place of effective management as the leading connecting factor for solving dual residency of companies, one would expect to receive some guidance on the interpretation of the term. When a term becomes part of EU law, interpretation by reference to Member States' domestic law would be conceptually wrong. The concept of "management" is typically associated with different levels of management, such as the board, the senior executives and the day-to-day managers (so-called "shop floor management"). From the author's point of view, the general idea of the concept of "place of effective management" should follow the OECD approach and consider the place of effective management as the place where the "day-to-day" management decisions are made. This day-to-day management should not refer to "shop-floor management" but to the management that determines the key activities of the company. Those activities are the primary economic tasks actually fulfilled by the taxpayer. 598 Consequently, one should look at where the top management is actually exercised to influence the usual conduct of business. In other words, it should be decisive where the decisions are taken not where they are executed on a day-to-day basis. Absence of any guidance on the interpretation at EU level, should there be a case on the interpretation, implementation or application of this term brought before the CJEU, the latter would be in a position to develop its definition of the term "place of effective management".

597 For a more detailed discussion on DTC interpretation, see for instance, Vogel \& Prokisch (1993), 55-85; Wattel \& Marres (2003), 222-235; Lang \& Brugger (2008), 95-124.

${ }^{598}$ See also Burgers (2007), 378-386. 
The definition of residence under national laws is typically drawn up taking into account the legal framework, needs and policies of each Member State. Consequently, relying on the national laws of Member States for the purposes of the CCCTB Directive would not represent the interests of the EU and it would create a different scope of application of the system. Given that the scope of each company's residence has an effect on the whole CCCTB group because of the consolidation of the individual tax bases, a uniform definition appears particularly relevant. Finally, in the absence of a homogeneous definition, companies would still need to cope with the national rules of all Member States. Hence, there is an obvious need to provide a uniform definition of a company's residence within the CCCTB context.

The CCCTB proposal provides for a harmonised definition of residence. The definition uses three non-cumulative criteria out of which only one - the place of effective management - is referred to in the OECD MC as a criterion for residency. The two remaining criteria - the place of incorporation and the place of registered office - are rarely used as connecting factors in DTCs, mainly if patterned on the OECD MC. Consequently, the definition of residence under the proposed CCCTB Directive is broader compared to the definition provided for in Member States' DTCs. On the one hand, such a wide definition satisfies the majority of the residency criteria currently used by Member States in their national law and, therefore, should be acceptable from the Member States tax policy perspective. Moreover, the use of a broader personal scope works well for companies, because they would be able to benefit from the CCCTB system in more instances. On the other hand, a broad range of residency-criteria may leave more room for tax planning, which might erode Member States' tax bases. Furthermore, by limiting the personal scope of DTCs via a narrow definition of residence compared to the CCCTB residency, Member States may be able to share the burden of foreign withholding taxes with other Member States. It is worth bearing in mind that there is no sharing obligation of withholding taxes on outbound payments.

The proposed CCCTB Directive includes a tie-breaker rule only with regard to dual (or multiple) residency issues within the CCCTB jurisdiction but not with regard to third countries. In terms of the latter, the only requirement is that a company is a resident in the 
Member State based on a DTC with the third country. This is probably because of the concern that, in case of conflicts, the DTC with a third country would prevail over the CCCTB Directive. Indeed, Member States will have to respect the obligations that they have undertaken towards third countries in their DTCs to the extent that their country's rights are adversely affected. Nevertheless, they would be obliged to renegotiate the (conflicting provisions) of the DTCs. The author discusses the issue in more detail in section II7.3 below.

In a nutshell, one must recognise that solving double residency of companies within the context of the CCCTB in the light of Member States' DTCs with third countries avoids potential conflicts between the two sources of law. Nevertheless, the adoption of a uniform tiebreaker rule within the context of the CCCTB seems desirable, mainly for the purposes of achieving a unanimous treatment of all cases, despite which third country/DTC is concerned. Moreover, a CCCTB uniform test would reduce the possibilities for DTC shopping, where a company could try to allocate its activities in a way that fits in its business organisation better. The absence of harmonisation in the definition would thus also work against the requirement of all-in/all-out principle.

From the author's point of view, in line with the current interpretation of the OECD MC, for the purposes of the CCCTBresidency, the decisive factor should be whether the place of effective management of the company is within the CCCTB jurisdiction. The concept refers to the place of the executive top managers that make the key decisions for the company rather than non-executive and "shop-floor" managers.

\subsubsection{DEFINITION OF PERMANENT ESTABLISHMENT}

The existence of a permanent establishment affects the territorial borders of the CCCTB from two main perspectives: (i) subjective scope, i.e. the extent a non-resident can participate in the CCCTB system; and (ii) objective scope, i.e. determination of income to be included in the CCC tax base. The current CCCTB proposal limits its subjective scope at water's edge. Nevertheless, third-country companies may opt for the CCCTB in terms of their permanent establishments located in the Member States. In terms of the objective scope, while the proposed Directive is not explicit whether it is limited at water's edge regarding the income derived through 
foreign permanent establishments, exempting it certainly appears to be the overarching idea of taxing such income under the (proposed) Directive. The author will discuss the objective scope of the CCCTB in relation to third countries in the next chapter of this dissertation.

In order to provide consistency between the laws of the Member States, the proposed CCCTB Directive includes an autonomous definition of permanent establishment in Article 5. The definition applies at two levels: (i) permanent establishments of non-residents located within the CCCTB jurisdiction (inbound investment); and (ii) permanent establishments of CCCTB residents located outside the CCCTB jurisdiction (outbound investment). 599 The CCCTB Member States are bound by the definition in the application of the common system, even if the concept has a different scope in their domestic laws.

One could suggest two alternatives for defining the notion of permanent establishment for CCCTB purposes: (i) leave it up to the Member States (based on their domestic law and DTCs); or (ii) refer to the definition used in the OECD MC. In fact, during the preparatory works, the latter option was preferred, mainly because majority of the EU Member States are members of the OECD and the remaining EU Member States follow the OECD principles. 600 Reference to the OECD MC would have automatically included the guidance provided by the OECD, primarily by means of the OECD Commentary as well as avoided prospective conflicts with existing DTCs with third countries. The main concern for using a newly developed, uniform CCCTB concept was that it might lead to a number of different interpretations by Member States, especially given the long history of the concept of permanent establishment. ${ }^{601}$ Therefore, using the existing OECD definition, which has proven

\footnotetext{
${ }^{599}$ European Commission (2006d).

${ }^{600}$ European Commission (2005c), para. 10.

601 The notion of permanent establishment was first introduced into international fiscal law approximately 100 years ago in connection with the second industrial revolution which involved several new industries, many inventions and the revolution in international trade. Due to such a development, the business activities were expanded to foreign countries which in effect brought the consequence of double taxation. For this reason, a number of countries that were economically at the same stage felt the need for a remedy against double taxation. The principle of permanent establishment was originally developed under German domestic law with respect to Prussian business legislation and was soon implemented into the business law of Northern German States and the German Empire. Còrabi (2000).
} 
workable on an international basis, as a blue-print, and relying on the experience of the OECD instead of duplicating that work, seemed appealing for several Member States. ${ }^{602}$

In the drafting of EU legislation, it is not allowed to refer to definitions contained in other (legal) instruments (e.g. the OECD $\mathrm{MC})$, which can be modified based on a procedure other than that of the EU Treaties. This is because, for the purposes of EU law, there is only one legal instrument which explains how legislation can be enacted - the Treaties - which provides for the possible instruments (directives, regulations, etc.) and the relevant institutions (the European Commission, the European Parliament, the European Council, etc.). For this reason, the CCCTB proposal includes an autonomous definition of permanent establishment, without being dependent on international (DTC) law. Such an approach provides consistency in the application of the CCCTB system and reflects the specific nature of the EIM. If Member States were left free to define permanent establishment under their national law, the CCCTB system would still include 28 divergent concepts. In that case, a permanent establishment could exist under one Member State's law while it would not exist under another Member State's law in the same situation. Such a result is undesirable from the perspective of an EIM.

In drafting the definition of permanent establishment, the CCCTB Working Group finally agreed to make use of the work carried out by the OECD. ${ }^{603}$ As it currently stands, the definition is almost identical to the one provided in Article 5 of the OECD MC. In such a way, the proposed Directive promotes consistency with the existing DTCs of the Member States with third countries. Coherence between the CCCTB definition and the definition in DTCs helps to avoid unnecessary administrative complications, respect Member States international obligations as well as prevent potential conflicts with DTC's non-discrimination clause. Despite a great advantage of adopting an almost identical definition of permanent establishment to that of the OECD definition, it may be criticised from several perspectives. In spite of the long existence and practice, the OECD definition of permanent establishment is certainly not clear. ${ }^{604}$ On the contrary, it has been subject to several international discussions and

${ }^{602}$ Staringer (2008), 124.

${ }^{603}$ European Commission ((2006j), para. 20.

${ }^{604}$ For instance, see OECD (2012b). 
disputes. Also, in several aspects of the determination and interpretation of the concept, OECD member countries have not reached a consensus. This is also one of the main reasons why the definition of permanent establishment in Member States' DTCs often deviates from the definition set forth in the OECD MC. Finally, considering that the OECD is a multilateral organisation, its model convention and the commentary represent a number of different OECD Member States' views instead of those of the EIM. ${ }^{605}$ In that sense, one would definitely welcome an interpretation of the term for the purposes of EU law once a relevant case is brought before the CJEU.

\subsubsection{DTC APPLICATION}

The fact that the definition of a CССТB permanent establishment largely corresponds to the definition set forth in the OECD MC does not automatically avoid conflicts with Member States existing DTCs. While Member States' DTCs with developed countries typically go hand-in-hand with the OECD MC, differences are more likely to occur when the treaty partner is a developing country. Against this background, one may wonder whether drafting the CCCTB definition of a permanent establishment based on Member States' DTCs would be more desirable. Taking into account the vast number of DTCs between Member States and third countries reflecting different levels of development, it might have turned out to be an impossible Sudoku to reach a consensus. Moreover, as bilateral treaties, they take into account the interests of the concerned parties. However, reflecting the interests of third countries should not be the (primary) goal of the CССTB.

In the case of inbound and outbound investments, one must analyse the concept of permanent establishment in the light of Article 351 of the TFEU. ${ }^{606}$ First, in the case of inbound investment, if the CCCTB definition of a permanent establishment was broader compared to the relevant DTC concept, the core question is whether the rights of the third country would be affected if the CCCTB Member States taxed the income attributed to the permanent establishment that would not exist under the relevant DTC. From the author's perspective, if the income of a non-resident were taxed in the CCCTB jurisdiction, due

\footnotetext{
${ }^{605}$ Staringer (2008), 124.

${ }^{606}$ See further discussion vide infra at II7.3. See also European Commission (2007a), para. 15; European Commission (2010d), para. 3.
} 
to the existence of a permanent establishment only under the Directive, the rights of the third countries would be affected. Indeed, from the standpoint of the residence country (i.e. the third country), the source country (i.e. the CCCTB Member State) would exercise its taxing right even if it was prohibited from doing so under the DTC. In such a case, the third country would not eliminate double taxation over income, because, from its perspective, the source country wrongfully taxed the income. In the light of this conclusion, in the absence of a permanent establishment under a DTC, the subjective scope of the CCCTB Directive would not be fulfilled and the source State (i.e. the CCCTB Member State of the permanent establishment) could not include the income of a non-resident in the CCC tax base.

In the opposite situation, in the setting of inbound investment, if the CCCTB Directive included a narrower definition of permanent establishment compared to the definition in a DTC with a third country, the non-resident taxpayer would not be eligible to apply the CCCTB system even if it had a permanent establishment in the Member State under the relevant DTC. This may happen, for instance, if, in a DTC, the Member State has agreed upon the definition of "construction site permanent establishment" as defined in Article 5(3) of the UN MC, which sets forth a time-limit of 6 months rather than 12 months. In addition, unlike the CCCTB, DTCs are generally not limited to specific (similar) company forms. Hence, a permanent establishment could be constituted to any nonresident taxpayer from whatever DTC country (provided that the other conditions for the DTC applicability in Article 1 of the OECD MC are fulfilled). Such a permanent establishment could not claim the application of the DTC non-discrimination clause (Article 24(3) of the OECD MC), because it would not be deemed to be in a similar situation to businesses that do constitute a permanent establishment under the CCCTB rules. Therefore, if a permanent establishment is deemed to exist only under a DTC, it would not be eligible to participate in the CCCTB system. However, this does not imply that the State of source (i.e. the CCCTB Member State) would be limited in taxing the profits attributed to the permanent establishment under its domestic law and the DTC given that they fall outside the scope of the CCCTB Directive.

The definition of a permanent establishment for the purposes of CCCTB also comes into play in outbound situations, i.e. when a CCCTB resident taxpayer carries on business through a permanent establishment in a third country. Such foreign permanent 
establishments fall in the scope of the (proposed) CCCTB regulatory framework mainly in terms of taxing their income (i.e. exempting it or applying the switch-over clause, to be discussed below in Chapter II7) and treating dealings with associated enterprises (e.g. the transfer of assets towards third countries) in the Member State of the head office.

In outbound cases, if the definition in the CCCTB Directive was broader than the one provided in a DTC with a third country, in the opinion of the author, in the light of Article 351 of the TFEU, the rights of the third country would not be affected, because its taxation rights would not be at stake. Therefore, a permanent establishment could be deemed to exist even if it was restricted under the relevant DTC (unless grandfathered according to Article 351 of the TFEU, see below). In such a case, the income attributed to the permanent establishment under the AOA principle would be fully taxable in the CCCTB jurisdiction, because the application of the switch-over clause set forth in Article 73 of the (proposed) CCCTB Directive. In case of DTCs grandfathered under Article 351 of the TFEU, the (non-) existence of a permanent establishment in the third country would be limited to the DTC definition. Thus, in the present case, a permanent establishment would not be deemed to exist. In the absence of a permanent establishment under a DTC, the CCCTB Member State shall be entitled to exclusive taxation of all the profits earned in the third country. This would not lead to double taxation or non-taxation of the profits, because the source State (the third country) would be restricted in taxing the profits. Hence, in effect, the outcome of the two scenarios would be the same despite whether a permanent establishment was deemed to exist or not.

In the opposite scenario, if the activity of the taxpayer created a permanent establishment under the Member State's DTC with a third country, but not according to the CCCTB, the former would (normally) override the CCCTB definition, because the (taxing rights) of the third country would otherwise be affected in the light of Article 351 of the TFEU. Hence, a narrower definition in the CCCTB Directive compared to the DTC definition would imply that the Member State would share its taxing right over these profits with the third country. In such a case, the profits of the permanent establishment would have to be exempted in the CCCTB jurisdiction 
in the light of Article 11(e) of the (proposed) CCCTB Directive, subject to the switch-over clause. ${ }^{607}$

Another question is how to deal with income derived from real estate located within the CCCTB location. The general rule is that income from immovable property may be taxed in the country of situs (i.e. source State). Such an approach is also envisaged in Article 6 of the OECD MC. As per the latter, it is important to remember that Article 6 of the OECD MC acts as lex specialis to all other articles dealing with the allocation of taxing rights between the DTC partners. ${ }^{608}$ Therefore, immovable property as such should not create a permanent establishment, although the income derived from it may be attributed to a permanent establishment.009 If income from immovable property located in a CCCTB Member State is not attributed to a CCCTB-located permanent establishment of a thirdcountry company, it will remain taxable according to the domestic rules of that Member State. Such a split of taxation is undesirable from an international tax neutrality perspective as well as inconsistent with the aim of reducing compliance costs of EU businesses. ${ }^{610}$ Actually, if the real estate does not constitute a permanent establishment, it should be seen as a capital investment rather than business activity. Notably, the CCCTB is aimed at eliminating obstacles to businesses and, from the author's standpoint, pure capital investment entities were not meant to benefit from the CССТВ. ${ }^{611}$ On the other hand, from the business perspective, the inclusion of such capital investment entities into the CCCTB is desirable. This could be achieved, for instance, by the introduction of a fictitious notion of permanent establishment in the context of the CCCTB. Such a fiction would typically not contradict the provisions of DTCs, because the source country (i.e. the Member State of the real estate) would in any event have the primary, unlimited right to tax the income from real estate. This would ensure that the income from pure capital investment attributed to a deemed permanent establishment would always be calculated on a net basis, even if some Member States preferred taxing it on a gross basis under their domestic law. Moreover, from a cash-flow perspective, consolidating

\footnotetext{
607 Vide infra at II7.4.2.3.

608 OECD Comm. on Article 6, para. 4.

609 Note also that the OECD MC prohibits force of attraction. OECD Comm. on Article 7, para. 12.

610 Kemmeren \& Smit (2013), 81.

611 Recital 1 of the Preamble of the proposed CCCTB Directive.
} 
the tax bases with the rest of the group members would allow offsetting of the losses in relation to the acquisition of the real estate against the group's profits and thereby lowering the group's CCC tax base in the year of the acquisition of the real estate.

\subsubsection{EU LAW ASPECTS}

In case of enhanced cooperation, the CCCTB system has to ensure the freedom of secondary establishment protected by EU primary and secondary law. It is worth noting that primary EU law does not employ the term "permanent establishment", because it uses only legal concepts, while "permanent establishment" is merely a tax law concept. Nevertheless, such establishments (branches) are covered by Article 49 of the TFEU, which aligns primary and secondary establishments and has been repeatedly dealt with by the CJEU in its case law. ${ }^{612}$ Secondary EU law, by means of EU corporate tax directives, explicitly mentions permanent establishment in its core provisions. While the Parent and Subsidiary Directive and the Interest and Royalty Directive define the term under their provisions, ${ }^{613}$ there is a lack of the definition in the Merger Directive. It is worth noting that the definition of permanent establishment is much more comprehensive under the proposed CCCTB Directive than under the Parent and Subsidiary and the Interest and Royalty Directives. Certainly, on the one hand, the CCCTB Directive reaches the international arena for the purposes of defining and using a common tax base (which does not necessarily lead to a 'direct' advantage). On the other hand, the other EU corporate tax directives aim at enhancing the pan-European movement of EU establishments by eliminating double taxation of certain types of income. Although the concept of permanent establishment has become an EU law term (in the context of the EU corporate tax directives), it has never been interpreted by the CJEU. In fact, the Court has, in the context of the fundamental freedoms, referred to the definition of permanent establishment used in the OECD MC as guidance for the EU Member States. ${ }^{614}$

\footnotetext{
${ }^{612}$ For instance, cases Commission v France [Avoir Fisca] (270/83); Commerzbank (C330/91); Royal Bank of Scotland (C-311/97); Saint-Gobain (C-307/97); AMID (C$141 / 99)$.

${ }^{613}$ Article 2(2) of the Parent and Subsidiary Directive and Article 3(c) of the Interest and Royalty Directive.

${ }^{614}$ Case Lidl Belgium (C-414/06), para. 22.
} 


\subsubsection{PRELIMINARY CONCLUSIONS}

The definition of permanent establishment in the CCCTB Directive is two-dimensional: inbound and outbound. The former covers situations in which a third country company carries on its business within the CCCTB jurisdiction via a permanent establishment. Outbound movement covers situations in which a CCCTB resident company carries on its business via a permanent establishment in a third country. The CCCTB proposal provides for an autonomous definition for the concept of "permanent establishment", which implies that Member States will be bound by it for the application of the CCCTB rules. The provision of a harmonised definition among the Member States is justified, because it ensures (or at least tries to ensure) a homogeneous personal scope of the Directive in all Member States. However, whether the "blind" adoption of the concept in line with the OECD MC is the most appropriate approach is subject to criticism. Furthermore, given the fact that it is already in the other EU corporate tax directives, the concept has become an EU term. Therefore, if a case is brought before the CJEU, the Court will have to develop its own interpretation of the term in the light of EU law. In such a case, the definition and guidance provided for by the OECD becomes irrelevant, because the EU law is independent from DTC law.

It follows from the analysis above that, in case of inbound situations, despite whether the CCCTB provided for a broader or narrower definition of the concept of permanent establishment compared to the definition in a relevant DTC of a Member State with a third country, the non-resident company could not opt into the CCCTB system. It would only be able to opt in if it had a permanent establishment under both the CCCTB and the relevant DTC. Such a limitation could not be challenged by the non-discrimination clause contained in the DTC. In case of outbound movements, despite whether the definition set forth in the CCCTB Directive is narrower or broader than in the applicable DTC, in order to protect third countries' rights, the latter would always be decisive. In the absence of a permanent establishment under a DTC, the CCCTB Member State shall be entitled to exclusive taxation of all the profits earned in the third country. In the existence of a permanent establishment under a DTC, the Member State would share its taxing right over these profits with the third country (thus, as a residence State avoid double taxation). 
Table 1: Definition of permanent establishment

\begin{tabular}{|c|c|c|c|c|}
\hline $\begin{array}{c}\text { CCCTB-definition } \\
\text { compared to DTC } \\
\text { definition }\end{array}$ & $\begin{array}{c}\text { Inbound } \\
\text { investment }\end{array}$ & $\begin{array}{c}\text { Outbound } \\
\text { investment }\end{array}$ & $\begin{array}{c}\text { Existence of a PE } \\
\text { under CCCTB }\end{array}$ & $\begin{array}{c}\text { Effect on the } \\
\text { CCCTB }\end{array}$ \\
\hline Broader & $\mathrm{x}$ & & no & excluded \\
\hline Narrower & $\mathrm{x}$ & & no & excluded \\
\hline Broader & & $\mathrm{x}$ & no & exclusive taxing right \\
\hline Narrower & & $\mathrm{x}$ & yes & shared taxing right \\
\hline
\end{tabular}

Finally, from the author's perspective, when a non-resident derives income from real estate located within the CCCTB jurisdiction, the income should be attributed to its permanent establishment only if the non-resident carries on business through that place. In such a case, the income falls under 'revenues' (Article 4(8) of the proposed CCCTB Directive) and is consolidated with rest of the group member's individual tax bases. Deeming a permanent establishment to exist in cases of pure capital investment does not reflect the aims of the CCCTB, even if it was preferred from a business perspective. Consequently, in the light of the proposed framework of the CCCTB, there would be a split of the taxation of income from real estate: (i) that attributed to a permanent establishment of a non-resident and taxed under the CCCTB rules and (ii) that derived through capital investment and taxed according to each member State national law.

\subsubsection{Possible Scenarios Under the Proposed CCCTB DiRECTIVE}

Table 2 below indicates the eligibility requirements for a company to participate in the CCCTB system under the proposed CCCTB Directive. Table 3 is based on the analysis of the current section on eligible companies and suggests a broader personal scope of the Directive. The analysis above shows that, for the purposes of the CCCTB, there is little need to differentiate between companies established under the laws of a Member State and that of a third country. In the end, the calculation of the CCC tax base and the application of the sharing mechanism can be achieved without the validation of the legal form of the entity. Furthermore, in the light of the international neutrality principle, the CCCTB Directive should not only accept companies subject to corporate income taxation but also other entities whose business profits are taxable in a CCCTB Member State despite the form of the tax. 
Table 2: Eligibility criteria under the current proposed CCCTB Directive $e^{615}$

\begin{tabular}{|c|c|c|c|c|c|c|c|}
\hline $\begin{array}{c}\text { Possible } \\
\text { combination }\end{array}$ & $\begin{array}{c}\text { Co. } \\
\text { established } \\
\text { under the } \\
\text { laws of a MS }\end{array}$ & $\begin{array}{c}\text { Co. } \\
\text { established } \\
\text { under the } \\
\text { laws of a } \\
\text { third } \\
\text { country }\end{array}$ & $\begin{array}{c}\text { Annex I- } \\
\text { Legal Form }\end{array}$ & $\begin{array}{c}\text { Similar } \\
\text { legal forms }\end{array}$ & $\begin{array}{c}\text { Annex II - } \\
\text { Corporate } \\
\text { Tax }\end{array}$ & $\begin{array}{c}\text { Tax } \\
\text { resident in } \\
\text { a Member } \\
\text { State }\end{array}$ & $\begin{array}{c}\text { Non- } \\
\text { resident in } \\
\text { the } \mathrm{EU} \\
\text { with } \mathrm{EU} \text { - } \\
\text { located PE }\end{array}$ \\
\hline 1 & $\mathrm{x}$ & & $\begin{array}{c}\mathrm{x}(\mathrm{MS} \text { of } \\
\text { incorporation) }\end{array}$ & & $\mathrm{x}$ & $\mathrm{x}$ & \\
\hline 2 & $\mathrm{x}$ & & $\begin{array}{c}x(\text { MS of } \\
\text { incorporation } \\
\text { \& of another } \\
\text { Member } \\
\text { State) }\end{array}$ & & $\mathrm{x}$ & $\mathrm{x}$ & \\
\hline 3 & & $\mathrm{x}$ & & $\mathrm{x}$ & $\mathrm{x}$ & & $\mathrm{x}$ \\
\hline 4 & & $\mathrm{x}$ & & $\mathrm{x}$ & $x$ & $\begin{array}{c}\mathrm{x} \text { (also } \\
\text { based on } \\
\text { the DTC) } \\
\end{array}$ & \\
\hline 5 & & $\mathrm{x}$ & $\mathrm{x}$ & & $x$ & $\begin{array}{c}\mathrm{x} \text { (also } \\
\text { based on } \\
\text { the DTC) }\end{array}$ & \\
\hline
\end{tabular}

Table 3: Revised criteria for the CCCTB-eligibility

\begin{tabular}{|c|c|c|c|}
\hline $\begin{array}{c}\text { Possible } \\
\text { combination }\end{array}$ & $\begin{array}{c}\text { Business } \\
\text { income tax }\end{array}$ & $\begin{array}{c}\text { Tax resident } \\
\text { in a Member } \\
\text { State }\end{array}$ & $\begin{array}{c}\text { Non- } \\
\text { resident in } \\
\text { the EU with } \\
\text { EU-located } \\
\text { PE }\end{array}$ \\
\hline 1 & $\mathrm{x}$ & $\mathrm{x}$ & \\
\hline 2 & $\mathrm{x}$ & $\mathrm{x}$ & \\
\hline 3 & $\mathrm{x}$ & $\begin{array}{c}\mathrm{x} \text { (also based } \\
\text { on the DTC) }\end{array}$ & \\
\hline
\end{tabular}

4.3 BINDING EFFECT OF THE OPTION AND THE ALLIN/ALL-OUT PRINCIPLE FOR CONSOLIDATION

\subsubsection{THE BINDING EFFECT}

Whether the CCCTB should be optional or compulsory has been the subject of various discussions. While the business community wishes to see the CCCTB as an increase in their tax-planning opportunities, the Member States are not interested in promoting such possibilities. Moreover, running two parallel systems of corporate taxation

615 Based on Mitroyanni (2012). 
simultaneously - the CCCTB and the national system - increases administrative difficulties for Member States' tax authorities. The European Commission's 2011 proposal envisages an optional CCCTB. Of course, the latter does not consider the optionality as a tax planning tool but a possibility to improve the functioning of the EIM. ${ }^{616}$

According to the proposed CCCTB Directive, eligible companies resident in the EU may opt for the CCCTB. If an eligible company is resident in a third country, the CCCTB regime will be available with regard to its permanent establishments located within the CCCTB jurisdiction. Therefore, the right to opt for the CCCTB remains with the individual company. However, in case of a group of companies, if the parent company opts for the system, all the group members fulfilling the eligibility criteria have to become part of the group (the "all-in/all-out" principle). ${ }^{617}$ Such a rule eliminates tax-planning opportunities via excluding or including selected group members from the tax base calculation. In any case, the option would be binding for a minimum of five tax years, which could be subsequently prolonged. ${ }^{618}$ The implementation of a minimum period of participation in a corporate group either for domestic or foreign subsidiaries is also common in Member States with group regimes, ranging from three years to ten years. ${ }^{619}$

One may argue that such an overarching 'all-in/all-out' approach is inappropriate or undesired for multinationals engaged in various, independent fields of business, but it is commonly controlled by a single entity (typically, a holding company). ${ }^{620}$ For example, the US states' 'unitary business' approach looks at the economic integration of different entities to define a group instead. Such an approach seems to fit better with the economic reality and respects the fact that there could be valid business reasons for separating different fields of business from each other. Therefore, one may consider that the proposed all-in/all-out rule for the CCCTB is too rigid and propose a possibility for the establishment of several CCCTB groups for

\footnotetext{
616 Article 6 of the proposed CCCTB Directive, which follows the European Commission's earlier opinion in European Commission (2006o), para. 3.4. See also European Commission (2007a), para. 11.

617 Article 55 of the proposed CCCTB Directive.

618 Article 105 of the proposed CCCTB Directive.

${ }^{619}$ Oestreicher, Spengel, Koch (2011), 10.

${ }^{620}$ Staringer (2008), 129.
} 
different areas of business. ${ }^{621}$ However, different from the US subnational rules, the CCCTB group membership looks exclusively at the formal ownership criterion. Therefore, from the author's perspective, differentiating between different types of businesses within a CCCTB group seems rather challenging.

An interesting issue is to know whether a company, which has opted into the system and subsequently changes its residence, must re-opt into the system after the change or whether it continues to apply the system without interruption. In case of a CCCTB group, one must further analyse how such a movement will affect the other group members. The answer depends on the fact whether the migrating company participates in the CCCTB system via permanent establishments or as resident companies:

(1) In case of companies established in third countries with CCCTB-located permanent establishments - whether it has to re-opt for the system depends on the national company law of the departing (non-CCCTB) country, i.e. whether it allows the real seat and the legal seat of a company to be located in different States. ${ }^{622}$ If the company law allows the change of residence (transfer of real seat) without the transfer of legal seat (i.e. without liquidation and reestablishment in another Member State), the change of residence should not introduce an interruption in the application of the CCCTB system. If the third country's company law does not accept the transfer of real seat without the transfer of its legal seat, the company will cease to exist in its home State and must be re-established in another State. In that case, the "new" legal person would have to opt for the CCCTB system with regard to its permanent establishment. In the case of a group of companies, the company will not "re-opt" for the system, but it will have to join the group under the entering rules. ${ }^{623}$

(2) In case of a single CCCTB-resident company of a third country - as long as the transfer does not cancel the residence in the CCCTB jurisdiction (i.e. any of the CCCTB Member States), their CCCTB participation would not be

${ }^{621}$ Ibid., 129.

${ }^{622}$ See also case Cartesio (C-210/06).

${ }^{623}$ For further reading vide infra at II5.5.1. 
interrupted. However, if the company transfers its residence out of the CCCTB, it would cease to be subject to the CCCTB system (possibly subject to national exit tax). In the case of a group of companies, the company will have to leave the system under the leaving rules. ${ }^{624}$

It is noteworthy that, if a taxpayer leaves a CCCTB group before the determined term, it shall continue to apply the system for the remainder of the period, even if the taxpayer has no permanent establishment or ceases to be resident in a CCCTB Member State. 625 The question is to what extent the company will continue to apply the system. It is also challenging to deem a permanent establishment for that company to exist in the CCCTB jurisdiction because of the restricting effect of Member States' DTCs with third countries, as discussed above.

\subsubsection{THE ALL-IN/ALL-OUT PRINCIPLE}

The binding effect of an option for the CCCTB has an important effect at the group level, because it depends solely on the decision of the top-level company of the group. The straightforward 'all-in/allout' (or 'all-or-none') approach effectively means that once the toplevel eligible company has opted for the regime, the decision affects the entire group, subject to the eligibility criteria discussed earlier. The general objective of this principle is to prevent so-called 'cherry picking' by including in the group loss-making or profit-making affiliates for the most optimal outcome. A group would most likely prefer to exclude affiliates with profits and strong factors in high-tax Member States. One could argue that departure from the 'all-in/allout' rule creates additional complexity in the consolidation regime and allows unintended tax benefits to be derived from transactions between group members and non-member entities. ${ }^{626}$

The proposed CCCTB group definition is limited at water's edge. Hence, non-resident subsidiaries and permanent establishments of a CCCTB resident company located in a third country would not be covered by the 'all-in/all-out' principle. A worldwide 'all-in/all-out' principle for CCCTB purposes is a policy choice of the Member States. For example, some US states' worldwide unitary taxation

\footnotetext{
${ }^{624}$ See further reading vide infra at II5.5.2.

625 Article 105 of the proposed CCCTB Directive.

${ }^{626}$ Ting (2005), 311-334.
} 
system extends the application of the system to foreign affiliates. The advantage of a CCCTB group definition with a worldwide scope is that it would reduce tax planning opportunities, eliminate certain complexities (such as transfer pricing between group members) and reflect the 'ability-to-pay' of the group. On the other hand, the water's edge system seems better to administer. Furthermore, taking into account the main objective of the CCCTB, which is to enhance the functioning of the EIM and eliminate market distortions owing to the existence of 28 diverse national laws, extending the scope of a group to the worldwide definition might exceed that objective. The latter is prone to Member States' negative reactions based on the principles of subsidiarity and proportionality.

According to Article 104 of the proposed CCCTB Directive, only the principal taxpayer, as defined in Article 4(6), may give the notice to opt for the CCCTB. ${ }^{627}$ Consequently, even if a lower-tier company wished to opt into the system, its participation would be determined by the decision of the top company. Non-resident companies 'may opt' for the CCCTB system in respect of their CCCTB-located permanent establishment according to Article 6(2) of the proposed CCCTB Directive. In case of a group, the decision has to be made by the "principal taxpayer" as defined in Article 4(6) of the CCCTBproposal. ${ }^{628}$ The definition of "principal taxpayer" does not include the possibility for a non-resident to be the principal taxpayer of a CCCTB group, unless the group consists of only CCCTB-located permanent establishments). In all other cases, a CСCTB resident company would act as the principal taxpayer of the group and therefore it would be in a position to opt for the CCCTB on behalf of the group. The question is whether a lower-tier resident company (subsidiary) can decide on the participation of its non-resident parent company. This option does not appear under Article 55(1)(b) of the proposed CCCTB Directive, which allows a resident taxpayer to form a group only with permanent establishments of its non-resident subsidiaries. According to Article 55(2) of the proposed CCCTB Directive, a non-resident taxpayer shall form a group with all its EUlocated permanent establishments and qualifying resident subsidiaries. In the light of the foregoing, it should be only for the non-resident to decide its participation in a CCCTB group. The general idea should be that the group opts into the СССТВ as a whole, despite which entity submits the notice. From the author's perspective, the articles

627 Article 104 of the proposed CCCTB Directive.

628 Article 104(1) of the proposed CCCTB Directive. 
of the CCCTB proposal lack clarity in this field and should be amended to include the possibility for a non-resident company to act as the principal taxpayer of the group. The answer would be different if a CCCTB group already existed according to Article 55(1). In such an event, the creation of a permanent establishment for the nonresident parent company in the subsequent years would imply that the latter would be bound by the decision made by its subsidiary in the previous year(s).

In other situations, the effectiveness of the 'all-in/all-out' requirement depends on the fact whether the interest in the subsidiary is held directly or indirectly. According to Article 54 of the proposed CCCTB Directive, group membership is defined at each tier separately. In terms of the profit entitlement- and ownershiptests, the interests held in intermediate subsidiaries would be calculated by multiplying the interests held at each tier. In other words, the ultimate parent company would not have to meet the threshold in each lower-tier subsidiary directly. In the following example (Example 7: 'All-in/all-out principle'), based on Article 54(2) of the CCCTB Directive, CoA and CoD could form a CCCTB group, while $\mathrm{CoC}$ would remain outside the group. The "all-in/all-out" requirement should be interpreted as to exclude all resident subsidiaries (and their permanent establishments) that do not meet the threshold and restrict them forming a separate CCCTB group with the lower-level subsidiaries. Consequently, in the example below, CoD could not simultaneously belong to two separate CCCTB groups (i.e. one with $\mathrm{CoA}$ and another with $\mathrm{CoC}$ ). In addition, $\mathrm{CoB}$ as a non-resident subsidiary, would not be included into the CCCTBgroup, because of the water's edge limitation. 
Example 7: 'All-in/all-out principle'

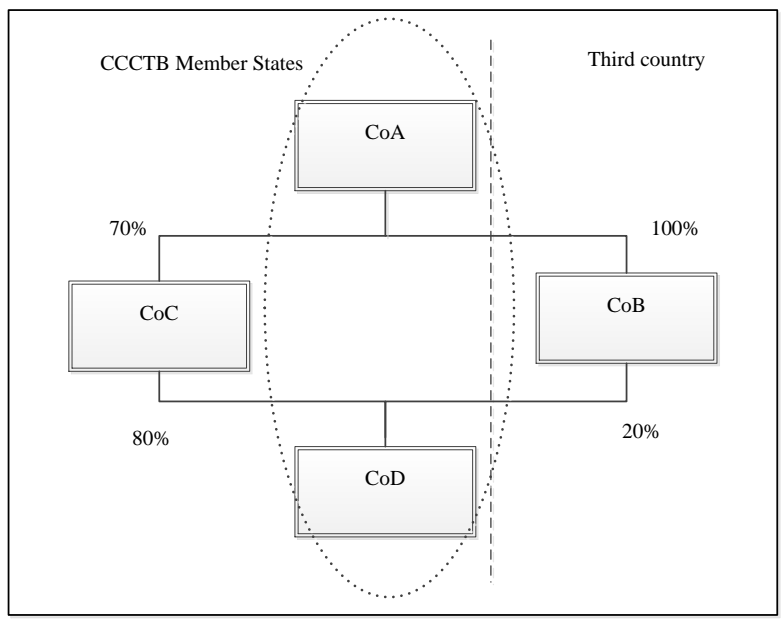

\subsection{GROUP ENTITLEMENT}

A CCCTB group definition involving third countries is twodimensional: (i) outbound investment towards third countries and (ii) inbound investment towards CCCTB Member States. The two most common approaches for group definition for tax purposes include (i) a test based on ownership (e.g., under consolidation) and (ii) a test established on the economic connections and integration among affiliated entities and their parent companies (e.g., under unitary taxation). On the one hand, an approach based on objective criteria establishes simple and clear boundaries of the group and thereby provides the highest amount of legal certainty. This is also the most common test used in national group taxation regimes in the EU as well as in the EU corporate tax directives. ${ }^{629}$ On the other hand, a straightforward legal ownership test makes undesired tax planning and avoidance more reachable for taxpayers, because it increases the possibilities of manipulation with corporate structure to minimise taxation. ${ }^{630}$ A group taxation system with formula apportionment

${ }^{629}$ Article 3 of the Council Directive 2011/96/EU of 30 November 2011 on the Common System of Taxation Applicable in the case of Parent Companies and Subsidiaries of Different Member States; and Article 3 letter b of Council Directive 2003/49/EC of 3 June 2003 on a Common System of Taxation Applicable to Interest and Royalty Payments made between Associated Companies of Different Member States.

630 Agúndez-García (2006), 13. 
based solely on legal ownership may introduce distortions, because the apportionment would not accurately reflect the values generated from closer economic and operational ties within a single enterprise. ${ }^{631}$

The other, economic-connection approach would subject entities to two tests: (i) the existence of common control and (ii) the existence of single economically-integrated business between the entities. Theoretically, this approach is more consistent with the idea of merging group's income and allocating it by means of an apportionment mechanism. However, it may also create complications in practice, mainly because it requires agreement on the criteria and tests to measure the degree of economic integration of the related units. ${ }^{632}$

Finally, an alternative way of defining a group of companies is based only on control, which is commonly accepted in company law. In tax law, this test is typically applied as a supplement to shareholding rather than as an independent criterion.

\subsubsection{DEFINITION OF A CCCTB GROUP}

The definition of a CCCTB group consists of two separate parts: (i) entitlement to group membership as either a subsidiary or a permanent establishment and (ii) mapping a group's territorial scope by means of residence of a subsidiary or location of a permanent establishment.

The definition of a CCCTB group lies essentially with Article 54 and 55 of the proposed CCCTB Directive. First, Article 54 sets forth the criteria for qualifying subsidiaries via a two-part test: (1) control (>50 per cent of voting rights) and (2) ownership ( $>75$ per cent of capital) or rights to profits $(>75$ percent of rights giving entitlement to profit). ${ }^{633}$ Second, Article 55 of the CCCTB-proposal defines a CCCTB group as such. According to this definition, third-country entities fall within a CCCTB group at different levels. For example, a resident taxpayer must form a CCCTB group with a CCCTB-located

\footnotetext{
631 Mitroyanni (2007), 42.

632 Agúndez-García (2006), 13-14.

633 Article 54 of the proposed CCCTB Directive.
} 
permanent establishment of its non-resident qualifying subsidiaires ${ }^{634}$ (Article 55(1)(b)) and with its qualifying resident sister company in the case of non-resident parent company (Article 55(1)(d)).

The following example envisages a CCCTB in the framework of enhanced cooperation, whereby a company established in a nonCCCTB Member State (CoB) is a subsidiary of a CCCTB-resident company $(\mathrm{CoA})$ and which has a qualifying resident subsidiary $(\mathrm{CoC})$ and a permanent establishment in the CCCTB jurisdiction. (Example 8: A non-resident first-tier subsidiary with subsidiaries and permanent establishments in the CCCTB jurisdiction)

Example 8: A non-resident first-tier subsidiary with subsidiaries and permanent establishments in the CCCTB jurisdiction

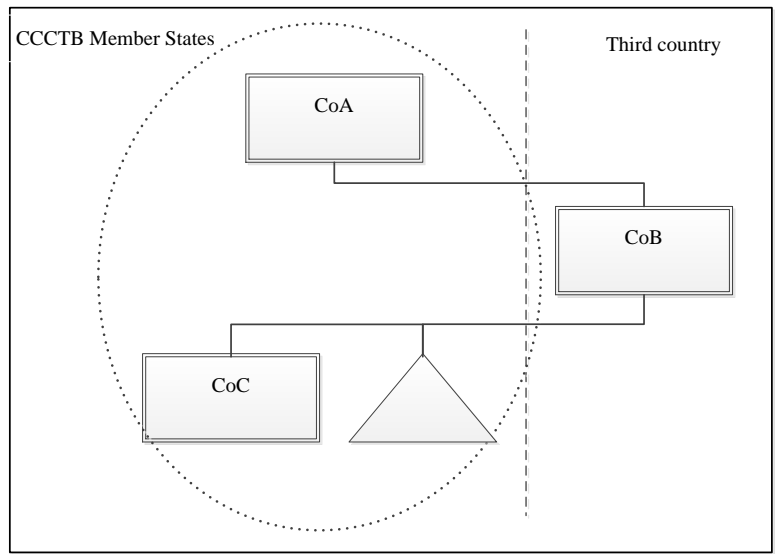

Under the proposed framework of CCCTB, CoA could form a group with $\mathrm{CoC}$ and the permanent esablishment. The question is whether the inclusion of such entities reflects the requirements of EU law in terms of freedom of establishment. In Papillon, the CJEU held that national law of a Member State that prohibited a domestic parent company from forming a fiscal unity with its domestic second-tier subsidiary, which was held through a foreign (EU) first-tier subsidiary, constituted a restriction on the freedom of establishment. ${ }^{635}$ Hence, the question is whether the decision in

${ }^{634}$ Such permanent establishments would be treated as individual group members in case of allocation of their apportioned share and all inbound and outbound group payments.

${ }^{635}$ Case Papillon (C-418/07), para. 32. 
Papillon can be transposed into the context of the CCCTB. In order to conclude that a discriminatory restriction exists, one must assess whether taxpayers in comparable circumstances are treated differently, leading to a disadvantageous treatment of the crossborder movement. From the author's perspective, the CCCTB system should not be seen as a (tax) advantage itself, which companies from non-participating Member States are deprived of. The idea of the CCCTB is to improve the functioning of the EIM in the broad sense not to offer individual (group) advantages. Furthermore, unlike national consolidation regimes, the CCCTB includes a second step - the apportionment - which may, but does not necessarily have to, lead to a benefit at the group's level. ${ }^{636}$ Hence, the CCCTB is a package deal, which involves all related tax consequences and not only the beneficial ones.

If one nevertheless concludes that the CCCTB leads to an advantage, one must identify a proper benchmark for comparability to assess whether discriminatory restriction exists. First, for such an analyis, it would be inappropriate to refer to domestic rules covering the group definition of each Member State in non-CCCTB situations (i.e. where the group has not opted for the CCCTB). Hence, one would have to compare the sitution of $\mathrm{CoC}$ (as permanent estalishments would always be part of the group) with that of a CCCTB resident qualifying subsidiary held directly by a CCCTB resident company. Second, the question is whether the adoption of the CCCTB enhanced cooperation places taxpayers whose immediate parent company/head office is in a participating or a non-participating Member State in different circumstances. In the example above, the fact that the ultimate parent company (CoA) could form a CCCTB group with a lower-tier resident subsidiary (CoC) or a permanent establishment of a non-resident company does not imply that this runs counter to the basic idea of enhanced cooperation. Indeed, the fact that certain Member States opted for enhanced speed of cooperation with each other would not be adversely affected by the fact that the lower-tier subsidiary or the permanent establishment was (directly) held by a non-resident company. It can be argued that if one accepted that

\footnotetext{
636 From the author's perspective, consolidation under CCCTB should not be compared to a group relief system under which losses or profits of one member of the group can be transferred to another member of the same group, where there is a clear advantage for the companies. See, in that effect, case The Felixstowe Dock. And Railway Company Ltd \& Ors v Revenue \& Customs ([2011] UKFTT 838 (TC)) and subsequent appeals. For the relevant comments, see Silva (da) (2013), 90-117.
} 
Member States might freely apply a different treatment solely because a company's registered office was situated in another Member State, it would deprive the rules relating to the freedom of establishment of all meaning. ${ }^{637}$ The fact that the EU Treaties allow Member States to use enhanced cooperation does not imply that they can always deny the application of the fundamental freedoms. In the present example, the fundamentals of the enhanced cooperation would only be affected if one claimed the application of the CCCTB system to the nonresident first-tier subsidiary $(\mathrm{CoB})$.

Consequently, if the premise was that the CCCTB represents a tax advantage for companies, the CCCTB system could not preclude the two resident companies ( $\mathrm{CoA}$ and $\mathrm{CoC}$ ) from forming a CCCTB group. In such a case, the Court's judgment in Papillon could be transposed into the CCCTB-context.

With regard to establishments from EEA Member States, in certain cases, such restrictions could be justified, in particular, by the need to combat tax avoidance and ensure the effectiveness of fiscal supervision. The author will come back to the issue further below. ${ }^{638}$

A final remark here is that the Court in Papillon recognised that, in such a group structure, there exists a risk that losses would be used twice (first, by consolidation, and second, because of depreciation of shares in the first-tier subsidiary). ${ }^{639}$ However, such a risk would not appear under the CССТВ framework because (i) devaluation of shares in the third country subsidiary would not affect the CCCTB tax base as the proceeds from the disposal of shares would be exempt and (ii) financial assets would not subject to depreciation. ${ }^{640}$

If there was a DTC between the relevant CCCTB Member State and the third country (including a non-CCCTB Member State, as in the example above), the dispute centers around whether a limitation to form a group with foreign-held resident subsidiairies and permanent establishments could be challenged as violating the nondiscrimination clause (which is based on the OECD MC). With regard to subsidiaries, Article 24(5) of the OECD MC precludes

${ }^{637}$ Case Papillon (C-418/07), para. 26 et seq.

${ }^{638}$ Vide infra at II5.5.4.4.

639 Note that the justification failed the proportionality-test. Case Papillon (C418/07), paras. 53 et seq.

${ }^{640}$ Articles 11(d) and 40(b) of the proposed CCCTB Directive. 
discrimination against enterprises that are owned or controlled by non-residents. The provision reads as follows:

"Enterprises of a Contracting State, the capital of which is wholly or partially owned or controlled, directly or indirectly by one or more residents of the other Contracting State, shall not be subjected in the first mentioned State to any taxation or any requirement connected therewith which is other or more burdensome than the taxation and connected requirements to which other similar enterprises of the first mentioned State are or may be subjected."

This paragraph relates only to the taxation of resident enterprises and not to the taxation of the person owing or controlling the capital of the resident enterprises and, thus, it does not extend the benefits available to the relationship between resident companies. ${ }^{641}$ For example, if the domestic law of a State allowed consolidation between a resident parent company and its resident subsidiary, Article 24(5) would not require that State to allow such consolidation between a resident company and its non-resident parent company. ${ }^{642}$ In the example above, the resident subsidiary (CoC) could not claim consolidation with the non-resident subsidiary $(\mathrm{CoB})$. The question in the light of the DTC non-discrimintion clause is whether denial of the CССТВ between a resident parent company and its foreign-held lower-tier resident subsidiary could lead to a disadvantage for the latter. With the presumption that the CCCTB system does not create a tax advantage but rather is an alternative system of corporate taxation, in the opinion of the author, the denial of group membership to foreign-held lower-tier subsidiaires would not violate the non-discrimination clause (based on Article 24(5) of the OECD MC) in Member States' DTCs with third countries. Equally, the participation of permanent establishments in a CCCTB group could not be challenged as violating the non-discrimination clause based on Article 24(3) OECD MC. This issue will be addressed further below. 643

The next example illustrates a group structure in which a CCCTB qualifying resident company (CoB) forms a CCCTB group with another qualifying resident company $(\mathrm{CoC})$ of the same non-resident

${ }^{641}$ OECD Comm. on Article 24, para. 77.

${ }^{642}$ OECD Comm. on Article 24, para. 77.

${ }^{643}$ Vide infra at I4.4.3.1. 
company (CoA) of a third country (Example 9: EU sister companies of a third-country company).

\section{Example 9: EU sister companies of a third-country company}

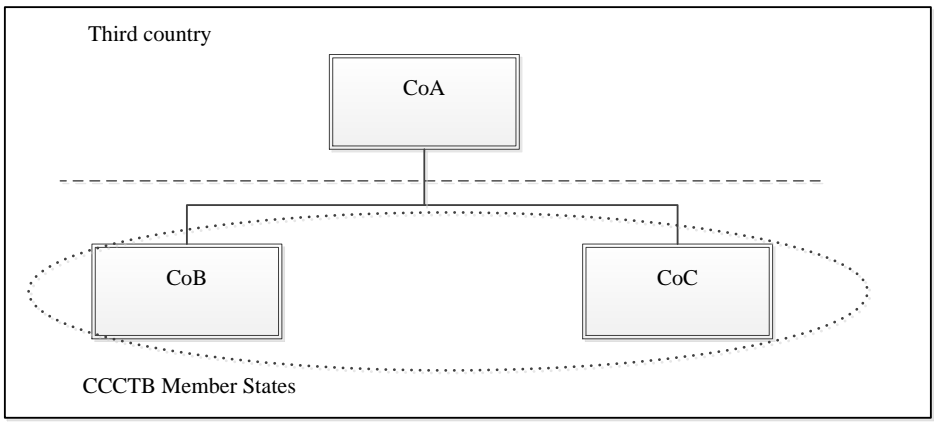

The proposed CCCTB Directive does not restrict the sister companies from forming a CCCTB group. 644 Such an approach reflects the requirements of freedom of establishment under EU law, set out in Article 54 of the TFEU, which causes the status of being considered an EU company is based on the location of the corporate seat and the legal order in which the company is incorporated and not the nationality of its shareholders. ${ }^{645}$ Therefore, whether the ultimate shareholder is a company established under the law of a CCCTB Member State or that of a third country is irrelevant. In the case that the third coutry is a non-CCCTB EU Member State in the setting of enhanced cooperation, in the opinion of the European Commission, freedom of establishment precludes a Member State from having a national law that prohibits two domestic subsidiaries, with a parent company in another Member State, from benefitting from a domestic fiscal unity between them. ${ }^{646}$

As above, unlike domestic consolidation regimes, the CCCTB does not always represent a benefit. For example, where a higher amount of the CCC tax base is allocated to a group member in a high-tax CCCTB Member State, the overall tax burden of the group may

${ }^{644}$ Article 55(1)(d) of the proposed CCCTB Directive.

${ }^{645}$ See opinion of Advocate General Jääskinen delivered on 24 October 2013 in case Felixstowe (C-80/12), paras. 59-60. See also requests for a preliminary ruling lodged on 25 January 2013 in case SCA Group Holding, X AG and MS A International Holdings (Joined Cases C-39/13; C-40/13 \& C-41/13).

${ }^{646}$ See European Commission Press Release IP/11/719 of 16 June 2011. 
increase. This does not normally happen in domestic situations in which the corporate income tax rates are the same. Therefore, in the opinion of the author, allowing a CCCTB group between CCCTB resident sister companies is not implied but it is a matter of policy choice. However, if one maintains that the CCCTB equally represents a tax advantage to domestic consolidation regimes, the existence of a discriminatory restriction would be assessed in the same way as in the previous example (Example 8: A non-resident first-tier subsidiary with subsidiaries and permanent establishments in the CCCTB jurisdiction).

Under the CCCTB proposal, a non-resident taxpayer forms a group with regard to all of its CCCTB-located permanent establishments and resident qualifying subsidiaries and their CCCTB-located permanent establishments (Example 10: A CCCTB group consisting of subsidiaries and permanent establishments of a third-country company). ${ }^{647}$ International tax neutrality requires businesses to compete with businesses not stakeholders with stakeholders. 648 Hence, the legal form through which the activities of a non-resident enterprise in the CCCTB jurisdiction are carried out should not play a decisive role in taxation. ${ }^{649}$ Also, considering that one of the objectives of the CCCTB is to make the EU more attractive for (foreign) investors, the choice of allowing both subsidiaries and permanent establishments of third-country companies to participate in a CCCTB group appears to be justified.

Example 10: A CCCTB group consisting of subsidiaries and permanent establishments of a third-country company

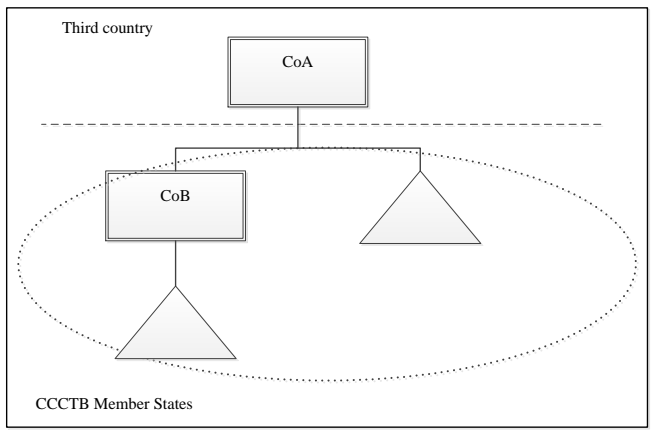

${ }^{647}$ Article 55(2) of the proposed CCCTB Directive.

${ }^{648}$ Kemmeren 2008a, 673.

${ }^{649}$ See also discussion supra at I4.2.1.3. 
Finally, if a CCCTB resident taxpayer (CoA) holds shares in another CCCTB resident company (CoB), but the shares of that subsidiary are attributed to a permanent establishment located in a third country, the two resident companies can still form a CCCTB group between them (Example 11: Shares in a subsidiary that are attributed to a permanent establishment in a third country). ${ }^{650}$ The fact that shares of a company are attributed to a permanent establishment under tax law does not affect the criteria for qualifying as a subsidiary (under company law).

Example 11: Shares in a subsidiary that are attributed to a permanent establishment in a third country

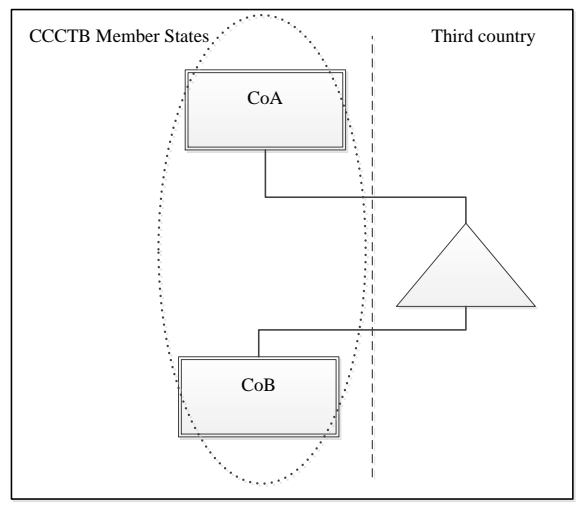

\subsubsection{QUALIFYING SUbSIDIARIES}

A choice between economic and formal criteria to define a CCCTB eligible subsidiary is challenging. As discussed earlier, on the one hand, a test based on substantive elements would better meet the objectives of a single market compared to a test based solely on ownership and control. On the other hand, the determination of a group based on economic facts and circumstances may create uncertainty and difficulties in its practical application. ${ }^{651}$ With this in mind, the European Commission's proposal of a two-part test, which would take into account the rights attached to the shares, being control ( $>50$ per cent) and ownership or entitlement to profits $>75$ per cent), seems an appropriate choice. Such a test is expected to ensure a high level of economic integration between the group

${ }^{650}$ Article 55(1)(c) of the proposed CCCTB Directive.

${ }^{651}$ Mitroyanni (2008), 111. 
members, as indicated by the extent of control and a high level of participation. ${ }^{652}$ By comparison, several EU Member States have implemented different types of group taxation regimes, such as group contribution systems, group pooling systems, group relief and asset transfer systems, and consolidation. In these regimes, the main requirement for eligibility is common control by way of participation, varying from at least 50 per cent to 100 per cent in (i) voting rights and/or (ii) share capital and/or (iii) rights in profits and capital repayment on winding-up. .53

The CCCTB proposal further requires the thresholds to be met throughout the year. Otherwise, the company would have to leave the group. A company joining the group would have to meet the thresholds during the nine consecutive months following joining the group. Failure to comply with these requirements would mean that the taxpayer would be treated as if it had never been a member of the group. 654

\subsubsection{THE TwO-PART TEST}

The two-part test for qualifying subsidiaries has resulted from the discussions between the European Commission and various levels of stakeholders, including businesses, politicians, and academics. Initially, a three-part-test based on ownership, control and profit entitlement was considered to be the most appropriate method as it encompasses the three main aspects of economic ownership. ${ }^{655}$ However, following the criticism and concern of several participants in the CCCTB Workshop of 20 October 2010 related to the potential complexity of such a test, the threshold was reconsidered and a twopart test was proposed. ${ }^{656}$

As a result of the change from the three-part test (the so-called 'andand' test) to the two-part test (the so-called 'and-or' test), ${ }^{657}$ it seems that a company could be part of a CCCTB group even if the majority of its profits or the ownership of the capital is in the hands of third parties. Thus, compared to the "and-and" test, the "and-or" criteria

\footnotetext{
${ }^{652}$ Recital 16 of the proposed CCCTB Directive.

653 Oestreicher, Spengel, Koch (2011), 8.

654 Article 58 of the proposed CCCTB Directive.

655 European Commission (2010b), paras, 9-13.

${ }^{656}$ European Commission (2010b), 2.

657 This test can also be called the 'and-and/or' test.
} 
definitely allows businesses to be more creative in forming joint ventures and cooperation agreements without being left out of the CCCTB group. On the other hand, the two-part test leaves more room to manoeuvre with regard to which companies should be part of the group for an optimal tax outcome. For instance, the fact that shares represent a number of rights that may or may not include distribution rights (i.e. rights to dividends or assets of a company), stakeholders who were not intended to participate in the CССТВ system may still benefit from it.

In the following example, a CCCTB resident company (CoC) is held for more than 75 per cent by another CCCTB resident company (CoA). The two companies could form a CCCTB group, even if a third-country company $(\mathrm{CoB})$ were entitled to the majority of profits of the subsidiary.

Example 12: A two-part test and profit entitlement

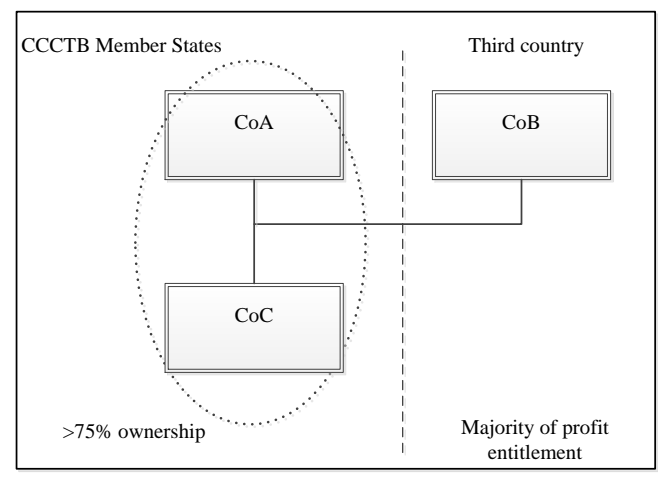

If one assumes that $\mathrm{CoC}$ makes profits while $\mathrm{CoA}$ suffers losses, because of consolidation, the group's taxable profits are lower than the profits generated by $\mathrm{CoC}$ individually. This, however, does not necessarily entail that $\mathrm{CoC}$ loses the right to distribute profits under the national law of the Member State. Indeed, the proposed CCCTB Directive does not deal with the right to distribute profits (because such a distribution would not affect the tax base as such). Furthermore, the fact that company law as well as accounting law have not been harmonised within the EU, it remains at the discretion of Member States to determine according to which criteria a company can distribute profits. In principle, one could argue that dividend distribution should take place only after the tax liability of each group member has been established, based on the tax base allocated via 
formula apportionment. Therefore, if a company was not liable to tax on the profits due to the CCCTB, it should not be entitled to distribute profits. The issue could not be solved in the framework of the CCCTB Directive, given its general aim, and could be challenged against the subsidiarity principle. In the light of the above, if the national law of a Member State allowed distribution of profits by a profit-making individual group member of a loss-making CCCTB group, the taxation of such (outbound) dividends would depend on that State's national law. Unlike withholding tax on interest and royalty payments, withholding tax on dividends would not be shared according to the apportionment formula. ${ }^{658}$

\subsubsection{THE OWNERSHIP TEST}

The ownership test is not a new concept in EU corporate tax directives, as the Parent and Subsidiary Directive and the Interest and Royalty Directive ${ }^{659}$ also include such a requirement. ${ }^{660}$ While the tests in the former directives are relatively low, the ownership requirement for the CCCTB is rather high $(>75$ per cent of the capital). Such a high requirement may exclude several companies from the group, which in economic terms may play an important role in the company's policy. According to Ting, disallowing companies with less than 100 per cent common ownership to consolidate and to enjoy the benefit of consolidating the full amount of a member's tax loss violates the economic perspective, i.e. the economic integration between group members may justify treating them as a single economic unity. ${ }^{661}$ Member States' practice with group regimes shows that it is possible to operate a system with a lower threshold

\footnotetext{
${ }^{658}$ For further discussion on this particular subject matter, vide infra at II7.4.3.2.

659 Article 3(1) of the Parent and Subsidiary Directive foresees a $10 \%$ threshold; Article 3(b) of the Interest and Royalty Directive currently foresees a 25 per cent threshold, which has been proposed to be reduced to $10 \%$ in the Interest and Royalty Recast Directive.

660 One may draw a parallel between consolidation and CFC rules, because both systems typically include an ownership test, even though they serve different purposes. Both consolidation and CFC regimes typically ignore the separate legal entity approach, although the reasoning of the two systems is based on different grounds: while consolidation looks at the strong integration of different legal entities from a business perspective, CFC regimes are anti-abuse measures targeting arrangements concerning tax deferral. Since policy options of both regimes are different, the requirements of ownership typically differ, being higher for consolidation (typically close to $100 \%$ ) and lower to CFC regimes (usually, at least $50 \%$ ). For the analysis of the proposed CCCTB-CFC system, vide infra at II8.3.3. 661 Ting (2005), 311-334.
} 
requirement (e.g., $>50$ per cent). However, group regimes based on a low ownership threshold typically only apply to domestic entities and do not include full consolidation such as the CCCTB but use less comprehensive methods, such as pooling (based on a contract between group members). Typically, a high threshold for consolidation regimes is based on a number of reasons, such as the prevention of reverse effects on revenue caused by loss offset. In addition, if one wishes to treat subsidiaries equally to permanent establishments, there should be no allowance for minority interests, which do not exist in the case of permanent establishments. Furthermore, the protection of minority interests creates complexities in the application consolidation regimes. ${ }^{662}$

For the purposes of the CCCTB, the 75 per cent ownership requirement stems mainly from the object and purpose as well as the overall system of the CCCTB. Most importantly, considering that intra-group transactions between the group members will be neutral, it seems (politically) difficult to accept a lower threshold, because the CCC tax base would directly affect Member States' revenue. Furthermore, the rather high threshold is justified by the fact that the CCCTB group definition includes permanent establishments of nonresidents as qualifying subsidiaries. Therefore, the threshold aims at including only those permanent establishments that have a strong link with the rest of the group members.

Another reason for a high threshold of ownership concerns administration and exchange of information matters. Exchange of information with third countries normally takes place by means of either a DTC or a TIEA. However, in the absence of an exchange of information agreement, it is questionable to what extent the Member States' tax authorities would receive the necessary information. In fact, under the CCCTB proposal, participation in the CCCTB is not conditional upon the existence of an exchange of information agreement. The principal reason for not requiring the exchange of information with third countries is probably linked to the functioning of the 'all-in/all-out' principle. In particular, by interposing a company in a non-cooperative country, the group could divide into two separate branches for tax-planning purposes.

662 Ting (2011), 463. 
The definition of qualifying subsidiaries looks both at direct and indirect ownership of the company's capital. The calculation of such participation requires multiplying the interests held in intermediate subsidiaries at each tier. The inclusion of multiple-tier subsidiaries in the group definition is also present in the Parent and Subsidiary Directive, ${ }^{663}$ in the proposal for the Interest and Royalty Recast Directive, ${ }^{664}$ as well as in several Member States' national laws. ${ }^{665}$ The consideration of indirect ownership allows more companies to participate in a corporate group. It also reduces complexities in compliance and administration resulting from the co-existence of different national tax systems and is therefore consistent with the aims of the CCCTB. Finally, it prevents cherry picking where lowertier affiliates are effectively owned by the ultimate parent company.

In the following example, a CCCTB resident company (CoA), which is controlled by a third-country resident company (CoX), wishes to form a CCCTB group with its CCCTB resident subsidiary (CoB) (Example 13: CCCTB resident company controlled by a CCCTB non-resident company).

Example 13: CCCTB resident company controlled by a CCCTB non-resident company

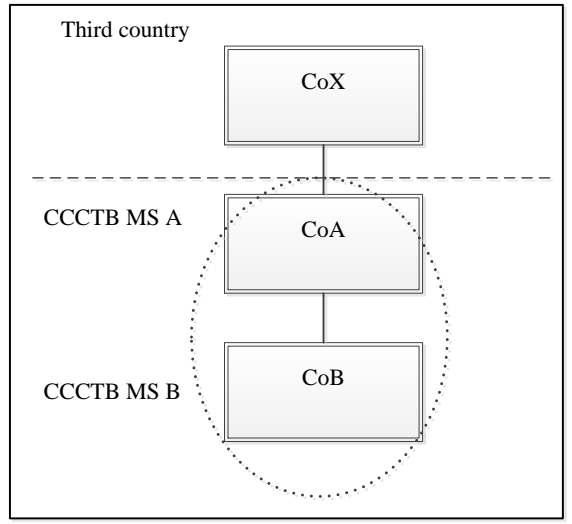

The question is whether the CoA could be precluded from forming such a group given that ultimately a non-resident company controls

\footnotetext{
${ }^{663}$ Article 3 of the Parent and Subsidiary Directive.

${ }^{664}$ Article 2(d) of the Interest and Royalty Recast Directive.

665 Oestreicher, Spengel, Koch (2011), 8.
} 
it. One could argue that a third-country company (CoX) should not have the possibility to circumvent access to the Treaty by setting up so-called "letterbox companies" to benefit from the freedom of establishment. In fact, during the negotiations of the TEC, a proposal to include a control test under Article 48 of the TEC (Article 54 of the TFEU) was brought forward. Under this test, the nationality of the shareholders or the managers of the company would have determined the nationality of the company exercising the secondary establishment in another Member State. However, the proposal was rejected because it was felt that Article 43 of the TEC (Article 49 of the TFEU) sufficiently handled the possibility of abuse, because it protects secondary establishments only where it is exercised by nationals "established" in the territory of any Member State. 606 According to the general programme for the elimination of restrictions on the freedom of establishment, companies and firms that have their seat within the Union can benefit from the freedom of (secondary) establishment only if "their activity shows a real and continuous link with the economy of a Member State". ${ }^{667}$ Furthermore, pursuant to the second sentence of Article 54 of the TFEU, only companies and firms formed in accordance with a Member State's law with a profit-making purpose can rely on the freedom of establishment. Consequently, freedom of (secondary) establishment may not be made dependent on satisfying further conditions concerning the nationality of the shareholders or directors of EU-established companies. ${ }^{668}$ Against this background, provided that the EU first-tier subsidiary $(\mathrm{CoA})$ satisfies the conditions set forth in Article 54 of the TFEU, that first-tier subsidiary may not be restricted from forming a CCCTB group with the EU second-tier subsidiary $(\mathrm{CoB})$.

\subsubsection{The CONTROL TEST}

The control test in the proposed CCCTB Directive is based on voting rights ( $>50$ per cent). Such a criterion is also present in two other EU corporate tax directives, with the difference that the proposed CCCTB Directive provides as an option for replacing the minimum holding in the capital rather than a separate requirement as in the

\footnotetext{
${ }^{666}$ Bammens (2009), 405.

${ }^{667}$ Council of the European Union (1962), 7.

668 Ibid., 7. See also case Commission v the Netherlands (C-299/02), para. 19 and the opinion of Advocate General Lèger delivered on 27 May 2004 in this case, para. 3839.
} 
other directives. ${ }^{669}$ The different approach in the CCCTB Directive is justified by its dissimilar scope and purpose. The requirement for voting rights in parallel to an ownership threshold is important for the purposes of the CCCTB, because the rights attached to shares may or may not give control over the legal entity. For example, preference shares ${ }^{670}$ typically do not give control over the company's affairs, while certain priority shares entitle appointment to the board of directors.

At first sight, the 50 per cent voting right requirement is logical, because a company either has control or does not have control over another company. Nevertheless, it is disputable whether the minimum percentage of voting rights always gives control to a particular shareholder over a company's decision. Actually, control may be established in a number of ways, inter alia: (i) via options and convertible securities; (ii) power to make the financial and operating decisions of another company; (iii) control over the composition of the board of directors and/or key executives; (iv) a general de facto control or special shareholder agreements; and (v) power to cast the majority of votes at the meeting of the board of directors. Control also depends on the provisions of the company's articles of association, which might require, for instance, a qualified (rather than simple) majority for decision making. In Denmark, for instance, among other criteria, control is presumed to exist when a company owns the majority of voting rights, unless it is clearly substantiated that such ownership does not constitute a decisive influence. ${ }^{671}$ By ignoring the control conditions set forth in the articles of association, the subsidiary may be required to join a CCCTB group, even if the parent company has no factual control over the subsidiary. It is subject to dispute whether such a requirement then meets the overarching idea of the 'all-in/all-out' principle. It is noteworthy that the working papers on the CCCTB indicated a requirement of more than 75 per cent direct or indirect voting rights. ${ }^{672}$ In such a case, the CCCTB would only encompass those companies that have decisionmaking powers in other companies, despite whether the articles of

\footnotetext{
${ }_{669}$ Article 3(2) of the Parent and Subsidiary Directive, which gives such an option due to bilateral agreements; and Article 3(b) of the Interest and Royalty Directive.

670 Preference shares can be defined as shares that carry a right to a prior and typically fixed dividend, ahead of dividends paid to ordinary shareholders, as well as a prior claim to repayment of capital upon liquidation.

671 Pakarinen (2012), section 8.1.

${ }^{672}$ European Commission (2007a), para. 89.
} 
association require a qualified majority for decision-making. On the other hand, the reduction of the threshold for voting rights allows more companies to be included in a CCCTB group.

According to the CCCTB proposal, once the voting right threshold is met in immediate and lower-tier subsidiaries, the parent company shall be deemed to hold 100 per cent of the voting rights. ${ }^{673}$ This ensures the group control in the chain of lower-tier subsidiaries. Otherwise, a group of companies held through a number of tiers could lead to a number of overlapping groups. ${ }^{674}$ Likewise, 50 per cent or less voting rights would be counted as zero for the purposes of this test. It is noteworthy that the control requirement also takes into account indirect holdings of voting rights through third-country subsidiaries. Therefore, such a holding would not necessarily break the chain of companies. ${ }^{675}$ This approach reduces tax-planning opportunities via cherry picking when a company uses a third-country affiliate to circumvent the inclusion of certain companies in its CCCTB group (Example 14: Indirect control via a third-country company).

\section{Example 14: Indirect control via a third-country company}

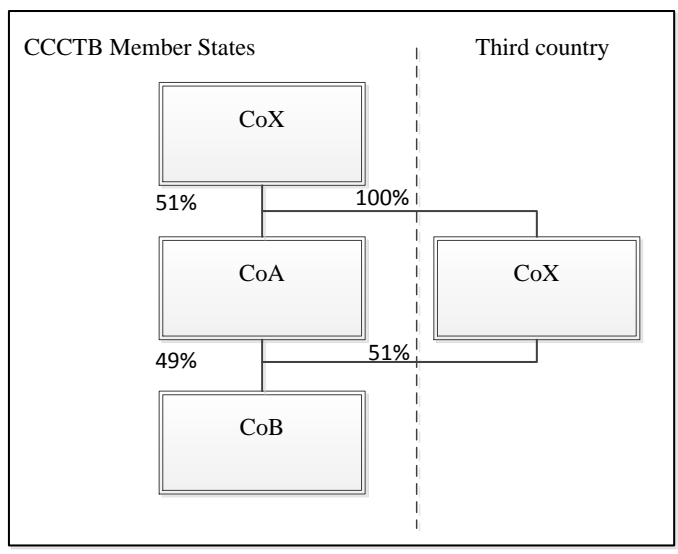

The $>50$ per cent threshold of voting power in a company generally suffices to give the power to elect the majority of directors and hence gain control over the company. What constitutes a "voting power"

\footnotetext{
673 Article 54(2)(a) of the proposed CCCTB Directive.

674 European Commission (2007a), para. 89.

675 European Commission (2010b), para. 12.
} 
under CCCTB is a subject for discussion, because voting rights attached to a specific class of shares may be limited or have a different weight. For example, the appointment of directors does not necessarily coincide with the general distribution of voting power among shareholders. ${ }^{676}$ In addition, options and convertible securities may affect the determination of control, because they provide the person the power or option to acquire rights that may affect the rights of other shareholders. As follows, a control test based solely on "voting power" is deficient and sensitive to avoidance. Therefore, it is necessary to link such rights to other factors, such as the "value of shares", which can be seen as the entitlement of the shareholders to the income and assets of the company. ${ }^{677}$

According to Advocate General Leger, the "criterion of control means that a company's link with the legal system of a particular State is determined by the nationality of the persons who have certain powers within the company, such as members of the company." 678 Against this background, the essential questions are (i) whose voting power matters? and (ii) this voting power is to decide what?679 The test of control for the purposes of consolidation is linked to the shareholder's decision-making rights, which includes voting rights in the following decisions:

(i) dividend or other distribution by the company;

(ii) a company's constitution;

(iii) capital variation; and

(iv) the appointment of directors. ${ }^{6} 80$

Although the reason for the definition of control for the purposes of consolidation and $\mathrm{CFC}$ rules is different, it may still be interesting to consider the criteria of control for CFC purposes. The CCCTB proposal of 2011 does not help in this matter. ${ }^{681}$ Nevertheless, according to the Danish compromise proposal, in order to avoid the circumvention of the criteria for control, a taxpayer is deemed to have a control over a foreign company for the purposes of the CFC rule if, by itself, or together with associated enterprises:

\footnotetext{
676 Ting (2006), 45.

677 Ibid., 53.

678 Opinion of Advocate General Lejger delivered on 27 May 2004 on case Commission v the Netherlands (C-299/02), footnote 17.

679 Ting (2006), 45.

680 Ibid., 46.

681 Article 82 of the proposed CCCTB Directive.
} 
(i) it holds, directly or indirectly, more than 50 per cent of the voting rights; or

(ii) because of an agreement with other investors it holds more than 50 per cent of the voting rights; or

(iii) because of an agreement, it has full control over the financial and operating policies of the entity; or

(iv) it has the authority to appoint or dismiss members of the board of directors jointly holding more than 50 per cent of the voting rights in the board of directors; or

(v) it has power to cast more than 50 per cent of the votes in the board of directors. ${ }^{682}$

By comparison, the US Court of Appeal in Alumax $x^{683}$ concluded that "voting power" implies:

(i) voting power of shareholders and directors; and

(ii) voting power of shareholders to appoint directors who have regular power to manage the company's business and voting power of directors to control the board of directors. ${ }^{684}$

Another point relates to the possible means of financing a company: while group definition typically excludes holders of "debt interest", it usually includes holders of "equity interest". In practice, the classification of debt and equity may create severe difficulties. For instance, a "debt interest" (such as a convertible note) may carry substantial voting powers, while a "non-share equity interest" would generally not be recognised as "shares" for company law purposes. ${ }^{685}$ In order to avoid the need for such distinctions - which can be numerous and very difficult to identify ex ante - the control test under the CCCTB proposal only refers to "voting rights".

\subsubsection{The Profit ENTITLEMENT TEST}

According to the current CCCTB proposal, the profit entitlement test entails that the parent company must be entitled to at least 75 per

\footnotetext{
${ }^{682}$ Council of the European Union (2012), Article 82 and comments therewith. The remaining two conditions are based on the ownership of capital and entitlement to profits.

683 Alumax Inc (165 F 3d 822).

${ }^{684}$ Ting (2006), 48.

685 Ibid., 40.
} 
cent of the profits from direct and lower-tier subsidiaries. Generally speaking, the requirement to have rights to profits refers to the "economic ownership" in a company while the requirement to have voting rights and ownership in capital implies the "legal ownership". The fact that the CCCTB tow-part test requires the profit entitlement test to be accompanied by the control test eliminates the possibility of a company to participate in a CCCTB group if it were not intended to do so. The latter includes, for instance, companies that only hold the usufruct for shares. From the author's perspective, it is arguable whether the proposed profit entitlement test implies not only the rights to profit distributions during the lifetime of the subsidiary but also rights to proceeds on the liquidation of the subsidiary. At the national level, the taxation of liquidation proceeds varies from country to country, but normally they are treated as either dividends or capital gains. By comparison, the Parent and Subsidiary Directive, which applies to the "distribution of profits", does not include liquidation proceeds. ${ }^{686}$ On the contrary, many Member States have extended their domestic participation exemption system to include liquidation proceeds. According to Article 4(8) of the proposed CCCTB Directive, revenues include proceeds from the disposal of assets, profit distributions and proceeds from liquidation. Pursuant to Article 4(15) therewith, assets include shares in affiliated companies. In the light of these articles, the proposed CCCTB Directive makes a difference between capital gains, profit distributions and liquidation proceeds. Therefore, from the author's perspective, the CCCTB profit-entitlement test should include rights to liquidation proceeds, which should be seen as the fruits of a company during its lifetime. If that is the intention of Member States, the wording of the Directive should mention it explicitly.

\subsubsection{THE PERIOD THRESHOLD}

The CCCTB group definition requires the conditions of a qualifying subsidiary to be met throughout the tax year. In the case of joining group members, the threshold would have to be met during the following nine consecutive months from entering the CCCTB group. The failure to comply with these requirements would mean that the company would be treated as if it had never been a member of the group. ${ }^{687}$ The proposed CCCTB Directive does not specify what a tax year is. It only requires all group members to have the same tax year.

${ }^{686}$ Article 1 of the Parent and Subsidiary Directive.

${ }^{687}$ Article 58 of the proposed CCCTB Directive. 
Therefore, the tax year of the group does not have to coincide with the calendar year. As it appears, the principal taxpayer may indicate the most appropriate tax year for the group, despite any national tax law, when it submits the notice to opt in on behalf of the group. ${ }^{688}$

\subsubsection{PRELIMINARY CONCLUSIONS}

A choice between economic and formal criteria to define a CCCTBeligible subsidiary is challenging. On the one hand, a test based on substantive elements would be in a better position to meet the objectives of a single market compared to a test based solely on ownership and control. On the other hand, determination of a group based on economic facts and circumstances may create uncertainty and difficulties in applying the concept in practice. The European Commission's proposal to take into account the rights attached to shares of the subsidiary seems an appropriate choice. The two-part test based on voting rights ( $>50$ per cent) and ownership or entitlement to profits ( $>75$ per cent) covers all immediate and lowertier subsidiaries. Compared to the original three-part test, the twopart test provides businesses with more opportunities to create a CCCTB group. However, it also leaves more room to manoeuvre as to which companies to include or exclude from the CССТВ group.

Out of the three criteria, the validation of the legal ownership via shareholding is probably the simplest. Also the profit-entitlement test could well be validated, although it may require additional paperwork, for example, in case of usufructs. The last criterion voting rights - is probably the most disputable one, because the proposed simple majority requirement may but does not necessarily imply control in a company. The fact that the CCCTB proposal does not foresee a case-by-case analysis to that end makes the system easier to apply. On the other hand, rejecting a case-by-case analysis may imply that a subsidiary must join a CCCTB group even if its parent company does not have control over it. In that sense, a caseby-case analysis would be more suitable for the purposes of taxing highly integrated groups. In such a case, one would expect the European Commission to provide guidance as to what control means for CCCTB purposes. Alternatively, the original idea of a higher threshold ( $>75$ per cent) of voting rights could be an option,

688 Articles 104(1) and 108 of the proposed CCCTB Directive. 
but, in that case, the CCCTB will likely be available for a smaller group of businesses.

\subsubsection{PERMANENT ESTABLISHMENTS}

According to the proposed CCCTB Directive, permanent establishments of non-resident companies could participate in the CCCTB system as either individual entities or members of a CCCTB group. The question is whether such an approach is just a matter of policy decision or drafted in the light of non-discrimination clauses.

There are a number of reasons for including permanent establishments of non-resident companies into the CCCTB group definition. First, despite the fact that they do not have a separate legal personality, permanent establishments are typically treated as separate entities for tax purposes and they are subject to tax on profits attributed to them in the country of their location. Considering that permanent establishments often perform functions that contribute to the overall profitability of the head office/group of companies, it is difficult to find a solid argument why such establishments should be treated differently from resident companies. Within the CCCTB system, permanent establishments would participate in the profits of the CCCTB group based on the same apportionment factors as the rest of the group members, i.e. sales, payroll and property. ${ }^{689}$

${ }^{689}$ Permanent establishments of non-resident companies qualify as CCCTB group members under the first sentence of Article 4(7) of the proposed CCCTB Directive, which refers to "any taxpayer" belonging to the same CCCTB group as defined in Articles 54 and 55. The definition creates some confusion and some authors have even argued that, based on the wording of the proposed CCCTB Directive, a permanent establishment of a non-resident company cannot qualify as a separate "group member" and, hence, they cannot be allocated part of the group's profits based on the sharing mechanism. According to these authors, a permanent establishment is not a "taxpayer" as defined in Article 4(1) of the proposed CCCTB Directive, because it is not a "company" and, consequently, does not fall under Article 4(7). See, in particular, Kemmeren \& Smit (2013), 83. However, from the author's perspective, one must read the definition in conjunction with other provisions of the proposal, such as Article 4(1) and (5) and Article 6. In particular, a "taxpayer" is a company, which has opted to apply the system, and a "non-resident taxpayer" is a taxpayer, which is not a resident for tax purposes. A non-resident taxpayer may opt into the system with regard to its EU-located permanent establishments. It follows that the "taxpayer" in Article 4(7) also covers non-resident taxpayers which have opted to apply the CCCTB system with regard to their EUlocated permanent establishments. 
At the same time, including permanent establishments of third country companies in a CCCTB group may lead to undesirable results, such as the double deduction of losses. For instance, if a third-country company has a fully-owned subsidiary and permanent establishment within the CССТВ jurisdiction, the latter may constitute a CCCTB group and aggregate their tax bases. If the permanent establishment suffers losses while the subsidiary generates profits, the losses of the permanent establishment may be taken into account twice, i.e. in the CCC tax base and in the third country if the latter taxes income on a residence basis. In case of a loss-making group, an option would be to limit the possibility for loss carryforward. In the author's opinion, such a limitation is undesirable from an economic perspective and may infringe the constitutional principle of ability-to-pay.

The inclusion of a permanent establishment of a non-resident taxpayer is likely to introduce further complexities given that the CCCTB sharing mechanism and the AOA use different allocation factors. Globally, the AOA is still the leading method for determining the income of permanent establishments. If the head office State supports the AOA and does not accept the tax base of a permanent establishment attributed to it under the CCCTB sharing mechanism, double taxation might arise. ${ }^{690}$ The Member States' existing DTCs with third countries would not solve the conflict, because they also follow the AOA. This conflict could be solved through the renegotiation of the DTCs to bring them in line with the principles of the CCCTB Directive (for instance, based on an EU Model DTC). However, considering the comprehensive DTC-network of the Member States and the predicted time requirements for negotiation, one may question whether the CCCTB automatically presupposes the parallel development of a DTC network between the EU Member States and at least the most important trading partners. ${ }^{691}$ Alternatively, the EU could negotiate DTCs with third countries (at least as far as the CCC tax base is concerned). ${ }^{692}$

${ }^{690}$ For further analysis, vide infra at II7.4.3.1.

691 There is no legal base set forth in the Treaty that allows restricting the Member States sovereignty in terms of their DTCs. Hence, the EU cannot achieve a uniform set of DTCs via approximation of Member States laws in this area. Hence, a solution could be found in some form of directed coordination of Member States laws by means of e.g. a Multilateral DTC or an EU Model DTC. For further discussion, see Pistone (2002a), 129-136.

${ }^{692}$ For further discussion on EU treaty-making competence, vide infra at 7.3. 
From an EU law perspective, there would be nothing wrong with excluding permanent establishments of third-country residents from the scope of the CCCTB. The CJEU has consistently held that Member State legislation, which primarily affects freedom of establishment, should be considered in the light of Article 49 of the TFEU rather than Article 63 of the TFEU. ${ }^{693}$ In that case, the restriction on the free movement of capital is an unavoidable consequence of the restriction on the freedoms of establishment. ${ }^{694}$ The CCCTB primarily concerns groups of companies and thus falls within the scope of the freedom of establishment only. ${ }^{695}$ Furthermore, the concept of establishment involves the actual pursuit of economic activity through a fixed establishment in another Member State for an indefinite period. Consequently, the CCCTB provisions concerning the taxation of permanent establishments as single taxpayers also fall within the scope of the freedom of establishment only. However, unlike the freedom of capital movement, the freedom of establishment does not have an external scope. Accordingly, as far as companies from non-EU Member States are concerned, the exclusion of their CCCTB-located permanent establishments from the scope of the CCCTB Directive would not infringe the EU fundamental freedoms.

\subsubsection{DTC APPLICATION}

The principle of non-discrimination in Member States' DTCs, based on Article 24(3) of the OECD MC, aims at granting equal treatment to permanent establishments compared to resident companies of the contracting State where the permanent establishment is located. Thus, the ultimate goal of the non-discrimination clause is to establish a level playing field between resident and non-resident enterprises in the source State. However, the DTC non-discrimination clause generally does not prohibit the taxation of non-residents differently compared to residents under domestic law of the source State as long as such taxation does not result in more burdensome taxation of the non-residents. ${ }^{696}$ The principle of equal treatment applies only to the taxation of the permanent establishment's own activities compared to the taxation of similar business activities carried on by a resident

\footnotetext{
${ }^{693}$ Case Cadbury Schweppes (C-196/04), para. 32.

694 Case Thin Cap Group Litigation (C-524/04), para. 34 (and the case law cited therein).

695 Case FII Group Litigation I (C-446/04), para. 118.

696 OECD Comm. on Article 24, para. 34.
} 
enterprise. ${ }^{677}$ Accordingly, the DTC non-discrimination clause seems to require a case-by-case analysis of whether the tax base of a permanent establishment, which carries on the same activities as a CCCTB resident company in that State, is higher under the CCCTB or domestic rules and apply the lower of the two. It is noteworthy that the OECD official commentaries on Article 24(3) are rather vague as to the scope of application of the provision. Paragraph 39 therewith explicitly states that, given the fact that permanent establishments are not separate legal entities but part of an enterprise, the situation of the permanent establishment is different from a domestic enterprise, which constitutes a single entity. For example, the principle of equal treatment in DTCs does not extend to rules covering the relationship between an enterprise and other enterprises, such as the possibility for consolidation, transfer of losses, tax-free transfers of property between the related entities, and transfer pricing. ${ }^{998}$ Against this background, the non-discrimination clause in DTCs seem to require that the permanent establishment has access to the uniform rules with regard to the calculation of its tax base as a single taxpayer but not with regard to group membership that includes consolidation and apportionment of the tax base.

\subsubsection{ENHANCED COOPERATION}

In the setting of enhanced cooperation, the definition of the personal scope of the CCCTB Directive can be analysed only in the light of EU freedom of establishment given it is mainly targeted at groups of companies. The proposed CCCTB Directive includes permanent establishments of third-country companies in the borders of CCCTB group, despite the head office's State. The question is whether, in the context of enhanced cooperation, including permanent establishments in the group definition would be a policy choice or an obligation in the light of the freedom of (secondary) establishment. Article 49 of the TFEU prohibits the imposition of restrictions on the freedom on setting up of agencies, branches or subsidiaries by nationals of a Member State in the territory of another Member State. In order to conclude that a discriminatory restriction exists, one must assess whether the taxpayers are treated differently in objectively comparable circumstances, which leads to disadvantageous treatment of the cross-border movement. As enunciated above, in the opinion of the author, the CCCTB system should not be seen as a (tax)

697 OECD Comm. on Article 24 para. 35.

${ }^{698}$ Brown \& Mintz (2010), 597. 
advantage in itself, which companies from non-participating Member States are deprived of. The idea of the CCCTB is to improve the functioning of the EIM not to introduce another means of tax planning. In the light of this premise, the restriction question is outside the scope of the discussion.

However, if one disagrees that the CCCTB does not provide an advantage to participating companies, one must assess whether companies from CCCTB participating and non-participating Member States are objectively in comparable circumstances in terms of their CCCTB-located permanent establishments. ${ }^{699}$ The concept of residence has a different purpose in direct tax law compared to other fields of law and the situations of residents and non-residents are generally not comparable. ${ }^{700}$ However, once a Member State exercises its taxing power over the non-resident company, the situation of resident and non-resident companies becomes comparable. ${ }^{701}$ Therefore, if a company is subject to tax in a CCCTB Member State, due to the existence of a permanent establishment, the situation of the company becomes comparable to that of the resident. In the light of the foregoing, permanent establishments of non-resident companies may generally be regarded as being in comparable circumstances with resident companies in the State where they are located. ${ }^{702}$ The fact that those permanent establishments are subject to limited tax liability, while resident companies are subject to unlimited tax liability, is irrelevant because both of them are taxable on the same grounds, i.e. based on their profits. ${ }^{703}$ The extension of the CCCTB personal scope to cover permanent establishments of third-country residents would not run counter to the fundamental idea of enhanced cooperation. The fundamentals of enhanced cooperation would only be affected if one claimed the extension of the personal scope to companies resident in non-CCCTB Member States. Against this background, on the assumption that the CCCTB provides for a tax benefit, the personal scope of the CCCTB Directive could not be limited to exclude permanent establishments

${ }^{699}$ Cases Schumacker (C-279/93), para. 30; Royal Bank of Scotland (C-311/97), para. 26; Schempp (C-403/03), paras. 21-26.

700 Cases Shumacker, para. 31.

${ }^{701}$ Cases Saint-Gobain (C-307/97), para. 47; Amurta (C-379/05), para. 41

702 Cases Commission v France [Avoir Fisca] (270/83); Halliburton (C-1/93); Futura (C250/95); Royal Bank of Scotland (C-311/97); Saint-Gobain (C-307/97); CLT-UFA (C253/03).

${ }^{703}$ In case of permanent establishments, this refers to profits attributed to the permanent establishment. 
of companies of non-CCCTB Member States without restricting the freedom of establishment.

Restriction on the freedom of establishment is permissible only if it is justified by overriding reasons in the public interest. In cases of permanent establishments, the most likely justification brought forward is the risk that losses are taken into account twice and the prevention of tax avoidance or evasion concerns. Even if the relevant national measure were appropriate to ensuring the attainment of its objective, it must not go beyond what is necessary to attain it. ${ }^{704}$ The inclusion of permanent establishments of third-country companies typically raises administrative issues, such as those related to the exchange of information. However, within the EU, such administrative concerns can hardly be accepted, mainly because the relations between EU Member States take place against a common legal background, characterised by the existence of Union legislation, such as Directive 2011/16/EU705 on administrative cooperation. Moreover, the validity of a taxpayer's action could be confirmed based on the agreement on the exchange of information of Member States' DTCs or any other comparable binding agreement between the relevant Member States or, alternatively, a taxpayer may be in a position to provide all the relevant documentary proof itself. ${ }^{706}$

In case of outbound investments, carrying on business in another State via a permanent establishment or a subsidiary differs, because the taxation of the non-resident in the source State is limited only in the former case. Carrying on business in another State through a subsidiary implies that the taxation of the latter is on a residence basis, i.e. its taxation is unlimited in that State. This basic difference is jurisprudentially confirmed in X Holding, where the Court held that, whereas a subsidiary constitutes an independent legal person subject to tax unlimited tax liability in its residence State, a permanent establishment remains in principle and in part subject to the fiscal jurisdiction of the head office's residence State. ${ }^{707}$ Despite such a difference in the two forms of establishment, the proposed CCCTB Directive limits its geographical scope at the water's edge, i.e. it

\footnotetext{
${ }^{704}$ Cases Marks \& Spencer (C-446/03), para. 35; Cadbury Schweppes (C-196/04), para. 47; Lidl Belgium (C-414/06), para. 27.

705 Council Directive 2011/16/EU on Administrative Cooperation in the field of Taxation and Repealing Directive 77/799/EEC.

706 Also vide infra at II5.5.4.4.

${ }^{707}$ Case X Holding (C-337/08), para. 38.
} 
excludes both non-resident subsidiaries and permanent establishments located in non-participating Member States. Such a limitation would not infringe the freedom of establishment, because the taxpayers carrying on business within the CCCTB jurisdiction and those carrying on business in non-participating Member States would not be in objectively comparable situations. Any contrary interpretation would defeat the purpose of enhanced cooperation.

\subsubsection{EEA TREATY APPLICATION}

The definition of the personal scope of the CCCTB Directive concerns only the provisions of the freedom of establishment. The author concluded earlier that, in the case of enhanced cooperation, limiting the access of CCCTB-located permanent establishments of companies of non-participating Member States would likely infringe the freedom of establishment, if one assumed that the CCCTB provides a tax advantage. Article 34 of the EEA Agreement foresees similar criteria for companies to benefit from the EEA Agreement, as Article 54 of the TFEU does for EU-established companies. In addition, Article 31 of the EEA Agreement grants those companies the freedom of primary and secondary establishment. Jurisprudence of both the CJEU and the EFTA Court confirm that the provisions contained in the EEA Agreement that are identical in substance to those of the Treaty have to be interpreted uniformly. ${ }^{708}$ In the light of the foregoing, on the assumption that the CCCTB provides for an advantage, limiting the application of the CCCTB system to CCCTBlocated permanent establishments of EEA-established companies would also restrict the freedom of establishment of those companies under the EEA Agreement.

As in case of the provisions of the TFEU, restrictions on the freedom of establishment under the EEA Agreement are permissible only if it is justified by overriding reasons of public interest and when the measure does not go beyond what is necessary to attain it. The Court has accepted that prevention of tax avoidance may be an appropriate justification for a restriction. Unlike in the EU-setting, such a restriction may be proportional to its aim considering that it involves third-country nationals. Indeed, while the exchange of information between the EU Member States is based on Directive 2011/16/EU on administrative cooperation, a similar framework for

708 Case Keller Holding (C-471/04), para. 48 and the case law sited therein. 
cooperation between the competent authorities of the Member States does not exist between those authorities and the competent authorities of a third country where the latter has given no undertaking of mutual assistance. Therefore, case law, which relates to restrictions on the exercise of freedom of movement within the Union, cannot be transposed in its entirety to movements of capital between Member States and third countries, since such movements take place in a different legal context. ${ }^{709}$ For that reason, in the present case, the restriction on the freedom of establishment under the EEA Agreement could be justified on grounds of proportionality.

\subsubsection{PERMANENT ESTABLISHMENT AS A TOP-LEVEL ENTITY OF A CCCTB GROUP}

Another question is whether a permanent establishment could act as the top-level entity of a CCCTB group. In fact, Member States' practice shows that there is nothing wrong with accepting a permanent establishment as a top-level entity of a group. ${ }^{710}$ As a rule, the State where a permanent establishment is situated has the primary right to tax the income attributed to it and DTCs typically do not limit this right. For example, where shares of resident subsidiaries are effectively connected to a CCCTB-located permanent establishment, it seems agreeable to allow such a permanent establishment to act as the top-level entity of the group. However, such a possibility is not present under the CCCTB proposal, which only allows resident companies to act as the principal taxpayer, unless the group consists of only permanent establishments. ${ }^{711}$ Accordingly, where a nonresident carries on business in the CCCTB jurisdiction through resident subsidiaries and permanent establishments, only the former can be regarded as the principal taxpayer of the group, even if the shares of the subsidiary are effectively connected to the permanent establishment. It is noteworthy that only the principal taxpayer can opt for the CCCTB. ${ }^{712}$ The articles of the proposed Directive are not entirely clear whether this implies that a resident qualifying subsidiary can also opt for the CCCTB on behalf of the non-resident parent

709 Cases A. (C-101/05), paras. 60-61; Commission v Italy (C-540/07), paras. 69-70. Also vide infra at II5.5.4.4.

${ }^{710}$ E.g. in Italy, one of the conditions on which a non-resident could opt for Italian consolidated regime is that it must reside in a country with which Italy has concluded a DTC containing an exchange of information clause. Adda (2008), 239.

711 Article 4(6)(c) and (d) of the proposed CCCTB Directive.

712 Article 104 of the proposed CCCTB Directive. 
company who carries on business in a CCCTB Member State through a permanent establishment. Against this background, in the opinion of the author, the articles of the CCCTB-proposal should be amended to include the possibility for a non-resident company to act as the principal taxpayer of the group..$^{713}$

According to the CCCTB-proposal, a non-resident company shall form a CCCTB group in respect of all its CCCTB-located permanent establishments and all its resident qualifying subsidiaries, including the permanent establishments of the latter located in the Member States. ${ }^{714}$ In the following example, a non-CCCTB resident company (CoA) has a non-CCCTB resident subsidiary (CoB). Both CoA and $\mathrm{CoB}$ have a permanent establishment in the CCCTB jurisdiction (Example 15: Permanent establishment as a top-level entity of a CCCTB Group).

Example 15: Permanent establishment as a top-level entity of a CCCTB Group

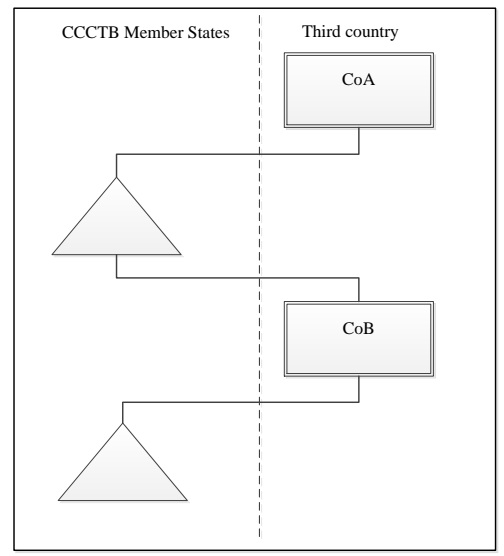

Under the current proposed rules regarding the formation of a CCCTB group between two CCCTB-located permanent establishments requires that they belong to different affiliated nonresidents. Hence, both non-resident companies would be eligible to opt into the CCCTB separately in terms of their CCCTB-located permanent establishments. In the example above, if the ultimate parent company is a CCCTB-resident company, both permanent establishments would be part of its CCCTB group, if the ultimate

${ }^{713}$ See also discussion supra at I4.3.2.

${ }^{714}$ Article 55(2) of the proposed CCCTB Directive. 
parent company opted for the CCCTB. ${ }^{715}$ Taking into account that such permanent establishments could participate in the CCCTB individually or as part of a group of a resident taxpayer, it seems unreasonable to exclude such entities from the possibility to form a CCCTB group between themselves, especially in the case of qualifying participations under the proposal. In fact, the current set of CCCTB rules allows a permanent establishment of the same nonresident taxpayer to act as the "principal taxpayer" of the group consisting of only permanent establishments in the CCCTB jurisdiction. Therefore, if a permanent establishment can act as the principal taxpayer in one case, there should be nothing to prevent it from acting as the principal taxpayer in other similar cases.

\subsubsection{THE NEED FOR THE NOTION OF PERMANENT ESTABLISHMENT}

The interpretation of the concept of permanent establishment is not undisputed, despite its long history. As it often appears, the concept does not properly reflect the current state of global economics and international taxation, especially in terms of e-commerce. Therefore, some scholars have pointed out the need to reconceptualise the notion and move towards a different concept, for instance, a "virtual permanent establishment" or a "quantitive economic presence test". 716 These concepts would be similar to the "nexus" approach present in the US state taxation systems and would not require the existence of a "fixed place" as such. As one may recall, the formula apportionment used by the US states apportions the relevant income to a particular state (and only in the second step to a particular taxpayer), while the proposed CCCTB sharing mechanism apportions the income to a particular member. Hence, while the "nexus" approach may well function at the US subnational level, a similar concept would not fit into the currently proposed CCCTB sharing formula. In other words, while the CCCTB, in its first step, defines the member of a group and, in the second step, apportions the income to that member, the US approach would imply skipping the first step. If the CCCTB employed a similar formula to that used by the US states, it could deem a permanent establishment to exist if certain de minimis portion of the consolidated income was apportioned to a particular Member State or exceeded specific absolute monetary threshold. On the other hand, this approach would definitely require the

715 Article 55(1)(b) of the proposed CCCTB Directive.

716 Pinto (2006), 276; Cockfield (2003), 400-424. 
renegotiation of existing DTCs of the Member States in terms of business income taxation. Consequently, the European Commission stands in between contradictory solutions: on the one hand, the necessity for the notion of permanent establishment for the purposes of the CCCTB is disputable and, on the other hand, the abolition of it may require that the Member States renegotiate all their DTCs with third countries. Against this background, it may be practical to exclude such entities from the CCCTB group definition all together, subject to EU law requirements explained above. Yet, for a number of solid reasons, such entities should be included in the CСCTB group definition..$^{717}$

\subsubsection{PRELIMINARY CONCLUSIONS}

Permanent establishments do not have legal personality, but they are often treated as separate entities for taxation purposes. This approach is also reflected in the CCCTB proposal, which includes CCCTBlocated permanent establishments in its group definition despite the State of the head office. From the author's perspective, the blind adoption of the definition of permanent establishment in the proposed CCCTB Directive in line with the OECD MC is subject to criticism, especially because practice shows that the concept is not clear and has been subject to several discussions and disputes. Moreover, several authors argue that the concept does not properly reflect the current state of global economics and international taxation, especially in terms of e-commerce and therefore it should be reconsidered. However, within the current framework of the CCCTB, which apportions income to a particular group member rather than to a particular State, the abolition of the proposed notion is hard to achieve, even if it was replaced by a revised definition. This change would definitely require renegotiating Member States' DTCs with third States. The same concern does not arise at the US subnational level, because the states are not bound by the US DTCs (with an exception to the non-discrimination clause) concluded at the federal level.

The extension of the CCCTB group definition to CCCTB-located permanent establishments is sustainable, because they often perform functions that contribute to the overall profitability of group of companies. However, as far as permanent establishments of non-

717 Vide supra at I4.4.3. 
residents are concerned, the inclusion of permanent establishments may also make the CCCTB system sensitive for tax planning, for example, due to a double-dip with regard to the losses attributed to the permanent establishment. At the same time, there would be no one-way benefit, as profits attributed to permanent establishments would also be taxed twice (which would be eliminated on unilateral or bilateral basis in the head office's State). The exclusion of permanent establishments from the scope of the CCCTB group definition would probably not infringe the non-discrimination clause contained in Member States' DTCs with third countries nor the freedom of establishment under the TFEU and the EEA Agreement on the assumption that the CCCTB does not provide for a tax benefit but represents an alternative corporate tax system.

\section{5 \\ CONCLUSIONS}

There is a substantial difference between the definition of the personal scope for the purposes of the US subnational taxation and that proposed for the CCCTB. While the US states look at the substantial nexus of an entity to a state, the CCCTB defines the personal scope via a list of eligible company forms and their permanent establishments. In the light of the analysis, the author concludes that the introduction of a list of eligible company forms would limit the effectiveness and functioning of the CCCTB system. This is especially true with regard to companies from third countries which, under the current CCCTB proposal, have to pass a similarity analysis as to their legal form. Instead, the CCCTB eligibility should be determined solely on the subject-to-tax criterion, which would look not only to companies that are subject to corporate income tax in a Member State but whose business profits are taxable there.

Business profits of companies from third countries are included in the scope of the CCCTB if the company resides or carries on its business through a permanent establishment in a CCCTB Member State. The CCCTB proposal defines residence by reference to three non-cumulative criteria: place of incorporation, registered office or place of effective management. However, in international (DTC) law, only the latter is normally considered as an appropriate criterion for determining a company's residence. The broad definition of residence under the CCCTB has several benefits, but it may also leave more room for undesired tax planning. Against this background, in the opinion of the author, the CCCTB residency should be determined solely based on the company's place of effective management. The 
latter refers to the place of the top executive managers, i.e. where the key management and commercial decisions that are necessary to conduct the entity's business are made.

The proposed CCCTB Directive includes an autonomous definition of permanent establishment and it largely corresponds to the definition provided for in the OECD MC. In the case of both inbound and outbound investments, one must analyse the concept of permanent establishment in the light of Article 351 of the TFEU. The author concluded that, in the case of inbound investments, a taxpayer could participate in the CCСТВ system only if it was deemed to have a permanent establishment under both the CCCTB and the relevant DTC. In the case of an outbound investment, in order to respect Member States obligations under DTCs, the taxation of the permanent establishment would always depend on the definition established in Member States' DTCs. However, as will be discussed below in this dissertation, Member States would be obliged to renegotiate their DTCs with third countries to bring them in line with the CCCTB Directive. Despite the merits of adopting the notion of permanent establishment in line with the OECD MC, this approach can be criticised for several reasons. At the same time, to define a taxable nexus to a Member State differently (e.g., based on a substantial economic presence) would most likely conflict with Member States' obligations that they have undertaken in their DTCs with third countries. Against this background, the definition of permanent establishment as included in the current CCCTB proposal is not an ideal solution but, compared to the current practice of the Member States, it would also not introduce many new difficulties to businesses or Member States.

As per the CCCTB group definition, in the early phases of the project, the European Commission considered both legal and economic ownership approaches as possible policy choices. ${ }^{718}$ The final decision favoured legal criteria, so that the CCCTB group is defined via a two-part test consisting of control and ownership or entitlement to profits. Such a formal approach suits better from a business perspective, because it provides legal certainty and is more attractive to Member States, because it reduces implementation and application complexities. This technique is also preferred in Member States national group taxation regimes. In terms of the threshold for

${ }^{718}$ European Commission (2006e), paras. 15 et seq. 
qualifying subsidiaries, it was essential to analyse whether the current threshold suffices to cover only those entities that have a strong link with the rest of the group members, without being too restrictive. From the author's perspective, the criterion based on voting rights is subject to criticism, because it may require subsidiaries (and their permanent establishments) to participate in a CCCTB group, even where the parent company effectively does not have control over that subsidiary. In that sense, a criterion of "control" based on a case-bycase analysis would be more appropriate. By comparison, the US states place their emphasis on the economic relationship and disregard the organisational borders of a unitary business. Such an approach fits better with the highly integrated market of the US and respects the constitutional obligations of the states. On the other hand, the definition of a unitary group varies from state to state and most state statutes and regulations give little practical guidance as to what should be regarded as a unitary group. This leads to uncertainty, more complex audits, appeals, and litigation.

With regard to the geographical borders of the CCCTB, the policy choice has always been water's edge. ${ }^{719}$ This approach is also common in national group regimes, especially with regard to subsidiaries, because of the political acceptance that extending general residence taxing rights to non-residents is disputable and raises revenue and anti-avoidance concerns. ${ }^{720}$ On the contrary, the US states apply either worldwide combined reporting or separate accounting at the water's edge. Furthermore, almost all of the states that require combined reporting have included either water's edge election or some other statute that permits the exclusion of certain foreign income. ${ }^{721}$ From an EU law perspective, there is nothing wrong with limiting the group definition at water's edge, because it would be analysed only in the light of the provisions on the freedom of establishment, which does not have external scope. Finally, even if the CCCTB is introduced via enhanced cooperation, it will be appropriate to limit the group definition at the CCCTB water's edge, because any other interpretation would run counter to the fundamental idea of enhanced cooperation.

\footnotetext{
719 European Commission (2001d), paras. 15-16; European Commission (2003b), paras. 4,16 et seq.

720 Ting (2011), 434.

${ }^{721}$ Fox et al. (2009), 405.
} 
The final definition of a group membership goes hand-in-hand with the definition of the CCC tax base, in particular, establishing which foreign income should be included in the group tax base and how to deal with foreign losses of the group. The following Chapter will take a closer look at this issue. 
The second key aspect in determining the territorial scope of the CCCTB is the definition of income to be included in the CCC tax base. The proposed CCCTB Directive provides for a new, selfstanding corporate income tax system. It is built on the residency principle and thus requires the inclusion of all the worldwide income of the resident into its tax base. ${ }^{722}$ The tax base of a non-resident taxpayer consists of all the income derived from an activity carried on through its CCCTB-located permanent establishments. ${ }^{723}$ The starting point for a CCC tax base is that, once an entity becomes part of a CCCTB group, its whole tax base is added to the rest of the group members' tax bases. ${ }^{724}$ In other words, despite whether the parent company holds 100 per cent of the subsidiary's capital, voting rights or rights to profits of the subsidiary, the total tax base of the subsidiary is aggregated with the rest of the group members' individual tax bases. Furthermore, intra-group transactions are ignored, but they are recorded for administrative purposes. ${ }^{725}$

The main purpose of the current Chapter is to analyse the policy choices and the technicalities of the proposed CCCTB Directive with regard to the definition of tax base. In particular, the author will study which income from which jurisdictions is included in the CCC tax base and the related tax consequences, e.g. whether a distinction should be made between active and passive income. ${ }^{726}$ The author will further analyse the impact of the policy choices and the corresponding articles of the proposed CCCTB Directive on Member States international obligations - their DTCs with third countries. Finally, in certain cases, the author will analyse whether, and if so, to what extent, the current CCCTB proposal would have to be adjusted

\footnotetext{
722 Article 6(6) of the proposed CCCTB Directive.

${ }^{723}$ Article 6(7) of the proposed CCCTB Directive.

${ }^{724}$ Determination of corporate taxable income of CCСТВ group members based on a harmonised set of tax accounting rules is set forth in Articles 9-43 of the proposed CCCTB Directive; Consolidation of the individual group members' corporate income tax bases to the common tax base is set forth in Articles 54-60 of the proposed CCCTB Directive.

725 Article 59 of the proposed CCCTB Directive.

726 This consideration has been brought up by the European Commission during the preparatory work on the CCCTB. See European Commission (2006b), paras. 24-25.
} 
if the CCCTB was adopted in the framework of enhanced cooperation.

\subsection{COnsolidated TAx Base}

In 2002, the EU adopted a regulation requiring listed companies, including banks, to prepare their accounts on a consolidated basis using the International Accounting Standards/International Financial Reporting Standards (IAS/IFRS). ${ }^{727}$ The coincidence of the adoption of the regulation and the European Commission's conclusion that EU businesses should have the possibility to use a consolidated tax base for their EU activities, along with the European Commission initiative on company taxation, ${ }^{728}$ led to the interest in an IAS/IFRS common tax base for companies. ${ }^{729}$ At first, rather than putting the CCC tax base dependent on the IAS/IFRS, the European Commission stressed the advantages of the IAS/IFRS for the CCCTB as a starting point for a system of common consolidated tax accounting. ${ }^{730}$ However, later documents of the European Commission do not refer to the IAS/IFRS as a "starting point" but as a "tool for defining the base" because they provide a common language and some common definitions. ${ }^{731}$ Finally, in 2007, the European Commission explicitly stated that it is not possible to establish a formal link between the rules of the CCCTB Directive and those of the IAS/IFRS. ${ }^{732}$ As it currently stands, the rules set forth in the proposed CCCTB Directive for the determination and calculation of the CCC tax base do not link to the IAS/IFRS. ${ }^{733}$ Presumably, Member States rejected the option of linking the CCCTB with the IAS/IFRS because, at the current stage, few companies are required to use the IAS/IFRS in the EU and they did not wish to extend the scope of the regulation to cover more companies. Moreover, the IAS/IFRS are not specifically designed for taxation purposes.

\footnotetext{
727 Regulation (EC) No. 1606/2002/EC on the Application of International Accounting Standards. Unlisted companies remain subject only to the EU Accounting Directives, principally the Fourth Council Directive 78/660/EEC on the Annual Accounts of Certain Types of Companies and the Seventh Council Directive 83/349/EEC on Consolidated Accounts.

${ }^{728}$ European Commission (2001d) and European Commission (2001a).

${ }^{729}$ European Commission (2003c), 8.

${ }^{730}$ European Commission (2003b), 16-21.

${ }^{731}$ European Commission (2006o), para. 3.2.

732 European Commission (2007a), para. 9.

${ }^{733}$ For a further discussion on the matter, read, for instance, Essers (2008), 363-84; Gammie et al. (2005).
} 
The CCCTB rules also do not formally link to national tax accounting principles (generally accepted accounting principles (GAAP)). According to Article 7 of the proposed CCCTB Directive, when a company opts into the system, it shall cease to be subject to the national corporate tax arrangements in respect of all matters regulated by the Directive, unless otherwise stated. The Directive provides for a comprehensive system. Consequently, in the opinion of the author, the absence of common rules in the CCСТВ Directive should not be interpreted as to allow Member States to refer to their national tax rules or the GAAP for the purposes of interpreting the Directive, unless explicitly provided therein. Hence, any provision contained in the Directive would have to be interpreted in the light of EU law.

Both neutrality and horizontal equity propose a comprehensive and general definition of tax base to avoid unintentional distortions caused by the inclusion of certain income into the tax base in some situations while excluding it in similar circumstances. ${ }^{734}$ The proposed CCC tax base corresponds to these principles because it is described broadly: the tax base includes all revenues less exempt revenues, deductible expenses and other deducible items. ${ }^{735}$ The definition includes two important characteristics: (i) it relies on a company's profit and loss account rather than on its balance sheet; ${ }^{736}$ and (ii) it does not differentiate between active (business income) and passive (investment) income. First, according to the European Commission, not all Member States that establish the tax base via adjustments to the profit registered in the financial accounts use the concept of "tax balance sheet". Instead, these Member States follow a "profit/loss approach". ${ }^{737}$ With regard to the second point, the European Commission discussed in its earlier documents whether a distinction should be made between ordinary business income and investment income for CCCTB purposes. In such cases, the investment income would be subject to specific tax treatment or a tax on it would be collected by a different technique. ${ }^{738}$ This possibility was later rejected

\footnotetext{
734 Freedman \& Macdonald (2008), 232.

735 Article 10 of the proposed CCCTB Directive.

${ }^{736}$ Even though the balance sheet approach, which compares the net asset values at the beginning and end of the year plus dividends distributed by the taxpayer, is different from that of the profit and loss account, the end result of the two systems should be equal, provided that the scope of the taxable revenues and tax deductible expenses is the same.

${ }^{737}$ European Commission (2005a), para. 17; European Commission (2006i), para. 8.

${ }^{738}$ European Commission (2005b), para. 14.
} 
so that all income would be considered taxable income. ${ }^{739}$ Indeed, it is generally accepted among States that all income derived by an enterprise should be treated as ordinary business income and the distinction between the two types of income only complicated matters. ${ }^{740}$ By contrast, as will be discussed below, US states commonly separate business income from non-business (investment) income.

Despite the obvious need to define the CCC tax base broadly, all States have to respect other States fiscal sovereignty. A State could subject a company to its taxation system if a sufficient connection by means of a physical or intangible presence of that company exists in its jurisdiction. Consequently, the CCC tax base must be defined in a way that it does not violate other States' fiscal sovereignty. In addition, it must also respect the principles of subsidiarity and proportionality. ${ }^{741}$

The territorial scope of the CCC tax base in relation to third countries generally boils down to the following two categories:

(i) Taxation of foreign income of CCCTB tax resident companies (outbound investment); and

(ii) Taxation of income of CCCTB non-resident companies from the CCCTB jurisdiction (inbound investment).

The income of CCCTB non-residents from sources outside the CCCTB jurisdictions are not covered by the CCCTB rules, because the taxing rights would be outside the CCCTB jurisdiction according to international tax principles. In that case, transactions involving related parties inside and outside of the CCCTB jurisdictions will have to be measured according to the AOA/arm's length principle. ${ }^{74}$ This approach will not be challenged in the current thesis.

\footnotetext{
${ }^{739}$ European Commission, 'An Overview of the Main Issues That Emerged at the Second Meeting of the Subgroup on Taxable Income of 1 March 2006', Common Consolidated Tax Base Working Group (Brussels, 2006), para. 7.

${ }^{740}$ Note that in some countries such a difference is still made. For example, in the Netherlands, a foreign subsidiary's income is not included in the income of the parent company if it is considered business income, while it is included if it is deemed to be investment income.

${ }^{741}$ For a further discussion, vide supra at I2.1.3.

742 Article 79 of the proposed CCCTB Directive.
} 
A taxation system, such as the CCCTB, may be built on a number of international principles. Taxation without a genuine link to the territory would violate public international law. Traditional grounds for exercising taxing rights over income look at the residence of a taxpayer or the source of income. The former supports the taxation of worldwide income of tax residents (comprehensive/unlimited tax liability), i.e. the income of a tax resident of a State includes the entire income the person has received from inside and outside the borders of its home country. To tax income on a residence basis, States need to implement residency rules, which bind the taxpayer and the jurisdiction, based on specific factors. As discussed in the previous Chapter, the current wording of the CССТВ proposal addresses three non-cumulative factors for defining residence: registered office, place of incorporation and place of effective management. Once the residency of a person has been established in a specific jurisdiction, it further depends on that jurisdiction whether double taxation of such income is avoided under its domestic law, taking into account the requirements stemming from DTCs and EU law, if applicable. If a country eliminates double taxation, the system is no longer pure worldwide taxation but a kind of a mix between worldwide and territorial taxation (to be discussed below).

Source-based taxation, on the other hand, aims at taxing nonresidents on their income sourced from a certain jurisdiction, i.e. only income generated or derived from sources within a jurisdiction is subject to taxation in that jurisdiction. Source-based taxation looks at the links between a taxing jurisdiction and a taxpayer based on several factors, such as the location of the events generating income, a taxpayer's property, etc. The problem of taxing based on the source of income is that there is no international consensus regarding the definition of "source". The absence of such an agreement, however, may lead to double (non-) taxation of the income. ${ }^{743}$ Normally, the source State is not limited in respect of the tax rate applicable to a non-resident's income or required to avoid double taxation. However, it may be required to reduce its tax rate or it may even be prohibited from levying any withholding tax on such income because of its DTCs or EU law. The CCCTB proposal includes rather limited rules for source taxation as it targets only income and payments that

${ }^{743}$ Read further, for instance, Kemmeren (2006), 430-52; Easson (2006), 495-500. 
affect the CCC tax base. All other income and payments derived by or made to non-residents will remain taxable according to national rules of each Member State. For example, CCCTB-located permanent establishments of non-resident companies are included in the CCCTB group definition and, consequently, all the income attributed to these permanent establishments forms part of the CCC tax base. Similarly, if a CCCTB Member State decides to charge a withholding tax on interest or royalty payments made to non-residents, that tax must be shared according to sharing mechanism (Article 77). ${ }^{744}$ With regard to the latter, one may wonder whether such a provision leads to "tax rate competition" among Member States (in addition to the current situation), as companies might find it attractive to establish financing and/or IP-companies in Member States with low withholding tax rates. ${ }^{745}$ To illustrate (Example 16: Withholding tax on interest payments), a non-resident company (CoX) has a subsidiary $(\mathrm{CoB})$ in Member State B. Instead of lending money directly to $\mathrm{CoB}$, CoX lends the money through its newly established subsidiary, an interposed holding company (CoA) in Member State A. Based on the DTC with third State X the withholding tax on interest payments in Member State A is 5 per cent, while it would have been 15 per cent in Member State B. Since CoA and CoB form a CCCTB group, transactions between them are ignored.

\footnotetext{
${ }^{744}$ See also Recital 18 of the Preamble of the proposed CCCTB Directive. Actually, careful reading of Article 77 in conjunction with Article 86 of the proposed CCCTB Directive, which provides for the sharing formula, does not lead to a desired result. First, a division of a withholding tax based on sales, employment and assets makes little sense. Second, a withholding tax could not be seen as a "tax base" as required in the formula. Third, if "share A" leads to a tax base attributed to a particular group member, it means that the relevant Member State does not receive a share of the withholding tax itself but a portion of that tax (tax rate multiplied by the "tax base"). One may assume that the European Commission has intended to allocate each relevant Member State a share of the withholding tax in proportion to the tax base attributed to each member of the group. Hence, instead of using the apportionment formula itself, the allocation of the withholding tax should only refer to predetermined apportionment factors resulting from the apportionment of the tax base.

${ }^{745}$ European Commission (2007a), para. 18.
} 


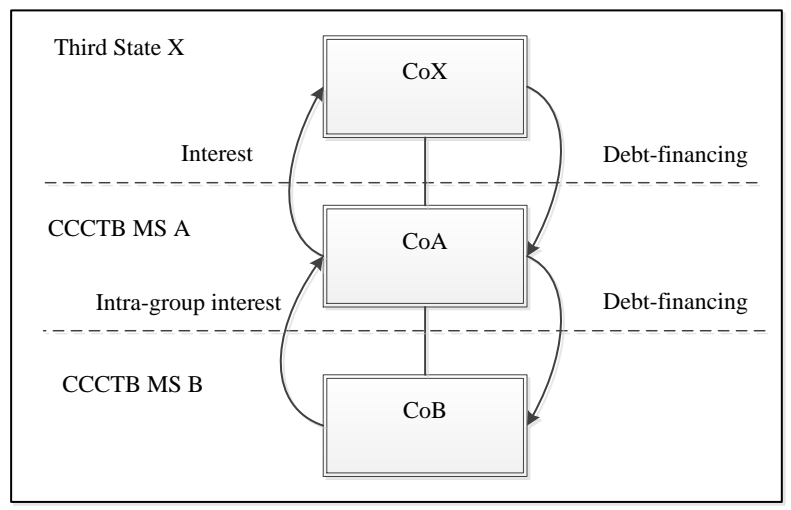

In fact, the example also presents a case of so-called "treaty shopping", where CoX makes use of the DTC between the CCCTB Member States in order to obtain benefits that it would otherwise not get if it had applied the DTC between the third State and CCCTB Member State B directly. This is an existing problem within the EU, mainly due to the existence of the Parent and Subsidiary Directive and the Interest and Royalty Directive for intra-EU payments, which allow taxpayers to design the outflow of dividends, interest and royalty payments to a third country from the most beneficial EU Member State. However, such a structure would not be caught by the CCCTB GAAR. The application of lower withholding taxes to outbound payments would not affect the tax base calculated in accordance with the CCCTB Directive even if it would affect the amount of withholding tax to be shared. In any event, in case there is an improper use of the relevant DTC, national tax authorities would be able to deny the application of the benefits of the DTC even in the absence of a GAAR dealing with such situations. ${ }^{746}$

The third option could be the application of a territorial system, which, in its purest form, would only subject the income earned within a certain jurisdiction by residents and non-residents to tax ${ }^{747}$

\footnotetext{
${ }^{746}$ For further discussion, vide infra in II8.

747 Note that the CJEU seems to understand the principle of territoriality as a criterion for the division of the authority to tax as used in international law, as opposed to the definition used in international tax law as defined herein. For further discussion, see Marres (2011), 112-125.
} 
(such a system is sometimes also called "strict territoriality principle" to differentiate it from the CJEU understanding of "territoriality" 748 ). The logic behind the system is that income should be subject to net income tax only in the jurisdiction where it makes most sense to tax it on a source basis, i.e. where the taxpayer undertakes the economic processes and activities necessary to generate income. ${ }^{749}$ In case of residents, this is typically accomplished by exempting income derived from its foreign permanent establishment and dividends from (substantial) shareholding in a non-resident company. With regard to non-residents, the State is limited by the same rules as States that tax income at source. The pure forms of a territorial system are rare in Member States taxation systems, although some impure versions exist, for instance due to the application of CFC regimes. These systems are rather similar to the impure "worldwide" taxation systems.

\subsubsection{PRINCIPLE OF REALISATION}

The overarching principles in the proposed CCCTB framework foresee the adoption of the realisation principle ${ }^{750}$ for recognising profits and losses, the item-by-item principle and the requirement for consistency. ${ }^{71}$ The realisation principle (also called the "revenue recognition principle") is an accounting standard that recognises revenue only when it is earned. The principle is the cornerstone of both the accrual and cash method of accounting. If a State adopts an accrual basis of accounting for recognising taxable income, it will consider income and expenses from when they are incurred, despite when cash is received or paid in respect of that income or expense. The cash accounting principle, on the contrary, recognises revenues when cash is received and records expenses when they are paid in cash, irrespective of when the respective goods or services are sold or provided. The accrual principle is not a general principle ${ }^{752}$ in the

\footnotetext{
748 Arginelli (2007), 112-113.

${ }_{749}$ NFTC (2002), 7.

750 The proposed CCCTB Directive contains three exceptions to the realisation principle: financial assets and liabilities held for trading (Article 23), long-term contracts (Article 24) and income from CFCs (Article 82).

751 Article 9 of the proposed CCCTB Directive.

752 Although the accrual principle is not a general principle for the purposes of the interpretation of the Directive, it can be seen as an underlying principle of the Directive. For example, losses incurred in a previous regime (i.e. national rules or CCCTB system) shall be available for use in the new system againt the taxpayer's apportioned share in case of a group.
} 
proposed CCCTB Directive but it is reflected in Articles 17-19 therein: revenues, expenses and other deductible items are recognised when they accrue or incur.

\subsubsection{TYPE OF INCOME}

If one distinguishes between so-called active (business) income and passive (investment) income, one should justify doing so and establish the relevant criteria for the relevant differentiation. This would urge the European Commission to provide a definition of business as such. However, each new term tends to bring along with it questions of interpretation. If the interpretation was left as a competence of the (tax) authorities from different Member States, an income may qualify as business income in one Member State but not in another. Moreover, differentiation between the two types of income leads to increased administrative complexity. On the other hand, sharing passive income among the relevant Member States may not be appropriate. As will be discussed below, most US states distinguish between 'business income', which is subject to apportionment, and 'non-business income', which is subject to specific allocation rules. Such a distinction is a natural outcome of the functioning of unitary taxation, where the taxpayer is interested in the business of a group as a "going concern" irrespective of corporate structures. The CCCTB is built on a different principle and thus reference to the US subnational taxation is inappropriate in that regard. In fact, the US states' experience shows that distinguishing between various types of corporate income - i.e. business income and non-business income - often leads to conflict between taxpayers and state authorities.

For the purposes of discussion in the light of the proposed CCCTB Directive, the author will distinguish between three main groups of income derived by residents from third countries or by non-residents from the CCCTB jurisdiction:

(1) Active (business) income, which includes income from permanent establishments;

(2) Passive (investment) income, which includes dividends from major shareholding (direct investment) and portfolio investment, ${ }^{753}$ interest and royalty income; 754

753 Portfolio dividend for CCCTB purposes would mean dividends from a shareholding that would not qualify as a from "major shareholding" as defined in European Commission (2007a), para. 125. Accordingly, "major shareholding" would 
(3) Income from immovable property.

With regard to capital gains, the proposed CCCTB Directive is in line with the earlier suggestions of the CCCTB Working Group, which had suggested treating capital gains together with ordinary business income, ${ }^{755}$ and provides that capital gains form part of revenue of a CCCTB taxpayer. ${ }^{756}$ Indeed, a tax system built on the principle that profits and losses arising in a business shall be treated equally, despite how they have been materialised - from working capital or from other assets -treats capital gains as part of ordinary business income. ${ }^{757}$ Such gains are similar by nature to revenues, which therefore supports including them under business income.

\subsection{OUtBound INVESTMENT: TAXATION OF Foreign INCOME OF CCCTB GROUP MEMBERS}

As referred to earlier, the European Commission has provided a broad definition of a CCC tax base. The chosen approach relies on the residency principle, although it cannot be characterised as a pure worldwide taxation system. Instead, like typical Member States' tax systems, it taxes all the income of CCCTB residents, ${ }^{758}$ but it exempts certain items of income under Article 11 or allows for credit for foreign taxes paid under Article 76 of the proposed CCCTB Directive. The wording of the exemption method (Article 11) suggests that the CCCTB system does not exclude foreign income from the tax base, but it includes it in the individual tax base of a group member under the CCCTB rules and (base) exempts before aggregating the tax base with the rest of the CCCTB group members' tax bases. Therefore, income that is 'exempt' under the proposed CCCTB rules is exempted before the application of the sharing mechanism. If foreign income was excluded from the tax base under the CCCTB rules, it would be taxed (and relieved from double taxation) in accordance with each Member State's national laws. However, the functioning of the credit method (Article 79) is different, because the relevant foreign income is first included in the

mean a shareholding that represents more than $10 \%$ of the capital or voting rights in the distributing company and held for at least 12 months.

754 European Commission (2006b), para. 24.

755 European Commission (2005b), para. 17.

756 Article 4(8) of the proposed CCCTB Directive. Note that Article 11(b) of the proposed CCCTB Directive exempts capital gains from pooled assets.

757 UNICE CCCTB Task Force (2005), 1.

758 Article 6(6) of the proposed CCCTB Directive. 
CCC tax base of the group and shared among the members and only thereafter includes credits received in the relevant Member State. The author will discuss these policy choices in detail below in Chapter 7 .

\subsubsection{INCOME FROM Foreign PERMANENT ESTABLISHMENTS}

Corporate tax systems based on the residency principle include income derived through a foreign permanent establishment of a resident company into its worldwide tax base, normally as part of ordinary business income of that entity. The fact that permanent establishments are not separate legal entities implies that that their income may be included in the worldwide tax base of their (CCCTB) resident head offices, without infringing third countries' fiscal sovereignty. In case a company opts for the CCCTB as a resident taxpayer, generally speaking, it is a matter of policy choice whether such income should be covered by the CCCTB rules or national tax provisions of each individual company. In case of a CCСТВ group, foreign permanent establishments of group members might effectively contribute to the overall productivity of the group and, therefore, there is a stronger incentive to include them under the umbrella of the common rules. Moreover, the exclusion of such establishments from the scope of the CCCTB would likely lead to inconsistencies in the treatment of a permanent establishment's income and increase in administrative difficulty. For example, taxpayers would still need to deal with each Member State's national tax rules with regard to the determination of income from foreign permanent establishments, which would be added to their share of the CCC tax base. In the light of the aims of the CCCTB, specifically to create an incentive for international investment and provide consistency between national laws of Member States, the inclusion of the income of a third country permanent establishment under the CCCTB rules appears to be the most appropriate solution. As stated earlier, this approach has also been taken in the CCCTB proposal, which includes the income from third-country permanent establishments within its scope.

Having accepted that income attributed to a foreign permanent establishment should be (and is, according to the CCCTB proposal) covered by the common system, one must further agree on the policy of calculating such income. This policy choice depends on the choice of the method of eliminating double taxation of the income derived through foreign permanent establishments. The general rule under the proposed CCCTB Directive is that income attributed to 
foreign permanent establishments is (base) exempted (Article 11(e)). ${ }^{759}$ However, if the income of such a permanent establishment is considered to be derived in a low tax country, it will not be exempted from the tax base of the head office but will receive a credit due to the application of the switch-over clause (Article 73). ${ }^{760}$ In case of the base exemption method, foreign income of a resident company is eliminated from its tax base before consolidation. Unless the country applies an exemption with the progression method, there is no reason to calculate the income of the foreign permanent establishment in the residence State of the head office. However, when a country uses the credit method, such foreign income of residents is included in their worldwide tax base, consolidated and shared among the group members. In such a case, the taxpayer(s) will receive a credit for foreign taxes paid. The application of the credit method requires the determination of the tax base of such foreign permanent establishments.

Generally speaking, in the case of the credit method for the elimination of double taxation, the income attributed to foreign permanent establishments could be calculated based on either the rules of the CCCTB Directive or the rules of the relevant source State's domestic rules. Compared to the former, the source-State approach offers an advantage of not needing to re-calculate the profits of the permanent establishment. Moreover, it would respect business location choices. However, reference to third countries' national rules may lead to administrative complexities, especially in terms of receiving the appropriate information as well as auditing. In fact, it is rather a common practice of Member States to recalculate the profits of foreign permanent establishments to correspond to their national tax rules. ${ }^{761}$

\footnotetext{
${ }^{759}$ In the opintion of the author, although the wording of the proposed CCCTB Directive is not entirely clear whether the chosen method for the elimination of double taxation is indeed the base exemption method, its context appears to reflect that it is indeed the base exemption method.

${ }^{760}$ Note that the Danish Presidency has proposed to eliminate the application of the switch-over clause and the calculation of the income accordingly. However, it has proposed to deal with the issue under the rules dealing with the CFC provisions and calculate the income of a foreign permanent establishment equally to the income of a CFC. Council of the European Union (2012), comments on Articles 73-74 and 8283 of the proposed CCCTB Directive.

${ }^{761}$ For further reading, vide infra at II6.5.5.
} 
It is noteworthy that the proposed CCCTB switch-over clause suggests determining such income in accordance with the CCCTB rules and sharing it between the relevant group members according to the formula (Articles 73 and 74). In any event, the inclusion of foreign business income into the CCC tax base would lead to double taxation of such income to the extent that both the source State and the residence State exercise their taxing right. The application of the switch-over clause implies the application of the credit method for the elimination of such double taxation. The application of the credit method can be less advantageous only if the tax rate in the source State is (considerably) lower, which is the case of the proposed CCCTB switch-over clause.

In the following example, (Example 17: Calculation of the income of a foreign permanent establishment), assume that a CCCTB resident company (CoA) has a foreign permanent establishment (PE). CoA forms a CCCTB group with another CCCTB resident company $(\mathrm{CoB})$ from Member States B. The individual tax base, as calculated according to the CCCTB rules of CoA is 100, plus the income attributed to the foreign permanent establishment (100). The individual tax base of $\mathrm{CoB}$ is 100 .

\section{Example 17: Calculation of the income of a foreign permanent establishment}

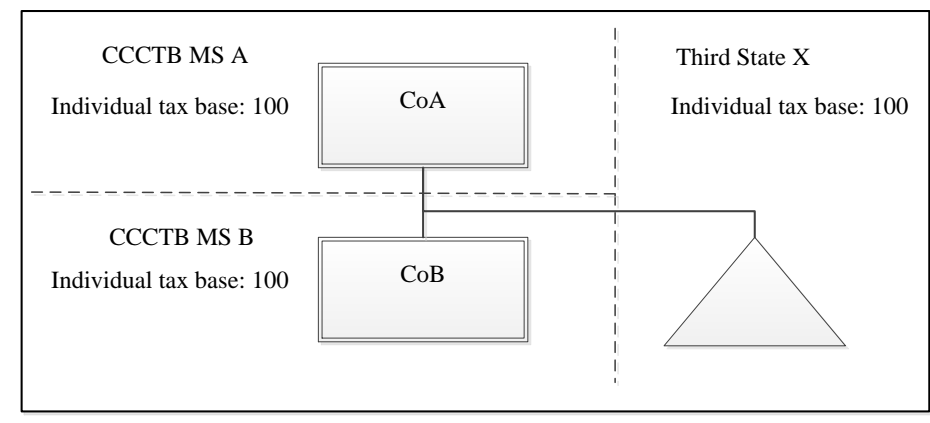

\begin{tabular}{|c|c|c|c|c|}
\hline Option & PE income & $\begin{array}{c}\text { CCC tax } \\
\text { base }\end{array}$ & $\begin{array}{c}\text { Share CoA } \\
\text { based on }\end{array}$ & $\begin{array}{c}\text { Tax base in } \\
\text { MS A }\end{array}$ \\
\hline Option (1) & 100 & 200 & 100 & $100+100$ \\
\hline Option (2 & 100 & 300 & 150 & 150 \\
\hline
\end{tabular}

In light of the example above:

(1) If the income of the foreign permanent establishment was added only to the tax base (and taxed accordingly at the 
level) of the head office (CoA) (i.e. added to its share of the apportioned CCC tax base), CoA would have a higher tax base in its Member State of residence (Member State A) (option (1)). In this case, double taxation would be avoided in accordance with the DTC between Member State A and the third country. In the opinion of the author, applying the credit method under the switch-over clause, rather than exemption method under the DTC, would not lead to the infringement of Member States' international obligations under the DTC. Indeed, in such cases, the rights of third countries would not be affected as the elimination of double taxation concerns the taxation of the resident head office in the Member State (despite whether the interests of the third country would be affected). ${ }^{762}$

(2) If the income was aggregated with the tax base of $\mathrm{CoB}$, both companies $\mathrm{CoA}$ and $\mathrm{CoB}$ would be attributed a share of the income of the foreign permanent establishment in accordance with the sharing mechanism (option (2)). In the example, it is assumed that the sharing mechanism attributes half of the CCC tax base to CoA and the other half to CoB. The DTC between Member State B and the third State would not be applicable because the subjective scope of the DTC would not be fulfilled (i.e. there is no resident person of a Contracting State).

The author discussed in the previous Chapter of this dissertation that the policy for the geographical borders of the CCCTB group definition has always been water's edge. Despite this option, it is worthwhile noting that the CСCTB could, in principle, function across the water's edge. In such a case, the CCCTB group definition would include foreign affiliates that would be attributed part of the CCCTB based on the formula. Foreign entities belonging to a CCCTB group would then benefit from the CCCTB as their CCCTB-located affiliates, such as from the immediate loss offset and absence of transfer pricing rules.

Extending the CCCTB group definition to include foreign permanent establishments might lead to double (non-) taxation, because the income would be attributed to the permanent establishment based on different attribution rules than generally

${ }^{762}$ Vide infra at II7.3 
accepted in Member States' DTCs. As far as DTCs based on the OECD MC (2010) are concerned, profit attribution to permanent establishments is based on the AOA, taking into account the functions performed, assets used and risks assumed. ${ }^{763}$ On the other hand, the CCCTB uses a sharing mechanism, which attributes profits to a particular group member based on a three-factor formula based on sales, employment and assets. Consequently, since the two methods of attribution of profits to a permanent establishment/group member employ fundamentally different principles, double (non-) taxation could arise in the related jurisdictions. ${ }^{764}$ Such conflicts could be eliminated by a renegotiation of Member States' DTCs with third countries, so that the attribution of profits to permanent establishments would be made based on the three-factor formula apportionment rather than the AOA. However, the OECD has been explicitly against using global formula apportionment for groups of companies, amongst other reasons, because " $\mathrm{t}]$ he transition to a global formulary apportionment system therefore would present enormous political and administrative complexity and require a level of international cooperation that is unrealistic to expect in the field of international taxation". 765

Despite the opinion of the OECD, if CCCTB Member States were willing and able to renegotiate all of their DTCs to attribute profits to permanent establishments based on a predetermined formula, a CCCTB group definition could reach across the water's edge and include foreign permanent establishments. ${ }^{766}$ For that purpose, Member States could agree on an EU model DTC and commentary, which would meet the specific requirements of EU membership as proposed by the European Commission in 2001. ${ }^{767}$ Alternatively, the EU, probably under the coordination of the European Commission, could negotiate a DTC on behalf of all the participating Member

\footnotetext{
763 Article 7 of the OECD MC and the respective Comm., para. 15 et seq. Note that the proposed CCCTB sharing mechanism also differs fundamentally from Member States DTCs that attribute business profits to a permanent establishment based on the separate entity approach as provided for in pre-2010 OECD MC and the UN MC.

${ }^{764}$ For further discussion, vide infra at II7.4.

765 OECD (2010b), paras. 3.58 et seq.

766 A worldwide CCCTB group definition could also include foreign affiliated companies. Differently from permanent establishments, such entities are not taxed under the AOA as they are separate resident entities.

${ }^{767}$ European Commission (2001d), 14.
} 
States which would replace the existing DTCs of these Member States, at least as far as companies participating in the CCCTB are concerned. ${ }^{768}$ As mentioned earlier, the EU's legal personality confers on the Union a treaty-making competence and authorises it to negotiate and conclude treaties with international organisations and third countries.769 For example, the EU has negotiated and concluded an agreement on the taxation of savings with Switzerland. ${ }^{770}$ Otherwise, an EU regulation, which could be used as a blue print for Member States' DTCs with third countries, could be an option.

In conclusion, the income of a foreign permanent establishment could either be included or excluded from the CССТВ territorial scope. Both policy choices should be legally acceptable. The author supports the former approach in order to provide consistency in the taxation of such income despite the Member State of the head office. Under the current proposal, the income derived through a permanent establishment located in a third country is not excluded from the scope of the directive but it is (base) exempted, subject to a switch-over clause. In the latter case, the income is included in the consolidated tax base of the group and double taxation is eliminated via the application of the credit method. The application of the credit method is less advantageous only if the tax rate in the source State is (considerably) lower, which is the case of the proposed CCCTB switch-over clause. In the opinion of the author, the application of the credit method to the income of low-taxed permanent establishments would not infringe the DTC of the Member State, where the head office is located, with the relevant third country, because the rights of the latter would not be (negatively) affected. Finally, the DTCs of the other Member State of the group members would not be applicable in the case of sharing

\footnotetext{
768 A complete, single EU Model DTC or an EU multilateral DTC, replacing all the existing DTCs, has been discussed by many authors. See Lang et al. (1998); Pistone (2002a), 129-136. However, so far the Member States have not managed to agree on such a DTC. With regard to a global multilateral DTC, see Kobetsky (2008), 201 215. The introduction of the CCCTB appears to be a good incentive to reconsider such a possibility especially between CCCTB participating Member States despite whether it would replace the existing DTCs or apply only to CCCTB participating companies. For further discussion, vide infra II7.3.

${ }^{769}$ Vide supra at I2.1.5.4.

770 Article 15 of the Agreement between the European Community and the Swiss Confederation Providing for Measures Equivalent to Those Laid Down in Council Directive 2003/48/EC on Taxation of Savings Income in the Form of Interest Payments - Memorandum of Understanding.
} 
and taxing the income of the foreign permanent establishments, because the relevant subjective scope would not be fulfilled.

\subsubsection{DIVIDENDS}

The taxation of dividends within the scope of the CCCTB Directive first requires the determination of the term as such. The Proposal does not define the concept, even though it is included under the revenues and used in throughout the directive. It is noteworthy that the Parent and Subsidiary Directive also does not define the concept of dividends but simply establishes that the Directive applies to "distribution of profits" received or paid.771 On the contrary, the OECD MC does provide for an autonomous definition of dividends in Article 10(3). The question thus is whether, for the purposes of the CCCTB, the concept will be attributed the meaning which it has in the domestic law of the Member States or whether it will become an autonomous EU term. In any event, Member States will have to respect the rights of third countries granted under DTCs to the extent that the Directive conflicts with the DTC at hand and restricts the third country's rights under the DTC.

Actually, in drafting EU legislation it is not permitted to refer to definitions provided in other (legal) instruments, which can be modified based on the procedure other than that stipulated in the EU Treaties. Consequently, the CCCTB Directive could define the notion of dividends equally to the definition in Member States' DTCs with third countries, but it may not refer to the DTCs (or the OECD MC) explicitly. The European Commission has already taken such an approach for the purposes of defining the notion of "permanent establishment" in the CCCTB proposal, which, as discussed earlier, is almost identical to the definition provided in the OECD MC, without explicitly referring to the latter. Hence, as a matter of principle, the notion of dividends should be attributed an autonomous meaning under EU law. ${ }^{772}$ In the absence of a definition

\footnotetext{
771 Article 1 of the Parent and Subsidiary Directive.

772 See case CILFIT (283/81). According to the CJEU, Article 177(3) of the EEC Treaty imposes an obligation to refer a matter to the Court of Justice for a preliminary ruling where an interpretation is raised in a case pending before a court or tribunal of a Member State against whose decisions there is no judicial remedy under national law. Such an obligation is based on cooperation, established within a view to ensuring the proper application and uniform interpretation of Union law in all of the Member States, between national courts in their capacity as courts responsible for the application of Union law, and the CJEU. Furthermore, the Court
} 
in the Directive, if a case is brought before the CJEU, the latter would be in a position to provide the interpretation of the term in the light of EU law. ${ }^{773}$ Alternatively, the European Commission could provide for a detailed implementation of the definition of dividends under the comitology procedure. Such measures would be limited to those implementing the provisions within the CCCTB Directive and could not introduce new provisions. ${ }^{774}$

Despite the fact that the term "dividends" should have an autonomous meaning for the purposes of the CCCTB (EU law), one must observe that its application would not lead to the infringement of Member States' obligations towards third countries based on their DTCs. The question is whether such an obligation lies with the Member State of the 'principal taxpayer' under its DTC with the third country or with the Member State of the legal and/or beneficial owner 775 of the dividends. The application of the notion in line with the DTCs of the principal taxpayer would lead to a consistent determination of dividends within the group. Nevertheless, it would not imply a consistent application across the EU due to the DTC network of 28 Member States with third countries. Moreover, considering that DTCs are bilateral, it would be inappropriate to refer to the DTCs of the principal taxpayer (if there even is one with the particular third country). In the light of the foregoing, the

emphasised that Union law uses terminology which is peculiar to it and that legal concepts do not necessarily have the same meaning under Union law and in the law of the various Member States. Finally, every provision of Union law must be placed in its context and interpreted in the light of the provisions of the Union law as a whole, regard being had to the objectives thereof and state of evolution at the date on which the provision in question is to be applied.

773 Note that the CJEU has considered the OECD MC as a guidance for the Member States. See case Lidl Belgium (C-414/06), para. 22, and the case law cited therein.

${ }^{774}$ European Commission (2007b), para. 10.

775 It is noteworthy that the DTCs typically limit source taxation only when the recipient is the beneficial owner of the dividends. However, from the author's perspective, the fact that dividends received by a group member are consolidated with the tax bases (and shared according to the formula) of the other CCCTB group members does not imply that the taxpayer is not anymore the beneficial owner of the dividends for DTC purposes. This understanding is in line with decision of the Tax Court of Canada in Prévost Car (2008 TCC 231) [2008]. In paragraph 100 of this judgment, Judge Gerald J. Rip opined that the "beneficial owner" of dividends is the person who receives the dividends for his or her own use and enjoyment and assumes the risk and control of the dividend he or she received. Hence, the "beneficial owner" is a person who could ultimately exercise the rights of ownership of the property. 
following example envisages a CCCTB group between CoA and $\mathrm{CoB}$, where $\mathrm{CoA}$ acts as the principal taxpayer of the group. CoB's foreign subsidiary $\mathrm{CoC}$ distributes dividends to its parent company, i.e. $\mathrm{CoB}$ (Example 18: Dividend classification).

\section{Example 18: Dividend classification}

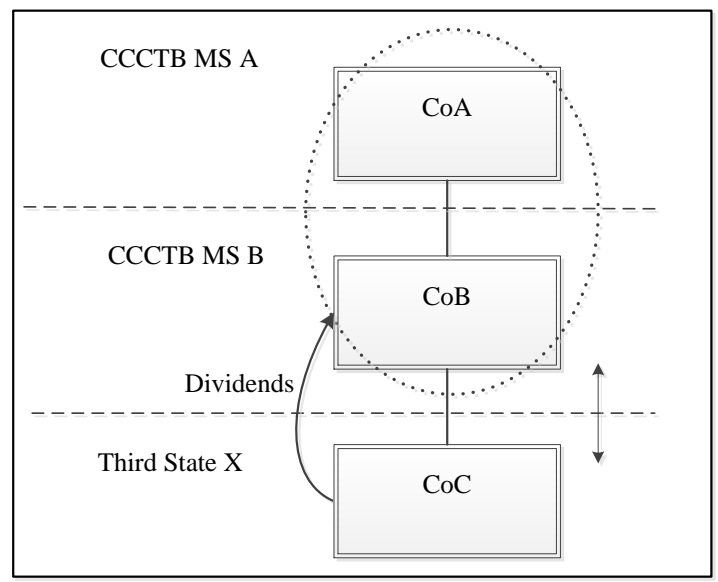

Classification of dividends under the DTC of the principal taxpayer $(\mathrm{CoA})$ rather than the legal owner of the dividends $(\mathrm{CoB})$ may affect the application of the DTC of CoB's residence State, i.e. Member State B. For example, if certain income from a third State X qualifies as a dividend under Member State B's DTC with that third country, but not under Member State A's DTC with that third country, the income may not be granted an exemption under Article 11 of the proposed CCCTB Directive. This remains the case even if the dividend had been exempted under the DTC between Member State $\mathrm{B}$ and the third country. In such a case, the interests of the third countries would certainly be adversely affected. However, in the present case, from the author's perspective, Member State B would not infringe its contractual obligations vis-à-vis the third country. Indeed, the rights of the third country would not be affected, given that the income (dividends) will be taxed in the hands of the (CCCTB) resident company with a credit for the taxes paid according to Article 76 of the proposed CCCTB Directive. The application of the credit method by no means affects the taxation of residents of the third country or limits its taxing rights. In any event, in the current EU legal framework, the definition of dividends would have to be attributed an autonomous interpretation, to be developed by the CJEU. 
It is also noteworthy that if there is a conflict of qualification with regard to dividends due to differences in domestic laws of the contracting States, the State of residence would be obliged to follow the definition as interpreted and applied by the source State. ${ }^{776}$ For example, the term "corporate right" has not been defined in the OECD MC, even though the definition of dividends therein uses such a notion. In cases of DTCs based on the OECD MC, the contracting States would have to, unless the context otherwise requires, refer to the national law of the source State. ${ }^{777}$ Against this background, in case of outbound investment, CCCTB Member States would be bound by the qualification provided for by the relevant third country.

\subsubsection{DIVIDENDS FROM FOREIGN DIRECT INVESTMENT}

The European Commission working papers reveal that the initial idea was to differentiate between dividends from portfolio investment and those from major shareholdings (i.e. interest in at least 10 per cent of either capital or voting rights that is held for at least 12 months). However, in the proposed CCCTB Directive, the European Commission has abandoned the idea. It is worth noting that the Danish compromise proposal seems to prefer the original policy where dividends from FDI receive different treatment compared to those from portfolio investment. ${ }^{778}$

In the international arena, FDI is typically taxed more beneficially compared to portfolio shareholdings. For instance, most DTCs foresee a (considerably) lower withholding tax on dividends from FDI in the source country (Article 10(2)(a) OECD MC), while the Parent and Subsidiary Directive prohibits any withholding tax on such income (Article 5). Furthermore, from the perspective of the residence country, DTCs or unilateral tax provisions often provide for a full exemption of such dividends and the Parent and Subsidiary Directive requires a full exemption or indirect credit on received profit distributions (Article 4(1)). On the other hand, contrary to portfolio investment, FDI may be caught by national CFC provisions, which eliminates the benefit of a tax deferral on

\footnotetext{
776 OECD Comm. on Article 23, para. 32.3.

777 Article 10(3) of the OECD MC.

778 Council of the European Union (2012), Article 11 and relevant comments therewith.
} 
(typically) passive income in the residence country of the parent company. 779

It is fair to consider the reasons for more the advantageous treatment of FDI compared to portfolio shareholding. According to the OECD, a lower withholding tax in a source country is aimed at avoiding recurrent taxation and facilitating international investment. ${ }^{780}$ Under Article 10(2) of the OECD MC, the source country may withhold 5 per cent of tax in case of dividends from FDI and 15 per cent in case of dividends from portfolio investment. In practice, the residence State is usually in a position to eliminate the disadvantage of portfolio dividends by applying the credit method for the elimination of double taxation, especially given that domestic corporate income tax rates are typically higher than 15 per cent. However, where the residence State applies the exemption method for the elimination of double taxation, portfolio dividends are clearly at a disadvantage, because they suffer a higher level of economic double taxation compared to FDI dividends in the source State, while there is no 'neutralisation' in the residence State.

Schön argues that the aim of multilayer taxation would justify tax relief for dividends from both controlling and portfolio shareholding. Portfolio shareholders typically cannot influence the decision of profit distribution. However, also in a large multinational company, the management may favour retention of profits instead of their distribution because of multilayer taxation. ${ }^{781}$ Consequently, the two types of investors are in a similar position with regard to profit distribution and should be treated similarly. Furthermore, from the author's perspective, the establishment of a rigid participation threshold is somewhat arbitrary: participation in a large multinational company under the respective threshold may involve a larger investment compared to participation in a smaller company that meets the threshold. Finally, when a country's policy favours equity financing, it should grant the beneficial treatment of portfolio investment equally to FDI.

Another common justification for favouring FDI is closely related to the choice between different forms of secondary establishments, such as permanent establishments and subsidiaries. Indeed, while

${ }^{779}$ For further discussion, vide infra at II8.3.3.

780 OECD Comm. on Article 10, para. 10.

${ }^{781}$ Schön (2010), 68. 
income from foreign permanent establishments is usually included in the worldwide tax base of its head office, it is not subject to a withholding tax in the source state (unless that country applies branch profit tax which in essence is similar to a withholding tax on dividend payments) and benefits from exemption or credit in the residence state. As a result, income from a permanent establishment is subject to single-level taxation. The taxation relief for substantial shareholdings attempts to approximate its legal treatment to the nonincorporated business activities, because the level of entrepreneurial activity in the two entities is comparable. ${ }^{782}$

The CCCTB proposal includes dividends from FDI (as well as from portfolio investment, which will be discussed below) into its scope and provides for the exemption method for such income, irrespective of whether it is received from an EU Member State or a non-EU Member State. This system is simple and neutral, because it does not discriminate between different sources of income. ${ }^{783}$ This approach is also in line with the principle of residence-based taxation, which is one of the overarching principles adopted in the proposed CCCTB Directive. If the CCCTB is adopted via enhanced cooperation, so that the opting-out Member States are deemed third countries, there are two additional points that need to be discussed.

First, the decision for enhanced cooperation would mean that the CCCTB rules would have to respect the requirements stemming from the Parent and Subsidiary Directive. The latter requires that the Member State of the parent company refrains from taxation or provides indirect credit for the dividends received from its qualifying subsidiary. Contrary to the proposed CCCTB Directive, the Parent and Subsidiary Directive, which applies only to intra-EU distributions, does not allow the application of the switch-over clause. ${ }^{784}$ Consequently, in case the CCCTB is introduced via enhanced cooperation, the respective Directive could not require the application of the switch-over clause to dividends that fall under the scope of the Parent and Subsidiary Directive, because that Directive

\footnotetext{
${ }^{782}$ For further discussion, see ibid., 69 et seq.

${ }^{783}$ European Commission (2006h), para. 8.

${ }^{784}$ Article 73 of the proposed CCCTB Directive. It is noteworthy that in its CCCTB Working Papers, the Commission recognised that income from major shareholdings from EU Member States would not be subject to a switch-over clause (European Commission (2007a), paras. 121-122, 127-128; see also footnote 39 therewith). However, the current proposal does not include such a different treatment (Article 73 of the proposed CCCTB Directive), vide infra at II7.5.1.
} 
remains applicable between CCCTB-participating and nonparticipating Member States. In any event, the adoption of the CCCTB via enhanced cooperation would require the European Commission to make the necessary adjustments to the proposed CCCTB Directive, which is addressed to all Member States.

It is also noteworthy that the wording "refrain from taxation" included in Article 4 of the Parent and Subsidiary Directive does not lead to conflicts with regard to the optional application of the exemption with progression provision in Article 72 of the proposed CCCTB Directive. In particular, "refrain from taxing" implies the option between the base exemption method and the tax exemption method, ${ }^{785}$ the former being used in the proposed CCCTB Directive (at least from the author's perspective).

The second point concerns the deductibility of expenses related to the acquisition of shareholdings in companies from non-CCCTB Member States in the framework of enhanced cooperation. The CCCTB Working Group has supported the deduction of such costs despite the exemption of dividends, because a denial would make the CCCTB unattractive for EU groups with subsidiaries outside the EU. 786 Despite these concerns, the proposed CCCTB Directive disallows a deduction of expenses at a fixed flat rate of 5 per cent of exempted income (inter alia received profit distributions), ${ }^{787}$ unless the taxpayer is able to demonstrate that it has incurred a lower cost (Article 14(1)(g)). ${ }^{788}$ Borrowing with deductible interest in order to generate tax-exempt dividends would lead to tax base erosion of

\footnotetext{
${ }^{785}$ From the author's point of view, this can be deduced from the general objective of the Parent and Subsidiary Directive to avoid economic (and juridical) double taxation of cross-border profit distributions.

${ }^{786}$ See European Commission (2007a), para. 130.

787 One could also discuss whether, in case of an exemption method supplemented with the interest deduction limitation, a country of the recipient of the dividends should allow for a credit for the withholding tax levied in the source country similarly to the available credit in case of the application of credit method for the avoidance of double taxation. The author will analyse this issue infra at II7.4.2.1.

788 It is noteworthy that the Danish Presidency has proposed to apply a full restriction on the deductibility of interest expenses incurred for the purposes of deriving income, which is exempt according to the proposed CCCTB Directive. In case the CCСТВ is introduced via enhanced cooperation, the CCCTB Directive would have to respect the interest deduction limitation stemming from the Parent and Subsidiary Directive, i.e. a fixed flat rate of 5 per cent of exempted income derived from companies of non-CCCTB Member States. See Council of the European Union (2012), comments to Article 14 of the proposed CCCTB Directive.
} 
CCCTB Member States. A similar approach has been taken in the Parent and Subsidiary Directive (Article 4(2)), which entitles the Member States to disallow the deduction of management costs at a maximum fixed rate of 5 per cent. The difference between the limitation rule in the CCCTB Directive and the Parent and Subsidiary Directive is that the former limits the deduction to 5 per cent of the total category of exempted income, while the Parent and Subsidiary Directive provides the limitation only regarding received profit distributions. Moreover, while the deduction limitation rule is an option for the Member State under the Parent and Subsidiary Directive, it is an obligation under the proposed CCCTB Directive.

The Court held in Bosal, 789 in which it interpreted the Parent and Subsidiary Directive in light of the freedom of establishment, that the Netherlands had not transposed the option contained in the Parent and Subsidiary Directive into its national law correctly. Accordingly, the Netherlands made the deductibility of the costs in relation to that company's holdings in a subsidiary established in another Member State subject to the condition that such costs are deductible only if the profits from the subsidiary are taxable in the Member State of the parent company. The Court found that the national measure was contrary to the aim and purpose of the Parent and Subsidiary Directive, because it hindered the establishment of subsidiaries in other Member States, despite the option for Member States to introduce limits to deduction of costs related to the holding pursuant to the Directive. The Court reiterated in substance its Bosal conclusions in Keller Holding 790 that the Member States must exercise the option afforded in the Parent and Subsidiary Directive only in compliance with the fundamental freedoms. A question arises whether, in the light of Bosal and Keller Holding, the CCCTB system can disallow interest deductions at a fixed flat rate of 5 per cent on dividends received from subsidiaries of other, non-CCCTB Member States, given that such a limitation does not exist in intra-group cases. Indeed, intra-group transactions are neutralised in the context of the proposed CCCTB Directive (Article 59). Hence, there is no "exempt" intra-group income on which a cost-deduction ban could apply. Therefore, the question is whether the above-mentioned 5 per cent-limitation measure constitutes a restriction on the freedom of establishment, because the different treatment might dissuade

\footnotetext{
${ }^{789}$ Case Bosal Holding (C-168/01), paras. 25-27.

${ }^{790}$ Case Keller Holding (C-471/04), para. 45.
} 
CCCTB-located parent companies from carrying on their activities through an intermediary subsidiary in non-CCCTB Member States.

The provisions of the freedom of establishment also prohibit the Member State of origin from hindering the establishment of its companies in another Member State. Therefore, whether discrimination exists, one must compare whether the Member State of origin treats parent companies that carry on their activities cross border via an intermediary subsidiary in the same way as parent companies that have only domestic subsidiaries. It is true that the proposed interest limitation rule also applies in case the subsidiaries are located in CCCTB Member States but which do not meet the CCCTB group participation threshold of Article 54 of the proposed CCCTB Directive. Consequently, for participations that do not meet the CCCTB threshold, there is no doubt that there is no infringement of the fundamental freedoms, because the Member State would treat domestic and cross-border movements equally.

For the purposes of the current discussion, one must analyse whether the national measure of a Member State of a parent company, which belongs to a CCCTB group, treats investment into subsidiaries of non-CCCTB Member States equally to investment into subsidiaries in CCCTB Member States. In the example below (Example 19: Interest limitation on tax-exempt dividends), a CCCTB-resident parent company (CoA) forms a CCCTB group with its CCCTB resident subsidiary (CoC) in Member State A.

\section{Example 19: Interest limitation on tax-exempt dividends}

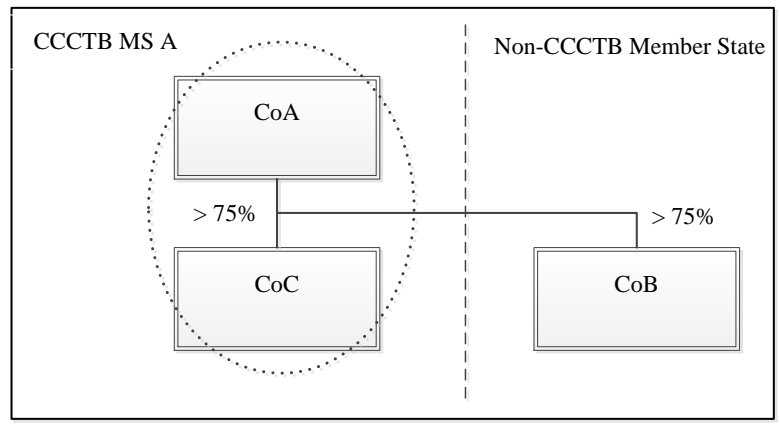

Under the proposed CCCTB Directive, each member of the group first calculates its individual tax base and thus first assesses the taxability of income and deductibility of expenses before 
consolidation. In the light of Article 59 of the proposed Directive, intra-group transactions are neutralised. Therefore, Article 11, which foresees the exemption method, does not apply in intra-group cases. Consequently, Article 59, read in conjunction with Articles 11 and 14 of the proposed CCCTB Directive, implies that interest expenses in the resident qualifying subsidiary is always deductible without limitations. However, since EU Member State B did not opt for the CCCTB, the non-resident subsidiary $(\mathrm{CoB})$ could not participate in the CCCTB group.

In order to determine whether a restriction on the freedom of establishment exists, one must assess whether parent companies investing domestically (or within the CCCTB jurisdiction) are in comparable circumstances to parent companies investing in nonCCCTB Member States. On the one hand, there is consolidation between the parent company $(\mathrm{CoA})$ and its subsidiary $(\mathrm{CoC})$ and, on the other hand, there is a dividend distribution (from $\mathrm{CoB}$ ) to the parent company (CoA). From the author's perspective, the possibility for consolidation under the CCCTB does not entail an objective difference between the parent companies investing into CCCTB Member States and non-CCCTB Member States. In the example above, CoA is subject to the CCCTB rules, while its subsidiaries are subject to different rules (i.e. the CCCTB or the national rule). However, in the present case, the existence of restriction boils down to the fact whether the parent company (CoA) is treated differently if it invests in subsidiaries in the CCCTB Member State $(\mathrm{CoC})$ or the non-CCCTB Member State (CoB), rather than comparing the treatment of the foreign subsidiaries. Against this background, in the opinion of the author, the fact that interest on intra-group investment is always deductible, while interest on investment into subsidiaries resident in non-CCСТB Member States is subject to limited deductibility, makes investment in nonCCCTB Member States less attractive and thus leads to a restriction of the freedom of establishment. In line with the judgments in Bosal and Keller Holding, the author does not see any appropriate ground for justifying the restriction of the fundamental freedom. Against this background, if the CCCTB is adopted via enhanced cooperation, CCCTB Member States will have to allow interest deductions related to investment towards non-CCСТB Member States on equal terms to interest deductions on investments into CCCTB Member States, provided that the non-resident subsidiary meets the group participation thresholds set forth in the Directive. The same requirement does not apply to investments into non-EU Member 
States, because the freedom of establishment does not offer protection to such movements.

One could try to explain the limitation to interest deductibility on exempt dividends because of the prospective double dip arising from the transactions. Indeed, on the one hand, the shareholder benefits from dividend exemption but, on the other hand, it deducts the relevant interest payment from its taxable base. As the example below shows, in case of consolidation (between CoA and CoB), such double dipping would not even be possible because the interest deduction at the level of COB would be correspondingly included into the tax base of CoA (i.e. hence, under the CCCTB, transactions between group members are ignored because of this symmetrical tax treatment) (Example 20: Interest deduction limitation).

\section{Example 20: Interest deduction limitation}

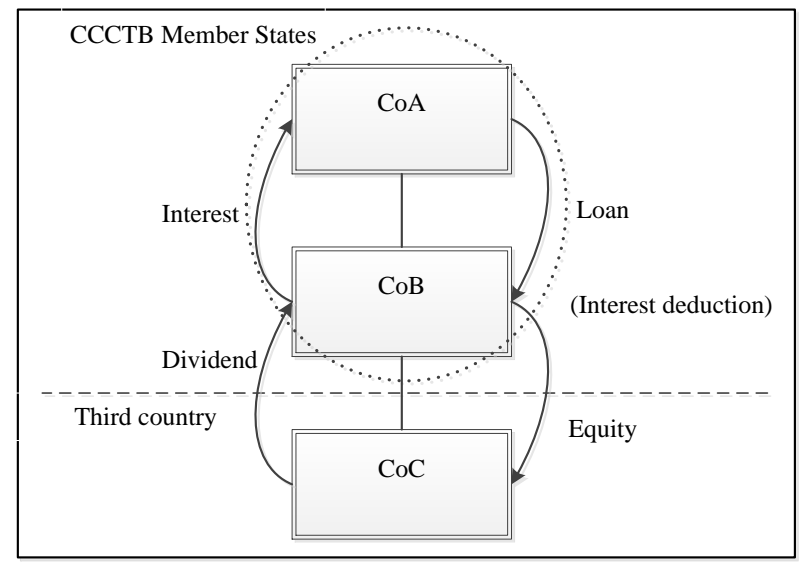

Even if the borrowing company (CoB) did not form a CCCTB group with the lender (CoA), despite the existence of a benefit for the former, the disallowance would still be conceptually wrong because, in effect, there is still one level of taxation - i.e. at the level of the lending company of the net interest received. ${ }^{791}$ It is also wrong to argue that the double-dip arising from this transaction is always motivated by tax avoidance by creating artificial structures (via special purpose vehicle) to obtain the tax advantage. Artificial

791 Pistone (2008), 862. 
transactions could be caught by anti-abuse measures, such as the CCCTB GAAR. ${ }^{792}$

\subsubsection{DIVIDENDS FROM PORTFOLIO INVESTMENT}

Portfolio dividends are all those dividends that are not derived from FDI investment and they are often treated less advantageously compared to the latter. As in the case of dividends from FDI, there would be conceptually nothing wrong with including portfolio dividends in the tax base of CCCTB resident companies. Portfolio investment normally falls into the scope of the free movement of capital, because such investment does not confer on the holder a definite influence over the company's decisions and does not allow it to determine the company's activities. ${ }^{793}$ Consequently, portfolio dividends received by a resident group member must be treated equally, despite whether the capital is invested in EU Member States (including non-CCCTB Member States in case of enhanced cooperation) or third countries. In this case, the relevant discrimination analysis is based on the fact whether a Member State treats dividends received by its resident CCCTB group member from companies established in other countries not belonging to the CCCTB group equally to dividends derived from its resident subsidiaries not belonging to the CCCTB group. Under the proposed CCCTB Directive there is no difference in treatment of such dividends received and, consequently, there are no grounds to invoke the EU non-discrimination clause.

With regard to the non-deductibility of costs related to exempt income, as discussed earlier, the limitation might dissuade companies from raising capital across the CCCTB territorial borders. It is noteworthy that portfolio investment as defined above does not fall within the scope of the Parent and Subsidiary Directive because the latter requires at least a 10 per cent holding in the capital or voting rights in the distributing company. ${ }^{794}$ Therefore, as far as the Parent and Subsidiary Directive is concerned, there are no limitations prohibiting cost deduction related to an exempt portfolio holding. However, the above should not be interpreted as the allowance of operating a national system under which foreign-sourced dividends

\footnotetext{
${ }^{792}$ For further discussion, vide infra at II8.3.1.

793 Cases Baars (C-251/98), paras. 21-22; FII Group Litigation I (C-446/04), para. 5859.

${ }^{794}$ Article 3 of the Parent and Subsidiary Directive.
} 
and nationally sourced dividends are not treated in the same way. In other words, consequently, Member States are still prohibited from treating cross-border investment less beneficially compared to domestic investment. However, according to Article 14(1)(g) of the proposed CCCTB Directive, there is no difference in the treatment of investment into subsidiaries that do not meet the CCCTB group threshold despite whether the subsidiary is located in a CCCTB Member State or in a third country (including a non-CCCTB Member State in case if enhanced cooperation). Against this background, the interest limitation rule with regard to portfolio investment could not be challenged against the free movement of capital.

\subsubsection{INTEREST AND ROYALTY INCOME}

The operation of a worldwide taxation system does not set limits on taxing interest and royalty income at the level of the recipient. In fact, it is often even expected because, unlike dividends, interest and royalty payments are typically considered deductible costs at the level of the payer. The overarching question is which country - the source or the residence country - should keep the primary taxing right over such income. With regard to interest payments, there seems to be a general acceptance that both the source country and the residence country should be able tax the income at the recipient level. Against this background, the OECD MC, the UN MC as well as the US MC provide for a shared taxing right between the source State and residence State over interest income. ${ }^{795}$ On the contrary, the Interest and Royalty Directive prohibits any withholding tax in the source country and therefore reserves the exclusive taxing right for the residence country of the recipient. ${ }^{796}$

\footnotetext{
795 In all the model conventions - the OECD, the UN, and the US - the corresponding article for interest income is Article 11.

796 Article 1(1) and (9) of the Interest and Royalty Directive. It is noteworthy that the Interest and Royalty Directive does not make the exemption from withholding tax conditional on the taxation of the income in the recipient State. Thus, it may happen that the income will not be taxed at all because, on the one hand, there is a deduction of the cost from the tax base of the recipient and, on the other hand, the recipient State does not tax it. For instance, some Member States have a system in which a majority of the royalties received are tax exempt. This Member State may be a reason why Article 1 of the Interest and Royalty Recast Directive of 11 November 2011 requires the income to be taxed in the recipient Member State.
} 
With regard to royalties, there appears to be a split between the opinion of industrialised countries and developing countries. On the one hand, the OECD MC and the US MC support the view of industrialised countries, where the innovative products and processes are developed, and foresee an exclusive taxing right for the countries where the "owners" 797 of the resulting intellectual property reside. On the other hand, the UN MC takes the view of developing and emerging countries, which plea for a taxing right in the source country where the income from the exploitation of the intellectual property right ${ }^{798}$ is generated. ${ }^{799}$ The Member States have taken the former view in the Interest and Royalty Directive in the sense that the source country does not have the right to tax income from royalties ${ }^{800}$ From the perspective of public international law, both countries indeed have the relevant grounds to tax income from royalties. For instance, the fact that royalties reflect both the amortisation of the original investment (in the country of the licensor) and the value of its use for manufacturing (in the country of the licensee) indicate that both countries can claim to have contributed to the creation of the value of the intellectual property. ${ }^{801}$ Thus, to decide on the split on the taxing rights might be difficult. The author finds stronger support for the approach adopted by the OECD. Moreover, the source country may be able to raise revenue through the collection of other taxes, for example taxes on consumption and employment, due to the use of intellectual property. The biggest problem appears to be the fact that, although the development of an intellectual property right may carry a high development cost, source countries usually levy withholding tax on gross income rather than on net income.

The inclusion of interest and royalty income from sources outside the CCCTB jurisdiction into the scope of the CCCTB Directive is

\footnotetext{
${ }^{797}$ In fact, the country where the intellectual property has been developed (where the research \& development department is located) does not necessarily have to and very often does not - coincide with the country where the "owner" of the intellectual property right resides.

798 The exploitation of an intellectual property right is usually the country where the manufacturing is carried out. However, a country where the final goods are sold could also try to claim to be the "source" country. For the purposes of the UN MC, the country where the payer of the royalty is resident is considered as the source country in Article 12(5).

${ }^{799}$ Schön (2010), 91.

800 Article 1(1) and (9) of the Interest and Royalty Directive. Ibid., 796 (footnote 710).

801 Schön (2010), 91.
} 
motivated by the same reasons as the inclusion of foreign dividends. In order to include a type of income in the CCC tax base, it is important to determine what interest and royalty income is. In fact, one can find a separate definition of the term "interest" from the proposed CCCTB Directive. However, the definition is not provided under the general definitions in Article 4 but in Article 81 of the proposed CCCTB Directive, which sets forth limitations for interest deductibility. ${ }^{802}$ The latter Article acts, however, as lex specialis to the other Articles in the proposed CCCTB Directive. Consequently, one could argue that this definition is not applicable to all other provisions dealing with interest income and payments in the Directive. If that were true, all these remaining provisions dealing with interest payments and income would have to be based on the autonomous interpretation of the term, without prejudice to Member States' obligations undertaken in their DTCs with third countries. It is doubtful that this was the intention of the European Commission. For the sake of clarity, the author suggests moving the definition from Article 81 to Article 4. It is noteworthy that discussions with the Member States point to an intention to abolish Article 81 of the proposed CCCTB Directive and introduce a horizontal interest limitation rule in Article 14a. ${ }^{803}$ Remarkably, the definition of interest is proposed to disappear together with Article 81, as it is not reintroduced in Article 14a.

Leaving this discussion behind, it is notable that the definition of "interest" provided in Article 81 of the proposed CCCTB Directive is identical to the one set forth in both the Interest and Royalty Directive as well as the OECD MC. ${ }^{804}$ Consequently, there is very little room for the Member States to disagree on the notion. In fact, this definition takes one back to the discussion concerning the definition of dividends in the proposed CCCTB Directive (actually, the absence of it). In particular, there is a general understanding that if a return on investment does not qualify as interest, it should be considered a dividend. Consequently, keeping the definition of interest set forth in the proposed CCCTB Directive in mind, one should be able to define dividends for CCCTB purposes.

${ }^{802}$ For further discussion, vide infra at II8.3.2.

${ }^{803}$ Council of the European Union (2012), Articles 14a and 81 and the comments therewith.

804 Article 2 of the Interest and Royalty Directive and Articles 11(3) and 12(2) of the OECD MC. 
To the extent that CCCTB Member States have transposed the definition of "interest" set forth in the CCCTB Directive into their national law correctly and have agreed in their DTCs to use the definition proposed in the OECD MC, the CCCTB system would not introduce a complication in that area. If, however, the terms differ, the result might lead to a different result depending on the Member State of the recipient of the income. For instance, it might happen that the same payment is qualified as interest income under one DTC while it would be qualified as a dividend in another DTC of that Member State or any other CCCTB Member State. Hence, double taxation of such income may differ, being the exemption method in the case of dividends and the credit method in case of interest income. In such a case, Member States would be bound by the CCCTB term, unless the latter conflicts with the corresponding definition in the DTC to the extent that the rights of third countries are affected. As in the case of business income, in the opinion of the author, the method for the elimination of double taxation of the income received in CССТВ Member States does not adversely affect the rights of the source country (i.e. the third State). In the light of the foregoing, such income would normally be defined under the CCCTB Directive, without limiting the taxing rights of the source country based on the relevant DTC.

With regard to the term "royalties", it is noteworthy that the proposed CCCTB Directive does not define the term, while the OECD MC and the Interest and Royalty Directive define it differently. ${ }^{805}$ The provision set forth in the latter is similar to the definition provided in Article 12(2) of the UN MC instead, because it includes the wording "for the use of, or the right to use, industrial commercial, or scientific equipment" (ICS equipment), which was deleted from the OECD MC in 1992.806 The fact that the Interest and Royalty Directive and Member States' DTCs with third countries are different does not create any complications with regard

805 Article 2 of the Interest and Royalty Directive and Article and 12(2) of the OECD MC.

806 Amended by the report entitled "The Revision of the Model Convention", adopted by the Council of the OECD on 23 July 1992. The 1992 amendment was made based on the recommendation from the OECD Committee on Fiscal Affairs that member countries should not subject rental income to tax at source under the royalty provision. This initiative, however, appears to have failed, because a number of member countries have entered reservations to Article 12 of the OECD MC, both with regard to the definition to include leasing and maintain taxing rights in the source State. Evans (2002), 492. See also OECD (1983). 
to the application of that Directive, because the former is applicable only to intra-EU payments. The CCCTB Directive, however, reaches its application beyond the EU water's edge in the sense that it includes income from third countries received by CCСТВ group members. The absence of a definition in the proposed CCCTB Directive does not imply that it will have the meaning under the national law of the relevant Member State. Instead, by introducing the term in the CCCTB Directive, the term will have to be interpreted autonomously. ${ }^{807}$ Furthermore, as in case of dividends, Member States would be obliged to respect the obligations they have undertaken in their DTCs with third countries. The term 'royalties' under DTCs functions bilaterally and hence one must look at the obligations arising from the DTC between the Member State of residence of the (legal) recipient of the royalty income and the third country. In fact, from the author's perspective, as far as outbound investment is concerned, whether the residence State treats the income as royalties or any other income - such as business income in case of income from ICS equipment - does not in any case affect the rights of the third country, even though it may affect the interests of the latter. In particular, whether double taxation of such income is avoided in the residence State (the CCCTB Member State) by means of the exemption or credit method does not infringe the rights as such of the third country. But, for instance, if the income is qualified as royalties in the source State with a right to levy a withholding tax on such income (as under the UN MC), the CCCTB Member State must respect such a qualification even if the income was qualified as business income under the CCCTB. In such a case, the right of the third country to withhold a tax would be at stake. In the same vein, the definition of royalties also becomes relevant when inbound investment into CCCTB Member States is concerned.

In the case of intra-EU payments of royalties between associated enterprises that opt out of the CCCTB system, the definition set forth in the Interest and Royalty Directive would still remain applicable. However, as far as income and payments of royalties concerning CCCTB participating companies are concerned, the CCCTB Directive, as the latest Directive, would override the Interest and Royalty Directive as far as taxation of such payments/income is

\footnotetext{
807 Note that M. Vogel is of a different opinion. From his perspective, if a term is not defined in the directive, it must be interpreted on the basis of the definitions in the domestic (tax) laws of the Member States. Vogel (2012), 195. For further discussion, vide supra at footnote 773 .
} 
concerned. The effect is smaller in case the royalties are paid to the CCCTB company, because neither the Interest and Royalties Directive nor the proposed CCCTB Directive limit the taxing right of the resident State. However, in case royalties are paid by a CCCTB resident company, the application of a narrower definition (i.e. excluding income from ICS equipment) implies that the source State (CCCTB Member State) would not be limited in terms of levying a withholding tax, while it would be if the Interest and Royalty Directive had remained applicable. Moreover, since the Interest and Royalty Directive does not include rules regarding the elimination of the double taxation of such income (because there should not be any double taxation under the current wording), whether double taxation in such cases is avoided depends on the policy choice of the recipient State. If the recipient state is a CCCTB Member State, royalties received would receive credit for the taxes paid in the source Member State. Hence, in such a case, companies participating in the CCCTB system would be worse-off compared to companies that opt out of the system. This conclusion should be acceptable in the light of the understanding that the CCCTB provides for a new, self-standing corporate tax system, which may or may not provide a (tax) benefit. Neutralisation of the disadvantage would imply the corresponding modification of the Interest and Royalty Directive. In that sense, the decision not to provide for a CCCTB definition of royalties appears to be optimal. In any event, considering that both the Interest and Royalty Directive as well as the CCCTB Directive would have to be transposed into the national law of Member States, differences between them would lead to unnecessary complications. As the Interest and Royalty Recast Directive from 11 November 2011 shows, the European Commission still considers the definition as it currently stands to include ICS equipment as the most appropriate approach for intraEU situations.

In case of payments involving non-EU Member States, there could be room for discussion as to whether the common definition for royalties should follow the approach of the OECD or that taken in the Interest and Royalty Directive. In the EU arena, the broader definition for royalties makes sense because, in that case, more payments fall within the scope of the Directive and receive beneficial treatment. It is worth reminding that, with regard to inbound payments, the Interest and Royalty Directive has little influence, because it only limits the source State's taxing rights. The broader scope of the concept in the UN MC has, however, a different 
objective - to allow more taxing rights to the source State. The OECD proposed a narrower definition of royalties in 1992 mainly because, unlike the other examples of the definition, leasing income does not deal with income from intangibles with a substantial intellectual content and is thus different by nature. Furthermore, from a doctrinal, economic and tax equity perspective, taxpayers in comparable circumstances must be accorded comparable treatment. ${ }^{808}$ Therefore, income from ICS equipment should be treated as part of business income rather than royalties. Thus, the only support for taxing such payments as royalties appears to be the protection of the tax base of the source country.

In conclusion, there is a significant difference between the definition of royalties in the Interest and Royalty Directive and that proposed in the OECD MC. If the CCCTB Directive were to include the definition of royalties, in order to avoid inconsistencies between the Interest and Royalty Directive and the CCCTB Directive, the latter should follow the definition set forth in the former. On the other hand, many EU Member States have adopted the wording as proposed by the OECD in their DTCs and inconsistencies between the two sources of national law might create discussions. It was pointed out that the inclusion of ICS equipment in DTCs, based on the UN MC and the Interest and Royalty Directive, serve a completely different purpose. Furthermore, from the doctrinal, economic and tax equity perspective, ICS equipment should not be included in the scope of royalties. In the light of the analysis above, the decision not to include a separate definition of royalties in the proposed CCCTB Directive seems to be the best option. In the absence of a common definition, inflows of royalties from entities that do not belong to a CCCTB group have to respect the following rules:

(1) Inflows from EU Member States (including non-CCCTB Member States in case of enhanced cooperation)

a. Participation between 25 per cent and 75 per cent the definition stipulated in the Interest and Royalty Directive prevails over definition provided in national law and DTCs. Hence, the definition would have to include income from ICS equipment.

b. Participation under 25 per cent - the definition set forth in the Interest and Royalty Directive is

808 Evans (2002), 492-494. 
irrelevant. Hence, the definition the term will be attributed an autonomous meaning under EU law ${ }^{809}$ and it is for each Member State to observe its obligations stemming from its relevant DTC with a third country.

(2) Inflows from non-EU Member States - Until renegotiated, Member States' DTCs with third countries prevail over national law and the CCCTB Directive as regards the obligations of Member States and rights of third countries.

\subsubsection{CAPITAL GAINS}

Capital gains are normally included in the worldwide tax base of residents. Moreover, the general rule of Article 13(5) of the OECD $\mathrm{MC}$ gives the residence country the exclusive taxing right over capital gains. Capital gains (and losses) may generally be divided into three main groups: (i) capital gains from tangible assets (including immovable property); (ii) capital gains from intangible assets (e.g., patents), ${ }^{810}$ and (iii) capital gains from financial assets (e.g., shares). However, there are very few reasons why these types of capital gains should be treated differently with regard to their inclusion into tax base, although some discussion may arise as to whether elimination of double taxation on gains from fixed assets and financial assets should be the same.

Capital gains may be taxed as ordinary business income or separate from it. The nature of capital gains suggests that it should be taxed together with business income. Furthermore, ring-fencing capital gains from business income may give rise to differentiation problems. For instance, in certain cases, it might become difficult to distinguish between true capital gains and the sale of inventory in the course of a trade or business. In addition, the different treatment of capital gains (and losses) and other business profits (and losses) infringes the principle of neutrality. ${ }^{811}$ The CCCTB system includes all capital gains under the ordinary business income when they are realised. Such an approach is desirable for the sake of simplicity, stability of public

\footnotetext{
809 See case CILFIT (283/81).

${ }^{810}$ For the purposes of CCC tax base calculation, both tangible and intangible assets are considered "fixed assets", although their depreciation rules differ. See Chapter 6 of the proposed CCCTB Directive.

811 UNICE CCCTB Task Force (2005), 1.
} 
finances and administration costs. ${ }^{812}$ The right to tax realised capital gains arises when the taxpayer ceases to own the asset as a result of the alienation or disposal of an asset. For the purposes of the CCСТB, disposal of an asset will only occur if it leaves the CССТВ group. Such an immediate, deemed disposal of an asset effectively means that the proposed CCCTB Directive includes exit taxation provisions on unrealised capital gains.

It is generally accepted that gains on the sale of immovable property or income from the rental of immovable property has its origin at the physical location of the property. The OECD MC in Article 6, which gives the unlimited taxing right to the source country, respects the same principle. Likewise, the notion of taxing gains and income on immovable property at situs is often extended to taxing shares of companies, the value of which consists directly or indirectly of immovable property (Article 13(4) of the OECD MC). The proposed CCCTB Directive does not include a specific provision with regard to the taxation of income from immovable property belonging to a group member, as such income forms part of the revenue in Article 4(8). Accordingly, if a non-resident owns real estate in the CCCTB jurisdiction and which is attributable to its CCCTB-located permanent establishment, the income may be taxed in a different Member State than the Member State of situs. Nevertheless, the fact that this leads to a different taxation result than envisaged under Article 6 of the OECD MC does not violate the relevant DTC, because the taxing rights of the third country would not be adversely affected in this case. In any event, as far as CCCTB Member States are concerned, according to Article 8 of the proposed CCCTB Directive, the Directive overrides agreements between Member States. ${ }^{813}$ Consequently, the fact that the income from immovable property located in a CCCTB Member State is not taxed in that State is just a result of switching to a new tax system.

The CCCTB proposal also does not define the term "immovable property". It simply requires such real property to be registered in the fixed asset register, which means that the income forms part of the CCC tax base and it is therefore subject to apportionment. ${ }^{814}$ It is worth reminding that concepts used in EU law shall be interpreted

\footnotetext{
812 Ibid., 1.

${ }^{813}$ See also the relevant discussion supra at I4.2.3.1.

814 Article 4(14) read in conjunction with Article 32 of the proposed CCCTB Directive.
} 
autonomously from the perspective of Member States' national law. However, it might be challenging to provide the notion of immovable property in the CCCTB Directive because, unlike dividends and other similar payments/income, the definition of immovable property may vary to a great extent in Member States' national laws. In any event, under the current proposal, such income is included under general business income and its overlap with other types of income is generally excluded. Thus, there are fewer reasons to provide a separate definition for such income.

As regards share disposals, in the absence of a DTC between the source State and the residence State, the source country is not limited in taxing such income. Such a right is also not restricted by EU secondary law, as the Parent and Subsidiary Directive does not cover share disposals. Therefore, to the extent that income from share disposals is included in the CCC tax base, any taxes levied on that income at source must be relieved under the CCCTB rules. It is noteworthy that the CCCTB proposal favours the exemption method for such income. However, if there is a DTC between the source country and the residence country of the recipient, the fact that Article 13(5) of the OECD MC allocates the exclusive taxing right to the residence state applied in conjunction with the participation exemption in the proposed CCСТB Directive would lead to double non-taxation of capital gains on share disposals. It is noteworthy that it is rather a common practice of Member States to extend the scope of their national participation exemption regimes to cover capital gains on share disposals. Consequently, not only the application of the (proposed) CCCTB Directive rules but also several national provisions would lead to double non-taxation of income from share disposals. By comparison, dividends falling under the participation exemption may still be subject to withholding taxes in the source State. Such systems may lead to dividend stripping, where company's profits are distributed to shareholders through a tax-free capital gains rather than taxable dividends in the source State. In the absence of a DTC with the source country, if the latter is a low-tax third country, such income would not be exempted but subject to the switch-over clause under the CCCTB Directive. ${ }^{815}$

${ }^{815}$ For further discussion, vide infra at II7.5. 


\section{3 .5}

The basic discussion on the taxation of the foreign income of resident taxpayers relates to the choice between taxation systems based on a taxpayer's residence (worldwide taxation) and territorial taxation. The proposed CCCTB Directive has been built on the residency principle, so that all the income of CCCTB residents will be included in the CCC tax base. However, several proponents argue that territorial systems improve tax competition between countries that wish to attract foreign investment and improve the global economy overall. ${ }^{816}$ From the author's point of view, the application of a territorial system would lead to the exclusion of foreign income from the scope of the CCCTB system. Consequently, the taxation rights over such income would fall back to the residence State of the taxpayer based on its domestic law. In such a case, if the relevant Member State based its national law on the residency principle, foreign income of CCCTB group members would be included into their worldwide tax base under the domestic law of their residence State (rather than under the CCCTB Directive) and added to the taxpayers share of the CCC tax base. In other words, the domestic tax base of a CCCTB group member would be equal to the CCC tax base apportioned share plus foreign income. In the author's opinion, the functioning of a CCCTB system based on territorial taxation in parallel to the Member States' domestic systems taxing worldwide income would not lead to a desirable result. As follows, the choice for a corporate taxation system based on the residency principle appears to be the most suitable for the purposes of the CCCTB. Given the worldwide scope of the tax base, the proposed CCCTB Directive includes specific rules for the elimination of the double taxation of foreign income. The author will elaborate on that issue further below in Chapter VIII.

The author further discussed the taxation of different types of foreign income, in particular business income, dividends, interest and royalty income, and capital gains. First, business income derived through foreign permanent establishments should be included in the scope of the CCCTB Directive. Double taxation on such income would be eliminated via the (base) exemption method and subject to the switch-over clause, where necessary. Compared to the tax exemption method, base exemption is simpler to apply, because it

816 NFTC (2002), 6. 
does not require re-calculating the income. However, in cases where the switch-over clause applies, such a re-calculation based on the CCCTB rules will still be relevant.

With regard to outbound investment, first, by providing a definition for interest income under the CCCTB provisions automatically leads to the definition of dividends for the CCCTB purposes. Next, from the author's point of view, there should be no difference between the taxation of dividends from FDI and those from portfolio investments and whether such income is derived from an EU Member State or a third country. Differences may only arise with regard to the elimination of double taxation on such income. For example, CCCTB Member States would be restricted in applying the switch-over clause to FDI dividends from non-participating CCCTB Member States due to the applicability of the Parent and Subsidiary Directive. ${ }^{817}$ Furthermore, analysis shows that the interest limitation rule on tax-exempted dividends derived from participations in subsidiaries from non-participating Member States that would meet the CCCTB group participation threshold (Article 54 of the proposed CCCTB Directive), contained in the proposed CCCTB Directive, would infringe the freedom of establishment. On the contrary, interest limitation rule on dividends from all remaining participations would be in line with both the EU fundamental freedoms, despite whether they are received from EU Member States or from non-EU Member States.

While the definition of interest in the proposed CCCTB Directive is consistent with the definition provided in the Interest and Royalty Directive and the OECD MC, the CCCTB proposal does not define royalties. Furthermore, the definition of royalties in the Interest and Royalty Directive and that in the OECD MC are not identical, because the former includes ICS equipment under the definition while the latter does not. On the other hand, the UN MC also includes the ICS equipment under the description of royalties. One cannot forget that the reason for the inclusion of the ICS equipment

\footnotetext{
817 Article 73 of the proposed CCСТВ Directive provides for the application of the switch-over clause with regard to income from third countries only. If the CCCTB is adopted by means of enhanced cooperation, also non-participating EU Member States would be deemed as third countries. Naturally, the CCCTB-proposal does not reflect the possibility for an enhanced cooperation. If that will be the case, the European Commission will have to revise and amend the CCCTB Directive accordingly.
} 
in the UN MC serves a different purpose than the one in the Interest and Royalty Directive: the former leaves more taxing rights to the source State, while the Interest and Royalty Directive limits them. However, the CCCTB Directive should avoid conflicts with both the Interest and Royalty Directive and Member States' DTCs with third countries. The analysis above shows that, in order to satisfy both the requirements of the Interest and Royalty Directive and Member States' DTCs, it appears better not to provide for the definition of royalties in the CCCTB Directive but to apply the definition depending whether the payment falls within the scope of the Interest and Royalty Directive or a DTC.

\subsection{INBOUND INVESTMENT: TAXATION OF SOURCE INCOME OF CCCTB NON-RESIDENT COMPANIES}

One of the general matters of the CCCTB is the definition of source rules in relation to non-residents' income from CCCTB jurisdictions. The overarching idea should be that the income is "sourced" within a taxing jurisdiction where a person has sufficient economic links. Such links may arise based on a number of criteria and may vary depending on the nature of the income. For instance, in case of active income, one may look the location of the taxpayer's activity; in case of passive income, the place of activity, incorporation or residence of the payer may matter. ${ }^{818}$ The CCCTB establishes a new, self-standing corporate taxation system based on the residency principle. Consequently, in order to tax non-residents, the latter must have sufficient economic links with that jurisdiction. Such economic links exist as long as the income of non-residents affects the CCC tax base. Otherwise, the income remains taxable according to each Member State's national laws.

Generally speaking, the CCCTB source rules could be based either on a new, common set of rules designed especially for the CСCTB system or adopt the principles used in Member States' DTCs with third countries. The adoption of a new set of rules could mark a new beginning regarding the taxation of non-residents, but it would risk creating conflicts with the existing Member States' DTCs with third countries. In addition, establishing the CCCTB source rules on the existing DTCs rules would avoid multiplying work that has already been done by the OECD and Member States. Moreover, as most

${ }^{818}$ European Commission (2005c), paras. 25-26. 
Member States' DTCs use more or less identical source rules, there would be little room for conflicts. One could actually argue that, over the years, DTC rules have evolved into general international taxation principles. Consequently, drawing up the CCCTB rules in line with DTC provisions would contribute to the consistency between the two sets of taxation rules. This does not imply copying the provisions of Member States' DTCs but using them as a blue print for the new CCCTB system.

It has been agreed that the CCCTB group definition will be limited to water's edge. Therefore, non-residents will not be able to participate in the CССТВ as group members. However, if a non-resident company has a permanent establishment in a CCCTB Member State, it may (shall) opt for the system in respect to that entity alongside with all companies qualifying for the membership of the same group based on the decision of the principal taxpayer. ${ }^{819}$ Consequently, the CCCTB provisions that deal with the income of such permanent establishments are the main "source rules" for the purposes of the system. Accordingly, Article 6(7) of the proposed CCCTB Directive requires that a non-resident company participating in the CCCTB system via permanent establishments is subject to tax on all the income from an activity of the permanent establishments. Therefore, it seems particularly important to lay down uniform rules for determining the taxable income attributed to CCCTB-located permanent establishments. Such rules should recognise Member States' international obligations derived mainly from their DTCs.

The proposed CCCTB Directive further contains provisions concerning the investment income of non-residents. It is noteworthy that it does not establish uniform rules for the taxation of such payments, but it makes it dependent on each Member State's national rules. Accordingly, Member States are free to levy withholding taxes on dividend, interest and royalty payments at the domestic rate or the relevant DTC, despite whether the payment is deductible from the CCC tax base. ${ }^{820}$ While such taxes on interest and royalty payments must be shared according to the pre-determined formula, there is no such requirement for taxes on dividends. ${ }^{821}$

\footnotetext{
${ }^{819}$ For further discussion, vide supra at I4.3.

${ }^{820}$ For further discussion, vide infra at II7.4.3.2.

821 Recital 18 of the Preamble and Article 77 of the proposed CCCTB Directive.
} 


\subsubsection{INCOME FROM CCCTB-LOCATED PERMANENT ESTABLISHMENTS}

Generally speaking, it is up to each sovereign State to define a sufficient link that allows them to tax the income of a non-resident derived from their jurisdiction. Such liberty may be limited by DTCs, which, in the case of active income, is the requirement for a permanent establishment to which the income is attributed. In the previous Chapter, the author argued that there is a fairly wide range of reasons why the CCCTB group definition should not include permanent establishments of non-resident companies. For example, with regard to the concept itself, it may be challenging to define it in a way that it would reflect all the requirements of Member States' DTCs with third countries and ensure that it is interpreted equally by all relevant authorities of the Member States. Furthermore, from a legal and technical point of view, it may even be challenging to integrate the income of EU-located permanent establishments of non-residents in the uniform CCC tax base, because such permanent establishments would be attributed a tax base based on the AOA principle, while the CCCTB uses a three-factor-formula for sharing the CCC tax base to such an entity. The fundamental difference in the attribution factors between the formula apportionment and the AOA could lead to double taxation.

While the exclusion of the income of non-residents sourced from the CCCTB jurisdiction via their permanent establishments might be the simplest solution, it would raise some important considerations. For example, such income would then remain taxable according to the national laws of the Member States. However, the application of divergent rules across the Member States complicate the achievement of one of the goals of the EU - i.e. making it more attractive for (foreign) businesses. In addition, the exclusion would make the CCCTB very sensitive to profit-shifting, which would prospectively lead to loss in tax revenue of participating Member States. ${ }^{822}$ Furthermore, as the activities of permanent establishments often represent an integral part of the business in the EIM, it would not make sense to give up the respective taxing rights over those profits. ${ }^{823}$ Above all, without giving equal treatment to permanent establishments and subsidiaries, a jurisdiction, such as the CCCTB, would bias the policy choice in favour of one or the other form of

822 European Commission (2006b), para. 31.

823 Ibid., para. 31. 
establishment. This, however, may trigger the application of the nondiscrimination clause included in Member States' DTCs with third countries as the taxation of such permanent establishments should not be less favourably levied than income of a resident taxpayer. ${ }^{824}$ Taking into account these factors, the inclusion of permanent establishments of non-resident companies within the scope of the CCCTB Directive seems to be appropriate.

The proposed CCCTB system does not distinguish between the income received by a resident taxpayer and that attributed to a CCCTB-located permanent establishment of a non-resident company. The attribution of profits to such permanent establishments would be made based on the best practice in international tax law, i.e. the arm's length principle between the permanent establishment and its third-country head office. By treating the permanent establishments as separate group members, the CCCTB implies that the new AOA must be followed (Article 7 of the OECD MC 2010). 825 Hence, all domestic and foreign income attributed to a permanent establishment forms part of its tax base (even if much of it is exempt). ${ }^{826}$ For instance, dividends where the participation is attributed to the activities carried on by a CCCTBlocated permanent establishment would be treated equally to dividends received by CCCTB resident taxpayers. There appears to be no general disagreement that the source country (CCCTB Member State) has unlimited taxing right over the income attributed to the permanent establishment.

The problem with permanent establishments does not relate so much to the attribution of (positive) income to permanent establishments but more in terms of its losses and the elimination of double taxation of such income. Still, the difficulty with regard to (positive) income arises due to the application of fundamentally different attribution factors for the purposes of the CCCTB sharing mechanism (formula apportionment) and the AOA. In case of CCCTB group membership, the tax base of the CCCTB-located permanent establishment would be determined based on the Directive, aggregated with the tax bases of the rest of the group

\footnotetext{
${ }^{824}$ For further discussion, vide supra at I4.4.3.

825 Note that the Danish Presidency compromise proposal makes this understanding explicit. Council of the European Union (2012), Article 79(2) and the relevant comments therewith.

826 European Commission (2007a), paras. 118-119, 132 and footnote 38.
} 
members and thereafter shared between the members according to the predetermined formula. As said earlier, a typical national tax system or a DTC provision relies on the AOA / arm's length principle. Therefore, compared to a typical national tax system and DTC rules, the CCCTB uses a two-step approach regarding the attribution of profits to a permanent establishment, i.e. first, attribution of profits based on the AOA and, second, consolidating and sharing these profits based on the three-factor formula with the rest of the CCCTB group members. If the results of the two systems do not match, the relevant income is potentially double taxed, in particular if the residence State of the head office eliminates double taxation by means of the credit method. ${ }^{827}$ In other words, the residence State is usually obliged to provide credit for taxes paid in the source State. From the perspective of the third country, the source State is the CCCTB Member State where the permanent establishment is located and hence it is obliged to provide credit for the taxes paid only in that State. ${ }^{828}$ In order to avoid such double taxation, a Member State would need to renegotiate their DTCs to reflect such a peculiarity ${ }^{829}$ In the absence of the relevant DTC there is very little more that could be done but to invite Member States to conclude DTCs with their relevant trading partners.

Given that Member States' DTCs with third countries shall prevail, until renegotiated, Member States will have to observe their obligations and respect the rights of the third countries derived from such DTCs. If the attribution of profits based on a Member State's DTC with a third country is not based on the AOA, but on the OECD previous - single entity - approach, the application of the CCCTB may lead to undesired results. For example, if one assumes that a non-resident head office provides a loan to its CCCTB-located permanent establishment, on the one hand, the interest payment would be recognised in the CСCTB jurisdiction as a deductible cost, because the CCCTB rules treat permanent establishments as separate entities (in line with the AOA). ${ }^{830}$ On the other hand, it would not be recognised in the third country as taxable income because of the

\footnotetext{
${ }^{827}$ It is true that the income might not be taxed at the head office's level (due to the application of the exemption method) nor at the permanent establishment's level (due to the sharing mechanism), but it would always be included into the tax base of other CCCTB group members and taxed accordingly.

${ }^{828}$ For further discussion, vide infra at II7.4.3.1.

${ }^{829}$ For further discussion, vide infra at II7.3.

830 Article 12 of the proposed CCCTB Directive.
} 
application of the single-entity approach in the DTC (drafted on the pre-2010 OECD MC). ${ }^{831}$ Limiting such interest deduction under the CCCTB would not infringe the rights of the third country under Article 7 of the DTC with regard to the taxation of business income, because it is generally up to each Contracting State to determine which costs shall be tax-deductible. However, such a limitation may be contrary to the non-discrimination clause of DTCs based on Article 24(3) of the OECD MC, which prohibits more burdensome taxation of permanent establishments compared to resident companies carrying out the same activities. ${ }^{832}$ In any event, the proposed CCCTB must be interpreted to allow the relevant deduction and hence the question of discrimination should not arise in the present case.

In the opposite case, where a CCCTB-located permanent establishment provides a loan to its third-country head office, under the pre-2010 OECD MC the interest payment would not be recognised at the head office's level, while it would be considered taxable income in the CCCTB Member State under the proposed CCCTB rules. Hence, the income would not be deductible at the level of the head office, while it would be included in the tax base of the permanent establishment. From the author's perspective, recognising such income in the CCCTB Member State would infringe the third country's rights under the DTC, because the CCCTB Member State would include the interest income in the tax base even though it was not allowed to do so under the relevant DTC (based on the pre-2010 OECD MC). Thus, in the light of Article 351 of the TFEU the CCCTB Member State could not include the interest income in the CCC tax base due to the limitations under the DTC. Furthermore, it would be under a general obligation to bring the DTC in line with the EU aquis communautaire. ${ }^{833}$

\footnotetext{
831 Pre 2010 OECD Comm. on Article 7, para. 41.

832 While Article 24(3) of the OECD MC explicitly prohibits more burdensome taxation of permanent establishments compared to resident companies, the corresponding commentary is rather ambiguous in that respect. For example, para. 39 therewith explicitly states that "the situation of a permanent establishment is different from that of a domestic enterprise, which constitutes a single entity all of whose activities, with their fiscal implications, can be fully brought within the purview of the State where it has its head office." Nevertheless, para. 40 therewith clarifies that permanent establishments must be allowed to deduct the same trading expenses from their taxable profits as resident entities generally are.

${ }^{833}$ For further discussion, vide infra at II7.3.
} 
The proposed CCCTB Directive does not provide for a separate rule with regard to the taxation of immovable property of a non-resident company within CCCTB territorial borders. As discussed in the previous Chapter, if a non-resident derives income from immovable property located within the CCCTB territorial borders, the income should be attributed to its permanent establishment only if the nonresident carries on business through that place. In such a case, the proposed CCCTB rules treat such income as part of the revenues of the permanent establishment and include it in the tax base. Deeming a permanent establishment to exist in cases of pure capital investment would not reflect the aims of the CCCTB and would possibly erode Member States' tax bases. Consequently, in the absence of a link between a permanent establishment and the income from the real estate, the income from real estate would be split for taxation purposes: first, that which would be attributed to a permanent establishment of a non-resident and taxed under the CCCTB rules, and second, that which would be derived through capital investment and taxed according to each Member State's national law. ${ }^{834}$

In some countries, if a non-resident company owns real property, the latter may be deemed to constitute a permanent establishment for the non-resident if the asset is rented out in a passive manner (passive holding). This approach is respected in some DTCs. ${ }^{835}$ Due to the priority clause of Article 6 of DTCs based on the OECD MC, such income will be taxed under the said article even if a permanent establishment was deemed to exist in the source State according to the domestic tax law of that State. The fact that the income is derived through a permanent establishment does not prevent it from being treated as income of the enterprise, but, nevertheless, it secures that the source State is not limited in taxing it. ${ }^{836} \mathrm{~A}$ permanent establishment would not be deemed to exist according to Article 5 of the proposed CCCTB Directive in the same situation, because the latter does not include investment in real estate as a criterion for

\footnotetext{
834 For further discussion, vide supra at I4.2.3.1.

835 Vermeulen \& Blaauw (2011), 534. Note that it is normally required that a nonresident is active in the source state to constitute a permanent establishment. Sasseville \& Skaar (2009), 39. Therefore, such "passive" activities would usually not constitute a permanent establishment for the company as it is not "carrying on" the activity in the source State.

836 Article 6(4) of the OECD MC and the respective comm., para. 4.
} 
creating a permanent establishment. In the absence of a fictional permanent establishment under the CCCTB rules, CCCTB resident companies might exclude income derived from real estate from the CCC tax base, as necessary, by interposing a third-country company holding such real estate (Example 21: Real estate as a permanent establishment).

Example 21: Real estate as a permanent establishment

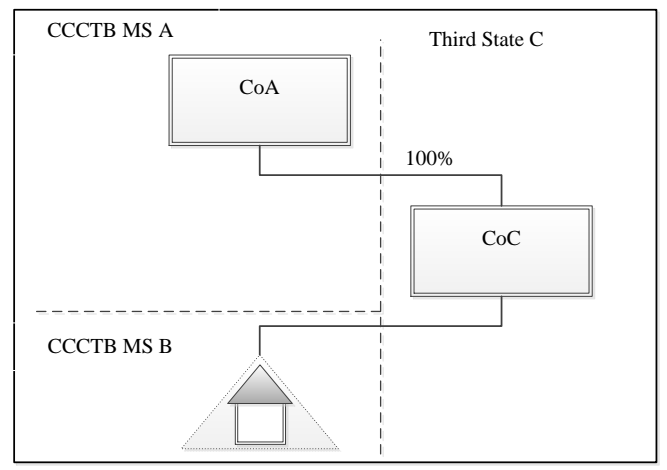

In the example above, if the real estate is owned through a nonresident company, the income derived from it would be excluded from the CCC tax base (provided that the real estate does not constitute a permanent establishment for the non-resident). Still, if such a transaction is considered artificial, it will be caught by the CCCTB GAAR and ignored. As a result, income from the real estate would still be included in the tax base of CoA according to the CCCTB rules. ${ }^{837}$

If, in the example above, there was no abuse under the GAAR, such income would fall within the scope of national law. According to Article 7 of the proposed CCCTB Directive, the Directive shall override all national corporate tax arrangements in respect of all matters regulated in the Directive. The proposed CCCTB Directive does not provide for source rules in terms of non-residents' income that does not come within the personal scope of the CCCTB Directive. Consequently, taxation of income from immovable property of non-resident entities is outside the scope of the (proposed) CCCTB Directive, provided that the income is not attributed to a permanent establishment existing under the CCCTB

${ }^{837}$ For further discussion about GAAR, vide infra at II8.3.1. 
rules. Against this background, even if under the national law of Member State B the passive rental income was deemed to constitute a permanent establishment, the taxation of such income would fall outside the CCCTB rules. Such national taxation would not be restricted under Article 7 of the proposed CCCTB Directive, because the absence of a permanent establishment under the CCCTB rules implies that the Directive does not regulate the matter.

\subsubsection{PRELIMINARY CONCLUSIONS}

The taxation of inbound investment requires the definition of source rules. As a general rule, a jurisdiction can tax income of nonresidents only if the latter have sufficient economic links to that jurisdiction. The current rules contained in the CCCTB proposal correspond in some parts to the OECD MC principles, for example, in that the business income of a non-resident falls within the scope of the CCCTB rules if it is derived through a CCCTB-located permanent establishment. The income of such permanent establishments would be determined under the AOA, but the final taxation of that income may differ if the permanent establishment belongs to a CCCTB group, because of the application of the sharing mechanism. Finally, if the relevant DTC with a third country reflects the single-entity approach (pre-2010 OECD MC), the application of the CCCTB rules may be limited in cases where the rights of third countries would be adversely affected, in particular, in terms of the recognition of dealings between the permanent establishment and the head office. Such DTCs would have to be renegotiated to bring them into line with the EU aquis communautaire.

In other parts, the proposed CCCTB Directive makes a direct link to Member States' domestic law (and DTCs), for example, with regard to the taxation of interest, royalties and dividends paid by a CCCTB group member to a non-resident entity. While any withholding tax levied on interest and royalty payments would have to be shared among the Member States, there would be no such requirement with regard to dividends. However, it was argued earlier that such a flexibility to levy withholding taxes by Member States, although providing absolute compliance with Member States international obligations, may lead to undesirable tax rate competition between Member States. ${ }^{838}$

${ }^{838}$ For further discussion, vide supra at II5.2.1. 
Last, in some parts, the proposed CCCTB Directive does not connect to international tax rules. For example, there is no reference to Member States' national law or a specific provision with regard to the taxation of immovable property located in a CCCTB Member State and owned by non-resident taxpayers. Due to such an approach, it was illustrated that companies may be able to choose whether they wish to include the income from immovable property under the scope of the (proposed) CCCTB Directive or remain taxable based on the domestic law of the country of situs.

\subsection{CORPORATE REORGANISATIONS}

The starting point for corporate reorganisation is the "all-in/all-out" principle in the water's edge context. As soon as the required eligibility criteria are fulfilled, the company or a permanent establishment must join the CCCTB group (Article 54). In the current section, the author will analyse how changes in a CCCTB group structure affect the CCC tax base of the group members. The section is broadly divided into two parts. First, the author will discuss the appropriate rules of the CCCTB proposal regarding entering and leaving of non-resident group members (i.e. their CCCTB-located permanent establishments). In the second part, the author will focus on the taxation of transactions involving asset transfers by CCCTB group members towards third countries.

\subsubsection{ENTERING A CCCTB GROUP}

Under the proposed CCCTB Directive, entering the CCCTB system does not trigger any taxation for the company. For instance, Article 61 of the proposed CCCTB Directive can be interpreted to secure that entering a CCCTB group will not cause the taxation of hidden reserves on fixed assets to which it is deemed to be the economic owner, including intangibles acquired for value. Article 7 of the CCCTB proposal prescribes that when a taxpayer enters the CCCTB system, it shall cease to be subject to all national corporate tax arrangements regulated by the Directive. The question is whether this provision can be interpreted to prohibit Member States from taxing their companies on hidden capital gains due to switching to the CСCTB system. The author agrees with Simonis that such an "exit" taxation would impede the smooth transition from national tax law to the common system and may form an obstacle to joining 
the CCCTB. ${ }^{839}$ On the other hand, without taxing upon exit, the Member States might lose (at least to a certain extent) their taxing rights on capital gains. ${ }^{840}$ In fact, the proposed CCCTB Directive is not explicit whether such an exit taxation, immediately before the switch, is indeed allowed. In the light of Article 61, the intention of the (proposed) Directive is to allow the taxation of hidden capital gains upon realisation, within five years of entering the CCCTB. Thus, immediate exit taxation of unrealised capital gains appears to be limited. Furthermore, one may assume that the European Commission has endorsed a tax-free rollover from the national tax law system to the CCCTB system. ${ }^{841}$ In any event, for the purposes of uniform interpretation, the Directive should make such an intention explicit.

The proposed Directive does distinguish between a resident company and a non-resident taxpayer that enters the system via its CCCTB-located permanent establishment. Therefore, assets attributed to the permanent establishment and to which it is the economic owner under the CCCTB will remain in the apportioned share of the permanent establishment. Article 61 of the proposed CCCTB Directive ensures that fixed assets disposed of during the five years following the entry of the taxpayer, the income will not form part of the CCC tax base. The purpose of the rule is to ensure that the taxation rights over the income generated in one jurisdiction before the entry (so-called 'hidden reserves' on entry) will not be passed to (or shared with) another jurisdiction via the apportionment formula. At the same time, it enables avoiding the need to value fixed assets on entering the CCCTB group. The rationale of the five years seems to be the need to protect Member States' tax bases from erosion in case of aggressive tax planning and to reflect business reality.

If such assets are disposed of after the five-year period, as prescribed under Article 61, the proceeds from such a disposal will be added to the CCC tax base and shared among the group members according to the apportionment formula. In some cases, such a rule may lead

\footnotetext{
839 Simonis (2012), 14.

840 In particular Article 61 reserves the taxing right on the capital gain to the particular group member for five years as of its group membership. After five years of group membership, the relevant capital gains would form part of the the CCC tax base. ${ }^{841}$ Ibid., 14.
} 
to distortions. The following example envisages a CCCTB group structure that is composed of two permanent establishments of a non-resident company (CoX) located in different CCCTB Member States (Member State A and Member State B) (Example 22: Disposition of assets of a permanent establishment).

\section{Example 22: Disposition of assets of a permanent establishment}

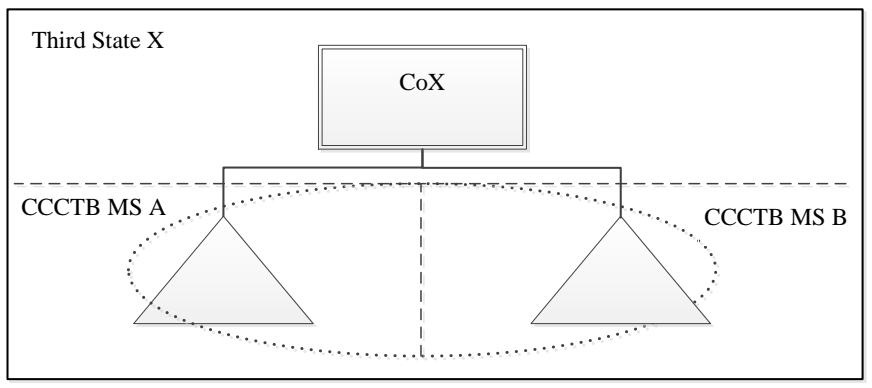

If the permanent establishment in Member State A is attributed a fixed asset and the economic ownership (via the non-resident taxpayer), if the asset is disposed after five years of entry into a group, the respective proceeds (say 100) are shared between the group members according to the formula. If the third State applied a (ordinary) credit method for eliminating juridical double taxation, it would give credit only for the underlying tax paid in the source country, (Member State A), i.e. 10. The third country would probably not recognise the income attributed via the sharing mechanism to the other permanent establishment (Member State B), i.e. 50, because, from its perspective, it is not the source country for the purposes of the relevant capital gains. Hence, it would not give credit for the tax paid in that other country (i.e. 15). Article 23B of the OECD MC only requires the State of the head office to give credit for the tax levied "in accordance with the provisions of this Convention". Taxation of capital gains derived in relation to the disposition of a fixed asset attributed to the permanent establishment in Member State A, due to the application of the CCCTB sharing mechanism, would not be levied in accordance with the DTC between Member State B and the third State. Hence, the third country would not be obliged to provide credit for the tax levied on the capital gains in that Member State under Article 23(B), based on the OECD MC. As a result, part of the income would remain double-taxed (i.e. the part that is allocated to the permanent establishment in Member State B, i.e. 15) (Example 23: Double 
taxation due to the application of the CCCTB sharing mechanism). Consequently, the renegotiation of DTCs to reflect such peculiarities is essential. ${ }^{842}$

Example 23: Double taxation due to the application of the CCCTB sharing mechanism

\begin{tabular}{|c|c|c|c|c|c|}
\hline $\begin{array}{c}\text { Group } \\
\text { member }\end{array}$ & Tax base & $\begin{array}{c}\text { Tax } \\
\text { rate } \\
(\%)\end{array}$ & Tax & $\begin{array}{c}\text { Tax } \\
\text { credit }\end{array}$ & $\begin{array}{c}\text { Total } \\
\text { tax }\end{array}$ \\
\hline $\begin{array}{c}\text { PE in } \\
\text { MS A }\end{array}$ & 50 & 20 & 10 & $\mathrm{n} / \mathrm{a}$ & 10 \\
\hline $\begin{array}{c}\text { PE in } \\
\text { MS B }\end{array}$ & 50 & 30 & 15 & $\mathrm{n} / \mathrm{a}$ & 15 \\
\hline CoX & 100 & 40 & 40 & 10 & 30 \\
\hline Total & 200 & $\mathrm{n} / \mathrm{a}$ & 65 & 10 & 55 \\
\hline
\end{tabular}

Pursuant to the proposed CCCTB Directive, when a company enters a CCCTB group, its whole tax base for that year is included in the CCC tax base. However, this does not imply that, upon entering, the calculation of the tax base ignores the number of calendar months during which the taxpayer formed part of the group. In particular, when a company enters the CCCTB system, it starts a new tax year, i.e. it must align its tax year with that of the group. ${ }^{843}$ Consequently, on entering the CCCTB system, the company's transitional tax year is cut into two parts. ${ }^{844}$ Joining a CCCTB and an existing CCCTB group also implies that the company's apportionment factors are computed proportionally having regard to the calendar months during which the company belonged to the CCCTB group during that tax year. 845

842 An option would be to include a clause in a DTC that, in such cases, the home State would give credit for the whole tax as if it were levied in the source State. In the previous example, the third State X would thus have to give credit of 20 (i.e. 100 x $20 \%$ ).

843 Article 108(2) of the proposed CCCTB Directive.

844 Article 108(4) of the proposed CCCTB Directive. See also European Commission (2006k), para. 13; European Commission (2007a), para. 97.

845 Articles 88 and 108(2) of the proposed CCCTB Directive. 
The proposed CCCTB Directive includes specific rules in relation to exiting from a CCCTB group, which are designed to protect the financial interests of CCCTB Member States. In general, a group member can exit in several ways:

(i) the threshold for group membership ceases to be met; ${ }^{846}$

(ii) the group member becomes insolvent or is liquidated ${ }^{847}$ or the permanent establishment is terminated;

(iii) a group member ceases to exist as a result of a business reorganisation (asset deal); $; 48$

(iv) the CCCTB group terminates;

(v) the CCCTB group merges with another CCCTB group. ${ }^{849}$

The current focus is on the CCCTB rules dealing with the departure of a permanent establishment of a non-resident company from a CCCTB group and the transfer of the residence of a company to a third country. The discussion will not involve questions related exiting CCCTB resident companies, as they do not affect the international aspects of the CCCTB. ${ }^{850}$

Like in case of entering, the transitional year when a taxpayer leaves a CCCTB group will be cut in two parts (unless it ceases to exist). The general rule for exiting a CCCTB group during a tax year is that the group member that is leaving will be attributed a share of the CCC tax base in proportion to the number of calendar months it formed part of the group in that tax year. ${ }^{851}$ On the one hand, including the entire tax base of a company in the CCC tax base would protect Member States' tax bases by capturing companies that enter and leave the group mainly for taxation purposes, On the other hand, this would certainly conflict with the principle of fiscal sovereignty of States.

Article 67 of the proposed CCCTB Directive prevents hidden reserves accrued during the period of group membership from

\footnotetext{
846 Article 54 of the proposed CCCTB Directive.

847 Article 56 of the proposed CCCTB Directive.

848 Article 70 of the proposed CCCTB Directive.

849 Article 71 of the proposed CCCTB Directive.

850 With regard to questions related to intra-CCCTB situations, one may read e.g. Streek (van den) (2012), 421-430.

851 Articles 88 and 108(3) of the proposed CCCTB Directive.
} 
escaping taxation by adding the relevant gain to the CCC tax base if the asset was disposed of within three years following the exit from the group by the economic owner of the asset. It is noteworthy that the proposal not only adds the entire gain from the disposal to the CCC tax base, but it does not allocate a smallest share to the leaving group member. ${ }^{852}$ Thus, the recaptured gain would not be limited to the amount of hidden reserves on the exit but it would include the entire gain derived from the disposal. In case a permanent establishment of a non-resident company is deemed to be the economic owner of an asset, 853 in case of exiting the CCCTB group, the gain may become taxable in both jurisdictions, i.e. the CCCTB and the State of residence of the head office, if the asset is alienated within three years of the exit.

Although opinions may differ, from the author's point of view, exit taxes are not prohibited in DTCs. As the author has argued elsewhere, taxes on hidden reserves, for which the tax base is not settled at the moment of departure of the asset, cannot be seen as exit taxes. ${ }^{854}$ Although some may disagree, in the opinion of the author, only immediate taxation and deferred taxation of capital gains, the base of which has been settled prior to emigration (socalled "trailing taxes"), can be seen as exit taxes in the light of DTCs. As follows, in a case in which there is a DTC between the relevant CCCTB Member State and the third country (the State of residence of the head office), the CCCTB Member State would infringe its DTCs if it taxed the total capital gain on the disposal of the asset (i.e. deferred exit taxation with a flexible tax base). Conflict with DTCs could be avoided if the CСCTB rules imposed immediate exit

\footnotetext{
852 It is quite interesting to note that no share of the received gain would be attributed to the "emigration" Member State (unless another group member exists in that State). Usually, the CCCTB system aims to protect the taxing rights of the Member States. However, in case of such asset transfer, the Commission has considered it to be "fair" not to allocate any capital gain to the departing taxpayer, despite when the asset was transferred to the latter. From the author's point of view, this approach seems too restrictive considering that the transfer and the later disposal could have been made only on business reasons.

853 Pursuant to Article 4(20) of the proposed CCCTB Directive, in this case, the economic owner is the non-resident company - a permanent establishment is the extension of its taxable presence in the CCCTB jurisdiction. If the asset is transferred from a CCCTB group member to the permanent establishment, the asset will be recorded in the balance sheet of the latter.

${ }^{854}$ In other words, as long as the tax liability over capital gains is established at the moment of the departure of the taxpayer, the "emigration State" may tax such gains. Man (de) \& Albin (2011), 613-625.
} 
taxation before the group member leaves the CCCTB group. In such a case, deemed capital gains would be added back to the CCC tax base and shared between all the group members, including the departing group member (the permanent establishment), based on the formula apportionment. However, such an approach may run the risk of being found contrary to the European Commission policy on exit taxation. ${ }^{855}$ Nevertheless, it is apparent after the Court's judgment in National Grid Indus that, as far as exit taxes are concerned, the CJEU makes a difference between the emigrating individual shareholders (as in case of $N .{ }^{856}$ ) and emigrating businesses. In particular, in the latter case, the country of exit does not have to take into account the future decreases in the value of an asset. Such a distinction stems from the fact that there will be no remaining link with the state of exit that, under international tax law, could allow the taxation of future capital gains or losses of the emigrating businesses. ${ }^{857}$

Due to the fact that the CCCTB group definition is limited to water's edge, when a CCCTB resident company transfers its residence to a third country, it would have to exit the CCCTB group. The following example envisages a CCCTB group that is composed of a CCCTB resident parent company (CoA) and its CCCTB resident subsidiaries $(\mathrm{CoB}$ and $\mathrm{CoC}$ ) (Article 55(1)(c)). Assume that $\mathrm{CoC}$ has been attributed the economic ownership of a particular asset as a result of an intra-group transfer of an asset.858 When $\mathrm{CoC}$ transfers its residence to a third country (through the transfer of its place of effective management) the company will have to exit the group. (Example 24: Change of residence following an intra-group transfer of asset).

855 See, in particular, European Commission Press Release IP/10/1565 from 24 November 2010. See also case National Grid Indus (C-371/10), para. 53.

${ }^{856}$ Case N. (C-470/04).

${ }^{857}$ Broek (van den) \& Meussen (2012), 194.

${ }^{858}$ The transfer of an asset is considered an intra-group transaction and is, therefore, ignored (Article 59 of the proposed CCCTB Directive). No withholding tax applies to intra-group transactions (Article 60 of the proposed CCCTB Directive). 


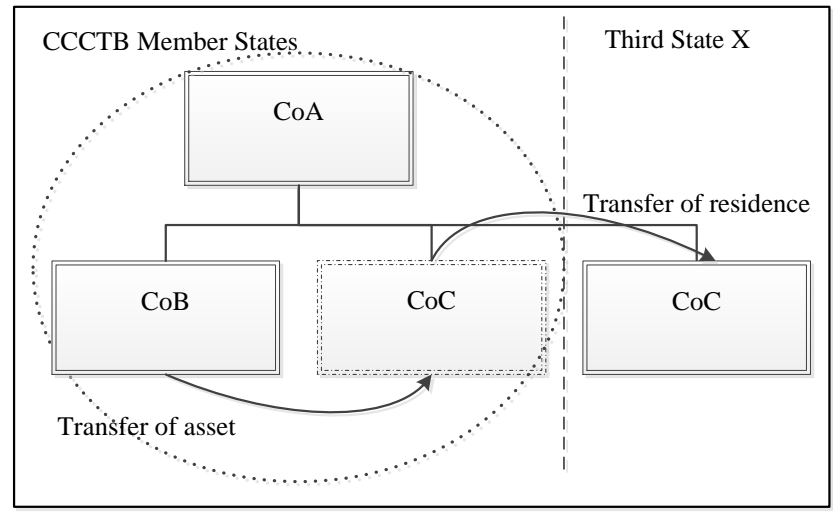

If the exiting company $(\mathrm{CoC})$ disposes of the asset within three years of its departure from the group, the total capital gain will become taxable at the group level. If the company (CoC) transfers its residence to a third country, the rules of the Directive will cease to apply. Typically, the right to tax capital gains is allocated to the State of residence (Article 13(5) OECD MC). As discussed earlier, in the opinion of the author, without having settled the tax liability of the leaving taxpayer immediately before the departure, the former (CCCTB) residence State would not be entitled to tax gains on the alienation of an asset that took place after the transfer of residence under the DTC between the two States concerned. Otherwise, the emigrating State (the CCCTB Member State) would infringe the rights of the third country as it would tax income that it was not allowed to tax. A solution could be to assess the taxpayer's liability on its emigration ("trailing taxes"). In such a case, CCCTB Member States would be left free to decide when to collect the tax, taking into account the requirements developed in the case law of the CJEU (in case the CCCTB is adopted in the framework of enhanced cooperation). ${ }^{859}$ In any event, if there is no step-up in the cost base on such (deemed) capital gains in the third State, the cost base for taxation purposes in that State would typically be the historical acquisition cost of the asset rather than the book value of the assets

${ }^{859}$ In particular, cases De Lasteyrie du Saillant (C-9/02); N. (C-470/04); National Grid Indus (C-371/10). It is worthwhile noting that the CCCTB Directive will not deal with the final tax liability of the each taxpayer. Consequently, it will be up to each Member State to decide when to collect such an exit tax, subject to EU and DTC obligations. 
plus the deemed capital gains. ${ }^{860}$ If neither of the States provided for a credit for the taxes levied by the other State, the capital gains would remain double-taxed. In order to avoid such distortions, Member States would have to discuss with their DTC partners as to how to deal with these issues.

\subsubsection{MERGER OR DIVISION INVOLVING THIRD-COUNTRY ESTABLISHMENTS}

A merger transaction typically involves a combination of businesses, either directly - i.e. by transferring ownership of the businesses to a single entity - or indirectly - i.e. by transferring ownership of the business-owning entities themselves by means of a transfer of shares, under common ownership. ${ }^{861}$ If the merger is carried out within the $\mathrm{EU}$, the Member States must observe the rules set forth in the Merger Directive, where appropriate. The latter directive defines the concept of "merger" in Article 2(a). Generally, a merger involves, by operation of the law, the transfer of all the assets and liabilities of one or more companies, on being dissolved without going into liquidation, to another existing company in exchange for the issue of shares of that company to the shareholders of the dissolving companies.

The proposed CCCTB Directive includes only rules with regard to business reorganisations within the group and between two or more CCCTB groups. ${ }^{862}$ Reorganisations concerning third-country establishments generally follow the rules concerning entering or leaving a group member. As with the first example here, one can discuss the taxation consequences when a CCCTB resident parent company leaves the CCCTB group due to a merger with a thirdcountry company by being dissolved in the CCCTB jurisdiction (Example 25: Merger of a CCCTB principal taxpayer).

\footnotetext{
860 Some scholars argue that, in the case of intra-EU movements, not providing a step-up in value in the host State results in a restriction on the freedom of establishment. For further analysis, read Hurk (van den), Broek (van den) \& Korving (2013), 257-67.

861 Rogers-Glabush (2009), 279.

862 For a discussion of business reorganisations within the CCCTB, read Mitroyanni \& Putzolu (2009), 436-448.
} 


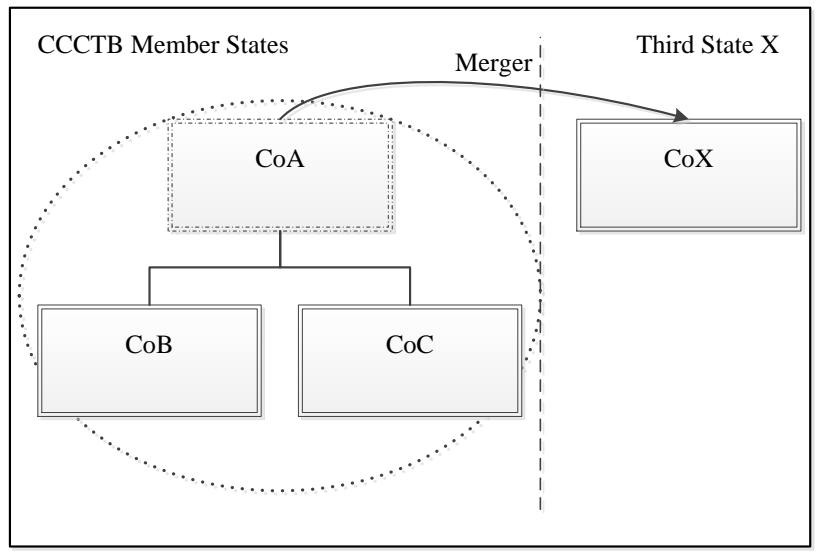

The question is whether the whole CCCTB group collapses if the principal taxpayer ceases to exist. If that were the case, it would create another possibility for tax planning by allowing groups to opt out of group treatment via reorganisation. Thus, from the author's point of view, the group would continue to exit for the remainder of the group term and a new principal taxpayer would be designated according to Article 116 of the proposed CCCTB Directive. ${ }^{863}$ The taxation of the exiting parent company would follow the general exiting rules of the CCCTB system, unless the dissolving company is converted into a CCCTB-located permanent establishment. In such a case, the permanent establishment would become part of the group (Article 55(2)), even though it could not act as the principal taxpayer, as discussed earlier. ${ }^{864}$

In the next example, $\mathrm{CoA}$ and $\mathrm{CoB}$ form a CCCTB group (Example 26: Merger of a CCCTB group member with a third-country company). However, during the CCCTB group term, $\mathrm{CoB}$ merges with $\mathrm{CoC}$, which is a third country resident. As a result, $\mathrm{CoB}$ is dissolved and its shareholders are issued the shares of $\mathrm{CoD}$.

863 In this example, the CCCTB-group was initially formed in accordance with Article 55(1). If the parent company ceases to meet the relevant criteria for being a member of the CCCTB group, the group would continue to exist as if it were formed in accordance with Article 55(2) of the proposed CCCTB Directive.

${ }^{864}$ For further discussion, vide supra I4.4.3.4 


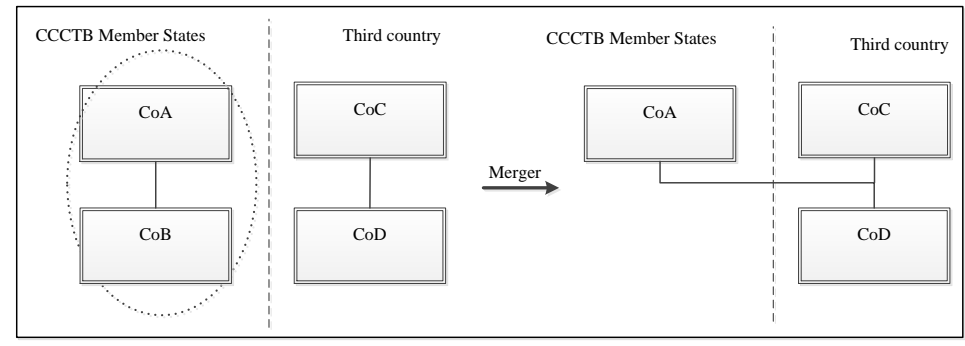

In this situation, the analysis involves two important transactions: first, $\mathrm{CoB}$ leaves the CCCTB group because it is dissolved. Second, since CoA would be the only company remaining in the group, the group as such will be terminated. If $\mathrm{CoB}$ does not leave a permanent establishment in the CCCTB jurisdiction, all the assets shall be deemed to be disposed of in the tax year of its departure. The relevant capital gain will be added to the CCCTB group's tax base of that tax year (which finishes when the group terminates) and shared between $\mathrm{CoA}$ and $\mathrm{CoB}$ according to the apportionment formula.

In the opposite scenario - i.e. where $\mathrm{CoD}$ is dissolved because it is absorbed by $\mathrm{CoB}$ and its shareholders are issued the shares of $\mathrm{CoB}$, one must analyse whether $\mathrm{CoB}$ continues to be treated as a CCCTB qualifying subsidiary. As long as the CCCTB-located parent company $\mathrm{CoA}$ continues to meet the requirement for qualifying subsidiaries in $\mathrm{CoB}$, there would be no CCCTB-related taxation consequences arising from such a merger and the group term would continue to apply. ${ }^{865}$ If that were not the case, $\mathrm{CoB}$ would have to leave the group and continue to be treated under the rules of the system for the remainder of the group term. 860

A similar discussion would arise if a CCСТB group member went through a division, where a company, upon being dissolved without going into liquidation, transfers all its assets and liabilities to two or more existing or new companies in exchange for shares of the capital of the companies receiving the assets and liabilities. ${ }^{867}$ In the following example, CCCTB resident companies $\mathrm{CoA}$ and $\mathrm{CoB}$ form a

\footnotetext{
865 Article 19592) of the proposed CCCTB Directive.

866 Article 105(3) of the proposed CCCTB Directive.

867 Article 2(b) of the Merger Directive. For the definition of "partial division", see Article 2(b)(a) therewith.
} 
CCCTB group (Group-AB). Following the division of $\mathrm{CoB}$, $\mathrm{CoA}$ becomes the shareholder of two newly established companies, a CCCTB resident company $\mathrm{CoC}$ and a CCCTB non-resident $\mathrm{CoD}$. In the example, it is assumed that $\mathrm{CoA}$ will meet the conditions for forming a CCCTB group with CoC. (Example 27: Division of a CCCTB subsidiary).

\section{Example 27: Division of a CCCTB subsidiary}

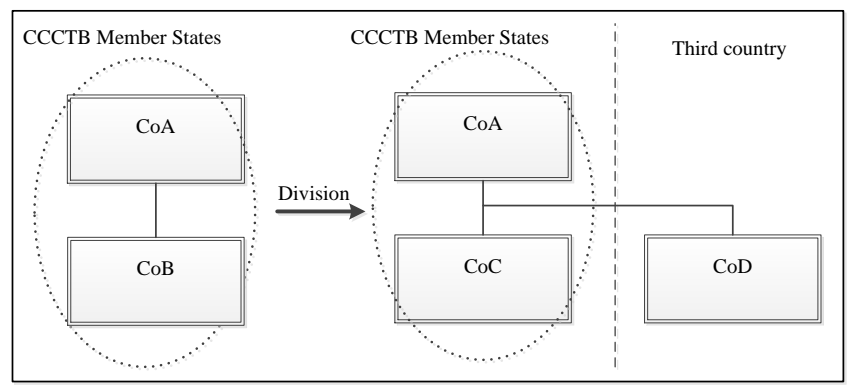

It seems difficult to uphold that the previous group term of Group$\mathrm{AB}$ continues to apply despite the fact that $\mathrm{CoC}$ became eligible only because $\mathrm{CoB}$ was dissolved. Otherwise, a number of issues could arise. For example, if Group- $\mathrm{AB}$ had suffered losses, the continuation of the CCCTB group with $\mathrm{CoC}$ would require those losses to be carried forward at the group level. In such a case, the existing group losses would affect Member States, which originally did not have any link to them, such as the State of residence of CoC. As follows, CoA would have to ${ }^{868}$ form a new CCCTB group with CoC. Any losses suffered at the Group-AB level would be allocated to each group member based on the sharing mechanism (Article 65). In case of $\mathrm{CoA}$, which is the surviving group member, such losses would be treated as "pre-consolidation losses" (Article 66(b)).

${ }^{868}$ Indeed, the formation of a new CCCTB group would be obligatory because CoA had previously exercised its option to participate in the CССТВ. In such a case, the obligation for CoA to apply the CCCTB system is automatically prolonged due to the group term conditions of Article 105 of the proposed CCCTB Directive. For example, if $\mathrm{CoB}$ had been dissolved in year four, $\mathrm{CoA}$ would still be obliged to apply the system for one remaining year. However, because CoA will meet the qualifying subsidiary conditions in $\mathrm{CoC}$, it would have to apply the system at least for the next five years. Consequently, CoA's obligation to apply the CCCTB system will be prolonged automatically for four years. 
The transfer of assets from a head office to its permanent establishment, and vice versa, is rather common practice in business. Many countries, however, fear losing taxing rights over the future capital gains on the assets being transferred and, therefore, may wish to exercise their right immediately before the transaction. Actually, from an international perspective, with regard to outbound transactions of tangible or intangible property, taxation upon transfer is seen as a norm rather than an exception. ${ }^{869}$ While outbound transactions to related parties typically require compensation at arm's length, in case of inbound transactions, it seems to be commonly accepted that the asset received is assigned a fair market value. ${ }^{870}$

The proposed CCCTB Directive contains a separate provision with regard to transfers of assets towards a third country in Article 31. Accordingly, such a transfer is considered to be a disposal of an asset, triggering an exit taxation. The provision covers only outbound transfers and has two dimensions: (i) the transfer of an asset from a CCCTB resident head office to a third-country-located permanent establishment; and (ii) the transfer of an asset from a CCCTB-located permanent establishment towards (any entity in) ${ }^{871}$ a third country. The purpose of the article is to reflect the consequences of applying the exemption method for the elimination of double taxation of foreign income under Article 11. By taxing the accrued capital gains incorporated in the asset, which is transferred to a permanent establishment in a third country, the CCCTB Member States are given the opportunity to tax some of the future revenues of that permanent establishment which they would not be entitled to tax when they are realised. If the CCCTB used a

\footnotetext{
869 The OECD MC does not directly deal with the issue, although its previous commentaries (before the 2010 changes) on Article 7 reveal an agreement with such exit taxation (see OECD Comm. on Article 7, para. 21). Notably, such a line has not been included in the latest OECD Comm. on Article 7. However, it is noteworthy that the OECD Comm. on Article 13, para. 10 appears to support this view.

${ }^{870}$ Kroppen \& Silva (2011), 32-33.

${ }^{871}$ For the purposes of the escape clause of Article 31(2), the transfer from a CCCTB-located permanent establishment can only be to its head office located in an EEA Member State. Otherwise, the transfer implies change of the legal owner of the asset, which is considered to be the sale of the asset triggering immediate taxation on realised capital gains.
} 
worldwide taxation system with a credit for foreign income, such a provision would be unnecessary. ${ }^{872}$

The proposed CCCTB Directive does not define the concept of "transfer", but one may assume that it refers to a change in the attribution of economic ownership. ${ }^{873}$ This conclusion is in line with the idea that an asset should be included in the asset factor of its economic owner. ${ }^{874}$ The question is whether the transfer includes a temporal element in the sense that the transfer would have to be "final". For instance, if a head office transfers the right to use an asset temporarily (e.g. for six months) to its third-country permanent establishment and the latter bears the related risks, it is questionable whether the rule stipulated in Article 31 should apply. The CCCTB proposal does not include any special provision with regard to inbound transfers of assets mirroring Article 31 situations. In light of this, even temporary transfers of assets towards third countries would trigger an exit taxation.

For the purposes of establishing the scope and consequences of Article 31 of the proposed CCCTB Directive, the author will elaborate on the following elements of the provision: (i) the concept of a permanent establishment; (ii) the type of an asset transferred; and (iii) the tax liability.

872 The article will also become inapplicable in situations in which the foreign income is subject to a switch-over clause. For a further discussion on the switchover clause, vide infra at II7.5.1.

873 Article 4(20) of the proposed CCCTB Directive defines the "economic owner" as the person who has substantially all the benefits and risks attached to a fixed asset, regardless of whether that person is the legal owner. A taxpayer who has the right to possess, use and dispose of a fixed asset and bears the risk of a loss or destruction shall in any event be considered the economic owner. The proposed Directive requires a "taxpayer" to be a company. A permanent establishment is neither a separate taxpayer nor a person for the purposes of the proposed CCCTB Directive. However, considering that a permanent establishment is a fictional extension of a non-resident taxpayer, which is a person and a taxpayer according to the CCCTB proposal, the permanent establishment can be deemed to be the economic owner of an asset if the legal ownership of that asset belongs to the non-resident head office. Consequently, based on the test of assets used, risks assumed and functions performed, an asset could be included in the balance sheet of a permanent establishment.

874 Article 93 of the proposed CCCTB Directive. See Gutmann (2013), 265. 


\subsubsection{THE CONCEPT OF "PERMANENT ESTABLISHMENT"}

The concept of a permanent establishment is defined in the proposed CCCTB Directive in Article 5 and almost exclusively corresponds to the wording provided in the OECD MC. 875 However, the OECD MC serves as a draft for concluding DTCs between countries. Hence, the definition of permanent establishment in a Member State's DTC with a third country may differ from the definition agreed upon in a DTC with another third country. Because of divergent definitions in DTCs compared to the proposed CCCTB definition of permanent establishment, the transfer of an asset towards a third country may lead to unintended results. Nevertheless, unless a DTC falls within the grandfathering clause of Article 351 of the TFEU, Member States will have to respect the Union acquis also with regard to their DTCs concluded with third countries. However, this does not imply that DTCs with third countries become ineffective, but that Member States must waive the rights that they derive from such DTCs, provided that this does not adversely affect the third country's rights under that DTC. On the contrary, the third country is not bound by the Union acquis. ${ }^{876}$ Consequently, when the definition of a permanent establishment under a Member State's DTC with a third country differs from that provided under the CCCTB Directive, the Member States shall continue to respect the rights of the third countries and observe their obligations. For example, assume that an asset is transferred from a CCCTB resident head office to a permanent establishment in a third country, where the DTC between the Member State and the third country includes a broader definition of a permanent establishment compared to the definition in the proposed CCCTB Directive, in such a case, the Member State shall recognise that transfer because the (taxing) rights of the third country are directly affected, despite the fact that a permanent establishment did not exist under the CCCTB provisions. Otherwise, the transfer would be taxed twice: first, in the third country due to the application of the AOA on the attribution of profits to the permanent establishment and, second, in the exiting CCCTB Member State, because the asset would be deemed to be economically owned by that resident taxpayer (and included it in the asset factor accordingly). Consequently, the asset would be considered to be in the balance sheet of both of the entities, i.e. the head office and the permanent establishment (if

\footnotetext{
875 For further discussion, vide supra at I4.2.3.
}

${ }^{876}$ For further discussion, vide infra at II7.3. 
applicable). However, it is arguable whether the asset transfer would trigger exit taxation under the CССТВ because, from the CССТВ rules, there should not have been any transfer in the first place. (Example 28: Transfer of an asset from a head office to its thirdcountry permanent establishment when the definition under the DTC is broader than that under the CCCTB).

Example 28: Transfer of an asset from a head office to its third-country permanent establishment when the definition under the DTC is broader than that under the CCCTB

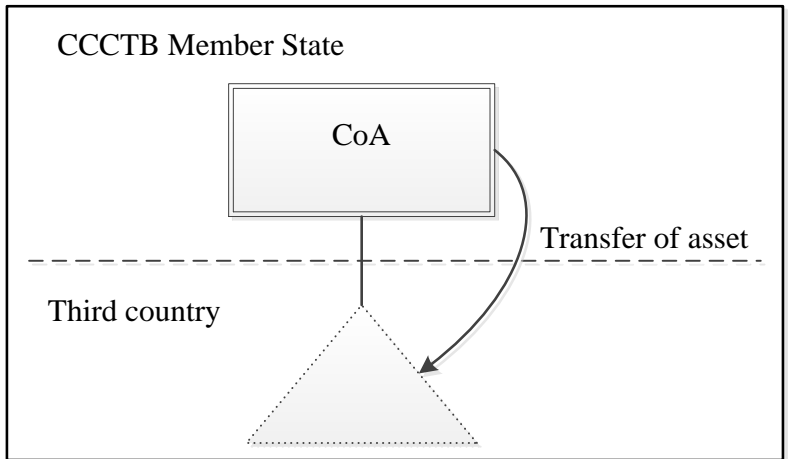

\begin{tabular}{|c|c|c|c|}
\hline & $\begin{array}{c}\text { recognition of } \\
\text { permanent } \\
\text { establishment }\end{array}$ & $\begin{array}{c}\text { recognition } \\
\text { of asset } \\
\text { transfer }\end{array}$ & $\begin{array}{c}\text { taxation after } \\
\text { transfer }\end{array}$ \\
\hline CCCTB & yes & Yes & no \\
\hline $\begin{array}{c}\text { Third } \\
\text { country } \\
\text { (DTC) }\end{array}$ & yes & Yes & yes (AOA) \\
\hline
\end{tabular}

In the opposite situation, a narrower definition of a permanent establishment in a DTC would lead to a scenario in which the existence of a permanent establishment is recognised under the CCCTB provisions but not under the DTC (Example 29: Transfer of an asset from a head office to its third-country permanent establishment when the definition under the DTC is narrower than that under the CCCTB). 877

877 It might be interesting to discuss herewith whether, in the case of outbound transfers, the taxation consequences could be different if the transfer of an asset would result in the creation of a permanent establishment in the source country. In that case, the literal reading of the provision suggests that no exit taxation should arise, because the asset had to be transferred to a permanent establishment. 
Example 29: Transfer of an asset from a head office to its third-country permanent establishment when the definition under the DTC is narrower than that under the CCCTB

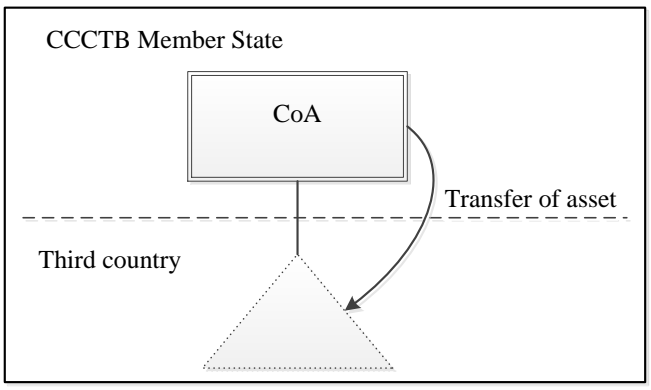

\begin{tabular}{|c|c|c|c|}
\hline CCCTB & $\begin{array}{c}\text { recognition of } \\
\text { permanent } \\
\text { establishment }\end{array}$ & $\begin{array}{c}\text { recognition } \\
\text { of asset } \\
\text { transfer }\end{array}$ & $\begin{array}{c}\text { taxation after } \\
\text { transfer }\end{array}$ \\
\hline yes & yes (exit tax) & $\begin{array}{c}\text { yes (CCC tax } \\
\text { base without } \\
\text { asset factor) }\end{array}$ \\
\hline $\begin{array}{c}\text { Third } \\
\text { country } \\
\text { (DTC) }\end{array}$ & no & no & no (AOA) \\
\hline
\end{tabular}

In this case, Member States will again be obliged to observe their obligations and rights of their treaty partners stemming from the specific DTC. However, if the third country does not recognise the existence of a permanent establishment under the relevant DTC, arguably, by charging an exit tax on the transfer, Member States would not infringe the rights of the third country, because the third country would not claim any taxing right over the asset. After the deemed transfer, the asset would not be recognised in the accounts of either the head office or the permanent establishment. The recognition of the transfer under the CCCTB rules implies that the head office loses its economic ownership over the asset for the purposes of calculating its share according to the formula apportionment (in particular, the asset factor). This outcome is remarkable given that, on the one hand, there would be exit taxation

However, the consistent approach would require the application of the same principles to the both situations, despite whether the transfer of an asset was made to a permanent establishment or whether it resulted in the creation of a permanent establishment. 
on the asset transfer, while on the other hand, the income generated thanks to the asset would still be included into the CCC tax base (because the third country would not claim that right based on the AOA).

In case of inbound investments, an asset is transferred from a CCCTB-located permanent establishment to its third-country head office. If the existence of a permanent establishment is not recognised under the DTC (due to a narrower definition) between the relevant Contracting States, while it is under the rules of the (proposed) CCCTB Directive, the head office's State would not recognise the transfer, while the CCCTB Member State would deem a capital gain to be realised under Article 31. (Example 30: Transfer of an asset from a CCCTB-located permanent establishment to a third-country head office, where the definition of a permanent establishment under the DTC is narrower than that under the CCCTB). From the author's perspective, the recognition of the transfer from the perspective of the CCCTB Member State and levying an exit tax accordingly would violate the rights of the third country. Indeed, the CCCTB Member State should not have any taxing right over that asset due to the absence of a permanent establishment under the relevant DTC. Consequently, in order to respect the third country's rights and observe its obligations under the DTC, the Member State could not charge any exit tax on the deemed transfer of the asset. From the third country's perspective, the asset was and will remain taxable according to its laws.

Example 30: Transfer of an asset from a CCCTB-located permanent establishment to a third-country head office, where the definition of a permanent establishment under the DTC is narrower than that under the CCCTB

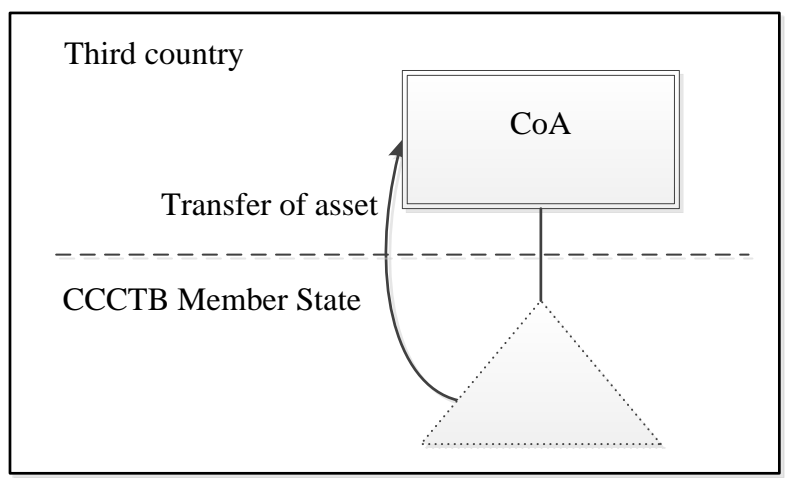




\begin{tabular}{|c|c|c|c|}
\hline & $\begin{array}{c}\text { recognition of } \\
\text { permanent } \\
\text { establishment }\end{array}$ & $\begin{array}{c}\text { recognition } \\
\text { of asset } \\
\text { transfer }\end{array}$ & $\begin{array}{c}\text { taxation after } \\
\text { transfer }\end{array}$ \\
\hline CCCTB & yes & no & no \\
\hline $\begin{array}{c}\text { Third country } \\
\text { (DTC) }\end{array}$ & no & no & yes \\
\hline
\end{tabular}

Last, in the case of a broader definition in a DTC, the transfer of an asset would be recognised only under the DTC, because, under the CCCTB rules, there would be no permanent establishment from which the asset could be transferred.

Example 31: Transfer of an asset from a CCCTB-located permanent establishment to a third-country head office, where the definition of a permanent establishment under the DTC is broader than that under the CCCTB

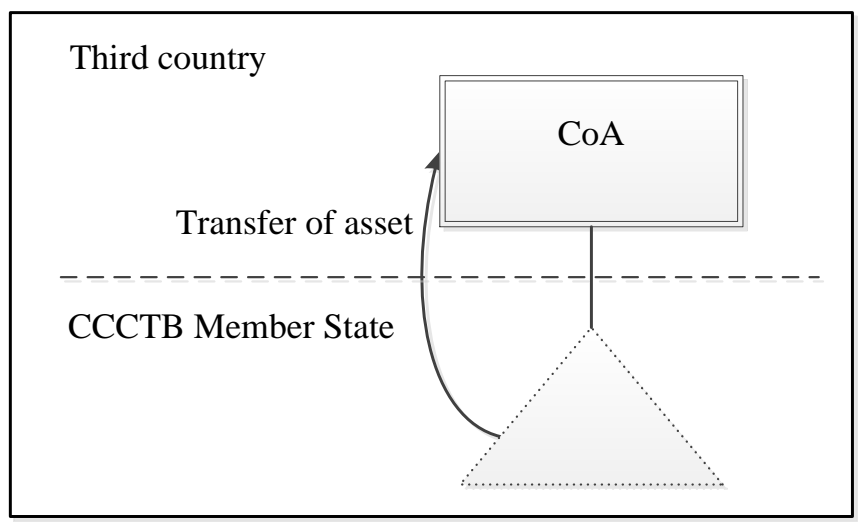

\begin{tabular}{|c|c|c|c|}
\hline & $\begin{array}{c}\text { recognition of } \\
\text { permanent } \\
\text { establishment }\end{array}$ & $\begin{array}{c}\text { recognition } \\
\text { of asset } \\
\text { transfer }\end{array}$ & $\begin{array}{c}\text { taxation after } \\
\text { transfer }\end{array}$ \\
\hline CCCTB & no & no & no \\
\hline $\begin{array}{c}\text { Third } \\
\text { country } \\
\text { (DTC) }\end{array}$ & yes & yes & yes \\
\hline
\end{tabular}

In the present example, from the CCCTB Member State's perspective, any gains from the asset would always be attributed only to the head office. Since the general understanding is that DTCs only limit a country's taxing rights, rather than create them, a permanent establishment would not be deemed to exist in the CCCTB Member 
State and hence there could be no source taxation over that asset. Without deeming a permanent establishment to exist, the CCCTB Member State would by no means infringe the (taxing) rights of the third country under the DTC. Here, the third country would still recognise the transfer and consider the asset to be linked to its taxpayer (for future taxation purposes), while no exit taxation would be triggered in the CCCTB jurisdiction.

\subsubsection{TYPE OF TRANSFERRED ASSET}

The current CCCTB proposal envisages exit taxation only in case of transfer of a fixed asset, i.e. all tangible assets acquired for value or created by the taxpayer, all intangible assets acquired for value, and financial assets. It therefore seems that assets, other than fixed assets, transferred to a third country would not trigger exit taxation. For instance, inventory would be excluded from the scope of the provision. Reasons for such an exclusion might have been practical rather than theoretical or political: control over assets other than fixed assets is typically more difficult and the amounts at stake are often inferior to those involved of transfer of fixed assets. ${ }^{878} \mathrm{It}$ is noteworthy that according to the Danish compromise proposal on the CCCTB, such an exit taxation should cover all assets and not only fixed assets. ${ }^{879}$

\subsubsection{TAX BASE}

Most importantly, it is necessary to agree on the tax base and the timing issues. In terms of the tax base, the proposed CCCTB Directive is silent on the matter whether the disposal is deemed to take place at market value, book value or any other value. Article 31, read in conjunction with Articles 78 and 79 of the proposed CCCTB Directive, allows concluding that the value must meet the arm's length standard, i.e. the capital gain equals to the difference between the fair market value and the accounting value. ${ }^{880}$ In terms of DTC law, taxes on hidden reserves may be levied either immediately upon the transfer or may be deferred, as long as the tax liability is established before the asset leaves the State (see also the next paragraph). Article 31 proposes that the gain on transfer of an asset be recognised in the year of the transfer but it is silent about the

\footnotetext{
878 Gutmann (2013), 266.

879 Council of the European Union (2012), comments to Article 31.

880 Kemmeren \& Smit (2013), 99.
} 
collection of the tax. Indeed, the CCCTB Directive will not deal with the tax liability or the collection the tax on the CCC tax base attributed to each relevant group member. Therefore, Member States will be left free to decide when to collect the tax, taking into account the requirements developed in the case law of the CJEU.

One may wish to take a step ahead and discuss the possibility for a Member State to tax hidden reserves only upon realisation in cases where the escape clause of Article 31(2) of the proposed CCCTB Directive applies. The clause provides for an exemption from exit tax concerning the transfer of assets in certain situations. In such cases, the proposed CCCTB Directive provides for the assessment of the amount of capital gains only when they are realised, i.e. the increases and decreases in value of the asset is taken into account. 881 First, one may recall that a deferral of taxation of hidden reserves can only be seen as a true exit tax when the tax base corresponds to the increase in value of the asset at the moment the asset was transferred, i.e. it is "frozen" until the moment of collection. The use of another tax base, for instance gains derived from the alienation of the asset, which could have increased or decreased after the transfer, are not in line with the idea of an exit tax. ${ }^{882}$ From the author's point of view, exit taxes are generally not prohibited in DTCs based on the OECD MC. Both immediate and deferred exit taxes fall under the scope of Article 13(5), which allocates the exclusive taxation right to the residence state of the alienator or a permanent establishment, 883 from which the assets departed. A question arises whether the tax deferral will still apply if, because of the transfer of the asset, a taxpayer ceases to have a taxable presence in a CCCTB Member State by means of its residence or a permanent establishment. It is noteworthy that the current CCCTB proposal does not include a final settlement tax for such situations. By comparison, according to Articles 61 and 70 of the CCCTB proposal, a permanent establishment is deemed to exist if, because of a business reorganisation, a taxpayer no longer exists or no longer has a permanent establishment in the Member State in which it was a

\footnotetext{
881 Although, as noted above, following National Grid Indus (C-371/10), it seems that from the Court's perspective, the country of exit does not have to take into account the future decreases in the value of an asset in case of emigrating companies (as opposed to emigrating individuals).

882 Man (de) \& Albin (2011), 613-625.

883 Transfer of an asset from a permanent establishment falls within the scope of Article 13(5) to the extent that it is in accordance with Article 7.
} 
resident. The purpose of this provision is to protect the taxing rights of Member States. Such a condition has not been included with regard to asset transfers towards third countries in Article 31 of the proposed CCCTB Directive. In principle, it is a matter of Member States' company law to establish whether, because of a transfer of assets, the real seat of the company was moved to another jurisdiction. If this is the case and the relevant Member State operates a real seat test in its company law, the company would have to be liquidated in that Member State. In such a case, tax will also become due on the hidden reserves of emigrated assets. However, when a Member State does not use the real seat test in its company law, in order to protect Member States' taxing rights, the establishment of a final settlement tax for the purposes of Article 31 is also necessary.

\subsubsection{THE "ESCAPE ClausE"}

Article 31 of the proposed CCCTB Directive applies to transfers of assets towards all third countries with an exception to transfers towards EEA Member States if there is an agreement on the exchange of information between that State and the CCCTB Member State of the resident taxpayer or of the permanent establishment comparable to Directive 2011/16/EU. The latter can be seen as the "escape clause" for the deemed capital gains taxation. Due to the limited scope of the "escape clause", it is necessary to consider two additional aspects: (i) which agreements would satisfy the comparability requirement; and (ii) whether EU law, in particular the TFEU provisions on the free movement of capital, require the extension of the scope of the "escape clause".

It is settled case law of the CJEU that a taxpayer cannot be denied access to the fundamental freedoms, except in situations in which the taxpayer is involved in abusive practice(s) or where he is not in a situation covered by the Treaty. ${ }^{884}$ Furthermore, it is generally accepted that taxation would be rendered illusory if Member States were not allowed to supervise compliance by its taxpayers. Thus, the effectiveness of fiscal supervision serves as a separate justification ground before the CJEU. ${ }^{885}$ The refusal of deferred taxation could be justified on the grounds of combating tax avoidance and the effectiveness of fiscal supervision. Nevertheless, even if appropriate,

${ }^{884}$ Case Werner (C-112/91).

885 See generally Hemels (2009), 583-91. 
the national measure must also be proportional to its aim, i.e. it shall not go further than necessary to attain the objectives pursued, in accordance with the principle of proportionality. The question is whether the requirement for the existence of an agreement on the exchange of information with the EEA Member State makes the CCCTB measure disproportional to its aim. The Court has consistently held that, where the legislation of a Member State makes the granting of a tax advantage dependent on satisfying requirements, compliance with which can be verified only by obtaining information from the competent authorities of a third country, it is in principle legitimate for the Member State to refuse to grant that advantage if, in particular, that third country is not bound under an agreement to provide information, it proves impossible to obtain such information from that country. 886 According to Advocate General Bot, if the national tax authorities are in a position to carry out such checks using their own resources, the absence of a convention providing for the exchange of information with the third country concerned does not preclude the Member State from conducting genuine and effective supervision of compliance with its legislation. ${ }^{887}$ Consequently, in the absence of an agreement on the exchange of information, national legislation cannot rule out, as a matter of principle, that the taxpayer may be in a position to provide relevant documentary evidence enabling the tax authorities of the Member State imposing the tax to ascertain, clearly and precisely, whether the taxpayer satisfies the requirements for receiving the tax advantage in question. 888 This is relevant when national legislation does not make the granting of a tax advantage dependent on satisfying requirements, compliance with which can be verified only by obtaining information from the competent authorities of a third State. In such a case, proof provided directly by the taxpayer should be acceptable. Compliance in satisfying requirements for the granting of a tax deferral on transferred assets for the purposes of the CCCTB definitely requires information from the competent authorities of a third State. In the light of the CJEU judgment in $A$., the relations between the EU Member States take place against a common legal background, characterised by the existence of Union

\footnotetext{
886 Cases A. (C-101/05), para. 63; CFC and Dividend Group Litigation (C-201/05), para. 95; Persche (C-318/07), para. 70; Rimbaud (C-72/09), para. 44; Haribo and Salinen (Joined Cases C-436/08 \& C-437/08), para. 67.

887 Opinion of Advocate General Bot delivered on 11 September 2007 on case $A$. (C-101/05), para. 145

888 Case Peeters (C-544/11), paras. 52-57.
} 
legislation, such as Directive 2011/16/EU on mutual assistance. That directive establishes a framework for cooperation between the competent authorities of the Member States that does not exist between those authorities and the competent authorities of a third country, where the latter has given no undertaking of mutual assistance. 889 Therefore, the possibility for a taxpayer to provide documentary proof in an intra-EU context is based on, and accordingly dependent on, the existence of the general system of exchange of information, as introduced by the Mutual Assistance Directive. ${ }^{890}$ It follows that a taxpayer cannot rely on the possibility to provide proof to the contrary when there is lack of any obligation on the tax authorities of the third country to lend assistance. ${ }^{891}$ Moreover, based on X and Passenheim-van Schoot, when tax authorities of a Member State have no evidence to enable them to initiate an investigation, e.g. based on an exchange of information agreement, the automatic exclusion of the tax deferral in the case of a transfer of assets towards EEA Member States would not constitute a disproportional restriction to the fundamental freedoms. ${ }^{892}$ In the light of the foregoing, the requirement for an agreement on the exchange of information for the purposes of granting a tax deferral would not, by itself, be disproportional.

However, another question is whether the fact that the proposed CCCTB Directive requires the standards of the agreement on the exchange of information with the EEA Member States to be as high as those provided in the Directive 2011/16/EU renders the measure disproportional to its aim. Directive 2011/16/EU provides for the following three means of exchange of information in Chapter II: (i) exchange of information on request (Section I); (ii) mandatory automatic exchange of information (Section II); and (iii) spontaneous exchange of information (Section III). EU Member States have access to a wide range of international instruments for the exchange of information between Member States and with third countries, such as the Convention on the Mutual Administrative Assistance in

\footnotetext{
${ }^{889}$ Case $A$. (C-101/05), para. 61.

890 Therefore, if the CCCTB Directive was introduced via enhanced cooperation, measures restricting capital movements to non-CCCTB EU Member States would not be proportionate if the taxpayer was able provide documentary evidence for the purposes of receiving the relevant tax benefit.

${ }^{891}$ Case Rimbaud (C-72/09), para. 50.

892 Case Passenheim-van Schoot \& X (Joined Cases C-155/08 \& C-157/08).
} 
Tax Matters ${ }^{893}$ exchange of information and mutual assistance in recovery in the tax claims on the basis of DTCs, ${ }^{894}$ tax information exchange agreements (TIEAs), ${ }^{895}$ and the Nordic Convention on Mutual Assistance in Tax Matters. ${ }^{896}$ The Convention on the Mutual Administrative Assistance in Tax Matters and DTCs based on the OECD MC have a broad scope of application and may serve to be sufficiently comparable because they include instruments, such as the spontaneous and automatic exchange of information as well as exchange of information on request. ${ }^{897}$ The TIEAs, on the contrary, include exchange of information only upon request and seem therefore incomparable to Directive 2011/16/EU. However, what should matter is the fact that Member States are able to exchange information to an extent that enables them to effect the correct assessment of taxes. ${ }^{898}$ Consequently, the CCCTB provisions provide for the deferral in the case of EEA Member States only if the exchange of information corresponded to the standards set forth in Directive 2011/16/EU would be disproportional to its aim.

On the other hand, exchange of information goes hand-in-hand with mutual assistance on the recovery of tax claims. Hence, only to the extent that exchange of information is accompanied by an agreement on the recovery of the tax claims, the limitation set forth in the current CCCTB proposal seems to be disproportional. For the sake of clarity, the condition for the recovery of tax claims should also be included in the escape clause of the CCCTB Directive. In this case, the CCCTB Directive would meet the requirements set by the CJEU in National Grid Indus ${ }^{899}$ in which the Court focused on the payment

\footnotetext{
893 The Convention on the Mutual Administrative Assistance in Tax Matters is a joint initiative of the OECD and the Council of Europe entered into force on 1 April 1995. The Convention was amended through the entry into force of a Protocol on 1 June 2011.

${ }^{894}$ Article 26 of the OECD MC for the exchange of information and Article 27 of the OECD MC for the mutual assistance in the collection of taxes.

895 TIEAs are a result of the OECD Report entitled Harmful Tax Competition: An Emerging Global Issue of 1998 (OECD (1998)). TIEAs are often concluded with jurisdictions, which are considered tax havens and with which the conclusion of DTC is not attractive for a country. TIEAs may be structured by the OECD Model Agreement on the exchange of information on tax matters (OECD 2002).

896 The Nordic Convention on Mutual Assistance in Tax Matters was signed by all Nordic States, including those that are not EU Member States. The Convention covers both supply of information and assistance in tax recovery.

${ }^{897}$ Articles 5-7 of the Convention and OECD Comm. on Article 26, para. 9.

${ }^{898}$ Kemmeren \& Smit (2013), 100.

${ }^{899}$ Case National Grid Indus (C-371/10).
} 
of taxes rather than the levying of taxes by the relevant Member State.

Next, there would be no deferral with regard to any other third country, even if there were an appropriate exchange of information agreement between the relevant States. According to the European Commission, the immediate collection of tax at the moment of the transfer of assets to a permanent establishment in a third country constitutes a restriction on the free movement of capital, ${ }^{900}$ unless there is a lack of administrative co-operation between the country of emigration and the third country. ${ }^{901}$ In the light of this premise, the limitation stemming from Article 31 of the proposed CCCTB Directive with regard to third countries, other than EEA Member States, would constitute a restriction on the free movement of capital, as it would make it less attractive for capital movements between those third countries and Member States compared to internal transfers of assets within the same Member State. The restriction may be justified based on the need to guarantee the effectiveness of fiscal supervision, as discussed earlier. Such restrictions to the free movement of capital may also be justified by the objective of ensuring the balanced allocation of taxing powers between the CCCTB Member States, taken collectively, and the third country. ${ }^{902}$ The transfer of an asset from a Member State to a third country cannot mean that the Member State of origin has to abandon its right to tax a capital gain that arose within the ambit of its powers of taxation before the transfer. Thus, in accordance with the principle of fiscal territoriality linked to a temporal component, a Member State is entitled to charge tax on those gains at the time when the asset leaves the country. Such a measure is intended to prevent situations capable of jeopardising the right of the Member State of origin to exercise its powers of taxation in relation to activities carried on in its territory, and it may therefore be justified on grounds connected with the preservation of the allocation of powers of taxation between the Member State and third countries..$^{903}$ However, from the author's perspective, the aim of the provision

900 It is noteworthy that in a pending case Commission v Denmark (C-261/11), the European Commission has challenged the Danish legislation which provides for immediate exit tax of companies' transfers of assets to another Member State without taxing corresponding transfers of assets within Denmark only against the freedom of establishment.

901 European Commission (2006n), section. 5

902 Gutmann (2013), 270.

903 See by analogy the wording of case National Grid Indus (C-371/10), para. 46. 
can also be achieved in the case of deferred taxation of capital gains. In conclusion, there should not be a difference whether the capital movement is made to an EEA Member State or any other third country to the extent that that country exchanges information, accompanied with an agreement on the recovery of tax claims, with the relevant CCCTB Member State ${ }^{904}$ through a DTC, a TIEA or any other instrument. ${ }^{905}$

\subsubsection{PRELIMINARY CONCLUSIONS}

The proposed CCCTB Directive correctly makes entering the CCCTB system tax neutral. Indeed, according to the current proposal, entering a CCСТB group will not trigger the taxation of hidden reserves on fixed assets. Furthermore, in order to protect Member States' tax bases, any gain derived from the alienation of such assets during five years following the entry will not be added to the CCC tax base, but it will form part of the tax base of that individual group member after apportionment. However, if that fixed asset is disposed of after the five-year period, the respective proceeds are shared between the group members according to the apportionment formula. It was illustrated that, in some cases, such a rule may lead to distortions by means of double taxation, in particular, where the asset is economically linked to a permanent establishment of a non-resident company. From the author's point of view, the relevant CCCTB rule should be acceptable as it links to the logic of group taxation. Inconsistencies arising from the application of this rule should be dealt with by the Member States in their DTC with third countries.

The CCCTB exit rules are particularly relevant when the leaving group member has become an economic owner of a fixed nondepreciable or individually depreciable asset. When such an asset is sold during the three years after exiting the group, the proceeds are added to the CCC tax base and apportioned only between the remaining group members. First, as no share is attributed to the

\footnotetext{
904 It is noteworthy that, unlike the Directive $77 / 799 / \mathrm{EC}$, which was repealed by the Directive 2011/16/EU, the latter provides for automatic exchange of information received by one Member State from a third country to another Member State. Accordingly, Article 24 of the Directive provides for an obligatory sharing of information from non-EU Member States, in so far as this is allowed pursuant to an agreement with the relevant third country.

905 Case Haribo and Salinen (Joined Cases C-436/08 \& C-437/08), paras. 64-75.
} 
former group member, the exit State would be deprived from taxing any revenue. Furthermore, from the author's point of view, such a provision - aiming at defending Member States' tax bases - may conflict with their DTCs with third countries. In particular, Article 13(5) OECD MC allocates taxing rights of capital gains only to the State of residence. In the absence of a specific provision in a DTC to regulate such a matter, the income would be taxed in both jurisdictions, the CCCTB and the State of the head office. A solution would be to levy an immediate exit taxation ${ }^{906}$ prior to the group member leaving the CCCTB group, as such taxation is not contrary to international tax law. Such a rule would also comply with the fundamental freedoms, as confirmed in National Grid Indus. The same conclusion holds true in the case of a transfer of assets towards third countries. It would be further important to agree on relevant step-up provisions on such (deemed) capital gains taxation, as otherwise the capital gain would be taxed twice by the migration State and the State of the head office.

The proposed CCCTB Directive includes only rules with regard to business reorganisations within the group and between two or more CCCTB groups. Reorganisations concerning third-country establishments generally follow the rules concerning a group member entering or leaving. The author discussed a number of examples related to mergers involving third-country establishments. First, it was concluded that when a CCCTB resident parent company leaves the group due to a merger with a third country company, the CCCTB group should continue to exist as long as at least two group members continue to exist. In such a case, a new principal taxpayer must be appointed. When the exit of a group member triggers the termination of a group (e.g. when less than one group member is left), the two transactions take place simultaneously. In such a case, the relevant capital gains and apportionment to group members takes place immediately before the group is terminated. In case of a division, where a group member is dissolved, so that it transfers all its assets and liabilities to two or more existing new companies, it is difficult to uphold that the previous group term continues to exist.

\footnotetext{
906 In case of nationals from non-CСCTB Member States and EEA Member States, each CCCTB Member State should provide for a possibility for the deferred payment of taxes. Such a requirement was made clear in National Grid Indus (C$371 / 10)$, para. 73 et seq.
} 
Consequently, the remaining taxpayer has to form a new CCCTB group..$^{907}$

Transfer of assets from a CCCTB head office to its foreign permanent establishment, and vice versa, generally triggers exit taxation under the proposed CCCTB Directive. The first point here is that changes in the definition of a permanent establishment may lead to undesirable results. In particular, the scope of permanent establishment will be determined by its existence under the CCCTB Directive and Member States' DTCs with third countries. In case of divergent definitions, the transfer of an asset may be recognised in one jurisdiction, while it may not be recognised in the other jurisdiction. However, until conflicting DTCs are renegotiated, Member States must continue to observe their obligations and respect the rights of third countries that derive from those DTCs. The author further elaborated on the "escape clause" from the exit tax on deemed capital gains with regard to the transfer of assets towards third countries that are a party to the EEA Agreement. The clause contains a further requirement that that country must exchange information based on an agreement between that State and the Member State of the resident taxpayer or of the permanent establishment comparable to Directive 2011/16/EU. From the author's perspective, such a requirement may constitute an infringement of the freedom of establishment and the free movement of capital contained in the EEA Agreement. In particular, tax benefits should be granted to a taxpayer when competent authorities of the Member State are able to assess, clearly and precisely, whether such benefits should be available based on accessible information, despite how such information has been gathered, i.e. through automatic or spontaneous exchange of information or exchange of information on request. However, this holds true only when exchange of information is accompanied by with an agreement on the recovery of the tax claims. Last, the requirement for an agreement on the exchange of information, for the purposes of obtaining deferred taxation on deemed capital gains, would also restrict the free movement of capital towards other third countries, because it would make it less attractive for capital

907 Article 105 of the proposed CCCTB Directive requires taxpayers to continue applying the system for the remainder of the term. Consequently, if a group member is dissolved, with a consequence that the CCCTB group is terminated, the remaining group member (now as a single taxpayer) is obliged to form a new CCCTB group due to the all-in / all-out principle. 
movements between those third countries and Member States, compared to internal transfers of assets within the same Member State. Justifications on such a restriction would be disproportional to the aim when the there is sufficient exchange of information, supplemented by an agreement on the recovery of tax claims between the relevant States.

\subsection{FLASHBACK TO US SUB-NATIONAL EXPERIENCE}

Most states use the federal tax base as the starting point for measuring the total taxable income and they make adjustments to this amount to reflect certain state economic and social policies by adding back items, which are deductible from the federal taxable income (state income taxes, foreign income taxes and capital losses) or by subtracting items (e.g. certain inter-company dividends). The states also offer various credits, depreciation rules, investment incentives for the income, etc., which are not available at the federal level.908 The fact that states' tax laws are not identical results in a situation in which a single federal tax base is transformed into 45 different tax bases. Moreover, they do not automatically adopt the federal definition of the taxable group but often use the concept of "unitary business" for determining a group. Because the concept of "unitary business" for state tax purposes differs considerably from the consolidated group for federal tax purposes, the determination of the tax base of a unitary group often differs from the consolidated income calculated for federal tax purposes.

The starting point for the US states using formula apportionment is to determine the income of companies arising in the ordinary course of trade or business. Standard rules adopted by the states apportion business income by formula and allocate non-business income by source. In the case that unitary taxation is applied for groups, there are two basic elements to the composition of a combined report of that group: (i) the determination of income of the unitary business and (ii) the calculation of the relevant factors. To determine the amount of tax due, the income (or loss) and the apportionment factors of all members of the unitary group are combined as if they were a single entity. ${ }^{909}$

908 Weiner (2006), 65.

${ }^{909}$ Fox et al. (2009), 400. 
Under the Due Process Clause and the Commerce Clause, states cannot tax income if there is a lack of sufficient nexus between the income and the state. However, income earned by a foreign corporation from out-of-state activities is deemed to have a nexus with that state if some or all of its income is earned by a unitary business (i.e. business income) that has a sufficient nexus with that state. Income that does not form part of the income of a unitary business (e.g. non-business income) of a group member cannot be taxed in that state. Consequently, business income can be subject to apportionment where a relevant nexus exists, while non-business income is generally assigned to a designated state by using specific allocation rules, typically to the state of the taxpayer's commercial domicile ${ }^{910}$ or asset-specific jurisdiction. ${ }^{111}$ As follows, the perplexity of state taxation does not only cover the determination of a group based on the notion of unitary business - as discussed in the previous Chapter - but also the inclusion and exclusion of types of income from the state tax base and the flows between the members of unitary business. States' experience shows that differentiating between various types of income earned within corporate taxpayer - some being subject to formula apportionment and others not (or being subject to a divergent formula apportionment) - often leads to conflicts between taxpayers and competent authorities.

In line with UDITPA, the determination of the state tax base of a corporate taxpayer has two steps. First, the taxpayer divides its income into "business income" and "non-business income". Business income is income arising from transactions and activity in the regular course of the taxpayer's trade or business and non-business income is all income other than business income. ${ }^{912}$ A majority of states identify business income based on a "transactional test" and/or a "functional test", in line with the MTC suggestion. ${ }^{913}$

910 Usually non-business interest, dividends and gains or losses from sales of intangibles. "Commercial domicile" is the principal place from which the trade or business of the taxpayer is directed or managed (Section 1(c) of the UDITPA).

911 Non-business gains and losses from sales of real property are typically allocated to the state in which the asset is located and rents and royalties to the state in which the property is used.

912 Section 1(a) and (e) respectively.

913 The "transactional test" implies that an income is business income if it arises from transactions and activity in the regular course of business or trade of the taxpayer. The "functional test" means that gains and losses from property shall be 


\section{6 .2}

The US' experience may give some thoughts with regard to the taxation of dividend income from non-consolidated affiliates. While the UDITPA allocates (taxable) inter-corporate dividends to the state of commercial domicile of the recipient, the US Supreme Court has been of the opinion that dividends, which are part of the unitary business income of the recipient, can be subject to apportionment. The constitutional clauses of Due Process and Commerce limit the apportionment of dividends from subsidiaries not included in a combined report only to cases where the payer and the recipient company of the dividends conduct a unitary business with each other or if the holding by the recipient company serves an operational function instead of a mere investment function. ${ }^{914}$ It is noteworthy that such an approach is not limited to domestic subsidiaries and dividends from foreign subsidiaries may also be included in the business income. ${ }^{915}$

The inclusion of dividends received from subsidiaries in the apportionable income base, without including the subsidiaries' factors in the apportionment formula, produces a more burdensome effect than applying worldwide combined reporting, which apportions the combined income by means of the combined factors of the taxpayer and its subsidiaries. ${ }^{916}$ However, several companies have failed to argue that, under the water's edge principle, the inclusion of foreignsourced income without factor representation infringes the Commerce Clause. For instance, Caterpillar ${ }^{917}$ argued that the water's edge combined report method coupled with the inclusion of foreignsource royalty and interest income in the tax base, without subjecting them to global apportionment (i.e. as if they were made by unrelated businesses), violated the Foreign Commerce Clause, because such income was treated disadvantageously compared to those received from domestic intra-unitary group transactions. However, the relevant state courts pointed out that the discrimination analysis required a comparison between foreign subsidiaries and unrelated

regarded as business income if that property forms an integral part of the taxpayer's regular trade or business operations. The MTC revised Model Regulation suggests that the two tests can be alternatives to each other in IV.1.(a).(4) and (5). MTC (2006).

914 Mayer (2009), Chapter 3.2.4.4; Case Allied-Signal (504 U.S. 768).

915 Case Mobil Oil Corp. (445 U.S. 425).

916 Peters (2001), 1312.

917 Case Caterpillar Inc. (No. 97-779). 
domestic entities, because the water's edge combined report method treats foreign subsidiaries as unrelated entities and not as part of the taxpayers unitary group. Therefore, as long as the state law treats these two groups of entities alike, no discrimination occurs against the foreign subsidiaries under US constitutional law.

The water's edge combined reporting without the elimination of foreign-source dividends, interest and royalties can lead to questions concerning equity and fairness. This is especially true when foreign dividends represent a substantial percentage of the apportionable income base because, unlike royalty and interest payments, dividend distributions do not lead to tax-deductible costs. In that case, some adjustment should be made to the standard apportionment formula. Some states employ specific methods to deal with foreign dividends. For instance, under the "Detroit method", the denominators of the parent corporation's property, payroll and sales are increased by adding a portion of the dividend-producing foreign corporation's property, payroll and sales. The portion is determined by dividing the net dividends received by the parent by the foreign subsidiaries' net profits. Such an apportionment formula ultimately lowers the multiplier used against a taxpayer's total income, which in turn lowers the state tax base. However, the "Detroit method" has been considered to violate the US Constitution if only foreign dividends are included in that way but domestic ones are excluded. ${ }^{918}$

The "Augusta method", upheld by the Maine Supreme Judicial Court, ${ }^{919}$ employs three different computations of taxable income of a combined group:

1. The water's edge combined reporting with foreign source dividends included in the tax base to be apportioned;

2. The worldwide combined report method; and

3. The water's edge combined method without foreign-source dividends included into the tax base to be apportioned..$^{920}$

Under this method, the corporate tax base is computed as follows:

a) If 2 exceeds 1 , taxable income is calculated under 1 ;

b) If 2 is less than 3 , income is calculated under 3 ; and

c) If 1 exceeds 1 and 2 exceeds 3 , income is calculated under 2.921

\footnotetext{
918 Case Conoco Inc. and Intel Corp. (931 P.2d 730) [1996]

919 Case E.I. du Pont De Nemours (675 A.2d 82).

920 Peters (2001), 578.

921 In other means, if i) $1<2=1$, or ii) $2<3=3$, or iii) $1>2>3=2$. Ibid., 578 .
} 
Another issue concerning the taxation of dividends from affiliated companies concerns the so-called dividend received deduction (DRD) that the states have generally copied from the federal rules. Under this rule, the recipient company can generally exclude all or part (usually 70 or 80 per cent depending on the ownership in the affiliate) of the dividends from their tax base to avoid economic double taxation at corporate level. The various DRD rules especially have led to many disputes between taxpayers and the states authorities. ${ }^{922}$ For example, in General Electric ${ }^{23}$ the taxpayer argued that disallowance of a DRD with regard to dividends received from foreign subsidiaries that did not have business activities in New Hampshire violated the (Foreign) Commerce Clause of the US Constitution. According to the New Hampshire's domestic law, unitary businesses were required to file a combined report on a water's edge basis. Furthermore, a parent company was allowed a DRD for dividends received from foreign subsidiaries only to the extent that the foreign subsidiary had activities in New Hampshire and paid business profit tax there. General Electric, the parent company of a large number of foreign and domestic subsidiaries, as well as some of its domestic subsidiaries had a place of business in New Hampshire, but none of its foreign subsidiaries carried out business in that state during the tax year at issue. Because of the water's edge rule, none of the foreign subsidiaries of General Electric were included into the combined return. Consequently, General Electric was denied a deduction of dividends it received from its foreign subsidiaries, while dividends from domestic subsidiaries were eliminated in the water's edge report. The relevant court decided that, since the earnings of a subsidiary with operations in New Hampshire and a foreign subsidiary with no such operations are each taxed only once by New Hampshire, the respective provision did not violate the US Commerce Clause. Consequently, according to the court, there was a taxing symmetry and no differential treatment that benefited intrastate commerce over interstate or foreign commerce existed. However, the decision does not take into account the fact that dividends from foreign subsidiaries not doing business in New Hampshire were included in the parent's business tax base while dividends from subsidiaries included in the combined report were eliminated. Therefore, the inclusion of the factors of a domestic

922 For further discussion, see McLoughlin (2007), 175-182; Hodges, Sutton \& Yesnowitz (2008), 49-56; Sollie \& Kleier (2010), 693-698;

${ }_{923}$ Case General Electric Co. (No 2005-668). 
subsidiary into the combined report but the absence of factor representation for the foreign subsidiaries' apportionment factors resulted in a higher burden being placed on the foreign subsidiary. Consequently, such a state measure discriminates against foreign subsidiaries distributing dividends by favouring investments in companies that do business in New Hampshire and is, therefore, arguably contrary to the Commerce Clause. ${ }^{924}$ It was mentioned earlier that the New Hampshire court had previously rejected the idea that factor representation was constitutionally required when taxing interest and royalties received from a foreign affiliate by New Hampshire's water's edge group. ${ }^{925}$

Some states have enacted specific interest deduction limitations concerning dividends that are deductible from the tax base of the recipient. For example, in California, if a taxpayer cannot prove that an interest was not attributable to its investment in foreign subsidiaries, which paid the deductible dividends, it may lose the right to deduct interest from its taxable base. ${ }^{926}$ Nevertheless, if the dividend is paid out of previously taxed earnings, the dividend from a foreign subsidiary can be eliminated, even if the latter is not currently included in a worldwide combined return. ${ }^{927}$ In such a case, the taxpayer would benefit from both the elimination of the dividend received as well as the interest expense deduction. Earnings and profits are previously taxed if, for example, they were earned by a foreign subsidiary during a prior year when it was included in the worldwide unitary group or if the earnings had been formed as part of subpart $\mathrm{F}$ income, which was included in the tax base of a water's edge group. ${ }^{928}$ In comparison, dividends paid between members of California unitary group corporations are eliminated, ${ }^{929}$ but any interest deduction cannot be denied as part of the elimination provision. ${ }^{930}$ Importantly, dividends subject to elimination are limited to the earnings and profits generated while the declaring and precipitant corporations were involved with a unitary business. ${ }^{931}$ If dividends between unitary corporations arising from unitary income

\footnotetext{
924 McLoughlin (2007), 175-177.

925 Case Caterpillar Inc. (No. 97-779).

926 California Revenue and Taxation Code section 24344(c).

927 California Revenue and Taxation Code section 25106.

928 Sollie \& Kleier (2010), 694.

${ }_{929}$ California Revenue and Taxation Code section 25106.

930 Hodges, Sutton \& Yesnowitz (2008), 55.

931 Ibid., 55.
} 
can qualify for both deduction and total elimination, the deduction of the dividends are to be taken first ${ }^{932}{ }^{933}$

\subsubsection{GEOGRAPHICAL LIMITATIONS}

There are two main approaches with respect to geographical borders of a unitary business of multinational corporations: (i) states applying worldwide combined reporting and (ii) states applying separate accounting at the water's edge. Worldwide combined reporting also extends the practice of unitary combination to foreign companies and deems them to be engaged with domestic affiliates, even if the former lacks activities in the state. On the contrary, water's edge combined reporting treats foreign affiliates not operating within the United States as distinct entities for taxation purposes. The MTC report suggests using elective water's edge approach with regard to the net business income or loss of a unitary group. Although the US Supreme Court upheld the worldwide combined reporting method in Barclays, many US states did not return to worldwide combination after the case. The states' water's edge regimes also continued to be used due to the pressure from the federal government and US trading partners. ${ }^{934}$ Almost all of the states that require combined reporting have included either water's edge election or some other statute that permits the exclusion of certain foreign income. ${ }^{935}$

\subsubsection{THE US DTC LIMITATIONS}

Since the US Constitution gives the exclusive responsibility for international tax relations to the federal government, the states are prohibited from negotiating DTCs with foreign nations. Moreover, the US DTCs generally apply only to federal income taxes as imposed by the IRC but not to state and local income taxes and corporate franchise taxes. Thus, the US DTCs do not directly limit the states

\footnotetext{
932 The CCCTB system does not directly deal with this issue. If a member of a group has left a CCCTB group, some income will be attributed to it and any following dividend payment will be treated as a regular dividend payment from third parties. If a company enters a CCCTB group, dividend payments between group members are eliminated. Hence, the CCСTB rules do not make a difference between pre-entry profits and profits generated during CCCTB group membership. For example, specific transposition rules will have to be drafted for companies resident in Estonia, which currently does not tax retained profits until they are distributed.

933 Hodges, Sutton \& Yesnowitz (2008), 55.

934 McLure (2007), 174.

935 Fox et al. (2009), 405.
} 
from exercising their taxation over income from businesses, which create a sufficient nexus with the state. Consequently, doing business via a branch in the US might not prevent the state from including the income from its foreign operations into the state's apportionment, even if the income is excluded from the federal tax base.936 Such worldwide taxation was confirmed in Reuters, 937 where the relevant court rejected the application of the non-discrimination clause of the DTC between the US and the United Kingdom to worldwide taxation of unitary business.

\subsubsection{PRELIMINARY CONCLUSIONS}

Most US states use the federal tax base as the starting point for measuring the total taxable income and make adjustments to this amount to reflect certain state economic and social policies. As a result, the single federal tax base is transformed into 45 different tax bases. In the EU, the Member States do not have a common tax base, which they could use as a starting point for establishing their taxing rules. Instead, their tax laws are based on divergent principles and take into account their specific economic and social policies. Consequently, companies doing business across the EU face 28 different tax systems. The EU could gain its competitive advantage through extensive approximation of laws, in particular, by the establishment of a common system, such as the CCCTB.

The US states using unitary business with formula apportionment look at the income of the unitary group, which is first apportioned to each State where the group members have a sufficient nexus, and only then it is attributed to a specific group member. The CCCTB uses a different technique by, first, calculating the tax base of each group member and thereby aggregating the tax bases of all the group members and only then apportioning the tax base between all the relevant group members. Therefore, there is a fundamental difference between the apportionment formula used by the US states and that proposed for the CCCTB system: the former attributes income to a particular State while the latter shares the tax base between the group members. Thus, for example, for the US subnational tax purposes it is not so relevant which group member owns the asset, which forms part of the apportionment factor, but in which state the asset is located. On the contrary, the CCCTB sharing

936 Faber (2000), 1049-1050.

${ }_{937}$ Case Reuters Ltd (82 N.Y.2d 112) 
mechanism allocates the (fixed tangible) asset to a particular group member, which is usually the economic owner of the asset. Due to the difference in the definition of the CCCTB group and the apportionment formula, it is particularly important that transactions between CCCTB group members are recorded, even though they are eliminated.

The starting point for the US states using formula apportionment is to determine income of companies arising in the ordinary course of trade or business on either a worldwide basis or limited to the water's edge. Standard rules adopted by the states apportion business income by formula and allocate non-business income by using specific allocation rules. This limitation is imposed by the US Constitutional Clauses of Due Process and Commerce, which prohibit states from taxing income if there is a lack of a sufficient nexus between the income and the state. Consequently, income earned by a foreign corporation from out-of-state activities is deemed to have a nexus to that state if some or all of its income is earned by a unitary business (i.e. business income) that has a sufficient nexus with that state. Income that does not form part of the income of a unitary business (e.g. non-business income) of a foreign corporation not operating in that state cannot be taxed in that state. The EU Member States do not face similar constraints as the US states. Nevertheless, as States, they have to respect other nation's fiscal sovereignty and obligations stemming from their agreements, such as their DTCs. Taking into account these requirements, compared to the US subnational system, the CCCTB has been built upon a completely different basis. In particular, it uses the residency principle, so that it includes all the worldwide income, despite its source in the CCC tax base, and the source principle, in that it taxes the income of non-residents that has sufficient economic links to the CCCTB territorial scope. Furthermore, it does not distinguish between business and non-business income. By this "allinclusive" approach, the CССТВ system aims to avoid complex disputes between taxpayers and tax authorities such as those taking place between states' tax authorities and businesses in the US. Moreover, it is generally accepted among States that all income derived by an enterprise should be treated as ordinary business income. 
Having defined the personal scope of the CCCTB in the previous Chapter, the principal aim of the current Chapter was to determine the income to be included into the CCСTB tax base. Throughout the dissertation, the author has made references to the US subnational taxation systems, which often use formula apportionment for the division of the business tax base among the states. However, as it follows from this, the US states and the CCCTB system have been built upon fundamentally different principles for group taxation: while the former looks for the existence of a sufficient nexus to a particular state, the CCCTB is primarily built on the residency principle. Moreover, the two jurisdictions have been structured to serve different objectives. Also, importantly, the US states and the EU Member States are subject to different constraints in taxing a particular income. The US states are primarily limited by the Due Process Clause and the Commerce Clause of the US Constitution, which prohibit the states taxing income in the absence of a sufficient nexus between the income and the state, but they are generally not limited by the DTCs of the US with foreign nations. The EU Member States are autonomous States, which implies that they are free to negotiate DTCs with other nations in order to allocate taxing rights between them. Despite such competence, the Member States must also respect their obligations stemming from EU law, essentially related to the fundamental freedoms and the vision of a single market, when designing their taxation rules. Against this background, to design a CCCTB system, which would protect the EU Member States' fiscal sovereignty but at the same time would accommodate their obligations, with a reference to the US subnational systems should not be overrated.

In the current Chapter, the author focused essentially on three situations: (i) outbound investments of CCCTB residents, (ii) inbound investments of CCCTB non-residents and (iii) corporate reorganisations. First, the author concluded in the previous Chapter that the CCCTB group definition should be limited to water's edge, as the European Commission also currently proposes it. Consequently, non-residents, without carrying out business via a permanent establishment in a CCCTB Member State, should not calculate their income from that Member State according to the CCCTB rules. On the contrary, with regard to the taxation of the foreign income of resident companies, the taxation of worldwide income seems to be the most optimal choice. Furthermore, the 
simplest approach is to treat different streams of income, such as business income, income from dividends, interest or royalties, as ordinary business income and include it in the apportionable CCC tax base. If the CCCTB were based on a territorial system, foreign income of CCCTB residents would be excluded from the material scope of the Directive and, thus, left for the Member States' taxing competence. However, the fact that the majority of Member States currently tax on a residence basis would not eliminate the current disadvantage of the EU compared to other competitive markets, which is the existence of 28 different taxation systems. In case of the taxation of the worldwide income of residents, international tax neutrality, which requires that income should be taxed only in the jurisdiction to which the income can economically be linked, can largely be achieved through the method of avoiding double taxation by means of either the exemption method or credit method.

A worldwide reach of the CCCTB group definition is unrealistic, mainly because it would contradict most Member States' DTCs with third countries and be unfeasible in practice. Consequently, the CCCTB rules need to be supplemented with appropriate source rules. The proposed CCCTB Directive source rules can roughly be divided into two categories: (i) income derived through a CCCTB-located permanent establishment and (ii) other income. By making this distinction, the proposed CCCTB system avoids potential conflicts with Member States' DTCs with third countries. For example, the CCCTB system makes a direct link to Member States' national law with regard to source taxation of dividends, interest and royalty payments to non-residents. Further, the proposed CCCTB system rightly extends the CCСТВ group definition to permanent establishments of non-resident companies. However, by doing so, the system risks taxing the income attributed to the permanent establishment twice. In particular, the common international approach is to apportion income to a permanent establishment based on the AOA / arm's length principle, while the CCCTB shares income between group members based on a predetermined formula, having regard to the AOA if the head office or the permanent establishment is located abroad. If the results of the two systems do not match, the income will be taxed twice, in the amount corresponding to the difference between the results of the permanent establishment tax bases attributed to it under different methods. ${ }^{938}$ If

938 If the profit attributed to the permanent establishment was higher under the CCCTB than under the arm's length standard, neither double taxation nor double 
the country of the foreign head office uses the credit method for the avoidance of double taxation, it would give credit only for the tax paid in the State of the permanent establishment but not in any other CCCTB Member State.

The author further elaborated on the proposed CCCTB Directive rules on corporate reorganisations. In principle, entering and leaving the system should be tax neutral. In certain cases, the CCCTB rules impose an exit taxation, for example, when a leaving group member has been attributed the economic ownership of a non-depreciable or individually depreciable asset and it subsequently disposes of the asset. From the author's point of view, deferred exit taxes on hidden reserves, the base of which is not settled prior to the departure, are contrary to DTCs that are in line with the OECD MC. Only immediate exit taxes and trailing taxes are acceptable under the OECD MC. Consequently, if the CCCTB Member States wish to levy tax on the hidden reserves of departing group members to third countries, they must do so immediately before the emigration. After National Grid Indus case, the same can be concluded with regard to companies moving between EU Member States.

Initiatives to create a multilateral DTC date back many decades. ${ }^{939}$ Indeed, multilateral DTCs have several advantages, for example advantages of facilitating trade, advantages in preventing or reducing tax avoidance and evasion, administrative advantages, and the potential for preventing tax competition between countries. 940 Multilateral DTCs can be global or between certain jurisdictions or address only certain aspects of international taxation. Having discussed potential problems arising from the parallel application of the CCCTB and Member States' DTCs, Member States may wish to reconsider the adoption of a multilateral DTC with third countries. In fact, it could be agreed that such a multilateral DTC would apply only where transactions affect the CCC tax base. Another option would be

non-taxation would arise. In that case, the profits of the permanent establishment corresponding to the difference between the CCCTB tax base and the arm's length tax base would be taxed once - in the Member State in which the permanent establishment is located.

939 On 12 October 1923, Austria, Hungary, Poland, Italy, Romania, and the Kingdom of Serbs, Croats and Slovenes signed a multilateral DTC. Furthermore, the League of Nations, the EFTA and the European Commission (then Commission of the European Communities) drew up draft MTCs, but they were not generally accepted. Read further Lang (1998), 189.

${ }^{940}$ Brooks (2010), 218-226. 
to agree on an EU model DTC, which stems out of a multilateral DTC, and a commentary, which would apply despite whether the transactions affect the CCC tax base. 


\section{$6.1 \quad$ INTRODUCTION}

A typical income tax system requires taxing profits when earned and allows deducting losses ${ }^{941}$ when incurred. International public law sets limits to the taxing power of countries by requiring a "genuine link" to the territory in order to levy taxes on a given economic event. Following this requirement, domestic and foreign or cross-border situations cannot be treated in identically. ${ }^{942}$ Against this background, EU Member States generally allow offsetting domestic losses but they are unwilling to do so in the case of cross-border losses where they do not have the right to tax the relevant profits. The problem arises especially in the context of taxing the (positive and negative) income of foreign-based legal persons (such as subsidiaries). In the case of permanent establishments, taxing foreign profits and offsetting foreign losses of a resident company is much easier to accept. Indeed, countries typically allow losses of a foreign permanent establishment to be offset against domestic taxable profits of the head office (i.e. losses are suffered within one company), ${ }^{943}$ while they usually reject such offsetting in the case of foreign subsidiaries. ${ }^{944}$ In fact, some EU Member States allow offsetting of losses of a foreign permanent establishment with the profits of the head office. By comparison, while it is the common practice of EU Member States to allow offsetting of profits and losses among domestic corporate group members, only a few Member States include cross-border subsidiaries in their group treatment. ${ }^{945}$

The differences in the consideration of cross-border losses by Member States do not support the most optimal functioning of the EIM. For more than two decades, in order to improve the competitiveness of businesses in the EU, the European Commission has been, among other initiatives, working on the issue of the absence of cross-border loss relief in the EU. In the beginning of

\footnotetext{
941 The term "losses" can broadly be defined as the excess of expenses over revenues for a given period, i.e. the result of a certain tax period is negative. See European Commission (2006r), 5.

${ }^{942}$ Schön (2008a), 815.

${ }^{943}$ It is usually provided that the residence State applies the credit method for the elimination of double taxation of cross-border business income.

${ }^{944}$ In practice, this implies that these Member States give relief for double taxation by credit or tax exemption with a recapture rule. European Commission (2006p), 2. 945 Oestreicher, Spengel, Koch (2011), 10-11.
} 
1990s, the European Commission launched a proposal for a directive providing arrangements for the treatment of losses of pan-European businesses. ${ }^{946}$ However, the proposal was withdrawn ${ }^{947}$ after the European Commission published its communication entitled "Towards an Internal Market without Tax Obstacles"948 and a Staff Paper949 a decade later. The European Commission further published a tax policy document in 2003, indicating that it was considering the Danish "joint taxation system" for the purposes of the EU group regime. The Danish system, in certain cases, enables international groups of companies with Danish parent companies to be taxed as if the subsidiaries were branches, thereby enabling the parent to take into account losses incurred not only by their foreign branches but also their foreign subsidiaries. ${ }^{950}$ Since then, rather than working on a new proposal on loss relief, the European Commission started a comprehensive project on the possibility for a CCCTB, which, among other goals, would foresee a cross-border loss relief 951 for EU groups of companies opting for the system.

Following the Marks \& Spencer ${ }^{52}$ judgment (to be discussed below), the European Commission presented a communication on tax treatment of cross-border losses, ${ }^{953}$ where it emphasised that the lack or limited availability of cross-border loss relief:

- favours domestic investments compared with investments to other Member States;

- favours cross-border investments into larger Member States;

- favours large companies compared to SMEs when it comes to cross-border investment; 954 and

- influences the choice between the form of a secondary establishment, i.e. subsidiary or a permanent establishment. 955

\footnotetext{
946 European Commission (1991).

947 European Commission (2001b).

948 European Commission (2001d).

${ }^{949}$ European Commission (2001a).

950 European Commission (2003b), 9.

${ }^{951}$ For an analysis about corporate average tax rates under the CCCTB and possible methods for international loss offset, see Oestreicher \& Koch (2008).

952 Case Marks \& Spencer (C-446/03).

953 European Commission (2006p).

954 For particular difficulties of SMEs, read further European Commission (2005d).

955 European Commission (2006p), 3.
} 
In the document, the European Commission considered three alternative methods for cross-border loss relief:

- Alternative 1: Definitive transfer of group company losses (without recapture) or profits ("intra-group loss transfer");

- Alternative 2: Temporary loss transfer ("deduction/reintegration method") along the lines of the withdrawn 1990 proposal for a Directive;

- Alternative 3: Current taxation of subsidiary's results ("system of consolidated profits" $"$ ). 957

As follows, attempts to harmonise cross-border loss relief in the EU have not yet been successful. However, in addition to positive harmonisation (integration), the CJEU, in the creation of a common interpretation of the four freedoms and non-discrimination clause guaranteed by the TFEU, has performed a significant amount of (negative) harmonisation within the EU. In its judgments with regard to direct taxation, the Court has repeatedly held that, although direct taxation falls within their competence, the Member States must none the less exercise that competence consistently with Union law. ${ }^{958}$ Such fiscal sovereignty means that Member States are at liberty to define their tax base, within the limits of international law. The CJEU has dealt with the issue of cross-border loss relief but, as it cannot replace the EU legislator, the outcome has been incomplete. ${ }^{959}$ Consequently, until the absence of harmonisation/approximation of Member States corporate tax laws, cross-border loss relief within a group of companies remains generally unavailable in the EU, as confirmed in Marks \& Spencer. ${ }^{960}$

\footnotetext{
956 This alternative was reintroduced as part of the proposed CCCTB Directive in 2011.

957 European Commission (2006p), 8-10.

958 See, for instance, cases Royal Bank of Scotland (C-311/97), para. 19; Manninen (C319/02), para. 19.

959 For instance, cases Futura (C-250/95); AMID (C-141/99); Lidl Belgium (C414/06).

960 Case Marks \& Spencer (C-446/03).
} 
The symmetrical tax treatment of positive and negative income generally means that permanent establishments and subsidiaries may offset their domestic losses against their domestic profits. ${ }^{961}$ Due to that, there appears to be little reason to provide for a possibility of carrying over losses of a permanent establishment or a subsidiary across the border to the head office or to the parent company, accordingly. However, the taxation of the worldwide income of resident companies typically implies that both positive and negative income of a single resident company is integrated into its tax base in its State of residence. As foreign permanent establishments are part of the undertaking of the head office, the (positive and negative) income generated through a foreign permanent establishment is typically automatically included in the tax base of the head office (with subsequent relief for double taxation under the DTC or domestic law of the head office, where necessary). The same is not true with regard to foreign subsidiaries, which are considered as separate legal entities for taxation purposes. Due to the principle of fiscal sovereignty, a parent company's State of residence cannot subject foreign subsidiaries to tax, unless they carry on business in that State. Hence, the tax base of a foreign subsidiary typically does not form part of the tax base of the parent company.962 Similarly, the proposed CCCTB Directive incorporates the worldwide taxation principle of CCCTB group members. However, rather than including the income of a foreign permanent establishment in the CCC tax base, the proposed Directive applies (arguably) the base exemption method on such income. In such a case, both the positive and negative income of the foreign permanent establishment is exempted under the common system. Since the CCCTB group definition is limited at the water's edge, the taxation of income of foreign

961 The fact that positive and negative components of the tax base should be treated symmetrically when they are similar by nature is derived from the guiding principle of neutrality. Gammie et al. (2005), 13-14.

962 It is noteworthy, however, that the subsidiary's results may be reflected in the parent company's results through the valuation of the respective holding in the subsidiary on the parent company's balance sheet. See also, for instance, the judgment in Papillon (C-418/07), in which the Court recognised that, in case of allowing a resident parent company to form a fiscal unity with its domestic secondtier subsidiary, which was held through a foreign first-tier subsidiary, there exists a risk that losses would be used twice (first, by consolidation, and second, because of depreciation of shares in the first-tier subsidiary). Profits of a foreign subsidiary may also be taxed in the parent company's State of residence if it is caught by a CFC provision of the latter State. For further discussion, vide infra at II8.3.3. 
subsidiaries is outside the scope of the Directive. By applying the base exemption method for the elimination of double taxation of business income derived by CCCTB resident companies through foreign permanent establishments, the taxation result of the two forms of secondary establishments - subsidiary and a permanent establishment - becomes alike, even though through a different technique. In both cases, the system is characterised by territorial taxation.

States commonly prevent international double taxation of business income by using either the direct credit method (leading to CEN) or the exemption method (leading to CIN). When a country uses the credit method, it includes foreign profits in the tax base of the resident company and allows a credit for the taxes paid in the foreign country. In such a case, the integration of foreign losses into the tax base of the resident company should also be automatic. As per the exemption method, one needs to distinguish between two submethods: tax exemption and base exemption methods. The base exemption method effectively leads to a territorial taxation, ${ }^{963}$ where the foreign income of a resident company is eliminated from its tax base in the residence State. In this case, both the positive and negative foreign income is ignored for domestic taxation purposes. ${ }^{964}$ The Federal Court of Germany has confirmed this "theory of symmetry", for instance. ${ }^{965}$ If losses in the source State are not

\footnotetext{
963 As referred to earlier, territorial taxation may be achieved either by limiting the tax base to locally sourced income (the pure form) or by exempting foreign source income from the tax base for the avoidance of double taxation (impure form).

964 A taxpayer acting cross-border shall not get the "best of all worlds" and enjoy benefits in one jurisdiction without having obligations in any other jurisdiction. According to the CJEU, cohesion of a tax system may serve as a valid justification for a restriction. This justification ground requires a direct link between a particular tax advantage and an offsetting tax levy (case Bachmann (C-204/90), para. 23). Such a direct link must be examined in the light of the aims and purpose of the national tax measure (case De Lasteyrie du Saillant (C-9/02), para. 67). For a further discussion on the requirements of cohesion of the tax system see Vanistendael (2005), 208-222; Verdoner (2009), 274-282.

965 Schön (2008a), 821-822. Note that it is arguable whether such a theory is indeed in line with the OECD MC Commentaries. According to Vogel, a general limitation on the consideration of foreign losses in the head office's State may be logically consistent with a tax system if the relevant tax law follows the territoriality principle. On the other hand, a general application of the 'theory of symmetry' may result in the creation of a tax liability not existing under domestic law or leads to an increase in domestic tax which would otherwise be lower. To derive such a conclusion from the DTC would violate the principle that a DTC can only restrict domestic tax liability rather than create or enhance it. Vogel (1997), 1182-1184. See also OECD
} 
allowed to be carried over, such losses will never be taken into account by either State. On the contrary, the tax exemption method implies that foreign income of residents is included in the tax base of resident companies with a subsequent deduction of the part of the home State total tax that is attributable to the foreign part of the total result. ${ }^{966}$ Consequently, such a method results in the inclusion of foreign losses with a recapture mechanism.

According to Article 10 of the proposed CCCTB Directive, the tax base of qualifying companies shall include revenues minus exempt revenues, deductible expenses and other deductible items. Exempt revenues are listed in Article 11 of the proposed Directive and include, among other items, received profit distributions and income of a permanent establishment in a third country. From the author's point of view, even though it is not a clear-cut case, the wording of the proposed Directive allows one to conclude that the CCCTB system uses the base exemption method rather than the tax exemption method for the elimination of double taxation of foreign dividends and business income. Under this assumption, the relevant CCCTB Member States are not allowed to include in the tax base neither positive nor negative income attributed to foreign permanent establishments. In that case, there is no need for a recapture mechanism for the reinstatement of such loss deduction in subsequent profitable years of the permanent establishment in the CCCTB Directive. It is noteworthy that, as a way of clarification, the Danish Presidency's compromise proposal specifically provides that losses of foreign permanent establishments are non-deductible from the CCC tax base. ${ }^{967}$

It is generally accepted that, for the purposes of neutrality, companies should pay taxes on the total income they have earned during their existence. Consequently, most countries provide for possibilities for loss carry-over. ${ }^{968}$ Restricting such a possibility would lead to over-

Commentaries on Article 23, para. 44, which do not explicitly exclude the 'theory of symmetry' for foreign loss consideration.

966 Terra \& Wattel (2012), 1021.

967 Council of the European Union (2012), comments on Article 14(j) of the CCCTB Directive.

968 It is noteworthy that on 11 September 1984, the Commission submitted a proposal to the Council which aimed to harmonise the domestic (and not crossborder) rules on the carry-over of losses independently from the other aspects of the tax base as liberally as possible. However, the proposal was withdrawn in 1996. According to the proposal, Member States should allow the indefinite carry-forward 
taxation $^{969}$ of business income. Nevertheless, countries often apply various limitations on loss carry-over, especially concerning the volume (either as a fixed amount or as a percentage of taxable income), type of income or the applicable term when such losses can be carried forward or back.970 The reasons for such limitations are typically linked to administrative considerations, state's budgetary implications and prevention of abuse. The proposed CCCTB Directive foresees a possibility for an indefinite carry-forward supplemented with the FIFO-method (i.e. the oldest losses shall be used first).971 However, the proposal does not provide for a possibility for a loss carry-back. From a business perspective, the option of carrying back losses is desirable for two main reasons: (i) the possibility to recover taxes paid in previous periods in case of losses in the subsequent years; and (ii) loss carry-back conforms to the principle of tax justice and equity. ${ }^{972}$ The reason for preferring loss carry-forward to carry-back from a government's perspective has a fiscal origin in the sense that such a carry-back may lead to difficulties in adapting government income to government expenses if in a tax year a number of claims for tax refunds owing to the availability of carry-back are raised. ${ }^{773}$ Although limitations on loss carry-back are rather common, some Member States still provide that possibility. From that perspective, the CCCTB loses its attractiveness compared to these national tax systems. On the other hand, unlike many Member States, the CCCTB provides for the unlimited carryforward of losses and thus there may be less need to access carryback provisions. Nevertheless, cash flow is one of the key elements

and three-year carry-back of losses. See European Commission (1984); European Commission (1985a).

969 Note that restrictions on loss carry-overs do not lead, strictly speaking, to juridical double taxation, as that concept requires the imposition of comparable taxes by two or more jurisdictions in the same taxable period on the same taxpayer in respect of the same taxable income or capital. Taxation arising from loss carryover limitations is caused by the imposition of tax by one jurisdiction and it affects at least two taxable periods. Also, such a limitation does not lead to economic double taxation, as the concept requires the imposition of comparable taxes by one or more jurisdictions in the same taxable period on different taxpayers in respect of the same taxable income or capital. Taxation arising from loss carry-over limitations is caused by the imposition of tax on the same taxpayer and it affects at least two taxable periods.

${ }^{970}$ For a comparative study involving 50 countries see Post \& Stals (2012), 232-244. See also Oestreicher, Spengel, Koch (2011), 6-7.

971 Article 43 of the proposed CCCTB Directive. See also European Commission (2007a), para. 84 .

972 FEE (2005), 9.

973 Michelsen (1998), 30. 
for businesses and an unlimited carry-forward might not suffice for meeting the expectations of businesses. Hence, from their perspective, the possibility of a loss carry-back remains desirable. It is noteworthy that discussions among the Member States point to a preference to limit the amount of loss available for carry-forward, which in turn eliminates part of the advantage that the CCCTB would offer to companies. ${ }^{974} \mathrm{Next}$, even if a loss carry-back sounds fair and necessary from a business perspective, such a possibility would introduce another difficulty - the negative apportionment of the CCC tax base. In other words, a loss carry-back would require the reassessment the tax results of past years for the entire group due to the consolidation of tax accounts. Consequently, the possibility would likely lead to increased compliance costs for companies and administration costs for tax authorities.

With regard to group losses, the proposed CCCTB Directive establishes a number of rules concerning the following categories:

(i) losses on entering the group (Article 64);

(ii) losses after the group terminates (Article 66);

(iii) losses on leaving the group (Article 69).

Losses falling under the first category, incurred by a taxpayer before entering a CCCTB group, may not be set off against the CCC tax base. Such losses shall be carried forward and may be set off against the apportioned share of the group member according to the rules of the system under which they were incurred (i.e. the national corporate tax system before entering the CCCTB or the CCCTB system before entering a group). ${ }^{975}$ If losses incurred under a different corporate tax system were transferred into the group's CCC tax base, they would lead to the erosion of the tax bases of other Member States where the rest of the group members are tax resident. Such a limitation set on pre-consolidation losses is a policy choice of Member States that takes into account national interests as well as anti-avoidance concerns. ${ }^{976}$

It is noteworthy that the afore-mentioned entering rule applies to both trading losses and capital losses. As the CCCTB system includes

974 Council of the European Union (2012), comments on Article 43(2) of the CCCTB Directive.

975 This policy choice can be found from the Commission earlier documents on the CCCTB. See, in particular, European Commission (2007a), para. 100.

976 Mitroyanni \& Putzolu (2009), 439. 
all capital gains under the ordinary business income, the treatment of capital losses follows the same pattern as the treatment of trading losses. The right to tax realised capital gains arises when the taxpayer ceases to own the asset due to the alienation or disposal of an asset. For CCCTB purposes, a disposal of an asset will only occur if it is sold out of the group or where the economic owner of the asset leaves the CCCTB group. Hence, while trading losses already exist when a company joins a CCCTB group, capital losses can be realised only when the asset is disposed of (including after entering the group). The proposed CCCTB Directive does not lay down a specific rule for a symmetrical tax treatment of capital gains and losses, because such (positive and negative) income forms part of the ordinary business income of the taxpayer. However, this treatment is subject to an exception following five years as of the date when the taxpayer joins a CCCTB group..$^{977}$

Next, the consideration of losses falling in the second category will depend on whether the taxpayer will remain in the system after the group terminates, whether it joins another CCCTB group or whether it leaves the system. Last, when a company leaves the CCCTB group, no losses shall be attributed to it. ${ }^{978}$ Leaving a CCCTB group means that the company will draw its assets away from consolidation, but since no disposal takes place, no gain or loss will be realised under the CCCTB system. Proceeds derived from a future alienation of assets, of which the leaving company is the economic owner, will exclusively be allocated to that company. An exception to this rule concerns non-depreciable and individually depreciable fixed assets and certain financial assets, which will be added to the CCC tax base of the remaining group members if they are disposed of within three years of the taxpayer's departure from the group. ${ }^{979}$

\subsection{LIMITATIONS ON CROSS-BORDER LOSS COMPENSATION WITHIN A GROUP OF COMPANIES}

It is generally accepted that EU Member States retain the competence to establish the criteria for the taxation of income and capital in their jurisdiction. In a cross-border context, each Member State is therefore free to decide, unilaterally or bilaterally, the connecting

\footnotetext{
977 See Article 61 of the proposed CCCTB Directive and the relevant discussion vide supra at II5.5.1.

978 Article 69 of the proposed CCCTB Directive.

979 Article 67 of the proposed CCCTB Directive.
} 
factors for the allocation of fiscal jurisdiction. Due to the absence of the harmonisation of direct taxes in the EU, there is a conflict between the power conferred on the Member States to tax income arising in their territory and the freedom conferred on the Union nationals to establish themselves within the Union. ${ }^{980}$ This is apparent since the judgment in Schumacker, in which the Court ruled that, although direct taxation does not as such fall within the purview of the Union, the powers retained by the Member States must nevertheless be exercised consistently with Union law.981 Consequently, the Court reaffirmed that the competence of the Member States is not unlimited but must be exercised in a manner that does not restrict the fundamental freedoms of one Member State national in another Member State. As follows from Schumacker, there is a difference between the existence (the so-called right to allocate taxing power) and the exercise of the Member States' taxing power. In other words, the scope of the Court's regulatory control on direct taxation covers only the exercise of the power to tax, but it does not extend to the existence of the Member States' power to impose direct taxes. The Member States, thus, remain free to determine the organisation and conception of their tax system and to determine the need to allocate the power of taxation among them. ${ }^{982}$

Due to the principle of fiscal sovereignty, Member States are limited in taxing the positive income of residents of other Member States, unless the latter carry on business in the former Member State. Therefore, Member States are also uninterested in taking into account the negative income related to such non-resident companies. The concept of the "balanced allocation of taxing rights" aims to protect the tax sovereignty of a Member State so that it is not overridden and legally or factually eroded by legislation of another Member State. ${ }^{983}$ The Court has further confirmed that Member States are not obliged to extend their group taxation regimes to cover non-resident companies. ${ }^{984}$ However, such a result is dissatisfying for groups of companies having members in several Member States. From the perspective of the EIM, a balanced allocation of taxing rights is not

\footnotetext{
980 Opinion of AG Maduro delivered on 7 April 2005 on case Marks \& Spencer (C446/03), para. 6.

981 Case Schumacker (C-279/93), para. 21.

982 Opinion of AG Maduro delivered on 7 April 2005 on case Marks \& Spencer (C446/03), para. 23.

983 Case Rewe Zentralfinanz.(C-347/04), para. 69.

984 Case X Holding (C-337/08).
} 
intended to divide the internal market into pieces, each of which is administrated under the jurisdiction of the respective Member State without looking across the borders. ${ }^{985}$ The CCCTB system aims to bring a solution for such an undesirable result. However, as far as establishments from third countries are concerned, the problem will remain because they do not fall within the personal scope of the CCCTB and there is no international obligation for cross-border loss offset. If the CCСТB is adopted via enhanced cooperation, the conclusion is not so straightforward. After Marks \& Spencer, 986 EU Member States have been put in a position of dealing with the concept of "final losses". The author will elaborate on this issue further below.

Another question is whether losses of a CFC should also be taken into account in the tax base of resident companies. From the author's perspective, the answer depends on the principle on which the residence State of the parent company has based its CFC law. Accordingly, CFC rules are commonly based on the following theories:

- Fair value of share theory - taxation of CFC shareholder is based on the fair value of the shares. Whenever the base company generates profit and does not distribute it, the value of its shares increases, which will be included in the parent company's tax base.

- Deemed dividend distribution theory - taxation of a deemed dividend payment which, in a fair market situation (from the shareholder's residence state perspective), would have been received in the hands of the shareholder.

- Piercing the corporate veil theory - the so-called "look through" approach, where the legal personality of the CFC is disregarded (due to the controlling power of the shareholder) by piercing its corporate veil and, thus, allocating the profits to the shareholder.

From the author's perspective, the first and the last theory imply the consideration of foreign losses in the State of the parent company. On the contrary, the second approach - deemed dividend distribution theory - does not sustain the consideration of losses at the parent company's level, because it assumes the taxation of only the positive income of the parent company. According to the

985 Schön (2008a), 820-821.

986 Case Marks \& Spencer (C-446/03). 
proposed CCCTB Directive, the tax base of resident companies shall include "non-distributed income" of a CFC. ${ }^{987}$ Hence, the proposal relies on the third, piercing the corporate veil theory and, thus, supports offsetting the losses of a CFC. Indeed, under the proposed Directive, those losses shall be carried forward and taken into account in the subsequent years. 988

\subsubsection{ENHANCED COOPERATION AND the Issue of Final LOSSES IN THE CCCTB}

The initial question is whether permitting unconditional cross-border loss relief between CCCTB group members, while restricting CCCTB parent companies to offset losses of subsidiaries from non-CCCTB Member States, would conflict with the acquis communautaire. In other words, measures adopted within the framework of enhanced cooperation have to comply with the Treaties and EU law in general, without undermining the internal market or economic and social cohesion and may not constitute a barrier to or discriminate against trade between Member States or distort competition between them. ${ }^{989}$ The introduction of the CCCTB via enhanced cooperation might create an incentive for parent companies from participating Member States to set up subsidiaries only in participating Member States and trade primarily with those subsidiaries. ${ }^{990}$ In that sense, one could try to argue that offsetting subsidiary losses depending on whether the latter belongs to a CCСТB group conflicts with the acquis communautaire. But enhanced cooperation is legitimate in the EU and allows Member States to move forward at different speeds and/or with different goals if some Member States are opposed to certain measures towards further integration. Through the consolidation of profits and losses of group members, the CCCTB aims at reducing over-taxation in cross-border situations and is thereby a step towards improving the tax neutrality conditions between domestic and crossborder activities to better benefit from the potential of the EIM. ${ }^{991}$ Against this background, a system of CCCTB that permits crossborder loss offset only between group members would fall within the ambit of Article 20 of the TEU because it aims at furthering the objectives of the Union, protects its interests and reinforces its

\footnotetext{
987 Articles 82 and 83(1) of the proposed CCCTB Directive.

988 Article 83(1) of the proposed CCCTB Directive.

989 Article 326(2) of the TFEU.

990 Cerioni (2006), 190.

${ }_{991}$ Explanatory Memorandum to the proposed CCCTB Directive, 5.
} 
integration process. Accordingly, the author is of the opinion that an unconditional loss offset within a CССТВ group would not conflict with the acquis communautaire.

To assess whether such a group benefit complies with the proportionality principle, one must determine up to which point the CCCTB could unconditionally allow cross-border loss offset within a group for the purposes of achieving one of its key objectives, without generating distortions to the functioning of the EIM. It is worth recalling that the conventional understanding of the principle of proportionality requires testing the content of the Union action against three criteria: (i) suitability test (or appropriateness test); (ii) necessity test; and (iii) stricto sensu proportionality test. First, unconditional loss offset within a CCCTB group is suitable because it reduces over-taxation of pan-European groups of companies and thereby promotes the functioning of the EIM. Next, the measure is necessary to achieve the objectives of the Treaties and does not go further than necessary to achieve that goal. Last, the measure complies with stricto sensu proportionality because it does not impose any excessive cost to Member State interest nor to individual rights compared to the goal to be attained.

Having established that the adoption of the CCCTB via enhanced cooperation does not imply any unconditional offset of losses of subsidiaries from other non-participating Member States, nor prohibits absolute loss consideration within a group, one needs to determine whether, and if so under which conditions, EU law requires cross-border loss consideration between CCCTB group members and affiliates of non-CCCTB Member States. For the purposes of this analysis, the author will herewith elaborate on the concept of final losses, as developed in Marks \& Spencer and its impact on EU-wide groups of companies under the CCCTB. On 13 December 2005, the CJEU delivered its judgment in Marks \& Spencer concerning the deduction of foreign, EU subsidiaries' losses at the parent company's level (in the UK). According to the UK domestic law, UK companies were allowed a deduction of (i) losses of foreign branches and (ii) losses of UK resident subsidiaries due to applicable group relief system. Marks \& Spencer argued that the UK should allow the deduction of foreign subsidiary losses by the UK's parent company. The Court assessed that there was a restriction to the freedom of establishment, but there were three justifications "taken together" to find such a restriction lawful: (i) the need for preservation of the allocation of power to impose taxes between the 
Member States; (ii) the risk of tax avoidance; and (iii) danger that losses would be taken into account twice. However, the Court specified that these justifications infringe the principle of proportionality if the subsidiary has exhausted all possibilities available, in its State of residence, of having the losses taken into account in the present, the past or the future, either by itself or by a third party in case the subsidiary has been sold (i.e. the so-called "no possibilities" test).

The Court took a similar approach to Marks \& Spencer with regard to foreign permanent establishment losses, where the relevant DTC exempted foreign profits from the head office's domestic tax base, in Lidl Belgium 992 (i.e. application of base exemption method). ${ }^{993}$ In these decisions, the Court did not specify whether the "no possibilities" test requires legal exhaustion (such as limitation on loss carryforward) or (also) factual exhaustion (such as a termination) of possibilities for loss compensation. ${ }^{994}$ With regard to the former, the CJEU clarified in Krankenheim 995 that the Member State of the head office was not obliged to adjust its domestic tax rules on the basis of those in another Member State in order to ensure, in all circumstances, taxation which removes any disparities arising from national tax rules, given that the decisions made by a company as to the establishment of commercial structures abroad may be to the company's advantage or not, according to circumstances. Hence, in Krankenheim, the home State did not have to consider foreign losses as final due to a specific legal limitation for the use of carry-forward rules in the host State. The Court further clarified in $K$ that the requirement of taking into account "final losses" in a Member State cannot be understood to require a Member State to take into account losses suffered in another Member State if the latter did not provide for such a loss deduction under its domestic law. Hence, due to disparities in the national laws of Member States, it cannot be ensured that the decision of a taxpayer to invest abroad will always be at his advantage. ${ }^{996}$ However, as per the factual exhaustion of possibilities for loss consideration, the Court ruled in $O y A^{997}$ that Member States

\footnotetext{
992 Case Lidl Belgium (C-414/06).

993 Note that different from Markes \& Spencer (C-446/03), in Lidl Belgium (C-414/06) losses of the permanent establishment had already been taken into account by another group company in the past.

994 Boulogne \& Slavnic (2012), 489.

995 Case Krankenheim (C-157/07), para. 50.

996 Case $K(\mathrm{C}-322 / 11)$, paras. 76-81 and the case law cited therein.

997 Case Oy A (C-123/11).
} 
are required to recognise non-recurring, irregular losses that are incurred not only due to liquidation, but also due to mergers and other factual circumstances. 998

The proposed CCCTB Directive does not contain any rule about the treatment of final losses. Obviously, the draft proposed in 2011 was meant to be adopted by all Member States and, hence, this issue had no relevance back then. However, if the CCCTB is indeed introduced in the framework of enhanced cooperation, one could expect the European Commission to give its view on which losses are to be treated as final in the light of the Court's jurisprudence. It would not be an option to rely on Member States practice on the issue, because by the adoption of the Directive, the term will have to be interpreted only in the light of Union law. ${ }^{999}$ Consequently, if a relevant case is brought before the CJEU, the latter would be in a position to provide the interpretation of the term in the light of EU law. ${ }^{1000}$ Due to limitations of the current dissertation, the author will not interpret the concept of "final losses" further for the purposes of this thesis. ${ }^{1001}$

The starting point for the discussion on final losses relates to the optional nature of the CCCTB and, therefore, its competitiveness in relation to national tax systems. Following Marks \& Spencer, Member States are not obliged to allow the deduction of losses of foreign subsidiaries from the profits of a resident parent company. Importantly, the Marks \& Spencer decision extended the obligation to provide cross-border relief for final losses only where loss relief was available domestically. Loss-relief is available under the CCCTB system within the group of companies. Hence, if the CCCTB is introduced via enhanced cooperation, the system has to allow the deduction of final losses incurred by subsidiaries from nonparticipating Member States under certain conditions. The benefit would have to be granted if the subsidiaries in non-participating Member States met the same conditions as subsidiaries from CCCTB Member States forming part of a CCCTB group. ${ }^{1002}$ Hence, the availability of the consideration of losses of foreign subsidiaries at the

998 Cohrs (2013).

${ }^{999}$ For German practice, see for instance, Bal (2012), 46-48; Cordewener (2011), 5961.

1000 See case CILFIT (283/81).

1001 However, the author would like to refer to the relevant discussion in Boulogne \& Slavnic (2012), 486-495; Mkrtchyan (2009), 54-67.

1002 In particular, the requirements listed in Article 54 of the proposed CCCTB Directive. 
level of the CCCTB group, only when they are deemed to be final, does not reduce its attractiveness compared to Member States' taxation systems. Following the decision in Marks \& Spencer both systems must allow the consideration of only final losses of foreign subsidiaries.

Following the conclusion that the CССТВ system must allow the deduction of final losses of subsidiaries from non-participating Member States, it is further necessary to assess whether such losses should be set off against the apportioned share of the parent company of the non-resident subsidiary or deducted from the CCC tax base. Again, the CCCTB will only have to deal with final losses of those subsidiaries if the parent company meets the same criteria that it meets in the CССТВ eligible subsidiaries (i.e. the two-part test). The Treaty freedoms do not require better treatment of cross-border groups than the treatment of domestic groups. Once a company opts into the CCCTB system, if the CCCTB resident parent company does not meet the necessary requirements, final losses of subsidiaries will remain non-deductible from the CCC tax base. In the light of Article 7 of the proposed CCCTB Directive, if the national law of a Member State established lighter conditions for loss offset compared to the CCCTB conditions, a company that had opted for the CCCTB could no longer benefit from those rules even if they were more beneficial.

Returning to the initial question whether a single group member or the whole group should benefit from the deduction of final losses of a non-resident subsidiary, the author concluded in the previous Chapter that all income, despite whether it is exempted or not, is included in the scope of the CCCTB. Hence, from the author's perspective, dividends from non-resident subsidiaries, which are exempted under Article 11 of the CCCTB Directive, would be covered by the CCCTB system. Against this background, the author concludes that final losses of non-resident subsidiaries should be deducted from the CCC tax base rather than from the apportioned share of the individual group members (their resident parent companies). Moreover, final losses of foreign subsidiaries do not fit within the concept of pre-consolidated losses of the parent company, as they do not arise before consolidation and should not be ringfenced. Furthermore, such losses relate to the activities of the whole group rather than the individual group member. However, this conclusion becomes weaker to uphold when those subsidiary losses, which are not yet final, were incurred before the entry of the parent company into the CCCTB group. These losses are expenses of the 
parent that were incurred before its group membership and should thus be considered only in its tax accounts. If the parent company could include stranded losses in the CCC tax base, ring-fencing preconsolidated profits may partly become obsolete and lead to erosion of other Member States' tax bases. In fact, in order to avoid Member States' tax-base erosion, it seems desirable to exclude preconsolidation losses from the CCC tax base, regardless of whether they have been incurred by the parent or subsidiary company. Hence, a provision requiring ring fencing of all pre-consolidation losses in the CCCTB Directive is defendable.

From another perspective, EU case law on cross-border loss relief would also be relevant for parent companies from non-CCCTB Member States. In general, the issue of final losses appears to have less of an impact on inbound investment, as the CCCTB is designed to prevent losses becoming final in the CCCTB jurisdiction. Indeed, according to the current proposal, the CCC tax base shall be shared only when it is positive. ${ }^{1003}$ When the consolidation results in an overall loss for the group, this loss would be carried forward at the group level and set off against future consolidated profits (before the net profits are shared out). The purpose of this rule is to avoid the creation of "stranded" losses. ${ }^{1004}$ Furthermore, no group losses would be attributed to a leaving group member. Thus, only when the group itself is terminated, losses may become final at its members' level. To illustrate (Example 32: Final losses of a CCCTB group), CoX is a company resident in a non-CCCTB Member State and holds a CCCTB resident company (CoA), which in turn forms a CCCTB group with its CCCTB resident subsidiary (CoB), i.e. Group-AB. Here, assume that group- $\mathrm{AB}$ suffers losses and both $\mathrm{CoA}$ and $\mathrm{CoB}$ are liquidated in a given year.

1003 Article 86(2) of the proposed CCCTB Directive.

1004 European Commission (2007a), paras. 101-102. 


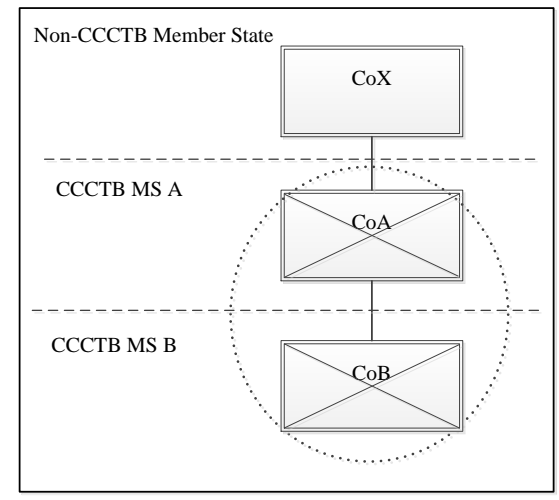

If a CCCTB group is terminated, any unrelieved losses of the group will be allocated to each group member in accordance with the apportionment formula. ${ }^{1005}$ Consequently, both $\mathrm{CoA}$ and $\mathrm{CoB}$ will be allocated a portion of the group's losses. As far as CoA's share of losses is concerned, based on Marks \& Spencer, such losses would have to be taken into account at the level of CoX, provided that the national law of its country included respective domestic loss-offset provisions. With regard to losses attributed to $\mathrm{CoB}$, based on the same reasoning, initially they would have to be taken into account at the level of CoA (as its parent company). However, as CoA is also liquidated, it would not be able to take those losses into account. The question, therefore, is whether such losses will have to be taken into account at the level of CoX. Whether a restriction to the freedom of establishment of the lower-tier subsidiary exists depends on the national law of the non-CССТВ Member State X. In particular, the question is whether it allows intra-group loss relief for domestic indirect subsidiaries. However, in the present case, as the first-tier subsidiary is liquidated, Member State A would be unable to take into account such losses, even if it allowed intra-group loss to be offset in a domestic scenario. Hence, unless the losses of $\mathrm{CoB}$ are considered under the domestic law of Member State X, its losses would be "lost" for taxation purposes.

In the example above, if the non-CCCTB Member State X does not provide for the consideration of losses of domestic lower-tier subsidiaries, it would also not be under a general obligation to allow

1005 Article 65 of the proposed CCCTB Directive. 
the deduction of final losses of a foreign sub-subsidiary. In light of this, one may wish to discuss whether the proposed CCCTB system allows for certain manipulation, given that no losses shall be attributed to a leaving group member. ${ }^{1006}$ In the example above, if $\mathrm{CoB}$ is liquidated before $\mathrm{CoA}$, at first sight, it may seem that no losses shall be attributed to the former. In such a case, CoA would stay within the CCCTB with all the losses of group AB. However, as a result of $\mathrm{CoB}$ 's departure (i.e. liquidation), group $\mathrm{AB}$ is left with only one group member. Hence, the CCCTB group will be terminated automatically, because, by definition, a CCCTB group cannot exist with less than two members. ${ }^{1007}$ Otherwise, the CCCTB rules would be vulnerable to manipulation as companies could choose where to take their losses into account. The Court has also pointed out several times that to give companies the right to elect where to have their losses taken into account would seriously undermine the balanced allocation of taxing rights between the Member States. ${ }^{1008}$ Consequently, in case of the termination of the CCCTB group $\mathrm{AB}$, the losses are attributed to both of the group members according to the formula. However, if a CCCTB group consisted of at least three group members, manipulation would become feasible, because the departure of one group member would not break the ties between the remaining group members. There is room for debate whether such an action would be caught by the CCCTB GAAR in Article 80 of the proposed Directive. ${ }^{1009}$

Another question is whether the application of the CCCTB in conjunction with the requirement for offsetting final losses in the EU may achieve a result in which losses of a subsidiary are not offset against the profits of the parent company, but vice versa, where losses of a parent company are offset against the profits of the subsidiary. In the following example (Example 33: Losses of an exiting parent company), a CCCTB group consists of a CCCTB ultimate parent company (CoA) and two lower-tier CCCTB resident subsidiaries $(\mathrm{CoB}$ and $\mathrm{CoC})$ of its qualifying non-resident subsidiary (CoX) (group-ABC). ${ }^{1010}$

\footnotetext{
1006 Article 69 of the proposed CCCTB Directive.

1007 Article 55 of the proposed CCCTB Directive.

1008 Cases Marks \& Spencer (C-446/03), para. 45; Rewe Zentralfinanz (C-347/04), para. 42; Oy $A A(\mathrm{C}-231 / 05)$, para. 55.

${ }^{1009}$ For further discussion on the interpretation of the CCCTB GAAR, vide infra at II8.3.1.

1010 Article 55(1)(c) of the proposed CCCTB Directive.
} 
Example 33: Losses of an exiting parent company

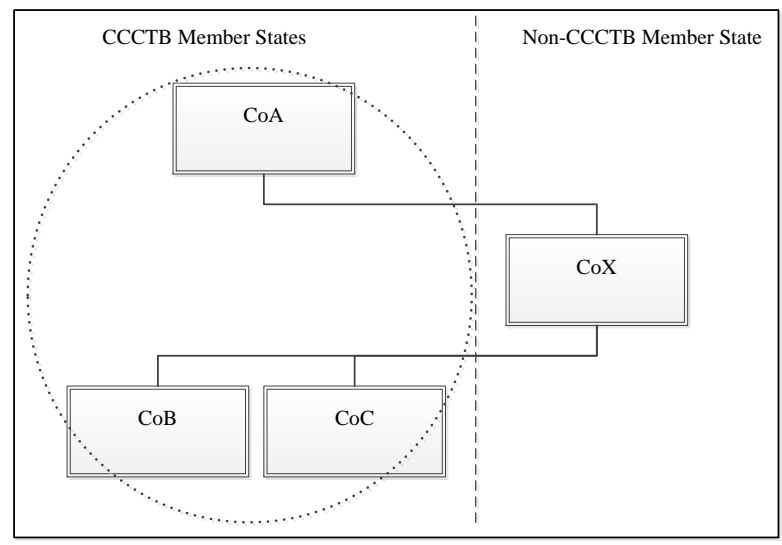

When the CCCTB group ABC incurs losses, they shall be carried forward at the group level. If the ultimate parent company is liquidated, rather then terminating the whole group $\mathrm{ABC}$, the two resident subsidiaries would continue to exist in the form of Group BC. In such a case, a new principal taxpayer would be designated according to Article 116 of the proposed CCCTB Directive. ${ }^{1011}$ In order to avoid stranded losses, the exiting parent company CoA would not be attributed any share of group ABC's losses based on Article 69 of the proposed Directive. If either one or both of the subsidiaries of CoX exits the group BC, which subsequently triggers the termination of the group, the loss accumulated during its existence would be shared between $\mathrm{CoB}$ and $\mathrm{CoC}$. If those losses become final, CoX, as the EU-located parent company, must take into account those losses based on Marks \& Spencer under the same conditions as it allows the offset of losses in the case of domestic groups. The idea of "the same conditions" covers not only the availability of loss consideration within a group in the home State but also the application of the same rules for the calculation of the tax base. Hence, despite that the ultimate parent company's (CoA) losses were left at the succeeding group level (group BC), upon its liquidation, those losses would still be lost to the extent that they are

1011 In this example, the CССТВ group was initially formed in accordance with Article 55(1). If the parent company ceases to meet the relevant criteria to be a member of the CCCTB group, the group would continue to exist as if it were formed in accordance with Article 55(2) of the proposed CCCTB Directive. 
not included in the (negative) tax base as calculated under the domestic law of the third State.

\subsubsection{PRELIMINARY CONCLUSIONS}

In this section, the author first questioned whether, in the framework of enhanced cooperation, unconditional loss offset between CCCTB group members compared to conditional loss offset between CCCTB parent companies with non-CCCTB subsidiaries would conflict with the acquis communautaire. The author concluded that the answer is negative, because the CCCTB does aim at furthering the objectives of the Union, protects its interests and reinforces its integration process and falls, thus, within the scope of Article 20 TEU. The author further concluded that unconditional loss offset within CCCTB group members, compared to limited offset of subsidiaries from other Member States, would also not infringe the proportionality principle, because it meets all the three required tests: the suitability, the necessity and the stricto sensu proportionality test.

As a general rule, the principle of fiscal sovereignty precludes a State from taxing non-residents on their income, unless the latter have a sufficient economic link to that State (such as a permanent establishment). Due to the symmetrical treatment of profits and losses, States also usually do not take into account the negative income of non-residents. Such sovereignty has been confirmed by the CJEU through the acceptance of the concept of "balanced allocation of taxing rights" in that "in tax matters profits and losses are two sides of the same coin and must be treated symmetrically in the same tax system". ${ }^{1012}$

Since Marks \& Spencer, the Member States have been left to deal with the issue of final losses of subsidiaries resident in other Member States. Although the proposed CCCTB Directive (naturally) does not deal with the issue, if the CCCTB is introduced by means of enhanced cooperation, the issue of final losses will also have to be dealt with from the CCCTB perspective. First, in case of outbound investments, CCCTB Member States will be obliged to consider final losses incurred by subsidiaries in non-CCCTB Member States if they meet the two-part test equal to CCCTB-located subsidiaries. From a conceptual point of view, final losses should not be treated as if they

1012 Case Marks \& Spencer (C-446/03), para. 43. 
were pre-consolidated losses of the parent company. Based on these arguments, final losses of subsidiaries in non-CCCTB Member States should be offset against the CCC tax base rather than the parent company's tax base following apportionment. However, when applied generally, this conclusion does not hold up against the idea of ring-fencing pre-consolidated losses. From the author's point of view, it seems desirable to offset losses which were incurred by subsidiaries before its parent company entered a CCCTB group and that subsequently became final, only against the apportioned share of the parent company equal to the pre-consolidated losses of the latter. Otherwise, parent companies would be allowed to bring stranded losses into the CCC tax base and thereby erode other Member States' tax bases. Nevertheless, one must also recognise that ringfencing such losses would add complexity to the operation and administration of the system.

From the opposite perspective - the case of inbound investment the question is how to deal with final losses incurred by a CCCTB group when it is terminated. In general, in the case of the termination of a CCCTB group, any unrelieved losses of the group will be allocated to each group member in accordance with the apportionment formula. Hence, a parent company in a non-CCCTB Member State would be in the position to consider final losses attributed to its CCCTB resident subsidiary under the same conditions as it allows loss consideration for domestic direct and indirect subsidiaries. Importantly, EU law does not oblige Member States to treat cross-border investments more advantageously than domestic investments. Consequently, in the absence of sufficient loss consideration in the parent company's Member State of residence, some losses of the CССТВ group may be lost in case of its termination.

\subsection{LIMITATIONS ON CROSS-BORDER LOSS COMPENSATION WITHIN A COMPANY}

A State corporate income tax system based on the residency principle will subject the total worldwide income of residents to taxation. As permanent establishments are not separate legal persons, the income derived through these entities will also be included in the worldwide tax base of the resident company. Typically, loss compensation in the case of permanent establishments depends on the method of elimination of double taxation that the resident country uses. In that sense, permanent establishments and subsidiaries are not treated 
equally, as losses of the latter are typically never taken into account in the home State (unless it is a final loss in an EU-setting). This distinction is in line with the CJEU's jurisprudence since $X$ Holding, where the Court explicitly stated that permanent establishments and non-resident subsidiaries are not in a comparable position with regard to the allocation of taxing power. ${ }^{1013}$ Also, the European Commission's 1990 proposal for cross-border loss consideration clearly distinguished between the treatment of permanent establishments and subsidiaries. ${ }^{1014}$ When the residence State taxes profits and allows cross-border loss relief of income attributed to a foreign permanent establishment, it does not infringe the fiscal sovereignty of the source State. Indeed, the latter will maintain the unlimited authority to tax the profits of a permanent establishment under its jurisdiction.

The elimination of double taxation, by means of either the exemption or credit method, implies that foreign source income is taxed differently from domestic income in the residence State. Hence, payments received and expenses made must be allocated as having a domestic or foreign source. In an exemption country, this is important for the purposes of determining the amount of income being exempted, while in a credit country this is necessary for the purposes of determining the limitation on available credit. ${ }^{1015}$ It was explained earlier that the application of the exemption method generally implies that foreign losses cannot be offset (or they are offset but later recaptured) against the domestic profits. On the contrary, under the credit method, States take into account the worldwide income received minus the worldwide expenses made by their resident taxpayers.

As a result of applying the credit method, foreign losses may usually be offset against domestic profits and carried over against both domestic and foreign income (subject to recapture, if applicable under the domestic law). ${ }^{1016}$ However, Harris and Oliver argue that the application of the credit method should lead to the same result as the application of the exemption method concerning the consideration of losses, because to the extent that foreign credits are available, foreign income is not taxed. From their perspective, a

1013 Case X Holding (C-337/08), para. 38.

1014 European Commission (1991).

1015 Harris \& Oliver (2010), 312.

1016 Michelsen (1998), 42. 
taxpayer should be allowed to use foreign losses only in the same way that foreign credits can be used. ${ }^{1017}$ Indeed, the inclusion of foreign income in the worldwide income tax base of a resident company with subsequent credit for foreign taxes, on the one hand, and deduction of foreign losses from domestic profits, on the other, results in two forms of relief for the same profits. However, from the author's perspective, this conclusion is true if one looks at the situation of the taxpayer only from the residence State's perspective but not from a global perspective of the taxpayer. Even though crediting foreign taxes reduces the domestic tax payable, it does not eliminate the fact that those profits were already taxable in the source country. Hence, the residence country only eliminates double taxation of foreign profits rather than taxes those profits at a different tax rate compared to domestic profits. If a taxpayer suffers a loss in the source country (e.g., through a permanent establishment), those losses will reduce the tax on profits in the residence State. However, when subsequent foreign profits occur, they will again be included in the domestic tax base and receive credit only up to the amount that taxes were actually paid in the source State. Hence, from a global perspective, the foreign income derived does not receive two types of relief, even if it appears so from a domestic perspective.

It is generally accepted that losses attributable to a permanent establishment shall be taken into account in the source State under the same conditions as losses incurred by resident companies, despite the treatment of the permanent establishment in the residence State of the head office. Also Article 7 of the OECD MC, read in conjunction with Article 24(3) therein, supports that view. ${ }^{1018}$ The CJEU generally appears to share the same approach, as confirmed in Futura. ${ }^{1019}$

\subsubsection{OUtBOUND INVESTMENT: COMPENSATION OF LOSSES OF A FOREIGN PERMANENT ESTABLISHMENT}

The CCCTB system has been built upon the residency principle and includes all income of residents in the tax base. For the purposes of eliminating double taxation of the income of a permanent establishment, the CCCTB Directive proposes the application of an

1017 Harris \& Oliver (2010), 322-323.

1018 OECD Comm. on Article 7, paras. 30-34 and on Article 24, para. 40.

1019 Futura (C-250/95). 
exemption method in Article 11(e). The author concluded earlier that, despite the confusing wording of the provision, it implies the use of a base exemption rather than a tax exemption method. The use of the base exemption method implies that foreign income is not included in the calculation of the tax base of resident taxpayers. In such a case, the overarching idea of the symmetrical treatment of profits and losses also does not require the consideration of foreign losses by a resident company given the logic of the system (i.e. territorial taxation). By comparison, the use of a tax exemption method would imply the inclusion of the income of a foreign permanent establishment in the tax base of the parent company and a subsequent deduction of the part of the home State total tax on worldwide income, which is attributable to the foreign part of the total income. Such a method eliminates the cash-flow disadvantage, which is typically caused by the application of the base exemption method. In order to preserve the right to taxation and avoid the double use of losses, the operation of the tax exemption method implies a parallel application of loss recapture provisions.

It is noteworthy that the literal reading of Article 23A of the OECD $\mathrm{MC}$, in particular the wording of "exempt from tax", hints at the application of the tax exemption method rather than the base exemption method. In fact, Article $23 \mathrm{~A}$ says nothing about the consideration of losses, because it is aimed solely at the elimination of double taxation (and ensuring at least single taxation). The OECD Commentary refers to the domestic law of the contracting parties, so that the latter are free to choose the method of exemption, i.e. tax exemption or base exemption. Yet, the OECD Commentaries suggest making their choice explicit. ${ }^{1020}$ The proposed CCCTB Directive does not allow the application of domestic provisions in respect of the matters regulated by the Directive. ${ }^{1021}$ Losses are an essential part of defining the taxable base. Hence, even when Member States' domestic laws foresee a tax exemption method with a foreign loss consideration, companies participating in the CCCTB system would not be entitled to apply those provisions in dealing with losses that fall within the ambit of the CCCTB, such as those incurred by a foreign permanent establishment.

1020 OECD Comm. on Article 23, para. 44.

1021 Article 7 of the proposed CCCTB Directive. 


\subsubsection{APPLICATION OF BASE EXEMPTION METHOD}

If one agrees that the proposed CCCTB Directive foresees a base exemption method, two additional questions arise. First, does the application of the switch-over clause to permanent establishment profits lead to the obligation to deduct its losses from the CCCTB tax base? Second, whether and if it does so, under which conditions are EU Member States obliged to allow for a cross-border offset of losses of foreign permanent establishments in case the CCCTB is introduced via enhanced cooperation?

The application of the switch-over clause to the income derived through a permanent establishment located in a low-tax third country leads to the application of the credit method instead of the exemption method for the elimination of double taxation of such income. ${ }^{1022}$ The author explained earlier that the application of the credit method generally results in the automatic consideration of foreign losses. Against this background, at first sight, one could deduce that, in certain cases, a permanent establishment located in a low-tax third country is treated more beneficially than permanent establishments located in countries with higher corporate tax rates. In particular, in the case of the latter, double taxation would be eliminated by the base exemption method, which generally does not support the consideration of foreign losses. Hence, the question arises whether the application of the switch-over clause to low-taxed permanent establishments' income would allow their losses to be taken into account in the CCC tax base. An affirmative answer would run counter to the purpose of the provision. Actually, the switch-over clause in the proposed CCCTB Directive is an ad hoc measure in the sense that it applies a year-by-year basis. Hence, if the low-tax country permanent establishment incurs losses, the fact that its profits were taxed in the CCCTB jurisdiction due to the switch-over clause in the previous year(s) is irrelevant. In other words, the application of the switch-over clause in one year does not create an obligation to continue applying it in the subsequent years. In any event, the compromise proposal of the Danish Presidency makes it clear that losses of foreign permanent establishments are not deductible from the CCC tax base. ${ }^{1023}$

\footnotetext{
1022 Article 73 of the proposed CCCTB Directive.

1023 Council of the European Union (2012), comments on Article 14(j) of the CCCTB Directive.
} 
It is worth noting that the Danish Presidency has proposed deleting the switch-over clause with regard to the income of foreign permanent establishments. Instead, it has proposed to integrate the income of a permanent establishment located in a low-tax territory in the provision taxing the income of controlled foreign companies (CFC). ${ }^{1024}$ The literal reading of this provision implies that the income must be "included in the tax base". The author will elaborate on this issue further in Chapter VII.

With regard to the second question, it is generally accepted that, under the base exemption method, losses of a foreign permanent establishment cannot be offset against profits in the residence State. Hence, the application of the base exemption method leads to a cashflow disadvantage of the parent company with a foreign permanent establishment located in a non-CCCTB Member State compared to parent company with a domestic permanent establishment. From the CJEU's opinion, a cash-flow disadvantage may result in unequal treatment. ${ }^{1025}$ The Austrian Administrative Court has decided that losses of an Austrian head office, incurred through a permanent establishment in Germany, should be allowed to transfer crossborder, even where the corresponding profits were exempted due to a DTC between the two Member States. ${ }^{1026}$ According to the Austrian court, the exemption method in the DTC can be applied only to positive income. Indeed, according to the OECD Commentary, the application of Article 23A of the OECD MC does not disallow the deduction of foreign losses from domestic or thirdstate profits. ${ }^{1027}$ On the contrary, the German Federal Finance Court (Bundesfinanzhoff), in the reference for a preliminary ruling in the case Lidl Belgium, interpreted that, based on the "symmetry principle", the (base) exemption method in DTCs implies the exemption of both positive and negative income. In the opinion of the CJEU, the balanced allocation of taxing power between Member States is a legitimate objective, which may make it necessary to apply the tax rules in respect of both profits and losses of taxpayers in that State. ${ }^{1028}$ However, that objective is designed, inter alia, to safeguard

\footnotetext{
1024 Council of the European Union (2012), Article 82.

1025 Cases Metallgesellschaft (Joined Cases C-397/98 \& C-410/98), paras. 44, 54 and

76; FII Group Litigation I (C-446/04), paras. 96, 97, 153 and 154; Rewe Zentralfinan: (C-347/04), para. 29.

1026 Wimpssinger (2008), 176.

1027 OECD Comm. on Article 23, para. 44.

${ }^{1028}$ Cases Marks \& Spencer (C-446/03), para. 45; Oy AA (C-231/05), para. 54.
} 
the symmetry between the right to tax profits and the right to deduct losses. ${ }^{1029}$ In the light of the Court's decision in $K$, if, due to the application of a DTC between Member States, the (residence) State does not exercise any taxing powers over the profits deriving from the activities in another Member State, the national measure which disallows the deduction of losses deriving from these activities in the other Member State is not contrary to EU law. ${ }^{1030}$ Furthermore, such a national measure is justified in the light of the need to ensure the cohesion of the tax system, which lies essentially with the symmetrical tax treatment of profits and losses. ${ }^{1031}$ Therefore, the CJEU also appears to support the principle of symmetry in order to ensure the balanced allocation of the power to impose taxes.

Advocate General Sharpston concluded in Lidl Belgium that a restriction on the freedom of establishment existed which could be justified by the need to preserve the balanced allocation of taxing rights and the risk that losses of the permanent establishment may be taken into account twice. ${ }^{1032}$ However, in her opinion, a less restrictive measure would be available, in particular, the application of a deduction-recapture method (i.e. the tax exemption method). ${ }^{1033}$ In this case, the Court agreed with the Advocate General that the Member State measure that allows losses incurred by a domestic permanent establishment to be taken into account at the head office level constituted a tax advantage, which, however, was not available in case of permanent establishments in other Member States. Hence, also in the Court's opinion, such a difference in treatment constituted a restriction on the freedom of establishment. ${ }^{1034}$ The Court also agreed with the Advocate General's opinion that the national measure could be justified by the need to preserve a balanced allocation of taxing rights and the risk that losses of the permanent establishment may be taken into account twice. However, it disagreed that the national measure infringed the proportionality principle. Differently from Marks \& Spencer, Lidl Belgium wanted a (temporary) loss deduction from its head office's tax base in Germany, i.e. the permanent establishment's losses were not final. Indeed, to require

\footnotetext{
1029 Cases Lidl Belgium (C-414/06), para. 33; Philips Electronics (C-18/11), para. 24. ${ }^{1030} \mathrm{~K}(\mathrm{C}-322 / 11)$, paras. 50-55.

1031 Ibid., paras. 66-71.

1032 Opinion of Advocate General Sharpston delivered on 14 February 2008 in case Lidl Belgium (C-414/06), para. 16.

1033 Ibid., paras. 23-24.

1034 Ibid., paras. 23-26.
} 
the home State of the taxpayer to apply the tax exemption rather than the base exemption method for foreign permanent establishment's income would have exceeded the Court's competence as prescribed in the Treaties. As follows, in line with Marks \& Spencer, losses of a permanent establishment in another Member State would have to be taken into account in the Member State of the head office only where they are considered final.

The same requirement does not apply in cases of losses of permanent establishments in non-EU Member States. In particular, the Court confirmed in Stablwerk Ergste ${ }^{1035}$ that national tax provisions that deny the deduction of losses of permanent establishments fall within the substantive scope of the freedom of establishment. As the freedom of establishment does not apply vis-à-vis third countries, EU law does not preclude the denial of the deduction of losses incurred by third-country permanent establishments of EU companies.

In conclusion, a tax system, such as that of the CCCTB, which uses the base exemption method for relieving double taxation of the income of a permanent establishment located in a non-CCCTB Member State, without taking into account the respective losses, does not constitute an restriction on the freedom of establishment. In particular, the base exemption method provides for symmetry between the treatment of profits and losses of such an entity. In other words, the base exemption method treats foreign permanent establishments like foreign subsidiaries. However, like in case of EUresident subsidiaries, the obligation to provide cross-border loss relief would arise only if the losses of the permanent establishment became final.

\subsubsection{APPLICATION OF TAX EXEMPTION METHOD}

From the author's perspective, the current CCCTB proposal uses the base exemption method for the elimination of double taxation of a foreign permanent establishment's income. However, the advantage of a tax exemption method, compared to the base exemption method, would be the elimination of cash-flow disadvantages due to the (immediate) consideration of losses incurred by foreign permanent establishments. Considering this advantage, the author will discuss whether a tax exemption method would be more

1035 Case Stablwerk Ergste Westig (C-415/06). 
appropriate for the purposes of the CCCTB system instead of the base exemption method.

First, if the CCCTB system used the tax exemption method with the consequence that losses incurred via foreign permanent establishments became deductible, a question remains whether such losses, if not absorbed by CCCTB profits, could be carried forward at the CCCTB group level under the general loss carry-forward provision. In light of the basic idea of tax exemption method, exempting income from taxation with subsequent recapture constitutes the retrospective taxation of resident taxpayers. In such a case, carrying over related losses normally falls within the scope of the domestic rules of the home State (or the CCCTB rules, if applicable). Such a carry-forward rule should not be dependent on the loss deduction limitations, such as time period for carrying over the losses or in terms of the amount in the source State. Consequently, losses incurred through foreign permanent establishments would be carried forward indefinitely at the CCCTB group level.

Allowing foreign losses to be deducted from the CCC tax base in cases where the corresponding profits are tax exempt may result in a loss being taken into account twice. ${ }^{1036}$ Consequently, national tax systems that incorporate the tax exemption method are typically supplemented with appropriate recapture rules. Similarly, if the CCCTB used the tax exemption method for the elimination of double taxation, the Directive would have to provide for appropriate recapture rules. ${ }^{1037}$ The typical technique for loss recapture is to tax income previously offset by foreign permanent establishment's losses if a profit is attributed to the latter in the following years. ${ }^{1038}$ Such a method should not be construed as the taxation of the profits of a permanent establishment in the subsequent years, but rather as a retrospective taxation of the domestic profits of the resident taxpayer, which had been reduced in the previous year(s). Otherwise, the residence State would infringe the application of the exemption

\footnotetext{
1036 If the source country does not allow any carry-over of losses, such a benefit would typically not lead to the double use of losses.

1037 It is noteworthy that the Austrian Administrative Court has ruled that foreign losses, subject to the condition that exemption method applies, require a recapturetaxation in the subsequent years, even where appropriate domestic law does not foresee it. Aigner (2005), 361.

1038 Recapture rules may be limited in years.
} 
method of the permanent establishment's profits as agreed in DTCs. ${ }^{1039}$ The CJEU has confirmed the legitimacy of the recapture mechanism from the perspective of EU law in Krankenheim. ${ }^{1040}$ Although the Court in this case found that the reintegration of losses of a permanent establishment constituted a restriction on the freedom of establishment, it was justified by the need to ensure the coherence of the Member State's tax system. According to the Court, the recapture of previously deducted losses reflected a "logical symmetry". ${ }^{1041}$ It is noteworthy that the Court actually found the existence of a restriction. In the light of the idea that the recapture mechanism introduces a retrospective taxation of resident companies rather than the taxation of the income of a permanent establishment, parent companies with foreign permanent establishments were not treated less favourably than parent companies with domestic permanent establishments. Consequently, it is arguable that any restriction on the fundamental freedoms existed in the first place.

In addition to a general recapture rule, if the CCCTB system used the tax exemption method, it could be important to provide specific recapture rules concerning entering and exiting a CCCTB group. With regard to entering the group, it is particularly important that when the State of residence has, under its domestic law, allowed a temporal offset of losses of a foreign permanent establishment, the recaptured profits of the latter would be added to the apportioned share of the CCCTB resident head office. ${ }^{1042}$ In case the resident head office of a foreign permanent establishment exits from a CCCTB group, recapturing the losses of a permanent establishment offset against the CCC tax base under the tax exemption method would have to take priority over the national tax base. For example, assume that losses of a foreign permanent establishment (e.g. 100) had been set off against the profits of a CCC tax base of the group in

1039 Vogel (1997), 1184. For a distinction between possible techniques of loss recapture see Cordewener (2004a), 138-139.

1040 Case Krankenbeim (C-157/07).

1041 Ibid., para. 42.

${ }^{1042}$ In the light of Article 7 of the proposed CCCTB Directive, in the case where the CССТВ system uses the base exemption method, it is questionable whether Member States would be allowed to apply their domestic recapture mechanism after the company has opted for the CCCTB. From the author's perspective, the current CCCTB proposal does not provide for such a recapture possibility. However, in order to avoid eroding Member States' tax revenues, the author is of the opinion that the CCCTB Directive should provide for a specific clause to deal with such a matter. 
year (Y1). In the next year, the permanent establishment is attributed profits (e.g. 75), which would be recaptured by the CCC tax base. When the head office of the permanent establishment exits the group (e.g. due to the sale of shares where the ownership in capital dropped below the required amount) in the following year (Y3), the unrecovered losses of the permanent establishment (25) would have to be recovered under the CCCTB rules when the corresponding profits are attributed to the permanent establishment. (Example 34: Consideration of foreign permanent establishment's losses and subsequent recapture under CCCTB)

Example 34: Consideration of foreign permanent establishment's losses and subsequent recapture under CCCTB

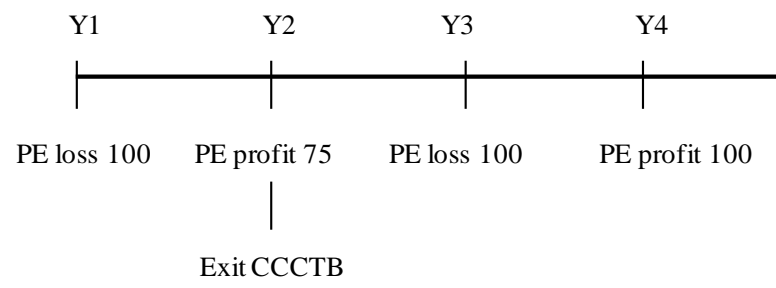

This recapture rule would have a particular relevance considering that no losses would be attributed to the group member leaving. As follows, the offset of losses of the foreign permanent establishment would have an effect only on the CCC tax base. Without recapture at the group level, the tax base of the remaining group members would be eroded. Losses incurred after the exit of the head office would be offset according to the domestic law to which the group member would become subject following the exit. Hence, when the foreign permanent establishment would be attributed a profit in the following year(s), these profits would be recaptured by the CCCTB rules, up to the amount previously unrecovered (25), as well as by the domestic law of the head office, up to the amount incurred after the exit of the head office from the CCCTB. Such a double-recapture would not lead to the double taxation of the profits of the permanent establishment. Indeed, both jurisdictions the CCCTB and the Member State of the head office would recover the reduced tax base of their resident taxpayer rather than tax the profits of the permanent establishment. In the same vein, the fact that the source State might tax the profits of the permanent establishment would not lead to double (or triple) taxation of the profits. Hence, none of the 
jurisdictions would maintain the priority over the taxation of the relevant profits.

\subsubsection{CONSIDERATION OF FINAL LOSSES OF A FOREIGN PERMANENT ESTABLISHMENT IN THE CONTEXT OF ENHANCED COOPERATION}

Considering that foreign losses, in the case foreign profits, are exempted, it is intriguing to wonder, if the CCCTB Member States followed opposing approaches with regard to the obligation to offset losses of a foreign permanent establishment, which view should prevail under the CCCTB. As mentioned earlier, according to the Austrian Administrative Court, the cross-border offset of a permanent establishment's losses must be available even in the case of the application of the exemption method (with a recapture mechanism). On the contrary, the German Federal Financial Court has opined that the "symmetry principle" requires the exemption of both positive and negative income. Compared to the latter, the Austrian view provides for a more beneficial treatment of crossborder investment. The CCСТВ aims at providing consistency between the taxation rules over corporate tax bases across the EU. Moreover, deductions of foreign losses would affect the total CCC tax base of the group not only that of the head office participating in the CCCTB. For these reasons, a uniform CCCTB approach is essential. Given that the proposed CCCTB Directive uses the base exemption method, in the light of the principle of symmetry confirmed by the CJEU's jurisprudence and the judgment in Lidl Belgium, as mentioned above, if the CCCTB were adopted via enhanced cooperation, losses of permanent establishments in nonCCCTB Member States would have to be taken into account in the CCC tax base only if they were considered final. On the other hand, it seems odd to require a Member State that follows the Austrian view to apply less beneficial rules (based on Lidl Belgium) to CCCTBparticipating taxpayers compared to taxpayers that opt out of the CCCTB. This issue would not arise if the CCCTB supported the application of the tax exemption method. Actually, the European Commission 1991 proposal on cross-border loss consideration already envisaged both the credit method and tax exemption method (with recapture) rather than base exemption method. ${ }^{1043}$

1043 European Commission (1991). 
One may further question whether, and if so which, final losses of a permanent establishment in a non-participating Member State should be offset against the CCC tax base. On the one hand, one could argue that all final losses of foreign permanent establishments should be offset exclusively against the apportioned share of the CCCTB resident head office, because that permanent establishment has never been part of the CCCTB group. Furthermore, the proposed CCCTB Directive uses the base exemption method, which implies that those losses never form part of the CCC tax base of the group, but they are exempted at the level of the head office. However, it seems desirable to offset a permanent establishment's losses, which arise from the group's activities, against the CCC tax base rather than the tax base apportioned to the head office. Furthermore, as in the case of final losses of foreign subsidiaries, final losses of permanent establishments arising during the group membership of the head office do not fit within the concept of pre-consolidated losses within the meaning of the proposed CCCTB Directive. Consequently, these losses should be offset against the CCC tax base. On the other hand, the current legal framework of the proposed CCCTB Directive does not allow such offsets because of the application of the base exemption method.

From the author's perspective, the proposed CCCTB Directive should be revised to provide explicit rules on the consideration of final losses of foreign entities of CCCTB group members, depending on whether these losses were incurred before the resident head office entered the CCCTB group, during its group membership or after its departure from the group. First, losses arising out of the group's activities should be offset against the CCC tax base. However, with regard to entering a CCCTB group, when the permanent establishment is terminated during the CCCTB group membership of the head office, only those foreign losses, which were incurred during the CCCTB group membership of the head office, should be offset against the CCC tax base. Losses incurred before entering the CCCTB should be considered pre-consolidated losses and ringfenced. Otherwise, the tax bases of the remaining CCCTB group members from other Member States would be eroded.

In the following example (Example 35: Final losses of a foreign permanent establishment on entering a CCCTB group), a resident company CoA, which has a permanent establishment (PE) in a nonparticipating Member State, enters a CCCTB group in year 1 (Y1). The permanent establishment had not incurred any profits during its 
existence; however, it had incurred losses in the initial year (Y0) and in year 2 (Y2). Those losses had not been set off against profits of the head office by the time CoA entered the CCCTB group. When the permanent establishment is terminated (Y2), its losses become final, i.e. they cannot be taken into account in the future or in previous years by that entity. From the author's point of view, such losses should be partially (i.e. 100) set off against the apportioned share of the head office and partially (i.e. 50) against the CCC tax base. If such losses cannot be offset, they should be carried forward according to the appropriate law (either national law or the CCCTB rules).

\section{Example 35: Final losses of a foreign permanent establishment on entering a CCCTB group}

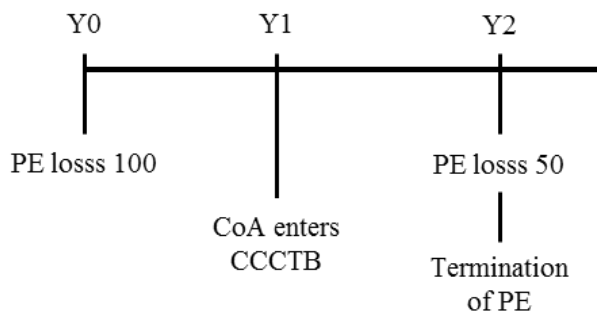

A similar approach should be followed with regard to (final) losses of a foreign permanent establishment incurred during the CCCTB group membership of the head office, when the permanent establishment is terminated after the head office ceased to belong to a CCCTB group. In the following example (Example 36: Final losses of a foreign permanent establishment on leaving a CCCTB group), a resident company, $\mathrm{CoA}$, which has a permanent establishment in a non-participating Member State, exits from a CCCTB group in year 5 (Y5). The permanent establishment had not incurred any profits during its existence; however, it had incurred losses in year 4 (Y4) and in year 6 (Y6). Those losses had not been set off against profits of the CCCTB group by the time CoA left the CCCTB group and, hence, they were carried forward at the group level. When the permanent establishment is terminated (Y6), its losses become final. The consistent treatment of entering and exiting a CCCTB group suggests that final losses of a permanent establishment incurred during the period when the head office belonged to the CCCTB group (i.e. 100) should be set off against the CCC tax base. The remaining final losses (50) should be set off against the tax base of the head office after exiting the CCCTB group. On the other hand, setting off part of the final losses against the CCC tax base might 
lead to a number of administrative difficulties, for example, when the CCCTB group ceases to exist before the termination of the permanent establishment.

Example 36: Final losses of a foreign permanent establishment on leaving a СССТВ group

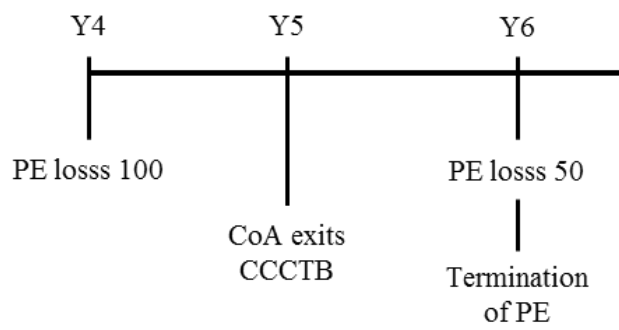

\subsubsection{INBOUND INVESTMENT: COMPENSATION OF THE LOSSES OF A PERMANENT ESTABLISHMENT OF A NON- RESIDENT COMPANY}

The consideration of losses of a CCCTB-located permanent establishment of a non-resident company can take two directions: (i) the rules applicable in the source country and (ii) the rules applicable in the residence country of the head office.

It is generally accepted that the source country may tax income where a sufficient nexus exists between the income and the territory. In the case of business income, this nexus is typically validated through the existence of a permanent establishment in that State. The proposed CCCTB Directive provides for an independent definition of permanent establishment (although it is almost identical to the definition proposed in Article 5 of the OECD MC) for the purposes of CCCTB. The fact that the proposed CCCTB Directive includes CCCTB-located permanent establishments of non-resident companies in the group definition automatically avoids discriminatory treatment of such permanent establishments in the CCCTB jurisdiction. According to the general international tax principle, the source State has the primary right to tax the income attributed to the permanent establishment (Article 7 of the OECD MC). Such limited source taxation can be seen as territorial taxation of non-residents as opposed to worldwide taxation of resident taxpayers. By treating permanent establishments as independent 
group members, the CCCTB proposal implies the use of the AOA for the purposes of attributing income to that entity.

Generally, permanent establishments of non-resident companies must be allowed the deduction of business expenses and the carryover of losses according to the same rules as resident companies in order to comply with non-discrimination rules.

If the residence State of the head office taxes the worldwide income of its residents, it may (unilaterally) or it has an obligation to (bilaterally ${ }^{1044}$ ) eliminate double taxation of the income attributed to foreign permanent establishments of that resident taxpayer. The author has already discussed above in this Chapter the general issues concerning cross-border loss consideration by the home State, which in the present case would be the third State. From the source State's perspective (i.e. CCCTB Member States), if the third State were a non-CCCTB Member State in the setting of enhanced cooperation, the CCCTB system could not limit the loss consideration of a CCCTB-located permanent establishment of a company of a nonCCCTB Member State only by reason that the latter allows the consideration of foreign losses under its domestic law (i.e. it taxes the worldwide income of tis residents). It is clear, in the light of Philips Electronics, that it is contrary to the freedom of establishment if the legislation of a Member State allows losses incurred by a permanent establishment in that Member State of a company in another Member State to be taken into account for the purposes of domestic group relief only if those losses cannot be used for the purposes of foreign taxation, but it allows the same relief in a purely domestic situation. Such a relief would not affect the balanced allocation of taxing rights, which is designed to safeguard symmetry between the right to tax profits and the right to deduct losses. Furthermore, such a measure could not be justified in the light of the need to prevent the double deduction of losses, because the fact that these losses may be used in both Member States does not affect the power of the host State to impose taxes over the profits of the permanent establishment. ${ }^{1045}$

Finally, in the setting of enhanced cooperation, it is also important to discuss the issue of final losses in relation to CCCTB-located permanent establishments of companies from non-CCCTB Member

1044 Article 23 of the OECD MC.

1045 Case Philips Electronics (C-18/11), paras. 21-35. 
States. The general principles regarding the consideration of losses in the proposed CCCTB Directive in relation to entering (ring-fencing of pre-consolidated losses) and leaving rules (no losses are attributed to the leaving group member) also apply in the case of permanent establishments of non-resident companies. Consequently, if a permanent establishment is terminated, there will be no issue of final losses of that entity under EU law, unless the termination triggers the automatic de-grouping of the CCСТВ group (i.e. when the group is left with less than two members). Such an approach makes the CCCTB attractive for foreign businesses. If the permanent establishment leaves the CCCTB group for a reason other than termination (e.g., when it belongs to a non-resident subsidiary, which ceases to meet the group eligibility requirements of Article 54), losses incurred after the exit of the permanent establishment from the group will be dealt with under the relevant national law or CCCTB rules.

The consideration of losses attributed to a permanent establishment in the residence State of the head office falls within the scope of the domestic law of the latter. From the residence States' perspective, the inclusion of CCCTB-located permanent establishments of their resident companies into the CCCTB group definition should generally be neutral in terms of the losses of the permanent establishment. However, the fact that the CCCTB uses a formula to apportion the tax base to the permanent establishment may lead to inconsistencies with regard to the consideration of losses and available credit when the home State applies worldwide taxation but uses, for instance, the credit method for the elimination of double taxation of foreign business income. In such a case, if the tax base apportioned to the permanent establishment under the CCCTB formula apportionment is positive, its income will be taxed in the CCCTB Member State in which it is located. If the tax base of the permanent establishment under the AOA is negative, the residence State of the head office will include these losses in the worldwide tax base of its resident and apply its domestic law for the possible carryover. Even if the overall tax base of the resident entity is positive in that tax year, its home State will normally not allow a credit for the taxes paid in the CCCTB Member State. Moreover, if the permanent establishment is allocated positive income in the following years according to the AOA in the head office's State, but not under the CCCTB rules, the home State will likely not give a credit for the taxes paid in the previous years in the CCCTB Member State. Had the profits and losses attributed to the permanent establishment 
been based on the CCCTB sharing mechanism and the AOA coincided in the given year, the home State would have allowed a credit for the tax paid in the source State in line with the AOA allocation. Of course, similar inconsistencies may currently arise when both countries use the AOA for profit attribution due to differences in their national law regarding the calculation of tax base, but these differences are presumably smaller compared to the application of two distinct systems such as the CCCTB and AOA.

Another question is how the home State of the head office should deal with final losses attributed to the permanent establishment in the case of enhanced cooperation. When a CCCTB group is terminated, any unrelieved losses shall be allocated to each group member based on the sharing mechanism. When the permanent establishment ceases to exist following the termination of the group, losses attributed to it will become final. Normally, the home State will be obliged to take into account only those losses which are calculated according to its national law and attributed to the permanent establishment under the AOA. In that case, the home State treats the two situations - cross-border and domestic - equally. Although some losses attributed to the permanent establishment under the CCCTB may be lost, as national tax laws differ, the same may occur even without the existence of the CCCTB system. Actually, in some scenarios, a CCCTB group may get an advantage compared to non-CCCTB participating groups. In the following example (Example 37: Consideration of (final) losses of a CCCTBlocated permanent establishment in the home State) a company (CoA), resident in a CCCTB Member State A, forms a CCCTB group with a permanent establishment of its qualifying non-resident subsidiary (CoB) in a CCCTB Member State C. Both CoA as well as the permanent establishment incur losses, (e.g. 50 and 100 respectively), as calculated under the CCCTB rules. 
Example 37: Consideration of (final) losses of a CCCTB-located permanent establishment in the home State

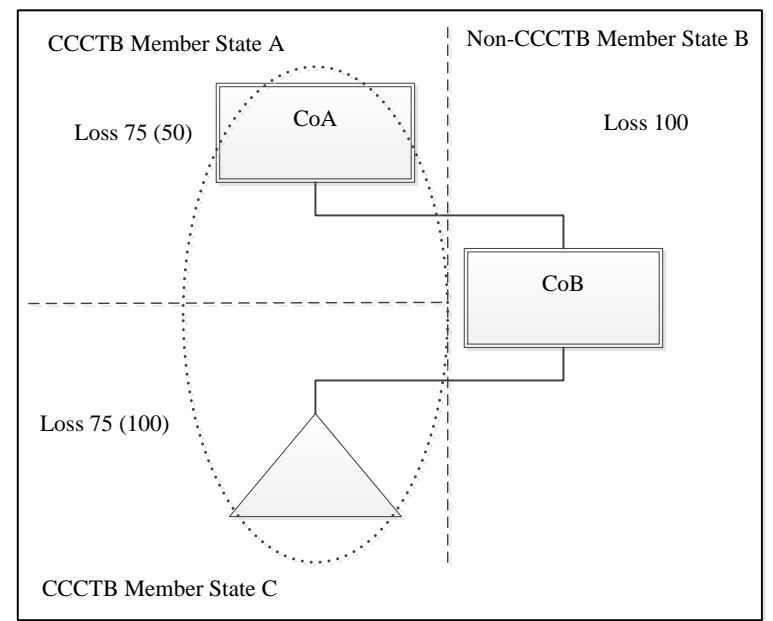

\begin{tabular}{|c|c|c|c|}
\hline Jurisdiction & $\begin{array}{c}\text { Loss } \\
\text { incurred }\end{array}$ & $\begin{array}{c}\text { Loss } \\
\text { attributed }\end{array}$ & $\begin{array}{c}\text { Loss offset } \\
\text { / carry-over }\end{array}$ \\
\hline MS A (CoA) & 50 & 75 & 75 \\
\hline MS C (PE) & 100 & 75 & $\mathrm{n} / \mathrm{a}$ \\
\hline MS B (CoB) & n/a & 100 & 100 \\
\hline
\end{tabular}

In the example, the termination of the permanent establishment triggers the termination of the group given that the group consisted of only two members. As a result, assume that both group members will be allocated a loss of 75 under the CCCTB apportionment formula. The loss of the permanent establishment, as calculated according to the domestic law of the home State of the head office, is 100. As the loss attributed to the permanent establishment becomes final, the non-CCCTB Member State will have to take into account that loss (100) in the tax base of the head office, provided that the conditions of the CJEU's jurisprudence are fulfilled. The loss attributed to CoA will be carried forward and set off according to the national law of its State of residence (Member State A) or the CCCTB rules.1046 It appears that, due to dissimilar bases of apportionment of the tax base under the CCCTB and the AOA, the group will get a benefit of 25 . In particular, on the one hand, there is

1046 Article 43 of the proposed CCCTB Directive. 
a consideration of a greater amount of losses at the level of $\mathrm{CoB}$ but, on the other hand, CoA can carry forward and offset more losses against its future profits than it could have in the absence of the CCCTB group. The non-CCCTB Member State may disallow the deduction of the total loss as calculated under the AOA (100) if, under its domestic law, it accepts the allocation of final losses based on the formula apportionment.

\subsubsection{COMPENSATION OF LOSSES BY A PERMANENT ESTABLISHMENT}

It is commonly accepted that the source State has limited taxing rights over the business income of a non-resident company. It can tax that income to the extent that it is attributed to a permanent establishment located in that State. This implies that the host state should normally take into account only those losses of the enterprise that are attributed to the permanent establishment located in its jurisdiction. In the EU setting, the CJEU has confirmed this understanding in Futura. Accordingly, national law of the host State does not restrict the freedom of establishment if, for the purposes of calculating the basis of assessment for non-resident taxpayers, only profits and losses arising from their activities in that State are taken into account in calculating the tax payable in the host State. ${ }^{1047}$ From the Court's perspective, the argument behind the "fiscal principle of territoriality"1048 is the idea of symmetry and consistency of a domestic tax system, so that when a State disregards foreign profits, it may symmetrically disregard foreign losses. ${ }^{1049}$

Against this background, it is not surprising that only a few countries allow downward loss-relief. For example, in 2010, while most Member States permitted upward loss relief, only two Member States allowed downward loss relief. ${ }^{1050}$ Nevertheless, for the purposes of the single market, downward loss-relief would be desirable. The adoption of the CCCTB through a unanimous vote by all Member States would create such a possibility. However, in case the CCCTB is introduced in the framework of enhanced cooperation, this

1047 Futura (C-250/95), paras. 18-22.

1048 Some scholars argue that the Court's interpretation of the term territoriality differs from the current understanding of the term under the international tax law. See, for instance, Marres (2011), 112-125; Arginelli (2007), 89-92.

1049 Cordewener (2004b), 220.

${ }^{1050}$ Kok (2010), 669. 
limitation will remain where the head office and the permanent establishment are located in different jurisdictions (i.e. in a CCCTB Member State and non-CCCTB Member State).

\subsubsection{PRELIMINARY CONCLUSIONS}

The CCCTB system has been built upon the residency principle, which implies the taxation of the worldwide income of resident taxpayers. Generally speaking, loss compensation in the case of foreign permanent establishments depends largely on the method of elimination of double taxation that the jurisdiction uses. The author concluded that the context and the definition of the CCC tax base assumes the use of the base exemption method rather than the tax exemption method for the elimination of double taxation of income derived through foreign permanent establishments. Hence, based on the theory of symmetry, CCCTB Member States are not obliged to consider the corresponding foreign losses. The Court ruled in Lidl Belgium that the application of the base exemption method does not infringe the proportionality principle. In line with Marks \& Spencer concerning subsidiary losses, the Court ruled in Lidl Belgium that losses of a permanent establishment in a Member State do not have to be taken into account at the level of the head office located in another Member State if the former Member State provides for the possibility of deducting a taxpayer's losses in the future years for the purposes of calculating the tax base. In other words, only final losses would have to be taken into account in the Member State of the head office. Due to the lack of external scope of the freedom of establishment, the same conclusion cannot be achieved in relation to final losses of permanent establishments from non-EU Member States.

The application of the base exemption method may be disadvantageous compared to the tax exemption method, in particular, because it leads to a cash-flow disadvantage for companies having foreign permanent establishments compared to companies having CCCTB-located permanent establishments. The tax exemption method typically allows the deduction of foreign losses incurred through a foreign permanent establishment, supplemented with appropriate recapture rules. The logic behind the application of the recapture mechanism is the retrospective taxation of domestic profits, which had been reduced in the previous year rather than the taxation of profits of a permanent establishment in the subsequent years. Under such a construction, the recapture mechanism is in line 
with DTCs as well as the EU law. If the CCCTB supported the application of tax exemption method, losses incurred through foreign permanent establishments should generally be carried forward indefinitely at the CCCTB group level. Due to the specificity of the CCCTB system, in addition to a general recapture rule, the Directive would have to provide specific recapture rules concerning entering and exiting a СССТВ group. With regard to entering, it would be particularly important that when, under its domestic law, the State of residence has allowed a temporal offset of losses of a foreign permanent establishment, the recaptured profits of the latter will be set off and carried forward against the apportioned share of the resident company. In the same vein, recapturing losses of a permanent establishment offset against the CCC tax base should have priority over the national tax base when a company (the head office) exits from the CССТВ.

With regard to the consideration of final losses in the current framework of the proposed CCСTB Directive (i.e. the application of the base exemption method), in the case of outbound investments, a difference should be made between the rules concerning the offset of final losses of a foreign permanent establishment, depending on whether the head office enters or leaves a CCCTB group. With regard to entering a CCCTB group, when the permanent establishment is terminated during the CCCTB group membership of the head office, only those foreign losses which were incurred during the CCСTB group membership of the head office should be set off against the CCC tax base. Losses incurred before entering the CCCTB should be ring-fenced and treated as pre-consolidated losses. The same conclusion was achieved with regard to final losses of subsidiaries of non-CCCTB Member States. The consistent treatment of entering and exiting a CCCTB group suggests that final losses of a permanent establishment incurred during the period when the head office belonged to the CCСТВ group should be set off against the CCC tax base. However, setting off part of the final losses against the CCC tax base might lead to a number of administrative difficulties, for example, when the CCCTB group ceases to exist before the termination of the permanent establishment.

In case of inbound investment, generally speaking, the consideration of losses of a permanent establishment in the home State will depend on the domestic law of the latter. From its perspective, the inclusion of CCCTB-located permanent establishments of resident 
companies into the CCCTB group definition should be neutral in terms of the consideration of losses of such permanent establishments. Normally, the home State will be obliged to take into account only those losses that are calculated according to the national law of the home State and attributed to the permanent establishment under the AOA. Otherwise, the State would risk the erosion of its tax base due to offsetting a higher amount of losses (of the total CCCTB group). Therefore, if the CCCTB is introduced in the framework of enhanced cooperation, the home State would be obliged to take into account the final losses of the CCCTB-located permanent establishments as calculated under its domestic law, despite the amount of (final) losses attributed to the permanent establishment under the CCCTB rules.

\subsection{COMPUTATION OF LOSSES}

Losses can be seen as negative profits, although normally they do not lead to negative taxes. ${ }^{1051}$ Hence, the definition of losses is typically derived from each country's domestic law, like the definition of profits. However, broadly defined, losses are the excess of expenses over revenues for a period, or the excess of the cost of the asset over the proceeds, when the asset is disposed of. ${ }^{1052}$ Due to differences in national laws, the calculation of positive and negative income under source and residence State laws is likely different. In such a case, (all) losses suffered in one jurisdiction may not be recognised in another when a country taxes the worldwide income of its residents. ${ }^{1053}$ On the other hand, profits recognised in one jurisdiction may also not be recognised in the other. Thus, both countries calculate profits and losses of their taxpayer in a consistent manner. The computation of foreign losses based on the domestic law of the State of residence is consistent, because it avoids situations in which a State has to accept more generous rules for foreign losses than those for domestic losses ${ }^{1054}$ or where foreign losses are treated disadvantageously compared to domestic losses. Hence, a computation of losses based on each State's domestic rules is much more common, although it is not a rule. On the other hand, the computation of foreign losses based on the residence State's domestic law increases administration and compliance costs caused

\footnotetext{
1051 Cordewener (2004a), 135.

1052 Rogers-Glabush (2009), 270.

1053 European Commission (2001a), 246.

1054 Ibid., 338.
} 
by the re-calculation of foreign losses (and profits). It is noteworthy that, with regard to foreign permanent establishments, the proposal for the loss directive suggested calculation of losses in accordance with the rules where they are incurred, i.e. as they are shown on the permanent establishments' tax accounts. ${ }^{1055}$ However, the proposed CCCTB Directive supports concluding that, where foreign income is by exception not exempted, it is calculated according to the CCCTB rules. ${ }^{1056}$ Hence, for the purposes of consistency, foreign losses would also be calculated based on the CССТB provisions.

With regard to final losses in the context of enhanced cooperation, it is important to note that it falls out of the CJEU's competence to decide whether such losses should be calculated based on the host State's or home State's domestic law. The Court in Marks \& Spencer did not define how to determine final losses, as the parties to the dispute had agreed that the losses should be calculated according to the tax law of the UK. ${ }^{1057}$ The UK domestic courts considered that only losses computed under national law would be deemed final. ${ }^{1058}$ In $O y A$, the Court explicitly recognised that, in the present state of EU law, freedom of establishment does not, as a matter of principle, imply the application of a particular law to the calculation of crossborder losses. However, EU law precludes calculation methods which would lead to an unequal treatment compared to the calculation used in a similar purely domestic case. ${ }^{1059}$ Indeed, allowing companies to deduct foreign (final) losses would imply that the home State may apply more generous rules for foreign losses than those for domestic losses. However, EU law does not require cross-border activities to be treated more beneficially than domestic activities - it only requires them to be treated equally. Hence, it is acceptable that, in the scenario of enhanced cooperation, the CCCTB Member States will calculate and provide for the offsetting of final losses of foreign permanent establishments and subsidiaries from non-CCCTB Member States according to the CCCTB rules. The same approach should be taken with regard to final losses in case of inbound investments into the CCCTB. Otherwise, the non-resident parent company or the head office may be left to face the final losses of a CCCTB group rather

\footnotetext{
1055 European Commission (1991).

$1056 \mathrm{See}$, for instance, provisions concerning the calculation of income when the CFC provision applies (Article 83 of the proposed CCCTB Directive).

1057 Case Marks \& Spencer (C-446/03), para. 22.

1058 Silva (da) (2011), 261.

${ }^{1059}$ Case $O y$ A (C-123/11), paras. 58-59.
} 
than the losses attributed to its subsidiary or a permanent establishment.

\subsection{CONCLUSIONS}

The starting point regarding the consideration of foreign losses within the CCCTB is the acceptance that Member States must be able to protect their share of the tax base against possible erosion and avoid a situation in which only losses can be imported into the CCCTB area, while the profits can be kept outside. ${ }^{1060}$ There is a fundamental difference between the taxation of foreign income derived through a foreign subsidiary and a permanent establishment. In particular, due to the principle of international fiscal sovereignty, States do not tax the income of a foreign separate legal person - a subsidiary. Due to such limited taxation, States typically disregard both the positive and negative income of such entities. Although there are some EU Member States that extend their domestic group regimes to cover foreign subsidiaries, the CJEU has confirmed that this is not a requirement for the Member States. Nevertheless, in the aftermath of Marks \& Spencer, Member States were left to deal with the concept of "final losses" in the EU setting.

If the CCCTB is introduced in the framework of enhanced cooperation, the Directive would have to reflect these matters. The core question would be whether final losses of a foreign subsidiary of a CCCTB group member should be offset against the CCC tax base or the individual tax base apportioned to the parent company of the subsidiary. In the opinion of the author, final losses that arise during the group membership of the parent company do not fit within the idea of pre-consolidated losses, unless they were incurred before the parent company joined a CCCTB group. Hence, in order to avoid the erosion of tax bases of other Member States, where the rest of the group members reside or locate, it seems desirable to separate subsidiary losses depending on whether they were incurred before or after the parent company joined the group. Following such a distinction, the relevant loss carry-over will accordingly depend on the CCCTB or the national rules. By comparison, when a US state uses the combined reporting method, it has a choice whether to allow the net operating losses of one company to be offset against another member of the combined group or allow such an offset only when

${ }^{1060}$ European Commission (2006o), Annex 2 'International Aspects’. 
NOLs were generated from the activities of the unitary business. ${ }^{1061}$ Under the CCCTB rules, such an option should not be available even in case of final losses of foreign subsidiaries, but it will have to be determined unanimously in the CCCTB Directive.

It is generally accepted that permanent establishments are not separate legal persons but form part of their head office. When a State subjects its residents' worldwide income to taxation, it also includes the profits and losses of foreign permanent establishments in the tax base of the taxpayer. As follows, there is an apparent distinction between the treatment of foreign income and losses of a foreign permanent establishment and of a non-resident subsidiary. This distinction is also in line with EU law, as confirmed in $X$ Holding. ${ }^{1062}$ Indeed, while the host State must grant the same treatment to permanent establishments and subsidiaries, the home State may establish a difference between the two forms of secondary establishments. This view has been expressed by Advocate General Geelhoed in that "as the nature of the tax jurisdiction being exercised in each case differs fundamentally, an economic operator subject to home State jurisdiction cannot per se be considered to be in a comparable situation to an economic operator subject to source State jurisdiction, and vice versa. As a result, Article 43 of the TEC (now article 49 of the TFEU) imposes two different categories of obligation on a State, depending upon the jurisdictional capacity in which it is acting in a particular case." 1063

Loss compensation in the case of permanent establishments depends largely on the method that a country uses for the elimination of double taxation. The general acceptance is that the application of the credit method leads to the automatic inclusion of the positive and negative income of the foreign permanent establishment in the tax base of the resident taxpayer. On the contrary, the application of the base exemption method normally exempts all foreign income from the tax base. This method has also been proposed as the method for the elimination of double taxation of foreign permanent establishment income in the proposed CCCTB Directive. Like in the

\footnotetext{
1061 Fox et al. (2009), 408.

1062 Case X Holding (C-337/08), para. 38.

1063 Opinion of Advocate General Geelhoed delivered on 23 February 2006 on case

Test Claimants in Class IV of the ACT Group Litigation (C-374/04), para. 57. See also opinion of Advocate General Kokott delivered on 19 April 2012 on case Philips Electronics (C-18/11), paras. 54-56.
} 
case of subsidiaries of non-CCCTB Member States, in the context of enhanced cooperation, there would be an obligation to consider the final losses of permanent establishments located in non-CCCTB Member States of CCCTB head offices. The idea of group taxation should be that all group members are considered as single taxpayers and include as much group income into the common base as possible. Consequently, from the author's perspective, a distinction should be drawn between the consideration of final losses that were incurred before or during CCCTB group membership of the head office. In spite of the fact that this will likely increase the administration and compliance costs, it protects Member States' tax bases from erosion. Despite the benefit, the current CCCTB framework does not allow such a distinction because it uses the base exemption method for the elimination of double taxation.

The discussion above shows that the introduction of a tax exemption rather than the base exemption method in the CCCTB Directive would be more beneficial for taxpayers. Indeed, it may eliminate a considerable cash flow disadvantage compared to the base exemption method, as it allows a temporary deduction of foreign losses from the tax base. Moreover, the application of the tax exemption method would diminish the discussion on the consideration of final losses of foreign permanent establishments. This method was also proposed as a more proportionate measure by Advocate General Sharpston in Lidl Belgium.1064 The application of the tax exemption method, if adopted, in the CCCTB should not introduce a conflict with Member States' DTCs with third countries, because the recapture mechanism implies the retrospective taxation of residents rather than the foreign permanent establishment. Nevertheless, Member States would be encouraged to specify this in their DTCs or the accompanying protocol. ${ }^{1065}$ On the other hand, the use of the tax exemption method may introduce additional costs related to the requirement of recalculating foreign profits and losses according to the CCCTB rules. Furthermore, the application recapture mechanism in the CCCTB system would require the introduction of appropriate rules concerning recovering of profits (i) that had been reduced in a Member State before the head office entered the group; and (ii) that had been deducted from the CCC tax base before the head office existed from the group. In the light of the foregoing, the author would propose an alternative method for the CCCTB: base

1064 Ibid., paras. 23-24.

1065 OECD Comm. on Article 23, para. 44. 
exemption method with a loss recapture mechanism. Such a method would benefit from the best of both worlds and thus make the CCCTB attractive for companies. 


\subsection{INTRODUCTION}

Most States have established their taxation rights over resident taxpayers either on worldwide taxation or on a territorial taxation basis. While taxing worldwide income typically leads to double taxation due to the concurrent taxing rights of the source and residence State, taxing on a territorial basis does not. There is a general agreement that countries should eliminate juridical double taxation, either unilaterally through domestic law or bilaterally by means of their DTCs. Meanwhile, the avoidance of economic double taxation remains arguable. As explained earlier, States taxing worldwide income normally eliminate or reduce double taxation of certain income by using the credit or exemption method. However, nowadays, the differentiation between territorial taxation and worldwide taxation is rather difficult, because countries typically apply systems of a hybrid character. In other words, countries normally do not operate a pure credit system, which is better designed for a worldwide taxation system, or a pure exemption system, which fits with the idea of territorial taxation.

The general understanding is that double taxation is an obstacle to the development of economic relations between countries. This is also the opinion of the OECD, according to which these obstacles arise due to the harmful effects on the exchange of goods and services and movements of capital, technology and persons that double taxation creates. ${ }^{1066}$ Therefore, one of the aims of concluding DTCs is the elimination of double taxation on cross-border movement. Nevertheless, there is no international consensus as to the preferred method for the elimination of double taxation and the OECD has not expressed a particular position on the matter. Hence, each State makes its decision based on a number of factors. From the author's perspective, the leading criteria should be simplicity, supporting foreign business and investment activities while protecting the State's revenues. The decision on the preferred method does not have to be applied uniformly to all foreign income, but a distinction could be made between different types of income, such as business income or investment income. Equally, the CCCTB Directive

1066 Introduction of the OECD Comm., para. 1. 
proposes the application of the exemption method ${ }^{1067}$ on some foreign income (Article 11), while it foresees the prevention of double taxation by the credit method on other types of income (Article 79) of taxpayers.

The European Commission has been clear that, from its perspective, double taxation is an obstacle to cross-border activity in the EU. Despite that, in the current EU setting, Member States remain free to decide whether they wish to eliminate double taxation and, if so, determine which method fits their policy goals better. Member States' domestic rules aimed at avoiding double taxation have never been found by the CJEU to infringe EU law. Indeed, it is also not a competence of the Court to set a rule for the Member States as to which method they should use for the elimination of double taxation, ${ }^{1068}$ as long as the national measures are implemented in a non-discriminatory manner. ${ }^{1069}$ Case law of the CJEU shows that Member States are at liberty to choose their system for the elimination of double taxation, ${ }^{1070}$ but they must ensure that the two methods - exemption and credit - in practice produce an equivalent result as per the elimination of double taxation of residents and nonresidents in equal situations. ${ }^{1071} \mathrm{In}$ fact, it is rather common that the credit and the exemption method do not lead to the same result. Hence, following the FII Group Litigation II judgment, ${ }^{1072}$ the tendency is that the two methods for the elimination of double taxation lead to a different result and, thus, Member States must make the necessary adjustments on a case-by-case basis.

1067 The inclusion of both the credit and exemption method in the CCCTB Directive does not mean that Member States could choose which method of elimination of double taxation they prefer, but the Directive is strict on the matter. Nevertheless, it remains the choice of the Member States whether they wish to apply exemption with progression provision for income exempted under the CCCTB Directive.

1068 See CJEU in Lidl Belgium (C-414/06), where the Court - correctly - did not take a position with regard to the elimination of double taxation of income derived through a foreign permanent establishment by means of tax exemption or base exemption method.

1069 See, for example, cases Commission v France [Avoir Fisca] (270/83); Manninen (C319/02).

1070 Cases Gilly (C-336/96); Saint-Gobain (C-307/97). Based on Kerkbaert \& Morres, the Court considers the exemption and credit to be equivalent methods for giving relief for double taxation.

1071 Case FII Group Litigation II (C-35/11).

1072 Ibid. 
Theoretically, both the credit method and the exemption method should provide relief from double taxation, even though they do not always produce the same economic result. Indeed, in the context of international taxation, the widely accepted supporting rationale behind the two methods is different. In other words, the traditional questions of choosing between the exemption or credit method for the prevention of double taxation of foreign income points to the choice between CEN and CIN. CEN, which aims at home market neutrality, is typically achieved by taxing the accrued worldwide income of residents by giving a credit for juridical double taxation. On the other hand, CIN, which aims at source market neutrality, is typically realised by applying the exemption method to mitigate international double taxation.

\section{2 (ELIMINATION OF) DOUble TAXATION IN THE EU}

Clearly, double taxation is an obstacle to the EIM and its abolition is one of the objectives of the Union. ${ }^{1073}$ The European Commission has recognised the negative effect of double taxation on the EIM. In fact, its first initiative in this field dates back to 1968 when the European Commission proposed the text for a multilateral DTC between Member States for the avoidance of double taxation of income and capital and for mutual assistance in the field of direct taxes. This was based on the then Article 220 of the TEC (later Article 293 of the TEC). ${ }^{1074}$ Due to its broad scope, the proposal was politically unacceptable to Member States. In addition to that, Member States did not consider such an instrument relevant. Since then, the European Commission has been looking for more possibilities to improve European tax policies in the area of double taxation, for example, by means of a proposal for a directive concerning an arbitration procedure ${ }^{1075}$ and the discussion draft on

1073 Cases Gilly (C-336/96), para. 16; Damseaux (C-128/08), para. 28. Note that, in these cases, the Court based its argument on Article 293 of the TEC (ex-Article 220 of the TEC). Although there is no equivalent provision in the current Treaties, the elimination of double taxation remains an objective of the EU.

1074 Preliminary Draft of a European Double Taxation Convention (Multilateral Agreement of the Member States of the European Communities for the Avoidance of Double Taxation on Income and on Capital and on Mutual Assistance in the Field of Direct Taxes) of 1st July 1968 (Lehner 1997, 10, footnote 48).

1075 European Commission (1976). Although the proposal was never accepted by the Council, it led to the Arbitration Convention, which was part of the tax package of 1990, alongside the Parent and Subsidiary Directive and Merger Directive. 
taxation in the EU.1076 At this point, the issue of double taxation and its elimination within the EIM has again become a burning issue. The CCCTB initiative can definitely be considered as one of the most relevant initiatives for the elimination of double taxation in a specific field in the EU.

Since double taxation occurs due to concurring taxing rights, it is difficult to point towards a country - source or residence - that would be responsible for the elimination of double taxation in a particular situation. According to the Court, Union law, in its current state, does not lay down any general criteria for the attribution of areas of competence between the Member States. ${ }^{1077}$ In the light of this, the Court accepts that Member States may tax resident taxpayers on their worldwide income and non-residents only on the income sourced within the relevant Member State, even if such a system leads to double taxation. Moreover, as case law shows, there is no general prohibition of double taxation in the EIM.1078

Prior to the Treaty of Lisbon, the second indent of Article 293 of the TEC created a link between the (then) Community law and DTCs as it required that "Member States shall, so far as is necessary, enter into negotiations with each other with a view to securing for the benefit of their nationals /.../ the abolition of double taxation within the Community." The provision could have been interpreted in three distinct ways: (i) it required the elimination of double taxation within the Union only by the Member States; (ii) it required the Member States to adopt measures only to the extent that their involvement was essential; or (iii) it required the EU institutions to intervene only if the Member States refrained from doing so or when they were not able to achieve the same result. ${ }^{1079}$ It is also noteworthy that the Court explicitly ruled in Gilly that Article 293 of the TEC did not have direct effect. ${ }^{1080}$

The elimination of Article 293 of the TEC from the Lisbon Treaty has led to a debate on whether Member States are obliged to abolish double taxation based on other articles of the Treaties, such as Article

\footnotetext{
1076 European Commission (1996).

1077 Cases Kerckhaert and Morres (C-513/04), para. 22; Columbus Container Services (C298/05), para. 45; Damseaux (C-128/08), para. 33.

1078 Cases Kerckhaert and Morres (C-513/04); Block (C-67/08); Damseaux (C-128/08).

1079 Pistone (2002b), 74.

1080 Case Gilly (C-336/96), para. 14-17.
} 
4(3) of the TEU, which incorporates the EU loyalty principle, together with the provisions on the fundamental freedoms and the general non-discrimination requirement of the TFEU. First and foremost, rather than being a direct source of legally binding obligations for Member States to eliminate double taxation, the loyalty principle only ensures the effective functioning of the more specific articles of the Treaties and the provisions of secondary EU law. ${ }^{1081}$ In fact, Article 4(3) of the TEU does not - as Article 293 of the TEC also did not - set forth any specific time limits as to when Member States shall provide for a solution to remove double taxation as an obstacle to the EIM. Accordingly, it does not require that the consequences of (the absence of) Member State action in this field are considered. Hence, the current state of EU law does not require Member States to adopt an effective solution for the elimination of double taxation within the EIM, as the CJEU has confirmed. ${ }^{1082}$ Others claim that the elimination of Article 293 of the TEC also cancels the discussion of the functioning of that article in conjunction with Article 94 of the TEC (Article 115 of the TFEU). ${ }^{1083}$ Prior to the deletion of Article 293 of the TEC, questions were raised as to the impact of that article on the competence of the Member States in relation to Article 94 of the TEC, i.e. whether Article 293 of the TEC had a carve-out effect vis-à-vis Article 94 of the TEC. Other scholars argue that Article 293 of the TEC did not grant the Member States absolute or exclusive power concerning the elimination of double taxation and thus did not have such an effect. On the contrary, its language ("in so far as necessary") confirms the subsidiary character of the instrument to Article 94 of the TEC and only invites Member States to enter into negotiations for the purposes of abolishing double taxation. ${ }^{1084}$ This conclusion finds support, for instance, in the adoption of the Parent and Subsidiary Directive, which is designed to abolish double taxation in the EIM at least as far as the distribution of profits by certain associated companies is concerned.

While Article 293 of the TEC foresaw tax coordination, Article 115 of the TFEU (Article 94 of the TEC) provides for the approximation of Member States' laws to improve the functioning of the EIM. However, due to the subsidiarity principle in Article 5(3) of the TEU, the competence of the Union may be limited. In fact, there has been

\footnotetext{
1081 Nieminen (2010), 331.

1082 Cases Kerckhaert and Morres (C-513/04); Block (C-67/08); Damseaux (C-128/08).

1083 Kemmeren (2008b), 157.

1084 Hinnekens (2009), 605.
} 
some controversy amongst scholars as to whether the subsidiarity clause prevents the EU from acting in the field of the elimination of double taxation. ${ }^{1085}$ Hence, the question is whether the Union or the Member State are in a "better" position to eliminate double taxation within the EIM. Despite the comprehensive DTC network amongst Member States, double taxation of cross-border activities has not been completely eliminated yet. Abolishing double taxation via the approximation of Member States' laws would presumably be better achieved by Union action, although the question remains whether individual Member State action can also obtain results to a "sufficiently" high standard. Of course, the introduction of the CCCTB would bring a solution in that field at least as far as situations within the group are concerned. However, in case the CCCTB is introduced only in some Member States via enhanced cooperation, the risk of double taxation concerning income flows between group members in participating and non-participating Member States would remain.

\subsection{EFFECTIVENESS OF MEMBER STATES’ DTCS}

The Treaty of Lisbon catalogues three areas of competences of the Union as exclusive, shared and complementary competences. ${ }^{1086}$ In some policy areas, the Union does not have competence and, hence, the Member States hold exclusive competence in these areas. In the field of direct taxation, the Court has repeatedly held that in the absence of unifying or harmonising measures adopted by the Union, the Member States remain competent to determine the criteria for taxation of income and wealth with a view to eliminating double taxation by means, inter alia, of international agreements. ${ }^{1087}$ However, as far as the exercise of the power to tax so allocated is concerned, the Member States may nevertheless not disregard Union rules. ${ }^{1088}$ In the light of this, Member States retain the competence to enter into DTCs between each other and with third countries, but they must exercise this capacity in line with the Union law.

\footnotetext{
1085 Nieminen (2010), 332.

1086 Articles 3-6 of the TFEU.

1087 Cases Saint-Gobain (C-307/97), para. 56-57; Test Claimants in Class IV of the ACT Group Litigation (C-374/04), para. 52.

1088 Cases Schumacker (C-279/93), para. 21; ICI (C-264/96), para. 19; Futura (C250/95), para. 19.
} 
The introduction of the CCCTB would raise a question as to the potential conflict between EU law and Member States' DTCs with third countries, for example, with regard to the differences in the allocation of taxing rights and methods for relieving double taxation. On the one hand, Member States are required to respect EU law, which prevails over their domestic law due to the supremacy principle of the Treaties. This does not mean that, in the case of conflicts between domestic provisions and Union law, the former would become invalid but that it would nonetheless become inapplicable. On the other hand, Member States must respect their international obligations stemming from their DTCs. ${ }^{1089}$ Under international law DTCs become binding upon a declaration of intent to contract (ratification or other means). However, they do not form part of national law until their internal applicability. In monistic countries, international treaties automatically form part of national law from the moment of the declaration of intent, without any further measures of implementation. On the contrary, a dualist system requires international treaties to be implemented into national law to become part of it. Once they are part of domestic law, Union law prevails over the DTCs. The question is whether potential conflicts between the articles of the CCCTB Directive and those of Member States' DTCs with third countries could be solved without the requirement to renegotiate existing DTCs or whether negotiation of the DTCs (or at least parts of them) is inevitable. In any event, the guiding approach should be that the Directive should provide an adequate level of protection of Member States' tax bases while minimising potential conflict with existing DTCs. ${ }^{1090}$

Further, one may necessitate the negotiation of a multilateral DTC between the EU and third countries (in the first phase, at least with the most important trade partners). Such a DTC could be limited to businesses that participate in the CCCTB. The Court held in Van Gend en Loos that the Community constitutes a new legal order of international law, for the benefit of which states have limited their sovereign rights. ${ }^{1091} \mathrm{~A}$ year later, the Court confirmed in Costa $v$ Enel that the Treaty has created its own legal system that binds the Member States. ${ }^{1092}$ Finally, the Treaty of Lisbon expressly confers

\footnotetext{
1089 See also European Commission (2005c), 6.

${ }^{1090}$ European Commission (2007a), para. 117.

1091 Case V an Gend en Loos (26/62).

1092 Costa v E.N.E.L. (6/64), para. 3.
} 
legal personality on the Union, giving it the capacity to enter into legal relationships in its own right. ${ }^{1093}$

The TFEU grants the Union a number of express competences. Article 216 of the TFEU provides for an explicit provision on the conclusion of international agreements by the Union in the scope of its responsibilities, or where the conclusion of an agreement is necessary in order to achieve, within the framework of the Union policies, one of the objectives referred to in the Treaties, or the competence is provided for in a legally binding Union act or is likely to affect common rules or alter their scope. ${ }^{1094}$ In addition, Article 352 of the TFEU authorises the Council to adopt appropriate measures if action by the Union should prove necessary to attain one of the objectives set out in the Treaties, but where the Treaties have not provided the necessary powers. Finally, Article 37 of the TEU confers upon the Council the capacity to conclude agreements in relation to common foreign and security policy.

The CJEU has held in a series of cases that the Union has certain implied powers, even though they have not been specified in the Treaties. The Court held in ERTA that each time the Community acted to implement a common policy envisaged by the Treaty, the Member States no longer have the right, acting individually or even collectively, to take external action where this would affect the rules thus established or distort their scope. ${ }^{1095}$ In the Court's opinion expressed in Kramer, the Union ${ }^{1096}$ could have implied external powers even though it had not effectively exercised its internal powers to implement the relevant policy, but Member States retained competence to act as long as the Union had not duly exercised its

\footnotetext{
1093 Article 47 of the TEU.

${ }^{1094}$ Kuijper claims that Article 216 of the TFEU attempts to lay down more precise rules with regard to the Union's external competence, but it appears a rather clumsy attempt to codify the treaty-making power of the Union, based on the CJEU's case law. According to him, the provision is odd, except for the words "where the Treaty provides," because it takes elements from the case law of the CJEU on the exclusive external Union competence to define the potential treaty-making power of the Union. This is basically contrary to the case law of the CJEU which has determined that the Union disposes of potential treaty-making power across the whole spectrum covered by the Treaty and not only "where the Treaty so provides," or to passages adapted from opinion Inland Waterways (1/76) and Commission v Council [ERTA] $(22 / 70)$.

1095 Case Commission v Council [ERTA] (22/70), para. 17.

1096 Please note that the author uses the term 'Union' whereas in the case the Court referred to 'Community'.
} 
internal power, provided that their action was compatible with the Union objectives. ${ }^{1097}$ In Inland Waterways, the Court held that the Union could have exclusive external competence, even though it had not exercised its internal powers, if the Member State action could jeopardise the Union objective. ${ }^{1098}$ The latter view was modified in the Court's opinion on the WTO Agreement in that the Union's exclusive external competence was normally dependent on the actual exercise of the Union's internal power rather than its existence. ${ }^{1099}$ Finally, the Court confirmed in the 'Open Skies' litigation"1100 that an implied external competence could exist not only where the internal competence had already been used to adopt measures for implementing common policy, but also where the internal Union measures are adopted only when the international agreement was concluded and implemented. ${ }^{1101}$ However, in line with the opinion on the WTO Agreement, the principle applied only where the internal competence could only be exercised at the same time as the as the external competence on the ground that the conclusion of an international agreement was necessary for the attainment of the Union objective. ${ }^{1102}$ Finally, the Court held that where the Union made common rules pursuant to its internal powers, the Union acquired exclusive competence to contract with non-member countries on the obligations relating to matters which affected those rules or their scope. ${ }^{1103}$

Internal competences/powers are those granted by the Treaties to the Union to meet a specific Union objective. External competences/powers are Union competences in relation to agreements with third countries. The authority of the Union to deal with Member States' DTCs concluded with third countries is implied in its internal authority under the Union primary and secondary law. When concluding DTCs with third countries, the Union may have to be involved to the extent that certain provisions of those DTCs risk distorting intra-Union trade or risk discriminating vis-à-vis nationals

\footnotetext{
1097 Kramer (Joined Cases C-3/76, C-4/76 \& C-6/76).

1098 Opinion Inland Waterways (1/76), para. 4. Craig \& Burca (de) (2008), 97.

1099 WTO Agreement (1/94).

1100 Cases Commission v United Kingdom (C-466/98); Commission v Denmark (C-467/98); Commission v Sweden (C-468/98); Commission v Finland (C-469/98); Commission v Belgium (C-471/98); Commission v Luxembourg (C-472/98); Commission v Austria (C-475/98).

${ }_{1101}$ Commission v Denmark (C-467/98), para. 56.

1102 Ibid., para. 57.

1103 Ibid., para. 77.
} 
of Member States. ${ }^{1104}$ In the light of ERTA and the subsequent jurisprudence, where the Union has exercised its internal competences by putting in place harmonised rules, the Member States give up their right, acting either individually or collectively, to enter into international agreements, such as DTCs, with third countries, which might affect those common rules in certain circumstances. ${ }^{1105}$

Against this background, one should be able to find an answer to the initial question of whether, due to the adoption of the CCCTB, the EU gains its external competence to conclude DTCs with third countries. Accordingly, by conferring the Union with certain internal powers, Member States have agreed to limit their own rights in that field. To the extent that the conclusion of DTCs with third countries at the EU level is necessary for the attainment of the Treaty objective (including that of secondary EU law), the Union's external competence in this field is implied. In case of the adoption of the CCCTB, Member States confer the power on the Union to establish rules for the common base of certain companies and groups of companies and the rules for the calculation and the use of that base. The aim of the CCCTB is to tackle some major fiscal impediments, such as double taxation and over-taxation, for the growth of the EIM. Consequently, to the extent that DTCs with third countries do not affect the achievement of the Union objectives, the EU does not have the competence to enter into bilateral or multilateral DTCs with third countries. In sum, the Treaties still confer the authority to conclude DTCs on the Member States, rather than conferring this authority on the EU as such. ${ }^{1106}$ Such a competence, however, is implied if the Union has exercised its internal competence and the action at the Union level is necessary for the attainment of the Treaty objective. An explicit EU competence to negotiate DTCs with third countries would require an amendment of the Treaties. It is noteworthy that an EU Model DTC in this field would be possible based on the current provisions of the Treaties, although such an

\footnotetext{
1104 Hinnekens (1994), 156-157.

1105 O'Shea (2010), 78.

1106 It is noteworthy that even before the amendments introduced by Treaty of Lisbon, Article 293 of the TEC did not reserve this authority for the EU either, but it solely invited the Member States to undertake negotiations with each other with a view to eliminating double taxation of their nationals. Moreover, that article did not cover situations involving third countries' nationals.
} 
instrument would potentially be less efficient compared to an EU multilateral DTC.

The starting point in solving the possible clash between international and EU law would be to look at Article 30 of the VCLT, which deals with the application of successive treaties relating to the same subject matter. Accordingly, the fact that one of the contracting parties enters into a treaty with another State, a group of States or an organisation, does not mean that the new treaty will automatically supersede the previous treaty with another party. This implies that EU Member States shall not infringe the provisions of international law, which were applicable at the time the Communities were founded, i.e. the principle of status quo ante preserves following the customary law rule pacta sunt servanda. ${ }^{1107}$ This principle is also transposed into Article 351 of the TFEU, which stipulates that EU law is regarded as having supremacy over treaty law, save when an international agreement with a third country has been concluded before January 1, 1958, or to the accession date of the Member State. The general application of this provision has been confirmed by the CJEU. ${ }^{1108}$ Article 351 of the TFEU implies a distinction between three main categories of international (tax) treaties and Union law:

(i) Treaties concluded between the founders of the Community before 1958;

(ii) Treaties between a country that already was a member of the Community (Union) and a third country which became a member only after signing the Treaty; and

(iii) All other treaties with third countries by States before joining the Community (Union). ${ }^{1109}$

Furthermore, the Court has ruled that the pre-accession of treaty is to be respected, although the Community itself was not bound by it. ${ }^{1110}$ In practice, this implies that Member States shall continue to observe the obligations which they have undertaken vis-à-vis a third country under a DTC concluded prior the afore-mentioned dates and they shall also respect the rights of the third country. However, with

\footnotetext{
1107 Pistone (2002b), 83.

1108 Case Burgoa (812/79), para. 6. According to the Court, Article 351 of the TFEU applies to any international agreement, irrespective of the subject-matter, which is capable of affecting the application of the Treaty.

1109 Pistone (2002b), 83-85.

${ }^{1110}$ Case Burgoa (812/79), para. 6. Hence, the subordination clause is directed only at a respective Member State to perform its obligations under the prior agreement and does not bind the Union as regards the third country in question. Panayi (2007), 123.
} 
regard to the rights that Member States derive from a DTC, these rights should be waived in line with the acquis communautaire (including instruments of secondary EU law), provided that this does not adversely affect the third country's rights under the same DTC.1111 For example, if a Member State has agreed in its DTC with a third country to eliminate double taxation on business income attributed to a permanent establishment in the third country by means of the credit method, while the CCCTB Directive provided that the exemption method be applied to the same income, the Member State should apply the latter method. This is so because waiving its right to tax does not affect the third country's taxing rights over such business income. It is undisputable that a third State is not bound by EU law, neither by the principles of equality nor by the fundamental freedoms. Furthermore, it is clear that the principle of reciprocity of DTCs, which generally assumes that the contracting States grant similar privileges to residents of both States and investments into each other's States, does not imply that Union law would (indirectly) affect the rights and obligations of the third countries. Consequently, even if the Member State would be obliged to apply the exemption method to a foreign permanent establishment's income, as in the earlier example, the third country would not be obliged to grant the same benefit to the dividends received from the Member State.

It is noteworthy that, according to the European Commission, DTCs pre-dating the CCCTB Directive would not be affected by the Directive. ${ }^{1112}$ However, from the author's perspective, Article 351 of the TFEU must be read in its narrow sense, i.e. it covers only DTCs with third countries that predate the foundation of the Community or accession of a Member State. Hence, if the European Commission wishes to clarify that all DTC predating the CCCTB Directive remain unaffected, it could introduce an appropriate "savings clause" in the Directive itself. On the other hand, such a clause would mean that secondary EU law would violate primary EU law and it would be, thus, unacceptable. Otherwise, EU law will claim primacy over all existing DTCs except the "prior agreements"

\footnotetext{
1111 Case Commission v Italy (10/61). According to the Court, the principles of international law require that a Member State which, by virtue of the entry into force of the Treaty, assumes new obligations which conflict with the rights held under an earlier agreement, refrains from exercising such rights to the extent necessary for the performance of its new obligations; the Treaty (Article 351 of the TFEU) only guarantees the rights held by third countries under earlier agreements.

1112 European Commission (2010d), para. 3.
} 
in Article 351 of the TFEU. Below, the author will separately analyse the legal consequences of DTCs concluded by Member States before and after the dates mentioned in Article 351 of the TFEU.

First, if an international agreement, predating the foundation of the Community or the accession of a Member State, to which a Member State is a contracting party is incompatible with EU law, the Member State shall take all appropriate steps to eliminate the incompatibilities established.1113 For instance, if the application of the switch-over clause under the CCCTB Directive was contrary to a DTC with a third country, the relevant Member State would have to renegotiate the relevant parts of the DTCs and amend them accordingly to allow the switch-over clause to apply. Until this task is accomplished, these DTCs with third countries would continue to apply without being subject to the switch-over clause. It is noteworthy that Article 351 of the TFEU does not appear to provide for a timeframe within which such incompatibilities must be removed. Furthermore, taking appropriate steps would generally point to the requirement to renegotiate the existing inconsistencies, but one nonetheless misses a legal base to require the Member States to achieve a solution. Thus, in the absence of an agreement between the CCCTB Member State and the third country, the provisions of the existing DTC will remain in place despite any particular timeframe. Of course, all new DTCs following the adoption of the CCCTB Directive will have to be concluded in such a manner as to avoid any incompatibilities with Union law.

With regard to all other DTCs with third countries - i.e. those concluded between a Member State and a third country after 1958 or the accession of a Member State - Article 351 of the TFEU should be read a contrario, with a consequence that Member States are under a general obligation to ensure the compatibility of their DTCs with third countries with EU law. On the contrary, DTCs that infringe EU law do not become invalid and may be applied by the third State. ${ }^{1114}$ Consequently, with regard to Member States, EU law is regarded as having supremacy over the DTCs they concluded before the afore-mentioned dates. Against this background, Member States would be under a general obligation to renegotiate any conflicting provisions of their pre-existing DTCs with third countries and amend them accordingly to bring them in line with the provisions of

1113 Article 351 of the TFEU.

1114 Hinnekens (1994), 162. 
the CCCTB Directive. According to the European Commission, in "certain cases", it may be necessary to allow Member States to derogate temporarily in order to respect existing obligations under agreements with third countries. ${ }^{1115}$ Questions remain whether DTCs concluded after the above-mentioned dates fall under the concept of "certain cases" and, if they do, how long the derogation could last. There is a fundamental difference between, on the one hand, DTCs with third countries concluded before the foundation of the Community or the accession date of the Member State, and on the other hand, DTCs concluded after these dates. Consequently, from the author's point of view, DTCs falling within the latter category should not fall under the scope of "certain cases", but they should be renegotiated immediately to bring them into line with the CCCTB provisions. On the other hand, the re-negotiation of DTCs may be a time-consuming process, which implies that Member States should be allowed a "reasonable timeframe" within which to do that. Of course, the availability of such a leeway to the Member States would assume that Member States provide evidence of their action to achieve the desired result in order to justify the continuous application of the inconsistency. With regard to the rights that Member States derive from those DTCs until the necessary changes take effect, they should waive these rights in line with the CCCTB provisions, provided that this does not adversely affect the third country's rights under the same DTC.

Article 8 of the proposed CCCTB Directive stipulates that the provisions of the Directive prevail over the provisions of the DTCs concluded between Member States. However, the proposed Directive remains silent on potential conflicts between the provisions of the Directive and Member States' DTCs with third countries. Consequently, conflicts between the provisions of the CCCTB Directive and DTCs with third countries would have to be solved according to the requirements of Article 351 of the TFEU, as discussed earlier. In the setting of enhanced cooperation, the question remains: if there is a conflict between the provisions of the CCCTB Directive and those of a DTC concluded between a participating Member State and a non-participating Member State, then how shall this incompatibility be solved? Article 8 does not concern a situation in which some Member States opt out of the CCCTB, so that the Directive would be introduced by means of

1115 European Commission (2007a), para. 117. 
enhanced cooperation. This is only natural because enhanced cooperation can only be a next step when Member States do not manage to reach unanimity with regard to the adoption of a Directive. The question is, if Article 8 is silent on the matter, how would future conflicts between the provisions of the DTCs concluded between CCCTB Member States and non-CCCTB Member States and the CCCTB Directive be solved? Notably, Article 351 of the TFEU only applies to pre-accession treaties entered into between a Member State and a third country and not between two Member States. Against this background, neither Article 351 of the TFEU nor Article 8 of the proposed CCCTB Directive require participating Member States to renegotiate a DTC with non-participating Member States where the provisions of the DTC conflict with the provisions of the CCCTB Directive. However, one could refer to the EU supremacy principle as the general requirement to remove all tax provisions that constitute a barrier to pan-European movement. Union law has supremacy over DTCs between Member States due to its hierarchical status: it does not form part of ordinary international law but has a supranational nature, which has resulted from the Member States acceptance that the Union law has a higher legal status and, for the same reason, it takes supremacy over national law. ${ }^{1116}$ Hence, the relationship between Member States' national law and EU law is covered by the principle lex superior derogate legi inferiori. Pursuant to Commission v. Italy, ${ }^{1117}$ primary and secondary Union law takes precedence over agreements concluded between Member States, even if such agreements were concluded prior to the Union law in question. As the Court has held several times, Member States retain the power to define, by treaty or unilaterally, the criteria for taxation for the purposes of allocating taxing power, so long as they exercise their competence consistently with Union law. There is nothing in the Treaties that would require non-participating Member States to cooperate with the Union with regard to the CCCTB. From the author's perspective, Article 4(3) of the TEU, which provides for the loyalty principle, does not suffice to establish such a requirement, mainly because the non-participating Member States are not bound by the CCCTB acquis. Consequently, conflicts following from DTCs between participating and non-participating EU Member States would be dealt with in a similar manner as conflicts stemming from DTCs with third countries that have been concluded after 1958 or

1116 Hinnekens (1994), 160-161.

1117 Case Commission v Italy (10/61). 
the accession of a Member State, as discussed earlier. It is noteworthy that, as far as rights and obligations of non-participating Member States are concerned, they would not be affected by the provisions of the CCCTB Directive until changes in relevant DTCs take place.

In conclusion, for CCCTB purposes, it is important to differentiate between three categories of DTCs concluded by CCCTB Member States:

1) DTCs concluded between Member States and third countries concluded prior the foundation of the Community or the accession of the Member State are covered by Article 351 of the TFEU and, as far as the third country's rights are concerned, will not be affected by the provisions of the CCCTB Directive. However, Member States have to waive the rights they derive from such DTCs in line with the acquis communautaire, provided that this does not adversely affect the third country's rights under the same DTC.

2) DTCs concluded between Member States and third countries concluded after the foundation of the Community or the accession of the Member State fall outside of the scope of Article 351 of the TFEU, with the consequence that Member States are under a general obligation to ensure EU law-compatibility of their DTCs with third countries. Hence, Member States would be under a general obligation to renegotiate any conflicting provisions of their pre-existing DTCs with third countries and to amend them accordingly to bring them in line with the provisions of the CCCTB Directive. On the contrary, DTCs that infringe EU law may be applied by the third country.

3) DTCs concluded between CCCTB participating and nonparticipating Member States (i.e. enhanced cooperation) do not fall within the scope of Article 351 of the TFEU. However, Union law has supremacy over DTCs between Member States due to its hierarchical status. Hence, Member States would be under general obligation to renegotiate any conflicting provisions of their pre-existing DTCs with nonparticipating Member States, while non-participating Member States would not be affected by the provisions of the CCCTB Directive until changes in relevant DTCs take place. 


\subsection{Elimination OF DOUble TAXATION UNDER THE CCCTB}

The CCCTB establishes a new, self-standing corporate income tax system built upon the residency principle. Consequently, the tax base of resident companies under the CCCTB comprises the worldwide income of resident companies. On the contrary, the tax base of nonresident taxpayers comprises all income derived from an activity carried on through its CCCTB-located permanent establishment and other income derived from sources within the CCCTB jurisdiction. As a result of applying the residency principle, the CCCTB system runs a risk that the foreign income of resident companies will be double taxed due to conflicting taxing rights of source and residence jurisdictions. The CCCTB working group has acknowledged that, in theory, the elimination of double taxation and the avoidance of less than single taxation should be continued to be dealt by Member States, either unilaterally or bilaterally, and that the CCCTB should not concentrate on the issue of the elimination of juridical double taxation. Nevertheless, it has emphasised that juridical double taxation should be avoided irrespective of the DTC network in the case of CCCTB resident companies. Furthermore, the CCCTB has to provide for anti-avoidance rules to deal with the non-taxation of income. 1118

The author concluded earlier that the proposed CCCTB system has been built on the principle of worldwide taxation in the sense that generally it does not exclude foreign income from the material scope of the proposed Directive. As an exception to the principle of worldwide taxation, it uses the base exemption method for the elimination of certain types of income, such as business income derived through a foreign permanent establishment and received foreign dividends. For other types of income, the proposal foresees relief for double taxation by the credit method. Such an approach makes the CCCTB system a "hybrid", which combines features of a residence-based and territorial system. Such an approach is rather common among States' tax policies as well. If the proposed CCCTB Directive did not provide for the elimination of double taxation and this was left solely to the Member States, issues would be likely to arise as some Member States could choose the credit method for giving relief whereas others would exempt foreign income or base

1118 European Commission (2005c), para. 15. 
their tax system on the territoriality principle. At the national level, there is currently no consensus between the Member States on the application of the credit or exemption method for providing relief from double taxation, although a majority of Member States seems to prefer the exemption method as a general method for the elimination of double taxation. If the CCCTB Directive left the decision to the Member States, the application of different methods for the elimination of double taxation would imply that foreign income would have to be treated separately from the income sourced within the water's edge area. In particular, all foreign income would be excluded from the CCC tax base. Instead, the foreign income would be added to the tax share allocated to a Member State by the apportionment formula and Member States would eliminate double taxation through the credit method. ${ }^{1119}$ On the contrary, Member States using the exemption method would not have to make adjustments to the apportioned taxable share, unless they allow foreign losses to be deducted or apply exemption with progression method. Despite many Member States applying the exemption method in their national law, it does not seem to be efficient to give participating Member States a choice of the two methods.

The current CCCTB proposal incorporates provisions for the elimination of double taxation, but it does not have a general preference for one method over the other. In particular, it uses the exemption method for certain types of income, subject to a switchover clause, and the credit method for other types of income. Below, the author will analyse the application of the proposed provisions under the current Directive in order to assess whether the European Commission has reached the most optimal solution with regard to the elimination of double taxation of income and the avoidance of less than single taxation.

\subsubsection{ECONOMIC AND JURIDICAL DOUBLE TAXATION}

One can generally distinguish between two types of double taxation. First, there is juridical double taxation, which implies the imposition of comparable taxes by two or more jurisdictions in the same taxable period on the same taxpayer in respect of the same taxable income or capital. Typically, juridical double taxation takes place when a source State levies a withholding tax on income and the residence

${ }^{1119}$ European Commission (2006b), para. 28. 
State includes the income in the worldwide tax base of the recipient. Similarly, juridical double taxation takes place if a source country taxes the income attributed to a permanent establishment located in its territory and the residence State includes the same income into the worldwide tax base of the head office. Second, economic double taxation involves the imposition of comparable taxes by one or more jurisdictions in the same taxable period on different taxpayers in respect of the same taxable income or capital. The most typical example of economic double taxation is the payment of dividends, where the source country taxes the profits of the distributing company and thereafter levies withholding tax on the distributed dividends or where the residence State includes the distributed dividends in the worldwide tax base of the recipient. There is a general agreement among States that juridical double taxation leads to inefficiencies and distortions of international investment flows and, as evidenced by a large number of DTCs, this form of double taxation should be eliminated. On the contrary, despite the distortions caused by economic double taxation, the abolition of economic double taxation remains arguable. When a residence State applies the exemption method, it generally eliminates both forms of double taxation. On the other hand, when it applies the (direct) credit method, economic double taxation will often remain. In the EU, the Parent and Subsidiary Directive requires the elimination of both economic and juridical double taxation of profit distributions between certain related companies by prohibiting any withholding taxes in the source State and requiring the residence State to provide an exemption or indirect credit relief for transactions that fall within its scope. Furthermore, the Interest and Royalty Directive aims at eliminating juridical double taxation ${ }^{1120}$ on cross-border intra-EU interest and royalty payments between certain associated entities by prohibiting any source taxes on such payments. The CCCTB Directive will have to be implemented by the Member States in a way that it reflects the requirements of these earlier Directives. These issues will be discussed further below.

The proposed CCCTB Directive provides for some form of relief for double taxation of all types of income from outbound investment. In such a way, it fully or partly eliminates double taxation. With regard to inbound investment, Member States are free to levy withholding taxes on outbound payments. However, in the

1120 In case of interest and royalty payments/income, economic double taxation normally does not arise. 
case of interest and royalty payments, they must share the taxes charged in line with the apportionment formula. The absence of a prohibition on the Member States to levy withholding taxes may lead to economic and/or juridical double taxation and, unless the residence State of the recipient provides for an appropriate relief, the may make the EU less attractive for foreign investment.

\subsubsection{OUTBOUND INVESTMENT}

For the purposes of this thesis, outbound investment refers to investments made by CCCTB-resident companies towards third countries. Due to the worldwide taxation of those entities, the CCCTB Directive brings with it prospective double taxation of its resident companies. In this section the author will first focus on the specificities of the two main methods for relieving double taxation, i.e. the exemption and credit method, and analyse their suitability for the CCCTB system. The author will carry out this analysis based on the main types of income from outbound investment, such as business income, dividends, interest and royalty income.

\subsubsection{EXEMPTION METHOD}

The exemption method for the elimination of double taxation has two branches: (i) the base exemption method, which eliminates foreign income of a resident company from its tax base in the residence State, and (ii) the tax exemption method, which includes foreign income in the tax base of resident companies with a subsequent deduction of a part of the home-State total tax that is attributable to the part representing the foreign income. While the application of the exemption method effectively leads to territorial taxation, under which both positive and negative foreign income is ignored for domestic taxation purposes, the tax exemption method ensures that foreign (positive and negative) income is at least, at a certain phase, reflected in the domestic tax base of resident taxpayers.

The proposed CCCTB Directive uses the base exemption method for certain types of income but, at the same time, it limits the deductibility of costs incurred by a company for the purposes of deriving such income at a flat rate of 5 per cent of that income. ${ }^{1121}$

1121 Articles 11 and 14(g) of the CCCTB Directive. Note that the Danish Presidency has proposed to eliminate the possibility to allow any deduction of costs for raising 
The author concluded earlier (see Section 5.3.2.1) that, at least as far as the CCCTB parent company does not meet the level of participation in the foreign subsidiaries as compared to subsidiaries located in the CCCTB jurisdiction, such a limitation would not constitute a restriction on the fundamental freedoms. In fact, currently some Member States provide such a limitation in their national law and this option is also not restricted under the Parent and Subsidiary Directive concerning intra-EU profit distributions between the qualifying parent and subsidiary companies. However, the question is whether such a limitation is justified in the sense that deduction of costs directly related to tax-exempt income would constitute a "double dip". "Double dipping" arises due to arrangements under which a tax benefit is obtained in more than one jurisdiction normally due to differences in national tax rules, for example with regard to the qualification of income or an entity. ${ }^{1122}$ In that sense, exempting income, on the one hand, and allowing a deduction of related costs, on the other, would not constitute a "double dip" under its general meaning. Moreover, one could argue that the application of the exemption method does not constitute a benefit for the taxpayer when receiving profits, but it should be seen as a result of country's tax policy for avoiding double taxation..$^{1123}$ Consequently, it is difficult to defend such a general prohibition based on the "double dipping" argument. It is worth mentioning that in the earlier documents, the CCCTB Working Group had supported the deduction of such costs despite the application of the exemption method, at least as far as dividends from major shareholdings are concerned, as otherwise the CCCTB would appear "extremely unattractive" for EU groups with subsidiaries outside the CСCTB jurisdiction. ${ }^{1124}$

It is intriguing to discuss whether the exemption method supplemented with a ban on cost deductibility would require the country of the income recipient to allow a credit for the withholding taxes levied in the source country, similar to the application of the credit method for the avoidance of double taxation. In other words, the question is whether the limitation to cost deductibility (e.g., 5 per cent) effectively leads to the same result as exempting only part of the

tax-exempt income. Council of the European Union (2012), comments on Article 14 and $14 \mathrm{a}$ of the CCCTB Directive.

1122 Rogers-Glabush (2009), 141.

1123 Oestreicher, Spengel, Koch (2011), 14-15.

${ }^{1124}$ European Commission (2007a), para. 130. 
income received (e.g., 95 per cent). Of course, there is no general requirement for a country to eliminate or reduce double taxation, but it depends solely on its tax policy considerations. Moreover, a literal reading of the provision does not lead to the conclusion that such a restriction leads to juridical double taxation. The income being taxed through the application of the non-deductibility provision is different from the foreign income received: the former refers to the taxable profits while the latter refers to the exempt income. Hence, the principle of symmetry would demand that no credit be given on (fully) exempt income. However, from an economic perspective, taxing de facto part of the income due to the deductibility limit would require that such income is treated equally to other types of income on which double taxation is eliminated via the credit method. In such a case, a credit for foreign withholding taxes would be given in proportion to the "taxed" income." This is, however, not the case for the proposed CCCTB Directive.

Last, the proposed CCCTB Directive leaves it up to each Member State whether it wishes to apply exemption with progression for eliminating double taxation of income that is exempt under the CCCTB Directive. ${ }^{1125}$ First, it is arguable whether the Directive should even regulate such a matter, as it has been clear from the outset that the CCCTB does not aim at dealing with Member States' tax rates. Second, as in the case of the credit method, one may question the compatibility of the exemption with progression method with the Treaties (see below for further discussion) as far as investment into other EU Member States is concerned. Indeed, if the home State includes foreign income in its domestic tax base for the purposes of determining the applicable tax rate, it eliminates the attractiveness of investment originating from another Member States and, consequently, it protects its home market. However, as far as the home State treats domestic and cross-border investment equally, it is doubtful whether the exemption with progression provision could be challenged against the fundamental freedoms. Moreover, the Court has already confirmed the legality of the exemption with progression method in a number of cases. ${ }^{1126}$ However, following Ritter-Coulais, ${ }^{1127}$ when a Member State takes into account positive income for the purposes of determining the applicable tax rate under the exemption

\footnotetext{
1125 Article 72 of the proposed CCCTB Directive.

1126 Cases Asscher (C-107/94); De Groot (C-385/00); Van Hilten-van der Heijden (C513/03).

1127 Case Ritter-Coulais (C-152/03).
} 
with progression method, it shall also consider foreign losses for the purposes of determining applicable tax rate. ${ }^{1128}$ Furthermore, the application of the exemption with progression method ${ }^{1129}$ would not lead to the infringement of Member States' DTCs with third countries. In particular, the idea of the exemption with progression method is to allow the income of the resident company in a Member State to be taxed at a higher tax rate (due to the inclusion of the income of the foreign permanent establishment), but it does not lead to the taxation of the income attributed to the permanent establishment itself in that Member State. Such taxation is also reflected in Article 23(A)(3) of the OECD MC. In any event, the current trend among Member States is to apply a flat tax rate for business income.

\subsubsection{CREDIT METHOD}

The CCCTB proposal foresees the credit method for the elimination of juridical double taxation of all income which is not listed as exempt. ${ }^{1130}$ In addition, the exemption method in the proposed Directive is supplemented by a switch-over clause, under which a taxpayer shall shift from the exemption method to the credit method in certain cases. ${ }^{1131}$ The wording of the provision prescribing the credit method in the proposed CCCTB Directive is unclear whether a credit would be given to the "tax paid" or the "tax assessed" - it only refers to the income as being "taxed". By comparison, the literal reading of the OECD MC obliges the residence State to give a credit for the tax "paid". ${ }^{1132}$ However, the OECD Commentary creates some confusion as, in one situation, it requires the residence State to provide relief despite when the tax is "levied" by the source State, but, in another situation, it refers again to the tax "paid" in the source State. ${ }^{1133}$ According to Vogel, if the payer has withheld tax but has not remitted it to the tax authorities in the source State, the recipient of the income will not become eligible for the credit in its

\footnotetext{
${ }^{1128} \mathrm{It}$ is noteworthy that, in the latter judgment, although the question was referred for a preliminary ruling, the CJEU did not analyse the issue whether the negative income should be taken into account for the purposes of determining the tax base, but it analysed the case only with regard to the applicable tax rate. See case RitterCoulais (C-152/03), paras. 11-17.

1129 Article 72 of the proposed CCCTB Directive.

1130 Article 76 of the CCCTB Directive.

1131 Article 73 of the CCCTB Directive.

1132 Article 23A(2) and 23B of the OECD MC.

1133 OECD Comm. on Article 23, paras. 32.8 and 57.
} 
residence State. ${ }^{1134}$ Hence, for DTCs purposes, a credit should be given only for the taxes paid in the source State.

The European Commission has proposed the application of an ordinary credit method, which limits the amount of credit relief to the domestic tax corresponding to the received foreign income (Article 76(3)). The ordinary credit method is by far more common than the full credit method among states. The latter allows the deduction of the full amount of foreign taxes from domestic tax on income of any kind. Also, the OECD is of the opinion that the ordinary credit method is the preferable option for the contracting States. ${ }^{1135}$ If taxes paid in the source State are higher than taxes paid in the residence State, the relief by the (ordinary or full) credit method does not lead to home market neutrality but to host market neutrality. The wording of that provision of the CCCTB proposal allows one to conclude that it also includes credit limitations per country and source of income, under which the credit may not exceed the domestic income tax computed on income from one particular Member State or third country, or one particular type of income, accordingly. ${ }^{1136}$ From the author's perspective, there is no need for such limitations, mainly because they complicate compliance and administration. In addition to that, such limitations can quickly lead to excess tax credits, which, according to the proposed Directive, cannot be carried forward to future periods. Hence, the limitations lead to double taxation, which is not in line with the general acceptance and EU policy, as discussed earlier. The credit relief in the proposed CCCTB Directive is further subject to an additional limitation, which restricts the available credit up to the domestic tax on the total foreign income, unless a DTC with a third country provides otherwise, following the application of the formula apportionment (Article 76(5)). One could interpret the last part of that provision so that Member States would not be under a general obligation to renegotiate their DTCs with third countries for an additional credit limitation if the relevant DTC provided otherwise.

1134 Vogel (1997), 1223.

1135 OECD Comm. on Article 23, para. 29. From the exemption methods, in the same commentary, the OECD prefers exemption with progression method.

1136 In practice, such a limitation may be eliminated through the establishment of a so-called 'mixer company', i.e. an intermediate holding company the purpose of which is to optimise foreign tax credits on foreign income. In such a case, the income from various sources is 'mixed' via the holding company to form a single source in respect of which foreign tax is treated as having been paid at the average of the rates applicable to the various sources. Rogers-Glabush (2009), 282. 
However, this understanding would go against with the provisions of primary EU law, in particular Article 351 of the TFEU. If the last sentence was not included in the provision of the Directive, the Member States' obligation to respect their DTCs would be implied, but they would, nevertheless, be responsible for renegotiating the conflicting provisions of their DTCs, as discussed earlier.

Last, the CCCTB proposal does not provide for a possibility for the carry-over of foreign (withholding) tax credits. Stricto sensu, a limitation on tax credit carry-overs does not lead to juridical double taxation, because the criteria of "same taxable period" would not be fulfilled. One may recall that the same is true with regard to limitations on foreign loss carry-overs. This would imply that, even if the general understanding is that juridical double taxation should be avoided, it would not be applicable with regard to the carry-over of foreign tax credits. However, lato sensu and neglecting the time requirement, such a limitation could, indeed, result in juridical double taxation. Nevertheless, the residence State of the taxpayer would not be under a general obligation to avoid juridical double taxation arising from the limitation. On the one hand, the fact that the proposed Directive provides for the ordinary credit method implies that the existence of a carry-over limitation of excess credit would not, in any case, provide for a benefit for the taxpayer, provided that the foreign source income was higher than the attributable domestic tax, or there was no foreign source income in the previous or subsequent years. ${ }^{1137}$ On the other hand, such a carry-over may become relevant when the taxpayer suffers losses in one of the jurisdictions, either the source or the residence State, while its tax base, as calculated under the other State's tax law, is positive. In the case of existence of a credit carry-forward, the taxpayer would be able to credit the tax paid in the source State against its positive CCCTB tax base. As a result, the CCCTB system becomes less attractive compared to Member States' tax systems that provide for such a carry-over possibility. Above all, limiting the loss carry-over of excess foreign tax credits may, in certain cases (such as in the case of the existence of losses as calculated in one jurisdiction) lead to the infringement of the ability-to-pay principle. In the light of the foregoing, from the author's perspective, the CCCTB Directive should provide for the possibility to carry-over excess foreign tax

1137 Terra \& Wattel (2012), 214. 
credits, unless the excess credit was caused by the higher tax rate in the source State.

The OECD MC does not require, as a matter of principle, the carryforward of unused foreign tax credits, but it leaves this decision up to the contracting States. ${ }^{1138}$ Nevertheless, the State of residence is required to give a credit for foreign withholding taxes, despite timing mismatches, if the State of source taxed an item of income or capital in an earlier or later year. For example, this can occur due to differences in domestic law with regard to the application of the accrual method or cash method, or when the source State requires the prepayment of taxes. ${ }^{1139}$ In terms of EU law, in its current state, it does not require the elimination of juridical double taxation. The Court has confirmed this understanding in Haribo and Salinen. ${ }^{1140}$ The Court emphasised that the fact that both the host State and the home State may tax the income does not mean that the home Member State is obliged, under EU law, to prevent disadvantages which could arise from the exercise of competence thus attributed by the two Member States. Therefore, in the Court's opinion, juridical double taxation within the EU is a consequence of disparities in Member States' laws. Furthermore, this holds a fortiori true as far as non-Member States are involved. ${ }^{1141}$

In sum, the CCCTB Directive proposes the following restrictions on available credit for foreign income: (i) ordinary credit (as opposed to full credit); (ii) per country limitation; (iii) source-by-source limitation; (iv) additional limitation following the application of formula apportionment; and (v) no carry-over of excess credit.

From a historical perspective, there is no general preference for credit or exemption as a method of eliminating double taxation. Residencebased taxation with foreign tax credits is without doubt challenging and administratively more burdensome, ${ }^{1142}$ especially taking into account all kinds of limitations, such as those foreseen under the

\footnotetext{
1138 OECD Comm. on Article 23, para. 66.

1139 Ibid., para. 32.8.

1140 Haribo and Salinen (Joined Cases C-436/08 \& C-437/08).

1141 Ibid., paras. 166-172.

1142 On the other hand, one could argue that the application of the exemption method is less burdensome only if it is a pure exemption system. Hence, what creates complexity is the coexistence and simultaneous application of the two methods, for example, due to different types of income or the application of switchover clause or $\mathrm{CFC}$ rules.
} 
proposed CCCTB system. On the other hand, the general advantage of credit systems is that they are less sensitive to tax planning and (fair and unfair) tax competition between countries as well as to expense allocation. ${ }^{1143}$ From the Member States' constitutional perspective, a credit method is likely to give rise to fewer issues compared to the exemption method, in particular, if it is considered in the light of the ability-to-pay principle, which forms part of the equality principle prescribed in Member States' constitutional law. Credit relief generally guarantees that taxpayers deriving foreign income are subject to taxation in their residence State in proportion to their actual available income, despite whether this is sourced within the territory or abroad. ${ }^{1144}$ However, if the residence State disallows the carry-over of excess foreign credits, the compliance of the credit method with this constitutional principle becomes questionable. In other words, the absence of excess credit carry-over leads to (lato sensu) juridical double taxation, which cannot occur in a domestic situation. In such a case, the country avoids double taxation in the domestic scenario, while it does not do so in the case of cross-border investment. In the light of the foregoing, one can argue that, based on the ability-to-pay principle, States are obliged to avoid double taxation if they tax the worldwide income of their residents. Being part of Member States' constitutional law, the ability-to-pay principle is also contained in the legal order of the EU. Indeed, the CJEU1145 has included general principles within the term of law and a breach of these general principles leads to an infringement of the Treaties. The most important source for the CJEU in formulating these general principles are the laws of the Member States, as indicated in Article 340(2) of the TFEU. In fact, to become a general EU law principle, the principle does not have to be common in all the Member States, but it suffices that a principle is common to most of the Member States' legal systems. ${ }^{1146}$ Importantly, general principles of Union law have a constitutional status and are equal, in terms of hierarchy, to the Treaties and, hence, they are binding on the Union institutions

\footnotetext{
1143 The issue of the allocation and deductibility of expenses incurred by a resident taxpayer in relation to cross-border investment is perhaps noticed the most in case of allocation and deductibility of interest expenses. In particular, countries are usually not prepared to take into account costs related to exempt income, as explained earlier.

1144 Maisto (2010), 331.

1145 Based on Article 19 of the TEU, the Court shall ensure that, in the interpretation and application of the Treaties, the law is observed.

${ }^{1146}$ Lenaerts (2010), 1124.
} 
and on the Member States. ${ }^{1147}$ In the light of the foregoing and in an equal vein to the above, one can argue that the elimination of double taxation is a general obligation in the EU. Furthermore, from an EU law perspective, when a Member State does not eliminate double taxation, it provides for a non-discriminatory restriction (the so-called "quasi-restriction") to the fundamental freedoms. Despite the foregoing, the CJEU has never upheld this understanding and, therefore, the elimination of double taxation remains an issue within the EIM.

The exemption method is much more sensitive to be challenged against the equality principle, especially when the source State levies no or lower level tax on certain items of income compared to the residence State. Moreover, the exemption method risks infringing the ability-to-pay principle when a taxpayer is not allowed to deduct foreign losses from its domestic income and thus becomes subject to tax on unrealised income in its residence State. It is noteworthy that in 2008, the German Bundesfinanzhof rejected the argument that the disallowance of foreign loss deduction under the exemption method for foreign income infringed the equality principle. ${ }^{1148}$

From an economic perspective, the application of the credit or exemption method for relieving double taxation is associated with a certain approach to neutrality. In the EIM, the non-discriminated inbound investment from third countries requires CIN, in the sense that foreign capital must receive the same treatment in a Member State as domestic capital. On the contrary, non-discriminatory outbound investments into third countries requires at least CEN, so that investing abroad would not be disadvantaged compared to investing home. ${ }^{1149}$ Next, CEN is normally associated with the free movement of capital, because it establishes equal treatment between capital invested at home and that moving into third States, and is thus in line with Article 63 of the TFEU. ${ }^{1150}$ Some scholars argue that the application of CEN within the EIM is inconsistent with the principle of freedom of establishment of Article 49 of the TFEU. ${ }^{1151}$ This is because pan-European companies could be subject to different tax

\footnotetext{
1147 Ibid., 1124.

1148 Maisto (2010), 332.

1149 Bezborodov (2007), 673.

1150 Ibid., 682.

1151 Wattel (1996), 159-62.
} 
rates, depending on their place of residence ${ }^{1152}$ despite where the freedom of (secondary) establishment (in particular, by means of a permanent establishment/branch) is exercised. In such a case, the residence State eliminates any possible tax advantage of carrying out cross-border economic activity and, consequently, protects its home market. Furthermore, the application of the credit method interferes with the EU principle of national treatment of non-residents in the host State, because it removes any tax relief extended by the latter State to non-residents due to EU fundamental freedoms and thereby abolishes the reason to require national treatment in the host State. ${ }^{1153}$ Based on this line of reasoning, CEN would also be contrary to the free movement of capital in terms of portfolio investment in other Member States. Hence, CIN seems to fit better with the requirements of the EIM. But one should not forget that discrimination and restriction (specifically the distortion of competition introduced by the use of credit method) often result from the combined action of two Member States. ${ }^{1154}$ Thus, the negative effect of the credit method is not caused by the method itself but by the fact that Member States use different tax rates and tax bases. Also, from the perspective of the CJEU, both CEN and CIN are compatible with primary EU law. Again, the Treaties in their current state do not require the Member States to abolish double taxation, and they certainly do not require this according to a specific method, as discussed earlier. In addition to that, the choice between CIN and CEN may be influenced by the fact that CIN is generally easier to administer and is more cost efficient. ${ }^{1155}$ Furthermore, by relying on CIN rather than (pure) CEN, Member States would increase their economic efficiency, as competition in third countries would be on equal terms and thereby enhance the attainment of the Lisbon objective. ${ }^{1156}$

\subsubsection{BUSINESS INCOME}

Under the proposed CCCTB system, income of a third country permanent establishment of a group member forms part of ordinary business income. In order to avoid international double taxation, such income is subject to the (base) exemption method. The application of the exemption method to income derived from

\footnotetext{
1152 McLure (2007), 157.

1153 Terra \& Wattel (2012), 222.

${ }^{1154}$ Lehner (2000), 10.

${ }^{1155}$ European Commission (2001a), 135-136.

1156 Andersson (2006), 395.
} 
foreign permanent establishments does not normally prevent the shift of investment from high-tax to low-tax jurisdictions. Nevertheless, under the proposed CCCTB Directive the exemption method covering such income will be accompanied by a switch-over clause in cases in which profits from foreign permanent establishments have been taxed with low statutory corporate tax rate or where it has been subject to a special regime resulting in a substantially lower level of taxation. The application of the switchover clause triggers the calculation of income attributed to such a permanent establishment and the elimination of double taxation by the credit method. It is worth noting that the Danish Presidency has proposed to eliminate the switch-over clause regarding income from foreign permanent establishments but to deal with the issue together with the CFC provision. ${ }^{1157}$ In such a case, the income taxed in the source State would receive a credit for the taxes paid by the permanent establishment under Article 76 (in conjunction with Article 73) of the CCCTB Directive. On the other hand, the application of the "semi-CFC" rule would not provide a benefit of the consideration of future losses of the CFC. Indeed, as an antiabuse rule, the switch-over clause applies on a yearly basis in cases where the permanent establishment generates profits. ${ }^{1158}$

The application of the switch-over clause or the "semi-CFC" rule with a credit for source taxes on the income of foreign permanent establishments could lead to mismatches in terms of available credit. In particular, the inclusion of the permanent establishment's income in the tax base of the resident company, consolidating the result with the rest of the group members' individual tax bases and thereafter attributing the profits to the resident entity based on the formula could mean that the available credit in the residence State does not suffice to eliminate double taxation. In the following example (Example 38: Elimination of double taxation of a foreign permanent establishment), one can assume that two CCCTB resident companies ( $\mathrm{CoA}$ and $\mathrm{CoB})$ form a CCCTB group, i.e. AB Group. The individual income tax bases of both of those companies are $50 . \mathrm{CoB}$ has a permanent establishment in a country that is considered to be a lowtax territory for the purposes of the CCCTB (i.e. third-country X). The income attributed to the permanent establishment based on the $\mathrm{AOA}$ is 100 and it is included into the CCC tax base of AB Group.

1157 Council of the European Union (2012), comments on Articles 73-74 and 82-83 of the proposed CCCTB Directive.

1158 See also discussion supra at II6.4.1.1 and infra II7.5.1. 
The individual tax base of CoA is 100 and it is also included into the CCC tax base. Following the apportionment based on the CCCTB sharing mechanism (assuming that the ratio is 75-15), CoA is attributed a tax base of 150 and the remaining 50 is attributed to CoB. The proposed CCCTB Directive solves the issue by explicitly requiring the credit to be shared among the group members based on the same apportionment formula as applicable to the sharing of the income of the permanent establishment. ${ }^{1159}$

Example 38: Elimination of double taxation of a foreign permanent establishment

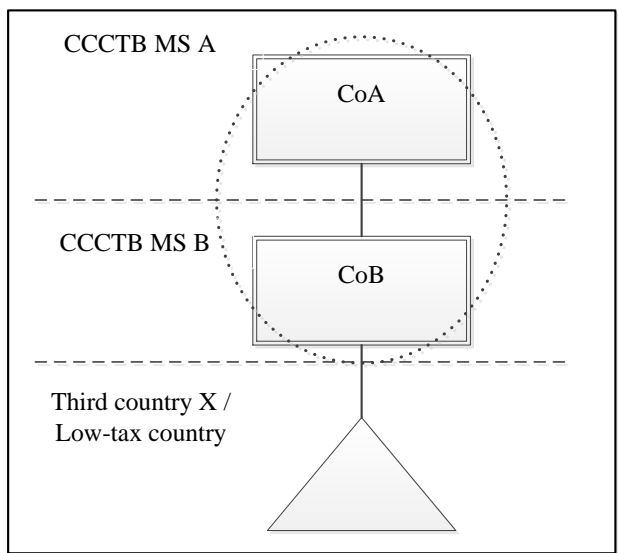

\begin{tabular}{|c|c|c|c|c|}
\hline & $\begin{array}{c}\text { PE income } \\
\text { (AOA) in third } \\
\text { country X }\end{array}$ & $\begin{array}{c}\text { CCC-tax } \\
\text { base }\end{array}$ & $\begin{array}{c}\text { Share CoB } \\
\text { (FA) in MS B }\end{array}$ & $\begin{array}{c}\text { Share CoA (FA) } \\
\text { in MSA }\end{array}$ \\
\hline Tax base & 100 & 200 & 50 & 150 \\
\hline $\begin{array}{c}\text { Tax rate (\%) } \\
\text { applicable in the } \\
\text { relevant country }\end{array}$ & 9 & $\mathrm{n} / \mathrm{a}$ & 15 & 30 \\
\hline $\begin{array}{c}\text { Tax amount in } \\
\text { the relevant } \\
\text { country }\end{array}$ & 9 & $\mathrm{n} / \mathrm{a}$ & 7,5 & 45 \\
\hline Tax credit & $\mathrm{n} / \mathrm{a}$ & $\mathrm{n} / \mathrm{a}$ & 2,25 & 6,75 \\
\hline
\end{tabular}

The application of the exemption method to the income derived from a foreign permanent establishment in a third country, as foreseen under the proposed CCCTB Directive, is more beneficial compared to the application of the credit method if the foreign tax is

1159 Article 76(1) and (2) of the proposed CCCTB Directive. 
higher than the tax in the CССТВ Member State. However, as the author discussed earlier, the disadvantage of the base exemption method is that it does not allow foreign losses to be taken into account at the level of the head office. It was also explained earlier that if provisions between the DTC and the CCCTB Directive conflict, until renegotiated, Member States shall continue to observe their obligations under the DTC. However, as far as Member States' rights are concerned, they should waive these rights to comply with their obligations under EU law, provided that this does not adversely affect the rights of the other contracting party (i.e. the third country) under the DTC.

The question is whether the application of the exemption method with a limitation on loss deductibility would violate the third country's rights under the DTC. In the author's opinion, limiting such deductibility of its own resident companies by a Member State would not violate the obligations that the Member State has undertaken vis-à-vis the other contracting State. Consequently, the application of the exemption method with a ban on foreign loss deductibility should be seen as a consequence of the introduction of the CCCTB system. In any case, a better solution for the CCCTB would be the application of a base exemption method with a temporary loss consideration, i.e. a loss recapture rule, as discussed earlier. Such an approach would eliminate any discussion and conflicts arising from the simultaneous application of the CCCTB system and Member States' DTCs with third countries.

\subsubsection{DIVIDENDS}

The discussion on the taxation of dividends within the CCCTB should begin with the definition of the term as such. The proposed CCCTB Directive does not define the concept, even though it is included under the revenues and used in its further provisions. Consequently, the term will be attributed the meaning which it has in the domestic law of the Member States. Nevertheless, one could very well argue that the term "dividend" for the purposes of the CССТВ becomes an EU term, so that recourse to the Member States' national law would be conceptually wrong. In the absence of any definition in the CCCTB Directive, it would be for the CJEU to develop the definition of the term, if a case is brought before the Court which raises the issue. Despite the foregoing, from the author's perspective, the concept of dividends for the purposes of the CCCTB Directive can be deduced from the notion of interest, 
which is defined therein. Nevertheless, since DTCs with third countries will remain applicable, the interpretation of the definition shall be in line with those agreements. It is noteworthy that the Danish Presidency has proposed to abolish Article 81 of the proposed CCCTB Directive and introduce a horizontal asset-based interest limitation rule in Article 14a. ${ }^{1160}$ Remarkably, it is proposed that the definition of interest will disappear together with Article 81, as it is not reintroduced in Article 14a.

The European Commission working papers reveal that, with regard to the method for the elimination of double taxation, the initial idea was to differentiate between dividends from portfolio investments and those from major shareholdings. However, the European Commission has abandoned the idea in the proposed CCCTB Directive. Nevertheless, the discussion between the Member States seems to be leading back to the original track where dividends from FDI received different treatment compared to those from portfolio investment. In particular, the Danish Presidency has proposed to apply the exemption method on dividends from direct investments and the credit method on dividends from portfolio investment. ${ }^{1161} \mathrm{In}$ the documents, it is not clear why the Member States prefer to make such a distinction, but one can only assume that it mainly relates to revenue concerns. The author discussed earlier that, in the international arena, making a distinction between portfolio dividends and dividends from FDI is quite common and this is also reflected in the OECD MC and the Parent and Subsidiary Directive. However, as the author concluded earlier, the common reasons to justify the different treatment do not hold strong and, thus, there should be no difference between the taxation of dividends from FDI and those from portfolio investments or whether such income is derived from an EU Member State or a third country.

As in the case of permanent establishments, the proposed CCCTB Directive requires the application of the switch-over clause in cases in which the dividends are paid by a company that is subject to a low tax or a special regime in its country of residence. It is noteworthy that the proposed CCCTB Directive allows the application of the switch-over clause only if the permanent establishment is located in a third country, i.e. a non-EU Member State. However, if the CCCTB

1160 Council of the European Union (2012), Articles 14a and 81 and the comments therewith.

${ }^{1161}$ Ibid., comments to Article 11of the proposed CCCTB Directive. 
is introduced via enhanced cooperation, non-CCCTB EU Member States would also be treated as (a special category of) third countries for the purposes of the CССТВ. In that case, the minimum tax rate to trigger the application of the switch-over clause would presumably be determined based on the statutory tax rates applicable only in the participating Member States. In such a case, the chances that one or another non-CCCTB Member State would fall within the category of a low-tax territory for the purposes of the switch-over clause is higher. However, even though the non-participating EU Member States would be treated as third countries for the purposes of the CCCTB, they would still benefit from the EU's acquis communautaire. Consequently, all Member States remain sovereign concerning the decision of their national corporate tax rate, despite whether they will opt into the CCCTB system or not. The Court ruled in Cadbury Schweppes ${ }^{1162}$ that freedom of establishment precludes a national measure which makes a difference in the treatment of resident companies on the basis of the level of taxation to which their subsidiaries are established, unless it is applied only to wholly artificial arrangements intended to escape the normally due national tax. Hence, the fact that a company of a Member State invests in another Member State through a secondary establishment (in that case, a subsidiary) does not automatically imply abuse. Therefore, if the CCCTB is introduced via enhanced cooperation, the European Commission should amend the provision accordingly. In any case, with regard to intra-EU qualifying distributions, the Member States would need to respect the requirements of the Parent and Subsidiary Directive, which does not allow the application of the switch-over clause.

\subsubsection{INTEREST AND ROYALTY INCOME}

The definition of "interest" provided in Article 81 of the proposed CCCTB Directive is identical to the definition set forth in both the Interest and Royalty Directive as well as in the OECD MC. Consequently, there is very little room for the Member States to look at their domestic law. To the extent that CCCTB Member States have transposed the definition of "interest" set forth in the Directive into their national law correctly and have agreed in their DTCs on the definition proposed by the OECD, the CCCTB system would not introduce a complication in that area. With regard to the term

1162 Case Cadbury Schweppes (C-196/04). 
"royalties", the proposed CCCTB Directive does not define the term, while the OECD MC and the Interest and Royalty Directive define it differently. The provision set forth in the latter is similar to the definition provided in the UN MC instead, because it includes the wording "for the use of, or the right to use, industrial commercial, or scientific equipment" (ICS equipment), which was deleted from the OECD MC in 1992. The author concluded earlier that, taking into account the conflicting approaches between Member States' DTCs and the Interest and Royalty Directive, the European Commission decision not to provide a specific definition under the CCCTB Directive is wise. ${ }^{1163}$ The absence of a definition in the CCCTB Directive implies that the term will be attributed an autonomous meaning under EU law. ${ }^{1164}$ In the absence of a definition in the Directive, if a case is brought before the CJEU, the latter would be in a position to provide the interpretation of the term in the light of EU law. It is highly likely that the Court would interpret the term with reference to other sources of EU law, such as the Interest and Royalty Directive, which provide the definition of the term. In such a case, it is for each Member State to assure that the application of the CCCTB Directive does not lead to conflicts with its international obligations.

The need for a uniform definition of dividends, interest and royalties from outbound investments is not essential to determine whether the income forms part of the CCC tax base or not, because the CCCTB system is based on the principle of worldwide taxation. However, the definition starts playing an important role with regard to the elimination of double taxation of these types of income. In particular, under the proposed CCCTB Directive, while dividends benefit from base exemption, interest income is subject to the credit method; while business income from foreign permanent establishments is subject to the base exemption method, double taxation on royalties is eliminated via the credit method. Hence, it seems particularly important to develop a uniform definition of these types of income, with due regard to Member States' bilateral arrangements, rather than relying on the definition as it stands in the domestic law of the (legal) recipient.

From an international perspective, there seems to be a general acceptance that the source country has the primary right to tax

1163 Vide supra at II5.3.3.

${ }^{1164}$ Case CILFIT (283/81). 
interest income, while the residence country may also tax but it would have to provide relief from double taxation. On the contrary, from the EU perspective, the source country is prohibited from levying withholding tax on interest payments, while the residence country enjoys unlimited taxing rights over such income, as prescribed in the Interest and Royalty Directive. With regard to royalties, industrialised countries and developing countries seem to support a conflicting approach: the former sustain the exclusive taxing right of the residence country, whereas the latter plead for a shared taxing right with a primary taxing right for the source country. The EU Member States have taken the former view in the Interest and Royalty Directive. It is noteworthy that the Interest and Royalty Recast Directive of 11 November 2011 requires the income to be taxed in the recipient Member State.

The proposed CCCTB Directive includes interest and royalty income of CCCTB residents into the CCC tax base with a credit for any withholding tax levied abroad in Article 76. The Directive proposes the same treatment to inflows despite whether the income is received from a third country or whether it falls within the Interest and Royalty Directive. The application of a credit method normally does not lead to conflicts with Member States' DTCs with third countries, because the latter usually also employs the credit method for the elimination of double taxation of such income. Furthermore, the application of the credit method ensures at least one level of taxation, for example, when a DTC follows the OECD MC and allocates the exclusive taxing rights over royalties to the residence State.

\subsubsection{PRELIMINARY CONCLUSIONS}

The proposed CCCTB Directive provides for some form of relief for double taxation of all types on income from outbound investment. For example, it proposes an exhaustive list of income that is subject to the base exemption method for relieving double taxation, such as income from foreign permanent establishments (subject to a switch-over clause) and received dividends. The credit method would apply for all non-exempt income. If tax in the foreign country is higher, the application of the base exemption method is more beneficial than the credit method. However, this is not necessarily true with regard to the income derived through a foreign permanent establishment. In particular, the base exemption method also eliminates the possibility for foreign loss consideration. Nevertheless, the author argued that the base exemption method for 
foreign permanent establishment's income in the proposed CCCTB Directive remains in place despite whether the relevant DTC with a third country requires relieving double taxation by credit (and, hence, consider foreign losses). In particular, by taxing own residents, the CCCTB Member State would not violate the rights and obligations they have undertaken vis-à-vis the third country.

The credit method is an appropriate means of relieving double taxation of other types of income, such as interest and royalty income, especially within the EIM. In particular, considering that the Interest and Royalty Directive prohibits any withholding taxes at source, the application of the exemption method would lead to double non-taxation of intra-EU interest and royalties. Moreover, Article 12 of the OECD MC allocates the exclusive taxing right over royalties to the residence State. Thus, also from a global perspective, the inclusion of royalties in the tax base of the recipient is normally implied. In that sense, the credit method in the proposed CCCTB Directive is in line with the requirements of both the secondary EU law as well as Member States' DTCs. Nevertheless, the proposed CCCTB Directive lays down several limitations for foreign credits, which may make the system less attractive for companies.

Arguably, there is no general requirement for the States to eliminate double taxation, even within the EIM, as the case law of the CJEU shows. Nevertheless, the general understanding is that double taxation constitutes an obstacle to the development of economic relations between countries. As per the EIM, the abolition of double taxation is one of the objectives of the Union. However, in the light of the judgments of the CJEU, there is no general requirement to eliminate double taxation or preference for credit or exemption as a method for eliminating double taxation, as long as these methods produce in practice an equivalent result. The main advantage of the exemption method compared to the credit method is that it is easier to administer and is more cost efficient. On the other hand, the leading advantage of the credit system is that it is less sensitive to tax planning and tax competition between countries. From an economic perspective, the application of the credit or exemption method for relieving double taxation is associated with a certain approach to neutrality, i.e. CEN or CIN. Some scholars argue that CIN, which is typically achieved through the exemption method, fits better with the idea of the EIM, because it does not tax companies differently depending on where they exercise their secondary establishment, as protected by Article 49 of the TFEU. Hence, through the application 
of CIN, the State does not per se protect its home market, but it actually respects the choice of investment. Nonetheless, from the perspective of the CJEU, both CEN and CIN are compatible with primary EU law.

\subsubsection{INBOUND INVESTMENT}

The taxation of inbound investments requires the definition of source rules. It is generally accepted that each jurisdiction can tax the income of non-residents only if the latter have sufficient economic links to the jurisdiction. Consequently, non-residents are subject to limited taxation in the source State. As the author discussed earlier in Chapter 6, the source rules in the proposed CCCTB Directive can roughly be divided into two groups: (i) income derived through a CCCTB-located permanent establishment of a non-resident company and (ii) other income of a non-resident company. The taxation of the latter payments, which includes dividends, interest and royalty payments, will depend on each Member States' domestic law and DTCs. Due to such a link, the CCCTB system will avoid potential conflicts with Member States' DTCs with third countries. On the contrary, permanent establishments of non-resident companies will be attributed income according to the AOA and taxed in accordance with the CCCTB rules. Payments to non-residents that do not affect the CCC tax base, such as business income not attributed to their CCCTB-located permanent establishments, will remain taxable according to each Member State's source rules. Inevitably, taxation of non-residents in the source State (i.e. the CCCTB jurisdiction) will lead to double taxation if the residence State of the recipient operates a tax system based on worldwide taxation rather than territorial taxation. In the following sections, the author will elaborate on the issue and analyse whether double taxation of such income could and should be reduced or eliminated in either of the jurisdictions. Due to the specific requirements of EU law, the author will also discuss the hypothetical scenario of the CCCTB being introduced via enhanced cooperation.

\subsubsection{BUSINESS INCOME}

The proposed CCCTB Directive limits the group definition at the water's edge. Therefore, non-residents will be able to participate in the CCCTB group only to the extent that they have a taxable presence by means of a permanent establishment in a CCCTB Member State. According to Article 6(7) of the proposed CCCTB 
Directive, all income from an activity of such a permanent establishment will be covered by the CCCTB system. Hence, the tax base of the CCCTB-located permanent establishment would be attributed to such permanent establishments according to the AOA, calculated based on the CCCTB Directive, added to the tax bases of the rest of the members of the same CCCTB group and finally attributed to each group member according to a predetermined formula. However, the inclusion of permanent establishments of non-resident companies into the CCCTB group may lead to double taxation of the income attributed to such entities. Specifically, while the CCCTB attributes income to a permanent establishment based on a predetermined formula, the common international practice is that income is attributed to a permanent establishment based on the AOA/arm's length principle. Apportionment based on different factors - i.e. functions performed, risks assumed and assets used in the case of the AOA, and sales, employment and assets in case of the CCCTB - may lead to different results and consequently to double (non-) taxation. The question is whether such double taxation could be eliminated or whether it is just an unavoidable consequence of introducing the CCCTB system. Of course, the easiest way to avoid such a disadvantage would be to exclude permanent establishments from the scope of the CCCTB and leave their taxation solely under each Member State's national sovereignty. However, as discussed in the preceding Chapters of this dissertation, based on a number of grounds, the exclusion of permanent establishments from the CCCTB system is unreasonable. Another option would be to advise Member States to renegotiate their existing DTCs with third countries, when applicable, to the extent that they cause double taxation of the income of permanent establishments. A suggestion rather than a requirement to enter into negotiation with third countries stems from the fact that Article 351 of the TFEU requires Member States to enter into negotiations only where an international treaty conflicts with the acquis communautaire. But the double taxation of non-residents' income would not, per se, be contrary to the CCCTB system or EU law, even though it would run contrary to the general objective of making the EU more attractive for foreign investments. Moreover, as far as investments from non-CCCTB Member States, in the setting of enhanced cooperation for the CCCTB is concerned, double taxation is an obstacle to the EIM, even though the EU law in its current state does not impose a general obligation on the Member States to eliminate it. 
One could argue that Article 7 of the OECD MC restricts the taxation of business income by imposing a requirement of the existence of a permanent establishment. According to that Article, the income attributed to such a permanent establishment has to be made under the AOA and, therefore, it does not allow the source State to tax more income at the level of the permanent establishment than attributed to it under that approach. In the light of Commission v. Italy, ${ }^{1165}$ Member States must respect the rights and obligations that they have undertaken vis-à-vis third countries. In that sense, CCCTB Member States would be prohibited from taxing more income, allocated through the formula, at the level of a CCCTB-located permanent establishment than would be allowed under the AOA. In the light of this conclusion, the double taxation of permanent establishment's income would not arise from the outset. In the absence of the relevant DTC, it seems that there is very little that could be done to eliminate double taxation arising from the different approaches of the two systems, but the Member States may be invited to conclude DTCs with their relevant trading partners that would reflect such a peculiarity.

Further, when a permanent establishment participates in a CCCTB group, its income will be consolidated with the rest of the group members' tax bases and apportioned based on the specific sharing mechanism. When, following the application the formula, part of the permanent establishment's income attributed to it under the AOA forms part of the tax base of another group member, the head office of the permanent establishment in a third country will still receive relief only for the taxes paid in the source State (i.e. where the permanent establishment is located). In the following example (Example 39: Double taxation arising due to formula apportionment), a permanent establishment of a non-resident company (CoA) forms a CCCTB group with a qualifying resident subsidiary of the non-resident in Member State B. Let one assume that the income attributed to a CCCTB-located permanent establishment under the AOA is 100. However, following the consolidation and the application of the CССТВ sharing mechanism, the permanent establishment is attributed income in the amount of 50. The remaining income of the CССТВ group will become taxable at the level of the other group member $(\mathrm{CoB})$ in Member State B.

1165 Case Commission v Italy (10/61). 
Example 39: Double taxation arising due to formula apportionment

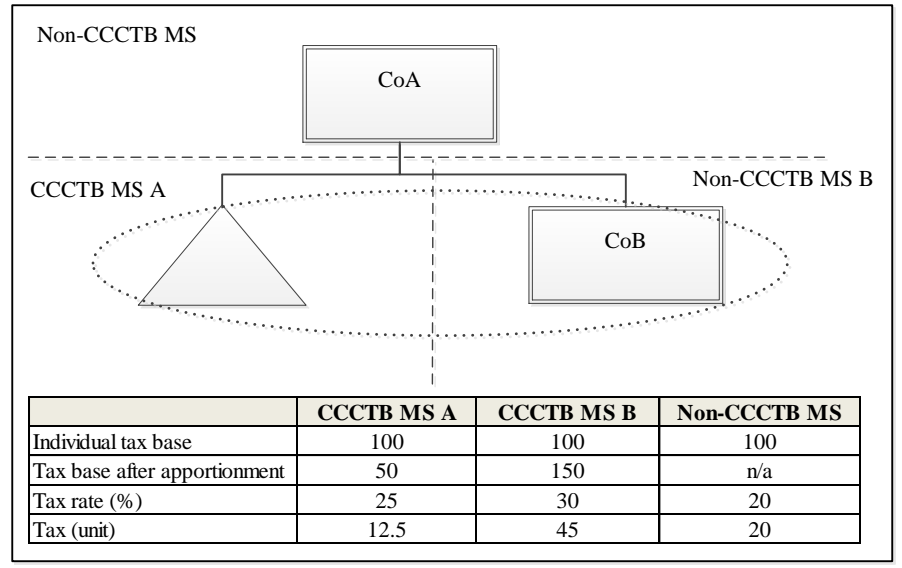

In this example, if the non-CCCTB Member State applies a credit method (either unilaterally or bilaterally) for relieving double taxation of a permanent establishment's income, it will give a credit only for the taxes paid by the permanent establishment (i.e. 12.5). Hence, the taxes paid on that income in the other Member State $(50$ x 30 per cent $=15)$ will normally not receive a credit in the State of the head office. Hence, part of the income remains double taxed $(20-12.5=$ 7.5). Such double taxation would not have occurred if the permanent establishment was not part of a CCCTB group. However, that does not sound like a fair result: if a country taxes the total income, it should also provide a credit for the total income, rather than only for part of it. However, third countries are not bound by the EU acquis communataire and hence cannot be required to consider the taxes on the profit of attributed to the permanent establishment under the AOA paid in another Member State due to the application of the CCCTB sharing mechanism. Hence, Member States would be invited to renegotiate their DTCs with third countries, so that a credit would be provided for the total amount of tax despite in which Member State they were paid (possibly with tax rate limitation set on the rate applicable in the State of source).

It is noteworthy that both methods, the AOA and the CCCTB sharing mechanism, use 'assets' as one of the profit allocation factors. Since the CCCTB follows the AOA, attribution of profits to CCCTB-located permanent establishments involves two steps: (i) attribution of profits linked to, inter alia, assets under the AOA, and (ii) sharing the CCC tax base based on, inter alia, assets of the 
permanent establishment under the CCCTB. According to the proposed CCCTB, for the purposes of the sharing mechanism, assets include fixed tangible assets (i.e. tangible, intangible and financial assets as defined in Article 4(14) and (15)) (Article 92). Such assets shall be included in the asset factor of their economic owner, i.e. the person who has substantially all the benefits and risks attached to fixed assets, regardless of whether that person is the legal owner (Article 93(1) in conjunction with Article 4(20)). Similarly, assets are attributed to their economic owner under the OECD MC. 1166 The latter implies that assets are attributed to "the part of the economic enterprise which performs the significant people's functions relevant to the determination of economic ownership of assets", i.e. their 'use'. ${ }^{1167}$ In the light of the foregoing, the allocation of the economic ownership under the AOA is strongly linked to the 'extent' assets are used in the functions of the permanent establishment. In that sense, deeming the economic ownership under the CCCTB appears less strict. Therefore, under the CCCTB, once the asset is deemed to be economically owned by a permanent establishment, the asset is fully included in its asset factor, despite the 'extent' its profits are linked to the asset. In such cases, the profits attributed to the permanent establishment under the CCCTB are likely higher than under the AOA only.

The attribution of all income to permanent establishments under the CCCTB system means that they would face similar problems under the CCCTB system as they currently do under Member States domestic systems. For example, under AOA, where the participation is attributed to the activities carried on by a CCCTB-located permanent establishment of a non-resident company, it would face double taxation if the source country levied a withholding tax on such dividends and the State of the permanent establishment did not provide (unilateral) relief for double taxation. According to the OECD Commentary, when a permanent establishment acts in the capacity of a holding entity of shares, Contracting States should clarify the matter in their DTC negotiation whether, from their perspective, the non-discrimination clause contained in Article 24(3) of the OECD MC extends national double taxation relief to permanent establishments. ${ }^{1168}$ In other words, it is up to each Contracting State to allow double taxation relief on dividends

1166 OECD Comm. on Article 7, para. 21.

1167 OECD (2010a), para. 18.

1168 OECD Comm. on Art 24(3), para. 48 et seq. 
attributed to permanent establishments located in their territory. According to the European Commission, dividends attributed to CCCTB located permanent establishments should be treated equally to the dividends received by CCCTB resident taxpayers. ${ }^{1169}$ As it currently stands, the proposed CCCTB Directive exempts dividends from the calculation of the tax base despite whether they are paid to a resident company or attributed to a permanent establishment. Through such an approach, the CCCTB Directive automatically prevents conflicts related to the non-discrimination clause in Member States' DTCs with third countries, especially if the latter have agreed in their DTC negotiation that national double taxation relief would be extended to the income attributed to permanent establishments.

By applying the base exemption method on received dividends, the CCCTB Directive automatically avoids conflicts based on EU law. The Court ruled in Saint-Gobain ${ }^{1170}$ that a permanent establishment of a company of a Member State receiving domestic and foreign-source dividends must be granted relief from double taxation, including the relief provided for by a DTC, equally to relief available to resident companies. According to the Court, the Member States must exercise their sovereignty to allocate taxing power of taxation between themselves, having due regard for Union law. Furthermore, from the Court's perspective, the unilateral extension of benefits under Member States' DTCs with third countries, due to the requirement of national treatment, does not disturb the balance and the reciprocity of the DTCs, because it would not affect the rights of the non-Member State that are parties to the DTC, nor would it impose on them any new obligation. Hence, the application of the exemption method on dividends attributed to permanent establishments under the same conditions as applicable to resident companies eliminates any disadvantage that the former might face due to the parallel application of the CССТВ system and Member States' DTCs with third countries and each other, despite whether the latter participate in the CCCTB system.

Article 60 of the proposed CССТВ Directive requires the elimination of any withholding and source taxation on transactions between group members, including permanent establishments of non-resident companies. It is noteworthy that the concept of source

${ }^{1169}$ European Commission (2007a), para. 132.

1170 Case Saint-Gobain (C-307/97). 
taxation under this article shall be interpreted as referring only to corporate tax arrangements within the meaning of Annex II of the Directive. Hence, all other source taxes, such as real estate transfer tax, capital duties, etc., will remain the competence of each Member State. As the author already discussed above in Chapter 4, permanent establishments will be able to participate in certain intra-group transactions without risking their income being (double-) taxed. According to Article 59(2) of the proposed CCCTB Directive, elimination of intra-group transactions (and hence withholding taxes) is applicable only if both parties of the transaction belong to the same CCCTB group and the transaction is effected and the associated revenues and expenses will be recognised (i.e. the accrual of revenues/incurrence of expense condition). If the group membership of the permanent establishment is invalidated retroactively, the prohibition to levy withholding taxes during the "preliminary" group membership would turn out to be a retrospective disproportionate interference with the sovereignty of the respective Member State. ${ }^{1171}$ However, this could not represent a reason why permanent establishments of non-resident companies should be excluded from the group definition. In any case, the same would be valid in case of payments between resident companies and their CCCTB-located permanent establishments. It is worth reminding that the same issues could equally arise under the current Parent and Subsidiary Directive and the Interest and Royalty Directive. Member States would also not be in a position to require that the minimum group membership period has already been met in order to abstain from levying withholding taxes on intra-group transactions. This conclusion can be deduced from Denkavit $I$, in which the CJEU ruled that the exemption method for withholding tax provided for in the Parent and Subsidiary Directive has direct effect. ${ }^{1172}$ Accordingly, the option for the Member States to introduce a minimum holding period as a condition for the exemption from withholding tax does not imply that Member States can require the minimum holding period to already come to an end at the time when the profit distribution is made. ${ }^{1173}$ However, the Court added that Member States are free to determine, in the light of the requirements of their domestic legal systems, the detailed arrangements for ensuring that this period is observed. ${ }^{1174}$ In the

${ }^{1171}$ Englisch (2013), 164.

1172 Denkavit I (Joined Cases C-283/94, C-291/94 \& C-292/94).

1173 Ibid., paras. 32 and 40.

1174 Ibid., para. 33. 
light of the foregoing, the CCCTB Member States will remain free to determine the administrative arrangements through which the Member States can ensure the observance of the minimum CCCTB group participation period where the Directive benefits are requested before the expiry of this period.

Another issue concerns the attribution of profits to a permanent establishment when a DTC with a third country is based on the OECD MC before the AOA was introduced in 2010. In particular, the previous OECD MC did not recognise the permanent establishment as a separate taxable entity and thus certain transactions between the head office and the permanent establishment were ignored. However, the CCCTB treats the permanent establishment as a separate group member and thus follows the AOA. The conflict between the two methods might lead to more advantageous or disadvantageous treatment of the transaction. Assume that a third country (State X) head office has a permanent establishment in the CCCTB jurisdiction (Member State A). If the head office provides a loan for the permanent establishment, the interest paid on that loan would be deductible from the individual tax base of the permanent establishment under the CCCTB rules. ${ }^{1175}$ On the other hand, since the DTC between State $\mathrm{X}$ and Member State A does not recognise the AOA (because it is concluded before the 2010 amendments), the interest paid to the head office would not be recognised as a taxable income in the State of residence. Consequently, the taxpayer would achieve an advantage due to the simultaneous application of the CCCTB system and the DTC. In the opposite situation, where the loan was provided by the permanent establishment to the head office, State $\mathrm{X}$ would not allow an interest deduction on the loan, while the CCCTB would require the interest to be paid based on the transfer pricing requirements and the taxpayer would suffer from a disadvantage due to the parallel application of the CCCTB system and the DTC. The same discussion would arise in the reverse situation in which the head office would be located in a CCCTB Member State with a permanent establishment in a third country. It was explained earlier that, in principle, the DTCs with third countries would prevail over the conflicting CCCTB rules until they are renegotiated. However, Member States should waive the rights they derive from DTCs in line with the CCCTB Directive, provided that this does not adversely

1175 Article 12 of the proposed CCCTB Directive. 
affect the third country's rights under the same DTC. Against this background, the tax base of the CССТВ resident or a permanent establishment would need to reflect these differences between Member States' DTCs with third countries. In the light of the example given earlier, the question is, if under the CCCTB rules the interest became deductible from the permanent establishment's tax base, whether such a deduction at the level of the CCCTB-located permanent establishment would violate the other contracting State's rights (as opposed to its interests) under the DTC. From the author's perspective, the answer should be negative. In the opposite situation, if under the CCCTB rules the interest received by a permanent establishment became taxable under the AOA, the rights of the third country would be affected and, thus, such taxation would be prohibited under the DTC.

\subsubsection{WiTHHOLDING TAXES}

The traditional understanding of withholding taxes is that they are levied at source on the income of the recipient of the respective payment rather than on the income of the paying entity. Hence, for the purposes of the withholding tax, the former should be considered as the taxable entity, whereas the latter should merely be deemed to be carrying out the task of a tax collector by deducting the tax from certain payments and remitting that amount to the government. This understanding has also been confirmed by the CJEU.1176 The (non-) existence of withholding taxes under the proposed CCCTB Directive lies essentially in Article 77, which entitles Member States to levy withholding taxes on interest and royalty payments paid to a recipient outside the CCCTB group according to its national law (with due regard to EU law) and any applicable DTC. ${ }^{1177}$ However, this wording may be misleading in the sense that it is silent on the matter whether withholding taxes could be levied on other payments made outside the group. Indeed, the wording "may be subject to a withholding tax" seems to be giving a mandate to levy withholding taxes, but only with regard to these payments. If that was the case, the wording of Article 77 would be contrary to Recital 18 of the Preamble of the Directive, which also mentions the sovereignty of the Member States to levy withholding taxes on dividends.

\footnotetext{
1176 Cases Epson Europe (C-375/98), para. 23; Athinaïki Zythopö̈a (C-294/99), paras. 28 and 29; Burda (C-284/06), para. 52.

1177 Note that Article 60 of the proposed CCCTB Directive abolishes all withholding taxes or other source taxation on intra-group transactions.
} 
Consequently, Article 77 of the proposed CCCTB Directive should be read a contrario, leaving the levying of withholding taxes on all kind on payments to non-group members to the sovereignty of each Member State. ${ }^{1178}$ Furthermore, based on Article 7 of the proposed CCCTB Directive, on matters about which the Directive is silent, the national corporate tax arrangements apply. This conclusion is also in line with the earlier suggestion of the European Commission. ${ }^{1179}$

There are a number of fundamental issues arising in relation to the requirement that any withholding tax levied on interest and royalty payments would have to be shared among the Member States according to the apportionment formula. First and foremost, one could submit a sub-question why withholding taxes levied on interest and royalty payments have to be shared between the group members, while withholding taxes on all other payments outside the group would not. Recital 18 of the proposed CCCTB Directive aims to shed some light on the matter and explains that withholding taxes on dividends should not be shared because, unlike interest and royalty payments, dividends do not lead to a previous deduction from the CCC tax base. Against this background, it seems that the criterion for the application of the sharing mechanism for withheld tax is its deductibility from the CCC tax base. However, there are some arguments that prove such a distinction invalid. First, considering that Member States keep the full sovereignty to levy withholding taxes, they might also do so with regard to other payments that are deductible from the CCC tax base, in particular those listed in Article 12 of the proposed CCCTB Directive, such as payments to nonresidents on the provision of services and rental payments. Second, if withholding taxes are charged on non-deductible interest and royalty payments, such as interest falling under Article 81 of the proposed CCCTB Directive, the Member States would still be obliged to share the tax levied on it (at least the proposed Directive does not seem to indicate otherwise). In addition to that, the logic of the interrelationship between the levying of withholding taxes and deductibility of the relevant costs does not hold strong in the light of the Interest and Royalty Directive. The latter prohibits the levying of any withholding taxes on certain interest and royalty payments, even though they may be considered to be deductible expenses for corporate tax purposes in the relevant Member States. In the light of these arguments, from the author's perspective, the reason for

1178 Englisch (2013), 167.

1179 European Commission (2007a), para. 18. 
sharing withholding taxes only in the case of interest and royalty payments brought forward in the proposed CCCTB Directive becomes obsolete.

The initial question on the validity of the application of the sharing mechanism on withholding taxes should be answered mainly in the light of the general idea of a withholding tax. Namely, the idea behind a withholding tax is that the person who is subject to tax is the recipient of the income; the obligation to withhold tax is put on the payer, mainly due to administrative reasons, so that it acts as an "agent" between the recipient and the government. On the contrary, the idea of the CCCTB is to tax group members on the basis of their consolidated income. Consequently, the idea of sharing a tax withheld on income of a recipient outside the CССТВ group runs contrary to the overall idea of the CCCTB itself. Furthermore, as the author discussed earlier, sharing a withholding tax based on the same formula as sharing a tax base makes little sense, because, in essence, a tax withheld does not form part of a CCC tax base (even if they are shared separately from the tax base, as currently proposed). The issue could be solved either by abolishing the requirement to share withholding taxes or by applying a separate formula (which may be built on the same factors as used for sharing a tax base). However, the application of the sharing mechanism for a tax might increase compliance costs for companies and administration costs for governments and thus run contrary to one of the aims of the CCCTB, for example, when a taxpayer is entitled to a withholding tax refund due to the retroactive application of a DTC. In addition to that, sharing a withholding tax should not, in any case, represent the compensation to the Member States for the deduction of the CCC tax base, because the allowance or disallowance of a deduction of certain costs should be a matter of policy choice rather than the remuneration of a deduction in a Member States' tax revenue.

If Member States considered levying withholding taxes necessary but, at the same time, also required sharing such taxes among themselves, the question is whether the CCCTB Directive itself should regulate the matter. The establishment of uniform rules for the imposition of withholding taxes would eliminate a number of issues. For example, the author argued earlier that the freedom to levy withholding taxes might lead to (undesirable) tax rate competition between Member States (Example 16: Withholding tax on interest payments). Also, the European Commission has raised concerns that a lack of uniform rules could lead to distortions in patterns of investment in the 
EIM. ${ }^{1180}$ In addition to that, making Member States' tax revenue dependent on the applicable tax rate in another Member State, due to the national preferences and DTC policy of the latter, seems to be a rather peculiar approach. ${ }^{1181}$ However, establishing a uniform withholding tax rate within the CCCTB system may require Member States to infringe their international obligations, where tax rates in their DTCs with third countries are lower than those fixed by the CCCTB Directive. However, more importantly, such an approach infringes the Member States' sovereignty to establish their tax rates and thus runs contrary to the subsidiarity requirements of EU law. Consequently, either the CСCTB leaves the establishment of the tax rates to the Member States (as it is currently proposed) or it eliminates any withholding taxes altogether. The latter approach could lead to a number of benefits from an economic perspective, for example, by attracting foreign investment. Nevertheless, the requirement to eliminate withholding taxes completely in the CCCTB Directive would most probably be challenged by the Member States due to revenue-related reasons.

It is undisputable that the application of the CCCTB Directive, in particular Article 77, does not override the Member States obligation to respect EU primary law. Consequently, despite the fact that the proposed CCCTB Directive does not restrict the Member States' sovereignty to levy withholding taxes based on their national law and DTCs, they must nonetheless exercise that power consistently with Union law. In the light of Denkavit II and Amurta, ${ }^{1182}$ when a Member State does not levy a withholding tax on domestic payments, it has to grant the same or similar treatment to outbound payments to companies residing in other Member States. The same is not necessarily true when the payments are made to companies resident in the EEA Member States, because the restriction could be justified by the need to prevent tax evasion. ${ }^{1183}$ Furthermore, the application of the CCCTB Directive would not override the application of other secondary EU legislation with regard to the imposition of withholding taxes on outbound payments. Thus, the prohibition on levying withholding taxes on interest and royalty payments that fall within the scope of the Interest and Royalty Directive and on dividends that fall within the Parent and Subsidiary Directive remains

\footnotetext{
1180 Ibid., para. 18.

${ }^{1181}$ Englisch (2013), 171.

1182 Cases Denkavit II (C-170/05); Amurta (C-379/05).

1183 Case Commission v Italy (C-540/07).
} 
applicable, regardless of the fact that the payments are made to companies not belonging to a CCCTB group. Hence, even if the CCCTB Directive was introduced via enhanced cooperation, such payments would continue to benefit from the other secondary EU legislation.

\subsubsection{Elimination OF DOUble TaXation By Third COUNTRIES}

DTCs generally do not take into account the specific situation of a CCCTB linked with an apportionment mechanism. Instead, they make use of rather different criteria for the allocation of income between the DTC partners. The issue is particularly relevant with regard to the taxation of the income attributed to a permanent establishment. If the third country uses the credit method for avoiding double taxation of income, it computes the underlying income and the available credit based on its domestic law. Due to conflicting taxation rules, the third country might not allow credit for the whole tax levied in the CCСТВ Member State. Of course, such double taxation may also take place in the current setting of international taxation due to conflicts arising from transfer pricing requirements. However, such differences allegedly have a smaller impact, because both jurisdictions involved would (typically) base their calculations on the AOA/arm's length principle. Furthermore, part of the double taxation could be solved based on a DTC (Article 9 of the OECD MC). There is currently no agreement between the EU and third countries with regard to the taxation of associated enterprises. Consequently, this is an issue to be solved either by an agreement between the EU and third countries (at least as far as most important trading partners are concerned) or by Member States themselves in their DTCs with third countries. However, it seems that taxpayers will not be entitled to launch the mutual assistance procedure contained in DTCs (Article 25 of the OECD MC) as the latter covers only situations which relate to taxation "in accordance with the provisions" of the relevant DTC. Hence, as DTCs generally do not support profit apportionment according to a predetermined formula, double taxation arising from the conflicts in the allocation mechanism could not be challenged based on Member States' DTCs.

\subsubsection{PRELIMINARY CONCLUSIONS}

The discussion on the elimination of double taxation from the source State's perspective must be approached from two angles. 
First, the income attributed to a CCCTB-located permanent establishment of a non-resident company under the AOA is included into the CCC $\operatorname{tax}$ base. However, since the CCCTB includes additional step by means of the sharing mechanism, it may happen that the income attributed to the permanent establishment in a CCCTB Member State is different from that attributed to the head office based on the AOA. In the existence of a DTC between the relevant States, the head office would receive credit only for the amount of taxes paid in accordance with the DTC. Hence, part of the income may be double taxed. The proposed CCCTB Directive does not provide a solution for such double taxation. Unless Member States renegotiate their DTCs with third countries to reflect such differences, double taxation arising from the conflicting attribution mechanisms appears to be an unavoidable consequence of introducing the CCCTB system. However, one could argue that Article 7 of the OECD MC restricts the taxation of permanent establishments as calculated under the AOA. In order to respect Member States' international agreements, CCCTB Member States would be prohibited from taxing more income at the level of a CCCTB-located permanent establishment than would be allowed under the AOA. In such a case, double taxation of permanent establishment's income would not arise. This conclusion is not applicable in situations in which the CCCTB does not attribute more income to a permanent establishment than the AOA does, but where the income becomes taxable in another Member State due to the sharing mechanism. In such a case, double taxation is inevitable, as the third country would give credit only for taxes paid in the State of the permanent establishment.

Another issue concerns the attribution of profits to a permanent establishment when a DTC with a third country is based on the OECD MC before the AOA was introduced in 2010. In such a case, the permanent establishment is not recognised as a separate taxable entity and thus transactions between the head office and the permanent establishment are ignored. However, the CCCTB treats the permanent establishment as a separate group member and thus follows the AOA. From the author's perspective, the taxation of dealings between the head office and the permanent establishment will depend on the fact whether it affects the Member States' obligations, which they have undertaken vis-à-vis a third country under a DTC. Provided that the CCCTB requirements do not adversely affect the third country's rights under the DTC, Member 
States should waive their rights that they derive from those DTCs in line with the CCCTB Directive.

The other group of income includes all other income that nonresidents derive from CCCTB Member States. With regard to this income, the proposed CCCTB Directive leaves the choice of levying withholding taxes entirely on the source State (i.e. the CCCTB Member State). Remarkably, while the proposed Directive requires withholding taxes on interest and royalty payments to be shared between the Member States, it does not require the same in the case of withholding taxes on other types of income, despite whether they are deductible from the CCC tax base or not. In fact, the idea of sharing withholding taxes among Member States is an odd requirement, mainly because of the following reasons:

1) Sharing a tax withheld on income of a recipient outside the CCCTB group runs contrary to the overall idea of the CCCTB, which is to tax group members on the basis of their consolidated income.

2) Sharing a withholding tax should not represent the compensation of the Member States of the deduction of the CCC tax base, because the allowance or disallowance of a deduction of certain costs should be a matter of policy choice rather than the remuneration of a deduction in Member States' tax revenue.

3) Sharing a withholding tax among Member States based on the same apportionment formula as used for sharing the CCC tax base is illogical;

4) Sharing a withholding tax might increase compliance costs for companies and administration costs for governments and thus run contrary to one of the aims of the CССТВ, especially when a taxpayer is entitled to a withholding tax refund due to the retroactive application of a DTC.

\section{CCCTB}

The elimination of double taxation and avoidance of double nontaxation are frequently seen as two sides of the same coin. There is no question that from a purely tax policy perspective the avoidance of both double taxation and double non-taxation are perfectly 
legitimate. ${ }^{1184}$ Member States usually prevent double non-taxation in their national law and/or DTCs. It is noteworthy that not all DTCs pursue the aim of eliminating double non-taxation. If contracting States wish to do so, they must contain a specific provision for that purpose in the DTC, such as a subject-to-tax test or a switch-over clause. Otherwise, in the opinion of the author, the avoidance of double non-taxation under domestic law provisions would constitute a DTC override. This conclusion stems from the fact that DTCs merely allocate taxing rights between the contracting parties but do not impose an obligation to exercise that right. Hence, if one of the contracting States chooses not to tax certain items of income due to its national policy, it does not mean that the other party can tax it as if the right was exclusively allocated to it.

Within the EU, the CJEU has upheld a number of national measures that are aimed at preventing double non-taxation. For example, in Marks \& Spencer, 1185 the Court held that a restrictive national measure in the EIM was justified due to the need to prevent double use of losses. In $O y A A,{ }^{1186}$ the Court held that a national measure, which limits a transfer of profits from a Member State company to a company in another Member State, did not infringe the freedom of establishment, because otherwise companies could choose where they prefer their losses to be deducted and profits to be taxed. This option would, however, jeopardise the fair and balanced allocation of taxing powers among the Member States, which is based on the principle that every State has the sovereignty to tax profits arising from activities in its territory. It is true that, in both cases, the CJEU combined the need to safeguard the balanced allocation of taxing power between Member States together with the justification based on the need to prevent tax avoidance. According to the Court, "the objectives of safeguarding the balanced allocation of the power to impose taxes between Member States and the prevention of tax avoidance are linked". ${ }^{1187}$ Further, following Schempp ${ }^{1188}$ and Columbus Container, 1189 it seems that a Member State's national measure, the purpose of which is to ensure at least single taxation, could justify a different treatment between domestic and cross-border situations.

\footnotetext{
${ }^{1184}$ Lang (2007), 19.

1185 Case Marks \& Spencer (C-446/03).

1186 Case Oy $A A(\mathrm{C}-231 / 05)$.

1187 Case $O y A A(\mathrm{C}-231 / 05)$, para. 62.

1188 Case Schempp (C-403/03).

1189 Case Columbus Container Services (C-298/05).
} 
The proposed CCCTB system is designed in a manner that it ensures at least single taxation within a group of companies. It is worth reminding that this is not necessarily the case in the US subnational taxation, as the states remain free to determine their group tax bases and apportionment factors, without prejudice to the Commerce Clause and the Due Process Clause. Some states, however, have implemented specific rules, such as "throwback" and "throwout" rules, to ensure at least single taxation of income. With regard to transactions with third parties, the proposed CCCTB Directive attempts to ensure at least single taxation mainly through the application of a switch-over clause, whereby the exemption method applicable to certain income is replaced by the credit method under certain circumstances. ${ }^{1190}$ Other than that, it contains certain antiavoidance provisions, such as CFC rules, that also safeguard at least single taxation of cross-border investment. The author will focus on these anti-avoidance provisions in detail in the next Chapter. On the other hand, the proposed Directive does not include the concept of beneficial owner in any of its provisions. Indeed, the requirement for beneficial ownership in the OECD is contained under the provisions dealing with source State taxing rights and it assures that the source State is not obliged to give up taxing rights over income merely because the income was immediately received by a resident of a State with which the source State had concluded a DTC.1191 When a Member State acts in the capacity of a source State, the proposed CCCTB Directive leaves the right to levy withholding taxes on that State. Hence, there would be no need to introduce the concept in the CCCTB Directive. The proposed CCCTB Directive also contains a specific subject-to-tax requirement. However, rather than testing whether there is actual taxation in the residence State or the source State, the clause forms part of the eligibility requirements with regard to opting for the CССТВ system. Hence, the definition of the subject-to-tax provision in the proposed CCCTB Directive is different from the typical definition in Member States' DTCs based on the OECD MC. However, the subject-to-tax requirement in the proposed CCCTB Directive does play a role with regard to the avoidance of double non-taxation, for example, in the case of hybrid entities. In particular, the fact that it allows companies to participate in the system only if it is subject to one of the taxes listed in Annex II of the CCCTB Directive ensures that Member States' tax bases are

\footnotetext{
1190 Article 73 of the proposed CCCTB Directive.

1191 OECD Comm. on Article 10, para. 12, Article 11, para. 9, and Article 12, para. 4.
} 
not eroded due to the use of hybrid entities as CCCTB group members.

Due to the fact that the proposed CCCTB Directive does not define dividends, taxpayers may attempt to take advantage of the system through the use of hybrid instruments, where a payment would be considered to be deductible interest in the State of the payer, while it would fall within the scope of a participation exemption as a dividend in the State of the recipient. Of course, taxpayers have also been able to achieve such a result under the current Member States' national system due to differences in national law. Moreover, the definition of dividends under the CCCTB would not necessarily imply that such mismatches would be removed in the international context. It is worth reminding that the Parent and Subsidiary Directive also does not define dividends - it simply establishes that the material scope of the directive is the "distribution of profits" received or paid. It also does not define the concept of "distribution". Given the number of hybrid instruments, it would be almost futile to attempt to provide a definition of "dividends" or "distribution". The same reasoning applies equally to the absence of the definition of dividends in the CCCTB Directive. However, it was argued earlier that the concept of dividends for the purposes of the Directive could be deduced from the definition of interest, which is provided therein. In particular, the general understanding should be that all income and payments that do not constitute interest would be considered dividends. However, it was also suggested earlier that the definition of dividends in the IAS/IFRS could serve as a source of inspiration for the determination of dividends, for example, in that a payment or income does not need to be qualified either as a dividend or interest, but it could be split between the two, depending on the proportion of its characteristics. During the discussions following the proposal for a CCCTB Directive, the Danish Presidency recognised the problems related to hybrid mismatches and proposed a separate Article to protect the CCC tax base from tax planning with hybrid instruments and hybrid entities. ${ }^{1192}$ The European Commission has indicated in its action plan against aggressive tax planning from 2012 that tackling hybrid mismatches in tax law will be dealt with. ${ }^{1193}$ It is also noteworthy that the OECD is continuously concerned about tax base erosion due to, inter alia, hybrid mismatches. ${ }^{1194}$

1192 Council of the European Union (2012), Article 83a and the comments herewith.

${ }^{1193}$ European Commission (2012c), para. 14.

1194 See OECD (2012a); OECD (2013). 

SWITCH-OVER CLAUSE

In order to apply a subject-to-tax test in a DTC, contracting States must have included the condition under the relevant article in the DTC itself. 1195 The subject-to-tax test in the OECD MC makes the availability of DTC benefits in one contracting State dependent on the actual taxation in the other contracting State. Hence, they can function in both directions - from the perspective of the source State and that of the residence State. The switch-over clause contained in Article 23(4) of the OECD MC is aimed at avoiding double non-taxation due to disagreements between the contracting States on the facts of the case or on the interpretation of the provisions of the DTC. ${ }^{1196}$ Hence, the meaning and application of the switch-over clause in DTCs is not dependent on the actual taxation in the other contracting State. On the opposite, the application of the switch-over clause under the proposed CCCTB Directive is triggered where income, which is normally exempted in the CCCTB jurisdiction, is subject to low or no taxation in the source State due to low statutory corporate tax rate or due to the application of a special regime. ${ }^{1197}$ In that sense, the switch-over clause in the proposed CCCTB Directive is more similar to the subject-to-tax clause rather than the switch-over clause within the meaning of the OECD MC. The provision in the Directive has been influenced by Member States' national switch-over clauses, which shift from the application of the exemption method to the credit method in cases where the income is subject to low or no taxation in the other State. Against this background, Member States will be able to apply the switch-over clause in the CCCTB Directive only if their DTCs with third countries include a specific subject-to-tax provision. Otherwise, the Member States would infringe their international obligations by overriding their DTCs with third countries due to the application of the CCCTB Directive. In the absence of such provisions in the DTCs, Member States would be invited to or obliged to (depending on the status of the DTC as discussed earlier) enter into negotiations to amend their DTCs with third countries.

From the EU perspective, the application of a unilateral switch-over clause from the exemption method under the DTC to the credit

\footnotetext{
1195 OECD Comm. on Article 23, paras. 35 and 37.

1196 OECD Comm. on Article 23, paras. 56.1-56.3.

1197 Article 73 of the proposed CCCTB Directive.
} 
method in case of low passive income of foreign permanent establishments has been upheld in Columbus Container ${ }^{1198.1199}$ According to the Court, it follows from the Member States' fiscal autonomy that the freedom of companies and partnerships to choose, for the purposes of establishment, between different Member States does not imply that the Member States are obliged to adapt their own tax systems to the different systems of other Member States, in order to guarantee that a company or a partnership that has chosen to establish itself in a given Member State is taxed, at national level, in the same way as a company or a partnership that has chosen to establish itself in another Member State. It is noteworthy that Columbus Container has given rise to disputes among scholars that the Court's decision created uncertainties, especially considering its earlier decision Cadbury Schweppes. ${ }^{200}$

Another question is whether the application of the switch-over clause from the exemption method to the credit method automatically triggers the possibility to consider foreign losses in the CCC tax base. It was discussed earlier that the base exemption method currently proposed in the CCCTB Directive with regard to a foreign permanent establishment's income does not allow losses attributed to the permanent establishment to be taken into account at the head office's level. Furthermore, it imposes a restriction on the deductibility of costs related to such exempt income. It was also explained earlier that the application of the credit method normally results in the automatic consideration of foreign losses. However, allowing the consideration of foreign losses due to the application of the switch-over clause would run contrary to the purpose of the provision itself. In other words, the application of the clause should not lead to a more beneficial treatment of low-tax profits and losses. Therefore, the switch-over clause in the proposed CCCTB Directive should be seen as ad hoc measure that applies on a year-by-year basis. In other words, if the low-tax country permanent establishment incurs losses, the fact that its profits had been taxed in the CCCTB

\footnotetext{
1198 Case Columbus Container Services (C-298/05).

${ }^{1199} \mathrm{It}$ is noteworthy that an earlier working document of the CCCTB indicates that there was some uncertainty whether a switch-over clause could be applied in intraEU situations. At the time of drafting the document, case Columbus Container Services (C-298/05) had been referred for a preliminary ruling to the CJEU, but it was still undecided. European Commission (2007a), para. 79.

1200 Calderón \& Baez (2007).
} 
jurisdiction due to the switch-over clause in the previous year(s) is irrelevant. It is noteworthy that the Danish Presidency has proposed to eliminate the applicability of the switch-over clause to income of foreign permanent establishments, but rather it has proposed dealing with the issue together with the CFC provision. ${ }^{201}$ Through such an approach, it becomes clear that foreign losses attributed to permanent establishments falling within the scope of the anti-abuse provision are not taken into account at the head office's level but carried forward according to Article 83(1) of the proposed CCCTB Directive.

\subsubsection{PRELIMINARY CONCLUSIONS}

Generally speaking, from a tax policy perspective, the avoidance of both double taxation and double non-taxation are perfectly legitimate. This also holds true within the EU, where the Court has upheld a number of national measures that are aimed at preventing double non-taxation. The proposed CCCTB system is designed in a manner that it ensures at least single taxation within a group of companies. However, with regard to payments from outbound investment, the proposed Directive incorporates methods to ensure an acceptable level of taxation. For example, the switch-over clause triggers the application of the credit method instead of the exemption method for the elimination of double taxation in cases in which the income is subject to low or no taxation in the source State due to low statutory corporate tax rates or due to the application of a special regime. Nonetheless, not all DTCs pursue the aim of eliminating double nontaxation. If contracting States wish to do so, they must include a specific provision for that purpose in the DTC. Consequently, in order to respect the obligations of the Member States that derive from their DTCs with third countries, the switch-over clause in the CCCTB Directive can be applied only if it is allowed under the relevant DTC. In the absence of such provisions in the DTCs, Member States would be invited to or obliged (depending on the status of the DTC as discussed afore) to enter into negotiations to amend their DTCs with third countries. It is noteworthy that the CJEU has upheld a unilateral switch-over clause from the exemption method under the DTC to the credit method in the case of low passive income of foreign permanent establishments in Columbus Container.

1201 Council of the European Union (2012), comments on Articles 73-74 and Articles 82-83 of the proposed CCCTB Directive. 
With regard to the relationship between the consideration of foreign losses of a permanent establishment and the application of the switch-over clause, the author concluded that the application of the latter does not require the consideration of foreign losses. This is because the switch-over clause in the proposed CCCTB Directive is an ad hoc provision that applies on a year-by-year basis. Consequently, if the low-tax country permanent establishment incurs losses, the fact that its profits had been taxed in the CCCTB jurisdiction due to the switch-over clause in the previous year(s) is irrelevant. The Danish Presidency has approached the issue from a different perspective and has proposed dealing with the income of a foreign permanent establishment together with the CFC provision. As the author has concluded earlier, taxing the income of a foreign permanent establishment under a "semi-CFC" with a credit for foreign taxes would violate Member States' DTCs: they would conflict with either Article 7 or Article 23A (if based on the OECD $\mathrm{MC})$. On the other hand, the application of the "semi-CFC" rule would provide for a benefit of the consideration of losses for the future CFC income and would thus be more interesting for businesses However, for such a measure, renegotiation of (certain parts) of Member States' DTCs is inevitable.

\section{6 \\ CONCLUSIONS}

The leading understanding is that double taxation is an obstacle to the development of economic relations between countries. Nevertheless, it is generally accepted that the international legal order does not create an obligation to design tax systems with a view to preventing double taxation or to eliminating double taxation when it arises. Despite that, most countries have committed themselves to do so, at least to a certain extent, and have adopted unilateral measures in their national law or have concluded DTCs with other countries. The EU is much less tolerant of double taxation than the US. The latter understands market efficiency to be primarily related to tax competition and deregulation rather than to harmonisation, and, therefore, double taxation is not considered to be a distorting factor, which should necessarily be eliminated. ${ }^{1202}$ By contrast, the EU seems to establish market efficiency via neutral treatment and harmonisation/approximation of laws. While the EU endorses

1202 Mitroyanni (2008), 152. 
cooperation between the Member States for the better functioning of the EIM, the US states find themselves in a different setting. Although the states are part of one federal market, they often compete for other purposes, subject to few federal limitations, within a single, rather well-defined and regulated market. One other reason why the elimination of double taxation in the EU is a bigger concern compared to in the US is that in the US vast majority of activities are carried out domestically, while the smaller EU countries have many activities abroad and a considerable participation in world trade. Consequently, large, closed economies, such as the US, can afford to have heavier taxation compared to small, open economies, such as the EU Member States. Therefore, the choice for the method for the elimination of double taxation in the EU needs to take into account other factors, such as the promotion of foreign investment.

Tax reform work within the EU has been focussed largely on improving the EIM by removing tax obstacles, reducing compliance costs and resolving double taxation within the EU. Elimination of double taxation is also one of the key issues for achieving the Lisbon objectives. In fact, the Court has recognised in a number of cases that double taxation is an obstacle to the EIM and its abolition remains one of the objectives of the Union. Regardless of this view, the Court is of the opinion that Union law, in its current state, does not lay down any general criteria for the attribution of competences between the Member States and there is no general prohibition of double taxation in the EU.

The proposed CCCTB Directive eliminates double taxation of transactions between group members. With regard to transactions with third parties, in case of outbound payments, the Proposal entitles Member States to levy withholding taxes. With regard to inbound payments to CCCTB entities, the proposed Directive provides for either the exemption or credit method for the elimination of double taxation of such income. With regard to the latter, the question is whether the elimination of double taxation via these methods complies with the ability-to-pay principle. The abilityto-pay principle forms part of the equality principle prescribed in Member States' constitutional law. Being part of Member States' constitutional law, the ability-to-pay principle forms part of the general principle of Union law. Such general principles in EU law have a constitutional status and are equal, in terms of hierarchy, to the Treaties, and hence, they are binding on the Union institutions and on the Member States. 
The elimination of double taxation via the credit method is often challenging and administratively burdensome, especially if it includes limitations, such as those foreseen in the proposed CCCTB Directive. Furthermore, by relieving double taxation by the credit method, countries effectively export their high tax levels to foreign markets. In such a case, domestic businesses often face more burdensome taxation compared to their competitors in the home market. As a result, businesses are discouraged from benefiting from new markets. However, small, open economies, such as the EU Member States, often cannot afford such constraints. On the other hand, the general advantage of credit systems is that they are less sensitive to tax planning and (fair and unfair) tax competition between countries. Moreover, the elimination of double taxation via the credit method is less sensitive to challenge against the ability-to-pay principle. However, when the credit method is subject to limitations, such as excess credit carry-over limitations such as foreseen by the CССТВ Proposal, it likely infringes the principle. From the author's perspective, the absence of excess credit carry-over leads to (lato sensu) juridical double taxation, which cannot occur in a domestic situation. In such a case, the country avoids double taxation in the domestic scenario, while it does not do so in case of cross-border investment. In the light of the foregoing, the author is of the opinion that certain credit limitations may infringe the ability-to-pay principle, which forms part of general EU principles and must thus be eliminated.

The exemption method generally eliminates double taxation of outbound investment and thus it would comply with the general ability-to-pay principle. Such taxation would recognise the principle of net taxation over a business's lifetime and provide a competitive advantage in relation to other tax jurisdictions. The application of the exemption method also promotes simplicity and clarity with respect to its jurisdiction. ${ }^{1203}$ In fact, in the US there is a movement to an exemption system, because it is believed that it will make the US corporations more competitive as well as make them pay more tax. ${ }^{1204}$ Nonetheless, compliance with the ability-to-pay principle is not achieved if the taxpayer is not allowed to deduct foreign losses from its domestic income, because it would become taxable on unrealised income in its residence State. The latter is exactly what is suggested in the proposed CCCTB Directive. In that sense, the

1203 Andersson (2006), 399.

1204 Nikolakakis (2012), subchapter 4.1. 
application of a base exemption method with a temporary loss consideration (loss recapture) may be a better alternative.

From an EU law perspective, the exemption method, which is often associated with CIN, seems to fit better with the requirement of freedom of establishment and free movement of capital in terms of outbound investment. Some scholars argue that the credit method, which is often associated with CEN, is incompatible with the requirements of the EIM, in particular, with the freedom of establishment and free movement of capital, because the residence State removes any possible tax advantage of carrying out cross-border economic activity and, thus, protects its home market. Despite these concerns, the CJEU considers both CIN and CEN to be in line with primary EU law. Another advantage of an exemption method (or territorial system) is that it generally does not conflict with Member States' DTCs. However, a pure territorial system, where all foreign income is (base) exempted in the residence State, is also not desirable. For example, interest and royalty payments are often tax deductible in the source State at the level of the payer, so that their exemption in the residence State would lead to double non-taxation, especially if the payment falls within the EU Interest and Royalty Directive.

The taxation of business income derived through permanent establishments located in the CCCTB jurisdiction of non-resident companies may result in double taxation where the results of the CCCTB and AOA do not mach. In particular, the two systems use different factors for the purposes of attributing income to a permanent establishment: while the AOA looks at functions performed, risks assumed and assets used, the CCCTB uses factors based on sales, employment and assets. The question is whether such double taxation could be eliminated or whether it is just an unavoidable consequence of introducing the CCCTB system. Furthermore, it is questionable whether Article 7 of the OECD MC prohibits a higher level of taxation than calculated under the AOA. If the tax base attributed to a CCCTB-located permanent establishment of a non-resident company is higher than under the applicable DTC that uses the AOA, the Member State of the permanent establishment would infringe its international obligations. Article 351 of the TFEU requires Member States to enter into negotiations only where an international treaty conflicts with the acquis communautaire, subject to a grandfathering clause. Under this provision, the Member States would not be under a general obligation to renegotiate such conflicting provisions of their DTCs, because the double taxation of 
non-residents does not violate the acquis. However, according to the CJEU, without prejudice to Article 351 of the TFEU, Member States must respect the rights and obligations that they have undertaken vis$\grave{a}$-vis towards third countries. In that sense, CCCTB Member States would be prohibited from taxing more income, allocated through the formula, at the level of a CCCTB-located permanent establishment than allowed under the AOA. In the light of this conclusion, the double taxation of permanent establishment's income would not arise from the outset.

Some authors have suggested that a provision should be introduced in the critical articles of Member States' DTCs to the effect of expressly stating that, in the case of conflict, Union law is superior to the DTC law. ${ }^{1205}$ While this is obvious in cases of Member States, such a result seems highly unlikely when the contracting party is a third State, because of the disinterest of the latter to be subjected to EU law. ${ }^{1206}$ In case the CCCTB is introduced via enhanced cooperation, from the author's perspective, non-participating Member States would not be under a general obligation to respect the Union acquis related to the CCCTB. Although Article 351 of the TFEU is not applicable in this case, as it applies only to treaties concluded with third countries, in the case of conflicts between the DTC with a non-participating Member State and the CCCTB, it seems reasonable to follow the same approach as in the case of third countries. Hence, also in these cases, the rights and obligations of the non-participating Member States would not be affected.

Considering that greater or smaller conflicts will arise from the simultaneous application of Member States' DTCs and the CCCTB, the question is whether these conflicts could be overcome through a renegotiation of the DTCs or whether a solution should be found at the EU level, such as through an EU model DTC or a multilateral DTC between the EU and third countries, limited to entities participating in the CCCTB. Despite the EU's international legal personality, its treaty-making power is only residual and it must be exercised in compliance with the specific attribution of powers set by primary EU law. The Treaties still confer the authority on the Member States to conclude DTCs, rather than conferring this authority on the EU as such. Such a competence, however, is implied

${ }^{1205}$ Hinnekens (1994), 161.

1206 Of course, Member States remain fee to mention the hierarchical status of the EU law compared to DTC law in their DTC negotiations. 
if the Union has exercised its internal competence and the action at the Union level is necessary for the attainment of the Treaty objective. Secondary EU law, such as the EU directives, pursue the Union objectives provided in the Treaties. In the light of the principle of subsidiarity, the Member States have agreed that the Union objectives cannot be sufficiently achieved by the Member States and they can better be achieved by the action taken at the Union level in certain matters. Hence, through the adoption of secondary EU law, Member States give up some of their rights. For example, through the adoption of the CCCTB, Member States relinquish their power to regulate in this field, because they believe that the objectives of the Union, which are reflected in the objectives of the (proposed) CCCTB Directive, can better be achieved at the Union level. ${ }^{1207}$ Therefore, the Union will have an implied competence to conclude DTCs with third countries if the objectives of the CCCTB (and consequently the objectives of the Treaty) cannot be achieved otherwise. From the author's perspective, the current proposal for a CCCTB Directive entails little, if any, such conflict with third countries. It is worthwhile reminding that in case a DTC with a third country conflicts with the CCCTB rules, Article 351 of the TFEU requires Member States to enter into negotiations to eliminate such conflicts, subject to a grandfathering clause. Until the renegotiation takes place, Member States shall continue to observe the obligations which they have undertaken vis-à-vis a third country under a DTC and respect the rights of the third country. In the light of the primacy of the EU law, the Member States must waive the rights that they derive from the conflicting DTC in line with the acquis communautaire (including instruments of secondary EU law), provided that this does not adversely affect the third country's rights under the same DTC. Hence, the Union's action in this field is limited. An explicit EU competence to negotiate DTCs with third countries would require an amendment of the Treaties. It is noteworthy that an EU Model DTC in this field would be possible based on the current provisions of the Treaties, although such an instrument would potentially be less efficient compared to an EU multilateral DTC.

Last, while single (juridical) double taxation is a standard, both double taxation and double non-taxation are undesired deviations from this benchmark. The proposed CCCTB system is designed in a manner that it ensures at least single taxation within a group of companies. By

1207 Vide supra at I2.1.3. 
comparison, this is not necessarily the case at the US subnational level, as the states remain free to determine their group tax bases and apportionment factors, without prejudice to the Commerce Clause and the Due Process Clause. Some US states, however, have implemented specific rules, such as "throwback" and "throwout" rules, to ensure at least single taxation of income. With regard to transactions with third countries, the proposed CCCTB Directive attempts to ensure at least single taxation mainly through the application of a switch-over clause, whereby the exemption method applicable to certain income is replaced by the credit method under certain circumstances. Importantly, not all DTCs pursue the aim of eliminating double non-taxation. If contracting States wish to do so, they must contain a specific provision for that purpose in the DTC. Consequently, in order to respect the obligations of the Member States that they derive from their DTCs with third countries, the switch-over clause in the CCCTB Directive can be applied only if it is allowed under the relevant DTC. In the absence of such provisions in the DTCs, Member States would be invited to or obliged to (depending on the status of the DTC as foreseen in Article 351 of the TFEU) enter into negotiations to amend their DTCs with third countries.

Further, the application of the switch-over clause does not require the consideration of a foreign permanent establishment's losses. The proposal of the Danish Presidency, which treats low-tax permanent establishment's income under a "semi-CFC" rule, makes this understanding explicit. Nevertheless, such a rule would imply a conflict with Member States' DTCs with third countries, either because of an infringement of Article 7 or Article 23A (if based on the OECD MC). In the light of Article 351 of the TFEU, Member States would be obliged to respect the rights of the third countries and, thus, the "semi-CFC" rule would turn out to be impracticable. 


\section{$8.1 \quad$ INTRODUCTION}

Under EU law, direct taxation falls within the competence of the Member States, provided that they exercise that competence in conformity with Union law. Hence, as a matter of principle, the Member States are also free to decide on their domestic anti-abuse rules. Typical national anti-abuse rules include a GAAR and/or SAARs. Due to such a freedom to legislate in the field, the current national anti-abuse rules of Member States are not consistent, for instance, concerning the existence of thin capitalisation rules (e.g. through the set arm's length proportion between related parties or a fixed debt-to equity ratio) or CFC rules.

In 2007, the European Commission published a communication in which it set forth its action plan concerning the application of national anti-abuse measures in the area of direct taxation within the EU and the EEA in relation to third countries. ${ }^{1208}$ The communication provides for an analysis of the principles flowing from the relevant jurisprudence of the CJEU with a view to promoting a more general debate on appropriate responses to the challenges faced by Member States in this area. In 2010, the ECOFIN adopted a resolution on the coordination of the CFC and thin capitalisation rules within the European Union. ${ }^{1209}$ The resolution recommends that Member States adopt certain common guiding principles when applying cross-border CFC and thin capitalisation rules within the EU (provided that the rules are also applicable in similar domestic situations). In 2012, in response to the European Council, the European Commission launched a communication to develop concrete ways to improve the fight against tax fraud and tax evasion. ${ }^{1210}$ Furthermore, in December 2012, as a follow up to the June 2012 communication, the European Commission published its action plan ${ }^{1211}$ presenting the initiatives that it has already taken, new initiatives that can progress in short term and those that require long-term action, and two

\footnotetext{
1208 European Commission (2007d).

1209 Council of the European Union (2010), 1-2.

1210 European Commission (2012b).

1211 European Commission (2012c).
} 
recommendations to Member States on aggressive tax planning ${ }^{1212}$ and the promotion of good governance in tax matters globally. ${ }^{1213}$

The existence of national anti-abuse rules naturally invoked discussions in the CCCTB working group whether the new system should rely on the Member States' domestic rules or whether there is a need for a common standard. The latter was considered more desirable where the CCC tax base is directly affected. ${ }^{1214}$ Of course, the CCCTB system should be flexible enough to allow CCCTB taxpayers to arrange their economic affairs in a most advantageous manner, but such flexibility should not imply that tax planning should be tolerated despite its extent. ${ }^{1215}$ As it currently stands under the Proposal, within a CCCTB group, the need for anti-abuse rules is less relevant compared to transactions involving entities outside the group. This is because the CCCTB abolishes the separate entity/arm's length principle within a group - instead, the aggregated profits of all the group members are shared based on a predetermined formula. On the contrary, transactions between CCCTB group members and entities outside the group still have to take place at arm's length. In order to protect Member States' tax bases, the proposed CCCTB Directive includes under the anti-abuse chapter both a GAAR, which applies to both transactions involving Member States and third countries, and two ad hoc SAARs, which apply only to transactions involving entities from third countries.1216 Because of their limited role as provisions of last resort, GAARs are typically designed to prevent abuse where ordinary tax rules and SAARs fail to prevent a tax benefit that is incompatible with the object and purpose of the relevant provision or statutory scheme. ${ }^{1217}$ According to the European Commission, this two-level system provides the tax administrations with easy and straight-forward specific rules to combat specific and well-known cases of abuse and a general rule could be applied to combat possible abuse that was not foreseen when designing the common rules. ${ }^{1218}$ Further to that, the proposal includes some other SAARs, such as the switch-over clause, which

\footnotetext{
1212 European Commission (2012e).

1213 European Commission (2012d).

1214 European Commission (2005c), paras. 37-38.

1215 European Commission (2008a), para. 3.

1216 Chapter XIV of the proposed CCCTB Directive.

1217 Duff (2009), 493.

1218 European Commission (2008a).
} 
are not included under the anti-abuse chapter of the Directive. ${ }^{1219}$ From the author's perspective, these rules cannot be considered as anti-abuse rules, because they apply whether or not the specific transaction implies abuse as such. For example, the switch-over clause will be used depending on the level of taxation in the third country rather than establishing that abuse exists. Moreover, the fact that they are excluded from the anti-abuse chapter of the proposed CCCTB Directive indicates that there is no connection between the remaining measures and the GAAR. As a result, the escape clause contained in the latter does not allow the taxpayer to bring forward evidence proving the existence of genuine economic activity.

In the current Chapter, the author will mainly focus on the interpretation and application of the GAAR and the two ad hoc SAARs of the proposed CCCTB Directive: an interest limitation rule and a CFC rule. In particular, the author will discuss the effectiveness of these provisions and their compatibility with EU law and Member States' DTCs to the extent that they affect transactions involving third-country entities.

\subsection{CONCEPT OF “ABUSE” UNDER EU LAW}

The starting point for the application of an anti-abuse rule is to determine what constitutes ( $\operatorname{tax})$ abuse. Tax abuse does not mean mitigation or planning. Actually, tax abuse, tax avoidance and tax evasion are interconnected but they do not coincide. Tax avoidance (also sometimes called aggressive tax planning) is illegitimate behaviour of a taxpayer, which implies artificiality, and often takes advantage of loopholes in the law for purposes for which they were not intended and for the purpose of obtaining a tax benefit. Put differently, tax avoidance is typically within the letter of law but it offends the spirit of the law. Tax evasion or fraud is the illegal behaviour of the taxpayer, who introduces false information or omits information in order to benefit from the Union law, and this behaviour is often subject to criminal sanctions. Hence, generally speaking, tax avoidance and tax evasion are specific expression of abuse in the field of tax law.

1219 European Commission (2010e), para. 9. Despite that the mentioned working document explicitly considers these measures as SAARs, the fact that they are not included under the anti-abuse rules in the proposed CCCTB Directive indicates that the European Commission officially does not consider them to be SAARs. 
The CJEU's jurisprudence primarily refers to the necessity to safeguard the effectiveness and even-handed application of Union law. According to the Court, EU law has to be given effet utile, i.e. effective application in order to pursue the goals of the EU primary and secondary law. ${ }^{1220}$ However, primary Union law does not contain general anti-abuse provisions. The Treaties protect the fundamental freedoms in order to achieve a better functioning of the EIM. The fundamental freedoms aim at ensuring that domestic (tax) law does not impede the choice between domestic and cross-border investment. The CJEU has repeatedly held that the specific objective of freedom of establishment is "to enable companies formed in accordance with the law of a Member State and having their registered office, central administration or principal place of business within the [Union] to pursue activities in other Member States through an agency, branch or subsidiary" and that the "right to form a company in accordance with the law of a Member State and to set up branches in other Member States is inherent in the exercise, in a single market, of the freedom of establishment guaranteed by the Treaty." 1221

Consequently, the concept of anti-avoidance shall also not be employed in order to create new distortions to the free flow of resources envisaged by the EIM.1222 However, the jurisprudence shows that the doctrine of abuse does exist in Union law. The Court has made clear that the application of the anti-abuse doctrine under Union law is essentially related to the aims and goals of the abused or circumvented Union law provisions themselves. ${ }^{1223}$ According to the Court, "[Union] law cannot be relied on for abusive or fraudulent ends" and "[t]he application of [Union] legislation cannot be extended to cover abusive practices by economic operators, that is to say transactions carried out not in the context of normal commercial operations, but solely for the purposes of wrongfully obtaining advantages provided for by [Union] law. ${ }^{1224}$ Consequently, the Court has recognised principally that Member States have the right to take anti-abuse measures with a view to preventing the

\footnotetext{
1220 Schön (2008b), 80.

1221 Case Centros (C-212/97), paras. 26-27.

1222 Schön (2008b), 82.

1223 Ibid., 79 .

1224 Case Halifax (C-255/02), paras. 68-69.
} 
improper circumvention of national legislation through the application of Union law. ${ }^{1225}$

In EU law, one may draw a distinction between two categories of abuse: first, cases in which a person seeks to rely on a European legal right (the fundamental freedoms) to circumvent or displace national law, i.e. it is illegitimate from the instrument perspective (abusive is the technique used); ;226 and second, cases in which a person seeks to take advantage of a right in EU law (a norm) but in a manner running contrary to its spirit, i.e. it is illegitimate from the result point of view (devices used are legitimate, but the end is illegal).1227 This distinction appears in Centros, where the Court entitled Member States to take measures designed to prevent some of its nationals from attempting, under cover of the rights created by the Treaty, "improperly to circumvent their national legislation" or to "prevent individuals from improperly or fraudulently taking advantage of provisions of [Union] law". 1228 These two categories form the notion of "abuse of rights", which is understood as seeking to prevent a person from deriving a benefit, which although being formally compliant with a rule pursues results that go beyond its objective. ${ }^{1229}$ In other words, the doctrine of abuse of rights in EU law is a doctrine against the circumvention of law. ${ }^{1230}$ Hence, the notion of "abuse of rights" looks at whether a person is entitled to undertake a certain action or receive a benefit (i.e. rights in the subjective perspective). ${ }^{1231}$ The subjective rights derived from EU legal norms may also be subject to abuse.

The CJEU has confirmed that the principle of the prevention of abuse of rights exists and it has the status of a general principle of Union law. ${ }^{1232}$ However, the Court's doctrine on the abuse of rights is limited to the interpretation of Union provisions. Therefore, to determine whether an abuse of rights exists, one must examine whether the alleged abusive behaviour falls within or outside the

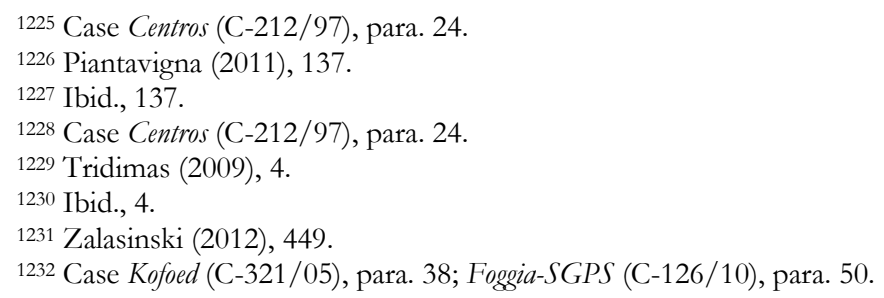


scope of the Union provision. ${ }^{1233}$ At least as far as direct taxes are concerned, there is no general principle of prevention of abuse in EU law that requires Member States to combat abusive practices when the taxpayer claims its benefit by improperly relying on the protection of the Treaties. ${ }^{1234}$ Member States are only allowed to combat such abuse, provided that they respect the requirements of EU law.

The doctrine of abuse of rights in tax matters in the jurisprudence of the CJEU has mostly been inspired by civil law countries, where abuse means the mistreatment of legal instruments and norms. However, the Court also uses common law doctrines, such as the "business purpose test" and the "substance over form test", to deny taxpayers the desired tax benefits. The business purpose test looks at whether transactions are driven by business rather than tax to distinguish between transactions with a valid business purpose and those artificially designed to avoid tax. ${ }^{1235}$ The so-called substance over form principle requires the assessment of the facts according to their commercial substance rather than their formal content. In Emsland-Stärke, ${ }^{1236}$ for the first time the Court created a Union principle of prohibition of abuse of rights. ${ }^{1237}$ In this landmark case, the Court determined that, for the purposes of establishing abuse, the action of the taxpayer must include the following elements:

(i) Objective element, which presupposes the combination of the objective circumstances in which, despite the formal observance of the conditions laid down by the Union rules, the purpose of those rules has not been achieved; and

(ii) Subjective element consisting of the intention to obtain an advantage from the Union rules by artificially creating the conditions laid down for obtaining it. ${ }^{1238}$

The principle of abuse of rights in tax matters is closely related to the prevention of tax avoidance. Based on the Court's jurisprudence, the abuse of rights doctrine has been used in harmonised tax areas (in

1233 Opinion of Advocate General Poiares Maduro delivered on 7 April 2005 on case Halifax (C-255/02), para. 69.

1234 Weber (2004), 54-55; Case 3M Italia (C-417/10), para. 32.

1235 Lampreave (2012), 155.

1236 Case Emsland-Stärke (C-110/99).

1237 Before Emsland-Stärke, case law of the CJEU had made some references to the doctrine of abuse, but they remained isolated. Instead, the Court opted for a broad definition of the fundamental freedoms. Tridimas (2009), 3.

1238 Case Emsland-Stärke (C-110/99); paras. 52-53. 
the interpretation of directives on both direct and indirect tax), where abuse implies the circumvention of law. ${ }^{1239}$ According to Advocate General Maduro in Halifax, case law shows a consistent pattern on the notion of abuse, whereby the assessment of the abuse depends on whether the right claimed complies with the purposes of the rules that formally give rise to it. Hence, the person claiming to have the right can be restricted from invoking it only if the Union law provision conferring that right is relied upon for the achievement of "an improper advantage, manifestly contrary to the objective of that provision. ${ }^{1240}$ The Court applied the same test of abuse of rights in Halifax as in Emsland-Stärke. Accordingly, an abusive practice can be found to exist if the two tests are fulfilled: (i) accrual of a tax advantage, the granting of which would be contrary to the purpose of Union law; and (ii) the essential aim of the transactions concerned is obtaining a tax benefit. ${ }^{1241}$

In non-harmonised tax areas (i.e. national direct tax measures), the Court has been reluctant to apply the principle of abuse of rights explicitly. On the contrary, it considers tax avoidance ${ }^{1242}$ as one of the justifications for a restriction of the fundamental freedom in question based on the rule of reason doctrine developed in Gebhard. By using the latter test, the Court has tried to balance the Member States' right to protect their tax bases from erosion, due to artificial cross-border transactions, with the freedom of movement of nationals by accepting restrictive national tax measures only when they target at "wholly artificial arrangements", which - following the

\footnotetext{
1239 Piantavigna (2011), 138, 142.

1240 Opinion of Advocate General Poiares Maduro delivered on 7 April 2005 on case Halifax (C-255/02), para. 68.

${ }^{1241}$ Case Halifax (C-255/02), paras. 74-75. It is noteworthy that the second criterion - "the essential aim" - remained controversial as the wording in Halifax was inconsistent. Nevertheless, the Court upheld the interpretation in case Part Service (C-425/06), para. 45 , by referring to the "principal aim" of the transaction or transactions.

1242 Tax avoidance as a justification first appeard in case Commission v France [Avoir Fisca] (270/83), para. 25, in which the Court rejected the risk of tax avoidance as an acceptable justification for a restriction. The Court recognised the justification of prevention of tax avoidance for a restrictive national measure in principle for the first time in case ICI (C-264/96), where it held that such measures may be justified by the "specific purpose of preventing wholly artificial arrangements, set up to circumvent /... tax legislation". The concept of artificiality is not a specific product of tax law, but it has been progressively developed by the CJEU in its earlier cases, mainly in company law, such as cases Segers (79/85); Daily Mail (81/87); Centros (C-212/97); and Inspire Art (C-167/01).
} 
general formulation found in ICI - was specified in Cadbury Schweppes. ${ }^{1243}$ Accordingly, the Court in Cadbury Schweppes:

(i) reaffirmed that a national measure restricting the freedom of establishment with the purpose of preventing tax avoidance will only be justifiable if it specifically relates to wholly artificial arrangements aimed at circumventing the application of the legislation of the Member State concerned; $; 244$

(ii) reaffirmed that, in order to verify the existence of a wholly artificial arrangement of a taxpayer, the objective pursued by the freedom has to be taken into account; ${ }^{1245}$

(iii) reaffirmed that the objective of the freedom of establishment is the actual pursuit of an economic activity through a fixed establishment in the host State for an indefinite period; $; 246$

(iv) established that wholly artificial arrangements imply arrangements which do not reflect economic reality, with a view to escaping the tax normally due on the profits generated by activities carried out on national territory; ${ }^{1247}$

(v) explained that the assessment whether genuine economic activities exist must be based on objective factors which are ascertainable by third parties; ${ }^{1248}$

(vi) established that, for the sake of proportionality, the taxpayer must be allowed to produce evidence that the activities are genuine. ${ }^{1249}$

Some scholars argue that the distinction between tax harmonised and tax non-harmonised area is disappearing, ${ }^{1250}$ because, in both cases, the fundamental analysis lies with the economic substance of the transaction. ${ }^{1251}$ They sustain that the Court's hesitance to apply the doctrine of abuse of rights in non-harmonised fields of tax law is

\footnotetext{
1243 Case Cadbury Schweppes (C-196/04).

1244 Ibid., para. 51.

1245 Ibid., para. 52; referring to Centros (C-212/97), para. 25, and $X$ and $Y$, para. 42.

1246 Case Cadbury Schweppes (C-196/04), para. 54.

1247 Ibid., para. 55.

1248 Ibid., para. 67.

1249 Ibid., para. 70.

1250 Others argue that the difference between the concept of abuse applied in direct tax and indirect tax cases continues to exist, at least as far as non-harmonised direct taxes are concerned. Zalasinski (2012), 446-454.

1251 Piantavigna (2011), 146.
} 
illogical: it is unreasonable to first conclude that an arrangement is in accordance with the objective of the fundamental freedom and thereafter find that the same objective does not cover artificial arrangements. ${ }^{1252}$ Moreover, the Court has interchangeably referred to the case law of the relevant fields. For example, it referred to Emsland-Stärke and the Halifax-test to define the concept of "wholly artificial arrangements" in Cadbury Schweppes. 1253

\subsection{ANTI-ABUSE RULES UNDER THE CCCTB DiRECTIVE}

The discussion earlier shows that the concept of anti-abuse is a known concept under EU law. The EU corporate tax directives explicitly deal with abusive situations ${ }^{1254}$ and the CJEU has developed its own doctrine of general anti-abuse mainly within the framework of the fundamental freedoms. Of course, the anti-abuse provisions in the proposed CCCTB Directive are somewhat different from the provisions in the other mentioned directives due to their dissimilar scope of application. Moreover, the anti-abuse clauses in the earlier corporate tax directives were drafted when the CJEU's anti-abuse jurisprudence was less developed. The author will elaborate on the proposed CCCTB Directive, including a specific GAAR, which is closely linked to the jurisprudential concept of "wholly artificial arrangements" and two ad hoc SAARs below.

For CCCTB purposes, the initial question was whether there is a need only for a GAAR or SAARs or whether abusive practices affecting the CCC tax base could be effectively combated only with the existence of the both. On the one hand, the existence of only the GAAR would provide Member States with a flexible tool to fight tax abusive practices. On the other hand, with a GAAR alone, it might be a difficult provision to apply, because it could be understood differently by the Member States and it could therefore introduce uncertainty. ${ }^{1255}$ Such uncertainty could be solved by the Court, which would be in a position to give its interpretation on the term included in EU law. However, one must recognise that guidance given by the

\footnotetext{
1252 Karimeri (2011), 309.

1253 Case Cadbury Schweppes (C-196/04), para. 64. See also the opinion of Advocate General Léger delivered on 2 May 2006 in case Cadbury Schweppes (C-196/04), paras. 117-122.

1254 Article 1(2) of the Parent and Subsidiary Directive; Article 5 of the Interest and Royalty Directive; Article 15(1) of the Merger Directive.

1255 European Commission (2008a), para. 8.
} 
CJEU through its jurisprudence may work from a long-term perspective, while in the short-term the interpretation and application of the GAAR would rest with the national competent authorities. It is noteworthy that some organisations have been opposed to the introduction of the GAAR in general, because it reduces legal certainty for the taxpayers. ${ }^{1256}$

Another question is if the CCCTB Directive did not include a uniform GAAR, then would the Member States remain free to apply the GAAR under their national law? The Court held in Kofoed that Member States are obliged to adopt, within the framework of their national legal system, all the measures necessary to ensure that the Directive is fully effective, in accordance with the objectives that it pursues. In that regard, Member States may choose the form and methods for implementing directives which best ensure the result to be achieved by those directives. Furthermore, all authorities of a Member State, in applying national law, are required to interpret it as far as possible in the light of the wording and purpose of the Union directives in order to achieve the result pursued by those directives. ${ }^{1257}$ As noted earlier, the case law of the CJEU shows that Member States have the right to take anti-abuse measures with a view to preventing the improper circumvention of national legislation through the application of Union law. Against this background, from the author's perspective, even if the CCCTB Directive did not provide for a uniform GAAR, Member States would remain at liberty to apply their national GAAR to the extent that this is necessary for the proper application of the directive to achieve its objective. Importantly, the Member States could revert to their national GAAR only in issues that the EU legislator could not have predicted when drafting the SAARs. With regard to the use of only SAARs in the CCCTB Directive, it is without doubt that, due to the specific definition of SAARs, they contribute legal certainty to tax legislation and foster a better understanding of the object, spirit and purpose of the legislation. ${ }^{1258}$ Yet, a major disadvantage of the use of SAARs only is that they apply only to stipulated or suspected situations and, thus, they cannot prevent avoidance transactions not previously detected. ${ }^{1259}$

\footnotetext{
1256 BusinessEurope (2010), 1.

1257 Case Kofoed (C-321/05), paras. 41 et seq.

1258 Finance Quebec, 'Aggressive Tax Planning', (Quebec, 2009), 28.

1259 Ibid., 28.
} 
In any event, the current proposal for a CCCTB Directive does include a two-level structure for dealing with abuse through a uniform GAAR, which would apply in domestic and cross-border situations confined to the EU and situations involving third countries and SAARs. The GAAR of Article 80 reads as follows:

"Artificial transactions carried out for the sole purpose of avoiding taxation shall be ignored for the purposes of calculating the tax base.

The first paragraph shall not apply to genuine commercial activities where the taxpayer is able to choose between two or more possible transactions which have the same commercial result but which produce different taxable amounts."

In the October 2010 workshop on the CCCTB, the European Commission proposed six SAARs, most of which have been incorporated into the proposed CCCTB Directive:

(i) Disallowance of third-country source interest deduction (Article 81 of the proposed CCCTB Directive);

(ii) Switch-over from a tax exemption of foreign income to relief by credit (Article 73 of the proposed CCCTB Directive);

(iii) Controlled Foreign Company (CFC) legislation (Article 82 of the proposed CCCTB Directive);

(iv) Disallowance of the participation exemption in share disposals (Article 75 of the proposed CCCTB Directive);

(v) Rules to tackle double deductions in the so-called "sandwich cases" (which was eventually not included into the proposed CCCTB Directive);

(vi) Rules to avoid a manipulation of the asset factor (Article 94(5) of the proposed CCCTB Directive). ${ }^{1260}$

The existence of both a GAAR and SAARs in the proposed CCCTB Directive causes one to question the relationship between those provisions. According to the European Commission, the GAAR is aimed at combating possible abuse that was not foreseen when designing the common rules, while the purpose of the SAARs is to combat specific and well-known cases of abuse. It has explicitly stated that the GAAR would only be relevant if a potentially abusive practice does not fall within the scope of any of the SAARs. ${ }^{1261}$ Nevertheless, such a relationship is not apparent from the wording

${ }^{1260}$ European Commission (2010e), para. 9.

${ }^{1261}$ Ibid., para. 9. 
of the GAAR in the articles and the Preamble ${ }^{1262}$ of the proposed CCCTB Directive. Without a clear wording in the Directive, the issue should be considered under Member States' constitutional law, which normally requires tax to be explicit and specific. The CCCTB GAAR, which does not itself impose tax, could thus only be considered as a default rule. The relationship becomes vaguer considering that only the rules concerning interest deduction limitation and CFC income have been introduced under the antiabuse chapter of the proposed CCCTB Directive, while the remaining SAARs have been spread in the Directive. From the author's perspective, the statement of the European Commission should be interpreted broadly, in the sense that the GAAR applies to all artificial transactions that do not fall under the SAARs. In that case, Member States' tax authorities would be left with a broader base to deal with the limited scope of the SAARs that apply only to situations involving third countries to extend their application to intra-EU situations. ${ }^{1263}$ Such a result would clearly go against the intention of the European Commission to limit the application of certain SAARs, such as the CFC rule, only to situations involving third countries. On the other hand, in the absence of a particular order between the GAAR and the SAARs, a genuine commercial activity in the third country could, in certain circumstances, exclude the application of the SAAR. However, the cumulative application of the GAAR and the SAARs can also be subject to criticism due to the increased complexity in the application of the CCCTB anti-abuse rules, mainly because each transaction with a third country will have to be tested against both the SAAR and the GAAR.

\subsubsection{GENERAL ANTI-AbusE RulE}

Article 80 of the CCCTB proposal provides for a "general antiabuse" rule and it is not limited only to third-country situations, because abusive behaviours of taxpayers should not be tolerated, neither in intra-EU situations, in situations involving third countries nor in a purely domestic context. Despite the literal reading of the

\footnotetext{
1262 Para. 20 of the Preamble of the CCCTB Directive provides that the system should include a GAAR, supplemented by measures designed to curb specific abusive practices.

1263 According to Panayi, this unclear hierarchy between the two provisions must be subject to criticism, because it leaves national tax authorities with a broader base to circumvent the limited scope of the SAARs and to apply it to EU situations. Panayi (2012), 263.
} 
title, the article uses the wording "avoiding taxation" rather than "abuse", which suggests that the rule is aimed to be similar to the general anti-avoidance rules (GAARs) that exist in several countries' domestic law. By definition, a GAAR is an anti-avoidance measure which applies generally to combat perceived tax avoidance, with an aim to promote taxation in accordance with the legislative purpose. Within the EU, a GAAR should fall within the doctrine of "abuse of rights", so that it would seek to prevent a person from deriving a benefit, which, although being formally compliant with a rule, pursues results that go beyond its objective. However, this intention does not appear from the CCCTB GAAR. On the contrary, its definition is very closely linked to the concept of "wholly artificial arrangements" found in the CJEU's jurisprudence, which tests the compatibility of national anti-abuse provisions against the fundamental freedoms. As Harris points out " $[\mathrm{t}] \mathrm{he}$ jurisprudence is not a tool for counteracting tax avoidance (which a GAAR should be); it is a tool for checking the excess of such a tool". ${ }^{264}$ Taking into account that the GAAR is intended to operate in a completely different system from that of the CJEU's jurisprudence, it should follow that the abuse of rights doctrine is used in harmonised tax areas, where abuse implies circumvention of law. As follows from Halifax, abuse exists if the two following tests are fulfilled: (i) accrual of a tax advantage the granting of which would be contrary to the purpose of Union law; and (ii) the essential aim of the transactions concerned is obtaining a tax benefit. ${ }^{1265}$ The criteria brought forward by the Court in Halifax coincide with the definition of a typical statutory GAAR, which also follows two elements: (i) whether the result of the transaction or series of transactions in questions are in accordance with the purpose of the tax legislation; and (ii) the purpose (determined objectively) of the transaction or series of transactions in question. ${ }^{2266}$ It is noteworthy that these two elements make up the test of DTC abuse in the OECD MC. ${ }^{1267}$

The content of the GAAR in the proposed CCCTB Directive can be criticised from several aspects. First, it applies only to "artificial

1264 Harris (2012), 276.

1265 Case Halifax (C-255/02), paras. 74-75. It is noteworthy that the second criterion - "the essential aim" - remained controversial as the wording in Halifax was inconsistent. Nevertheless, the Court upheld the interpretation in case Part Service (C-425/06), para. 45, by referring to "principal aim" of the transaction or transactions.

1266 Arnold (2008), 12.

1267 OECD Comm. on Article 1, para. 9.5. 
transactions". However, due to the use of such terminology, the proposed CCCTB GAAR deviates from a typical national GAAR, which targets tax avoidance in general. In other words, whereas the latter applies to "real" transactions with economic substance, the former only looks to whether the transactions entered into are artificial. ${ }^{1268}$ By comparison, the CJEU anti-abuse approach in the context of harmonised tax law (tax directives) can also apply in real transactions, while in the context of the fundamental freedoms the matter concerns artificiality. ${ }^{1269}$ By applying the GAAR only where the transactions entered into by a taxpayer are artificial, it is questionable how courts should deal with situations where real transactions exist but for which the sole purpose is to avoid tax. ${ }^{1270}$ Yet, when the sole purpose of a transaction is to avoid tax, one may find it difficult to vest it with economic substance successfully.

Second, the CCCTB GAAR looks at "transactions" rather than "arrangements", as used in the Court's jurisprudence. Case law requires the term "arrangements" to be interpreted broadly in the sense that the arrangements can consist of several steps. ${ }^{1271}$ However, it is questionable whether the term "transactions" in the proposed CCCTB Directive could be interpreted broadly. In particular, arrangements can be viewed both narrowly and broadly: the GAAR could be applied to an arrangement that is part of a wider arrangement or to the wider arrangement as a whole. This prevents the weighting of purposes from being manipulated, such as by combining a tax scheme with a commercial transaction. ${ }^{1272}$ Hence, a taxpayer may be able to provide an explanation for each step of an arrangement (a transaction), while it could fail to be able to do so with regard to the arrangement as a whole. ${ }^{1273}$ However, when considering a tax arrangement, which is part of a wider arrangement, in determining whether that part is abusive, one must also consider the wider arrangement of which it is part. ${ }^{1274}$ In this sense, the CJEU's approach to use "arrangement" rather than "transaction" makes it more similar to the so-called step-transaction doctrine developed in common law States. Under the step transaction

\footnotetext{
1268 Harris (2012), 284.

1269 Schön (2008b), 92.

${ }^{1270}$ Harris (2012), 285.

1271 Case De Lasteyrie du Saillant (C-9/02), para. 54.

1272 HM Revenue \& Customs (2013), part C4.3.

1273 Lang (2011), 224.

${ }^{1274}$ HM Revenue \& Customs (2013), part C4.4.
} 
doctrine, courts deem a series of connected transactions to be a single transaction depending on the ultimate result of the steps. Under this doctrine, transactions may be disregarded, even if they are bona fide, and several related transactions can be treated as a single transaction. The courts typically use three tests to determine whether or not it is appropriate to invoke the step transaction doctrine:

(i) The "binding commitment test" examines whether, at the time the first step was entered into, there was a binding commitment to take the later step;

(ii) The "end result test" examines whether separate steps constitute parts of a single transaction intended to reach an ultimate result;

(iii) The "mutual interdependence test" examines whether separate parts are so interdependent that the legal relations created by one step would have been vain without a completion of series of steps. ${ }^{1275}$

It is noteworthy the European Commission's action plan against aggressive tax planning uses the language of "arrangement" or "series of arrangements" rather than "transaction", which suggests recognising the weakness of the latter. ${ }^{1276}$

Perhaps the biggest criticism of the proposed GAAR lies with the wording "sole purpose", in that it unreasonably narrows the scope of the provision. This approach was also criticised by three Member States during the workshop on CССТВ before the release of the proposal for a CCCTB directive by the European Commission. ${ }^{1277}$ The "sole purpose" test suggests that the GAAR is more open to abuse than the test for a "wholly artificial arrangement" in Cadbury Schweppes, ${ }^{1278}$ the "essential aim" in Halifax and the "principal aim" in Part Service. ${ }^{279}$ Furthermore, compared to the requirement for the "principal purpose" of tax avoidance or evasion in the Merger Directive, the choice for "sole purpose" sets a higher threshold for establishing abuse for CCCTB purposes. The reason for such a narrow provision may be derived from the judgment in

\footnotetext{
${ }^{1275}$ Lampreave (2012), 155.

1276 European Commission (2012e), para. 4.2 et seq. Note that the proposed clause continues by specifying the elements of the general provision.

1277 European Commission (2010f), part VI.

1278 It is true that the CCCTB GAAR does include the requirement of a "wholly artificial arrangement". Nevertheless, by adding the requirement of "sole purpose" it definitely goes further than "wholly artificial arrangements intended to escape the national tax normally payable" as required in Cadbury Schweppes.

${ }^{1279}$ Cases Cadbury Schweppes (C-196/04); Halifax (C-255/02); Part Service (C-425/06).
} 
Ampliscientifica, in which the Court ignored its earlier decisions and held that the principle of abuse of rights is to "prohibit wholly artificial arrangements which do not reflect economic reality and are set up with the sole aim of obtaining a tax advantage". ${ }^{1280}$ It is noteworthy that the fact that Danish compromise proposal on the CCCTB Directive changed the provision to include both "sole or main purpose" indicates that Member States have not abandoned the Court's earlier jurisprudence. ${ }^{1281}$ Furthermore, the European Commission seems to be endorsing the Member States' view in its action plan on aggressive tax planning. In the action plan, it has proposed a comprehensive, uniform definition for a GAAR as follows: "An artificial arrangement or an artificial series of arrangements which has been put into place for the essential purpose of avoiding taxation and leads to a tax benefit shall be ignored. Participating Member States shall treat these arrangements for tax purposes by reference to their economic substance." 1282 It is further noteworthy that the same definition has been adopted in the proposal for a directive implementing enhanced cooperation in the area of financial transaction tax in February 2013. ${ }^{1283}$

In any event, the question is whether and, if so, under which conditions the aim of achieving a tax benefit can constitute an abuse in EU law. Within the context of the CCCTB GAAR, another question is which tax and whose tax must be aimed to be avoided. First, the Court is of the opinion that benefits of Union law should apply despite the reasons, whether financial, economic or fiscal, for those operations. ${ }^{1284}$ Hence, a transaction is not artificial and does not constitute abuse only because it leads to a tax saving or has tax objective. ${ }^{1285}$ However, for the enjoyment of benefits of a directive, it is important that the taxpayer has acted in order to pursue valid commercial reasons. ${ }^{1286}$ According to the Court, abusive practices must be assessed by weighting the object and effects of those

\footnotetext{
${ }^{1280}$ Case Ampliscientifica (C-162/07), para. 28.

1281 Council of the European Union (2012), Article 80 and comments therewith.

1282 European Commission (2012e), para. 4.2 et seq.

1283 European Commission (2013), Article 13.

1284 Cases Leur-Bloem (C-28/95), para. 36; Kofoed (C-321/05), para. 30, Zwijnenburg (C-352/08), para. 41.

1285 Case Barbier (C-364/01), para. 71. This understanding confirms previous jurisprudence of the Court that taking advantage of beneficial legislation of a Member State does not constitute abuse of the fundamental freedoms. Cases Centros (C-212/97); Inspire Art (C-167/01).

1286 Case Leur-Bloem (C-28/95), para. 38.
} 
transactions, as well as their purpose. ${ }^{1287}$ Hence, taxpayers are free to structure their business in the most favourable way, as long as the arrangements or transactions are not artificial and go beyond the applicable law (the directive).1288 However, the concept of "valid commercial reasons" involves more than the attainment of a purely fiscal advantage and, where the transaction is based on several objectives, tax considerations cannot be predominant in the context of the transaction. ${ }^{1289}$ Moreover, the fact that the transaction, such as a merger within the Merger Directive, results in the cost saving, due to the reduction of administrative and management costs, must be assessed having regard to the magnitude of the anticipated benefit of the transaction and, therefore, cannot automatically be considered as having valid commercial reasons. ${ }^{1290}$ In other words, an ancillary purpose, inherent to the form of a given transaction and not to the substance of it, does not validate what in effect is a tax purpose contrary to the form used. ${ }^{1291}$

With regard to the second question, the author discussed earlier that a company can opt for the CCCTB if, among other criteria, it is subject to one of the taxes listed in Annex II of the Directive. ${ }^{1292}$ The first impression thus may be that the CCCTB GAAR targets only those taxes. From the author's perspective, the interpretation of the GAAR should not be confused with the interpretation of the eligibility criteria for companies. In other words, for the purposes of the GAAR, it is irrelevant to which taxes the relevant companies are subject; the GAAR is only concerned with protecting the Member States' tax bases from erosion. Above all, once a company opts into the CCCTB, it ceases to be subject to national corporate tax arrangements as stipulated in Article 7 of the proposed CCCTB Directive. Therefore, the national taxes listed in Annex II no longer govern the calculation of the tax base of the CCCTB company (but they remain relevant in connection with the tax rate which remains at the sovereignty of each Member State).

The other EU corporate tax directives do not include a GAAR. ${ }^{1293}$ Different from the Interest and Royalty Directive and the Merger

1287 Case Weald Leasing (C-103/09), paras. 32-33, 44.

1288 Jiménez (2012), 279.

1289 Case Foggia-SGPS (C-126/10), paras. 34-35.

1290 Case Foggia-SGPS (C-126/10), paras. 47-49.

1291 Jiménez (2012), 284.

1292 Vide supra at I4.2.1.3.

1293 Article 11 of the Merger Directive; Article 5(2) of the Interest and Royalty Directive; Article (1) of the Parent and Subsidiary Directive. Note that on 25 
Directive, which entitle Member States to withdraw the benefits of the Directive or refuse to apply them in case of abuse, the proposed CCCTB Directive requires artificial transactions to be ignored. First and foremost, while the two earlier Directives allow the Member State not to apply the benefits of the Directive concerning artificial transactions, the proposed CCCTB Directive imposes an obligation on the Member States to disregard such transactions. The reason for using the language of "allow" in the earlier Directives probably relates to the fact that, different from the proposed CCCTB Directive, these Directives do not provide for a GAAR. Hence, those Directives effectively refer back to the national anti-abuse provisions of each Member State. According to the CJEU, if the legal situation arising from the national transposition measures is sufficiently precise and clear and that the persons concerned are put in a position to know the full extent of their rights and obligations, the transposition of a directive into national law does not necessarily require legislative action in each Member State. ${ }^{1294}$ However, in case Kolpinghuis, the Court held that "a directive may not of itself impose obligations on an individual and that a provision of a directive may not be relied upon as such against such a person before a national court". ${ }^{1295}$ Hence, in the absence of general legal context, including general principles of national constitutional law or administrative law, Member States are precluded from applying the anti-abuse provision of the specific directive directly or from having direct recourse to the general Union prohibition on the misuse of law. ${ }^{1296}$ Second, the difference in the language of "withdraw the benefits of the directive" in the two earlier Directives compared to the requirement "to ignore" in the proposed CCCTB Directive boils down to the fact that the Interest and Royalty Directive and the Merger Directive exclusively involve benefits, while the proposed CCCTB is a fully-fledged system which does not aim at only providing benefits. In effect, there is little difference between "withdrawing benefits" and "ignoring transactions", because it is highly likely that the "artificial transactions carried out for the sole purpose of avoiding taxation" also aim at achieving a tax advantage.

November 2013, the European Commission proposed amendments to the Parent and Subsidiary Directive (2011/96/EU), which inter alia include a GAAR in line with its 2012 recommendations.

1294 Case Kofoed (C-321/05), para. 44.

1295 Case Kolpinghuis (80/86), para. 9.

1296 Opinion of Advocate general Kokott delivered on 8 February 2007 on case Kofoed (C-321/05)5, paras. 66-68. 
In any event, in the case of adoption of the CCCTB Directive, Member States would be obliged to transpose the CCCTB GAAR into their national law. In such a case, the interpretation of the GAAR would fall within the competence of the CJEU. Furthermore, Member States would have to interpret the GAAR in the light of their general legal context, having regard for the wording and purpose of the Directive, in order to have recourse to that provision in the case of artificial transactions. The fact that the proposed CCCTB Directive includes a specific GAAR results in its application as a general principle being excluded, because the general principle of Union law prohibiting misuse of law has been given specific effect in that Directive and it has been expressed in a concrete manner. ${ }^{1297}$ Hence, the case law on the prohibition of abuse in other contexts may not apply to the fields covered by the CCCTB Directive. ${ }^{1298}$

Following on from this, whereas the Interest and Royalty Directive and the Merger Directive define the anti-abuse provision in a negative manner, i.e. withdraw the benefits or refuse to apply the Directive, the CCCTB requires the establishment of a hypothetical situation, i.e. ignore the transaction. Similarly, the Court held in Halifax that transactions involved in an abusive practice must be redefined to re-establish the situation that would have prevailed in the absence of the transactions constituting that abusive practice, and hence also establishing a hypothetical situation. ${ }^{1299}$ Although both of the situations deem a fictitious situation to exist, the scope of the situations is different: one of them reconstructs the legislative intent (the Halifax-test) while the other simply ignores the transaction (the CCCTB GAAR). However, the general idea of a GAAR should be to apply tax law to an abusive transaction according to legislative intent. From the author's perspective, simply to ignore that an artificial transaction exists may not suffice, because it does not guarantee the basis to tax as redefining normally would. In addition, the nature of the abusive behaviour is normally determined by reference to a counterfactual. ${ }^{1300}$ Hence, the recharacterisation of a transaction to bring it in line with the purpose of the law seems more appropriate. It is worth noting that a recharacterisation also appears to have been the initial idea of the

\footnotetext{
${ }^{1297}$ Ibid., para. 67.

1298 Jiménez (2012), 290.

${ }^{1299}$ Case Halifax (C-255/02), para. 94.

${ }^{1300}$ Harris (2012), 289.
} 
GAAR. ${ }^{1301}$ As referred to earlier, the European Commission in its action plan has also proposed to ignore the artificial arrangement, but it has added that such arrangements should be treated by reference to their economic substance. ${ }^{1302}$ Such an additional element shows that the latest opinion of the European Commission supports the re-characterisation of abusive transactions.

The proposed GAAR is limited for the purposes of calculating the tax base, although it is not limited to Chapter IV of the proposed Directive ("Calculation of the tax base"), but it should be interpreted to cover the tax base in general. ${ }^{1303}$ Consequently, from the author's perspective, the GAAR also applies to (artificial) transactions not explicitly regulated in the Directive, such as distinguishing debt from equity, sale of loss companies or - the opposite - crystallisation of losses through the sale of shares, etc. On the contrary, the proposed GAAR does not cover anything that does not affect the calculation of the tax base, such as the rules on the application of the sharing mechanism. One could try to argue that the GAAR also covers the sharing mechanism, because the sharing determines the final tax base of each group member. However, from the author's perspective, the apportionment of the CCC tax base does not relate to its calculation, but it is a subsequent step to determine which Member State may levy tax on which share of the CCC tax base. Against this background, Article 80 of the proposed CCCTB Directive does not concern allocation of employees and payroll (Article 91) or assets (Article 93) or whether the sales (Article 96) have been manipulated for the purposes of the apportionment formula. In such a case, group members may be able to achieve a result by which more profits are allocated to the Member State where the tax rate is lower. If those profits are attributed to a permanent establishment of a nonresident company and a DTC between that country and a third country provided for the exemption method for the avoidance of double taxation of profits of a permanent establishment, the group may be able to achieve a lower overall tax burden.

Last, because the CCCTB will be introduced in parallel to national corporate tax systems and will be optional for companies, a question arises as to what extent the CCCTB GAAR covers transactions affecting the CCC tax base that take place before or after the

\footnotetext{
${ }^{1301}$ European Commission (2008a), para. 6.

1302 European Commission (2012e), para. 4.2 et seq.

${ }^{1303}$ Lang (2011), 226.
} 
company opts for the CCCTB system. From the author's perspective, the answer boils down to the fact whether the effect of artificiality touches upon the computation of the CCC tax base for a specific year. If that is indeed the case, the CCCTB GAAR should remain applicable to these transactions, provided that the Member State has transposed the GAAR into its national law. Otherwise, taxpayers could arrange their transactions, which would otherwise be caught by the CCCTB GAAR, to take place before entering or after leaving a CCCTB group, so that they would not be caught by the CCCTB GAAR. Yet another question is whether the answer would be different if those transactions took place prior to the adoption of the CCCTB system by Member States or prior to when the CCCTB Directive became operational in Member States, especially if the national corporate tax system did not include a GAAR. In other words, the question is can a CCCTB GAAR have a retroactive application? From the author's perspective the answer should remain affirmative, because the taxpayers - knowing that the Directive will become effective at certain point - could structure their affairs so that they would not be caught by the CCCTB GAAR.1304 What if the transaction is aimed at affecting the CCC tax base, but its (sole) aim is to avoid domestic corporate tax? In such a case, the CCCTB GAAR will still be applicable and apply retrospectively, because the relevant company has opted for the system and thus ceases to be subject to any national corporate tax arrangement regulated in the Directive.

\subsubsection{THE ESCAPE ClAusE}

The motives for introducing the escape clause in Article 80 of the proposed CCCTB Directive are arguable. As it currently stands, it is contradictory: if a transaction is genuine, there is no reason to cover it under an anti-abuse provision from the outset. ${ }^{1305}$ This is apparent from Cadbury Schweppes in which the Court considered that genuine

\footnotetext{
1304 The same view seems to be shared by Harris in Harris (2012), 285.

1305 The relevance of the escape clause becomes even more questionable if one looks at the revised escape clause under the Danish Presidency's CCCTB compromise proposal, which is worded as follows: "The first paragraph shall not apply to genuine commercial activities carried out for valid commercial reasons". It is noteworthy that GAAR in the European Commission action plan, as well as in the proposal for an enhanced cooperation in the area of financial transaction tax referred to earlier, do not contain an escape clause. Based on the wording of these provisions, the burden of proof that abuse exists appears to be on the tax authorities and, thus, there is no need for an escape clause.
} 
economic activities do not constitute wholly artificial arrangements. ${ }^{1306}$ Like the first intent of the GAAR, the requirement for a commercial justification seems to originate from the CJEU's jurisprudence in the context of fundamental freedoms applying to domestic tax laws. Consequently, applying the commercial justification test as a general rule may do more than necessary, because it also applies to measures that do not impose a restriction on the fundamental freedoms. To limit the GAAR and give it a caselaw compliant structure appears to be a superfluous limitation, because the GAAR will apply in parallel at three levels: domestic, intra-EU and international.

There are two possible reasons for introducing such a clause under the GAAR. First, the provision could confirm that a transaction is not considered artificial only because a taxpayer chooses a structure that provides him with reduced taxation. In that case, Article 80 second, indent recalls, the language of the CJEU in that if the taxable person can choose from among a number of transactions it may choose to structure the business in such a way as to limit tax liability. ${ }^{1307}$

The second possible reason could relate to the burden of proof indicating that genuine commercial activities of a specific transaction exist. As discussed earlier, it seems that the CCCTB GAAR has been drafted closely in line with the concept of "wholly artificial arrangement" of the CJEU's jurisprudence and it should, thus, be interpreted in the light of the jurisprudence. According to the Court in Cadbury Schweppes, the taxpayer must be allowed to produce evidence that the activities are genuine. ${ }^{1308}$ Nevertheless, that statement should not be interpreted as there is an automatic general presumption that an arrangement is considered to be wholly artificial. Hence, the tax authorities may not assess the tax without having confronted the taxpayer with the argument that the arrangement is artificial: the tax authorities must first prove the subjective element of abuse by resorting to objective signs. ${ }^{1309}$ Further case law shows that tax authorities cannot entirely shift the

\footnotetext{
1306 Case Cadbury Schweppes (C-196/04), para. 75. See also Lang (2011), 227.

1307 Cases Halifax (C-255/02), para. 73; RBS Deutschland Holdings (C-277/09), para. 33.

1308 Case Cadbury Schweppes (C-196/04), para. 70. See also Advocate General opinion delivered on 16 July 2009 in Zwijnenburg (C-352/08), paras. 44-45.

1309 Lang \& Heidenbauer (2008), 614. Jiménez (2012), 286.
} 
burden of proof to the taxpayer, unless the national legislation provides for a consideration of objective and verifiable elements in order to determine whether a transaction contains a specific, rational and proportional indication of abuse as a relevant presumption (e.g. the arm's length principle). ${ }^{1310}$ The latter approach appears in the ad hoc SAARs of the proposed CCCTB Directive, which will be discussed below. Hence, Article 80 of the proposed CCCTB Directive could be interpreted as confirming that the tax authorities of the relevant Member State would first be obliged to establish that the taxpayer is involved in artificial transactions, which could thereafter be refuted by the taxpayer by providing appropriate proof. It is worth noting that the Court has not been precise as to whether such a possibility to provide counterevidence has to stand literally in the law or whether it is a matter of a procedure, i.e. whether the tax authorities have to include the evidence provided by the taxpayer in their investigation of abuse. It is worth reminding that national GAARs are usually not built on the concept of "wholly artificial arrangements". In such cases, the burden of proof that abuse exists rests generally (only) upon the tax authorities..$^{1311}$

\subsubsection{THIN CAPITALISATION AND LIMITATIONS ON INTEREST DEDUCTIBILITY}

It is difficult to provide a distinct definition of thin capitalisation, but, in general, it describes a situation in which a company has a high proportion of debt capital in relation to its equity capital. ${ }^{1312}$ The OECD uses the concept of thin capitalisation as a generic term to cover a range of hidden equity contributions. ${ }^{1313}$ The latter approach is in line with the understanding of thin capitalisation of the CCCTB working group, which accordingly refers to a disparity between the existing equity and equity needs in the future and/or a situation in which the debt/equity ratio is smaller than is usual in the comparable business area. ${ }^{1314}$ It follows that thin capitalisation is considered to be an abusive practice mainly because of the special relationship between the lender and the debtor, i.e. typically between the parent company and its subsidiary. Furthermore, by manipulating the manner in which capital - i.e. equity or loan - is provided, a parent

\footnotetext{
${ }^{1310}$ Case Thin Cap Group Litigation (C-524/04), para. 82.

1311 See, for instance, HM Revenue \& Customs (2013).

1312 Rogers-Glabush (2009), 441.

1313 OECD (1986), para. 12.

${ }^{1314}$ European Commission (2006g), para. 24.
} 
company can effectively choose where it wishes profits to be taxed, because the return on a loan (interest) paid to the shareholder is usually deductible for the subsidiary, while a return on equity (dividend) is ordinarily not. ${ }^{1315}$ Pursuant to the CCCTB working group, the taxation treatment of thin capitalisation varies among Member States: (i) those using the arm's length standard to determine whether a company would be able to get a loan from an independent person under comparable conditions; (ii) those laying down a fixed debt to equity ratio and making the interest nondeductible when it is exceeded; (iii) those that do not have any thin capitalisation rules. 1316 However, differences in thin capitalisation rules have made the latter a popular method for international tax planning. ${ }^{1317}$ The issue of thin capitalisation was considered during the preparatory work of the CССТВ when the working party considered whether the system should adopt harmonised rules on thin capitalisation within the framework of the CCCTB. ${ }^{1318}$ Since the interest paid on loans provided by a non-CCCTB parent company to its subsidiary would generally be deductible from the subsidiary's tax base, the deduction would affect the total CCC tax base once the individual tax bases are aggregated. Hence, the establishment of uniform rules seems justifiable.

According to the current CCCTB proposal, interest paid by a CCCTB group member to a non-CCCTB affiliate would generally be deductible from the CCC tax base, unless caught by the SAAR setting forth an interest deduction limitation. The limitation is not a thin capitalisation rule per se, because it ignores the consideration of the subsidiary's capital in relation to the loan provided to it. On the contrary, interest deduction under the CССТВ rules is prohibited if it is paid to an associated enterprise in a third country (i.e. it does not apply on intra-EU payments) under certain conditions. The reasons for proposing an interest limitation rule, rather than a thin capitalisation rule, can stem from several aspects. First, as some Member States do not currently employ thin capitalisation rules, imposing this standard may make the CCCTB less attractive for both

1315 Case Thin Cap Group Litigation (C-524/04), para. 76; See also opinion of Advocate General Geelhoed delivered on 29 June 2006 in this case, paras. 3-4; European Commission (2007d), 7-8.

1316 European Commission (2005c), para. 41; European Commission (2006g), paras. 22-23.

1317 Dourado \& Feria (de la) (2008), 787.

1318 European Commission (2005c), para. 39. 
Member States as well as companies. Next, on the one hand, uniform thin capitalisation rules based on the arm's length standard would have a disadvantage compared to the currently proposed rule as they would be more flexible and, thus, more prone to manipulation and would increase the costs of compliance and administration. On the other hand, uniform thin capitalisation rules based on a fixed debt and equity ratio would require the agreement between Member States as per the ratio between the two means of financing. With regard to the latter, the uniform ratio could, but would not have to, correspond to the domestic ratio of the Member State applicable to non-participating companies. Hence, depending on the proportion, the CCCTB thin capitalisation rules may be more advantageous or disadvantageous compared to the domestic ratio to the companies. Furthermore, such an approach would require an agreement on whether the debt obligation vis-à-vis the nonconsolidated lender would focus on the equity of the borrower or the equity of all of the CCCTB group members. ${ }^{1319}$ Additionally, in the light of CJEU's jurisprudence, a fixed debt to equity ratio would be against the fundamental freedoms. ${ }^{1320}$ Of course, with regard to third-country companies, only the freedom of capital movement could be challenged. It is noteworthy, however, that the Court has recognised the use of the arm's length standard in order to determine abuse. ${ }^{1321}$ Moreover, one may argue that thin capitalisation rules based on the debt and equity ratio could infringe the nondiscrimination clause contained in Member States' DTCs with third countries. The author will elaborate on the issue further below. Last, the application of thin capitalisation rules, either based on the arm's length principle or the fixed debt to equity approach (or a combination of both), would require Member States to decide whether the excessive interest payment would be generally nondeductible to the subsidiary or whether it would be re-qualified as a hidden profit distribution. It is worth reminding that, under the proposed CCCTB Directive, Member States remain free to levy withholding taxes on dividends and the taxes withheld would not be shared among the relevant Member States. On the other hand, withholding taxes on interest would have to be shared despite the fact that they would be regarded as non-deductible costs. Hence,

1319 Panayi (2008), 119.

1320 Cases Thin Cap Group Litigation (C-524/04); Lammers \& V Van Cleeff (C-105/07). See also the opinion of Advocate General Geelhoed delivered on 29 June 2006 in case Thin Cap Group Litigation (C-524/04), paras. 67.

${ }^{1321}$ Case Thin Cap Group Litigation (C-524/04), para. 80. 
Member States could find the re-characterisation of excessive interest to be a more attractive option.

The proposed interest deduction limitation (inbound investment) is conditional on the fulfilment of a number of criteria:

(i) the lender and the debtor are associated enterprises; and

(ii) there is no agreement on the exchange of information comparable to the exchange of information on request provided for in Directive 2011/16/EU between the country of the lender and the debtor; and

a. a tax on profits under the general regime in the third country at the statutory corporate tax rate is lower than 40 per cent of the average statutory corporate tax rates applicable in the Member States; Or

b. the lender is subject to special regime in the third country, which allows for a substantially lower level of taxation than that under the general regime.

The author does not consider it necessary to elaborate on the definition of interest in the current chapter, because this was addressed in Chapter 5 (5.3.3). Instead, the author will elaborate on the four afore-mentioned criteria that determine under which exact conditions an (outbound) interest payment becomes non-deductible from the tax base of a CCCTB participating company.

\subsubsection{ASSOCIATED ENTERPRISES}

The subjective condition of the interest deductibility rule has been determined by reference to associated enterprises, which are defined in Article 78 of the proposed CCCTB Directive. It is noteworthy that the definition under the proposed CCCTB Directive strongly relies on the definition provided for in Article 9 of the OECD MC. However, in certain aspects, the definition under the proposed CCCTB Directive is more detailed compared to that under the OECD MC, because it gives more details on what control ${ }^{1322}$ shall

1322 See also the relevant discussion presented earlier under group definition in I4.4.2.3. It is noteworthy that, unlike Article 54, which defines qualifying subsidiaries, the definition of associated enterprise does not look at the profit participation requirement. Hence, instruments that give a right to the (majority of) the profits of the enterprise, without fulfilling the requirements of Article 78 of the proposed CCCTB Directive, would not lead to an association between the relevant 
mean. On the one hand, such a definition aims at providing more certainty to the associated entities but, on the other hand, it may leave some room for manipulation due to the existence of the specific threshold requirements in paragraph 2 of the Article. In other aspects, the concept of associated entities under the CCCTB is broader compared to that of the OECD MC. For example, it specifically refers to the relationship between permanent establishments and their head offices, where one of them is located in a third country while the other in the CCCTB jurisdiction. The enactment of such special rules under the CCCTB is necessary due to the logic of the two systems. Despite the difference in the definition, the treatment of permanent establishments as separate entities is in line with the AOA.

\subsubsection{ABSENCE OF AN AGREEMENT ON THE EXCHANGE OF INFORMATION}

The second criteria for triggering the application of Article 81 is that there is no agreement on the exchange of information or the agreement does not include similar conditions as the exchange of information that applies between the Member States based on the Mutual Assistance Directive. The exchange of information is referred to in the several parts of the proposed CCCTB Directive with regard to third countries. Nevertheless, the requirements for the exchange of information may vary depending on the transaction at issue. For example, with regard to the transfer of assets towards third countries, the escape clause requires the existence of an agreement on exchange of information that corresponds to the Mutual Assistance Directive (see above in Chapter 5). On the contrary, Article 81 of the proposed CCCTB Directive does not apply if there is an agreement on the exchange of information comparable to the exchange of information on request provided for in the Mutual Assistance Directive. Hence, it seems that, for the purposes of Article 81, it suffices that the agreement on the exchange of information between the relevant EU Member State and the third country does not correspond to the other parts of the Mutual Assistance Directive, for example, provision of mutual assistance on recovery of tax claims. The EU Member States have access to a wide range of international instruments for the exchange of information

entities. Consequently, for example in the case of usufruct arrangements, the owner of the shares may be considered associated while the holder of the usufruct would not. 
between Member States and with third countries, such as the Convention on the Mutual Administrative Assistance in Tax Matters, exchange of information and mutual assistance in recovery in the tax claims on the basis of DTCs, ${ }^{1323}$ tax information exchange agreements (TIEAs), and the Nordic Convention on Mutual Assistance in Tax Matters. The Convention on the Mutual Administrative Assistance in Tax Matters and DTCs drafted in accordance with the OECD MC have a broad scope of application and include instruments, for example, on the spontaneous and automatic exchange of information as well as exchange of information on request. ${ }^{1324}$ On the contrary, the TIEAs include the exchange of information only upon request and seem therefore incomparable to the Directive 2011/16/EU with regard to the extent exchange of information that is provided for. Nevertheless, as Article 81 requires the exchange of information only upon request, the latter agreements would also suffice. In fact, the existence of the variety of instruments for the exchange of information on request is probably one of the main reasons why the Danish Presidency's compromise proposal for the CCCTB eliminated Article 81 entirely and introduced a new, distinct article on interest deduction limitation which would be applicable despite whether the interest has been paid to an EU Member State or a non-EU Member State. ${ }^{1325}$

According to Article 81 of the proposed CCCTB Directive, the agreement on the exchange of information must exist between the country of the lender and that of the debtor of the interest. However, the question is whether such a rule is too restrictive considering that the loan provided may be used to generate the profits for the whole CCCTB group, which would be attributed according to the apportionment formula. Thus, a greater amount of profits, which are generated due to the existence of the loan, may be attributed to a CCCTB group member other than to the group member which formally obtained the loan. Against this background, in a consolidated group, it may be more appropriate to rely on an exchange of information agreement of another group member with the country of the lender. As mentioned earlier, the exchange of information with third countries normally takes place on bilateral

1323 Article 26 of the OECD MC for the exchange of information and Article 27 OECD MC for the mutual assistance in the collection of taxes.

1324 Articles 5-7 of the Convention and OECD Comm. on Article 26, para. 9.

1325 Council of the European Union (2012), Articles 14a and 81 and comments therewith. 
grounds, such as based on a DTC or a TIEA. On the one hand, an option could be to refer only to the agreements of the Member State of the principal tax authority. However, this solution may also appear to be too restrictive. On the other hand, an alternative solution of involving all Member States of the group members would seem to be impractical, taking into account the vast number of bilateral agreements of Member States with third countries. Considering that interest deduction normally takes place before the consolidation of individual tax bases of the relevant CCСТB group members, and taking into account the bilateral character of majority of the agreements providing for the exchange of information, it still seems appropriate to look only at the agreements of the Member States directly involved in the transaction, as proposed in the CССТВ Directive.

However, one may question whether such agreements on the exchange of information actually allow the contracting parties to share the relevant information with other tax authorities from other Member States. As far as exchange of information in DTCs is concerned, the information received by a contracting party may generally not be disclosed to a third country. ${ }^{1326}$ However, the fact that the CCCTB system foresees the aggregation of individual tax bases of the group members, it seems particularly relevant that such information is indeed available at least for the Member State of the principal taxpayer. Hence, in order to respect their international arrangements (grandfathered according to Article 351 of the TFEU as discussed earlier), Member States would need to specify in their treaty negotiations that such information could be disclosed to the Member State of the principal taxpayer within the context of the CCCTB. It is worth noting that the Mutual Assistance Directive explicitly precludes providing information received from a third country, unless such sharing is allowed under the relevant agreement with that third country. ${ }^{1327}$

The wording of Article 81 suggests that, even if an appropriate agreement on the exchange of information exists, if the third country is unwilling to exchange the relevant information requested by the CCCTB Member State, this failure should not have any effect on the taxation consequences for the relevant taxpayer. ${ }^{1328}$ Nevertheless, as

1326 OECD Comm. on Article 26, para. 12.2.

1327 Article 24(1) of the Mutual Assistance Directive.

1328 Pistone (2013), 282. 
there is no clear hierarchy between the GAAR and the SAAR, if the third country does not provide the relevant information, the Member States would still be entitled to refuse an interest deduction if the transaction is considered to be abusive under the GAAR. In such a case, from the author's perspective, the burden of proof lies with the tax authorities to prove that there is abuse, as discussed earlier. If there is abuse, the other thresholds set forth in Article 81 for interest limitation certainly becomes irrelevant.

\subsubsection{LOW TAXATION IN A THIRD COUNTRY}

The cumulative conditions (the interest must be paid to an associated enterprise in a third country and that there is no appropriate agreement on the exchange of information) are further supplemented with two alternative criteria, which are based on the taxation of the recipient's profits (not only the interest received) in the third country. The first condition makes a direct link to the statutory corporate tax rate applicable to the profits in the third country. Accordingly, it shall not be less than 40 per cent of the average statutory corporate tax rates applicable in the Member States. Hence, the rule does not look at the effective tax burden but at the fixed, statutory corporate tax rate applicable in the third country. On the one hand, the determination whether profits are subject to low taxation in the third country based on statutory corporate tax rate, while ignoring the definition of the tax base, provides for legal certainty and simplicity for the taxpayers. On the other hand, it may lead to situations in which interest deduction limitation in the CCCTB jurisdiction applies, even if the corporate profits have effectively been subject to a higher level of taxation due to the fact that corporate tax base is defined broadly in that country. A solution could be to require the profits to be calculated in accordance with the rules of the CCCTB (like proposed in case of the application of the switch-over clause to the income of foreign permanent establishments in Articles 73-74). However, this would certainly increase the compliance costs for the CCCTB-participating companies and, thus, run contrary to one of the aims of introducing the system. Moreover, in the absence of an agreement on the exchange of information with the relevant third country, it may be difficult to obtain information from the tax authorities, especially when the interest has been paid to an entity other than a permanent establishment. In the light of the CJEU judgement in Rimbaud, in the case of transactions involving third countries, Member States would not be obliged to accept proof 
provided by the taxpayer itself where there is a lack of any obligation on the tax authorities of the third country to lend assistance. ${ }^{1329}$

Further, having recourse only to the statutory "corporate tax rate", but ignoring all other taxes levied on corporate profits, seems arbitrary and may lead to situations in which interest at the level of the CCCTB group members becomes non-deductible, even if it has been subject to a higher level of taxation. In comparison, according to the CJEU, the notion of taxes levied on corporate profits under the Parent and Subsidiary Directive is deemed also to include any other identical or similar tax other than corporate tax that nevertheless affected the amount of profits. ${ }^{1330}$ Against this background, if the CCCTB system ignores the existence of other taxes on corporate profits in the third country, it concentrates on the form rather than substance of the level of taxation in that jurisdiction. This approach, however, ignores the principle of horizontal equity, which assumes that taxpayers who are in the same economic circumstances should be treated equivalently. Moreover, the idea of the ad hoc rule should be to deal with abusive practices. In the light of this understanding, when a company is subject to an acceptable level of taxation on its profits from the perspective of CCCTB Member States, payments to it should not be caught by the anti-abuse provision.

The second alternative condition looks at whether the lender is subject to a "special regime" in the third country that allows for a "substantially lower level of taxation" than that of the general regime. Accordingly, the special-regime test would be assessed on case-bycase basis. It seems that the test implies the calculation of the effective (overall) tax burden of the particular lender compared to the effective tax burden of other taxpayers in the third country. However, as discussed earlier, in the absence of the relevant agreement on the exchange of information, the determination of the effective tax burden may be difficult in practice. In addition, even if one is able to determine the effective tax burdens for the purposes of the comparison, it is still questionable what is meant by a "substantially lower level of taxation". Furthermore, it is interesting to note that the current drafting of the provision does not create a link between the two alternative provisions. Hence, interest payments to companies that are subject to a special regime but whose profits are nevertheless

${ }^{1329}$ Case Rimbaud (C-72/09), paras. 49-50.

1330 Case Epson Europe (C-375/98), para. 22. 
taxed with a statutory corporate tax rate higher than the 40 per cent requirement will be caught by the provision. For example, assume that the average statutory CIT rate in EU Member States is 10 per cent ${ }^{1331}$ and the statutory tax rate of the third country is 30 per cent. If the enterprise of the third country benefits from a special regime that exempts 50 per cent of its income from taxation, the interest payment will be caught by the ad hoc rule in the CCCTB Member State, even though the effective tax rate of the recipient is 15 per cent, which is considerably higher than the average statutory tax rate. Hence, from the author's perspective, the provision concerning the existence of a special regime is too flexible, leaves too little room for legal certainty and does not necessarily accurately reflect the taxation in the third country.

The cumulative requirements provided for in Article 81(1) lead to a conclusion that, if one of the conditions is not fulfilled, interest payments would not be caught by the ad hoc anti-abuse clause. For example, if the interest is paid to a company that is a resident of a third country with which there is an appropriate exchange of information agreement, but where the company is subject to a low level of taxation as described earlier, the interest would still be deductible from the CCC tax base. The strong reliance on the existence of the agreement on the exchange of information with the third country is presumably due to the Court's jurisprudence with regard to the free movement of capital, which - as one may recall has an external dimension. ${ }^{1332}$ Again, given the large number of agreements that allow exchange of information on request concluded by EU Member States with third countries, Article 81 of the proposed CCCTB Directive appears to be almost an "empty" provision. Hence, the proposal of the Danish Presidency to substitute the provision with a general interest deductibility rule appears to be more efficient.

\subsubsection{THE ESCAPE CLAUSE}

The CCCTB interest limitation rule includes a specific escape clause, which allows the deduction of interest even in the absence of an agreement on the exchange of information between the relevant

\footnotetext{
1331 According to Article 73 of the proposed CCCTB Directive, the European Commission shall annually publish the average statutory corporate tax rate of Member States, which is calculated as an arithmetic average.

1332 Case Rimbaud (C-72/09).
} 
States. Unlike the general rule, which disallows the deduction of the total amount of interest paid, the escape clause limits the deduction of interest to arm's length. However, this does not imply that if there were an appropriate exchange of information agreement that the deduction would not have to meet the arm's length standard transactions between CCCTB group members and associated enterprises would always have to comply with that rule. ${ }^{1333}$ The arm's length standard is an internationally accepted principle for determining prices between associated enterprises for taxation purposes and it depends on each jurisdiction whether it wishes to apply it. Likewise, it depends on the EU, in particular the Member States, to determine which standards they wish to follow in the secondary law of the EU. The CJEU has accepted the arm's length as a safe haven. ${ }^{1334}$ Nevertheless, this does not imply that transactions that do not meet the arm's length standard should automatically be considered abusive. The taxpayer must be given an opportunity - at least as far as taxpayers from EU Member States are concerned - without being subject to undue administrative constraints, to provide evidence of any commercial justification that there may have been for that transaction. 1335 The author will explain below to what extent this conclusion affects transactions involving third countries.

The escape clause includes three non-cumulative conditions for interest deductibility:

(a) the amount of interest is included in the tax base as income under the CCCTB CFC provision (to be discussed below);

(b) the interest is paid to a company whose principal class of shares is regularly traded on recognised stock exchange;

(c) the interest is paid to an entity engaged in the active conduct of a trade or business in its country of residence.

With regard to the first rule, the purpose of the provision is to avoid double taxation if the income has already been included into the CCC tax base due to the application of the CFC rule. It is noteworthy that, even though under the CFC provision the total income of the foreign entity is included in the CCC tax base, the arm's length principle for the purposes of interest deduction stays in place. As follows, if the interest payment exceeds the arm's length

1333 Article 79 of the proposed CCCTB Directive.

${ }^{1334}$ Cases Thin Cap Group Litigation (C-524/04), para. 80; SGI (C-311/08), para. 72.

1335 Case SGI (C-311/08), para. 72 and the case-law cited therein. 
standard, double taxation will remain in the amount of the excessive payment. It seems fair to argue that if the principal aim of the clause is to avoid the double taxation of income, it should function independently from the arm's length standard.

The second rule of the escape clause aims at excluding companies that are presumed to be carrying on genuine economic activities. Moreover, companies on the stock exchange are normally subject to extensive reporting obligations, which makes it highly unlikely that they are involved in abusive practices. Hence, since the interest limitation is a SAAR, companies involved in genuine trade or business should be excluded from its scope, even if they are subject to low taxation in their country of residence. It is worth noting that the provision is very similar to the limitation of benefits clause included in some DTCs, in particular those based on the US MC. 1336

The last exception to the general interest limitation rule requires the recipient of the income to be engaged in the active conduct of trade or business, i.e. not being abusive. The article further defines the conditions when an entity is deemed to be carrying on such activities based on two criteria. First, it must carry on independent economic activities for the purposes of deriving profit. Second, such activities must be carried out in the context in which officers and employees perform substantial managerial and operational activities. One may recall that, according to the Court in Cadbury Schweppes, a company is considered to carry on genuine economic activities if an entity (in that case, the CFC) "in particular" physically exists in terms of premises, staff and equipment. ${ }^{1337}$ On the one hand, the wording "in particular' suggests that the three criteria are not necessarily cumulative but, on the other hand, the conjunction "and" between the objective criteria suggests the opposite. Taking into account the vast number of businesses that exist, it is obvious that they do not all need premises, staff and equipment for the purposes of carrying on business or trade. ${ }^{1338}$ Instead, the three criteria should be seen as key elements that indicate that the activities of the entity are genuine. The proposed CCCTB Directive places the emphasis only on the existence and performance of staff. Hence, it seems that even in the absence of an agreement on the exchange of information, the

\footnotetext{
1336 Article 22(2)(c) of the US MC.

1337 Case Cadbury Schweppes (C-196/04), paras. 66-68.

1338 A similar position has been taken by Lang and Heidenbauer in Lang \& Heidenbauer (2008), 603-604.
} 
relevant CCCTB tax authorities would have to accept that the activities of the company receiving the interest are genuine as long as the requirement of having staff is met. Against the background that there is no clear hierarchy between the GAAR and the SAAR on interest deductibility, the question is if an entity lacks, for instance, a premises or equipment, the transaction could still be caught by the GAAR with a consequence that the escape clause would become inapplicable. If that were the case, the specific part of the escape clause would be an empty provision. Nevertheless, the existence of this provision should also not be interpreted as precluding the application of the GAAR.

It is unclear, however, whether in this particular case the burden of proof would lie with the taxpayer or the tax authorities. In the light of the jurisprudence of the CJEU, tax authorities cannot entirely shift the burden of proof to the taxpayer, unless the national legislation provides for a consideration of objective and verifiable elements in order to determine whether a transaction contains a specific, rational and proportional indication of abuse as a relevant presumption. ${ }^{1339}$ Hence, one may conclude that the escape clause assumes that the burden of proof lies with the taxpayer due to the existence of the objectively verifiable elements (profit purpose and the existence and performance of the staff), even though it is not explicitly provided in the provision. In any event, due to the fact that there would be no agreement on the exchange of information between the States concerned, the verification of the required elements might turn out to be difficult in practice. In other words, even though the principal aim of the provision is to exclude the application of the SAAR in the case of genuine economic activities, the real administration of the transaction might be complicated. One may recall that, in the case of GAAR, the burden to prove that there is abuse would be with the tax authorities, subject to proof to the contrary by the taxpayer. For the purposes of consistency between primary EU law, as interpreted by the CJEU, and the CCCTB Directive, as a means of secondary EU law, it seems reasonable to leave the definition of "active conduct of a trade or business" out of the CCCTB Directive or formulate it differently and include a reference to the CCCTB GAAR. ${ }^{1340}$

1339 Case Thin Cap Group Litigation (C-524/04), para. 82. See also the opinion of Advocate General Geelhoed delivered on 29 June 2006 in this case, paras. 67-68. 1340 Pistone (2013), 292. 


\subsubsection{DTC APPLICATION}

The author elaborated earlier (in Chapter 7.3 - Effectiveness of Member States' DTCs) on the effectiveness of Member States' DTCs with third countries. Specifically, Article 351 of the TFEU provides for a grandfathering clause, based on which the CCCTB Directive shall not affect the rights of third countries agreed upon in DTCs predating the foundation of the Community or the accession of the Member State. On the contrary, Member States are under a general obligation to renegotiate and amend accordingly (provisions of) DTCs that conflict with the acquis communautaire that do not fall under the grandfathering clause. If a DTC with a third country, not falling within the scope of Article 351 of the TFEU, does not include the exchange of information based on the criteria as discussed earlier, interest paid to an entity resident in that third country would generally not be deductible from the CCC tax base, provided that the other conditions of Article 81(1) are fulfilled and the transaction is not covered by the escape clause. Nevertheless, the question is, if the particular DTC (not grandfathered based on Article 351 of the TFEU) includes a provision based on Article 24(4) of the OECD $\mathrm{MC}-$ which is a specific non-discrimination provision, whether the Member States would be obliged to allow the deduction of interest despite the applicable SAAR. According to the OECD, the nondiscrimination clause does not apply if the national thin capitalisation rules are compatible with Article 9(1) of the OECD MC (i.e. transactions between associated enterprises) or Article 11(6) of the OECD MC (i.e. the arm's length principle). However, if such treatment results from rules which are not compatible with these articles and which apply only to non-resident creditors, then this treatment is prohibited under the non-discrimination clause. ${ }^{1341}$ The CCCTB interest limitation rule applies despite whether the interest paid meets the required standards as referred to earlier. Moreover, it applies only to payments towards third countries and not within the EU. Hence, the CCCTB system would lead to different treatment of payments paid domestically and those paid out of the EU's water's edge if the CCCTB resident would be deprived to deduct the interest paid to the third country entity. Against this background, in the existence of a DTC between a Member State and a third country, a general limitation on the deductibility of interest paid to creditors of that third country from the CCC tax base would be prohibited based

1341 OECD Comm. on Article 24, para. 74. 
on the non-discrimination clause contained in that DTC. In any event, the current proposal does not provide for such a limitation. Member States would, however, be allowed to disallow an interest deduction in the amount exceeding the arm's length standard. It is worthwhile noting that the non-discrimination clause of the 1963 OECD MC did not include such a specific provision as provided for in Article 24(4) of the 2010 OECD MC. Therefore, the application of Article 81 of the proposed CCCTB Directive would not be affected by DTCs based on that model.

\subsubsection{EU ASPECTS}

The application of the interest limitation rule from the perspective of EU law can be approached from two perspectives: (i) to which extent are third countries affected; and (ii) if the CCCTB is introduced via enhanced cooperation, what affect would the provision have with regard to payments towards non-CCCTB Member States.

To begin with, it is undisputable that non-EU Member States have less protection under the Treaties compared to EU Member States, as only the free movement of capital has an external dimension. ${ }^{1342}$ However, national tax measures that restrict the freedom of establishment are likely to restrict the free movement of capital as well. Nevertheless, according to the CJEU, since the freedom of establishment does not extend to third countries, it is important to ensure that the interpretation of Article 63(1) of the TFEU as regards relations with third countries does not enable economic operators from third countries to profit from that freedom..$^{1343}$ However, the dividing line between the free movement of capital and the freedom of establishment is thin, especially as far as direct taxes are concerned. According to the Court, in order to assess whether national legislation falls within the scope of one or the other freedoms of movement, its purpose must be taken into consideration. ${ }^{1344}$ National legislation intended to apply only to those shareholdings that enable the holder to exert a definite influence on a company's decisions and to determine whether its activities fall

\footnotetext{
1342 Cases $A$ and B (C-102/05), para. 29; Holböck (C-157/05), para. 28.

${ }^{1343}$ Case FII Group Litigation II (C-35/11), paras. 99-100.

1344 Cases Cadbury Schweppes (C-196/04), paras. 31-33; Thin Cap Group Litigation (C524/04), paras. 26-34; Haribo and Salinen (Joined Cases C-436/08 \& C-437/08), para. 34.
} 
within the scope of Article 49 of the TFEU on the freedom of establishment. ${ }^{1345}$ In such a case, neither Article 49 of the TFEU nor Article 63 of the TFEU may be relied upon in cases involving third countries. ${ }^{1346}$ However, national legislation, which applies equally irrespective of the extent of the holding which the shareholder has in the company making the distribution, may fall within the scope of both the freedom of establishment and the free movement of capital. ${ }^{1347}$ In such a case, it cannot therefore be determined from its purpose whether it falls predominantly within the scope of Article 49 of the TFEU or Article 63 of the TFEU. ${ }^{1348}$ If the case at hand affects movement between the Member States, then the Court takes account of the facts of the case in order to determine whether the situation to which the dispute in the main proceedings relates falls within the scope of one or other of those provisions. ${ }^{1349}$ Nevertheless, in cases concerning third countries, a company resident in a Member State may therefore rely on the free movement of capital provision in order to call into question the legality of such rules, irrespective of the size of its shareholding in the company paying dividends established in a third country. ${ }^{1350}$ As discussed earlier, the CCCTB interest limitation rule applies if payments are made to associated enterprises that are not per se defined as targeting only situations in which a person is in a position to exercise a definite influence over the decisions of the company. ${ }^{1351}$ Consequently, it is not possible to establish the purpose of such a provision whether it applies exclusively on the freedom of establishment or the free movement of capital. In the light of the foregoing, Article 81 of the proposed CCCTB Directive must therefore be assessed in the light the free movement of capital only (as the freedom of establishment does not include external dimension).

In order to assess whether Article 81 of the proposed CCCTB Directive leads to a discriminatory restriction of a free movement of

\footnotetext{
1345 Cases Baars (C-251/98), para. 22; FII Group Litigation I (C-446/04), para. 37.

1346 Case Lasertec (C-492/04), paras. 22-27.

1347 Case Holböck (C-157/05), para. 24.

1348 Case FII Group Litigation II (C-35/11), paras. 96 and 99.

1349 Cases Burda (C-284/06), paras. 71-72; SGI (C-311/08), paras. 33-37; FII Group Litigation II (C-35/11), paras. 94.

1350 FII Group Litigation II (C-35/11), paras. 94.

1351 The same view seems to be shared by Pistone (Pistone (2013), 298).
} 
capital, ${ }^{1352}$ one must first find an appropriate benchmark for comparability analysis. However, the establishment of such a benchmark may be tricky. First, one cannot establish a comparison between, one the one hand, payments to CCCTB group members and, on the other hand, payments to associated enterprises in the Member States that are ineligible for group membership, because those entities would be operating in dissimilar corporate tax systems. Second, one cannot compare the taxation treatment of CCCTB ineligible group members in Member States between their domestic and foreign associated enterprises, because these national provisions would not be dependent on the СССТВ rules and may thus vary from Member State to Member State. However, as referred to earlier, EU law also prohibits so-called non-discriminatory restrictions (so-called "quasi restrictions") that make the exercise of the fundamental freedoms less attractive. Hence, for the purposes of Article 81, one must assess whether the interest limitation rule makes the exercise of the freedom of capital movement towards third countries less attractive. ${ }^{1353}$ Clearly, under the rule, movements of capital and payments with associated enterprises from third countries are made less attractive compared to movements within the EU. Having confirmed that a restriction on the free movement of capital exists, it is further necessary to assess whether the restriction can be justified, in particular, by the need to combat tax avoidance (or tax evasion) and/or the need for effectiveness of fiscal supervision.

As discussed earlier, it is settled case law of the CJEU that a taxpayer cannot be denied access to the fundamental freedoms, except in situations where he is involved in abusive practice(s). Furthermore, it is generally accepted that taxation would be rendered illusory if Member States were not allowed to supervise compliance by its taxpayers. Thus, the effectiveness of fiscal supervision serves as a separate justification ground before the CJEU.1354 According to the CJEU, a national anti-abuse measure cannot be applied in generic terms, but tax authorities must prove in each case that abuse exists, subject to proof to the contrary of the taxpayer. But if the national legislation provides for a consideration of objective and verifiable elements in order to determine whether a transaction contains an

1352 In the case of EEA Member States, the freedom of establishment may also be at issue because Article 40 of the EEA Agreement has the same legal scope as the substantially identical provisions of the TFEU.

${ }^{1353}$ Case Lankhorst-Hohorst (C-324/00), para. 32.

1354 See generally Hemels (2009), 583-91. 
indication of abuse as a relevant presumption, the burden of proof that abuse does not exist lies with the taxpayer. Moreover, in the light of Passenheim-van Schoot \& X, when tax authorities of a Member State have no evidence to enable them to initiate an investigation, e.g. based on an exchange of information agreement, the automatic application of the SAAR in case of payments towards these countries would not constitute an infringement on the free movement of capital. ${ }^{1355}$

The author concluded earlier that Article 81 of the proposed CCCTB Directive provides for objective and verifiable elements that allow tax authorities to presuppose the existence of abuse. Nevertheless, in order for the restrictive measure to be proportional, a taxpayer must be given an opportunity to prove that that abuse does not exist and the limitation should not apply. In the absence of an agreement on the exchange of information, national legislation cannot rule out, as a matter of principle, that the taxpayer may be in a position to provide relevant documentary evidence enabling the tax authorities of the Member State imposing the tax to ascertain, clearly and precisely, whether he satisfies the requirements for receiving the tax advantage in question. ${ }^{1356}$ In other words, where when national legislation does not make the granting of a tax advantage dependent on satisfying requirements, compliance with which can be verified only by obtaining information from the competent authorities of a third State, proof provided by a taxpayer himself should be acceptable if such an agreement is normally necessary. If that is not the case, according to the Court, because of the different level of integration between Member States and, in particular, because of Union legislation which seeks to ensure cooperation between national tax authorities, such as the Mutual Assistance Directive, the taxation by a Member State of economic activities having crossborder aspects which take place within the Union is not always comparable to that of economic activities involving relations between Member States and non-member countries. ${ }^{1357}$

In the absence of exchange of information with a third country, a taxpayer cannot rely on the possibility to provide proof to the contrary when there is a lack of any obligation on the tax authorities

\footnotetext{
1355 Case Passenheim-van Schoot \& X (Joined Cases C-155/08 \& C-157/08).

1356 Case Peeters (C-544/11), paras. 52-57.

1357 Case FII Group Litigation I (C-446/04), para. 170.
} 
of the third country to lend assistance.1358 From the author's perspective, the aim of the ad hoc interest limitation rule can only be achieved if the proof provided by the taxpayer can be verified by obtaining information from the competent authorities of a third state based on a convention or an agreement. Consequently, from the author's perspective, the ad hoc anti-abuse provision concerning interest deductibility under the CCСТВ system does not violate the EU fundamental freedoms.

If the CCCTB is introduced via enhanced cooperation, the existence of the Mutual Assistance Directive obviously puts non-CCCTB Member States in a different position compared to other third countries, including EEA Member States. Hence, even though the effectiveness of fiscal supervision serves as a proportional ground for a restriction in the case of third countries, it would not be the same in the case of movements involving non-CCCTB Member States. ${ }^{1359}$ In any event, the fact that Article 81 of the proposed CCCTB Directive refers to the Mutual Assistance Directive applicable between all Member States, the provision would never have an effect on nonCCCTB Member States if the CCCTB was introduced by means of enhanced cooperation. Nevertheless, since the application of the SAAR does not prevent the application of the GAAR of the CCCTB Directive, abusive transactions carried out by companies of EU Member States could always be challenged under the latter provision. However, in that case, the burden of proof to show that abuse exists would always first lie with the tax authorities, subject to the proof to the contrary by the taxpayer.

\subsubsection{AN ALTERNATIVE INTEREST LIMITATION RULE}

The author briefly referred earlier to the fact that the Danish Presidency proposed to delete Article 81 from the proposed CCCTB Directive and apply an alternative interest limitation rule of Article 14a. ${ }^{1360}$ Such a limitation would be applicable generally and not only to cases concerning third countries. The alternative rule takes a fundamentally different approach to that of Article 81: it makes the

1358 Cases A. (C-101/05), para. 63; Commission v Italy (C-540/07), paras. 68-69-72; Rimbaud (C-72/09), para. 50; Haribo and Salinen (Joined Cases C-436/08 \& C437/08), para. 68.

${ }^{1359}$ Cases Wielockx (C-80/94), para. 26; Skandia and Ramstedt (C-422/01), para. 42.

${ }^{1360}$ Council of the European Union (2012), Articles 14a and 81 and the comments therewith. 
deductibility dependent on the amount of the positive tax base rather than the level of taxation of the recipient. The proposed rule aims to reflect the basic aim of Article 14 of the proposed CCCTB Directive that expenses related to tax exempt income cannot be deducted. Hence, the proposed Article 14a is nothing about abuse as such.

Due to its general application, the issue on the existence of a possible restriction on the fundamental freedoms is also out of the question, because the interest limitation rule proposed by the Danish Presidency applies indiscriminately to domestic or cross-border borrowings. Furthermore, such a rule would not conflict with Member States' DTCs with third countries that are drafted in line with the OECD MC. The author discussed earlier that the nondiscrimination clause does not apply if the national thin capitalisation rule is compatible with Article 9(1) of the OECD MC (transactions between associated enterprises) or Article 11(6) of the OECD MC (i.e. the arm's length principle), even if it applies discriminately to resident and non-resident investors. ${ }^{1361}$ The alternative interest limitation provision would not discriminate between resident and non-resident creditors, because the interest deductibility would depend only on the existence of a sufficient amount of tax base of the borrower in a CCCTB Member State. This does not, of course, mean that interest that exceeds the arm's length standard paid to an associated enterprise would remain deductible - the excess would be caught by Article 79 of the proposed CCCTB Directive.

\subsubsection{CONTROLlED FOREIGN COMPANY (CFC) RulES}

While most countries tax their residents on a worldwide basis, they are limited in taxing income of non-residents not sourced within their jurisdiction. Otherwise, they would infringe the national tax sovereignty of the other country. Hence, as a separate legal entity and a non-resident, the profits of a foreign subsidiary are normally not taxable in the country of the parent company, unless they are distributed. Due to such deferred taxation, shareholders may wish to retain the profits of the subsidiary rather than distribute them, especially when the subsidiary is located in a jurisdiction that foresees low taxation or applies preferential tax regimes. On the one side, countries that have a considerably higher tax rate compared to the source State of the dividends and that apply credit method for the

1361 OECD Comm. on Article 24, para. 74. 
elimination of double taxation of dividend income of residents are particularly concerned about such deferred taxation. On the other side, countries applying the exemption method for the elimination of double taxation of dividends are often concerned with international (harmful) tax competition. ${ }^{1362}$

Harmful tax competition also seems to be reason for introducing a CFC rule into the CCCTB. In particular, because the latter system exempts certain foreign income (e.g. dividends and capital gains), businesses may be tempted to shift their profits to subsidiaries in lowtax jurisdictions. ${ }^{1363}$ Hence, in order to prevent the erosion of the domestic tax base, several countries have implemented CFC provisions, which, in essence, are anti-abuse rules designed to prevent domestic tax base erosion caused by the artificial shift of income to low-tax jurisdictions and, more specifically, into foreign companies controlled by resident taxpayers. ${ }^{1364}$ Depending on the jurisdiction, such rules may apply to individuals and/or to companies. The same concerns often do not arise in the case of foreign permanent establishments as they form part of their head office and their income (retained or repatriated) can thus be taxed at the level of the latter (unless the income is subject to the exemption method in the residence State). Moreover, shifting the income artificially to permanent establishments may be difficult, because a permanent establishment is a tax concept and it exists only if it carries out business in the source State. Also, importantly, the income is attributed to the permanent establishment based on the AOA, so that it would be allocated only that income that relates to the permanent establishment's assets used, risks assumed and functions performed.

By taxing the worldwide income of residents, countries generally encourage capital export neutrality (CEN). On the contrary, countries that exempt foreign income generally encourage capital import neutrality (CIN). The lack of residence taxation of retained profits of foreign subsidiaries is normally considered as violating the fundamental principles of equity and $\mathrm{CEN}$ on which worldwide

1362 The OECD has emphasised the importance of CFC legislation in combating harmful tax competition in its report (OECD (1998), 40-41), and in the subsequent reports.

1363 European Commission (2007a), para. 127.

1364 According to the European Commission, "[t]he main purpose of CFC rules is to prevent resident companies from avoiding domestic tax by diverting income to subsidiaries in low tax countries, and - as the ECJ has recognised - CFC rules are in general apt to achieve that purpose." European Commission (2007d), 6. 
taxation is based. ${ }^{1365}$ On the other hand, the preservation of deferral is believed to be consistent with CIN. ${ }^{1366}$ Nevertheless, CFC rules typically only apply in cases of abuse, so that they disallow instances of misuse of the principle of CIN. Hence, despite the apparent conflict between the two economic theories of neutrality, the use of CFC rules should be acceptable from the perspective of both neutrality theories. Lastly, if national CFC rules target mainly foreign subsidiaries with high amounts of passive investment income, while they exempt active business income, the taxation of CFC income based on CEN becomes weaker. ${ }^{1367}$

The main approaches for taxing CFC income can broadly be classified as follows: ${ }^{1368}$

(1) $\mathrm{CFC}$ rules that look at the amount of income of the CFC subject to taxation in the residence State of the parent company:

(i) Entity approach subjects the total (active and passive) income of the CFC to taxation at the level of the parent company; ${ }^{1369}$

(ii) Transactional approach requires case-by-case analysis to determine the (passive) nature of the income arising from each transaction enacted by the CFC. Active business income is usually exempt under this approach;

(2) CFC rules that look at the level of taxation in the foreign country:

(i) (Designated) jurisdictional approach triggers the application of the CFC rules if the CFC is located in a low-tax jurisdiction or in a jurisdiction with a preferential tax regime;

(ii) Global approach under which $\mathrm{CFC}$ rules apply to CFCs wherever resident, regardless of the rate of foreign tax imposed on its income.

\footnotetext{
1365 Arnold \& Dibout (2001).

1366 Harris \& Oliver (2010), 297.

1367 Panayi (2013), 314.

1368 National CFC legislation may combine such approaches.

1369 Nevertheless, the nature of the income of the CFC is usually an important factor in the determination of whether the CFC is exempt. Hence, in case of the entity approach, the focus of the rules is on the CFC as an entity with the result that all or none of its income is attributed to the parent company.
} 
CFC rules based on the national law of the residence State have been implemented in a variety of forms. Furthermore, the OECD is of the opinion that national CFC legislations do not infringe the OECD MC as long as the income of the CFC is taxed in the hands of the resident taxpayer. 1370 The most common theories supporting the taxation of CFC income without infringing other States' national sovereignty are as follows:

(i) The fair value of share theory aims at taxing a CFC shareholder on the basis of the fair value of the shares. In other words, whenever the base company earns income and does not distribute its profits, the value of its shares increases, which is then taxed at the level of the shareholder.

(ii) The deemed dividend distribution theory aims at taxing at the hands of the shareholder of a deemed dividend payment which, in a fair market situation (from the shareholder's residence state perspective), would have been received by the shareholder.

(iii) The piercing the corporate veil theory - the so-called "look through" approach - disregards the legal personality of the CFC (due to the controlling power of the shareholder) by piercing its corporate veil and thus allocating the profits to the shareholder.

One can find the CCCTB ad hoc anti-abuse provision concerning CFC income in Article 82 of the proposed CCCTB Directive. The first paragraph of the Article contains the objective and the subjective scope of the provision and reads as follows:

\section{"The tax base shall include the non-distributed income of an entity resident in a third country where the following conditions are met:"}

The Article further lists four cumulative conditions that must be fulfilled for the provision to be applicable:

\footnotetext{
1370 OECD Comm. on Article 1, para. 23. However, not all countries share the view: see, for instance, observations to the OECD Comm. on Article 1. See also Harris \& Oliver (2010), 303-308. There has also been some discussion as to whether DTCs based on the OECD MC (in particular, by reference to OECD Comm. on Article 1, para. 9.4) provide for an implicit authorisation to apply domestic anti-abuse provisions to tax CFC income. It seems that the prevailing view is that no general international law provision supports such a viewpoint. Gérard \& Traversa (2010), 200-201.
} 
(i) Holding more than 50 per cent of either voting rights, capital or profits of the entity;

(ii) Low taxation in the third State;

(iii) More than 30 per cent of the income earned by the CFC essentially involves passive income which originates from 50 per cent in transactions with associated enterprises;

(iv) CFC is not traded on recognised stock exchanges.

Accordingly, the wording of Article 82(1) it is based, first, on the entity approach, so that once a foreign subsidiary fulfils the conditions set forth in Article 82, all its income, despite whether it is derived from active or passive income, ${ }^{1371}$ will be included in the tax base of the controlling CCCTB taxpayer. ${ }^{1372}$ The "all-or-nothing" approach is often considered to be one of the biggest weakness of the entity approach, because, if a CFC has both tainted and non-tainted income, either the tainted income will escape the tax or the nontainted income will be taxable. ${ }^{1373}$ Hence, an entity-based CFC rule may catch entities that carry on genuine business activities in the foreign territory. Nevertheless, in practice it may be very difficult to distinguish between tainted and non-tainted income within the same entity. However, as the ad hoc anti-abuse rules of the proposed CCCTB Directive do not exclude the application of the GAAR, at least as far capital movements to third countries are concerned, this weak point does not appear within the context of the CCCTB. On the other hand, compared to the transactional approach, the entity approach reduces compliance costs for businesses and is easier to administer by tax authorities.

The idea is that CFC income is imputed to the CCCTB taxpayer's income in proportion to its share in profits of the CFC.1374 As the author will discuss below, the definition of control for the purposes of the CFC provision includes three non-cumulative criteria: (i)

1371 The CCCTB working group discussed a possibility that the CFC income imputed in the hands of the CССТВ company should only be the passive income of the CFC. See European Commission (2008a), paras. 30 and 32.

1372 Note that where a low-taxed entity does not fall within the scope of the CFC provision, it will remain subject to the switch-over clause in Article 73 of the proposed CCCTB Directive. The switch-over clause and the CFC rule are supplementary to each other and not as alternatives. This was made clear in the compromise proposal of the Danish presidency. Council of the European Union (2012), Article 73 and the comments therewith.

1373 Arnold (1994), 50.

1374 Article 83(2) of the proposed CCCTB Directive. 
participation in voting rights; (ii) ownership of capital; and (iii) entitlement to profits. For instance (Example 40: CFC income of a CCCTB group), if one of the CCCTB group members (CoA) fulfils the voting-rights test, while another $(\mathrm{CoB})$ meets the ownership-test, the income would be included in the tax base of both companies in proportion to their entitlement to profits (which does not necessarily have to correspond to the participation in the share capital of the $\mathrm{CFC}$ ). In the case of group taxation, it is irrelevant which proportion of $\mathrm{CFC}$ income is attributed to the relevant taxpayer, because the individual tax bases of the group members will be aggregated.

Example 40: CFC income of a CCCTB group

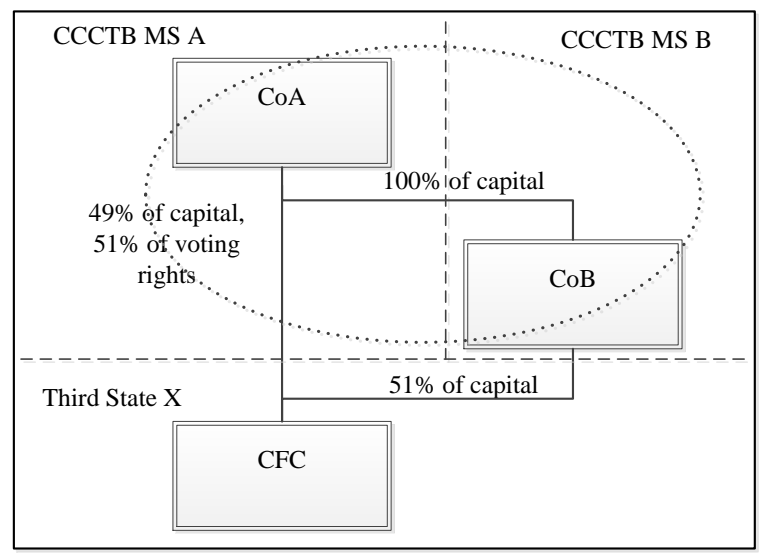

Second, the CFC provision in the proposed CCCTB Directive takes a jurisdictional approach, so that it defines under which criteria the company is considered to be subject to low taxation in its country of residence. Compared to the jurisdictional approach, a global approach would be much more comprehensive, but it would increase compliance costs for taxpayers and the administration burden for tax authorities. Moreover, the application of the global approach may lead to conflicts with primary EU law (in case of third countries, the free movement of capital), because it would ignore the jurisprudentially required criteria of the existence of an objective and a subjective element of abuse. The condition set forth under the CFC provision to define when an entity is subject to a low level of taxation is equal to the one provided under the ad hoc interest deductibility rule, discussed earlier. It is worth noting that national $\mathrm{CFC}$ rules based on the jurisdictional approach are often supplemented by a "black list" of low-tax jurisdictions (and/or regimes) or a "white list" 
of not low-tax jurisdictions (and/or regimes). The main benefit of listing countries and regimes is that it helps to target the rules on the clearest cases of unacceptable deferral and to reduce the significant compliance and administrative burden resulting from the rules. ${ }^{1375}$

In the past, the OECD has also published a list of "uncooperative tax havens". However, due to the commitment of those jurisdictions to implement the OECD standards of transparency and effective exchange of information, the OECD does not currently consider any jurisdiction to fall under that category. ${ }^{1376}$ Compared to a "black list", the use of a "white list" is politically more acceptable. Nevertheless, the major disadvantage of such a list is that businesses may try to shift more income into these jurisdictions. In that case, the burden of proof that abuse does not exist would lie with tax authorities. Taking into account the practice of States with (binding or non-binding) lists of countries for the purposes of the CFC rules, one may also hope that the European Commission would publish a list of jurisdictions that are assumed either to have or not to have a low taxation or a special regime available, subject to annual updating. Such a list, which could equally apply to the CCCTB ad hoc interest deductibility rule, would provide guidance for taxpayers and tax authorities and, thus, provide for legal certainty and reduce compliance and administration costs. Moreover, the fact that the current wording of the $\mathrm{CFC}$ rule looks at the corporate tax rate or a specific regime applicable in the third country should make the publication of such a list should feasible. Such a list would not be helpful if the CFC rules under the CCCTB system were based on the actual tax approach, which looks at whether each particular CFC pays no or a low level of taxes. On the other hand, a major disadvantage of a list - "black" or "white" is that it is typically too rigid and does not properly reflect the changes in countries' laws and practices. As a result, the list could discourage companies from investing in these jurisdictions and thus impede the global development.

The ad hoc CFC rule pierces the corporate veil and, thus, deems all the profits of an "entity resident in a third State" to be derived directly by the CCCTB taxpayer. The question is how to define an "entity resident in a third State". According to Article 82(1)(a) of the proposed CCCTB Directive, the CFC is triggered if the CCCTB

\footnotetext{
1375 Arnold (1994), 48.

1376 Read further at http://www.oecd.org/ctp/harmfultaxpractices/listofuncooperativetaxhavens.htm, last accessed 1 March 2013.
} 
taxpayer, together with its associated enterprise either: (i) holds a direct or indirect participation of more than 50 per cent of the voting rights; or (ii) owns more than 50 per cent of the capital; or (iii) is entitled to receive more than 50 per cent of the profits of that entity. Consequently, the CCCTB CFC rules assume that CCCTB taxpayers have a definitive influence and control over their CFCs. ${ }^{1377}$ However, rights to profits do not always ensure the control on the foreign entity's decision. ${ }^{1378}$ Although the European Commission has built its reasoning solely on the freedom of establishment, one cannot exclude the relevance of the free movement of capital a priori. Although the CJEU has considered the existence of a wholly artificial arrangement exclusively in the context of the freedom of establishment, it is not clear to what extent this concept has an effect on the freedom of capital movement. Despite the foregoing, from the author's perspective, the 50 per cent-profit right is normally a strong indication of a lasting economic link, thus falling within the concept of direct investment. Moreover, a 50 per cent-profit share normally confers a definite influence over the holding, although this is subject to discussion. The author will come back this issue later in this Chapter. ${ }^{1379}$

Because of the fact that the conditions are non-cumulative, it seems that the CFC does not need to be a legal person. However, this does not mean that the CFC rule applies to permanent establishments (in addition to the switch-over clause, as discussed earlier), because the latter cannot be deemed to be resident in the third country. Nevertheless, it is unclear whether the term "entity" also refers to entities that do not have legal personality, such as partnerships, investment funds, joint ventures, trusts, etc. The rules concerning the treatment of transparent entities may not suffice to deal with this matter. ${ }^{1380}$ From the author's perspective, the term "entities" should always be read in conjunction to the residency criterion, so that the CFC rule covers all entities that are considered residents of the third country. It is worth noting that the CFC provision does not define what residency for the purposes of that provision is. Such a definition is also not included under the definition in Article 4, nor is it covered

\footnotetext{
1377 European Commission (2010e), para. 20.

1378 For further discussion about the criteria, vide supra at I4.4.2.

1379 Vide infra at II8.3.3.2

1380 Articles 84-85 of the proposed CCCTB Directive.
} 
by Article 6 of the proposed CCCTB Directive. ${ }^{1381}$ Hence, the CFC provision relies on the definition provided for by the third country, despite whether or not there is a DTC or exchange of information agreement applicable between the relevant States. What is clear is that if a company is considered to be a CCCTB resident under Article 6 of the CCCTB proposal, the CFC rule contained therein does not apply to an entity that was initially deemed to be resident also in the third country. Apart from this, from the author's perspective, the fact that, in case of the existence of a DTC between the relevant Member State and the third country, the CFC rule is dependent on the definition of residence under the third country's law makes the rule vulnerable to manipulation. Consequently, it may be more reasonable to provide for a specific list of criteria - such as the place of incorporation, registered office, place of effective management - to determine under which conditions an entity would be, prima facie, deemed to be resident of a third country, subject to commitments undertaken by Member States in their DTCs with third countries. ${ }^{1382}$

Since the provision does not distinguish between resident and nonresident taxpayers, the income of the CFC may be included in the tax base of a permanent establishment of a non-resident company, provided that the shares of the $\mathrm{CFC}$ are attributed to the permanent establishment based either on a DTC or national (CCCTB/AOA) rules. If there is a DTC between the State of the head office and the State of the permanent establishment, double taxation of such CFC income should be normally avoided (Article 23 of the OECD MC). However, if there is no DTC between the relevant States, both the State of the head office as well as the State of the permanent establishment could tax such income to the extent that it is attributed to the permanent establishment under national law (CCCTB rules). Even though Member States have a wide network of DTCs, it is still incomplete. Against this background, the group should take these peculiarities into account when structuring its businesses. (Example 41: CFC income is attributed to a permanent establishment of a nonresident company)

\footnotetext{
1381 Article 6 of the proposed CCCTB Directive deals only with the conditions opting for the CCCTB. With regard to residency, it only defines when a company is deemed to be resident in a Member State in paragraphs 3 and 4 therein. For further discussion, vide supra at I4.2.2.

1382 Such a rule may need to be supplemented by an escape clause, where an entity could prove that it is deemed to be resident in another country.
} 
Example 41: CFC income is attributed to a permanent establishment of a nonresident company

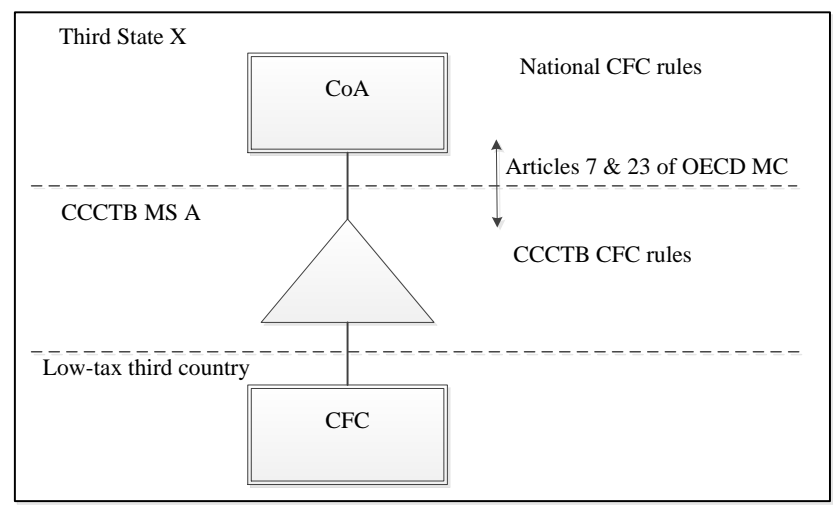

The third condition for taxing a CFC's income under the CCCTB system addresses the type of income realised by the CFC. This condition includes two cumulative sub-tests: (i) more than 30 per cent of the income accruing to the entity falls within at least one of the categories listed in Article 82(3) of the proposed CCCTB Directive; and (ii) more than 50 per cent of the category income comes from transactions with the taxpayer (the parent company) or its associated enterprises. Although Article 82(3) does not explicitly limit its scope to passive income, it lists categories of income that are often considered to be of a passive nature for taxation purposes. In particular, Article 82(3) includes interest and royalty income, dividends and capital gains from the disposal of shares, income from movable property, income from financial activities and income from immovable property ${ }^{1383}$ subject to DTC limitations. In fact, focusing on the nature of the income is a common feature of national CFC rules, especially if they were based on the transactional approach (note that the CCCTB system takes the entity approach). Nevertheless, it was noted earlier that when CFC rules target only (or mainly) passive income, the taxation of such income based on CEN becomes weaker. It is noteworthy that the ECOFIN has not

1383 Under DTCs based on the OECD MC, a difference must be made between income from immovable property (Article 6 of the OECD MC) and income from the realisation of immovable property (Article 13(1) of the OECD MC). In both cases, the State of situs has the primary taxing right over the income. The wording of Article 82(3)(e) does not provide for a clear answer whether both income from immovable property (such as rent) as well as capital gains are included in the tax base of a CCCTB taxpayer. 
considered passive income as an indicator suggesting that profits may have been artificially diverted to a CFC in its 2010 resolution on antiabuse. ${ }^{1384}$ Instead, the ECOFIN has focused on the existence of genuine economic activities. Hence, the ECOFIN approach supports the correct application of CEN. In any event, it is worth noting that if there is no exchange of information between the State in which the CFC is located and the relevant CCCTB Member State, it is highly unlikely that the tax authorities of that Member State are able to determine the proportion of passive income derived by the CFC. Importantly, the provision also does not require the CCCTB resident taxpayer to cooperate in this respect. In such a case, the application of the CFC provision may turn out to be difficult to apply in practice.

The inclusion of a rather comprehensive list of (passive) income finds some support, because it excludes companies that are assumed to be carrying on genuine economic activities. Despite its extent, it leaves some uncertainty. For example, it is not clear whether Article 82(3)(e) includes income from capital gains derived through the alienation of immovable property. ${ }^{1385}$ DTCs based on the OECD MC distinguish income from immovable property (Article 6 of the OECD MC) from income from the realisation of immovable property (Article 13(1) of the OECD MC). In both cases, the State of situs has the primary taxing right over the income. The wording of Article 82(3)(e) does not provide for a clear answer whether both income from immovable property (such as rent) as well as capital gains are included in the tax base of a CCCTB taxpayer. From the author's perspective, "income from immovable property" does not include capital gains, because the latter reflects the increase in value of an immovable property rather than being an income derived "from" it. ${ }^{1386}$ However, the exclusion of capital gains may make the CCC tax base vulnerable, because CCCTB taxpayers may be tempted to hold (and alienate) real

\footnotetext{
1384 Council of the European Union (2010), 2. Note that this was not even under question, as appears from the draft resolution, 4.

1385 The proposed CCCTB Directive does not provide for a definition of "immovable property", while Article 6 the OECD MC makes a reference to the domestic law of the contracting States. However, the absence of a uniform definition in the Directive should not imply that the definition will have the meaning as provided under the domestic law of the relevant Member State. On the contrary, through the introduction of the Directive, the term will become part of EU secondary law and will be subject to interpretation by the CJEU when referred for a preliminary ruling.

1386 Also, Tenore seems to share the view that the wording "income form immovable property" does not include capital gains. Tenore (2012), 309.
} 
estate through CFCs. In such instances, the verification of an abusive transaction could be caught by the CCCTB GAAR. In any event, it may be reasonable to supplement the provision to include capital gains.

For the purposes of calculating the 30 per cent threshold, assume (Example 42: Income of a CFC) that a CCCTB resident company $(\mathrm{CoA})$ has a subsidiary in a low-tax territory $(\mathrm{CFC})$, which together with CoA holds shares in a CCCTB resident company (CoB). CoA and $\mathrm{CoB}$ form a CCCTB group. In the case of option (1), the total income of the $\mathrm{CFC}$ is 1,000 and is comprised of (i) dividends from $\mathrm{CoB}$ in the amount of 200; (ii) interest from third parties in the amount of 100; and trading income in the amount of 700. In the case of option (2), the total income of the CFC is also 1,000 and is comprised of (i) dividends from $\mathrm{CoB}$ in the amount of 400; (ii) interest from third parties in the amount of 200; and trading income in the amount of 600.

Example 42: Income of a CFC

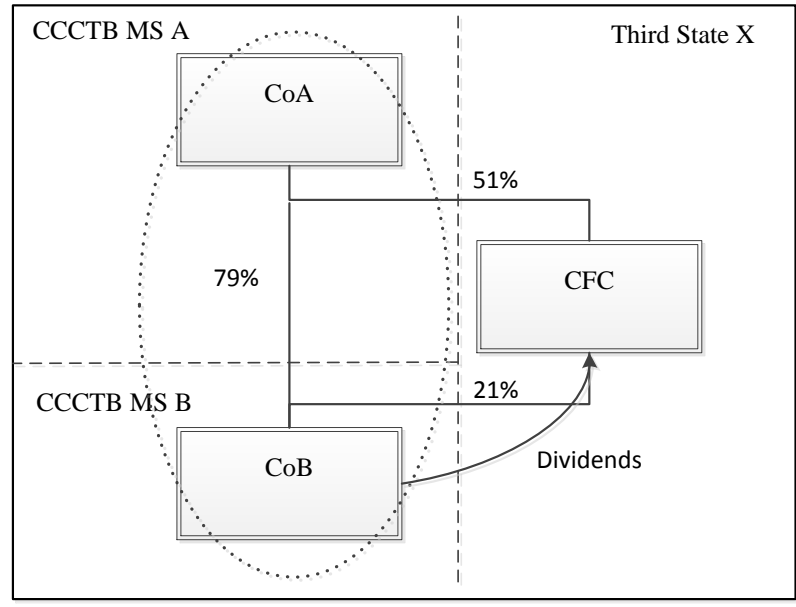

\begin{tabular}{|l|c|}
\hline \multicolumn{2}{|c|}{ Option (1) } \\
\hline Type of income & Amount \\
\hline Dividends from CoB & 200 \\
\hline Interest from third parties & 100 \\
\hline Trading income & 700 \\
\hline Total & 1000 \\
\hline
\end{tabular}

\begin{tabular}{|l|c|}
\hline \multicolumn{2}{|c|}{ Option (2) } \\
\hline Type of income & Amount \\
\hline Dividends from CoB & 350 \\
\hline Interest from third parties & 50 \\
\hline Trading income & 600 \\
\hline Total & 1000 \\
\hline
\end{tabular}


For the purposes of determining whether the CFC rule applies, one has to, first, examine whether 50 per cent of the listed income comes from transactions with associated enterprises (Article 82(3)). Only those categories of income, as established in the first step, shall be taken into account for the purposes of calculating the 30 per cent threshold (Article 82(1)(c)). Hence, in the first option, only 20 per cent of the entity's category income is derived from transactions with associated enterprises (as defined in Article 79 of the proposed CCCTB Directive) - i.e. (i) $200 / 300>50$ per cent, (ii) 200 out of $1,000<30$ per cent. Consequently, in this example, the income of the CFC would not be caught by the CCCTB CFC rule. On the contrary, the income of the CFC would be caught by the CFC rule in the second example, because 35 per cent of the listed income is derived from transactions with associated enterprises - i.e. (i) 350/600 $>50$ per cent, (ii) 350 out of 1,000 > 30 per cent.

Also in the example, if the CCCTB Member State B levies a withholding tax on dividends paid to the $\mathrm{CFC}$, the dividend income of the CFC will be subject to double taxation in the CCCTB jurisdiction. In fact, both economic and juridical double taxation would occur. More specifically, economic double taxation will arise, because the dividend will be, first, subject to a withholding tax at the level of the CFC in Member State B and, second, included in the CCC tax base. (Temporary) Juridical double taxation will occur, because the income will be, first, non-deductible from the CCC tax base in Member State B and, second, it will be included in the CCC tax base due to the application of the CFC provision. The juridical double taxation will be eliminated when the CFC distributes dividends and the corresponding amount will be deducted from the tax base of the CCCTB resident according to Article 83(4) of the Proposal. Furthermore, if the $\mathrm{CFC}$ had received dividends from another CFC (CFC 2) of a member of the same CCCTB group, the income would be double taxed in the CCCTB jurisdiction. Indeed, the profits of the first CFC would be taxed at the CCCTB resident company's level and thereafter included in the CCC tax base due to their distribution to the other CFC, whose income is also captured by the CFC rule. Such double taxation would be avoided if the CFCs distributed dividends, based on Article 83(4) of the proposed CCCTB Directive. These issues are summarised in the table below.

Table 4: Double taxation of CFC income 


\begin{tabular}{|c|c|c|c|c|}
\hline Situation & $\begin{array}{c}\text { CCCTB MS A } \\
\text { (CoA) }\end{array}$ & CCCTB MS B & $\begin{array}{c}\text { Third State X } \\
\text { (CFC) }\end{array}$ & $\begin{array}{c}\text { Third State Y } \\
\text { (CFC 2) }\end{array}$ \\
\hline $\begin{array}{c}\text { Economic double } \\
\text { taxation }\end{array}$ & $\begin{array}{c}\text { inclusion CCC tax } \\
\text { base }\end{array}$ & WHT & $\begin{array}{c}\text { Inclusion (possible } \\
\text { exemption) }\end{array}$ & $\mathrm{n} / \mathrm{a}$ \\
\hline $\begin{array}{c}\text { Juridical double } \\
\text { taxation }\end{array}$ & $\begin{array}{c}\text { inclusion CCC tax } \\
\text { base }\end{array}$ & non-deductible & $\begin{array}{c}\text { Inclusion (possible } \\
\text { exemption) }\end{array}$ & $\mathrm{n} / \mathrm{a}$ \\
\hline Two CFCs & $\begin{array}{c}\text { double inclusion } \\
\text { CCC tax base }\end{array}$ & n/a & $\begin{array}{c}\text { Inclusion (possible } \\
\text { exemption) }\end{array}$ & $\begin{array}{c}\text { non-deductible / } \\
\text { WHT }\end{array}$ \\
\hline
\end{tabular}

One can argue that dividends received by a CFC should be treated equally to dividends received directly by a resident corporation from a foreign corporation. ${ }^{1387}$ Under the CCCTB rules, this would imply the application of the exemption method under Article 11(c) of the proposed CCCTB Directive. Although the elimination of double taxation is arguably not required under international taxation principles and EU law, it seems nevertheless appropriate to exclude dividends which have already been taxed in the CCCTB jurisdiction (such as income of CFC 2 in the example above), from the income of the CFC. Such an approach would contribute to the achievement of $\mathrm{CIN}$ and thereby enhance the attainment of the Lisbon objective of making the EIM more attractive for foreign investment.

The forth sub-condition functions more like a safe harbour clause rather than a criteria per se. In particular, where the principal class of shares of the entity is regularly traded on one or more recognised stock exchanges, it is excluded from the application of the CFC rule. In other words, the criteria serves as a means of ensuring economic reality in the third country. Importantly, this criterion should not be interpreted as targeting wholly artificial arrangements, which is clear from the jurisprudence of the CJEU in the context of the interpretation of the freedom of establishment. It is noteworthy that the Danish presidency proposed to eliminate that condition, because, according to the presidency, such an exemption does not affect the need for CFC taxation. ${ }^{1388}$

Last, whereas CFC rules in the CCCTB Directive apply (obviously) only at the level of companies (whether or not they are residents within the CCCTB), some national CFC rules also apply at the level of individuals, i.e. the ultimate shareholder. However, such taxation is outside the scope of the CCCTB Directive as the latter applies only to corporate tax arrangements. As a result, the income of the CFC is

1387 Arnold (1994), 53.

1388 Council of the European Union (2012), Article 82 and comments therewith. 
subject to economic double taxation: once, at the group level according to the CCCTB rules and, again, at the ultimate shareholder's level according to the domestic law of its residence State. However, the CCCTB working paper reveals that the general idea should be that CFC income "can only be included once in the taxable base, regardless of the way it is included", i.e. it should not lead to higher taxation (than in a domestic situation) or be doubletaxed. 1389 The question is whether the "taxable base" includes only the taxable base calculated according to CCCTB rules or whether it also includes the taxable base, including that of an individual, under Member States national rules. Article 7 of the proposed CCCTB Directive prescribes that where a qualifying company opts for the CCCTB system it shall cease to be subject to all national corporate tax arrangements in respect of all matters regulated by this Directive. The question is whether the CFC clause contained in the CCCTB Directive automatically eliminates the application of national CFC rules that apply at the level of the individual shareholder. In other words, does a CFC rule qualify as a "corporate tax arrangement" despite whether it is applied at the level of an individual or that of a company?

The author explained earlier that CFC rules comply with international tax principles only if they apply at the level of the resident recipient. Otherwise, countries would infringe the national sovereignty of other countries. Consequently, States employing $\mathrm{CFC}$ rules tax the worldwide income of the recipient and not that of the CFC. As a result, Article 7 of the proposed CCCTB Directive does not preclude the application of Member States' national CFC rules if they apply at the level of the ultimate individual shareholder. Clarifying the hierarchy between national CFC rules covering personal income taxation and the CCCTB rules concerning corporate income taxation in the CCCTB Directive would likely infringe the principle of subsidiarity, because the CCCTB should not deal with personal income taxation. In that case, the discretion whether or not to eliminate double taxation on such income would remain with each national legislator. On the other hand, one could argue that Member States will have to take measures to adjust their national systems accordingly in the context of implementing the CCCTB. Hence, these implementing measures would involve changes in individuals' income

1389 European Commission (2008a), para. 32. 
tax if this were necessary for the proper transposition of the Directive into their national law.

\subsubsection{COMPUTATION OF CFC INCOME}

According to Article 83 of the proposed CCCTB Directive, the income of the CFC is calculated according to the rules of the CCCTB Directive. Importantly, its losses are not taken into account but are carried forward and taken into account in the subsequent years. The latter is in line with the entity approach on which the CFC rule in the proposed Directive has been based. If it used the transactional approach, the consideration of losses would have less relevance. Furthermore, the loss carry-forward rule is not limited in years, despite whether such a limitation exists in the third country.

Further, non-distributed income of the CFC is taken into account in proportion to the entitlement of the taxpayers share in the profits of the foreign entity in the end of the tax year of the foreign entity. However, appropriate adjustments are made when the CFC distributes income or if the CFC is disposed of, so that the CFC's income is not taxed again in the later phase. This rule aims to prevent economic double taxation, which would occur if the same amount of income were included in the CCC tax base as part of the CFC's income and as a profit distribution or capital gains in a later stage. The distributed dividends and capital gains will receive a credit for the taxes paid in the third country (Article 76 in conjunction with Article 73). Since the CFC rule targets artificial shift or retention of profits in a low tax country, the distribution of dividends or the sale of shares of the CFC goes beyond the aim of the rule.

Another question is whether and, if so, how the CCCTB system should deal with the elimination of double taxation in cases in which the income of the CFC has been taxed in another country. Generally speaking, if resident taxpayers are deemed to have earned the CFC income, they should be entitled for relief for foreign taxes paid by the CFC. ${ }^{1390}$ The proposed CFC rule in the CCCTB Directive is based on the so-called "piercing the corporate veil theory". Hence, the CFC income attributed to the resident shareholder should be deemed to have been earned directly by the latter. For example (Example 43: Taxes paid in third States), assume that a CCCTB

1390 Arnold (1994), 64. 
resident company holds shares in a $\mathrm{CFC}$, which received interest income from a non-CCCTB Member State (in the setting of an enhanced cooperation). The income has been subject to a withholding tax in the latter jurisdiction.

\section{Example 43: Taxes paid in third States}

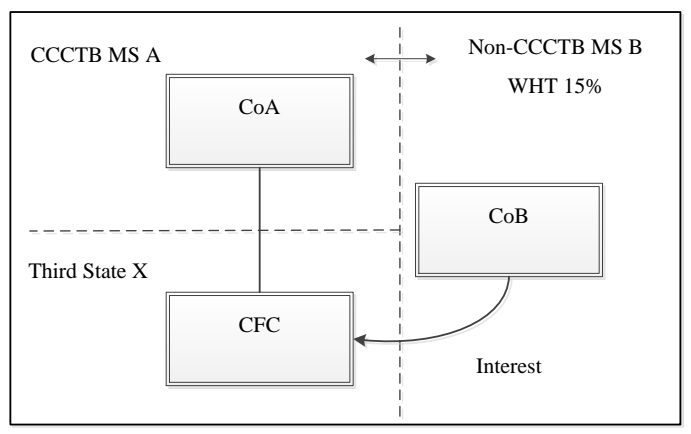

As discussed in the previous Chapter of this dissertation, when income has been taxed in another country, the taxpayer will normally be entitled to a credit for the foreign taxes paid (Article 76 of the proposed CCCTB Directive) or exemption (Article 11 of the proposed CCCTB Directive) of the foreign income in the CCCTB jurisdiction. Against this background, given that the $\mathrm{CFC}$ provision deems all the income of the CFC to be incurred directly by the taxpayer, it seems fair to argue that the relevant CCCTB Member State A should provide a credit for the foreign taxes. Therefore, the Member States should distinguish between income that is normally subject to the exemption method and that is subject to the credit method. In the example above, if there were a DTC between the relevant CCCTB Member State A and the non-CCCTB Member State B, the latter would not be limited to levying withholding taxes on the income (Article 10 of the OECD MC): from country B's perspective, the income has not been paid to CoA but to the CFC. In the same vein, the requirements of the Parent and Subsidiary Directive would not apply from the perspective of Member State B. The same conclusion could not be drawn if the CFC rule was based on the so-called "deemed dividend distribution theory". In such a case, the CFC income, despite its origin, would always be considered to be distributed to the shareholder, rather than derived by it directly. In the latter situation, the application of the exemption method for all the dividends distributed by the CFC is appropriate. 
Last, the author already discussed earlier that the Danish Presidency proposed to apply the CFC rule also to low-taxed foreign permanent establishments (i.e. the "semi-CFC" rule, as discussed in the previous Chapter). If the income of the permanent establishment is taxed in the third country and in parallel it is included in the CCC tax base, the CCCTB resident will receive a credit for the foreign taxes paid in accordance with Article 76 (in conjunction with Article 73). Despite the credit, the author discussed earlier that the application of a "semi-CFC" rule to foreign permanent establishments would likely violate Member States' DTCs with third countries (if they are based on the OECD MC). ${ }^{1391}$

\subsubsection{EU ASPECTS}

Although several EU Member States have implemented CFC rules in their national law, they do not apply them to purely domestic situations. In the landmark decision Cadbury Schweppes, the CJEU held that a national law that applied CFC rules to parent companies with foreign subsidiaries, but did not do so in case of parent companies with domestic subsidiaries, constituted a restriction on the freedom of establishment. However, such a restriction was justified on the ground of prevention of abusive practices, provided that the specific object of such a restriction is to prevent conduct involving the creation of wholly artificial arrangements. ${ }^{1392}$

Given that CFC rules usually imply that the parent company has a definite influence and control over its subsidiaries according to the Baars formula (i.e. controlling holdings), ${ }^{1393}$ the provisions of the freedom of establishment are normally at stake. ${ }^{1394}$ As will be argued below, due to the absence of a third country dimension in freedom of establishment, parent companies with subsidiaries outside the EU cannot rely on Article 49 of the TFEU to challenge the application of the CCCTB's CFC rules if they are indeed limited to apply to controlling holdings exclusively. Nevertheless, if those CFC rules would also apply to situations and transactions between related parties in which these parties does not have a definite influence over each other, the CFC rules would also need to comply with the provisions on the freedom of capital movement, as Article 63 of the

\footnotetext{
${ }^{1391}$ For further discussion, vide supra at II7.4.2.3.

1392 Case Cadbury Scbweppes (C-196/04), para. 55.

1393 Case Baars (C-251/98), para. 22.

${ }^{1394}$ European Commission (2010e), para. 20.
} 
TFEU also covers movements involving third countries. In such a case, the CFC rules may only be applied with regard to wholly artificial arrangements, subject to an exception where there is no adequate exchange of information with the third country concerned. ${ }^{1395}$

According to the CJEU's Grand Chamber judgment in FII Group Litigation II 1396, Article 63 of the TFEU is not liable to preclude provisions that exclusively target situations of establishment. Against this background, the material question is whether the $\mathrm{CFC}$ rules contained in the proposed CCCTB Directive target only cases of definite influence so that the CFC rules cannot be challenged in situations involving third countries. In the event that the CCCTB's CFC rules would not apply exclusively to situations involving controlling holdings, but also to other participations, the CCCTB's CFC rules would be liable to be precluded by Article 63 of the TFEU.

It is evident that the CCCTB's CFC rules do not apply exclusively to portfolio investments. If they did, FII Group Litigation II teaches that Article 63 of the TFEU would apply to the exclusion of Article 49 of the TFEU. In that regard, it is evident, without the need of further discussion, that the CCCTB's CFC rules do not apply to portfolio investments.

However, if the CCCTB's CFC rules would apply to a class of holdings, which is not limited to controlling holdings in terms of Baars, the Court's ruling in FII Group Litigation II requires that the compatibility of those CFC rules with EU law should also be evaluated against Article 63 of the TFEU in parallel to Article 49 of the TFEU, irrespective of the nature of the holding according to the facts in the case at issue. The reason is that the term "movement of capital" covers not only portfolio investments but also any direct investment in view of Article 64 TFEU. ${ }^{1397}$ Even though Advocate General Cruz Villalón admittedly stated that this judicial rule is a departure from previous case law with regard to situations involving third countries, insofar as it abolished a double test on the basis of the aim of the legislation and the facts of the case in favour of a

\footnotetext{
${ }^{1395}$ European Commission (2007d), 8.

${ }^{1396}$ FII Group Litigation II (C-35/11).

1397 Ibid., paras. 101-103.
} 
singular test on the basis of the aim of the national legislation, ${ }^{1398}$ it is, however, equally true that there is no direct evidence in the Court's previous case law in the field of direct taxes, up to FII Group Litigation II, to preclude the application of Article 63 of the TFEU with decisive reference to the facts of the case at issue. ${ }^{1399}$

Direct investments include, as indicated in Directive 88/361,1400 participations in companies with a view to establishing or maintaining lasting economic links. ${ }^{1401}$ That objective presupposes that the holding enables an effective participation of the shareholder in the management or control of the company concerned. In that context, it is evident that definite influence over a holding presupposes effective participation. Effective participation may be granted to the shareholder pursuant to the provisions of the national laws relating to companies limited by shares or otherwise. The open end of "otherwise" effective participation may, in view of the prior criterion that refers to national company laws, be interpreted primarily from a legal perspective. ${ }^{1402}$ The main question is thus whether the scope of legal rights attached to the holding or the voting rights at issue are such to confer an effective participation in management and control in the company concerned. In that context, it may also be necessary to evaluate the scope of legal rights of the shareholder in the case at hand relative to other shareholders in the same company, according to the circumstances of the case.

A "definite influence" (i.e. a controlling holding) is a higher threshold than "effective participation", although as stated before "definite influence" presupposes "effective participation". Establishment is thus the type of direct investment that allows a "definite influence" over holdings, but an "effective participation" in a holding does not need to be an establishment per definition (i.e. not every direct investment is an establishment). The specific issue to evaluate in order to decide the applicability of Article 63 of the

\footnotetext{
1398 Opinion AG in Case C-47/12 Kronos (pending), para. 34-44.

${ }^{1399}$ For a complete analysis of the previous case law in relation to direct taxation, see Schaper (2013), 82-98.

1400 Council Directive 88/361/EEC for the implementation of Article 67 of the Treaty.

1401 Cases FII Group Litigation I (C-446/04), para. 182; Holböck. (C-157/05), para. 35; Commission v Germany [Volkswagen] (C-112/05), para. 18.

1402 It remains arguable whether the open end of "otherwise" effective participation leaves an assessment of the facts of the case as a possibility.
} 
TFEU to the CCCTB's CFC rules is whether those rules may also be applied to effective participations other than controlling holdings.

The CCCTB CFC rules in Article 82(1)(a) foresee three noncumulative criteria for a company to be caught by the rule, i.e. if the taxpayer holds directly or indirectly more than 50 per cent of the voting rights, owns more than 50 per cent of the capital or is entitled to more than 50 per cent of the profits of that entity. The two former conditions - capital holding and voting rights - clearly confer an effective participation in the management and control which gives "definite influence" over the subsidiary. In contrast, the latter condition - entitlement to profits - is not similar to the two former criteria, in that having such a right does not provide a participation in management or control directly. Nonetheless, a 50 per cent profit share is typically a strong indication of a lasting economic link, thus falling within the concept of direct investment. Furthermore, a 50 per cent-profit share may confer a definite influence over the holding, but this is certainly debatable (e.g. in case of usufructs). In any event, in the light of the two other conditions, the purpose of the CFC rules in the proposed CCCTB Directive is clearly to apply exclusively to situations of establishment. Although the letter may give room for discussion, the aim and purpose of the provision is rather precise. Agreeing with this understanding, the CCCTB CFC rules do not apply to effective participations other than controlling holdings and thus cannot be challenged against the free movement of capital as laid down in Article 63 of the TFEU. ${ }^{1403}$

Despite the above, if one insists that a 50 per cent-profit entitlement does not provide a definite influence over the company, the CFC rules contained in the proposed CCCTB Directive would restrict the free movement of capital to the extent that it is not targeted exclusively at wholly artificial arrangements. The CCCTB's CFC rules have been drafted in a way that presumes abuse, without allowing the taxpayer to produce evidence that the CFC was established for the purposes of genuine economic activity. This irrefutable presumption, though not a forbidden general one that applies in every situation in which free movement of capital is exercised, appears contrary to the Cadbury Schweppes standard on justification for the prevention of abusive practices and fraud. The absence of a possibility for the taxpayer, without subjecting him to

1403 Case FII Group Litigation II (C-35/11). 
undue administrative constraints, to bring forward evidence to the contrary on each occasion on which an abuse is presumed goes further than necessary for the prevention of abusive practices and fraud. ${ }^{1404}$

As already discussed, in the case of third countries, the restriction may nevertheless be justified on the grounds of prevention of abusive practices and fraud if there is no appropriate exchange of information with the third country which would enable the tax administration of the EU Member State to evaluate the documentary evidence submitted by the taxpayer. ${ }^{1405}$ However, if an agreement for the exchange of information exists with the third country, the restrictive measure could be considered to be disproportional to its aim. In such a case, the taxpayer must be allowed to bring forward evidence to the contrary.

It is worth noting that, unlike the interest limitation rule, the proposed CFC rule does not include a general escape clause based on the existence of an agreement on the exchange of information on request similar to the exchange of information based on the Mutual Assistance Directive. The escape clause under the CFC rule is limited only to entities from EEA Member States. ${ }^{1406}$

\subsubsection{THE US EXPERIENCE WITH CFC TAXATION}

In order to combat a state's tax base erosion due to the use of corporate tax shelters, a significant number of US states have adopted unitary taxation and combined reporting system for integrated businesses. Nevertheless, under the combined reporting system, two means of avoiding taxes are still feasible. First, a multinational group might try to include or exclude some activities from a common enterprise to minimise its tax liability. ${ }^{1407}$ Second, a multinational group may try to manipulate the factors of the apportionment formula. Hence, the poorer the apportionments factors are defined, the more space to manoeuvre the taxpayers have.

A worldwide combined reporting method normally does not require the implementation of specific anti-avoidance rules. However, if

\footnotetext{
${ }^{1404}$ Cases Thin Cap Group Litigation (C-524/04), para. 82; SLAT (C-318/10), para. 50.

${ }_{1405}$ Case FII Group Litigation I (C-446/04), paras 170-171.

1406 Article 82(2) of the proposed CCCTB Directive.

${ }^{1407}$ McIntyre (2004), 935.
} 
worldwide combined reporting is made elective, states risk eroding their tax base. This is because foreign-source income is generally not included in the unitary group's tax base when a taxpayer has elected for its income to be apportioned on the water's edge basis. Hence, while elective water's edge combined reporting aims at decreasing administrative costs for the combined report for state, because the state will be able to avoid auditing the accounting documents of foreign affiliates, it inevitably reduces the effectiveness of combined reporting on preventing tax avoidance and tax base erosion via certain types of tax shelters. ${ }^{1408}$ To reduce tax avoidance opportunities, some states have adopted similar rules to the US federal subpart F rules and include passive income or "portable" income of certain foreign affiliates located in tax havens in the tax base, even if the group has opted for the water's edge combined reporting. Such an approach has been endorsed by the MTC, which in its model statute for combined reporting suggests water's edge election with specific exceptions, such as CFC's income.1409 According to the MTC, for the purposes of combined reporting, a tax haven is a jurisdiction which has been identified as a tax haven or as having a harmful preferential tax regime, as identified by the OECD, or exhibits the characteristics established by the OECD in its 1998 report entitled harmful tax Competition: An Emerging Global Issue ${ }^{1410}$ as indicative of a tax haven or as a jurisdiction having a harmful preferential tax regime, despite whether it is listed by the OECD as an uncooperative tax haven or not. ${ }^{1411}$

The federal subpart F rules, founded in 1962, establish a statutory regime under which the tainted income of foreign subsidiaries is imputed to their domestic shareholders on a current basis. The subpart F rules, thus, eliminate the "deferred" taxation of certain types of business income earned by US shareholders through CFCs. Under the subpart $\mathrm{F}$ rules, a deemed dividend equal to the US shareholder's pro rata share of the CFC's tainted earnings must be included in the shareholder's gross income.1412 A foreign entity is classified as a CFC if US shareholders own (i) more than 50 per cent of the combined voting power of all classes of stock or (ii) more than 50 per cent of the total value of the stock of the foreign

\footnotetext{
1408 Fox et al. (2009), 405.

1409 MTC (2006), Section 5.

1410 OECD (1998).

1411 MTC (2006), Section 1.I.

1412 Schadewald \& Misey (2005), 137.
} 
corporation. ${ }^{1413}$ A US shareholder in respect to subpart F is any US person $^{1414}$ owning $^{1415}$ at least 10 per cent of the total combined voting power of all classes of voting stock of the foreign corporation. ${ }^{1416}$

\subsection{CONCLUSIONS}

It has been jurisprudentially confirmed that direct taxation falls within the competence of the Member States. Consequently, Member States normally remain free to decide on their domestic anti-abuse rules. However, the introduction of a new corporate tax system at the EU level - the CCCTB - necessitates, but does not require, the establishment of a new set of anti-abuse rules that would apply to cases in which the CCC tax base is affected. The need for anti-abuse rules for transactions within a CCCTB group is smaller compared to transactions involving third countries, because the group taxation system has not been built on the separate entity/arm's length principle. Instead, the consolidated profits of the group are shared between the group members based on a predetermined formula.

Despite the fact that EU primary law does not contain any anti-abuse provisions, it is clear that the doctrine of abuse does exist under Union law. The CJEU's jurisprudence recognises two categories of abuse under EU law: fraus legis (avoidance of national law) and improper use of rights granted under EU norms. These two categories form the EU doctrine of "abuse of rights", which seeks to prevent a person from deriving a benefit, which, although formally compliant with a rule, pursues results that go beyond its objective. The Court has used the doctrine of abuse of rights in areas of harmonised tax law, where abuse means circumvention of law. Consequently, in this area, a taxpayer's right to invoke a certain norm in Union law can be restricted only if the provision conferring that right is relied upon for the achievement of an improper advantage that is contrary to the objective of that provision.

According to the Court's jurisprudence, in harmonised tax areas, abusive practices can be found if the taxpayer's action leads to (i) an accrual of a tax advantage, the granting of which would be contrary to the purpose of Union law (i.e. the objective test), and (ii) the essential

\footnotetext{
1413 IRS Code Sec. 957(a).

1414 As defined in IRS Code Sec. 957(c).

1415 As defined in IRS Code Sec. 958.

1416 IRS Code Sec. 951(b).
} 
aim of the transaction(s) concerned is obtaining a tax benefit (i.e. the subjective test). In non-harmonised tax areas, the Court has been reluctant to apply the principle of abuse of rights explicitly. Instead, it accepts tax avoidance as one of the justifications for a restriction of the fundamental freedom in questions. The Court opined in Centros that Member States have the right to take anti-abuse measures to prevent the improper circumvention of national law or to prevent individuals from improperly or fraudulently taking advantage of provisions of Union law. However, such measures cannot be applied indiscriminately, because they would run contrary to the proportionality principle. Since Emsland-Stärke, Member States are allowed to counter abusive practices only if the action of the taxpayer includes both an objective element and a subjective element. In the light of the foregoing, a taxpayer cannot invoke EU law only if his actions are actually abusive.

It is clear that EU secondary law cannot be contrary to EU primary law. Consequently, the drafting of the CCCTB anti-abuse provisions has to reflect the jurisprudence of the CJEU in the relevant field. Based on the latter, as long as a taxpayer's action does not include artificiality, tax-driven transactions are admitted for the purposes of primary and secondary EU law. Hence, the business purpose test should apply only where artificial elements, of an objective nature, are identified in the conduct of a taxpayer, and where the main purpose of the transaction is of a tax nature. ${ }^{1417}$

The proposed CCCTB Directive includes a separate chapter on antiabuse rules, which consists of a uniform GAAR and two ad hoc SAARs on interest deduction limitation and income of a CFC. Apart from these two provisions, the CCCTB proposal includes other provisions that provide for a shield to deal with potentially abusive transactions, such as the switch-over clause, etc. The inclusion of the GAAR and the SAARs into the CCCTB Directive implies that national anti-abuse measures that deal with the same matters will cease to be applicable based on Article 7 of the proposed CCCTB Directive.

The GAAR is enacted as a default rule, which targets cases of avoidance that the legislator could not envisage at the time it created the law. On the contrary, the SAARs target specific and well-known

1417 Jiménez (2012), 285. 
cases of abuse. The GAAR is not meant to apply to cases which the legislator has opted to fight against through SAARs, because this would go against the intention of the legislator as to where it would draw the limits of a SAAR. In other words, whereas the GAAR applies to abusive transactions, it cannot be used as a tool to circumvent the scope of the SAAR (e.g. to extend the application of the CFC provision to intra-EU situations). Absent any explicit hierarchy in the Directive, from the author's perspective, the GAAR should be applied to all artificial transactions that do not fall under the SAARs, despite whether the transactions at stake involve a domestic, intra-EU or a third-country entities. In such a case, the tax authorities are left with a broader base to deal with the limited scope of the SAARs that apply only to cases involving non-EU countries. Nevertheless, such an interpretation should not lead to the arbitrary application of the SAARs, which apply only to third countries, to intra-EU cases. On the other hand, a genuine commercial activity in a third country could, in certain cases, exclude the application of the SAAR due to the escape clause of the GAAR.

The general purpose of a GAAR is to promote taxation with a legislative purpose. Hence, in EU terms, a GAAR would fall under the doctrine of abuse of rights, so that it would preclude a person from deriving a benefit, which although being formally compliant with the rule pursues results that go beyond its objective. The core of the proposed CCCTB GAAR does not reflect this general aim. On the contrary, the CCCTB GAAR has been drafted on the jurisprudential concept of "wholly artificial arrangements", which has been used by the Court to challenge national anti-abuse rules against the fundamental freedoms. Thus, as it currently stands, the CCCTB GAAR does not properly deal with tax avoidance.

Some organisations have opposed to the introduction of a GAAR in general, because it allegedly reduces legal certainty for the taxpayers. Importantly, a GAAR can operate effectively to distinguish tax avoidance and tax planning only where the object or purpose of the relevant tax legislation is reasonably clear. ${ }^{1418}$ In any event, if the object and purpose of the substantive provisions of the Directive is apparent, a taxpayer's abusive action could be challenged based on the general EU principle of abuse of rights, as enunciated by the Court in cases concerning harmonised taxes. It seems that the

$1418 \operatorname{Duff}(2009), 494$. 
European Commission has recognised the weaknesses of the proposed CCCTB GAAR: in its recommendation against aggressive tax planning of late 2012, a GAAR has been drafted from a substantially different perspective. It is noteworthy that the recommended GAAR represents the latest thinking on the matter by the European Commission, because it has proposed the same definition in the proposal for a directive implementing enhanced cooperation in the area of financial transaction tax in early 2013.

The two ad hoc SAARs covered by the chapter of anti-abuse in the proposed CCCTB Directive provide for interest deduction limitation and taxation of CFCs. The interest limitation rule in Article 81 of the proposed CCCTB Directive does not contain a reference to abuse, but its essence still lies with the function of countering (tax-driven) abusive practices. According to the CJEU, a national measure that provides for objective and verifiable elements that allow national tax authorities to presuppose the existence of abuse does not infringe the fundamental freedoms, provided that it is proportional to its aim. From the author's perspective, the interest limitation rule provides for such criteria. However, the question is whether the measure is proportional to its aim, considering that it does not allow the taxpayer to provide evidence to the contrary that abuse did not exist. From the author's perspective, the aim of the ad hoc interest limitation rule can only be achieved if the proof provided by the taxpayer can be verified by obtaining information from the competent authorities of a third State based on a convention or an agreement. According to the Court, because of the different level of integration between Member States, the taxation by a Member State of economic activities having cross-border aspects, which take place within the Union, is not always comparable to that of economic activities involving relations between Member States and non-member countries. Consequently, as far as the interest limitation rule is concerned, the CCCTB provision does not violate the free movement of capital, because the existence of an agreement on the exchange of information on request automatically rules out the application of this limitation.

It is noteworthy that, due to the large number of TIEAs signed with third countries, the current proposal for an interest limitation rule appears to be without merit. Consequently, the Danish Presidency has proposed an alternative interest limitation rule, which would be applicable generally despite the residence of the creditor. The alternative rule makes the deductibility dependent on the amount of the positive tax base rather than the level of taxation of the recipient. 
It aims at reflecting the basic aim of Article 14 of the proposed CCCTB Directive that expenses related to tax exempt income cannot be deducted. Hence, the proposed rule does not address abuse as such.

The CFC rule catches only third-country subsidiaries that are subject to low taxation in their residence State. Despite the absence of a clear hierarchy between the GAAR and the SAAR, the tax authorities are precluded from extending the scope of the CFC rule to intra-EU cases through the arbitrary application of the GAAR. Nevertheless, the tax authorities would be entitled to catch abusive transactions involving intra-EU establishments through the GAAR.

From the author's perspective, the proposed provision could not be challenged against the free movement of capital, because its purpose is clearly to apply exclusively to situations of establishment. However, there is some room for discussion whether one of the three non-cumulative criteria of the CFC provision - the profit entitlement test - indeed targets definite influence, because it does not provide a participation in management or control directly. A 50 per cent-profit share usually (but not necessarily in each case) does confer a definite influence over the subsidiary. In the light of this understanding, the purpose of the proposed CCCTB CFC rule is to cover exclusively cases of definite influence and, consequently, thirdcountry establishments cannot rely on the free movement of capital to challenge the rule. In case of the opposite understanding, the provision may infringe the free movement of capital, because it does not include an escape clause even if there were an appropriate agreement on the exchange of information and mutual assistance. In fact, both the CJEU as well as the European Commission have recognised that CFC rules can restrict the free movement of capital. Nevertheless, although it is arguable, the purpose of the proposed CCCTB CFC rule is to apply exclusively to situations of definite influence and therefore it cannot be challenged against the free movement of capital.

If there is no exchange of information between the State in which the CFC is located and the relevant CCCTB Member State, it is highly unlikely that the tax authorities of that Member State are able to determine the proportion of passive income derived by the CFC. Importantly, the provision also does not require the CCCTB resident taxpayer to cooperate in this respect. In such a case, the application of the CFC provision may turn out to be difficult to apply in practice. 
PART IV: CONCLUSION 
At the starting point of this research, the European Commission, together with experts from Member States, businesses and academia, had already carried out the work on the CCCTB for several years. Despite an array of working documents on the matter, no directive had been proposed by the European Commission. Finally, in March 2011, under the lead of Commissioner Algirdas Semeta, the European Commission proposed a Directive for the CCCTB. The overarching purpose of the current dissertation was twofold: first, to analyse critically certain international aspects of the CCCTB, as regulated in the proposed Directive, to determine whether the current wording fits in the present global tax (legal) setting, among others, from the perspective of Member States' DTCs with third countries. Second, different from the proposed CCCTB Directive, which does not - and could not - reflect the possibility that the CCCTB system might be adopted (at least initially) through enhanced cooperation, the present dissertation follows that premise.

\section{MAIN FINDINGS OF THE RESEARCH}

The core of this dissertation lies in the five chapters of Part III, which scrutinise the provisions of the proposed CCCTB Directive in the light of the two central research questions. The main findings of these chapters are provided below.

\subsection{SubJECTIVE SCOPE OF THE CCCTB AND GROUP DEFINITION}

First, in the opinion of the author, the subjective scope as defined in Article 2(2) of the proposed CCCTB Directive with regard to thirdcountry companies unjustifiably complicates matters. This is especially true considering that the CCCTB aims, among other goals, to promote international investment and the attractiveness of the EU to foreign businesses and to simplify compliance for companies and administration for tax authorities. In addition to that, to require a third-country company to take a similar form to EU companies would prospectively infringe the non-discrimination clause of Member States' DTCs. In the light of the analysis, from the author's perspective, to assess whether a third-country entity could participate in the CCCTB system should be based only on the fact whether it is subject to business taxation in a CCCTB Member State. Hence, the 
criteria whether it is similar to listed EU company forms and whether it is "established" in a third country should be irrelevant.

Second, the definition of CCCTB residency based on three noncumulative criteria is broad and therefore works well from the perspective of both businesses and Member States. However, the absence of a specific tie-breaker rule with respect to third countries increases the possibilities for international tax planning and the erosion of Member States' tax bases. Against the analysis, from the author's perspective, the decisive factor for the purposes of the CCCTB system should be whether the place of effective management of the company is within the CCCTB jurisdiction rather than in an individual CCCTB Member State. This place of effective management should be understood to mean the "place of executive management", without prejudice to Member States' DTCs with third countries, until renegotiated.

The decision to provide a common definition of permanent establishment in the proposed CCCTB Directive is worth endorsing. In addition, one can understand the benefits of drafting the concept almost identically to that provided for in the OECD MC. For example, in such a case, the Member States can continue to search for guidance from the interpretation based on the official commentaries of the OECD MC. However, the fact that it has been blindly inspired by the definition set forth in the OECD MC can be subject to criticism, especially considering that it is rather unclear, as evidenced by the several disputes and international discussions. Furthermore, the over 100-year-old concept does not properly reflect the current state of international business taxation, especially in terms of ecommerce. Hence, instead of continuing with their current practice, which sometimes has to find the blurred line between the existence and non-existence of a permanent establishment, the CCCTB Directive could provide an opportunity to reconsider the definition and its interpretation. In addition to that, being a term in EU law, the CJEU would be in a position to provide for its interpretation if a case was brought before it. Of course, the introduction of a new definition could not require Member States to infringe their international obligations stemming from their DTCs with third countries until they are renegotiated. The current study shows that, in case of inbound investment, business profits of a non-resident could be included in the scope of the CCCTB system only if the non-resident had a permanent establishment under both the relevant DTC and the CCCTB Directive. In case of outbound investment into third 
countries, the scope of the definition as agreed upon in the specific DTC with the third country would always be decisive for the purposes of deciding the method for the elimination of double taxation of profits derived from the third country, i.e. the exemption method or the credit method.

Finally, the group definition in the proposed CCCTB Directive is comprehensive enough to allow businesses to participate in the system through either a subsidiary or a permanent establishment. Even though a group definition via economic integration would better reflect the economic reality of businesses, the strict participation criteria as set forth in the proposed CCCTB Directive is clearer, easier to apply and understandable considering the form of the EU. Indeed, a case-by-case definition of a group based largely on economic criteria fits better in a highly integrated market such as the US, where the states work under the regulatory umbrella of the federal state. Despite that exclusion of permanent establishments from the CCCTB framework would likely not infringe Member States DTC with third countries nor the freedom of establishment under the TFEU or the EEA Agreement, in the opinion of the author, the proposed CCCTB Directive correctly extends the CCCTB group definition to CCCTB-located permanent establishments. This is because such permanent establishments often perform functions that contribute to the overall profitability of a group of companies and there should be no particular reason for excluding them. Moreover, permanent establishments are often treated as separate entities for taxation purposes, such as under the AOA, which is also the approach in the proposed CCCTB Directive.

\subsection{THE CCC TAX BASE}

In terms of outbound investment, the author discussed the taxation of five different types of income: business income, dividends from FDI and portfolio investment, interest and royalty income and capital gains. First, capital gains are correctly treated as ordinary business income under the proposed CCCTB Directive. Indeed, it is generally accepted that profits and losses arising in a business should be treated equally, despite whether they are derived from working capital or other assets.

Second, business income derived through foreign permanent establishments is included in the scope of the proposed CCCTB Directive, even though such income is generally exempted in the 
hands of the CCCTB resident company. However, it is arguable whether the proposal provides the base exemption or tax exemption method for the elimination of double taxation of such income. From the author's perspective, there is more room - and reasons - to claim that the base exemption method is - or should be - applicable.

With regard to the taxation of dividends, interest and royalties, the author first concluded that these terms must be interpreted autonomously from Member States' national law as they form part of (secondary) EU law. The author noted that, while the proposed CCCTB Directive explicitly defines the notion of "interest", it does not do so regarding dividends or royalties. Nevertheless, through the definition of "interest" in the CCCTB Directive, one should be able to define "dividends" because the two types of income represent a return on the two possible ways of financing, i.e. loan financing and equity financing. Whereas both of these types of income are included into the CCC tax base, the distinction between them matters, above all, with regard to the elimination of double taxation.

With regard to royalties, the author concluded that the decision of the European Commission not to define royalties for the purposes of the Directive is justified in order to avoid conflicts arising from the parallel application of the Interest and Royalty Directive and Member States' DTCs with third countries. Indeed, the broader definition of royalties in the Interest and Royalty Directive and in Member States DTC, which use the definition of royalties as proposed in the UN MC, serves a different purpose. While the UN MC leaves more taxing rights to the source State of the royalties, the Interest and Royalty Directive limits them.

The proposed CCCTB Directive includes at least two explicit limitations on outbound investment, which, in the opinion of the author, may need to be reconsidered if the CCCTB were introduced in the setting of enhanced cooperation. First, CCCTB Member States would be limited in applying the switch-over clause to FDI dividends from non-CCCTB Member States due to the application of the Parent and Subsidiary Directive. This is because the switchover clause would be contrary to the existing Parent and Subsidiary Directive, which does not explicitly allow the application of the switch-over clause to income from distribution of dividends from qualifying EU subsidiaries. Second, the proposed interest limitation rule for intra-group financing would likely infringe the freedom of establishment in case CCCTB resident parent companies receive 
dividends from subsidiaries that meet the CCCTB group participation threshold but that are residents in non-CCCTB Member States.

With regard to inbound investment, the author focused on two types of income subject to CCCTB source taxation: business income derived through a CCCTB-located permanent establishment and income from immovable property. First, the problem with business income does not relate so much to the taxation of positive income allocated to the permanent establishment but more with regard to the elimination of double (non-) taxation. While typical national law taxes permanent establishments based on the AOA / arm's length principle, the CCCTB shares the common tax base based on a predetermined formula. If the residence State of the head office does not recognise that part of the income attributed to the permanent establishment has been taxed at the level of another CCCTB group member due to the application of the CСCTB sharing mechanism, double taxation arises. On the other hand, the different approaches to tax permanent establishment's income could also lead to double non-taxation, for example, where the DTC between the relevant Member State and the third country follows the OECD single entity approach applicable prior the 2010 amendments to the OECD MC. These inconsistencies with the current framework of international taxation could be solved only through the renegotiation of Member States DTC with third countries, if existing.

The problem of including the income from immovable property of non-residents located in CССТВ Member States arises because the current definition of a permanent establishment in the proposed CCCTB Directive does not deem a permanent establishment to exist in case the income is derived from a CCCTB-located immovable property. Hence, in such a case, companies would be able to choose - subject to the GAAR - whether they wish to include the income from the immovable property in the CCC tax base or be taxed under the relevant national law (due to the principle of situs). If the CCCTB Directive included such a provision, it would not imply the infringement of Member States' DTCs with third countries, because the income from immovable property is in any case subject to taxation at situs. Thus, the rights of third countries under DTCs would not be affected. Therefore, in the opinion of the author, it would be preferable to include such a fictitious notion of a permanent establishment. 
While entering the CCCTB is (tax) neutral, exiting it may lead to conflicts with Member States' obligations derived from DTCs with third countries. In particular, since the CCCTB applies the (potential) deferred taxation of an asset, in the opinion of the author, taxation of the asset on its disposal would infringe Article 13(5) of Member States' DTCs drafted on the OECD MC. A solution for this would be to levy immediate taxation of the asset, subject to collection of the tax on its actual disposition if done during the specified period. In a similar vein, taxation of outbound transfers of asset between the head office and its permanent establishment are in line with Member States' DTCs if they establish the tax base at the moment of departure of the asset rather than its sale. The CCCTB should provide for deferred taxation of such an asset if there is an agreement on the exchange of information between the CCCTB Member State and the third country, which allows the tax authorities to assess, clearly and precisely, whether such a benefit should be available and where the exchange of information is supplemented with an agreement of recovery of tax claims.

Finally, the proposed CCCTB Directive includes a specific provision regarding the transfer of assets towards third countries, which effectively forms part of the CCСТВ 'exit tax' rules. In this context, the scope of the definition of a permanent establishment is again particularly relevant. This is because the CCCTB Member States must preserve the rights of third countries that the latter derive from DTCs with CCCTB Member States. In addition, the "escape clause" of this provision may infringe the freedom of establishment under the EEA Agreement if the transfer involves a Member State that is a party to the EEA Agreement and there is an agreement for the exchange of information and an agreement on the recovery of tax claims between the CCCTB Member State and the third country. While the European Commission has considered that the transfer of an asset towards third countries may be considered in the light of the free movement of capital, the jurisprudence of the CJEU has not yet confirmed such understanding. ${ }^{1419}$ If one accepts that the freedom of capital of the TFEU is relevant in case of the exit tax at hand, the above conclusion should also apply to asset transfers to other third countries, other than EEA Member States.

${ }^{1419}$ European Commission (2006n), section. 5 
Consideration of losses within a group is one of the key issues of the CCCTB. However, consideration of losses where some group members are outside the CCCTB group is also relevant, especially in EU setting, where the CJEU has ruled on the matter in an array of cases. In case of outbound investments in the setting of enhanced cooperation, losses of subsidiaries in non-CCCTB Member States would have to be taken into account in the CCCTB Member State only under two conditions: (i) the parent company meets the participation thresholds as prescribed for eligible resident subsidiaries in the non-resident subsidiary; and (ii) the losses of the non-resident subsidiary are final. In the same vein, losses of such foreign permanent establishments should be taken into account at the level of the CCCTB head office only where they have become final. In both cases, a difference should be made between whether these (final) losses have been incurred during the group membership of the relevant parent company or the head office. In other words, losses incurred before the relevant taxpayer became part of the CCCTB group should be ring-fenced, while losses incurred during the membership should be taken into account at the level of the CCCTB group. Although this increases compliance and administration costs - which in principle runs contrary to the general aim of the CCCTB - it would properly reflect the reality taxing the CCCTB group in the relevant Member States.

Next, with regard to losses of foreign permanent establishment in general, the author concluded that the proposed CCCTB Directive foresees the application of the base exemption method for the elimination of double taxation of business income derived through a foreign permanent establishment, although there is room for discussion. The overarching idea of symmetrical treatment of positive and negative income implies that foreign losses connected to such a permanent establishment are also not taken into account in the CCCTB Member State. Nevertheless, in order to make the CCCTB attractive for foreign businesses and respect the company's ability to pay, from the author's perspective, the CCCTB should provide for the base exemption method accompanied by a temporary loss consideration through the application of an appropriate recapture rule. 
Elimination of double taxation is one of the key issues for achieving the Lisbon objectives. The proposed CCCTB Directive foresees the elimination of double taxation of foreign income through either the exemption method or credit method, depending on the type of income. The application of the credit method is often challenging and administratively burdensome, especially if it includes limitations, such as those foreseen in the proposed CCCTB Directive. Moreover, limitations for foreign credits, such as excess credit carry-over limitations such as foreseen by the CCCTB Proposal, likely lead to the infringement of the ability-to-pay principle. From the author's perspective, the absence of an excess credit carry-over leads to (lato sensu) juridical double taxation, which cannot occur in a domestic situation. In such a case, the country avoids double taxation in the domestic scenario, while it does not do so in case of cross-border investment. In the light of the foregoing, the author is of the opinion that certain credit limitations may infringe the ability-to-pay principle. Whereas ability-to-pay principle forms part of general principles of EU law, such restrictions should not be acceptable.

The exemption method generally eliminates double taxation of outbound investments and thus it complies with the general (EU) ability-to-pay principle. Such taxation would recognise the principle of net taxation of over business's lifetime and provide a competitive advantage in relation to other tax jurisdictions. Nonetheless, compliance with the ability-to-pay principle is achieved if the taxpayer is allowed to consider foreign losses in its residence State. Consequently, with regard to the income of foreign permanent establishments, the application of a base exemption method with a temporary loss consideration (loss recapture) is a better alternative for the CCCTB. In addition to that, the exemption method fits better with the idea of small open economies, such as in the EU Member States, which cannot afford to discourage their companies from investing in other markets. Furthermore, from an EU law perspective, the exemption method, which is often associated with CIN, seems to fit better with the requirement of freedom of establishment and free movement of capital in terms of outbound investment, although from the perspective of the CJEU both CIN and CEN are acceptable. Lastly, the general advantage of the exemption method is that it generally does not conflict with Member 
States' DTCs. Despite the advantages of the exemption method, a pure territorial system, in which all foreign income is (base) exempted in the residence State, is not desirable either. For example, interest and royalty payments are often tax deductible in the source State at the level of the payer, so that their exemption in the residence State would lead to double non-taxation, especially if the payment falls within the EU Interest and Royalty Directive.

With regard to the elimination of double taxation of business income derived through CCCTB-located permanent establishments, the application of the CCCTB system in parallel to the AOA may lead to double taxation of such income. This is because the CCCTB sharing mechanism uses different factors for attributing profits to a permanent establishment than the AOA. If the premise is that Article 7 of the OECD MC prohibits a higher level of taxation of permanent establishments than taxation under the $\mathrm{AOA}$, in order to preserve the rights of the third country under the relevant DTC, the CCCTB Member States would be limited in taxing the profits attributed to permanent establishments in their territory to the profits under the AOA. At the same time, the Member States would be obliged to renegotiate their conflicting DTCs with third countries to bring them in line with the EU acquis communautaire, subject to the grandfathering clause of Article 351 of the TFEU.

The switch-over clause in the proposed CCCTB Directive can be applied by the Member States only if the relevant DTC explicitly allows for such a provision. In the absence of such provisions in the DTCs, Member States would be obliged to, subject to the grandfathering clause of Article 351 of the TFEU to enter into negotiations to amend their DTCs with third countries.

\subsection{ANTI-ABUSE RULES}

The proposed CCCTB GAAR has not been drafted on the doctrine of abuse of rights, which precludes a person from deriving a benefit, which, although being formally compliant with the rule, pursues results that go beyond its objective. Instead, it is based on the the jurisprudential concept of "wholly artificial arrangements", which has been used by the Court to challenge national anti-abuse rules against the fundamental freedoms. This approach is subject to criticism, mainly because it applies indifferently at three different levels: domestic, intra-EU and international. Taking into account that abuse of rights forms part of the general principles of EU law, it is 
questionable whether there is a need for a specific GAAR in general. However, the absence of a specific GAAR could work if all Member States employed a GAAR in their national law.

Absent an explicit hierarchy in the (proposed) CCCTB Directive, the GAAR should be applied to all artificial transactions that do not fall under the SAARs. In the light of this conclusion, the tax authorities are left with a broader base to deal with the limited scope of the SAARs that apply only to cases involving non-EU countries. Nevertheless, such an interpretation should not lead to the arbitrary application of the SAARs to intra-EU cases. On the other hand, a genuine commercial activity in a third country could, in certain cases, exclude the application of the SAAR due to the escape clause of the GAAR.

The interest limitation rule in Article 81 of the proposed CCCTB Directive is in line with the CJEU's jurisprudence in that it provides for objective and verifiable elements that allow national tax authorities to presuppose that the existence of abuse does not infringe the fundamental freedoms. Moreover, it is proportional to its aim as it provides for an escape clause in case of the existence of an agreement on the exchange of information. It is noteworthy that, due to the large number of TIEAs signed with third countries, the currently proposed interest limitation rule appears to be without merit. Consequently, the Danish Presidency has proposed an alternative interest limitation rule, which would be applicable generally despite the residence of the creditor. The alternative rule makes the deductibility dependent on the amount of the positive tax base rather than the level of taxation of the recipient. It aims at reflecting the basic aim of Article 14 of the proposed CCCTB Directive that expenses related to tax exempt income cannot be deducted. Hence, the proposed rule does not address abuse as such.

The proposed CCCTB CFC rule could not be challenged against the free movement of capital, because the purpose of the rule is to apply exclusively to situations involving definite influence. However, the major flaw of the CFC rule is that it assumes exchange of information with the third country for the purposes of its application. If there is no exchange of information between the State in which the CFC is located and the relevant CCCTB Member State, it is highly unlikely that the tax authorities of that Member State are able to determine the proportion of passive income derived by the CFC. Importantly, the 
provision also does not require the CCCTB resident taxpayer to cooperate in this respect.

\subsection{LAST REMARKS}

The fact that the proposed CCСТВ system includes a sharing mechanism similar to the formula apportionment used in the US states naturally causes one to wonder what the EU can learn from the states in this field. However, the states' success with formula apportionment is largely because they can work under the regulatory umbrella of the federal system. Such a structure fits better with the principles of an internal market. On the contrary, EU Member States have not agreed on the federal system and hence lack such a possibility.

The introduction of the CCCTB would help the EU Member States to overcome this deprivation. Moreover, in addition to the formula itself, which is in fact different under the proposed CCCTB Directive, there is not much the EU Member States could learn from the US subnational experience with formula apportionment. The intergovernmental structures of the $\mathrm{EU}$ and the US differ fundamentally. In particular, while constitutional principles and the respective jurisprudence in the US concentrate on the protection of "commerce" from malicious state practices, EU law primarily focuses on the protection of (EU) citizens from discriminatory and restrictive Member States' laws in the light of the fundamental freedoms. Even the starting point of state taxation is different from that of EU Member States: the US states may tax business income if there is a sufficient link between the state and the person, object or activity ("nexus"), while most EU Member States tax based on residence and source principles. Hence, the focus of protection in the two cases is different. In addition, the US DTCs generally do not apply to state income taxes and corporate franchise taxes (except the nondiscrimination provisions), while EU Member States are bound by their DTCs. Hence, the CCCTB must consider the international obligations Member States have undertaken in their DTCs with third countries.

In case a DTC with a third country conflicts with the CCCTB rules, Article 351 of the TFEU requires Member States to enter into negotiations to eliminate such conflicts, subject to a grandfathering clause. Until the renegotiation takes place, Member States shall continue to observe the obligations, which they have undertaken vis- 
à-vis a third country under a DTC and respect the rights of the third country. In the light of the primacy of the EU law, the Member States must waive the rights that they derive from the conflicting DTC in line with the acquis communautaire (including instruments of secondary EU law), provided that this does not adversely affect the third country's rights under the same DTC. Hence, the Union's action in this field is limited. Furthermore, in case the CCCTB is introduced via enhanced cooperation, conflicts following from DTCs between participating and non-participating EU Member States would be dealt with in a similar manner as conflicts stemming from DTCs with third countries. Due to the fact that non-participating Member States would not be bound by the CССТВ acquis, their rights and obligations would not be affected by the provisions of the CCCTB Directive until changes in relevant DTCs take place.

Considering that bigger or smaller conflicts will arise from the simultaneous application of Member States' DTCs and the CCCTB, the question is whether these conflicts could be overcome through the renegotiation of the DTCs or whether a solution should be found at EU level, such as through an EU model DTC or a multilateral DTC between the EU and third countries, which would be limited to entities participating in the CCCTB. From the author's perspective, a multilateral EU DTC would be the most efficient means of dealing with the conflicts. However, despite the EU's international legal personality, its treaty-making power is only residual. The Treaties still confer the authority on the Member States to conclude DTCs, rather than conferring this authority on the EU as such. Also, the EU would not be allowed to negotiate a multilateral DTC with third countries based on the jurisprudentially developed concept of implied powers. In particular, an EU competence is implied if the Union has exercised its internal competence and the action at the Union level is necessary for the attainment of the Treaty objective. Therefore, the Union will have implied competence to conclude DTCs with third countries if the objectives of the CCCTB (and consequently the objectives of the Treaty) cannot be achieved otherwise. From the author's perspective, the current proposal for a CCCTB Directive entails little, if any, such conflict with third countries. Consequently, the Treaties do not confer the power on the EU to enter into a multilateral DTC with third countries to regulate in the field of the CCCTB. An explicit EU competence to negotiate DTCs with third countries would thus require an amendment of the Treaties. It is noteworthy that an EU Model DTC in this field would be possible based on the current Treaties. 
In the opinion of the author, the work carried out by the European Commission in relation to the CCCTB is remarkable. Even though the specific provisions of the proposed CCCTB Directive may be subject to criticism and further discussions among Member States, businesses and academics, the framework of the proposed Directive is rather complete.

The aim of the current study was to analyse specific international aspects of the CCCTB in the light of the proposed CCCTB Directive. The focus was on five topics that form the foundation of introducing a new corporate tax system, such as the CCCTB, in the network of corporate tax systems worldwide. Through this detailed study, the author has contributed to the discussions on the feasibility of the CCCTB in the setting of EU law. In the light of the research and analysis carried out, the author believes that the CCCTB can function well in parallel to the current international framework of corporate tax systems. However, given the existence of a wide network of DTCs that Member States have with third countries, the CCCTB framework should pay particular attention that the rights of third countries under these DTCs would not be infringed. In addition to the Sudoku of finding the most optimal legal framework for the CCCTB, the latter should serve as a vehicle for making the $\mathrm{EU}$ more attractive for foreign businesses. The analysis carried out in this dissertation takes both of these premises into account.

Given the specific EU element of the CCCTB, the author also discussed the EU law implications in the event that the CCCTB is introduced in the setting of enhanced cooperation. The European Commission could not have drafted the CCCTB Directive under this premise in March 2011, because enhanced cooperation among certain Member States can take place only as a last resort. However, the voices of the Member States indicate that the introduction of the CCCTB among all Member States will not be possible, at least not in the first phase. Therefore, the author believes that this research gives the European Commission a headstart when the Commission will start to work on the specific elements of the CCCTB for the purposes of its introduction in the setting of enhanced cooperation.

If introduced - either among all Member States or only among a number of them via enhanced cooperation - the author believes this research will serve as a valuable source of reference for interpreting 
the specific provisions of the CCCTB Directive in its transposition into national law by Member States and its application by businesses and tax authorities.

Finally, one cannot rule out that other groups of countries may one day move forward with the system of cross-border consolidation, accompanied by a formula apportionment. Therefore, the work carried out by the European Commission in the field of the CCCTB can serve as a blue print for those countries. Therefore, the author trusts that this research will also be relevant then for these countries.

\subsection{FINAL WORD}

The European Commission has been working on the CCCTB already for more than a decade. However, the Directive has not yet been approved by Member States. During these years, the intensity of discussions in this field has varied depending on the overall status of the EU economy as well as the changes in the sphere of politics. Some fear and others hope that this delay in introducing a common corporate tax system for the EU is an indication that Member States will never be able to agree on a common framework for corporate taxation.

One must remember that it took over 20 years for the Council to adopt the Parent and Subsidiary Directive, even though its scope was limited to a specific transaction. In that sense, the delay in agreeing on the CCCTB is not surprising, because the latter proposes a new, complete corporate tax system. Therefore, the experience with the Parent and Subsidiary Directive allows one to believe that the CCCTB is not destined to be unsuccessful.

Finally, on 15 July 2014, Jean-Claude Juncker, president-elect of the European Commission, published a paper on the priorities of his presidency even before the European Parliament approved his candidacy. ${ }^{1420}$ Notably, in relation to tax policy during his five-year term, Juncker explicitly promised to work on the adoption of the CCCTB:

"We need more fairness in our internal market. While recognising the competence of Member States for their taxation systems, we should step up our efforts to combat tax evasion and tax

1420 Jean-Claude Juncker (2014). 
fraud, so that all contribute their fair share. I will notably press ahead with administrative cooperation between tax authorities and work for the adoption at EU level of a Common Consolidated Corporate Tax Base and a Financial Transaction Tax."

In light of Juncker's paper, the work and discussions on the CCCTB among Member States will continue. 
11.1 LITERATURE

Marco Adda, 'Can a Permanent Establishment be a "Legitimate Heir" in a Domestic Consolidated Tax Regime?', 48 European Taxation 5 (2008).

Ana Agúndez-García, 'The Delineation and Apportionment of an EU Consolidated Tax base for Multi-National Corporate Income Taxation: A Review of Issues and Options', Taxation Papers (European Commission 2006).

Felix Aigner, 'Source versus Residence - Losses in the Light of the EC Freedoms', in Hans-Jörgen Aigner and Walter Loukota (eds.), Source versus Residence in International Tax Law (38 Series on International Tax Law; Linde Verlag Wien 2005)

Krister Andersson, 'An Economist's View on Source versus Residence Taxation - The Lisbon Objectives and Taxation in the European Union', 60 Bulletin for International Taxation 10 (2006).

Arginelli, Paolo, 'The Discriminatory Taxation of Permanent Establishments by the Host State in the European Union: a Too Much Separate Entity Approach', 35 Intertax 2 (2007).

Brian J. Arnold, A Comparison of Statutory General Anti-Avoidance Rules and Judicial General Anti-Avoidance Doctrines as a Means of Controlling Tax Avoidance: Which is Better? (What would John Tiley think?)', in John F. Avery Jones, Peter A. Harris, and David Oliver (eds.), Comparative Perspectives on Revenue Law: Essays in Honour of John Tiley (Cambridge University Press 2008).

Brian J. Arnold and Patrick Dibout, 'General Report', in Limits on the Use of Low-Tax Regimes by Multinational Businesses: Current Measures and Emerging Trends (86b IFA Cahiers de Droit Fiscal International; Kluwer Law International 2001).

Brian J. Arnold, 'General Report', in Deductibility of Interest and Other Financing Charges in Computing Income (79a IFA Cahiers de Droit Fiscal International; Kluwer 1994).

Michel Aujean, 'The CCCTB Project and the Future of European Taxation', in Michael Lang, et al. (eds.), Common Consolidated Corporate Tax Base (53 Series on International Tax Law; Linde Verlag Wien 2008). 
Hugh J. Ault and Brian J. Arnold (eds.), Comparative Income Taxation: A Structural Analysis (2nd edn., Kluwer Law International 2004).

Francesco Avella, 'Using EU Law To Interpret Undefined Tax Treaty Terms: Article 31(3)(c) of the Vienna Convention on the Law of Treaties and Article 3(2) of the OECD Model Convention', 4 World Tax Journal 2 (2012).

John F. Avery Jones, '2008 OECD Model: Place of Effective Management What One Can Learn from the History', 63 Bulletin for International Taxation 5/6 (2009).

Alexandra Bal, 'New Case Law Developments in Germany: Finality of Foreign Permanent Establishment Losses', 52 European Taxation (1) (2012).

Niels Bammens, 'Country Report: Belgium', in Guglielmo Maisto (ed.), Residence of Companies under Tax Treaties and EC Law (5 EC and International Tax Law Series; IBFD 2009).

Catherine Bernard, 'The Substantive Law of the EU: The Four Freedoms' (3rd edn.; Oxford University Press 2010).

Sergey Bezborodov, 'Freedom of Establishment in the EC Economic Partnership Agreements: in Search of its Direct Effect on Direct Taxation', 35 Intertax 12 (2007).

Jens Blumenberg and Richard G. Minor, 'Ruding Committee Report Unveiled; New Measures Proposed for Company Taxes in the EC, 4 Tax Notes International (23 March 1992).

Frederik Boulogne and Nana Sumrada Slavnic, 'Cross-Border Restructuring and "Final Losses", 52 European Taxation 10 (2012).

Martin Brenncke, 'Case C-58/08, Vodafone Ltd and Others v. Secretary of State for Business, Enterprise and Regulatory Reform, Judgment of the Court of Justice (Grand Chamber) of 8 June 2010', 47 Common Market law Review 6 (2010).

Harm van den Broek and Gerard Meussen, 'National Grid Indus Case: Re-Thinking Exit Taxation', 52 European Taxation 4 (2012).

Kim Brooks, 'The Potential Multilateral Tax Treaty', in Michael Lang, et al. (eds.), Treaties: Building Bdges between Law and Economics (IBFD 2010). 
Catherine Brown and Jack Mintz, 'On the Relationship between International Tax Neutrality and Non-Discrimination Clauses under Tax Treaties for Source-Based Taxes', in Michael Lang, et al. (eds.), Tax Treaties: Building Bridges between Law and Economics (IBFD 2010).

Bundesministerium der Finanzen, Franco-German Green Paper on Convergence in Business Taxation, (2012) available at http://www.bundesfinanzministerium.de/Content/EN/Sta ndardartikel/Topics/Europe/Articles/2012-02-08-FrancoGerman-greenpaper.html? act=renderPdf\& iDocId=199338, accessed 13 September 2013.

Irene J.J. Burgers, 'Some Thoughts on Further Refinement of the Concept of Place of Effective Management for Tax Treaty Purposes', 35 Intertax $6 / 7$ (2007).

BusinessEurope, Comments on Document CCCTB/RD/004, (2010), available at http://ec.europa.eu/taxation customs/resources/documen ts/taxation/company tax/common tax base/20-102010 busi-eur-comment antiabus.pdf, accessed 26 October 2014.

José Calderón and Andrés Baez, 'The Columbus Container Services ECJ Case and Its Consequences: A Lost Opportunity to Shed Light on the Scope of the Non-Discrimination Principle', 37 Intertax 4 (2007).

California Franchise Tax Board, Internal Procedural Manual. Multistate Audit Technical Manual, available at https://www.ftb.ca.gov/aboutFTB/manuals/audit/matm/3 000.pdf, accessed 26 October 2014.

George N. Carlson and Harvey Galper, 'Water's Edge Versus Worldwide Unitary Combination', in Charles E. (Jr.) McLure (ed.), The State Corporation Income Tax. Issues in Worldwide Unitary Combination (Hoover Institution Press 1984).

Luca Cerioni, 'The Possible Introduction of Common Consolidated Base Taxation via Enhanced Cooperation: Some Open Issues', 46 European Taxation 5 (2006).

Luca Cerioni, 'The Commission's Proposal for a CCCTB Directive: Analysis and Comment', 65 Bulletin for International Taxation 9 (2011).

Robert Cline et al. (Commissioned by the Irish Department of Finance), 'Study on the Economic and Budgetary Impact of the 
Introduction of a Common Consolidated Corporate Tax Base in the European Union' (Ernst \& Young 2010), available at https://www.eiseverywhere.com/file uploads/4e18cb3a213 56d80a74bbe60702bfa03 CCCTBrepjan2011.pdf, accessed 26 March 2012.

Arthur J. Cockfield, 'Reforming the Permanent Establishment Principle through a Quantitative Economic Presence Test', 38 Canadian Business Law Journal (2003).

Enken Cohrs, 'Unresolved Issues in the ECJ's Case Law on Cross-Border Intra-Group Loss Relief in the Light of $A O y^{\prime}, 53$ European Taxation 7 (2013).

Confédération Fiscale Européenne (CFE), 'CFE Opinion Statement on the Proposal for a Council Directive on a Common Consolidated Corporate Tax Base (CCCTB)', 52 European Taxation 2/3 (2012).

Convention on Mutual Administrative Assistance in Tax Matters, 25.01.1988, available at http://conventions.coe.int/treaty/en/treaties/html/127.ht $\underline{\mathrm{m}}$, accessed 25 July 2012.

Giampaolo Còrabi, 'Permanent Establishment: A Historical Analysis through Model Conventions', 27 Tax Planning International Review (2000).

Axel Cordewener, 'Cross-Border Loss Relief and the 'Effet Utile' of EU Law: Are We Losing It?', 20 EC 'Tax Review 2 (2011).

Axel Cordewener et al., 'The Tax Treatment of Foreign Losses: Ritter, M\&S, and the Way Ahead (Part One)', 44 European Taxation 4 (2004a).

Axel Cordewener et al., 'The Tax Treatment of Foreign Losses: Ritter, $M \& S$, and the Way Ahead (Part Two)', 44 European Taxation 5 (2004b).

Robert Couzin, Corporate Residence and International Taxation (IBFD 2002).

Paul Craig and Grainne de Burca, 'EU Law. Text, Cases and Materials' (4th edn.; Oxford University Press 2008).

Gareth Davies, 'Subsidiarity: The Wrong Idea, In the Wrong Place, At the Wrong Time', 43 Common Market Law Review 1 (2006). 
Joseph X. Donovan, David Nagle and Sarah Wellings, 'New Regs Set the Framework for Combined Reporting in Massachusetts', State Tax Notes (9 February 2009).

Ana Paula Dourado and Rida de la Feria, 'Thin Capitalization and Outbound Investment: Thin Capitalization Rules in the Context of the CCCTB', in M. Lang, et al. (eds.), Common Consolidated Corporate Tax Base (53 Series on International Tax Law; (Linde 2008).

Elliott Dubin, 'Changes in State Corporate Income Tax Apportionment Formulas and Changes in State Corporate Income Tax Bases', Tax Analysts (22 February 2010).

David G. Duff, 'Tax Avoidance in the 21st Century', in Chris Evans and Rick Krever (eds.), Australian Business Tax Reform in Retrospect and Prospect (Thomson Reuters 2009).

Alex Easson, 'Harmonization of Direct Taxation in the European Community: From Neumark to Ruding', 40 Canadian Tax Journal/Revue Fiscale Canadienne 3 (1992).

Alex Easson, 'Common Law Approaches to the Determination of the Source of Income: Pragmatism Over Principle', 60 Bulletin for International Taxation 12 (2006).

Joachim Englisch, 'Withholding Taxation', in Michael Lang, et al. (eds.), Corporate Income Taxation in Europe: The Common Consolidated Corporate Tax Base (CCCTB) and Third Countries (Edward Elgar 2013).

Peter Essers, 'The Precious Relationship Between LAS/IFRS and CCCTB', in L. Hinnekens and P. Hinnekens (eds.), A Vision of Taxes Within and Outside European Borders: Festschrift in Honor of Prof. Dr. Frans V anistendael (Kluwer Law International 2008).

Keith R. Evans, 'Leased Equipment: When Does a Permanent Establishment Exist?', 50 Canadian Tax Journal/Revue Fiscal Canadienne 2 (2002).

Federico Fabbrini, 'The Enhanced Cooperation Procedure: A Study in Multispeed Integration', Centro Studi Sul Federalismo (2012).

Peter L. Faber, 'Advising Foreign Companies Entering the U.S. on State and Local Taxes', State Tax Notes (27 March 2000).

FEE (Fédération des Experts Comptables Européens), FEE Position Paper on Take Over of Losses in the EU, (2005), available at http://www.fee.be/images/publications/direct- 
taxation/FEE Position Paper on Take Over of Losses 0501212200532148.pdf, accessed 26 October 2014.

Renata Fontana and Mario Tenore, 'Conference Report: The EU and Third Countries: Direct Taxation, 13-14 October 2006, Vienna', 35 Intertax 10 (2007).

William F. Fox and LeAnn Luna, 'Combined Reporting with the Corporate Income Tax', (NCSL Task Force on State \& Local Taxation of Communications and Interstate Commerce 2010).

William F. Fox et al., 'An Evaluation of Combined Reporting for Tennessee', State Tax Notes, (9 November 2009).

Judith Freedman and Graeme Macdonald, 'The Tax Base for CCCTB: The Role of Principles', in Michael Lang, et al. (eds.), Common Consolidated Corporate Tax Base (53 Series on International Tax Law; Linde Verlag Wien 2008).

Malcolm Gammie et al., Achieving a Common Consolidated Corporate Tax Base in the EU (Centre for European Policy Studies 2005).

Stephen A. Gardbaum, 'The Nature of Preemption', 79 Cornell Law Review 4 (1994).

Marcel Gérard and Edoardo Traversa, 'Supplementing Consolidation and Apportionment with Anti-Abuse Provisions', in Michael Lang, et al. (eds.), Tax Treaties: Building Bdges between Law and Economics (IBFD 2010).

Michael J. Graetz, Foundations of International Income Taxation (Foundations of Law Series; Foundation Press 2003).

Daniel Gutmann, 'Transfer of Assets to Third Countries', in Michael Lang, et al. (eds.), Corporate Income Taxation in Europe: The Common Consolidated Corporate Tax Base (CCCTB) and Third Countries (Edward Elgar 2013).

Peter A. Harris, 'The CCCTB GAAR: A Tootbless Tiger or Russian Roulette?', in Dennis Weber (ed.), CCCTB: Selected Issues (35 EUCOTAX Series on European Taxation; Kluwer Law International 2012).

Peter A. Harris and David Oliver, International Commercial Tax, ed. John Tiley (Cambridge Tax Law Series; Cambridge University Press 2010).

Jerome R. Hellerstein and Walter Hellerstein, 'State Taxation ' (Warren Gorham \& Lamont 1998- (loose-leaf publication). 
Jerome R. Hellerstein, 'State Taxation Under the Commerce Clause: The History Revisited, in Charles E. (Jr.) McLure (ed.), The State Corporation Income Tax. Issues in Worldwide Unitary Combination (Hoover Institution Press 1984).

Walter Hellerstein, 'Income Allocation in the 21st Century: The End of Transfer Pricing. The Case for Formulary Apportionment ', 12 International Transfer Pricing Journal 3 (2005).

Walter Hellerstein, 'The US Court's State Tax Jurisprudence: A Template for Comparison', in Reuven S. Avi-Yonah, James R. (Jr.) Hines, and Michael Lang (eds.), Comparative Fiscal Federalism: Comparing the European Court of Justice and the US Supreme Court's Tax Jurisprudence (14 EUCOTAX Series on European Taxation; Kluwer Law International 2007).

Walter Hellerstein and Dan T. Coenen, 'Scholarly Works. Paper 274. Commerce Clause Restraints on State Business Development Incentives', 81 Cornell Law Review 4 (1996).

Walter Hellerstein and Charles E. (Jr.) McLure, 'Lost in Translation: Contextual Considerations in Evaluating the Relevance of US Experience for the European Commission's Company Taxation Proposal, 58 Bulletin for International Taxation 3 (2004).

Marjaana Helminen, EU Tax Law: Direct Taxation (2nd edn.; IBFD 2011).

Sigrid Hemels, 'European Union - References to the Mutual Assistance Directive in the Case Law of the ECJ: A Systematic Approach', 49 European Taxation 12 (2009).

Johanna Hey, 'CCCTB - Optionality', in Michael Lang, et al. (eds.), Common Consolidated Corporate Tax Base (53 Series on International Tax Law; Linde Verlag Wien 2008).

W. Bartley Hildreth, Matthew N. Murray and David L. Sjoquist, 'Cooperation and Competition: The Multistate Tax Commission and State Corporate Tax Uniformity', State Tax Notes (5 December 2005).

Luc Hinnekens, 'Compatibility of Bilateral Tax Treaties with European Community Law. The Rules', 3 EC Tax Review 4 (1994).

Luc Hinnekens, 'The Uneasy Case and Fate of Article 293 Second Indent EC, 37 Intertax 11 (2009).

Luc Hinnekens, 'Story and fundamentals of direct taxation at work in the EU', 21 EC Tax Review 2 (2012). 
HM Revenue \& Customs, HMRC' GAAR Guidance (2013), available at available at http://www.hmrc.gov.uk/avoidance/gaar-part-abc.pdf, accessed 25 August 2013.

Jack W. Hodges, Giles Sutton and Jamie C. Yesnowitz, 'California Dividend Received Deduction: Overview, Current Status, And Related Considerations', State Tax Notes (7 April 2008).

Fred C. de Hosson, 'On the Controversial Role of the European Court in Corporate Tax Cases', 34 Intertax 6/7 (2006).

Kendall L. Houghton, Ferdinand Hogroian and Adam Weinreb, 'Unitary/Combined Filings: Old Concept, New Focus', State Tax Notes (9 August 2004).

House Committee on the Judiciary, Report of the Special Subcommittee on State Taxation of Interstate Commerce, House of Representatives Report No. 1480 ("Willis Committee Report") 88th Congress, 2nd Session (1964).

Lucia Hrehorovska, 'Tax Harmonization in the European Union', 34 Intertax 3 (2006).

Hans T.P.M. van den Hurk, Harm van den Broek and Jasper J.A.M. Korving, 'Final Settlement Taxes for Companies: Transfer of Seats, Interest Charges, Guarantees and Step-Ups in Value', 67 Bulletin for International Taxation 4/5 (2013).

Joseph Isenbergh, International Taxation (2nd edn., Concepts and Insights Series; Foundation Press 2005).

Martin Jann, Josef Schuch \& Gerald Toifl, Austria - Corporate Taxation, Country Analyses IBFD, (2012), available at http://online.ibfd.org/collections/cta/html/cta at s 008.h tml\#cta at s 8, accessed 14 June 2012.

Theo Jans and Sonia Piedrafita, 'The Role of National Parliaments in European Decision-Making', EIPASCOPE 2009/1, (2009), available at http://www.eipa.eu/files/repository/eipascope/200907091 11616_Art3_Eipascoop2009 01.pdf, accessed 25 May 2011).

Adolfo J. Martín Jiménez, 'Towards a Homogeneous Theory of Abuse in EU (Direct) Tax Law', 66 Bulletin for International Taxation $4 / 5(2012)$. 
Jean-Claude Juncker, 'A New Start for Europe: My Agenda for Jobs, Growth, Fairness and Democratic Change. Political Political Guidelines for the next European Commission. Opening Statement in the European Parliament' Plenary Session, Strasbourg, 15 July 2014, (2014), available at http://ec.europa.eu/about/junckercommission/docs/pg_en.pdf, accessed 8 October 2014.

Rami Karimeri, 'A Critical Review of the Definition of Tax Avoidance in the Case Law of the European Court of Justice', 39 Intertax 6/7 (2011).

Tracy A. Kaye, 'European Tax Hamonization and the Implications for U.S. Tax Policy', 19 Boston College International and Comparative Law Review 1 (1996).

Tracy A. Kaye, 'Tax Discrimination: A Comparative Analysis of US and EU Approaches', in Reuven S. Avi-Yonah, James R. (Jr.) Hines, and Michael Lang (eds.), Comparative Fiscal Federalism: Comparing the European Court of Justice and the US Supreme Court's Tax Jurisprudence (14 EUCOTAX Series on European Taxation; Kluwer Law International 2007).

Eric C.C.M. Kemmeren, 'Source of Income in Globalizing Economies: Overview of the Issues and a Plea for an Origin-Based Approach', 60 Bulletin for International Taxation 11 (2006).

Eric C.C.M. Kemmeren, 'CCCTB and Exemption Method for PEs and Major Shareholdings', in Michael Lang, et al. (eds.), Common Consolidated Corporate Tax Base (53 Series on International Tax Law; Linde Verlag Wien 2008a).

Eric C.C.M. Kemmeren, 'After Repel of Article 293 EC Treaty under the Lisbon Treaty: The EU Objective of Eliminating of Double Taxation Can Be Applied More Widely', 17 EC Tax Review 4 (2008b).

Eric C.C.M. Kemmeren and Daniel S. Smit, 'Taxation of EU NonResident-Companies under the CССТВ System: Analysis and Suggestions for Improvement, in Michael Lang, et al. (eds.), Corporate Income Taxation in Europe: The Common Consolidated Corporate Tax Base (CCCTB) and Third Countries (Edward Elgar 2013).

Michael Kobetsky, 'The Case for Unitary Taxation of International Enterprises', 62 Bulletin for International Taxation 5 (2008).

Reinout Kok, 'Domestic and Cross-Border Loss Relief in the European Union', 38 Intertax 12 (2010). 
Heinz-Klaus Kroppen and José Carlos Silva, 'General Report, in CrossBorder Business Restructuring (96a IFA Cahiers de Droit Fiscal International; Sdu Uitgevers 2011).

Patricia Lampreave, 'An Assessment of the Anti-Avoidance Doctrines in the United States and the European Union', 66 Bulletin for International Taxation 3 (2012).

Michael Lang, 'The Concept of a Multilateral Tax Treaty', in Michael Lang, et al. (eds.), Multilateral Tax Treaties: New Developments in International Tax Law (18 Series on International Taxation; Kluwer Law International 1998).

Michael Lang, 'The Marks \& Spencer Case - The Open Issues Following the ECJ's Final Word, 46 European Taxation 2 (2006).

Michael Lang, 'Double Taxation and EC Law', in Reuven S. AviYonah, James R. (Jr.) Hines, and Michael Lang (eds.), Comparative Fiscal Federalism: Comparing the European Court of Justice and the US Supreme Court's Tax Jurisprudence (14 EUCOTAX Series on European Taxation; Kluwer Law International 2007).

Michael Lang, 'The General Anti-Abuse Rule of Article 80 of the Draft Proposal for a Council Directive on a Common Consolidated Corporate Tax Base', 51 European Taxation 6 (2011).

Michael Lang and Florian Brugger, 'The Role of the OECD Commentary in Tax Treaty Interpretation', 23 Australian Tax Forum 2 (2008).

Michael Lang and Sabine Heidenbauer, 'Wholly Artificial Arrangements', in L. Hinnekens and P. Hinnekens (eds.), A Vision of Taxes Within and Outside European Borders: Festschrift in Honor of Prof. Dr. Frans Vanistendael (Kluwer Law International (2008).

Michael Lang et al. (eds.), Multilateral Tax Treaties: New Developments in International Tax law (18 Series on International Taxation; Kluwer Law International (1998).

Philip Laroma Jezzi, 'The Concept of "Comparability" in the Direct Taxation Jurisprudence of the European Court of Justice', 10 EC Tax Journal 2 (2010).

Moris Lehner, 'Limitation of the National Power of Taxation by the Fundamental Freedoms and Non-Discrimination Clauses of the EC Treaty', 9 EC Tax Review 1 (2000). 
Moris Lehner, 'EC Law and the Competence to Abolish Double Taxation' in Wolfgang Gassner, et al. (eds.), Tax Treaties and EC Law (16 Series on International Taxation; Kluwer Law International 1997).

Annekatrien Lenaerts, 'The General Principle of the Probibition of Abuse of Rights: A Critical Position on Its Role in a Codified European Contract Law', 6 European Review of Private Law (2010).

Richard Lyal, 'Non-Discrimination and Direct Tax in Community Law', 12 EC Tax Review 2 (2003).

Guglielmo Maisto, 'Credit versus Exemption under Domestic Tax Law and Treaties', in Michael Lang, et al. (eds.), Tax Treaties: Building Bridges between Law and Economics (IBFD 2010).

Guglielmo Maisto, 'The Meaning of 'Resident Taxpayer' and 'Non-Resident Taxpayer' under the Proposal for a Council Directive on a Common Consolidated Corporate Tax Base (CCCTB)', in Michael Lang, et al. (eds.), Corporate Income Taxation in Europe: The Common Consolidated Corporate Tax Base (CCCTB) and Third Countries (Edward Elgar 2013).

Fernando Souza de Man and Tiiu Albin, 'Contradicting Views of Exit Taxation under OECD MC and TFEU: Are Exit Taxes Still Allowed in Europe?', 39 Intertax 12 (2011).

Otto Marres, 'The Principle of Territoriality and Cross-Border Loss Compensation', 30 Intertax 3 (2011).

Stefan Mayer, Formulary Apportionment for the Internal Market (Doctoral Series; IBFD 2009).

Michael J. McIntyre, 'The Use of Combined Reporting by Nation States', 35 Tax Notes International 10 (2004).

Michael J. McIntyre, Paul Mines and Richard D. Pomp, 'Designing a Combined Reporting Regime for a State Corporate Income Tax: A Case Study of Louisiana', 61 Louisiana Law Review (2001).

Michael W. McLoughlin, 'Constitutionality of New Hampshire Taxation of Foreign-Source Dividends Upheld Despite Apparent Discrimination', State Tax Notes (22 January 2007).

Charles E. McLure (Jr.), 'Defining a Unitary Business: An Economist's View', in Charles E. (Jr.) McLure (ed.), The State Corporation Income Tax. Issues in Worldwide Unitary Combination (Hoover Institution Press 1984). 
Charles E. McLure (Jr.), Economic Perspectives on State Taxation of MultiJurisdictional Corporations (Tax Analysts 1986).

Charles E. McLure (Jr.), 'The Long and Shadow History: Sovereignty, Tax Assignment, Legislation, and Judicial Decisions on Corporate Income Taxes in the US and the EU', in Reuven S. Avi-Yonah, James R. (Jr.) Hines, and Michael Lang (eds.), Comparative Fiscal Federalism: Comparing the European Court of Justice and the US Supreme Court's Tax Jurisprudence (14 EUCOTAX Series on European Taxation; Kluwer Law International 2007).

Charles E. McLure (Jr.), 'Legislative, Judicial, Soft law, and Cooperative Approaches to Harmonizing Corporate Income', 14 Columbia Journal of European Law 3 (2008).

Charles E. McLure (Jr.) (ed.), The State Corporation Income Tax. Issues in Worldwide Unitary Combination (Hoover Institution Press 1984).

Aage Michelsen, 'General Report, in Tax Treatment of Corporate Losses (83a IFA Cahiers de Droit Fiscal International; Kluwer Law International 1998).

Benjamin F. Miller, 'Worldwide Unitary Combination: The California Practice', in Charles E. McLure (Jr.) (ed.), The State Corporation Income Tax. Issues in Worldwide Unitary Combination (Hoover Institution Press 1984).

David R. Milton, 'Comments on Miller', in Charles E. (Jr.) McLure (ed.), The State Corporation Income Tax. Issues in Worldwide Unitary Combination (Hoover Institution Press 1984).

Ioanna Mitroyanni, 'Delineating a Group Taxation System for the European Internal Market: Entitlement to Group Membership and Territorial Scope', 5 The Corporate Tax Review 3 (2007).

Ioanna Mitroyanni, Integration Approaches to Group Taxation in the European Internal Market (21 EUCOTAX Series on European Taxation; Kluwer Law International 2008).

Ioanna Mitroyanni and Chiara Putzolu, 'CCCTB and Business Reorganizations: The Common Consolidated Corporate Tax Base and Business Reorganizations', 37 Intertax 8/9 (2009).

Ioanna Mitroyanni, 'Resident \& Non-resident Taxpayers', Conference held in Vienna in 30 and 31 Januarz 2012 on CCCTB and Third Countries (Institute for Austrian and International Tax Law of the Vienna University). 
Tigran Mkrtchyan, 'In Search of Ariadne's Thread: Permanent Establishments and Losses in the European Union', 63 Bulletin for International Taxation 12 (2009).

Multistate Tax Commission (MTC), Allocation and Apportionment Regulations, (1973), available at http://www.mtc.gov/uploadedFiles/Multistate_Tax_Com mission/Uniformity/Uniformity_Projects/A Z/AllocaitonandApportionmentReg.pdf, accessed 26 October 2014.

Multistate Tax Commission (MTC), Proposed Model Statute for Combined Reporting, (2006), available at http://www.mtc.gov/uploadedFiles/Multistate Tax Com mission/Uniformity/Uniformity Projects/A Z/Combined $\% 20$ Reporting $\% 20$ \%20FINAL\%20version.pdf, accessed 26 October 2014.

Multistate Tax Commission, (2014), available at http://www.mtc.gov/The-Commission, accessed 25 September 2014.

Nellie Munin, 'The Lisbon Treaty and the CCTB (Common Corporate Tax Base): The Debate', Hebrew University International Law Research Paper 06-08 (2008).

National Foreign Trade Council (NFTC), Territorial Tax Study Report, (2002), availale at http://www.nftc.org/default/tax/Territorial\%20Report.pdf, accessed 26 October 2014.

Martti Nieminen, 'Abolition of Double Taxation in the Treaty of Lisbon', 64 Bulletin for Internation Taxation 6 (2010).

Angelo Nikolakakis, 'Credit versus Exemption - An Evolving Constellation of Constellations', 66 Bulletin for International Taxation 6 (2012).

OECD, Taxation of Income derived from the Leasing of Industrial, Commercial or Scientific Equipment, (OECD 1983).

OECD, Thin Capitalisation, (OECD 1986).

OECD, Harmful Tax Competition: An Emerging Global Issue, available at http://www.oecd.org/tax/transparency/44430243.pdf, (1998), accessed 26 October 2014. 
OECD, Model Agreement on Exchange of Information on Tax Matters, (2002), available at http://www.oecd.org/ctp/harmful/2082215.pdf, accessed 26 October 2014.

OECD, Draft Contents of the 2008 Update to the Model Tax Convention, (2008a), available at http://www.oecd.org/tax/treaties/40489100.pdf, accessed 26 October 2014.

OECD, The 2008 Update to the OECD Model Tax Convention, (2008b), available

at

http://www.oecd.org/tax/taxtreaties/41032078.pdf, accessed 17 August 2012.

OECD, 2010 Report on the Attribution of Profits to Permanent Establishments, (2010a), available at http://www.oecd.org/ctp/transfer-pricing/45689524.pdf.

OECD, Transfer Pricing Guidelines for Multinational Enterprises and Tax Administrations, (OECD 2010b).

OECD, Hybrid Mismatch Arrangements: Tax Policy and Compliance Issues, (2012a), available at http://www.oecd.org/tax/aggressive/HYBRIDS_ENG_Fi nal October2012.pdf, accessed 26 October 2014.

OECD, Interpretation and Application of Article 5 (Permanent Establishment) of the OECD Model Convention, (2012b), available

http://www.oecd.org/dataoecd/23/7/48836726.pdf, accessed 19 April 2012.

OECD, Action Plan on Base Erosion and Profit Shifting, (2013), available http://www.oecd.org/ctp/BEPSActionPlan.pdf, accessed 26 October 2014.

Tom O'Shea, 'Double Tax Conventions and the European Union', 10 EC Tax Journal 3 (2010).

Andreas Oestreicher and Reinald Koch, 'Corporate Average Tax Rates Under the CCCTB and Possible Methods for International Loss-Offset', Working Paper Series, (2008), available

http://papers.ssrn.com/sol3/papers.cfm?abstract $\mathrm{id}=1456$ $\underline{373}$, accessed 15 October 2012. 
Andreas Oestreicher, Christoph Spengel and Reinald Koch, 'How to Reform Taxation of Corporate Groups in Europe', 3 World Tax Journal 1 (2011).

Laura Pakarinen, Denmark - Corporate Taxation, Country Surveys IBFD, (2012), available at http://online.ibfd.org/kbase/\#topic=doc\&url=/collections $\angle \mathrm{cta} / \mathrm{html} / \mathrm{cta} \mathrm{dk}$ s 008.html\&WT.z nav $=$ search\&hash $=\mathrm{ct}$ a dk_s_8.3, (accessed 14 June 2012).

Christiana H.J.I. Panayi, 'The Effect of Community Law on Pre-Accession Tax Treaties', 16 EC 'Tax Review 3 (2007).

Christiana H.J.I. Panayi, 'The Common Consolidated Corporate Tax Base Issues for Member States Opting out and Third Countries', 48 European Taxation 3 (2008).

Christiana H.J.I. Panayi, 'Corporate Mobility in the European Union and Exit Taxes', 63 Bulletin for International Taxation 10 (2009).

Christiana H.J.I. Panayi, 'The Anti-Abuse Rules of the CCCTB', 66 Bulletin for International Taxation 4/5 (2012).

Panayi, Christiana H.J.I. (2013), 'The CFC rules within the CCCTB', in Michael Lang, et al. (eds.), Corporate Income Taxation in Europe: The Common Consolidated Corporate Tax Base (CCCTB) and Third Countries (Cheltenham: Edward Elgar).

James H. Peters, 'The Water's Edge Combined Report method: A Troublesome Concept', Tax Notes International (10 September 2001).

Paoblo Piantavigna, 'Tax Abuse in European Union Law: A Theory', 20 EC Tax Review 3 (2011).

Dale Pinto, 'The Need to Reconceptualize the Permanent Establishment Threshold, 60 Bulletin for International Taxation 7 (2006).

Pasquale Pistone, 'An EU Model Tax Convention', 11 EC Tax Review 3 (2002a).

Pasquale Pistone, 'The Impact of Community Law on Tax Treaties: Issues and Solutions' (4 EUCOTAX Series on European Taxation; Kluwer Law International 2002b).

Pasquale Pistone, 'Outbound Investments and Interest Deduction: An Era of Fat Cap in European International Tax Law?', in Michael Lang, et al. (eds.), Common Consolidated Corporate Tax Base (53 Series on International Tax Law; Linde Verlag Wien 2008). 
Pasquale Pistone, 'Five Years of EURYI Research on the Impact of European Law on Relations with Third Countries in the Field of Direct Taxes: Selected Remarks for a General Report', in Sabine Heidenbauer and Birgit Stürzlinger (eds.), The EU's External Dimension in Direct Tax Matters (66 Series on International Tax Law; Linde 2010).

Pasquale Pistone, 'The Limits to Interest Deductibility: An ad hoc AntiAbuse rule within the Proposal for a CCCTB Directive', in Michael Lang, et al. (eds.), Corporate Income Taxation in Europe: The Common Consolidated Corporate Tax Base (CCCTB) and Third Countries (Edward Elgar 2013).

Regulation (EC) No. 1606/2002/EC of the European Parliament and of the Council of 19 July 2002 on the Application of International Accounting Standards, OJ L 243, 11.9.2002, p. 1 , as subsequently amended.

Richard D. Pomp and Oliver Oldman, State \& Local Taxation, 3 vols. (5th edn., Richard D. Pomp 2005).

R.D. Post and K.P.E. Stals, 'The Tax Treatment of Corporate Losses: A Comparative Study', 40 Intertax 4 (2012).

Stella Raventós Calvo, 'EU Tax Harmonization: Why Don't We Start Again?', in Report of Proceedings of the First World Tax Conference Report: Taxes Without Borders (Canadian Tax Foundation 2000).

Julie Rogers-Glabush, International Tax Glossary (6th rev. ed.; IBFD 2009).

Julie Roin, 'Can the Income Tax Be Saved? The Promise and Pitfalls of Unitary Formulary Apportionment', Public Law and Legal Theory Working Paper, (2007), available at http://ssrn.com/abstract id $=984076$, accessed 10 February 2010.

H. Onno Ruding, 'The Long Way to Removing Obstacles in Company Taxation in Europe', 42 European Taxation 1 (2002).

Claudio Sacchetto, 'Member States Tax Sovereignty: Between the Principle of Subsidiarity and the Necessity of Supranational Coordination', in L. Hinnekens and P. Hinnekens (eds.), A vision of Taxes Within and Outside European Borders: Festschrift in Honor of Prof. Dr. Frans V anistendael (Kluwer Law International 2008). 
Jacques Sasseville and Arvid A. Skaar, 'General Report, in Is There a Permanent Establishment? (94a IFA Cahiers de Droit Fiscal International; Sdu Uitgevers 2009).

Michael S. Schadewald and Robert J. Misey (Jr.), Practical Guide to U.S. Taxation of International Transactions (5th edn.; $\mathrm{CCH}$ Incorporated 2005).

Marcel G.H. Schaper, The Structure and Organization of EU Law in the Field of Direct Taxes (27 IBFD Doctoral Series; IBFD 2013).

Ferdinand P. Schoettle, 'Comments on J. Hellerstein', in Charles E. (Jr.) McLure (ed.), The State Corporation Income Tax. Issues in Worldwide Unitary Combination (Hoover Institution Press 1984).

Wolfgang Schön, 'Losing Out at the Snooker Table: Cross-Border Loss Compensation for PEs and the Fundamental Freedoms', in L. Hinnekens and P. Hinnekens (eds.), A Vision of Taxes Within and Outside European Borders: Festschrift in Nonor of Prof. Dr. Frans V anistendael (Kluwer Law International 2008a).

Wolfgang Schön, 'Abuse of Rights and European Tax Law', in John F. Avery Jones, Peter A. Harris, and David Oliver (eds.), Comparative Perspectives on Revenue Law: Essays in Honour of John Tiley (Cambridge University Press 2008b).

Wolfgang Schön, 'International Tax Coordination for a Second-Best World (Part II)', 2 World Tax Journal 1 (2010).

Bruno da Silva, 'From Marks \& Spencer to X Holding: The Future of Cross-Border Group Taxation in the European Union', 39 Intertax 5 (2011).

Bruno da Silva, 'Felixstowe Dock and Railway Company and Others; UK Group Relief System: Non-Discrimination in Tax Treaties and EU Law. First Tier Tribunal, Highlights \& Insights on European Taxation 1 (2013).

Paul H.M. Simonis, 'Relevant Aspects When Entering the System/CCCTB Group', in Dennis Weber (ed.), CCCTB: Selected Issues (35 EUCOTAX Series on European Taxation; Kluwer law International 2012).

Timothy J. Slattery, 'The Dormant Commerce Clause: Adopting a new Standard and a Return to principle', 17 William \& Mary Bill of Rights Journal 4 (2009). 
Daniel S. Smit, 'The Position of the EU Member States' Associated and Dependent Territories under the Freedom of Establishment, the Free Movement of Capital and Secondary EU Law in the Field of Company Taxation', 39 Intertax 2 (2011a).

Daniel S. Smit, Freedom of Investment between EU and Non-EU Member States and its Impact on Corporate Income Tax Systems within the European Union, 3 vols. (Tilburg School of Economics and Management, (2011b).

Kyle O. Sollie and James P. Kleier, 'Foreign Dividends in Flux in California: Split Decision for Apple', State Tax Notes (8 March 2010).

Peter B. Sørensen, 'Company Tax reform in the European Union', 11 International Tax and Public Finance 1 (2004).

Rita Szudoczky, 'Is the CCCTB Proposal in line with the Principle of Subsidiarity?: Negative Opinions Submitted by National parliaments in the 'Yellow Card procedure", in Dennis Weber (ed.), CCCTB: Selected Issues (35 EUCOTAX Series on European Taxation; Kluwer Law International 2012).

Claus Staringer, 'Requirements for Forming a Group', in Michael Lang, et al. (eds.), Common Consolidated Corporate Tax Base (53 Series on International Tax Law; Linde Verlag Wien 2008).

Jan van de Streek, 'The CCCTB Rules on Leaving a Group', 40 Intertax 6/7 (2012).

UNICE CCCTB Task Force, Comments on Document CCCTB $\backslash W P \backslash 010$ - Common Consolidated Corporate Tax Base Working Group - Capital Gains and Losses, (2005), available

http://ec.europa.eu/taxation customs/resources/documen

ts/taxation/company tax/common tax base/comments w p010 capital gains1 en.pdf, accessed 26 October 2014.

Adam Zalasinski, 'The Principle of Prevention of (Direct Tax) Abuse: Scope and Legal Nature - Remarks on the 3M Italia Case', 52 European Taxation 9 (2012).

Mario Tenore, 'CFC Rule', in Dennis Weber (ed.), CCCTB: Selected Issues (35 EUCOTAX Series on European Taxation; Kluwer Law International 2012).

Ben J.M. Terra and Peter J. Wattel, European Tax law (2 edn., 10 Fiscale Handboeken; Kluwer 2012). 
H. Thurston, 'The Report of the Fiscal and Financial Committee and the reports of the Sub-Groups A, B and C. An Unofficial 'Translation', (IBFD 1963).

Antony Ting, 'Policy and Membership Requirements for Consolidation: A Comparison Between Australia, New Zealand and the US', British Tax Review 3 (2005).

Antony Ting, 'Definition of "Control" under the Consolidation and Controlled Foreign Company Regimes: A Comparison between Australia, New Zealand and the United States', 12 New Zealand Journal of Taxation Law and Policy, 12 (2006).

Antony Ting, 'The Unthinkable Policy Option? Key Design Issues Under a System of Full Consolidation', 59 Canadian Tax Journal / Revue Fiscal Canadienne 3 (2011).

Takis Tridimas, 'Abuse of Rights in EU Law: Some Reflections with particular Reference to Financial Law', Legal Studies Research paper No. 27/2009 (Queen Mary University of London, School of Law 2009).

Frans J.G.M. Vanistendael, 'The Compatibility of the Basic Economic Freedom with the Sovereign National Tax Systems of the Member States', 12 EC Tax Review 3 (2003).

Frans J.G.M. Vanistendael, 'Cohesion: The Phoenix 'Rises from the Ashes', 14 EC Tax Review 4 (2005).

Richard J. Vann, 'Taxing International Business Income: Hard-Boiled Wonderland and the End of the World, 2 World Tax Journal 3 (2010).

Louan Verdoner, 'The Coherence Principle under EC Tax Law', 49 European Taxation 5 (2009).

Hein Vermeulen and Marlien F.A. Blaauw, 'The Tax Treatment of Directly Held Real Estate under the Proposed CCCTB Directive', 51 European Taxation 12 (2011).

Klaus Vogel, Klaus Vogel on Double Taxation Conventions: A Commentary to the OECD-, UN and US Model Conventions for the Avoidance of Double Taxation on Income and Capital: With Particular Reference to German Treaty Practice (3rd edn.; Kluwer Law International 1997).

Klaus Vogel and Rainer Prokisch, 'General Report', in Interpretation of Double Taxation Conventions (78a IFA Cahiers de Droit Fiscal International, Kluwer 1993). 
Matthijs Vogel, 'Withholding Taxes and Relief for Double Taxation', in Dennis Weber (ed.), CCCTB: Selected Issues (35 EUCOTAX Series on European Taxation; Kluwer Law International 2012).

Peter Wattel, 'Home Neutrality in an Internal Market', 36 Bulletin for Internation Taxation 5 (1996).

Peter Wattel and Otto Marres, 'The Legal Status of the OECD Commentary and Static or Ambulatory Interpretation of Tax Treaties', 43 European Taxation 7/8 (2003).

Dennis Weber, 'Abuse of Law - European Court of Justice, 14 December 2000, Case C-110/99, Emsland-Stärke', 31 Legal Issues of Economic Integration 1 (2004).

Dennis Weber, 'In Search of a (New) Equilibrium Between Tax Sovereignty and the Freedom of Movement within the EC, 34 Intertax 12 (2006).

Joann Martens Weiner, 'Using the Experience in the U.S. States to Evaluate Issues in Implementing Formula Apportionment at the International Level, (Washington: Office of Tax Analysis, U.S. Department of the Treasury 1999).

Joann Martens Weiner, 'Company Tax Reform in the European Union: Guidance from the United States and Canada on Implementing Formulary Apportionment in the EU' (Springer Science + Business Media 2006).

Leanne M. Wilson, 'The Fate of the Dormant Foreign Commerce Clause After Garamendi and Crosby', 107 Columbia Law Review 3 (2007).

Christian Wimpssinger, 'Cross-Border Transfer of Losses, the ECJ Does not Agree with Advocate General Sharpston', 17 EC Tax Review 4 (2008).

Bruno de Witte, 'European Union Law: How Autonomous is its Legal Order?', Zeitschrift fur Offentliches Recht (2010). 


\section{2}

Agreement between the European Economic Community and the Swiss Confederation ("Free Trade Agreement"), OJ L 300, 31/12/1972, p. 0189 - 0280.

Agreement between the European Community and its Member States, of the One Part, and the Swiss Confederation, of the Other, on the Free Movement of Persons, OJ L 114, 30/04/2002, p. 6.

Agreement between the European Community and the Swiss Confederation Providing for Measures Equivalent to Those Laid Down in Council Directive 2003/48/EC on Taxation of Savings Income in the Form of Interest Payments, OJ L 385, 29/12/2004, p. 51.

Agreement on the European Economic Area (EEA), OJ L1, 3/01/1994, p. 3.

Directive 2005/56/EC of the European Parliament and of the Council of 26 October 2005 on Cross-Border Mergers of Limited Liability Companies, OJ L 310/1, p. 1-9.

Consolidated version of the Treaty on the Functioning of the European Union OJ C 115/47, p. 1-361.

Convention on the Elimination of Double Taxation in Connection with the Adjustment of Profits of Associated Enterprises (90/436/EEC), OJ L 225, 20.8.1990, p. 10-24.

Convention on the Mutual Recognition of Companies and Bodies Corporate, Bulletin of the European Communities, Supplement No. 2-1969, 29.02.1968, p. 7-16.

Council Directive 88/361/EEC of 24 June 1988 for the implementation of Article 67 of the Treaty, OJ L 178 , 08/07/1988 P. 5-18.

Council Directive 90/435/EEC of 23 July 1990 on the Common System of Taxation Applicable in the Case of Parent Companies and Subsidiaries of Different Member States, OJ L 225, 20/08/1990, p. 6-9.

Council Directive 2011/96/EU of 30 November 2011 on the Common System of Taxation Applicable in the case of Parent Companies and Subsidiaries of Different Member States, OJ L 345, 29.12.2011, p. 8-16. 
Council Directive 2003/49/EC of 3 June 2003 on a Common System of Taxation Applicable to Interest and Royalty Payments Made Between Associated Companies of Different Member States, OJ L 157, 26.6.2003 (2003), p. 4954.

Council Directive 2009/133/EC of 19 October 2009 on the Common System of Taxation Applicable to Mergers, Divisions, Partial Divisions, Transfers of Assets and Exchanges of Shares Concerning Companies of Different Member States and to the Transfer of the Registered Office of an SE or SCE between Member States, OJ L 310, 25.11.2009, p. 34-46.

Council Directive 2011/16/EU of 15 February 2011 on Administrative Cooperation in the Field of Taxation and Repealing Directive 77/799/EEC, OJ L 64, 11.3.2011, p. 1 12.

Council Directive 2011/96/EU of 30 November 2011 on the Common System of Taxation Applicable in the case of Parent Companies and Subsidiaries of Different Member States, OJ L 345, 29.12.2011, p. 8-16.

Council of the European Union, General Programme for the Abolition of Restrictions on Freedom of Establishment', OJ, English Special Edition, Second Series (IX) (1962).

Council of the European Union, Code of Conduct Group (Business Taxation) to ECOFIN Council on 29 November 1999, SN 4901/99 (1999).

Council of the European Union, Council Resolution of 8 June 2010 on Coordination of the Controlled Foreign Corporation (CFC) and Thin Capitalisation Rules within the European Union, OJ C 156, 16.6.2010, p. 1-2.

Council of the European Union, Proposal for a Council Directive on a Common Consolidated Corporate Tax Base (CCCTB) Presidency Comments on the Compromise Proposal, 2011/0058 (CNS) (2012).

Council Regulation 2137/85 of 25 July 1985 on the European Economic Interest Grouping (EEIG), p. 1-9.

Council Regulation 2157/2001 of 8 October 2001 on the Statute for European Company (SE), (2001) OJ L 204/01, p. 1-21. 
European Commission, The Development of a European Capital Market. Report of a Group of Experts appointed by the EEC Commission, (1966).

European Commission, 'Tax Harmonization Programme. Commission Memorandum to the Council of 26 June 1967 (Supplement No. 8), (1967).

European Commission, Corporation Tax and Individual Income Tax in the European Communities, Studies: Competition Approximation of Legislation 15 (1970).

European Commission, Draft Directive Draft Directive concerning the Harmonization of Systems of Company Taxation and of Withholding Tax on Dividends, COM(75) 392 (1975a).

European Commission, Action Programme for Taxation, COM(75) 391 final (1975b).

European Commission, Proposal for a Council Directive on the Elimination of Double Taxation in Connection with the Adjustment of Transfers of Profits between Associated Enterprises (Arbitration Procedure), CCM (76) 611 (1976).

European Commission, Report from the Commission to the Council on the Scope for Convergence of Tax Systems in the Community, Bulletin of the European Communities Supplement 1/80, $\operatorname{COM}(80) 139$ final (1980).

European Commission, Proposal for a Council Directive on the Harmonization of the Laws of the Member States relating to the Arrangements for the Carry-Over of Losses of Undertakings, COM/84/404 final (1984).

European Commission, Amendments to the Proposal for a Council Directive on the Harmonization of the Laws of the Member States Relating to Tax Arrangements for the Carry-Over of Losses of Undertakings, $\operatorname{COM}(85) 319$ (1985a).

European Commission, Completing the Internal Market. White Paper from the Commission to the European Council, $\operatorname{COM}(85) 310$ (1985b).

European Commission, Guidelines on Company Taxation, SEC(90) 601 (1990).

European Commission, Proposal for a Council Directive Concerning Arrangements for the Taking into Account by Enterprises of the Losses of Their Permanent 
Establishments and Subsidiaries Situated in other Member States, COM(90) 595 final (1991).

European Commission, 'Report of the Committee of Independent

Experts on Company Taxation ("Ruding Report')', Official Publications of the EC, ISBN 92-826-4277-1 (1992a).

European Commission, Commission Communication to the Council and to Parliament Subsequent to the Conclusions of the Ruding Committee Indicating Guidelines on Company Taxation Linked to the Further Development of the Internal Market, SEC(92) 1118 (1992b).

European Commission, 'Taxation in the European Union. Report on the Development of Tax Systems, COM(96) 546 (1996).

European Commission, A Package to Tackle Harmful Tax Competition in the European Union, COM(97) 564 (1997).

European Commission, Proposal on a Common System of Taxation Applicable to Interest and Royalty Payments Made between Associated Companies of Different Member States, COM(1998) 67 (1998a).

European Commission, Proposal for a Council Directive to Ensure a Minimum of Effective Taxation of Savings Income in the Form of Interest Payments within the Community, $\operatorname{COM}(1998) 295$ (1998b).

European Commission, Company Taxation in the Internal Market, SEC(2001) 1681 (2001a).

European Commission, Withdrawal of Commission Proposals which are No Longer Topical, COM(2001)763 final/2 (2001b).

European Commission, Guide to the Case Law of the European Court of Justice on Article 43 et. seq. EC Treaty. Freedom of Establishment, (2001c), available at http://ec.europa.eu/internal market/services/docs/infring ements/art49-establishment en.pdf, accessed 26 October 2014.

European Commission, Towards an Internal Market without Tax Obstacles. A Strategy for Providing Companies with a Consolidated Corporate Tax Base for their EU-Wide Activities, COM(2001) 582 (2001d).

European Commission, Tax Policy in the European Union Priorities for the years ahead, COM(2001) 260 (2001e). 
European Commission, Commission Recommendation of 6 May 2003 Concerning the Definition of Micro, Small and Medium-Sized Enterprises, 2003/361/EC (2003a).

European Commission, An Internal Market without Company Tax Obstacles. Achievements, Ongoing Initiatives and Remaining Challenges, COM(2003) 726 (2003b).

European Commission, Consultation Document. The Application of International Accounting Standards (IAS) in 2005 and the Implications for the Introduction of a Consolidated Tax Base for Companies' EU-Wide Activities, (2003c), available at

http://ec.europa.eu/taxation customs/resources/documen ts/iaspaper en.pdf, (2003c), accessed 26 October 2014.

European Commission, Commission Non-Paper to Informal ECOFIN Council, 10 and 11 September 2004. A Common Consolidated EU Corporate Tax Base, (2004), available at http://ec.europa.eu/taxation customs/resources/documen ts/taxation/company tax/common tax base/cctbwpnon paper.pdf, accessed 26 October 2014.

European Commission, Concept of the 'Tax Balance Sheet', $\mathrm{CCCTB} \backslash \mathrm{WP} \backslash 016 \backslash$ doc $\backslash$ en (2005a).

European Commission, Taxable Income, CCCTB \WP $\backslash 017 \backslash$ doc $\backslash$ en (2005b).

European Commission, International Aspects in the CCCTB, $\mathrm{CCCTB} \backslash \mathrm{WP} \backslash 019 \backslash$ doc $\backslash$ en (2005c).

European Commission, Implementing the Community Lisbon Programme. The Contribution of Taxation and Customs Policies to the Lisbon Strategy, COM(2005) 532 (2005d).

European Commission, Tackling the Corporation Tax Obstacles of Small and Medium-Sized Enterprises in the Internal Market - Outline of a Possible Home State Taxation Pilot Scheme, $\operatorname{COM}(2005) 702$ (2005d).

European Commission, Commission Summary Record of the Meeting of the Common Consolidated Corporate Tax Base Working Group, CCCTB/WP/025/en (2006a).

European Commission, The Territorial Scope of the CCCTB, $\mathrm{CCCTB} \backslash \mathrm{WP} \backslash 026 \backslash$ doc $\backslash$ en (2006b). 
European Commission, An Overview of the Main Issues that Emerged at the First Meeting of the Subgroup on International Aspects, CCCTB $\backslash W P \backslash 029 \backslash$ doc $\backslash$ en (2006c)

European Commission, An Overview of the Main Issues that Emerged at the Second Meeting of the Subgroup on International Aspects (SG 4), CCCTB \WP $\backslash 033 \backslash$ doc $\backslash$ en (2006d).

European Commission, Issues Related to Group Taxation, $\mathrm{CCCTB} \backslash W \mathrm{WP} \backslash 035 \backslash$ doc $\backslash$ en $(2006 e)$.

European Commission, Personal Scope of the CCCTB, $\mathrm{CCCTB} \backslash \mathrm{WP} \backslash 040 \backslash$ doc $\backslash$ en $(2006 \mathrm{f}$ ).

European Commission, Related Parties in CCCTB, $\mathrm{CCCTB} \backslash \mathrm{WP} \backslash 041 \backslash$ doc $\backslash$ en $(2006 \mathrm{~g})$.

European Commission, Dividends, CCCTB $\backslash \mathrm{WP} \backslash 042 \backslash$ doc $\backslash$ en (2006h).

European Commission, An Overview of the Main Issues that Emerged at the Fourth Meeting of the Subgroup on Taxable Income (SG3), CCCTB/WP/043 (2006i).

European Commission, Progress to Date and Future Plans for the CCCTB, CCCTB \WP $\backslash 046 \backslash$ doc $\backslash$ en (2006j).

European Commission, An Overview of the Main Issues that Emerged at the Second Meeting of the Subgroup on Group Taxation (SG5), CCCTB \WP \048\doc \en (2006k).

European Commission, An Overview of the Main Issues that Emerged at the Third Meeting of the Subgroup on International Aspects (SG 4), CCCTB \WP $\backslash 049 \backslash$ doc $\backslash$ en (20061).

European Commission, Co-ordinating Member States' Direct Tax Systems in the Internal Market, COM(2006) 823 (2006m).

European Commission, Exit Taxation and the Need for CoOrdination of Member States' Tax Policies, COM(2006) 825 (2006n).

European Commission, Implementing the Community Lisbon Programme. Progress to Date and Next Steps Forward Towards a Common Consolidated Corporate Tax Base (CCCTB), COM (2006) 157 (20060). 
European Commission, Tax Treatment of Losses in Cross-Border Situations, COM(2006) 824 (2006p).

European Commission, "A Citizens' Agenda - Delivering Results for Europe", (2006q), available at http://ec.europa.eu/citizens agenda/index_en.htm, accessed 25 May 2011.

European Commission, Communications on a Comprehensive Strategy to Promote Tax Co-Ordination in the EU Frequently Asked Questions, MEMO/06/499 (2006r).

European Commission, CCCTB: Possible Elements of a Technical Outline, CCCTB/WP057\doc \en (2007a).

European Commission, CCCTB: Possible Elements of Administrative Framework, CCCTB/WP061 \doc $\backslash$ en (2007b).

European Commission, Provisions on Capital Movements in Multilateral \& Bilateral Agreements of the European Union with Third Parties, (2007c), available at http://ec.europa.eu/internal market/capital/docs/multibilateral-agreements en.pdf, accessed 26 October 2014.

European Commission, The Application of Anti-Abuse Measures in the Area of Direct Taxation - Within the EU and in Relation to Third Countries, COM(2007) 785 (2007d).

European Commission, Anti-Abuse Rules, CCCTB/WP065 \doc \en (2008a).

European Commission, Proposal for a Council Regulation on the Statute for a European Private Company, $\operatorname{COM}(2008)$ 396/3 (2008b).

European Commission, Impact Assessment Guidelines, SEC(2009a) 92 (2009).

European Commission, Report from the Commission on Subsidiarity and Proportionality (16th Report on Better Lawmaking Covering the Year 2008) of 25 September 2009, $\operatorname{COM}(2009) 504$ (2009b).

European Commission, Communication from the Commission, EUROPE 2020 - A Strategy for Smart, Sustainable and Inclusive Growth, COM(2010) 2020 (2010a). 
European Commission, Eligibility Tests for Companies and Definition of a CCCTB Group, CCCTB/RD $\backslash 001 \backslash$ doc $\backslash$ en (2010b).

European Commission, Subsidiarity and Proportionality (17th Report on Better Lawmaking Covering the Year 2009), $\operatorname{COM}(2010) 547$ (2010c).

European Commission, Transactions and Dealings between the Group and Entities Outside the Group, CCCTB $/ R D \backslash 003 \backslash$ doc $\backslash$ en (2010d).

European Commission, Anti-Abuse Rules in the CCCTB, $\mathrm{CCCTB} / \mathrm{RD} \backslash 004 \backslash$ doc $\backslash$ en $(2010 \mathrm{e})$.

European Commission, Summary Record by the Chair of the Common Consolidated Corporate Tax Base Workshop held in Brussels on 20 October 2010, CCCTB $\backslash 20101020$ summary (2010f).

European Commission, Taxation: Commission Refers Denmark, The Netherlands and Spain to EU Court over Exit Taxes Rules, Press Release IP/10/1565 from 24 November 2010.

European Commission, Proposal for a Council Directive on a Common Consolidated Corporate Tax Base (CCCTB), $\operatorname{COM}(2011) 121 / 4$ (2011a).

European Commission, Impact Assessment Accompanying the Proposal for a CCCTB Directive, SEC(2011) 315 (2011b).

European Commission, Questions and Answers on the CCCTB, MEMO/11/171 (2011c).

European Commission, European Corporate Tax Base: Making Business Easier and Cheaper, Press Release IP/11/319 from 16 March 2011.

European Commission, Taxation: Commission requests The

Netherlands to Amend Discriminatory Tax Rules on Fiscal

Unities, Press Release IP/11/719 of 16 June 2011.

European Commission, Common Tax Base, (2012a), available at http://ec.europa.eu/taxation_customs/taxation/company t ax/common tax base/index en.htm, accessed 10 February 2012. 
European Commission, Concrete Ways to Reinforce the Fight Against Tax Fraud and Tax Evasion Including in Relation to Third Countries, $\operatorname{COM}(2012) 351$ (2012b).

European Commission (2012), An Action Plan to Strengthen the Fight Against Tax Fraud and Tax Evasion, $\operatorname{COM}(2012) 722$ (2012c).

European Commission, Commission Recommendation of 6 December 2012 Regarding Measures Intended to Encourage Third Countries to Apply Minimum Standards of Good Governance in Tax Matters, C(2012) 8805 final (2012d).

European Commission, Commission Recommendation of 6 December 2012 on Aggressive Tax Planning, C(2012) 8806 final (2012e).

European Commission, Proposal for a Council Directive Implementing Enhanced Cooperation in the Area of Financial Transaction Tax, COM(2013) 71 (2013).

European Council, Lisbon European Council 23 and 24 March 2000 Presidency Conclusions, (2000), available at http://www.europarl.europa.eu/summits/lis1_en.htm, accessed 26 October 2014 (2014).

European Parliament, European Parliament Resolution of 15 January 2008 on Tax Treatment of Losses in Cross-Border Situations, 2007/2144(INI) (2008).

European Parliament, Legislative Resolution of 19 April 2012 on the Proposal for a Council Directive on a Common Consolidated Corporate Tax Base (CCCTB) (COM(2011)0121, A7-0080/2012 (2012).

Fourth Council Directive 78/660/EEC of 25 July 1978 based on Article 54(3)(g) of the Treaty on the Annual Accounts of Certain Types of Companies (OJ L 222, 14.08.1978), p. 1131 , as subsequently amended.

Inter-Institutional Agreement on Subsidiarity, OJ C 329, 6.12.1993, p. 132.

Protocol (No. 2) on the Application of the Principles of Subsidiarity and Proportionality, annexed to the Treaty on European Union and to the Treaty on the Functioning of the European Union. OJ C 326, 26.10.2012, p. 1-390. 
Seventh Council Directive 83/349/EEC of 13 June 1983 based on the Article 54(3)(g) of the Treaty on Consolidated Accounts (OJ L 193, 18.07.1983), p. 1.-17 as subsequently amended.

Single European Act, OJ L 169 of 29.06.1987, p. 1-29.

The Platform for EU Interparliamentary Exchange (IPEX), COM $/ 2011 / 0121$ FIN, available at http://www.ipex.eu/IPEXL-

WEB $/$ dossier $/$ dossier.do? code $=\mathrm{CNS} \& y e a r=2011$ \&number $\underline{\equiv 0058}$, accessed 11 July 2013.

Treaty Establishing the European Atomic Energy Community

(EURATOM), (1957), (consolidated version), OJ C 327, 26.10.2012, p. 1-107.

Treaty Establishing the European Community ("TEC")

(Consolidated version 2002), OJ C 325, 24.12.2002, p. 33184.

Treaty on European Union ("Treaty of Maastricht"), OJ C 191 of 29.7.1992, p. 1-112.

Treaty of Amsterdam Amending the Treaty on European Union, the Treaties Establishing the European Communities and Certain Related Acts - Final Act, OJ C 340, 10.11.1997, p. 115.

Treaty of Nice Amending the Treaty on European Union, the Treaties Establishing the European Communities and Certa in Related Acts - Final Act, OJ C 80, 10.3.2001, p. 70-76.

Treaty of Lisbon amending the Treaty on European Union and the Treaty establishing the European Community, OJ OJ C 306, 17.12.2007, p. 1-271. 
11.3 LIST OF CASES

\section{Court of Justice of the European Union}

3M Italia (C-417/10) [2012] ECR nyr

$A$ (C-101/05) [2007] ECR I-11531

$A$ and $B$ (C-102/05) [2007] ECR I-3871

A Oy (C-123/11) [2013] ECR nyr

Aberdeen Property Fininvest Alpha (C-303/07) [2009] ECR I-5145

ACT Group Litigation (C-374/04) [2006] ECR I-11673

Alpine Investments (C-384/93) [1995] ECR I-1141

AMID (C-141/99) [2000] ECR I-11619

Ampliscientifica (C-162/07) [2008] ECR I-4019

Amurta (C-379/05) [2007] ECR I-9569

Asscher (C-107/94) [1996] ECR I-3089

Athinaïki Zythopö̈a (C-294/99) [2001] ECR I-6797

Baars (C-251/98) [2000] ECR I-2787

Bachmann (C-204/90) [1992] ECR I-249

Barbier (C-364/01) [2003] ECR I-15013

Biehl (C-175/88) [1990] ECR I-1779

Block (C-67/08) [2009] ECR I-883

Bosal (C-168/01) [2003] ECR I-9409

Bosman (C-415/93) [1995] ECR I-4921

British American Tobacco (C-491/01) [2002] ECR I-11453.

Burda (C-284/06) [2008] ECR I-4571

Burgoa (812/79) [1980] ECR 2787

Cadbury Schweppes (C-196/04) [2006] ECR I-7995

Cartesio (C-210/06) [2008] ECR I-9641

Cassis de Dijon (120/78) [1979] ECR 649

Centros (C-212/97) [1999] ECR I-1459

CFC and Dividend Group Litigation (C-201/05) [2008] ECR I-2875 
CILFIT (283/81) [1982] ECR 3415

CLT-UFA (C-253/03) [2006] ECR I-01831

Columbus Container Services (C-298/05) [2007] ECR I-10451

Commerzbank (C-330/91) [1993] ECR I-4017

Commission v Austria (C-475/98) [2002] ECR I-9797

Commission v Belgium (C-471/98) [2002] ECR I-9681

Commission v Denmark (C-467/98) [2002] ECR I-9519;

Commission v Denmark (C-261/11) (pending)

Commission v Finland (C-469/98) [2002] ECR I-9627

Commission v France [Avoir Fisca] (270/83) [1986] ECR 273

Commission v France (C-483/99) [2002] ECR I-4781

Commission v Germany [Volkswagen] (C-112/05) [2007] ECR I-8995

Commission v Italy (10/61) [1962] ECR 1

Commission v Italy (C-540/07) [2009] ECR I-10983

Commission v Ireland (61/77) [1978] ECR 417

Commission v Luxembourg (C-472/98) [2002] ECR I-9741

Commission v the Netherlands (C-299/02) [2004] ECR I-9761

Commission v Sweden (C-468/98) [2002] ECR I-9575

Commission v United Kingdom (C-466/98) [2002] ECR I-9427

Corsica Ferries France (C-49/89) [1999] ECR 4441

Costa v E.N.E.L. (6/64) [1964] ECR 585

Daily Mail (81/87) [1988] ECR 5483

Damseaux (C-128/08) [2009] ECR I-6823

Dassonville (8/74) [1974] ECR 837

De Groot (C-385/00) [2002] ECR I-11819

De Lasteyrie du Saillant (C-9/02) [2004] ECR I-2409

Denkavit I (Joined Cases C-283/94, C-291/94 \& C-292/94) [1996] ECR I-5063

Denkavit II (C-170/05) [2006] ECR I-11949 
Echouikh (C-336/05) [2006] ECR I-5223

Eman and Sevinger (C-300/04) [2006] ECR I-8055

Emsland-Stärke (C-110/99) [2000] ECR I-11569

Epson Europe (C-375/98) [2000] ECR I-4243

Commission v Council [ERTA] (22/70) [1971] ECR 263

Factortame II (C-221/89) [1991] ECR I-3905

Fedesa and others (C-331/88) [1990] ECR I-4023.

Felixstowe (C-80/12) [2014] nyr

FII Group Litigation I (C-446/04) [2006] ECR I-11753

FII Group Litigation II (C-35/11) [2012] nyr

Foggia-SGPS (C-126/10) [2011] ECR nyr

Futura (C-250/95) [1997] ECR I-2471

Gebhard (C-55/94) [1995] ECR I-4165

Germany v European Parliament and Council (C-233/94) [1997] ECR I2405

Gilly (C-336/96) [1998] ECR I-2793

Halifax (C-255/02) [2006] ECR I-1609

Halliburton (C-1/93) [1994] ECR I-1137

Haribo and Salinen (Joined Cases C-436/08 \& C-437/08) [2011] ECR I-305

Holböck (C-157/05) [2007] ECR I-4051

ICI (C-264/96) [1998] ECR I-4695

Inland Waterways (1/76) [1977] ECR 741

Inspire Art (C-167/01) [2003] ECR I-10155

K (C-322/11) [2013] nyr

Keck and Mithouard (Joined Cases C-267/91 \& C-268/91) [1993] ECR I-6097

Keller Holding (C-471/04) [2006] ECR I-2107

Kerckhaert and Morres (C-513/04) [2006] ECR I-10967

Kofoed (C-321/05) [2007] ECR I-5795 
Kolpinghuis (80/86) [1987] ECR 3969

Konle (C-302/97) [1999] ECR I-3099

Krankenheim (C-157/07) [2008] ECR I-8061

Kramer (Joined Cases C-3/76, C-4/76 \& C-6/76) [1976] ECR 1279

Kraus (C-19/92) [1993] ECR I-1663

Lammers \& V an Cleeff (C-105/07) [2008] ECR I-173

Lankhorst-Hohorst (C-324/00) [2002] ECR I-11779

Lasertec (C-492/04) [2007] ECR I-3775

Leur-Bloem (C-28/95) [1997] ECR I-4161

Leyla Ecem Demirkan (C-221/11) [2013] nyr

Lidl Belgium (C-414/06) [2008] ECR I-3601

Manninen (C-319/02) [2004] ECR I-7477

Marks \& Spencer (C-446/03) [2005] ECR I-10837

Metallgesellschaft (Joined Cases C-397/98 \& C-410/98) [2001] ECR I1727

Metalsa (C-312/91) [1993] ECR I-3751

N. (C-470/04) [2006] ECR I-7409

National Grid Indus (C-371/10) [2011] ECR nyr

Oy $A A$ (C-231/05) [2007] ECR I-6373

Papillon (C-418/07) [2008] ECR I-8947

Part Service (C-425/06) [2008] ECR I-897

Passenheim-van Schoot \& X (Joined Cases C-155/08 \& C-157/08)

[2009] ECR I-5093

Peeters (C-544/11) [2013] nyr

Perfili (C-177/94) [1996] ECR I-161

Persche (C-318/07) [2009] ECR I-359

Philips Electronics (C-18/11) [2012] nyr

Prunus and Polonium (C-384/09) [2011] ECR I-3319

RBS Deutschland Holdings (C-277/09) [2010] ECR I-13805

Rewe Zentralfinanz (C-347/04) [2007] ECR I-2647 
Rimbaud (C-72/09) [2010] ECR I-10659

Riseria Luigi Geddo (2/73) [1973] ECR 865

Ritter-Coulais (C-152/03) [2006] ECR I-1711

Royal Bank of Scotland (C-311/97) [1999] ECR I-2651

Saint-Gobain (C-307/97) [1999] ECR I-6161

SCA Group Holding, X AG and MSA International Holdings (Joined

Cases C-39/13; C-40/13 \& C-41/13) [2014] nyr

Schempp (C-403/03) [2005] ECR I-6421

Schumacker (C-279/93) [1995] ECR I-225

Scorpio (C-290/04) [2006] ECR I-9461

Segers (79/85) [1986] ECR 2375

SGI (C-311/08) [2010] ECR I-487

SIAT (C-318/10) [2012] nyr

Skandia and Ramstedt (C-422/01) [2003] ECR I-6817

Sotgiu (152/73) [1974] ECR 153

Stablwerk Ergste Westig (C-415/06) [2007] ECR I-151

Säger (C-76/90) [1991] ECR I-4221

Thin Cap Group Litigation (C-524/04) [2007] ECR I-2107

United Kingdom v. Council (C-84/94) [1996] ECR I-5755

Van Gend en Loos (26/62) [1963] ECR 1

Van Hilten-van der Heijden (C-513/03) [2006] ECR I-1957

Weigel (C-387/01) [2004] ECR I-4981

Weald Leasing (C-103/09) [2010] ECR I-13589

Werner (C-112/91) [1993] ECR I-429

Wielockex (C-80/94) [1995] ECR I-2493

WTO Agreement (1/94) [1994] ECR I-5267

$X$ Holding (C-337/08) [2010] ECR I-1215

Zwijnenburg (C-352/08) [2010] ECR I-4303

Überseering (C-208/00) [2002] ECR I-9919 


\section{Court of Justice of the European Free Trade Association States}

Fokus Bank (E-1/04) [2004] EFTA Court Report 11

\section{Courts of the United States of America}

Allied-Signal (504 U.S. 768) [1992] (US Supreme Court)

Alumax Inc (165 F 3d 822) [1999] (United States Court of Appeals)

A.M. Castle \& Co. (36 Cal.App.4th 1794) [1995] (Court of Appeals of California, First District, Division Three)

Appeal of Finnigan Corporation (No. 88-SBE-022) [1988] (California State Board of Equalization)

Appeal of Joyce, Inc. (No. 66 SBE 069) [1966] (California State Board of Equalization)

Barclay's Bank and Colgate Palmolive (Joined Cases 512 U.S. 298) [1994]

Butler Brothers v. McColgan (17 Cal.2d 664) [1941] (Supreme Court of California)

Butler Brothers v. McColgan (315 U.S. 501) [1942] (US Supreme Court)

Caterpillar Inc. (No. 97-779) [1999] (Supreme Court of New Hampshire)

Complete Auto Transit Inc. (430 U.S. 274) [1977] (US Supreme Court)

Conoco Inc. and Intel Corp. (931 P.2d 730) [1996] (Supreme Court of New Mexico)

Container Corp. (463 U.S. 159) [1983] (US Supreme Court)

Disney Enterprises Inc. (10 N.Y.3d 392) [(2008] (Court of Appeals of the State of New York)

Edison California Stores v. McColgan (30 Cal.2d 472) [1947] (Supreme Court of California)

E.I. du Pont De Nemours (675 A.2d 82) [1996] (Supreme Judicial Court of Maine)

Freeman v. Hewit (329 U.S. 249) [1946] (US Supreme Court)

General Electric Co. (No 2005-668) [2006] (Supreme Court of New Hampshire). 
Honolulu Oil Corp. (60 Cal.2d 417) [1963] (Supreme Court of California)

Japan Line (441 U.S. 434) [1979] (US Supreme Court)

Matson Navigation Co. (6 Cal.2d 557) [1935] (Supreme Court of California)

Mobil Oil Corp. (445 U.S. 425) [1980] (US Supreme Court)

Moorman Manufacturing Co. (437 U.S. 267) [1978] (US Supreme Court)

Northwestern States Cement Co. (358 U.S. 450 [1959] (US Supreme

Court)

Quill Corp. (504 U.S. 298) [1992] (US Supreme Court)

Reuters Ltd (82 N.Y.2d 112) [1993] (Court of Appeals of the State of New York)

Smith v. Alabama (124 U.S. 465) [1888] (US Supreme Court)

Superior Oil Co. (60 Cal.2d 406) [1963] (Supreme Court of California)

F.W. Woolworth Co. (458 U.S. 354) [1982] (US Supreme Court)

\section{Her Majesty's Courts of Justice of England and Wales}

The Felixstowe Dock. And Railway Company Ltd \& Ors v Revenue \& Customs ([2011] UKFTT 838 (TC)) (First-tier Tribunal) and subsequent appeals

Prévost Car (2008 TCC 231) [2008] (Tax Court of Canada) 


\section{CURriculum Vitae}

Tiiu Albin Pereira was born on 19 December 1984 in Tallinn, Estonia. She has studied tax law and tax administration in the Estonian Public Service Academy (2003-2006) and graduated with a master degree in tax law (specialisation in international and Europe) in 2009. As a PhD researcher at the Faculty of Law, Maastricht University, Tiiu drafted this doctoral dissertation between February 2009 and January 2014 under the supervision of Prof. Dr. Rainer Prokisch and Prof. Dr. Hans van den Hurk. In addition, during that time, she was a tutor of two master courses in the faculty of Law (Comparative Corporate Taxation and International and European Tax Law) and supervised several master theses. During her position at Maastricht University, Tiiu was a visiting research scholar in Levin G. College of Law (University of Florida, United States) in spring 2010 and carried out her six-month internship with the DG

TAXUD, the European Commission in Brussels (Belgium) in spring 2011. Tiiu is a member of the International Fiscal Association since 2006 and she was the representative of Young IFA Network (YIN) in Estonia during 2008 to 2011. 


\section{VALORISATION ADDENDUM}

On 16 March 2011, the European Commission proposed a Council Directive on a CCCTB. Considering that the European Commission had been working on the project for more than a decade before proposing the Directive, the aim of the dissertation was not to replicate this work. Instead, the overarching purpose of the current dissertation was to analyse specific aspects of the proposed Directive that influence the application of the CCCTB rules across the CCCTB water's edge and among Member States that will opt in or opt out of the CCCTB system in the future. In other words, the focus of this dissertation was on certain international aspects of the CCCTB, which in the opinion of the author, form the necessary basis for the possible introduction of a common European corporate tax system.

Since its inception, the idea of a CCCTB has found considerable criticism but also earned remarkable support from Member States, scholars, businesses within the EU and across its borders. From the author's perspective, the concept of a CCCTB is worth praising. It is expected to eliminate (or at least reduce) certain inefficiencies caused by the coexistence of the current corporate tax systems of EU Member States, which lead to high administration and compliance costs, risk of double taxation and double non-taxation, harmful tax planning, etc. As such, the CCCTB is expected to increase the competitiveness of the EU and become the preferred landscape for $\mathrm{EU}$ and foreign investment.

In order to achieve a well-functioning, business-friendly and transparent tax system, the provisions of the CCCTB Directive as well the policy behind them should be carefully (re-)considered. In particular, to achieve its goals, the provisions must be drafted on certain premises and limitations set, for instance, by the existing framework of DTCs of Member States with third countries or EU law, and it must be dynamic and attractive for businesses. In light of the foregoing and further to the analysis carried out, the author believes some of the currently proposed provisions of the CCCTB Directive require revisiting.

The current research addresses fundamental issues of the proposed CCCTB. Given that this study reaches across the EU's water's edge, it touches the general understanding of the concept of tax base harmonisation and its feasibility in the current international framework. For example, for decades, the provisions of the Member 
States DTCs and policies behind them were almost untouched by EU law. For the first time, the EU is proposing law that will have a direct impact on the DTCs of EU Member States. As such, the CCCTB will affect the policies of countries outside the EU, too. Thus, the CCCTB is an important, ground-breaking and probably one of the most ambitious initiatives in the context of EU tax law. Thanks to this research, the author believes that the idea and feasibility of tax base harmonisation in international context has got a solid step ahead.

In light of the foregoing, this study was addressed to various groups of tax law experts: agents of the European Commission, Member States' legislators and tax administrations, businesses and scholars. Through this detailed study, and as confirmed in numerous examples, the author has identified a number of weaknesses and strong points of the proposed CCCTB Directive and proposed solutions, where necessary. Therefore, the author has contributed to the discussions on the prospective framework of the CCCTB in the setting of the existing EU law as well Member States domestic laws, in conjunction with their international obligations, derived especially from their DTCs with third countries.

Whereas many articles have been written on the possible introduction of the CCCTB in general, this research is innovative because it is based on concrete provisions of the prospective CCCTB legal framework in combination to other sources of law, in particular, stemming from EU law in general or Member States DTCs with third countries. The analysis carried out in this dissertation is very detailed and complete and hence takes discussion in relation to the CССТВ in an international context to a new level.

In addition, given the specific EU element of the CCCTB, and the fact that some Member States have spoken against the CCCTB, the author has also discussed certain EU law implications in the event the CCCTB is introduced in the setting of enhanced cooperation. Until now, the literature on the possible introduction of the CCCTB in the framework of enhanced cooperation has been rather limited. This is because the current legal framework of EU law allows the use of enhanced cooperation only as a last resort. Hence, the European Commission could not have drafted the CCCTB Directive on the premise of enhanced cooperation, even if negative signals from the Member States were evident before proposing the Directive. Against this background, the discussions on this possibility among other 
scholars have been limited. Therefore, while the currently proposed Directive does not reflect the assumption of an enhanced cooperation among Member States, if at certain point of time the European Commission decides to move on with this premise, the current research will provide the European Commission a solid base for drafting the CCCTB provisions in the light of the enhanced cooperation framework.

If the CCCTB is adopted by the Member States (by all or by a certain group of Member States), the current research will be a considerable point of reference among legislators when transposing the CCCTB Directive into their national law, as well as the application of the provisions by businesses and national tax authorities.

The author is hopeful that the merits of a common corporate tax system are recognised also by other countries outside the EU. In such a case, the work carried out by the European Commission in the field of the corporate tax harmonisation may benefit these countries too. As such, the author trusts that this research will also be relevant for these countries.

In conclusion, the author believes that her research is relevant at social and economic levels. The conclusions reached in this research will be relevant in the different phases of the CCCTB - from the discussions of the potential provisions until their implementation and application - at the level of different interest groups bureaucrats, practitioners, academics - and has a broad geographical scope - from individual Member States to the EU to third countries. 